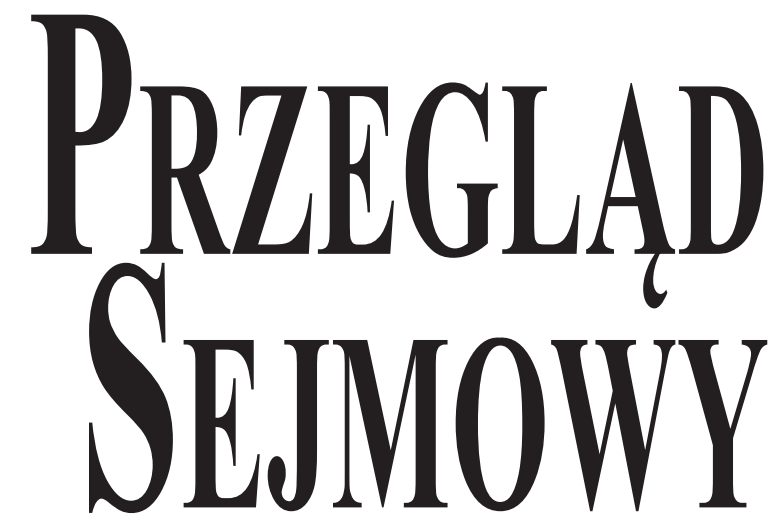

DWUMIESIECZNIK ROK XXVII $2(151) / 2019$

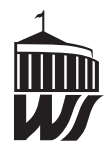


KOMITET REDAKCYJNY

Redaktor naczelny WALDEMAR PARUCH

Sekretarz naukowy WOJCIECH ARNDT

Redaktorzy tematyczni ARKADIUSZ ADAMCZYK, MAREK DOBROWOLSKI, PAWEE SOBCZYK, BOGDAN SZLACHTA, BARTOSZ WOJCIECHOWSKI

Czlonek WOJCIECH KULISIEWICZ

\section{RADA NAUKOWA}

Waldemar Paruch (Rzeczpospolita Polska - przewodniczący), Marek Bankowicz (Rzeczpospolita Polska), Igor Cependa (Ukraina), Tihomir Cipek (Chorwacja), Wojciech Dajczak (Rzeczpospolita Polska), Andrzej Dziadzio (Rzeczpospolita Polska), Maria Gintowt-Jankowicz (Rzeczpospolita Polska), Jan Holzer (Czechy), Ferenc Hörcher (Węgry), Bohdan Hud (Ukraina), Jolanta Jabłońska-Bonca (Rzeczpospolita Polska), Károly Kocsis (Węgry), Tomasz Kuczur (Rzeczpospolita Polska), Semjon Kundas (Białoruś), Pavol Mačala (Słowacja), Sergiu Miscoiu (Rumunia), Xavier Moreno Julia (Hiszpania), Vytautas Nekrošius (Litwa), Béla Pokol (Węgry), Herman H. Shugart (Stany Zjednoczone Ameryki), Tomasz Sikorski (Rzeczpospolita Polska), Vojtěch Šimiček (Czechy), Wojciech Sokół (Rzeczpospolita Polska), Rafał Sura (Rzeczpospolita Polska), Ewa Thompson (Stany Zjednoczone Ameryki), Antonio Varsori (Włochy), Michał Warciński (Rzeczpospolita Polska), Jan Wintr (Czechy).

Redaktorzy EWA ĆWIĘKAŁA, URSZULA NAŁĘCZ-RAJCA

Asystent redaktora naczelnego BARTOSZ JANIK

Tłumaczenia na język angielski KATARZYNA BARTUZI

„Przegląd Sejmowy” znajduje się w wykazie czasopism naukowych prowadzonym przez Ministra Nauki i Szkolnictwa Wyższego na potrzeby oceny jednostek naukowych z przyznaną liczbą 11 punktów.

„Przegląd Sejmowy” jest indeksowany w międzynarodowej bazie Index Copernicus Journals Master List ze wskaźnikiem ICV na poziomie 66.09.

„Przegląd Sejmowy” jest dostępny w bazach danych C.E.E.O.L., CEJSH, POL-index, Index Copernicus, BazHum, EBSCO Legal Source oraz w serwisie informacyjnym EMJS.

1 Clarivate „Przegląd Sejmowy” został objęty wsparciem Clarivate Analitics. Analytics

W wypadku wykorzystania tekstów i informacji z „Przeglądu Sejmowego" w innych publikacjach prosimy o powołanie się na nasze czasopismo.

U w a g a: Zastrzegamy sobie prawo do skrótów w tekstach nadesłanych do publikacji.

Na okładce laska marszałka Sejmu Ustawodawczego Wojciecha Trąmpczyńskiego

(C) Copyright by Kancelaria Sejmu, Warszawa 2019

„Przegląd Sejmowy” ukazuje się od 1993 r.

ISSN 1230-5502

\section{KANCELARIA SEJMU}

Przygotowanie: Wydawnictwo Sejmowe

Wydanie pierwsze

Nakład 350 egzemplarzy

Warszawa, kwiecień 2019

Adres: „Przegląd Sejmowy”, ul. Zagórna 3, 00-441 Warszawa, tel. 22 694-13-00

e-mail: przegsejm@ @ejm.gov.pl; http://www.sejm.gov.pl/publikacje/przegladsejmowy 


\section{SPIS TREŚCI}

\section{ARTYKULY}

Michał Bożek

W poszukiwaniu władzy stabilizującej porządek konstytucyjny (część II) . . . . .

Rafał Czarski

Wspótpraca parlamentów narodowych z Parlamentem Europejskim $w$ zakresie tworzenia prawa . . . . . . . . . . . . . . . . . . . . . . . . . . . . .

Jacek Falski

Dyskryminacja ze względu na religię w miejscu pracy w kontekście orzecznictwa Trybunału Sprawiedliwości Unii Europejskiej . . . . . . . . . . . . . . . . .

Anna Michalak

Skarga nadzwyczajna - dopetniający czy konkurencyjny wobec skargi konstytucyjnej instrument ochrony konstytucyjnych wolności i praw jednostki . . . . . . . . .

Kamil Stępniak

Koncepcja jurydyzacji czwartej generacji praw człowieka w międzynarodowym systemie ochrony.

Piotr A. Tusiński

Pozaustawodawcze procedury parlamentarne w pierwszym sejmie odrodzonej Rzeczypospolitej Polskiej (1919-1922). Regulacja prawna i praktyka parlamentarna . . .

\section{OPINIE, GLOSY, RECENZJE}

\section{OPINIE}

Ewelina Gierach

Na temat projektu uchwały Sejmu RP w sprawie zmiany regulaminu Sejmu Rzeczypospolitej Polskiej . . . . . . . . . . . . . . . . . . . . . . . . . .

Krzysztof Skotnicki

W sprawie ustalenia, który z kandydatów do Parlamentu Europejskiego uzyska przystugujący Polsce 52. mandat, w przypadku pozostawania Zjednoczonego Królestwa Wielkiej Brytanii i Irlandii Pólnocnej w UE na początku kadencji Parlamentu Europejskiego wybranego na lata 2019-2024 $i$ wystapienia przez Zjednoczone Królestwo z UE w trakcie tej kadencji . . . . . . . . . . . . . . . . . . . . . . .

\section{GLOSY}

Aleksandra Nadolska

Glosa do wyroku Sądu Apelacyjnego w Gdańsku z 14 grudnia 2017 r., sygn. akt I ACa 187/17

\section{RECENZJE}

Błażej Kmieciak, Prawa dziecka jako pacjenta (Paweł Dzienis) . . . . . . . .

Emil Brix, Erhard Busek, Mitteleuropa revisited. Warum Europas Zukunft in Mitteleuropa entschieden wird (Paweł A. Leszczyński) . 


\section{ŹRÓDŁA}

Mołdawia: Postanowienie Sądu Konstytucyjnego z 20 stycznia 2015 r. nr 2 o wykładni art. 1 ust. 3 w związku z art. 69 i 70 Konstytucji Republiki Mołdawii (immunitet i wygaśnięcie mandatu deputowanego) (tłumaczenie i opracowanie Andrzej Pogłódek) . . . . . . . . . . . . . . . . . . . . . . . . . . . . .

\section{VARIA}

\section{SPRAWOZDANIA}

Ogólnopolska Konferencja Naukowa XXIII Zjazd Katedr Teorii i Filozofii Prawa „Państwo - Społeczeństwo - Kultura: formalne i nieformalne źródła prawa”, Lublin, 23-26 września 2018 r. (Jadwiga Potrzeszcz) . . . . . . . . . . . . . . . . 


\section{TABLE OF CONTENTS}

\section{ARTICLES}

Michał Bożek

In search of a power to stabilize the constitutional order (part II) . . . . . . . .

Rafał Czarski

Cooperation of national parliaments with the European Parliament in the scope of lawmaking . . . . . . . . . . . . . . . . . . . . . . . . . . . . .

Jacek Falski

Religious discrimination in a workplace in view of the case law of the Court of Justice of the European Union . . . . . . . . . . . . . . . . . . . . . . . .

Anna Michalak

Extraordinary complaint - a supplementing or competing instrument of protecting constitutional freedoms and rights of an individual vis-à-vis the constitutional complaint

Kamil Stępniak

The concept of juridization of the fourth generation of human rights in the international protection system.

Piotr A. Tusiński

Extra-legislative parliamentary procedures in the first Sejm of the Renascent Republic of Poland (1919-1922). Legal regulations and parliamentary practice . . . . . .

\section{OPINIONS, COMMENTARIES, REVIEWS}

\section{OPINIONS}

Ewelina Gierach

On the draft resolution of the Sejm amending the Standing Orders of the Sejm of the Republic of Poland. . . . . . . . . . . . . . . . . . . . . . . . .

\section{Krzysztof Skotnicki}

With reference to establishing which of the candidates to the European Parliament shall be vested with the 52nd mandate allocated to Poland in case the United Kingdom of Great Britain and Northern Ireland remains in the EU at the beginning of the term of the European Parliament elected for the years 2019-2024 and withdraws during that term . . . . . . . . . . . . . . . . . . . . . . . .

\section{COMMENTARIES}

Aleksandra Nadolska

A commentary to the judgment of the Court of Appeal in Gdańsk of 14 December 2017, ref. no. I ACa 187/17 . . . . . . . . . . . . . . . . . . . . . .

\section{REVIEWS}

Błażej Kmieciak, Rights of a Child as a Patient (Paweł Dzienis) . . . . . . . .

Emil Brix, Erhard Busek, Mitteleuropa revisited. Warum Europas Zukunft in Mitteleuropa entschieden wird (Paweł A. Leszczyński) . 


\section{SOURCES}

Moldawia: judgment of the Constitutional Court of 20 January 2015 no. 2 on the interpretation of Article 1 para. 3 combined with Articles 69 and 70 of the Constitution of the Republic of Moldova (immunity and termination of mandate of a member of

Parliament) (translated and prepared by Andrzej Pogłódek) . . . . . . . . . .

\section{VARIA}

\section{SPRAWOZDANIA}

Report on the All-Poland Scientific Conference - 23 $3^{\text {rd }}$ Meeting of the Departments of Theory of Philosophy of Law "State - Society - Culture: Formal and Informal Sources of Law”, Lublin, 23-26 September 2018 (Jadwiga Potrzeszcz) . . . . . . . 


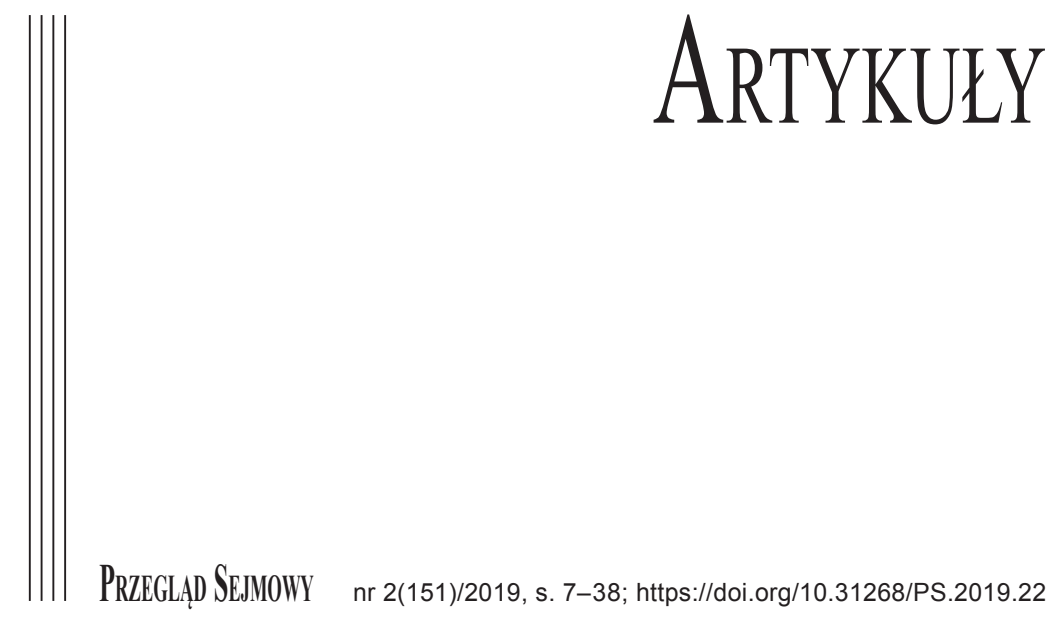

MICHAL BOŻEK*

\section{W POSZUKIWANIU WLADZY STABILIZUJĄCEJ PORZĄDEK KONSTYTUCYJNY (CZĘŚĆ II)**}

\section{IN SEARCH OF A POWER TO STABILIZE THE CONSTITUTIONAL ORDER (PART II)}

In modern constitutionalism, the systemic stabilization is represented in its two aspects. It is the primary systemic value of the constitutional order as a whole, guaranteeing the realisation of other values. In this context, it is most often understood as constitutionality and efficiency of the constitutional order. Systemic stabilization may also be regarded as a separate legal sphere of the state's activity, i.e., in this case the activity of organs of the state, whose purpose is to guarantee the constitutionality and efficiency of the constitutional order. As a separate sphere of the state's activity, it may only be distinguished within a parliamentary system. This is due to the specific form of the principle of separation of powers. Among various state organs capable of exercising this legal sphere, head of state and constitutional court are most often listed. However, as proven by the analysis of the manner of fashioning the office of the head of state in the parliamentary system, stabilization of the constitutional order may at most be regarded as one of its systemic functions. The core of the head of state's activity in this model of governance is representing the state in its external relations and before the society. Hence a thesis may be formulated, that in a parliamentary system, head of state is a separate power - the representing power (authority). Most arguments are in favour of vesting a constitutional court with systemic stabilization as a separate legal sphere of activity. The activity of a constitutional court displays numerous particular features that can not be assigned to the classic powers in the state. In a parliamentary system, a constitutional court is a holder of a separate state power-power stabilizing the constitutional order. At the same time, this does not preclude its legal status of a judicial organ.

Słowa kluczowe: stabilizacja ustrojowa, porządek konstytucyjny, władza neutralna, strażnik konstytucji, podział władzy, konstytucjonalizm

Key words: systemic stabilization, constitutional order, neutral power, guardian of the Constitution, separation of powers, constitutionalism

* Dr hab. Michał Bożek, Uniwersytet Śląski w Katowicach, Wydział Prawa i Administracji, Katedra Prawa Konstytucyjnego, mibok@poczta.onet.pl, https://orcid.org/0000-0002-2057-8921

** Część I artykułu została opublikowana w nr 5 „Przeglądu Sejmowego” w 2018 r. 


\section{STABILIZACJA USTROJOWA JAKO KATEGORIA AKSJOLOGICZNA}

tabilizacja ustrojowa jest we współczesnym konstytucjonalizmie sprawą o pierwszorzędnym znaczeniu. Jednak jej złożoność i wieloznaczność powodują, że wszelka dyskusja na ten temat musi zostać poprzedzona uporządkowaniem narosłych przez lata wokół niej problemów. Dwa z nich wydają się kluczowe. Pierwszy z nich to kwestia sprowadzenia dyskusji na właściwą płaszczyznę metodologiczną. Jak wynika z powyższych uwag, na problem stabilizacji ustrojowej można spojrzeć z dwóch perspektyw. Jej sens można bowiem rozpatrywać zarówno pod kątem aksjologii ustroju państwowego, jak i przez pryzmat jego struktury i zasad działania. Stabilizacja ustrojowa jest nadrzędną wartością porządku konstytucyjnego, głównym kryterium oceny jego efektywności i funkcjonalności, ale również jego demokratyczności i konstytucyjności. Jest to więc najważniejsza i najbardziej oczekiwana konsekwencja prawidłowej działalności konstytucyjnych władz państwowych. Efekty takiej działalności rozciągają się przede wszystkim na sferę funkcjonalno-instytucjonalną ustroju państwowego, czyli system wzajemnych relacji zachodzących między naczelnymi organami państwowymi. Jednak rezultaty stabilizującej działalności władz państwowych skutkują osiągnięciem równowagi społeczno-politycznej, a ponadto przekładają się w większą skuteczność ochrony podstawowych praw jednostki. Aksjologiczny wymiar stabilizacji ustrojowej stanowi równocześnie problem prawny i socjologiczno-politologiczny. Odnośne instrumenty prawne są tu przy tym jedynie środkiem do realizacji celu społeczno-politycznego, a analiza prawna odgrywa rolę systemowego wprowadzenia do właściwych badań socjologiczno-politologicznych. Można także stwierdzić, że aksjologiczne ujęcie stabilizacji ustrojowej czyni z niej kategorię statyczną.

Stabilizacja ustrojowa nabiera dynamiki, gdy zostanie potraktowana jako określone zjawisko prawne. Nieprzypadkowo bowiem równolegle do interesującej debaty nad jej wymiarem aksjologicznym w historii idei toczyła się równie fascynująca dyskusja dotycząca instytucji i mechanizmów służących jej osiągnięciu. Rozwiązaniem była początkowo optymalna konstrukcja ustroju państwowego. Z czasem zaś pojawił się pomysł, aby stabilizację ustrojową wyodrębnić spośród prawnych sfer działania państwa, a jej realizację powierzyć odpowiednim organom. Uznano więc, że stabilizacja to nie tylko nadrzędna wartość ustroju państwowego, ale również stosowny rodzaj działalności państwowej.

Działalność taka nie jest jednak sprawą prostą. W żadnym przypadku nie można zakładać jej jednolitego pod względem prawnym charakteru. Obejmuje ona tak wiele rozmaitych form działania, realizowanych przy tym tak różnymi narzędziami, że kwestia uznania stabilizowania ustroju państwowego za osobną prawną sferę musi budzić wątpliwości. Większość przecież z naczelnych organów państwowych dysponuje kompetencjami, które w mniejszym lub większym stopniu służą zagwarantowaniu stabilności ustrojowej. Parlament uchwalający ustawy w drodze mozolnych prac prowadzonych w wielu formach czy kontrolujący poczynania rządu przy zastosowaniu szeregu instrumentów prawnych także przyczynia się do stabilizacji porządku konstytucyjnego 
w odpowiednim zakresie ${ }^{1}$. Podobnie rzecz się ma z działalnością egzekutywy. W gestii rządu pozostaje wiele środków działania, które mogą zapobiegać destabilizacji ustrojowej. Określanie ogólnych kierunków polityki państwowej to powszechne zadanie rządu stwarzające chyba największe możliwości w tej mierze, przy czym szczegółowych uprawnień $\mathrm{z}$ dziedziny porządku i bezpieczeństwa państwowego również nie należy tu nie doceniać ${ }^{2}$. W tym kontekście o sądownictwie nie ma potrzeby nawet wspominać, uwzględniwszy, że rozstrzyganie najróżniejszych sporów prawnych to istota ich działalności ${ }^{3}$. Stabilizujący charakter ma również działalność wszelkich organów kontroli państwowej i ochrony prawa, niezależnie od ich ustrojowego usytuowania i konstytucyjnie określonego katalogu zadań i kompetencji ${ }^{4}$. Nie należy też zapominać o samorządzie terytorialnym, który jako stabilizujący element ustroju państwowego rozporządza całą paletą środków działania podejmowanych na różnych szczeblach podziału terytorialnego przez odpowiednie organy ${ }^{5}$.

Niezbędne jest najpierw zdefiniowanie samej istoty takiej działalności, aby rozstrzygnąć kwestię charakteru prawnego działalności stabilizującej ustrój państwa. Zgodnie $\mathrm{z}$ utrwalonym w języku polskim znaczeniem, stabilizowanie to doprowadzanie do stanu trwałości, zmierzanie do równowagi, ale zarazem normowanie i utrwalanie określonych zjawisk czy sytuacji. Jest to więc pojęcie o niezwykle szerokim spektrum zastosowania, a przy tym niezbyt precyzyjne. Mimo wszystko można w nim jednak dostrzec dwa elementy. Pierwszy wskazuje na podjęcie działań idących w kierunku opanowania sytuacji wyjściowej, którą cechuje labilność, niepewność, brak równowagi, tymczasowość czy wręcz chaos. Chodzi tu zatem o zaprowadzenie określonego porządku. Natomiast drugi element stabilizacji obejmuje wszelkie działania obliczone na ugruntowanie tego porządku, uczynienia go stanem trwałym i pożądanym. Innymi słowy, stabilizacja to przede wszystkim osiągnięcie czegoś stałego i przewidywalnego, a w dalszej kolejności utrzymanie tego w niezmienionej postaci.

Stabilizacja ustrojowa w takim rozumieniu oznaczałaby ufundowanie określonego porządku konstytucyjnego lub nadanie istniejącemu odpowiedniej formy, a następnie silne zakorzenienie ich w strukturach państwowych i społeczno-politycznych jako modelu optymalnego lub najlepszego w danych warunkach. Przy takim pozostawieniu sprawy dyskusja na temat charakteru prawnego działalności stabilizującej byłaby wyzwaniem karkołomnym. Trudno jednak o inną konkluzję, skoro działalność taka byłaby praktycznie zadaniem wszystkich konstytucyjnych władz państwa. Każda z nich zobowiązana jest bowiem działać na podstawie i w granicach obowiązującego prawa, którego

${ }^{1}$ R.R. Ludwikowski, Prawo konstytucyjne porównawcze, Toruń 2000, s. 302.

${ }^{2}$ M. Bożek, Rada Ministrów, [w:] Polskie prawo konstytucyjne na tle porównawczym, red. R.M. Małajny, Warszawa 2013, s. 513.

${ }^{3}$ B. Banaszak, Porównawcze prawo konstytucyjne wspótczesnych państw demokratycznych, Warszawa 2007, s. 503.

${ }^{4}$ A. Sylwestrzak, Wtadza czwarta - kontrolująca, „Państwo i Prawo” 1992, z. 7, s. 92.

5 B. Zawadzka, Samorzad jako forma sprawowania władzy publicznej, [w:] Prawo w okresie przemian ustrojowych $w$ Polsce, Warszawa 1995, s. 42-44. 
fundamentem jest konstytucja. Konstytucjonalizm liberalno-demokratyczny traktuje tę ostatnią jako rodzaj umowy, której przedmiotem jest nie tylko forma i warunki istniejącego ustroju politycznego, lecz także podstawowe założenia ustroju społeczno-ekonomicznego ${ }^{6}$. Stabilizacja ustrojowa wpisana jest tym samym w istotę działalności wszystkich władz państwowych, a wszelkie działania destabilizujące istniejący porządek konstytucyjny są poważnym naruszeniem jego podstawowych zasad i wartości ${ }^{7}$.

Hołdując takiemu rozumieniu stabilizacji ustrojowej, trzeba byłoby stwierdzić, że w gruncie rzeczy nie ma jakichkolwiek podstaw do wyodrębniania jej jako osobnej prawnej sfery działania państwa. Można byłoby ją co najwyżej potraktować jako ogólne zadanie wszystkich władz państwowych o bliżej niesprecyzowanych możliwościach realizacji. Z większym prawdopodobieństwem jednak stabilizacja ustrojowa jako zadanie władz państwowych byłaby konstrukcją czysto teoretyczną czy wręcz figurą retoryczną, a nie określonym katalogiem środków działania. Zważywszy bowiem, że stabilizacja taka powinna być nadrzędną wartością przyświecającą wszelkim działaniom władz państwowych, to nie pozostałoby nic innego, jak wszystkie znajdujące się w ich gestii kompetencje uznać za narzędzia jej realizacji jako określonego zadania. Na końcu takiego rozumowania musi czekać pułapka kwadratury koła. Nie sposób bowiem określić form realizacji tak zakreślonego zadania. A zadanie niemożliwe do zrealizowania pozostaje jedynie postulatem czy pobożnym życzeniem osiągnięcia pewnego stanu. W przypadku stabilizacji ustrojowej postulatem tym jest określona wartość konstytucyjna. Podążając zatem dalej tą drogą, nie da się wyjść poza warstwę aksjologiczną, a stabilizacja ustrojowa nie może zostać potraktowana jako cokolwiek więcej niż nadrzędna wartość porządku konstytucyjnego.

\section{STABILIZACJA USTROJOWA JAKO PRAWNA SFERA DZIALANIA}

Jak uczy doświadczenie, sakralizacja wartości przydaje im waloru metafizycznego i wynosi je na piedestał, lecz nie czyni ich odpornymi na działanie czasu i kaprysy natury ludzkiej. Dopiero oparcie ich na solidnym fundamencie może zapewnić im długowieczny żywot. Wartości konstytucyjne, jak wszelkie zjawiska z pogranicza prawa i polityki, są szczególnie podatne na dewaluację. Żeby stabilizacja ustrojowa rzeczywiście stała się naczelną wartością porządku konstytucyjnego, nie wystarczy sprowadzenie jej do poziomu ogólnej deklaracji ideowej czy też uczynienie z niej głównego celu działalności władz państwowych. Konieczne wydaje się podniesienie jej do rangi odrębnej prawnej sfery działania państwa i przypisanie przynależnych do niej zadań odpowiednim organom. Dzięki temu zostanie jej nadany realny wymiar, ponieważ stanie się konkretnym obszarem działalności określonych organów państwowych. Taki ustrojowy awans stabilizacji porządku konstytucyjnego jest o tyle uzasadniony, że nic tak skutecznie nie chroni założeń aksjologicznych państwa, jak odpowiedni system

${ }^{6}$ D.S. Lutz, Principles of Constitutional Design, Cambridge-New York 2006, s. 15-18; A. Pułło, Idea konstytucjonalizmu w systemie zasad prawa konstytucyjnego, „Przegląd Sejmowy” 1996, nr 5, s. 9-22.

7 W. Brzozowski, Stopniowalność naruszeń konstytucji, ,Ruch Prawniczy, Ekonomiczny i Socjologiczny" 2017, z. 4, s. 5-7. 
gwarancji prawnych. Stabilizacja ustrojowa zyska właściwe znaczenie i efektywną ochronę w efekcie wyodrębnienia jej w ramach prawnych sfer działania państwa i postawienia $\mathrm{w}$ szeregu z pozostałymi sferami odpowiedzialnymi za realizację innych wartości konstytucyjnych. Stabilizacja ustrojowa jako prawna sfera działania państwa byłaby poważną gwarancją stabilizacji ustrojowej jako naczelnej wartości jego porządku konstytucyjnego.

Za nadaniem stabilizacji ustrojowej charakteru samodzielnej prawnej sfery działania oprócz względów natury aksjologicznej przemawiają racje o charakterze systemowym. Chodzi tu mianowicie o często podkreślany literaturze przedmiotu fakt wieloznaczności teorii podziału władzy. Można nawet zaryzykować pogląd, że w ramach tej teorii występuje tyle doktryn i koncepcji, ilu jest autorów mierzących się z jej fenomenem. Rysujące się na tym tle różnice zdań dotyczą nie tylko kwestii liczby wyodrębnianych władz, ich nazwy czy zakresu działania. Kontrowersyjna jest już coraz częściej sama istota podziału władzy. Wśród rozpowszechnianych na ten temat poglądów można spotkać oceny o nieadekwatności formalnego podziału władzy we współczesnym państwie, opinie o anachronizmie jego klasycznych założeń i potrzebie ich redefinicji, jak również głosy o niezrozumieniu jego istoty i machinalnym powielaniu utartych schematów. Najwięcej zwolenników ma jednak konkluzja o konieczności poszukiwania nowych form podziału władzy, które odpowiadałyby realiom ustrojowym dzisiejszych państw. Za niewystarczający uznawany bywa nierzadko trójpodział władzy, zawężający katalog prawnych sfer działania państwa do klasycznej triady: władza ustawodawcza, wykonawcza i sądownicza. Zazwyczaj przy tej okazji podkreśla się, że oprócz tych trzech władz współczesny konstytucjonalizm zna wiele innych organów państwowych, których działalność nie mieści się w obszarze żadnej z nich ${ }^{8}$. Stąd coraz częściej podejmowane są próby wyodrębniania nowych prawnych sfer działania. Pod różnymi postaciami przewija się pośród nich idea władzy, która ma stać na straży szeroko rozumianej stabilizacji ustrojowej. Wprawdzie żaden z autorów takich pomysłów raczej nie używa formuły władza stabilizująca, lecz zadowala się zwykle ukształtowanymi na przestrzeni wieków i wspominanymi tu już nazwami ${ }^{9}$. Nie zmienia to jednak sensu takich starań, którym jest przekonanie o konieczności wyraźnego zaakcentowania w strukturze aparatu państwowego osobnej władzy, realizującej odrębną prawną sferę działania, a polegającą na stabilizacji ustroju państwowego.

${ }^{8}$ R.M. Małajny, Podziat czy trójpodział władzy?, [w:] Prawowitość czy zgodność z prawem? Legitymizacja władzy w państwach demokratycznych, red. A. Preisner, Wrocław 2010, s. 102-104; idem, Idea rozdziału władzy państwowej i jej interpretacje, „Przegląd Sejmowy” 2009, nr 1, s. 81-82; A. Pułło, O jedno rozumienie podziału władz w nauce prawa konstytucyjnego, „Państwo i Prawo” 1983, z. 3, s. 30; idem, „Podziat władzy”. Aktualne problemy w doktrynie, prawie i wspótczesnej dyskusji konstytucyjnej w Polsce, „Przegląd Sejmowy” 1993, nr 3, s. 12-13; W. Sokolewicz, Podziat władz — idea polityczna czy zasada prawna? Z dylematów wspótczesnego ustrojodawcy, [w:] Prawo w okresie..., s. 18-19.

${ }^{9}$ Confer A. Sylwestrzak, Aktualność problematyki podziału władz, [w:] Idee jako źródto instytucji politycznych i prawnych, red. L. Dubel, Lublin 2003, s. 145-159; G. Kuca, Zasada podziału i równowagi władz a inne organy państwowe, [w:] Ustroje, doktryny, instytucje polityczne. Ksiega jubileuszowa Profesora zw. dra hab. Mariana Grzybowskiego, red. J. Czajowski [i in.], Kraków 2007, s. 173-174. 
Żadnych wątpliwości nie budzi konstatacja, że warunkiem wyodrębnienia jakiejkolwiek prawnej sfery działania państwa jest zdefiniowanie określonego obszaru działalności władzy państwowej poprzez wskazanie ogólnego kierunku takiej działalności i przyporządkowanie do niej właściwych zadań. Jednak taka działalność musi charakteryzować się tym, że poza możliwością jej realizacji powinna wywoływać konkretne konsekwencje prawne. Co się tyczy tych ostatnich, to precyzyjniej można byłoby stwierdzić, że konsekwencje prawne powinny stanowić efekt wieńczący każdą formę działalności uznanej za osobną prawną sferę ${ }^{10}$. Dodatkowym kryterium pozwalającym potraktować daną działalność władzy państwowej za samodzielną prawną sferę działania jest możliwość ustalenia istoty czy głównego jej rdzenia (Kernbereich). Istota taka jest głównym zadaniem każdej prawnej sfery, czymś, bez czego straciłaby ona swą odrębność na tle innych prawnych sfer ${ }^{11}$. Prócz zadania głównego do każdej prawnej sfery przypisane są inne zadania, które można nazwać dodatkowymi. Zazwyczaj przywoływany bywa w tym kontekście przykład legislatywy, której istotą jest ustawodawstwo, zaś pozostałe pełnione przez nią funkcje - w tym tak doniosłe jak funkcja kontrolna - wyznaczają jej różne zadania dodatkowe ${ }^{12}$. Pierwotną płaszczyzną podziału władzy jest więc jej rozdział w aspekcie funkcjonalnym, który oznacza wyodrębnienie odpowiednich prawnych sfer działania w drodze sprecyzowania właściwych obszarów działalności władzy państwowej i następnie określenie ich istoty ${ }^{13}$.

Warunkiem uznania gwarantowania stabilizacji ustrojowej za osobną prawną sferę działania jest zdefiniowanie jej istoty. Wprawdzie niewystarczające okazało się w tej mierze sięgnięcie po czysto językową egzegezę samej stabilizacji. Jednak nie oznacza to, że egzegeza taka jest całkowicie bezużyteczna, stanowi ona punkt wyjścia do uchwycenia istoty stabilizacji ustrojowej jako określonej działalności władzy państwowej. Jednocześnie musi zostać uzupełniona podejściem teleologicznym. Skoro uzasadnione wydają się aspiracje szeroko pojętej stabilności ustroju państwowego do miana nadrzędnej wartości porządku konstytucyjnego, to równie bezsporne wydaje się oczekiwanie, aby działalność władzy państwowej była ukierunkowana przede wszystkim na osiągnięcie takiego celu ${ }^{14}$. Powierzenie zadania stabilizowania ustroju wszystkim władzom państwowym nie przyniosłoby spodziewanego efektu, gdyż powstałoby ryzyko wypaczenia istoty takiej działalności, albo — przy jej właściwym uchwyceniu — realna stałaby się groźba kumulacji nadmiernej władzy w rękach jednego lub kilku organów. Niezbędne zatem staje się umiejętne połączenie

${ }^{10}$ R.M. Małajny, Klasyfikacja prawnych sfer działania państwa — próba reinterpretacji, [w:] Rozważania o państwie i prawie, Katowice 1993, s. 125-138.

11 M. Bożek, Władza ustrojodawcza w konstytucjonalizmie niemieckim, Warszawa 2013, s. 116; K. Stern, Das Staatsrecht der Bundesrepublik Deutschland, t. II, Staatsorgane, Staatsfunktionen, Finanzund Haushaltsverfassung, Notstandsverfassung, München 1980, s. 541-542.

12 Ch. Starck, Der demokratische Verfassungsstaat. Gestalt, Grundlagen, Gefährdungen, Tübingen 1995, s. 24-25; B. Banaszak, Porównawcze..., s. 420.

13 R.M. Małajny, Zasady ustroju państwa, [w:] Polskie..., s. 174-176.

14 D.S. Lutz, Principles..., s. 143. 
stabilizacji ustrojowej rozumianej jako utrwalanie istniejącego porządku konstytucyjnego ze stabilnością ustroju państwowego, pojmowaną jako gwarantowanie jego konstytucyjności i efektywności. Stabilizacja ustrojowa musi mieć więc formę takiej działalności władzy państwowej, której konsekwencją będzie ochrona porządku konstytucyjnego, czyli zagwarantowanie przestrzegania przez tę władzę ustawy zasadniczej i zapewnienie skuteczności jej działań, co w rezultacie przyniesie trwałość podstawowych zasad i wartości takiego porządku.

Istotą działalności stabilizującej byłoby zapobieganie niekonstytucyjności i nieefektywności działań władzy państwowej oraz rozstrzyganie w jej obrębie sporów powstałych na tym tle. Jeśli założyć, że w ramach porządku konstytucyjnego nie ma miejsca na inne spory między władzami państwowymi niż spory prowadzone na podstawie i w granicach jego założeń wyrażonych w postanowieniach ustawy zasadniczej, to w gruncie rzeczy istotą działalności stabilizującej jest rozstrzyganie sporów konstytucyjnych i zapobieganie ich powstawaniu. Różne może być podłoże takich sporów. Raz mogą to być względy natury prawnej, które mogą przybrać postać sporu dotyczącego właściwej interpretacji postanowień konstytucyjnych. A innym razem mogą to być racje polityczne, gdy przedmiotem sporu będzie różnica zdań związana z kierunkiem prowadzonej polityki lub kształtem konkretnej decyzji politycznej. Zarówno w jednym, jak i w drugim przypadku kluczowe znaczenie ma fakt, że podstawą spornego stanowiska danego organu jest jego konstytucyjnie określony status. Koniecznie trzeba zastrzec, że spory w obrębie władzy państwowej to spory między konstytucyjnie wyodrębnionymi jej podmiotami, czyli konstytucyjnie określonymi organami państwowymi. Drugie zastrzeżenie niezbędne jest dla uniknięcia nieporozumienia terminologicznego. W polskim piśmiennictwie ustrojowym znaczenie sporu konstytucyjnego bywa na ogół zawężane do sporu kompetencyjnego, to znaczy sytuacji, gdy dwa lub więcej organy konstytucyjne uznają lub kwestionują swą właściwość do zajęcia się określoną sprawą ${ }^{15}$. Z kolei w literaturze niemieckiej sporem konstytucyjnym określa się zazwyczaj spór między konstytucyjnymi organami państwowymi odnoszący się do wykładni stosownego postanowienia konstytucji w zakresie ich praw i obowiązków, co często nazywane bywa sporem między organami (Organstreit $)^{16}$.

Zaproponowane ujęcie sporu konstytucyjnego wykracza zatem wyraźnie poza sens nadawany z reguły temu pojęciu w teorii prawa konstytucyjnego. Nie jest to jednak stanowisko całkowicie odosobnione. Można bowiem niekiedy spotkać podobne

15 Pogląd taki rozpowszechnił się zwłaszcza w związku z art. 189 Konstytucji RP, który rozstrzyganie sporów między centralnymi konstytucyjnymi organami państwowymi powierza TK. Confer W. Skrzydło, Rola Trybunału Konstytucyjnego w rozstrzyganiu sporów kompetencyjnych, [w:] Konstytucja $i$ władza we wspótczesnym świecie. Doktryna — prawo - praktyka. Prace dedykowane Profesorowi Wojciechowi Sokolewiczowi na siedemdziesięciolecie urodzin, Warszawa 2002, s. 484; M. Zubik, O rozstrzyganiu „sporów kompetencyjnych" przez Trybunat Konstytucyjny, [w:] Prawa człowieka — społeczeństwo obywatelskie — państwo demokratyczne. Księga jubileuszowa dedykowana Profesorowi Pawłowi Sarneckiemu, red. P. Tuleja, M. Florczak-Wątor, S. Kubas, Warszawa 2010, s. 232.

${ }^{16}$ K. Stern, Das Staatsrecht der Bundesrepublik Deutschland, t. II..., s. 978; M. Derlatka, Skarga konstytucyjna wiemczech, Warszawa 2009, s. 75. 
postulaty formułowane bądź wprost, bądź pośrednio ${ }^{17}$. Przede wszystkim jednak szeroka konwencja sporu konstytucyjnego wydaje się uzasadniona $\mathrm{z}$ dwóch powodów. Po pierwsze, nie sposób zaprzeczyć, że skoro podstawą działania konstytucyjnych władz państwowych musi być ustawa zasadnicza i zawarta w jej postanowieniach charakterystyka pozycji ustrojowej każdej z nich, to wszelkie czynności podejmowane $\mathrm{w}$ ich imieniu przez odpowiednie organy muszą znajdować oparcie w tych postanowieniach. Nawet gdy bezpośrednią podstawą określonej decyzji są przepisy ustawy, to decyzja taka i tak musi mieć potwierdzenie w konstytucyjnie określonych zadaniach każdej władzy ${ }^{18}$. Nie do przecenienia jest również drugi z argumentów przemawiających na rzecz szerokiej definicji sporu konstytucyjnego. Nie ma żadnych przeszkód, by spór kompetencyjny uznać za jedną z form sporu konstytucyjnego. Spór kompetencyjny byłby wówczas sporem konstytucyjnym o charakterze prawnym, gdyż dotyczyłby nieporozumienia między organami państwowymi co do ich formalnej właściwości w danej sprawie. Inna rzecz, że uwzględniając uczestniczące $\mathrm{w}$ takim sporze organy i mając na uwadze jego faktyczną przyczynę, nawet spór kompetencyjny obarczony może być nierzadko sporą dawką polityki ${ }^{19}$. Taka jest zresztą natura większości sporów konstytucyjnych, gdzie prawo do tego stopnia miesza się z polityką, że czasami trudno je od siebie oddzielić. Ich dwoistość przejawia się w tym, że możliwe są sytuacje inicjowania sporu z przyczyn czysto politycznych, który jednak poprzez charakter zaangażowanych weń organów oraz sposób i granice jego rozstrzygnięcia staje się sporem par excellence prawnym. I przypadek odwrotny, mimo że spór wybucha z powodów prawnych, to przez wzgląd na status prowadzących go organów i znajdującą się w tle jego rzeczywistą podstawę, stanie się on sporem politycznym.

\section{STABILIZACJA USTROJOWA A WSPÓŁCZESNE SYSTEMY RZĄDÓW}

$\mathrm{O}$ ile pierwszym kanonem teorii podziału władzy jest jej rozdział w aspekcie funkcjonalnym, o tyle kanonem drugim powinien być podział instytucjonalny. Wydzielona i wyraźnie zdefiniowana prawna sfera działania państwa musi zatem zostać przyporządkowana określonej grupie organów ${ }^{20}$. Uznanie stabilizacji ustrojowej za sferę odrębną od pozostałych powoduje tym samym konieczność znalezienia organu lub organów państwowych, które byłyby najwłaściwsze do jej sprawowania. Ich poszukiwanie należałoby rozpocząć od konkluzji, że jakkolwiek konstytucjonalizm wykształcił rozmaite formuły rządów, to modelem dominującym jest system parlamentarny. Pozostawiając na uboczu analizę przyczyn tego stanu rzeczy i nie wchodząc w szczegóły teorii systemów rządów, można jedynie odnotować, że źródłem tego fenomenu jest nadzwyczajna

${ }^{17}$ D. Rousseau, Sadownictwo konstytucyjne w Europie, Warszawa 1999, s. 80-83.

${ }^{18}$ Z. Tobor, Legalność a praworzadność, [w:] Rozważania..., s. 194.

${ }_{19}$ Najlepszym tego przykładem był spór między prezydentem a Radą Ministrów o prawo do reprezentowania Polski w posiedzeniach Rady Europejskiej, który został ostatecznie rozstrzygnięty orzeczeniem TK w 2009 r. Confer J. Kuciński, Legislatywa - egzekutywa - judykatywa: konstytucyjne instytucje i mechanizmy stużace równowadze władz w polskim systemie trójpodziału, Warszawa 2010, s. $192-196$.

${ }^{20}$ R.M. Małajny, Zasady..., s. 175. 
elastyczność podstawowych założeń systemu parlamentarnego. Założenia te w efekcie procesu racjonalizacji przeszły tak daleko idącą metamorfozę, że współczesny system parlamentarny niemal powszechnie bywa traktowany jako ogólna konstrukcja ustrojowa, która występuje w wielu różnych postaciach ${ }^{21}$.

Od wielu lat jedną z najbardziej kontrowersyjnych kwestii w ramach teorii systemu parlamentarnego jest fundamentalny dylemat dotyczący obecności zasady podziału władzy w obrębie tego systemu. Trzeba podkreślić (odnotowując opinie kwestionujące taką obecność) $)^{22}$, że większość badaczy jest zdania, że zasada podziału władzy stanowi podstawę systemu parlamentarnego. Pogląd taki opiera się zazwyczaj na przekonaniu, że wersji teorii podziału władzy jest sporo, a redukowanie jej wyłącznie do osławionego trójpodziału w wydaniu Monteskiusza jest nie tylko uproszczeniem, lecz przede wszystkim świadczy o całkowitym niezrozumieniu sensu tej teorii ${ }^{23}$. System prezydencki ze swym wzorcowym przykładem konstytucjonalizmu amerykańskiego najbliżej jest ideałowi owego trójpodziału, ale zrodził się on w tym samym stuleciu co doktryna Monteskiusza i na dobrą sprawę pozostał zgoła odosobnionym przypadkiem systemu rządów ${ }^{24}$. Równie osobliwą formułą ustrojową jest model określany często jako system rządów zgromadzenia, występujący w Szwajcarii ${ }^{25}$. Tamtejsi autorzy nigdy nie byli jednomyślni w ocenie tego, czy helwecki system rządów został zbudowany wokół założeń zasady podziału władzy, czy też raczej reguły jej jednolitości. Nawet jednak oni skłonni byli przyznać, że teoria podziału władzy jest na tyle bogata w doktryny i koncepcje, że kluczowy dla niej funkcjonalno-instytucjonalny wymiar rozdziału w szwajcarskim modelu rządów został zachowany ${ }^{26}$.

System parlamentarny jest nie tylko elastyczną formułą rządów, jeżeli chodzi o jego podstawowe założenia. Jego elastyczność widoczna jest również w kształcie zasady podziału władzy. Należy przypomnieć, że wszelkie modyfikacje doktryny Monteskiusza i postulaty uzupełnienia proponowanego przezeń trójpodziału o dodatkowe prawne sfery działania były prezentowane $\mathrm{z}$ reguły przez autorów europejskich z pozycji istoty systemu parlamentarnego $0^{27}$. Model prezydencki jest bowiem skomplikowaną i zarazem pełną paradoksów postacią systemu rządów, z pozoru zbudowany wokół kilku reguł ustrojowych o raczej prostej konstrukcji. Gdy jednak reguły te

${ }^{21}$ Confer szerzej na temat zjawiska racjonalizacji systemu parlamentarnego i jego konsekwencji J. Szymanek, Racjonalizacja parlamentarnego systemu rządów, „Przegląd Sejmowy” 2007, nr 1, s. 35-64.

${ }^{22} \mathrm{~W}$ literaturze polskiej konsekwentnym orędownikiem takiego stanowiska jest A. Pułło, O jedno..., s. 30-45; idem, „Podziat..., s. 9-26.

23 Confer R.M. Małajny, Rozdział władzy w systemie parlamentarnym, [w:] Parlamentarny system rządów. Teoria i praktyka, red. T. Mołdawa, J. Szymanek, M. Mistygacz, Warszawa 2012, s. 54-95.

${ }^{24}$ A. Pułł, System prezydencki, [w:] Konstytucyjne systemy rządów, red. M. Domagała, Warszawa 1997, s. 72-74.

${ }^{25}$ M. Bożek, System „,rządów zgromadzenia” — próba definicji, [w:] Systemy rządów w perspektywie porównawczej, red. J. Szymanek, Warszawa 2014, s. 201.

26 P. Sarnecki, Rząd a parlament w Konfederacji Szwajcarskiej, Kraków 1978, s. 199-200.

27 R.M. Małajny, Zasada podziału władzy a system rzadów parlamentarnych, "Państwo i Prawo" 2009, z. 12 , s. 16-30. 
podda się szczegółowej analizie, okazuje się, że w prostocie ich konstrukcji tkwią jednocześnie zagrożenia ${ }^{28}$. Koronnym argumentem na rzecz tej tezy jest właśnie zasada podziału władzy. Na poziomie konstytucyjnym została ona sprowadzona do trójpodziału, a relacje między poszczególnymi władzami bliższe są idei separacji niż kooperacji29. Jak niewdzięcznym materiałem do naśladownictwa jest ów model, najlepiej świadczą losy jego recepcji w państwach południowoamerykańskich ${ }^{30}$. Zamknięcie działalności aparatu państwowego w kręgu mitycznej bez mała triady prawnych sfer, której co jakiś czas towarzyszą nieformalne próby ustrojowego usamodzielnienia niektórych organów państwowych ${ }^{31}$, mogło zdać egzamin wyłącznie w ojczyźnie systemu prezydenckiego. Przy braku odpowiedniej kultury politycznej i głęboko zakorzenionych tradycji demokratyczno-wolnościowych system ten z góry skazany był na porażkę ${ }^{32}$.

Redukcja prawnych sfer działania państwa do „świętej trójcy podzielonych władz" ${ }^{33}$ praktycznie przekreśliła możliwość poszukiwania czynnika stabilizującego porządek konstytucyjny w formie władzy odrębnej realizowanej przez osobny organ państwowy. Za organy takie nie sposób uznać Sąd Najwyższy i sądy powszechne. Mimo że za sprawą przysługującej im kompetencji do interpretacji i kontroli konstytucyjności prawa (judicial review) niewątpliwie rozstrzygają one istotne spory konstytucyjne, to czynią to wyłącznie w związku z rozpatrywaniem konkretnych spraw sądowych. Rozstrzyganie tak rozumianych sporów konstytucyjnych jest zatem funkcją ich podstawowego zadania, którym jest sprawowanie wymiaru sprawiedliwości. Istotą działalności tamtejszych sądów jest więc rozstrzyganie konkretnych sporów prawnych, co stanowi kwintesencję władzy sądowniczej. Nie odmawiając instytucji judicial review waloru stabilizującego ustrój państwowy, nie można nie dostrzegać jej wtórnego charakteru w stosunku do rozstrzygania indywidualnych spraw sądowych ${ }^{34}$. System prezydencki wyklucza jakąkolwiek możliwość innego jej podziału w wymiarze instytucjonalnym wskutek formalnego zawężenia zasady rozdziału władzy w aspekcie funkcjonalnym do jej trójpodziału ${ }^{35}$. Stabilizacja ustrojowa nie może tym samym zyskać w ramach tego modelu rangi osobnej prawnej sfery działania. Może tam jedynie pozostać ogólnie sformułowanym zadaniem wszystkich władz państwowych, czyli w rzeczywistości nie wykroczyć poza sferę konstytucyjnej aksjologii ${ }^{36}$.

Do podobnych wniosków co w przypadku systemu prezydenckiego trzeba również dojść, poszukując stabilizacji ustrojowej jako odrębnej prawnej sfery działania

28 A. Stepan, C. Skach, Modele konstytucyjne a umacnianie demokracji (parlamentaryzm — system prezydencki), „Państwo i Prawo” 1994, z. 4, s. 39.

29 A. Pułło, System..., s. 63.

30 M. Bożek, Systemy rząów, [w:] Polskie..., s. 343.

31 M. Turek, System prezydencki w praktyce politycznej USA, [w:] Systemy..., s. 260-271.

32 J.J. Linz, Zagrożenia systemu prezydenckiego, „Res Publica” 1990, nr 12, s. 32-34.

${ }^{33}$ Ch. Starck, Der demokratische..., s. 13.

34 R.M. Małajny, Pozycja ustrojowa Kongresu USA, t. III, Katowice 1995, s. 215-217.

35 A. Pułło, System..., s. 64.

${ }^{36}$ Confer szerzej na temat czynników stabilizujących system rządów w USA: P. Laidler, Podstawowe założenia systemu prezydenckiego na przyktadzie USA, [w:] Systemy..., s. 235-244. 
w modelu rządów zgromadzenia. Jego rewolucyjna proweniencja związana z wyraźnym wyeksponowaniem zasady suwerenności narodu kosztem innych reguł ustrojowych od samego początku zakładała szczególną pozycję legislatywy ${ }^{37}$. Rządy próbowały pogodzić funkcjonalno-instytucjonalny trójpodział władzy z dominującą w jego obrębie rolą legislatywy, nawiązujące do założeń takiej konstrukcji ustrojowej formuły. Z biegiem lat formuły takie zaczęły jednak zanikać, ewoluując zazwyczaj w kierunku systemu parlamentarnego ${ }^{38}$. Wyjątkiem na tym tle okazał się porządek konstytucyjny Konfederacji Szwajcarskiej, który mimo uchwalania kolejnych ustaw zasadniczych w swym kluczowych elementach pozostał niezmieniony. Bazując na formalnym rozdziale władzy w aspektach funkcjonalnym i instytucjonalnym oraz dochowując wierności w tym względzie regule tradycyjnego trójpodziału, zachował jednocześnie wyraźnie uprzywilejowany status dwuizbowej legislatywy. Natomiast relacje tej ostatniej z pozostałymi władzami zostały ukształtowane — podobnie jak w modelu prezydenckim — w duchu formalnej separacji. Świadczą o tym wyjątkowo skąpe instrumenty wzajemnego oddziaływania na siebie poszczególnych władz ${ }^{39}$.

Deficyt ustrojowych hamulców przekreśla zatem możliwość działalności stabilizującej ustrój państwowy skoncentrowany w gestii określonej władzy. Wprawdzie z trzech wyodrębnionych konstytucyjnie władz aż dwie dysponują stosownymi środkami do rozstrzygania sporów konstytucyjnych, jednak żadna z nich nie czyni tego w ramach istoty swej działalności. Najbliżej statusu osobnego organu powołanego do zagwarantowania stabilizacji ustrojowej jest bez wątpienia Sąd Federalny. Odgrywa on rolę sądu konstytucyjnego ${ }^{40}$. Zakres jego działalności został jednak znacznie zawężony w porównaniu do klasycznych sądów konstytucyjnych. Spod jego właściwości zostało wyjęte bowiem prawo do kontrolowania konstytucyjności ustaw, zaś uprawnienie do rozstrzygania sporów kompetencyjnych ograniczono zaledwie do sporów między federacją a kantonami oraz między samymi kantonami. Oceniając rolę ustrojową Sądu Federalnego pod kątem wypełniania przezeń zadania stabilizacji porządku konstytucyjnego, trudno nie sformułować opinii, że jest on przede wszystkim strażnikiem federalnego charakteru szwajcarskiej państwowości i wynikającej z tego zasady wertykalnego podziału władzy między federacją a kantonami ${ }^{41}$.

Nie bagatelizując wagi sporów rozstrzyganych przez Sąd Federalny, wypada zauważyć, że stanowią one tylko jedną z postaci sporów konstytucyjnych. O wiele ważniejsze z punktu widzenia ogólnej stabilizacji ustrojowej są spory między naczelnymi organami konstytucyjnymi państwa. Prawo do ich rozstrzygania przysługuje w Szwajcarii

37 P. Sarnecki, Założenia systemu , rządów zgromadzenia” i możliwości ich adaptacji do przyszłej konstytucji, [w:] Konstytucyjne..., s. 138-139.

38 Ibidem, s. 144-145.

39 M. Aleksandrowicz, Model rządów zgromadzenia na tle rozwiązá ustrojowych Konfederacji Szwajcarskiej, [w:] Państwo prawa - parlamentaryzm - sadownictwo konstytucyjne. Pamięci Profesora Zdzisława Czeszejki-Sochackiego, red. A. Jamróz, Białystok 2012, s. 29.

${ }^{40}$ K. Prokop, Sąd Federalny Konfederacji Szwajcarskiej — pozycja ustrojowa, organizacja i kompetencje, [w:] Państwo prawa..., s. 255.

${ }^{41}$ Ibidem, s. 256. 
Zgromadzeniu Federalnemu. Potwierdza to tylko wyjątkową pozycję szwajcarskiej legislatywy, która wykonuje wiele różnych pod względem ustrojowym zadań, przynależnych zarówno organom władzy wykonawczej, jak i sądowniczej. Ten swoisty eklektyzm ustrojowy nie zmienia jednak faktu, że istotą działalności Zgromadzenia Federalnego pozostaje legislacja ${ }^{42}$. Wracając zaś do Sądu Federalnego, to warto dodać, że nie ma on monopolu na rozstrzyganie sporów kompetencyjnych ani na kontrolę konstytucyjności aktów niższej niż ustawa rangi. Z uprawnienia takiego korzystają bowiem również inne sądy, co nadaje szwajcarskiemu systemowi kontroli konstytucyjności prawa cech modelu kontroli zdekoncentrowanej. Co ważniejsze, Sąd Federalny stanowi najwyższy organ władzy sądowniczej, sprawujący nadzór orzeczniczy nad pozostałymi sądami federalnymi oraz sądami szczebla kantonalnego. Pełnienie szeroko pojętej funkcji sądu konstytucyjnego łączy z wykonywaniem zadań szeroko rozumianego sądu najwyższego. Działalność stabilizująca ustrój państwowy nie jest zatem istotą działalności Sądu Federalnego, lecz stanowi jeden z dwóch głównych obszarów jego jurysdykcji. W gruncie rzeczy jest to organ władzy sądowniczej o złożonym charakterze ustrojowym. $Z$ jednej strony odbiega od typowego europejskiego sądu najwyższego, z drugiej zaś trudno go zakwalifikować jako klasyczny sąd konstytucyjny ${ }^{43}$. Z pewnością jednak nie ma poważniejszych przesłanek uzasadniających powierzenie mu osobnej prawnej sfery działania państwa w postaci stabilizacji ustrojowej. Można co najwyżej potraktować go jako najwyższy organ władzy sądowniczej, realizujący w ograniczonym zakresie zadanie takiej stabilizacji.

Szwajcarski model ustrojowy nie znalazł jednak w Europie naśladowców. Konstytucjonalizm europejski podążył bowiem zgoła inna drogą. Na jej końcu wszędzie czekały konstrukcje ustrojowe mieszczące się w formule systemu parlamentarnego. Przyjmuje on zasadę podziału władzy jako podstawową regułę ustrojową w zakresie organizacji i działania aparatu państwowego. Rysem charakterystycznym tej zasady wkomponowanej w parlamentarny model rządów nie jest jednak separacja poszczególnych władz, lecz ich ścisła kooperacja. Funkcjonalno-organizacyjny rozdział władzy został uzupełniony rozbudowanym systemem hamulców ustrojowych, przy czym obie te reguły są względem siebie komplementarne. Pierwotny jest wprawdzie sam podział prawnych sfer działania państwa i ich przyporządkowanie odpowiednim organom, ale znaczenie instrumentów wzajemnej kontroli i równoważenia się wyodrębnionych władz jest bezdyskusyjne. Ekwiwalentność systemu hamulców wobec zasady podziału to zresztą główna przyczyna kwestionowania przez niektórych autorów sensu rozpatrywania podstawowych założeń systemu parlamentarnego przez pryzmat reguły rozdziału. Tak jak system prezydencki zbudowany został na kanonach zasady podziału władzy z czysto posiłkową rolą systemu hamulców, tak model parlamentarny skonstruowany został wokół kanonów tego drugiego przy nieznacznym współudziale tej pierwszej ${ }^{44}$. Diagnoza

42 P. Sarnecki, Stanowisko parlamentu wedtug nowej konstytucji szwajcarskiej, [w:] Konstytucja i władza..., s. 296-297.

43 Confer K. Prokop, Sąd..., s. 265.

44 A. Pułło, O jedno..., s. 44; idem, Podział..., s. 12. 
taka pozostaje jednak odosobniona. Zdecydowana większość wypowiadających się na ten temat badaczy konsekwentnie zajmuje stanowisko o równorzędnej pozycji obu tych reguł ustrojowych w ramach parlamentarnej formuły rządów ${ }^{45}$.

\section{STABILIZACJA USTROJOWA W SYSTEMIE PARLAMENTARNYM}

\section{Głowa państwa jako władza reprezentacyjna}

Tak daleko posunięte powiązanie zasady podziału władzy z systemem hamulców ustrojowych postawiło na porządku dziennym nie tylko kwestię wzajemnej relacji obu tych reguł. Pojawił się również problem adekwatności rozpowszechnionego w początkach konstytucjonalizmu trójpodziału władzy do zmieniających się realiów ustrojowych rozwijających się systemów parlamentarnych. Pierwszą okazję do przewartościowania dotychczasowych poglądów w tej materii przyniósł proces przenoszenia środka ciężkości władzy wykonawczej z monarchy na coraz bardziej od niego niezależny i coraz silniej związany z parlamentem rząd na czele z premierem. Okazało się bowiem, że dualizm egzekutywy coraz częściej ma charakter czysto pozorny, a rola ustrojowa monarchy, a później także prezydenta, wyraźnie odbiega od działalności właściwej egzekutywie. Przyniosło to szybko efekt w formie wspominanej już koncepcji władzy neutralnej głowy państwa, która choć zarezerwowana z początku wyłącznie dla monarchy, z czasem stała się kluczem do wyjaśnienia pozycji ustrojowej przede wszystkim prezydenta. Istoty takiej działalności głowy państwa zaczęto upatrywać w rozwiązywaniu sporów politycznych między parlamentem a rządem oraz w gwarantowaniu stabilności ustrojowej państwa. $\mathrm{W}$ drugiej połowie XX w. spory rozgłos zyskała koncepcja arbitrażu politycznego głowy państwa, która na dobrą sprawę weszła do europejskiego konstytucjonalizmu jako rodzaj syntetycznej definicji istoty działalności głowy państwa jako władzy neutralnej ${ }^{46}$. Skoro w obrębie porządku konstytucyjnego nie ma miejsca na inne spory niż spory konstytucyjne, warto zastanowić się, czy głowa państwa może zostać obecnie uznana za organ realizujący osobną prawną sferę działania państwa w postaci gwarantowania stabilizacji ustrojowej z racji wykonywania zadania politycznego arbitra, czy też zapewnianie takiej stabilizacji za pomocą instrumentów politycznego arbitrażu stanowi tylko jedną z jej funkcji lub tylko zadań.

Próbę udzielenia odpowiedzi na tak postawione pytanie wypada rozpocząć od stwierdzenia, że ochrona stabilizacji ustrojowej stanowi obecnie jedno z najważniejszych zadań głowy państwa w systemie parlamentarnym. Katalog pozostających w tym celu do dyspozycji głowy państwa środków jest zróżnicowany i uzależniony od modelu jej stanowiska. W większości jednak mają one charakter prewencyjny. Za ich pośrednictwem głowa państwa przede wszystkim zapobiega nieefektywnym i niekonstytucyjnym działaniom władzy państwowej ${ }^{47}$. Do takiej grupy można zaliczyć prawo weta ustawodawczego czy wnioski składane do sądu konstytucyjnego w sprawie uruchomienia odpowiedniej formy kontroli konstytucyjności prawa lub rozstrzygnięcia konkretnego

${ }^{45}$ R.M. Małajny, Rozdział..., s. 92-93.

46 J. Szymanek, Arbitraż polityczny głowy państwa, Warszawa 2009, s. 33-66.

${ }^{47}$ Ibidem, s. 106-107. 
sporu kompetencyjnego między naczelnymi organami państwowymi. Podobny wymiar mają kompetencje związane z wpływaniem na działalność rządu. Czyniąc użytek z prawa do zwoływania posiedzeń rządu w określonych przypadkach lub przewodniczenia im, głowa państwa może zapobiegać konkretnym decyzjom, których skutki mogłyby zagrażać szeroko rozumianej stabilności porządku konstytucyjnego. Również prawo inicjatywy ustawodawczej czy uprawnienie do zarządzenia referendum mogą odegrać taką samą rolę. Łatwo przecież sobie wyobrazić sytuację, gdy głowa państwa przedkłada w parlamencie projekt ustawy lub zwraca się do społeczeństwa z propozycją podjęcia stosownej decyzji, których konsekwencją byłoby zwiększenie skuteczności działania władzy lub poddanie jej działalności dodatkowej kontroli pod względem poszanowania podstawowych reguł i wartości porządku konstytucyjnego ${ }^{48}$.

Żaden z powyższych instrumentów wprawdzie nie stwarza głowie państwa szansy na ostateczne rozstrzygnięcie określonego sporu konstytucyjnego, ale wszystkie otwierają przed nią możliwość minimalizowania ryzyka powstawania takich sporów. Gwarantowanie stabilizacji polega tu na właściwej ocenie następstw poszczególnych decyzji innych organów państwowych pod kątem ich efektywności i konstytucyjności ustroju państwowego. W razie dojścia do przekonania, że działania władzy państwowej stwarzają zagrożenie dla tych wartości, na głowie państwa spoczywa obowiązek ich ochrony z wykorzystaniem wszelkich dostępnych jej w tym celu środków konstytucyjnych. Jeśli uwzględnić fakt, że prewencyjne środki gwarantowania stabilizacji ustrojowej wyraźnie dominują w zestawie kompetencji głowy państwa w systemie parlamentarnym, zapobieganie sporom konstytucyjnym trzeba uznać za główną formę jej działalności służącą realizacji omawianego zadania.

O wiele większe możliwości ochrony stabilizacji ustrojowej daje głowie państwa prawo do rozwiązywania parlamentu. $\mathrm{Z}$ uprawnienia stanowiącego przeciwwagę dla parlamentarnego prawa do odwoływania rządu i znajdującego się faktycznie w gestii samego gabinetu w toku ewolucji i racjonalizacji podstawowych założeń systemu parlamentarnego stało się ono najważniejszym w istocie instrumentem arbitrażu politycznego głowy państwa ${ }^{49}$. Dzięki niemu może ona nie tylko włączyć się w rozwiązanie konkretnego sporu politycznego między parlamentem a rządem, ale może także odegrać kluczową rolę w zażegnaniu poważnego kryzysu ustrojowego. Prawo do rozwiązywania parlamentu toruje tym samym głowie państwa drogę zarówno do zapobiegania sporom konstytucyjnym, jak i do ich rozstrzygania. Należy jednak poczynić istotne zastrzeżenie. Podjęte przez głowę państwa w takim wypadku rozstrzygnięcie nie ma charakteru ostatecznego. Nie kończy bowiem zaistniałego sporu, lecz jedynie go zawiesza i przenosi na nową płaszczyznę. Końcowy werdykt wyda dopiero społeczeństwo we wcześniejszych wyborach parlamentarnych, które są jedną z konsekwencji decyzji głowy państwa o rozwiązaniu legislatywy. Głowa państwa rozstrzyga taki spór

${ }^{48}$ B. Szczurowski, Prezydent Rzeczypospolitej jako organ czuwajacy nad przestrzeganiem konstytucji, Warszawa 2016, s. 128-129.

49 J. Szymanek, Arbitraż..., s. 109; A. Chorążewska, Prezydent jako czynnik równowagi. Arbitraż polityczny, „Przegląd Sejmowy” 2005, nr 6, s. 71-72. 
w wymiarze czysto formalnym. Natomiast faktyczne jego rozstrzygnięcie nastąpi wraz z ogłoszeniem wyników wyborów.

Spoglądając na decyzję głowy państwa z perspektywy jej skutków prawnych, można ją potraktować w kategoriach rozstrzygnięcia konkretnego sporu konstytucyjnego między parlamentem a rządem. Wszak podstawą takiej decyzji są zawsze konstytucyjnie określone przesłanki. Zazwyczaj przybierają one postać odpowiednich zdarzeń prawnych, które zagrażają stabilizacji porządku konstytucyjnego. Czasem przesłanka określana bywa na tyle ogólnie, że jej ocena pozostawiona jest swobodnemu uznaniu głowy państwa. Nie pozbawia to jej jednak waloru konstytucyjnego, skoro samo prawo do podjęcia decyzji o rozwiązaniu parlamentu wynika ze stosownego postanowienia ustawy zasadniczej. Jeżeli zaś na decyzję głowy państwa spojrzy się przez pryzmat jej konsekwencji politycznych, to jej efektem będzie przerwanie sporu parlamentu z rządem i zapobiegnięcie jego dalszej eskalacji ${ }^{50}$.

Instrumentem o najpoważniejszym ciężarze gatunkowym w zakresie gwarantowania stabilizacji ustrojowej jest ponad wszelką wątpliwość prawo głowy państwa do proklamowania stanów nadzwyczajnych. Wówczas bowiem występuje ona jako swoista ostoja stabilizacji i rzeczywisty strażnik podstawowych zasad i wartości porządku konstytucyjnego ${ }^{51}$. Ochrona istniejącego porządku jest w takim wypadku wartością absolutną, w imię której głowa państwa uprawniona jest nawet do czasowego zawieszenia lub ograniczenia niektórych jego reguł. Najpierw konieczne jest zabezpieczenie najważniejszych zasad i wartości porządku ustrojowego, które wyznaczają jego ustrojową tożsamość i którym grozi całkowita lub częściowa destrukcja. Dopiero zaś po zażegnaniu takiego niebezpieczeństwa głowa państwa powinna głównym kryterium swych działań uczynić przezwyciężenie powstałej destabilizacji ${ }^{52}$. Prawo do proklamowania stanów nadzwyczajnych nie jest jednak współcześnie powszechnym ani jednolitym uprawnieniem głowy państwa. Czasami głowa państwa prawem takim nie rozporządza wcale, a korzysta z niego rząd. Nawet jednak wtedy gdy je zachowała, reguła jest ograniczenie go do zatwierdzania decyzji podejmowanych przez rząd lub działanie na jego wniosek. Natomiast wyjątkiem są sytuacje, w których może ona decydować nie tylko o wprowadzeniu stanu wyjątkowego, ale również o charakterze podejmowanych później środków działania. Ostatni przykład to osławiony już art. 16 konstytucji V Republiki Francuskiej, który w ręce prezydenta składa iście dyktatorską władzę. W literaturze francuskiej podkreśla się jednak, że jest to dyktatura konstytucyjna. Celem zastosowania znajdujących się tam instrumentów działania nie jest bowiem podważenie zasad porządku konstytucyjnego, lecz jego należyta obrona i przywrócenie prawidłowej działalności władz państwowych, czyli stabilizacja ustrojowa ${ }^{53}$.

50 J. Stembrowicz, Rzad w systemie parlamentarnym, Warszawa 1982, s. 84.

${ }^{51}$ K. Prokop, Modele stanu nadzwyczajnego, Białystok 2012, s. 358; B. Szczurowski, Prezydent..., s. $186-187$.

${ }_{52}$ L. Richter, Die Vorgeschichte des Art. 48 der Weimarer Reichsverfassung, „Der Staat” 1998, nr 1, s. 9.

${ }_{53}$ E. Popławska, Instytucja prezydenta w systemie politycznym V Republiki Francuskiej, Warszawa 1995, s. 105; K. Prokop, Modele..., s. 261. 
Mimo że uprawnienia związane z proklamowaniem stanów nadzwyczajnych to wręcz synonim kompetencji służących stabilizacji ustrojowej państwa, to także one mają znaczenie prewencyjne. Środki zastosowane w wyniku ich działania nie rozstrzygają bowiem definitywnie żadnego sporu konstytucyjnego. Stwarzają jedynie podstawy do opanowania sytuacji kryzysowej i w dalszej perspektywie do powrotu konstytucyjnej normalności. Nie można zapominać, że współczesny konstytucjonalizm ufundowany został na zasadzie państwa prawa, rozumianej jako konglomerat szeregu reguł i wartości ustrojowych ${ }^{54}$. Jedną z nich jest wymóg kontroli władzy państwowej z punktu widzenia konstytucyjności i efektywności jej działań. Jakkolwiek efektywność jest wartością samoistną o ogromnym znaczeniu, to konstytucyjność z wkomponowanym w nią porządkiem organizacyjno-aksjologicznym jest wartością absolutną. Oznacza to, że nie ma takiej wartości, która usprawiedliwiałaby rezygnację z fundamentów konstytucjonalizmu wolnościowo-demokratycznego ${ }^{55}$. Dlatego też nawet konstytucyjna dyktatura stanu wyjątkowego nie jest celem samym w sobie, tylko środkiem do ochrony podstaw porządku konstytucyjnego ${ }^{56}$. Ponad władzą takiego dyktatora stoją tym samym niepodważalne zasady konstytucji. Stoi jednak również zwierzchnia władza społeczeństwa, której depozytariuszem jest parlament. Nic dziwnego, że wszelkie decyzje podejmowane w związku ze stanami nadzwyczajnymi podlegają kontroli legislatywy. Dotyczy to zarówno samego postanowienia o wprowadzeniu takich stanów, jak i późniejsze decyzje wydawane w trakcie jego trwania. Kontrola taka znajduje wyraz w obowiązku przedkładania wszystkich podjętych decyzji parlamentowi do zatwierdzenia, przy czym na ogół należy to uczynić niezwłocznie po przywróceniu legislatywie możliwości prawidłowego działania. Tym samym rozstrzygnięcia głowy państwa mają charakter tymczasowy. Zapobiegają pogłębianiu się destabilizacji ustrojowej i czasowo kładą kres największemu niebezpieczeństwu dla każdego porządku konstytucyjnego, jakim jest zagrożenie jego dalszej egzystencji. Jednak legitymizację i przymiot ostateczności takim rozstrzygnięciom nadaje dopiero odpowiedni akt parlamentu ${ }^{57}$.

O sile poszczególnych kompetencji każdego organu państwowego decyduje nie tyle sam fakt dysponowania nią, ile warunki jej realizacji. Tylko bowiem swoboda w zakresie korzystania ze swoich uprawnień nadaje im realne znaczenie i pozwala je uznać za instrumenty realizacji określonego zadania. Jeżeli ocenić kompetencje głowy państwa stwarzające jej szansę stabilizacji ustrojowej pod tym kątem, to pierwsza nasuwająca się refleksja jest taka, że panuje tu daleko posunięte zróżnicowanie. Stanowi to jednak pokłosie ogólnej sytuacji głowy państwa w systemie parlamentarnym, która charakteryzuje się brakiem uniwersalnego rozwiązania ustrojowego w tej mierze. Uwaga ta odnosi się do republikańskiej postaci tego stanowiska. Co się tyczy jej monarchicznego

${ }^{54}$ T. Pietrzykowski, Ujarzmianie Lewiatana. Szkice o idei rządów prawa, Katowice 2014, s. 87-89.

55 K. Stern, Das Staatsrecht der Bundesrepublik Deutschland, t. I, Grundbegriffe und Grundlagen des Staatsrechts, Strukturprinzipien der Verfassung, München 1984, s. 558.

56 K. Wołowski, Prezydent Republiki w powojennej Francji (IV i V Republika), Warszawa-Poznań 1973, s. 220; K. Prokop, Modele..., s. 227.

57 K. Prokop, Modele..., s. 359. 
odpowiednika, to sprawa przedstawia się prosto. Wszędzie sens działalności monarchy ogranicza się do odgrywania roli ceremonialno-protokolarnej. Ich rzeczywista władza jest żadna, a swą pozycję zawdzięczają autorytetowi instytucji, ugruntowanej wielowiekową tradycją ${ }^{58}$. Choć formalnie monarchowie zachowali rozmaite istotne $\mathrm{z}$ ustrojowego punktu widzenia uprawnienia, to ich faktycznym dysponentem stał się rząd lub jego szef. Zasadą jest tu więc pełna polityczna neutralizacja głowy państwa. Trudno w takim wypadku mówić o wypełnianiu jakiejkolwiek innej funkcji niż reprezentacyjna, a tym bardziej upatrywać w głowie państwa organu realizującego samodzielną prawną sferę działania państwa. Wszelka działalność stabilizująca ustrój państwowy w jej wydaniu może co najwyżej przybrać formę symboliczną. Monarcha jako symbol państwowej tradycji i uosobienie najważniejszych dla społeczeństwa wartości mógłby zatem przyczyniać się do stabilizacji porządku konstytucyjnego w wymiarze ogólnym. Jego faktyczne możliwości w tym względzie byłyby przy tym następstwem autorytetu samej instytucji i osobistego prestiżu osoby panującej, a nie efektem właściwych środków działania. Stabilizacja ustrojowa pozostałaby tym samym najważniejszą wartością poczynań monarchy czy też najistotniejszym punktem odniesienia dla oceny wszelkich jego państwowych inicjatyw i decyzji ${ }^{59}$.

Przechodząc do pozycji ustrojowej prezydenta w parlamentarnej formule rządów, na wstępie należy podkreślić, że trudności w skonstruowaniu określonego wzorca tej pozycji wynikają głównie z eklektyczności przyjmowanych w tym zakresie rozwiązań konstytucyjnych. Generalnie rzecz biorąc, można wyróżnić dwa modele stanowiska ustrojowego prezydenta $\mathrm{w}$ systemie parlamentarnym ${ }^{60}$. Pierwszy to model prezydenta o władzy neutralnej. Zasadniczy kształt pozycji ustrojowej takiego prezydenta nie odbiega znacząco od statusu monarchy. Pełni on bowiem głównie funkcję reprezentacyjną, a jego wszystkie lub wszystkie istotne uprawnienia zostały poddane regule ministerialnej kontrasygnaty. Jako współczesną ilustrację takiego modelu podawana bywa zwykle prezydentura włoska ${ }^{61}$. Na przeciwległym biegunie znajduje się model prezydenta o władzy regulującej. Rozporządza on szeregiem ważnych ustrojowo kompetencji realizowanych samodzielnie, czyli bez konieczności uzyskiwania ministerialnej kontrasygnaty. Dzięki takim kompetencjom prezydent jest w stanie znacząco oddziaływać na kształt polityki państwowej, a ponadto może on swobodnie korzystać z instrumentów politycznego arbitrażu. Regułą takiej prezydentury jest wpływ na bieg spraw państwowych poprzez współdziałanie w ustalaniu kierunków polityki państwa i istotny udział $\mathrm{w}$ ich wykonywaniu. $\mathrm{Z}$ kolei wyjątkiem są działania o charakterze stabilizacyjnym, które zarezerwowane zostały na czasy politycznych napięć i konfliktów w relacjach

${ }^{58}$ M. Wiszowaty, Zasada monarchiczna i jej przejawy we współczesnych ustrojach europejskich i pozaeuropejskich monarchii mieszanych, Gdańsk 2015, s. 287.

59 Ibidem, s. 261.

${ }^{60}$ E. Zwierzchowski, Wprowadzenie do nauki prawa konstytucyjnego państw demokratycznych, Katowice 1992, s. 103.

${ }^{61}$ Z. Witkowski, Prezydent Republiki Włoskiej (wybrane zagadnienia koncepcji ustrojowej i praktyki), [w:] Instytucja Prezydenta we współczesnym świecie: materiały na konferencję, Warszawa - Senat RP 22-23 II 1993 r., Warszawa 1993, s. 13. 
między parlamentem a rządem. Zwolnienie jednego i drugiego obszaru prezydenckiej działalności od obowiązku kontrasygnaty powoduje, że przysługujące mu w tych obszarach uprawnienia nabierają konkretnego kształtu i realnego znaczenia, czyniąc z głowy państwa organ o własnych ustrojowych funkcjach i odpowiadającym im zakresie zadań. Prezydenci zaliczani do tego modelu prezydentury pełnią również funkcję reprezentacyjną, która właściwa jest monistycznej głowie państwa. Dzisiejszym wzorcem takiego modelu jest status prezydenta V Republiki Francuskiej ${ }^{62}$.

Najczęściej jednak spotykanym obecnie modelem pozycji ustrojowej prezydenta w systemie parlamentarnym jest wariant pośredni, czerpiący z obu powyższych modeli, skutkiem czego cechuje go wspomniany eklektyzm. Z jednej strony nie jest to republikański monarcha o funkcji czysto reprezentacyjnej, z drugiej zaś nie dysponuje on instrumentami wpływania na kształt polityki państwa ${ }^{63}$. Dla takiego właśnie niejednolitego pod względem ustrojowym prezydenta bywa rezerwowany na ogół przymiot politycznego arbitra $^{64}$. Zestaw jego kompetencji obejmuje bowiem instrumenty zaliczane zwykle do takiego arbitrażu. Ich realizacja nie jest jednak w pełni swobodna. Postanowienia konstytucyjne precyzyjnie ustalają sytuacje, w których prezydent może sięgnąć po któryś z takich instrumentów. Wówczas może to uczynić samodzielnie, bez wymogu ubiegania się o kontrasygnatę lub inną formę zgody członka rządu. Jako egzemplifikację warunków działania w tym charakterze przez prezydentów przynależnych do eklektycznego modelu prezydentury można wskazać na przesłanki korzystania z prawa do rozwiązywania parlamentu. Są one zwykle ograniczone do kilku przypadków, gdy normalny tok współdziałania parlamentu z rządem został poważnie zakłócony, a inne formy rozwiązania powstałej sytuacji zostały już wyczerpane. Prawo do rozwiązania legislatywy stanowi więc ultima ratio, a prezydent zamiast arbitrem nierzadko staje się stróżem określonych konstytucyjnie procedur ${ }^{65}$. Ów eklektyzm tego modelu sprawia, że jest to nader pojemna kategoria ustrojowa, która mieści dziś rozwiązania $\mathrm{w}$ istocie tak różne jak prezydentura polska czy prezydentura niemiecka. Modelowość ma więc w tym przypadku znaczenie jedynie porządkujące. Pozwala tylko uchwycić zjawisko dużej indywidualizacji sposobu ukształtowania pozycji ustrojowej prezydenta w parlamentarnym systemie rządów. Przynależy do niego większość dzisiejszych prezydentów wkomponowanych w ogólne ramy systemu parlamentarnego, skoro poza rozwiązaniami eklektycznymi z mocy konstytucji ciążą ku niemu także w praktyce niektóre prezydentury odpowiadające pod względem formalnym założeniom dwóch modeli głównych ${ }^{66}$.

${ }^{62}$ E. Gdulewicz, Instytucja Prezydenta we Francji V Republiki, [w:] Instytucja Prezydenta..., s. 6.

${ }_{63}$ W. Kaltefleiter, Die Funktionen des Staatsoberhauptes in der parlamentarischen Demokratie, Köln-Opladen 1970, s. 130.

${ }^{64}$ M. Bożek, Znaczenie koncepcji władzy neutralnej Benjamina Constanta we wspótczesnym konstytucjonalizmie, [w:] Konstytucjonalizm a doktryny polityczno-prawne. Najnowsze kierunki badań, red. R.M. Małajny, Katowice 2008, s. 172.

${ }^{65}$ W. Skrzydło, Rozwiazanie Sejmu i jego prawne konsekwencje, „Przegląd Sejmowy” 1993, nr 1, s. 51.

${ }^{66}$ J. Szymanek, System pótprezydencki (mieszany). Metodologiczna zasadność i prakseologiczna użyteczność, [w:] Systemy..., s. 322. 
Skoro warunkiem instytucjonalnego podziału władzy jest możliwość przyporządkowania określonemu organowi państwowemu lub grupie takich organów istoty danej prawnej sfery działania jako jego podstawowej funkcji ustrojowej, to pod żadnym pozorem stabilizacji ustrojowej nie można w takim kontekście wiązać z głową państwa w systemie parlamentarnym. Może ona pełnić trzy funkcje ustrojowe ${ }^{67}$. Przede wszystkim jest to funkcja reprezentacyjna, która polega na reprezentacji państwa w stosunkach zewnętrznych (aspekt zewnętrzny) i reprezentowaniu państwa wobec społeczeństwa (aspekt wewnętrzny). Funkcję tę spełniają wszystkie głowy państwa w systemie parlamentarnym, niezależnie od formy rządu i modelu ustrojowego prezydentury. Druga funkcja to funkcja wykonawcza. Pełnią ją w gruncie rzeczy jedynie prezydenci. W największej mierze funkcja ta jest udziałem prezydentów o władzy regulującej, przy czym nawet oni nie są głównym organem egzekutywy, a jedynie dysponują kilkoma uprawnieniami z tego zakresu, pozwalającymi im na ewentualną korektę lub wpływ na kształt kierunków polityki państwowej ustalanej przez rząd. Prezydenci o władzy neutralnej takiej funkcji zasadniczo nie pełnią, a wszelkie możliwości oddziaływania na wytyczanie i realizację polityki państwa mają co najwyżej charakter nieformalny. Niewiele lepiej przedstawiają się egzekucyjne możliwości prezydentów o eklektycznej pozycji ustrojowej. Zasadą jest pozbawienie ich samodzielnych kompetencji z dziedziny władzy wykonawczej, a jeżeli takimi rozporządzają, to tylko w odniesieniu do polityki zagranicznej lub spraw bezpieczeństwa państwowego i mogą z nich korzystać wyłącznie we współpracy z rządem.

Funkcja stabilizowania ustroju państwowego byłaby więc trzecią z funkcji pełnionych przez głowy państwa w systemie parlamentarnym. Jednak nie wszystkim głowom państwa można ją przypisać, a jedynie prezydentom. Spośród tych ostatnich wypełnialiby ją przy tym jedynie prezydenci o władzy regulującej i prezydenci o eklektycznym kształcie stanowiska ustrojowego. Prezydenci politycznie zneutralizowani możliwości takiej nie mają, a wszelka działalność stabilizująca może być zaledwie pokłosiem działań nieformalnych, co często w literaturze przedmiotu bywa określane jako arbitraż moralny lub arbitraż autorytetu ${ }^{68}$. W grze pozostają zatem tylko prezydenci, których pozycja ustrojowa oscyluje od modelu prezydenta regulatora do modelu prezydenta eklektycznego. Bez porównania większe pole do działania otwiera się tutaj przed prezydentem o władzy regulującej, co stanowi konsekwencję jego ogólnego statusu ustrojowego. Na uwagę zasługuje zwłaszcza praktycznie nieograniczone w płaszczyźnie formalnej prawo do rozwiązania parlamentu, a także — szczególnie we Francji V Republiki czy niegdyś w Republice Weimarskiej - uprawnienia związane z proklamowaniem stanów nadzwyczajnych. Tak ukształtowanych kompetencji nie mają prezydenci o eklektycznym charakterze swej pozycji ustrojowej. Ich prawo do rozwiązywania legislatywy obwarowane jest takimi warunkami, że jego użycie wymaga praktycznie zaistnienia sytuacji patowej

${ }^{67}$ Confer R.R. Ludwikowski, Prawo..., s. 364-368.

${ }^{68}$ Confer J. Szymanek, Arbitraż..., s. 66; M. Bożek, Instytucja Prezydenta Republiki Federalnej Niemiec, Warszawa 2007, s. 89; Z. Witkowski, Prezydent Republiki w systemie ustrojowym wspótczesnych Włoch, Toruń 1991, s. 101. 
w stosunkach parlamentu z rządem, a nierzadko wręcz faktycznego zerwania tych relacji. Równie symboliczne są ich możliwości w zakresie stanów nadzwyczajnych, które zwykle nie wykraczają poza prawo do podejmowania decyzji o ich wprowadzeniu na wniosek rządu i czasem jeszcze prawo do wydawania aktów prawnych o mocy ustawy — jednak także na wyraźny wniosek rządu.

Widać więc, że nie ma podstaw do powierzania głowie państwa w systemie parlamentarnym osobnej prawnej sfery działania w formie gwarantowania stabilizacji ustrojowej. Można jedynie co niektórym postaciom stanowiska ustrojowego prezydenta powierzyć taką odrębną funkcję ustrojową. Funkcja stabilizacji ustrojowej byłaby wypełniana za pośrednictwem dwóch zadań. Pierwszym byłby polityczny arbitraż, czyli zapobieganie i rozstrzyganie sporów konstytucyjnych o podłożu politycznym. Natomiast drugim byłaby ochrona konstytucji, polegająca na zapobieganiu sporom konstytucyjnym natury prawnej. Pierwsze z tych zadań można by uznać za współczesną wersję realizacji koncepcji władzy neutralnej, z kolei w drugim można upatrywać dzisiejszego wariantu koncepcji strażnika konstytucji ${ }^{69}$. Mający zaś długą tradycję spór o rolę ustrojową głowy państwa w ramach parlamentarnej formuły rządów pozostawałby jednocześnie nierozstrzygnięty, chyba że zaakceptujemy fakt, że jedyną funkcją powszechnie tam spełnianą przez głowę państwa jest funkcja reprezentacyjna. Przyjęcie założenia, że istotą czy głównym rdzeniem działalności głowy państwa w systemie parlamentarnym jest reprezentacja państwa w wymiarze zewnętrznym i wewnętrznym, a pozostałe dwie jej funkcje mają względem niej charakter subsydiarny, pozwalałoby uczynić ją dysponentem osobnej prawnej sfery działania, a mianowicie władzy reprezentacyjnej ${ }^{70}$.

\section{Sąd konstytucyjny jako władza stabilizująca porządek konstytucyjny}

Adekwatność zasady trójpodziału władzy państwowej do realiów ustrojowych państw europejskich o parlamentarnym kształcie systemu rządów po raz drugi została wystawiona na próbę wraz z pojawieniem się i rozpowszechnieniem sądów konstytucyjnych. Rzeczą naturalną stało się klasyfikowanie ich jako szczególnego elementu władzy sądowniczej, zważywszy że u podstaw ich powołania leżała idea sądowej ochrony konstytucji nawiązująca do tradycji konstytucjonalizmu anglosaskiego ${ }^{71}$. Pogląd taki również dziś cieszy się uznaniem niemałej grupy znawców tematu. Nie wchodząc w jego szczegółową analizę ${ }^{72}$, warto jedynie odnotować, że zwolennicy takiego podejścia odwołują się zazwyczaj do kilku argumentów. Przede wszystkim wytrwale bronią opinii identyfikującej podział władzy z jej klasycznym już trójpodziałem. Przy takim postawieniu

${ }^{69}$ Confer B. Szczurowski, Prezydent..., s. 29-30.

${ }^{70}$ Podobną tezę od kilku już lat upowszechnia w polskim piśmiennictwie A. Sylwestrzak (Aktualność..., s. 152; Władza rządzaca, władza opozycji $i$ władza neutralna na tle tradycyjnych teorii podziatu władz, [w:] Wokót wybranych problemów konstytucjonalizmu, red. J. Ciapała, P. Mijal, Warszawa 2017, s. 328).

${ }_{71}$ M. Starzewski, Środki zabezpieczenia prawnego konstytucyjności ustaw, Warszawa 2009 (Kraków 1928), s. 190; E. Zwierzchowski, Sadownictwo konstytucyjne, Białystok 1994, s. 28.

72 Confer K. Stern, Das Staatsrecht der Bundesrepublik Deutschland, t. II..., s. 941; J. Trzciński, Czy Trybunat Konstytucyjny jest władza sądownicza?? [w:] W kręgu zagadnień konstytucyjnych. Prof. Eugeniuszowi Zwierzchowskiemu w darze, red. M. Kudej, Katowice 1999, s. 193-201. 
sprawy ustrojowym miejscem sądów konstytucyjnych jest sfera władzy sądowniczej. Wszystkie inne racje mające przemawiać na korzyść takiego stanowiska są w gruncie rzeczy konsekwencją tezy podstawowej, że sąd konstytucyjny to część władzy sądowniczej. Począwszy bowiem od samej jego nazwy i posługiwania się niemal powszechnie w odniesieniu do jego członków formułą sędzia, przez system gwarancji pozycji prawnej tych ostatnich zbudowany wokół zasady niezawisłości sędziowskiej, a na trybie postępowania przed takimi organami kończąc, charakter prawny sądu konstytucyjnego odpowiada wymogom właściwym dla wszystkich sądów. Pewne wątpliwości w tym kontekście może rodzić istota ich działalności, ale dzięki rozpatrywaniu skarg konstytucyjnych i instrumentom konkretnej kontroli konstytucyjności ustaw także pod względem funkcjonalnym wykazuje on najważniejsze cechy sądu. W konkluzji takiego stanowiska pojawia się zwykle ocena, że władza sądownicza nie jest jednolitą kategorią ustrojową, lecz obejmuje kilka rodzajów sądów. Czasami sąd konstytucyjny wraz z sądami administracyjnymi bywa zaliczany do grupy sądów szczególnych, które są przeciwstawiane sądom powszechnym. Innym razem wymieniany bywa jako jeden z trzech obok sądów powszechnych i sądów szczególnych. A jeszcze innym wraz z organami egzekwującymi odpowiedzialność konstytucyjną wysokich rangą funkcjonariuszy państwowych określany bywa mianem trybunałów. Władza sądownicza ma wówczas dwuczłonową postać — pierwszym są sądy, a drugim trybunały ${ }^{73}$.

U sporej grupy badaczy poklask wciąż zyskuje nieśmiertelna opinia Hansa Kelsena, jakoby sąd konstytucyjny był elementem legislatywy, czyli ustawodawcą negatywnym $^{74}$. Sam wprawdzie ustaw ani innych aktów prawnych stanowić nie może, ale może uchylać ich moc obowiązującą. Konsekwencje rozstrzygnięcia sądu konstytucyjnego mają więc charakter negatywny, gdyż w ich rezultacie dochodzi do wyeliminowania zakwestionowanej ustawy lub innego aktu z porządku prawnego. Biorąc pod uwagę, że kontrola konstytucyjności ustaw stanowi najważniejsze zadanie realizowane przez sąd konstytucyjny, przypisanie mu funkcji negatywnego ustawodawcy wydaje się w pełni zrozumiałe. Nie tyle jednak terminologia jest tu kluczowa, ile charakter działalności sądów konstytucyjnych. Jej sens polega na uchyleniu mocy obowiązującej konkretnego aktu prawnego ${ }^{75}$. Dodatkowo obrońcy takiego stanowiska powołują się jeszcze na okoliczność, że członków sądu konstytucyjnego wybierają zwykle parlamenty. Ma to podkreślać demokratyczną legitymizację sądu konstytucyjnego, który choć mandatu do wykonywania swych zadań nie wywodzi wprost od suwerena, to pośrednio to właśnie suweren za pośrednictwem swoich reprezentantów w parlamencie udziela mu pełnomocnictw do działania ${ }^{76}$. Niektórzy entuzjaści takiej klasyfikacji ustrojowej sądów

${ }_{73}$ B. Banaszak, Porównawcze..., s. 527; G. Kuca, Zasada podziału władzy w Konstytucji RP z 1997 roku, Warszawa 2014, s. 258-264.

${ }^{74}$ H. Kelsen, Istota i rozwój sądownictwa konstytucyjnego, Warszawa 2009, s. 63-65.

${ }^{75}$ M. Granat, Legitymacja sadu konstytucyjnego na gruncie czystej teorii prawa H. Kelsena, „Przegląd Sejmowy" 1999, nr 4, s. 13-14.

76 S. Wronkowska, Kilka uwag o „prawodawcy negatywnym”, „Państwo i Prawo” 2008, z. 10, s. 7; A. Sulikowski, Współczesny paradygmat sadownictwa konstytucyjnego wobec kryzysu nowoczesności, Wrocław 2008, s. 41-42. 
konstytucyjnych posuwają się tak daleko w swej argumentacji, że skłonni są traktować je jako kolejną izbę parlamentu ${ }^{77}$.

Co ciekawe, w ostatnich latach pojawiły się w piśmiennictwie konstytucyjnym głosy upominające się o modyfikację powyższej koncepcji w duchu ustrojowych realiów. Przywołując rosnące w lawinowym tempie znaczenie sądów konstytucyjnych w strukturze porządku konstytucyjnego, część autorów coraz śmielej zaczęła twierdzić, że stały się one nadzwyczajnym ustawodawcą ${ }^{78}$. Nie można bowiem dłużej ignorować faktu, że często obowiązującym przepisom zostaje nadawany całkiem nowy sens wskutek orzeczeń sądów konstytucyjnych. Jest to efekt coraz częstszej praktyki wydawania przez te sądy tzw. orzeczeń interpretacyjnych, które zakreślają ramy znaczeniowe danego przepisu. Brzmienie takiego przepisu nie ulega zmianie, ale jego rozumienie zyskuje nowy wymiar. Tym sposobem interpretacja staje się faktycznie prawotwórstwem, a ustawodawca negatywny staje się ustawodawcą pozytywnym ${ }^{79}$.

Również jednak i ten pogląd doczekał się twórczego rozwinięcia. Wszak znaleźli się tacy specjaliści przedmiotu, którzy sądy konstytucyjne okrzyknęli mianem aktywnego ustrojodawcy. Znów powrócił dobrze znany argument, że jakkolwiek sąd konstytucyjny sam konstytucji tworzyć nie może, to może zawarte w niej przepisy wypełniać określoną treścią. Bez niego konstytucja pozostałaby bowiem jedynie dokumentem zastygłym w skostniałych ramach historycznego kontekstu i odzwierciedlającej go ideologii, natomiast dzięki niemu jest żywym i ciągle się rozwijającym aktem prawnym i zjawiskiem społeczno-politycznym. Dopiero wykładnia z natury rzeczy ogólnych i wysoce abstrakcyjnych przepisów konstytucyjnych nadaje im właściwe znaczenie. Jako formalny interpretator ustawy zasadniczej sąd konstytucyjny urasta do roli jej faktycznego twórcy ${ }^{80}$.

Jednak wraz z pojawieniem się pierwszych sądów konstytucyjnych w literaturze europejskiej zaczął torować sobie drogę pogląd o specyficznym charakterze ustrojowym tych organów, odmiennym od pozostałych władz państwowych ${ }^{81}$. Szczególnie doniośle głosy takie wybrzmiały w drugiej połowie minionego stulecia, gdy sądy konstytucyjne stały się stałym elementem krajobrazu ustrojowego państw europejskich. Wskazywano

77 Confer W. Sadurski, Prawo przed sadem. Studium sadownictwa konstytucyjnego w postkomunistycznych państwach Europy Środkowej i Wschodniej, Warszawa 2008, s. 67.

78 Confer A. Sulikowski, Tworzenie prawa przez sądy konstytucyjne i jego demokratyczność, „Państwo i Prawo" 2005, z. 8, s. 19.

79 Confer K. Stern, Das Staatsrecht der Bundesrepublik Deutschland, t. II..., s. 958-959. Nawiasem mówiąc, podobnie brzmiące sugestie można wyczytać u autorów amerykańskich, którzy Sąd Najwyższy USA uznają za trzecią izbę tamtejszego Kongresu; R.M. Małajny, Pozycja..., s. 218.

${ }^{80}$ Gwoli ścisłości, także taki punkt widzenia nie jest obcy badaczom Sądu Najwyższego USA. Co niektórzy bowiem używają wobec niego określenia „stała konwencja konstytucyjna”, co ma podkreślić ustrojodawczy wymiar instytucji judicial review w jego wykonaniu. Confer R.M. Małajny, Pozycja..., s. 215-216; T. Stawecki, Dyskusje wokół aktywizmu i pasywizmu sądów konstytucyjnych jako spór o wykładnię konstytucji, [w:] Wykładnia konstytucji. Inspiracje, teorie, argumenty, red. T. Stawecki, J. Winczorek, Warszawa 2014, s. 351-354; B. Banaszak, M. Bernaczyk, Aktywizm sędziowski we współczesnym państwie demokratycznym, Warszawa 2012, s. 71.

${ }^{81}$ C. Schmitt, Der Hüter der Verfassung, Berlin 1996 (1931), s. 4-5. 
zazwyczaj, że inaczej niż w modelu amerykańskim, gdzie kontrola konstytucyjności prawa rozproszona została między wszystkie sądy powszechne i stanowi uzupełnienie ich podstawowego zadania w postaci rozstrzygania wszelkich sporów prawnych w trybie procedury sądowej, Stary Kontynent wypracował odrębny model takiej kontroli. Skoncentrowanie jej w gestii odrębnych sądów konstytucyjnych uzasadnia nie tylko wyodrębnienie kontroli konstytucyjności prawa spośród innych prawnych sfer działania państwa, ale pozwala również sferę tę przypisać grupie samodzielnych organów państwowych. Sądy konstytucyjne nie są zatem częścią ani władzy sądowniczej, ani też jakiejkolwiek innej znanej dotychczasowemu konstytucjonalizmowi władzy, lecz są władzą całkowicie odrębną. Za taką kwalifikacją ustrojową przemawia istota ich działalności, którą jest kontrola konstytucyjności prawa czy — szerzej rzecz ujmując ochrona konstytucji ${ }^{82}$. Kwestią drugorzędną była nazwa takiej władzy. Nieliczni autorzy zadawalali się formułą ,władza kontrolująca konstytucyjność prawa”" ${ }^{\text {" }}$. Pod wpływem jednak głównie niemieckich teoretyków ustroju państwowego do sądów konstytucyjnych przylgnęło określenie „strażnik konstytucji”" ${ }^{44}$. Co ciekawe, używają go zarówno zwolennicy pełnej odrębności ustrojowej sądów konstytucyjnych, jak i rzecznicy zaliczania ich w poczet organów władzy sądowniczej. Różnica między nimi jest taka, że o ile ci pierwsi stanie na straży konstytucji traktują jako osobną prawną sferę działania państwa, o tyle ci drudzy widzą w niej jedynie syntetycznie zdefiniowaną rolę ustrojową sądów konstytucyjnych jako organów władzy sądowniczej ${ }^{85}$.

Argumentu o odrębności ustrojowej sądów konstytucyjnych od pozostałych władz państwowych z racji istoty ich działalności nie sposób racjonalnie podważyć. Istota ta odbiega od kwintesencji działalności zarówno władzy sądowniczej, jak i ustawodawczej. To bowiem ona jest kluczowym czynnikiem przy ocenie i definicji każdej prawnej sfery działania państwa. Jeżeli podział władzy w aspekcie instytucjonalnym nie jest konsekwencją jego rozdziału funkcjonalnego, to kwalifikacja ustrojowa niektórych organów państwowych nastręcza szereg trudności, a jej efekt nie jest zwykle satysfakcjonujący. Taki los spotyka właśnie europejskie sądy konstytucyjne, którym nazbyt często odmawia się ustrojowej odrębności i sztucznie próbuje się je zaliczać do organów władzy sądowniczej. Tymczasem istota ich działalności ma niewiele wspólnego z tym, czym zajmują się sądy powszechne czy administracyjne. Pokutuje tu czysto podmiotowe podejście do definicji władzy sądowniczej, skutkiem czego krąg jej podmiotów obejmuje organy, które więcej dzieli niż łączy. Nieporozumień takich można byłoby uniknąć, gdyby punktem wyjścia ustrojowej klasyfikacji poszczególnych organów było kryterium istoty ich działalności. Nie tylko przecież ranga ustrojowa sądów konstytucyjnych w niczym nie doznałaby uszczerbku, ale wręcz przeciwnie - w wyniku uczynienia z nich władzy samodzielnej i odrębnej od pozostałych (w tym sądowniczej)

${ }^{82}$ Confer J. Trzciński, Trybunat Konstytucyjny — regulacja konstytucyjna i praktyka, [w:] Sądy i trybunały $w$ konstytucji i praktyce, red. W. Skrzydło, Warszawa 2005, s. 90.

83 Confer R.M. Małajny, Klasyfikacja..., s. 138.

${ }^{84}$ K. Doehring, Der „Pouvoir Neutre” und Grundgesetz, „Der Staat” 1964, nr 3, s. 209.

${ }^{85}$ K. Stern, Das Staatsrecht der Bundesrepublik Deutschland, t. II..., s. 952. 
niepomiernie by wzrosła. Omawiana kwestia na dobrą sprawę dotyczy tylko stosunku sądów konstytucyjnych do organów władzy sądowniczej, gdyż poza ciągle spotykanym w piśmiennictwie ustrojowym zwyczajem kwalifikowania sądów konstytucyjnych jako takich organów, kwalifikacji takiej dokonują również ustawy zasadnicze wielu państw ${ }^{86}$. Natomiast idea sądu konstytucyjnego jako określonego elementu legislatywy jest nie tyle koncepcją definiującą ich ustrojowy charakter, ile raczej próbą właściwego zinterpretowania praktycznych skutków ich działalności. Nigdy jednak nie nadano jej kształtu formalnego i nie znalazła odzwierciedlenia w konstytucji żadnego z państw jako formuła ustrojowej klasyfikacji sądu konstytucyjnego ${ }^{87}$.

Uznanie sądu konstytucyjnego za odrębną władzę państwową nie rozwiązuje do końca problemu jego charakteru ustrojowego. Poprzestanie bowiem na ogólnym wniosku, że istotą jego działalności jest kontrola konstytucyjności prawa, jest sporym uproszczeniem. To bez wątpienia jego podstawowe zadanie, ale ani nie wyczerpuje ono całej jego działalności, ani dobrze nie oddaje sensu jego pozycji ustrojowej. Jakkolwiek kontrola konstytucyjności prawa jest kontrolą szczególną, to jednak nie ma podstaw, aby zasadniczo przeciwstawiać ją innym rodzajom kontroli państwowej. Ryzyko takiego uproszczenia polega na tym, że sąd konstytucyjny wpadłby w podobną pułapkę, jak w przypadku traktowania go w kategoriach organu władzy sądowniczej. Tym razem miejsce tej ostatniej zastąpiłaby nieokreślona bliżej sfera kontroli państwowej. Sąd konstytucyjny znów więc nie byłby piastunem władzy odrębnej, lecz trafiłby do grona organów spełniających różne funkcje, których jedynym punktem stycznym jest realizacja jakiegoś aspektu szeroko rozumianej kontroli państwowej ${ }^{88}$. Ustrojowy status sądów konstytucyjnych zostałby wyraźnie rozmyty, a ich znaczenie mogłoby zostać zminimalizowane $\mathrm{w}$ ramach porządku konstytucyjnego.

Analogiczne niebezpieczeństwo pociąga za sobą poszukiwanie ustrojowej odrębności sądów konstytucyjnych za pomocą równie wieloznacznego zadania ochrony konstytucji. Już samo pojęcie ochrony konstytucji nie jest precyzyjne i może być różnie interpretowane. Sąd konstytucyjny w dziele ochrony konstytucji czy też porządku konstytucyjnego nie jest monopolistą. Współczesny konstytucjonalizm europejski zna przecież co najmniej kilka instytucji, których głównym zadaniem jest ochrona porządku konstytucyjnego ${ }^{89}$. Stąd także w tym przypadku sąd konstytucyjny byłby zaledwie jednym z organów realizujących nader złożone i niejednorodne pod względem ustrojowym zadanie.

Ranga ustrojowa sądu konstytucyjnego niepomiernie by wzrosła, gdyby zamiast podejmowania kolejnych karkołomnych prób wkomponowania go w strukturę wieloelementowych pod względem instytucjonalnym władz, został on przyporządkowany do całkowicie odrębnej prawnej sfery działania państwa. Podstawą takiej klasyfikacji

${ }^{86}$ W. Sadurski, Prawo..., s. 69; J. Trzciński, Trybunał..., s. 89-90.

${ }^{87}$ M. Granat, Legitymacja..., s. 18-19; D. Rousseau, Sądownictwo..., s. 31.

88 A. Sylwestrzak, Wtadza..., s. 328; K. Stern, Das Staatsrecht der Bundesrepublik Deutschland, t. II..., s. 954, 956.

${ }^{89}$ Confer S. Serafin, B. Szmulik, Organy ochrony prawnej RP, Warszawa 2010, s. 3-8, 323. 
byłby więc funkcjonalny rozdział władzy i wyodrębnienie z ogółu prawnych sfer działania takiej, która odpowiada istocie działalności sądu konstytucyjnego. A istotą tą nie jest kontrola konstytucyjności prawa, lecz rozstrzyganie sporów konstytucyjnych ${ }^{90}$. Kontrola konstytucyjności prawa stanowi niewątpliwie podstawową formę takiej działalności, lecz rola ustrojowa sądu konstytucyjnego wyraźnie poza taką kontrolę wykracza. Ustawa zasadnicza pozostaje najważniejszym punktem odniesienia w działalności sądu konstytucyjnego, który pod kątem ochrony jej ogólnych zasad i wartości oraz jej szczegółowych postanowień powinien realizować każdą ze swych kompetencji ${ }^{1}$. Nie można jednak z tego wyciągać wniosku, że działalność sądu konstytucyjnego zamyka się w kontroli konstytucyjności prawa. Jej celem jest bowiem zawsze ochrona porządku konstytucyjnego ${ }^{92}$, co w rzeczywistości równoznaczne jest ze staniem na straży jego stabilności. Stabilizacja ustrojowa z poziomu nadrzędnej wartości porządku konstytucyjnego i generalnej zasady działania wszystkich władz państwowych, staje się tym samym samodzielnym obszarem działalności o ściśle określonych zadaniach i formach ich realizacji. Stabilizacja taka zyskuje więc status odrębnej prawnej sfery działania państwa, której istotą jest rozwiązywanie sporów konstytucyjnych.

Zgodnie z poczynionym wcześniej ustaleniem konstytucjonalizm wolnościowo-demokratyczny każdemu sporowi powstałemu między władzami państwowymi lub w ich obrębie nadaje charakter sporu konstytucyjnego. Sąd konstytucyjny wszelkie swe działania podejmuje zawsze na wniosek odpowiedniego podmiotu. Podmiotem takim jest przede wszystkim określony organ państwowy ${ }^{93}$. Bez względu na charakter sprawy organ taki staje się zatem stroną sporu konstytucyjnego. W przypadku zainicjowania postępowania $\mathrm{w}$ przedmiocie kontroli konstytucyjności ustaw $\mathrm{z}$ formalnego punktu widzenia drugą stroną sporu jest parlament (w przypadku kontroli prewencyjnej) lub parlament wraz z głową państwa, jeśli podpisała ona ustawę i zarządziła jej publikację (na etapie kontroli następczej). Nawet w ramach procedury kontroli konkretnej uruchamianej w drodze pytania prawnego, które do sądu konstytucyjnego kieruje sąd powszechny w związku z wątpliwościami co do konstytucyjności przepisu ustawy stanowiącej podstawę wydawanego przezeń orzeczenia, strony powstałego sporu są określone. Z jednej strony będą to znów parlament i głowa państwa (jeśli uczestniczyła w postępowaniu ustawodawczym), z drugiej zaś — sąd zadający takie pytanie.

Jedynie w przypadku skargi konstytucyjnej zasada sporu konstytucyjnego jako sporu między organami państwowymi zostaje podważona. Jedną ze stron jest bowiem wówczas jednostka, która kwestionuje określoną decyzję władz państwowych. Sąd

90 Confer K. Stern, Das Staatsrecht der Bundesrepublik Deutschland, t. II..., s. 937.

91 P. Czarny, Konstytucyjne spory kompetencyjne, „Przegląd Prawa Konstytucyjnego” 2014, nr 2, s. 82.

92 P. Tuleja, Interpretacja konstytucji, [w:] Konstytucja i gwarancje jej przestrzegania. Ksiega pamiątkowa ku czci prof. Janiny Zakrzewskiej, Warszawa 1996, s. 485; M. Kordela, Kategoria norm, zasad oraz wartości prawnych. Uwagi metodologiczne w związu z orzecznictwem Trybunatu Konstytucyjnego, „Przegląd Sejmowy” 2009, nr 5, s. 29.

$93 \mathrm{Na}$ temat innych podmiotów uprawnionych do wnioskowania o wszczęcie takiego postępowania confer Z. Czeszejko-Sochacki, Sądownictwo konstytucyjne w Polsce na tle porównawczym, Warszawa 2003, s. 93-99. 
konstytucyjny rozpoznaje więc spór między państwem a jednostką, co działalność jego niemal zrównuje z działalnością sądów powszechnych czy administracyjnych ${ }^{94}$. Mimo tego procedurę rozpoznawania skargi konstytucyjnej można uznać za szczególną formę sporu konstytucyjnego. Wszak wydane w takim postępowaniu orzeczenie nie rozstrzyga konkretnej sprawy co do meritum, a jedynie otwiera przed podmiotem wnoszącym skargę drogę do dalszych czynności procesowych, które już jednak muszą zostać przeprowadzone przez właściwe organy władzy sądownicze lub organy administracji publicznej. Konsekwencją orzeczenia sądu konstytucyjnego również w takim przypadku często będzie uchylenie mocy obowiązującej zakwestionowanej ustawy lub niektórych jej przepisów. Nie tylko skutki rozstrzygnięcia zapadłego w postępowaniu w przedmiocie skargi konstytucyjnej przemawiają za potraktowaniem go jako szczególnej postaci sporu konstytucyjnego. Na korzyść takiej kwalifikacji działa także pośredni cel takiego postępowania. Jest nim ochrona porządku konstytucyjnego, ponieważ poszanowanie podstawowych praw jednostki stanowi jeden z najważniejszych jego filarów i jedną z jego najistotniejszych wartości. Bez zapewnienia takiemu porządkowi odpowiedniej stabilizacji gwarancje podstawowych praw jednostki zawsze będą miały charakter iluzoryczny ${ }^{95}$.

Przedmiotem sporu w przypadku kontroli konstytucyjności prawa jest ocena kwestionowanych przepisów lub całego aktu prawnego. Bezpośrednim następstwem decyzji sądu konstytucyjnego kładącej kres takiemu sporowi jest stwierdzenie konstytucyjności lub niekonstytucyjności podlegających kontroli przepisów lub aktu. Jeżeli chodzi o procedurę rozpatrywania skarg konstytucyjnych lub pytań prawnych, to dodatkowym skutkiem decyzji sądu konstytucyjnego może być możliwość zmiany sytuacji prawnej podmiotu skargi lub zmiana podstawy prawnej orzekania $\mathrm{w}$ danej sprawie sądowej. Niezależnie jednak od trybu kontroli konstytucyjności prawa ostateczną konsekwencją decyzji sądu konstytucyjnego będzie rozstrzygnięcie określonego sporu konstytucyjnego, a co za tym idzie — ochrona porządku konstytucyjnego i jego podstawowych wartości ${ }^{96}$.

Drugą formą rozwiązywania przez sąd konstytucyjny sporów konstytucyjnych jest rozstrzyganie tych sporów między naczelnymi organami państwowymi w zakresie ich konstytucyjnych kompetencji ${ }^{97}$. Sąd konstytucyjny jest gwarantem konstytucyjnie określonej zasady podziału władzy, skoro czuwa nad przestrzeganiem wynikającego z ustawy zasadniczej rozdziału zakresu działalności konstytucyjnych

94 P. Tuleja, M. Grzybowski, Skarga konstytucyjna jako środek ochrony praw jednostki w polskim systemie prawa, [w:] Sądy..., s. 122-123.

95 W. Osiatyński, Demokracja a prawa człowieka, [w:] Prawa człowieka w społeczeństwie obywatelskim, red. A. Rzepliński, Warszawa 1993, s. 40.

${ }_{96}$ M. Florczak-Wątor, Orzeczenia Trybunału Konstytucyjnego i ich skutki prawne, Poznań 2006, S. 119.

${ }^{97}$ Niektóre sądy konstytucyjne rozstrzygają ponadto szczególne spory kompetencyjne, których stronami są naczelne organy państwowe i organy określonych jednostek terytorialnych państwa (części składowych federacji, jednostek autonomicznych lub jednostek samorządu terytorialnego) oraz spory między samymi jednostkami terytorialnymi państwa. Confer E. Zwierzchowski, Sądownictwo..., s. 144-148. 
organów państwowych ${ }^{98}$. I choć najczęściej stosowaną w praktyce formą rozstrzygania przezeń sporów konstytucyjnych jest kontrola konstytucyjności prawa, to właśnie spory kompetencyjne stanowią kwintesencję sporów konstytucyjnych. Przedmiotem sporu kompetencyjnego jest bowiem konstytucyjnie określony zakres działalności organów państwowych. Dlatego też można przyjąć, że stroną takiego sporu są konstytucyjnie wyodrębnione władze państwowe lub ich poszczególne elementy. Sąd konstytucyjny, rozstrzygając taki spór, precyzuje zakres działalności uczestniczących w nim organów, co często wiąże się z definiowaniem istoty działania władz państwowych. Głównym kryterium oceny racji stron takiego sporu staje się zatem funkcjonalny podział władzy i konieczność ustalenia granic działania poszczególnych władz. Z jednej strony decyzja sądu konstytucyjnego rozstrzyga konkretny spór między odpowiednimi organami powstały na tle określonej sprawy, z drugiej zaś wywołuje skutek o wiele dalej idący w postaci zdefiniowania lub zrewidowania zakresu działalności zaangażowanych w spór organów ${ }^{99}$. Trudno o lepszy przykład stabilizacyjnej roli sądu konstytucyjnego. Sąd konstytucyjny stojąc na straży konstytucyjnej zasady podziału władzy wyrasta na głównego obrońcę porząaku konstytucyjnego i ostateczną instancję rozstrzygającą wszelkie spory powstałe w jego obrębie. Stabilizacja porządku konstytucyjnego jako rezultat działalności sądu konstytucyjnego przybiera tym samym najwłaściwszą i najpełniejszą postać, jaką jest ochrona jego konstytucyjności i efektywności. Nie sposób przecież za efektywny uznać taki porządek konstytucyjny, który byłby niekonstytucyjny. Efektywność musi bowiem stanowić konsekwencję konstytucyjności, a nie cenę jej braku lub jej poważnych problemów. $Z$ tego też powodu spory kompetencyjne można określić mianem sporów konstytucyjnych sensu stricto, w przeciwieństwie do kontroli konstytucyjności prawa, którą można nazwać sporami konstytucyjnymi sensu largo.

Z pozostałych kompetencji znajdujących się w gestii kilku sądów konstytucyjnych trzeba odnotować orzekanie w przedmiocie weryfikacji wyborów do organów przedstawicielskich i na stanowisko prezydenta, orzekanie o utracie mandatu członka organu przedstawicielskiego, kontrolę stosowania niektórych instytucji demokracji bezpośredniej, egzekwowanie odpowiedzialności konstytucyjnej wysokich rangą funkcjonariuszy państwowych oraz orzekanie w zakresie konstytucyjności celów i działalności partii politycznych ${ }^{100}$. Żadna z tych kompetencji nie zmienia przy tym ogólnego charakteru ustrojowego sądu konstytucyjnego. Nie są to bowiem uprawnienia przysługujące wszystkim sądom konstytucyjnym, a jedynie nielicznym. Ponadto stanowią one co najwyżej dodatek do podstawowych form działalności sądu konstytucyjnego ${ }^{101}$. Nawet jeśli przyjmiemy, że sąd konstytucyjny nie rozstrzyga za ich pośrednictwem jakiegokolwiek sporu konstytucyjnego, to nie one jednak decydują o jego kwalifikacji ustrojowej. Nie sposób również nie przypomnieć, że każda samodzielna władza państwowa ma swą istotę czy

98 P. Sarnecki, Spory kompetencyjne przed Trybunałem Konstytucyjnym, „Przegląd Sejmowy” 2009, nr 5, s. 14.

99 P. Czarny, Konstytucyjne..., s. 82.

100 Confer E. Zwierzchowski, Sądownictwo..., s. 97-98; L. Garlicki, Sądownictwo konstytucyjne w Europie Zachodniej, Warszawa 1987, s. 161.

101 B. Banaszak, Porównawcze..., s. 522. 
główny rdzeń swej działalności. Nie wyklucza to bynajmniej powierzenia jej innych zadań czy kompetencji, które mimo że nie mieszczą się w granicach istoty działalności danej władzy, to mogą stanowić jej uzupełnienie. Tak też jest w przypadku dodatkowych uprawnień sądów konstytucyjnych. Uzupełniają one istotę ich działalności, którą jest rozstrzyganie sporów konstytucyjnych, przy czym każda z tych kompetencji służy w gruncie rzeczy temu samemu celowi uprawnienia główne, czyli stabilizacji porządku konstytucyjnego.

\section{KONKLUZJE}

Wyodrębnienie stabilizacji ustrojowej spośród prawnych sfer działania państwa i przyporządkowanie jej sądom konstytucyjnym można uznać za jedno z największych osiągnięć europejskiego konstytucjonalizmu drugiej połowy $\mathrm{XX}$ w. W tym również tkwi fenomen europejskiego modelu sądownictwa konstytucyjnego. Wprawdzie idea sądowej ochrony konstytucji została urzeczywistniona ponad stulecie wcześniej na gruncie amerykańskim, ale dopiero Stary Kontynent idei tej nadał właściwe znaczenie. Dopóki bowiem kontrola konstytucyjności prawa stanowiła raptem jedną z funkcji sądów powszechnych, stabilizacja porządku konstytucyjnego pozostawała w sferze aksjologii lub co najwyżej mogła zostać potraktowana jako bliżej niesprecyzowane zadanie wszystkich władz państwowych. Funkcjonalne oddzielenie kontroli konstytucyjności prawa od wymiaru sprawiedliwości pozwoliło na powierzenie jej całkowicie odrębnym organom państwowym. Szybko okazało się, jak wielki potencjał funkcja ta niesie za sobą i jak wiele innych możliwości w dziedzinie szeroko rozumianej ochrony konstytucji dzięki niej stoi otworem. Wziąwszy zaś pod uwagę specyfikę samej kontroli konstytucyjności prawa na tle pozostałych form kontroli państwowej czy szczególny charakter sporów pojawiających się w tym kontekście między organami państwowymi, istoty takiej działalności należało poszukiwać poza tradycyjnymi wzorcami klasyfikacji prawnych sfer działania państwa. Z pomocą przyszła tu koncepcja sporów konstytucyjnych jako sporów powstających między poszczególnymi władzami państwowymi lub w ich obrębie, których przedmiotem jest określony aspekt organizacji i działania porządku konstytucyjnego. Konstytucyjność i efektywność takiego porządku to dwie główne cechy i zarazem warunki konieczne jego stabilizacji, która z kolei stoi na czele wartości ustrojowych. Wydarzeniem zagrażającym lub zakłócającym tak zdefiniowaną stabilizację ustrojową są właśnie wszelkiego rodzaju spory konstytucyjne. Nic więc dziwnego, że organ, którego istota działalności polega na rozstrzyganiu takich sporów, skutecznie może aspirować do roli piastuna osobnej władzy państwowej, a mianowicie władzy stabilizacyjnej.

Zaklasyfikowanie sądów konstytucyjnych jako organów władzy stabilizującej nie pozbawia ich bynajmniej sądowego charakteru. Kryterium oddzielenia ich od organów władzy sądowniczej jest istotą ich działalności. Pod względem funkcjonalnym sądy konstytucyjne są władzą odrębną od sądów powszechnych czy administracyjnych. W wymiarze organizacyjnym nic nie stoi jednak na przeszkodzie, by traktować je jak organy sądowe. Co więcej, ów sądowy charakter stanowi najskuteczniejszą gwarancję ich samodzielności i relatywnej niezależności od pozostałych władz. Już sama nazwa tych organów — sądy 
lub trybunały konstytucyjne ${ }^{102}$ - ma podkreślać ich sądowy charakter. Nie do przecenienia jest zwłaszcza status prawny członków sądów konstytucyjnych, którzy korzystają z większości dobrodziejstw zarezerwowanych dla sędziów. Przede wszystkim cieszą się przywilejem sędziowskiej niezawisłości oraz innymi prawami wynikającymi ze statusu prawnego sędziów. Ich pozycja prawna bywa ukształtowana z reguły na wzór pozycji sędziów sądów najwyższych ${ }^{103}$. Odmienności dotyczą zazwyczaj trybu powoływania na stanowiska sędziów sądów konstytucyjnych. Mimo nader rygorystycznie na ogół określonych warunków prawnych, stawianych kandydatom na takich sędziów, decyzje o ich wyborze podejmują zwykle organy legislatywy lub egzekutywy, co siłą rzeczy nadaje im poważny wydźwięk polityczny ${ }^{104}$. Po objęciu urzędu sędziowie sądów konstytucyjnych zyskują jednak istotną gwarancję politycznej niezależności w postaci stosunkowo długiej kadencji pełnienia swej funkcji oraz zasady nieusuwalności z zajmowanego stanowiska. Warto odnotować, że konstytucje wielu państw jako dodatkowe zabezpieczenie przed ewentualnym zarzutem o stronniczość polityczną sędziów wprowadzają wymóg ich wyboru przez parlament kwalifikowaną większością głosów, skutkiem czego akt wyborczy musi być rezultatem szerszego kompromisu politycznego reprezentowanych w parlamencie ugrupowann ${ }^{105}$. Jakkolwiek więc europejskie sądy konstytucyjne są władzą odrębną od pozostałych (władzy sądowniczej nie wyłączając), to ich organizacja i sposób działania w pełni odpowiadają konstytutywnym cechom organów sądowych ${ }^{106}$.

\section{BIBLIOGRAFIA}

\section{PIŚMIENNICTWO}

Banaszak B., Bernaczyk M., Aktywizm sędziowski we współczesnym państwie demokratycznym, Wydawnictwo Sejmowe, Warszawa 2012.

Banaszak B., Porównawcze prawo konstytucyjne wspótczesnych państw demokratycznych, Wolters Kluwer, Warszawa 2007.

Bożek M., Instytucja Prezydenta Republiki Federalnej Niemiec, Wydawnictwo Sejmowe, Warszawa 2007.

Bożek M., Władza ustrojodawcza w konstytucjonalizmie niemieckim, Wydawnictwo Sejmowe, Warszawa 2013.

102 Wyjątkiem jest tu francuska Rada Konstytucyjna, która choć nie jest klasycznym sądem konstytucyjnym, to w gruncie rzeczy wypełnia jego funkcje, a w ostatnich latach w wyniku kolejnych reform konstytucyjnych jej status coraz bardziej zbliżył się do statusu typowego sądu konstytucyjnego. Confer L. Garlicki, Rada Konstytucyjna w Republice Francuskiej, [w:] Sady konstytucyjne w Europie, t. I, red. J. Trzciński, Warszawa 1996, s. 91-105; A. Chmielarz, Rada Konstytucyjna po zmianach konstytucyjnych z lipca 2008 r., „Przegląd Sejmowy” 2010, nr 1, s. 125-143.

${ }^{103}$ W. Sokolewicz, Status prawny sędziego Trybunatu Konstytucyjnego, [w:] Księga XX-lecia orzecznictwa Trybunału Konstytucyjnego, red. M. Zubik, Warszawa 2006, s. 159-184.

104 J. Zajadło, Wewnętrzna legitymacja sądu konstytucyjnego, „Przegląd Sejmowy” 2009, nr 4, s. $133-134$.

${ }^{105}$ U. Kischel, Wybór sędziów niemieckiego Trybunału Konstytucyjnego w ujęciu porównawczym, „Państwo i Prawo” 2014, z. 9, s. 67-86.

${ }^{106}$ K. Stern, Das Staatsrecht der Bundesrepublik Deutschland, t. II..., s. 941-943; J. Trzciński, Trybunat..., s. 90; M. Granat, Trybunat Konstytucyjny. Osiagnięcie czy zadanie?, [w:] Trzecia władza. Sąy i trybunaty w Polsce, red. A. Szmyt, Gdańsk 2008, s. 36. 
Brzozowski W., Stopniowalność naruszeń konstytucji, „Ruch Prawniczy, Ekonomiczny i Socjologiczny" 2017, z. 4, https://doi.org/10.14746/rpeis.2017.79.4.1.

Chmielarz A., Rada Konstytucyjna po zmianach konstytucyjnych z lipca 2008 r., „Przegląd Sejmowy" 2010, nr 1.

Chorążewska A., Prezydent jako czynnik równowagi. Arbitraż polityczny, „Przegląd Sejmowy” 2005 , nr 6.

Czarny P., Konstytucyjne spory kompetencyjne, „Przegląd Prawa Konstytucyjnego” 2014, nr 2.

Czeszejko-Sochacki Z., Sądownictwo konstytucyjne w Polsce na tle porównawczym, Trybunał Konstytucyjny, Warszawa 2003.

Derlatka M., Skarga konstytucyjna w Niemczech, Wydawnictwo Sejmowe, Warszawa 2009.

Doehring K., Der „, Pouvoir Neutre” und Grundgesetz, „Der Staat” 1964, nr 3.

Florczak-Wątor M., Orzeczenia Trybunału Konstytucyjnego i ich skutki prawne, Ars boni et aequi, Poznań 2006.

Garlicki L., Rada Konstytucyjna w Republice Francuskiej, [w:] Sady konstytucyjne w Europie, t. I, red. J. Trzciński, Trybunał Konstytucyjny, Warszawa 1996.

Garlicki L., Sądownictwo konstytucyjne w Europie Zachodniej, PWN, Warszawa 1987.

Granat M., Legitymacja sądu konstytucyjnego na gruncie czystej teorii prawa H. Kelsena, „Przegląd Sejmowy” 1999, nr 4.

Granat M., Trybunat Konstytucyjny. Osiagnięcie czy zadanie?, [w:] Trzecia władza. Sądy i trybunały w Polsce, red. A. Szmyt, Wydawnictwo Uniwersytetu Gdańskiego, Gdańsk 2008.

Instytucja Prezydenta we współczesnym świecie: materiały na konferencję, Warszawa - Senat RP 22-23 II 1993 r., Senat RP, Warszawa 1993.

Kaltefleiter W., Die Funktionen des Staatsoberhauptes in der parlamentarischen Demokratie, Westdeutscher Verlag, Köln-Opladen 1970.

Kelsen H., Istota i rozwój sądownictwa konstytucyjnego, Trybunał Konstytucyjny, Warszawa 2009 (Berlin-Leipzig 1929).

Kischel U., Wybór sędziów niemieckiego Trybunału Konstytucyjnego w ujęciu porównawczym, „Państwo i Prawo” 2014, z. 9.

Konstytucjonalizm a doktryny polityczno-prawne. Najnowsze kierunki badań, red. R.M. Małajny, Wydawnictwo Uniwersytetu Śląskiego, Katowice 2008.

Konstytucyjne systemy rząów, red. M. Domagała, Wydawnictwo Sejmowe, Warszawa 1997.

Kordela M., Kategoria norm, zasad oraz wartości prawnych. Uwagi metodologiczne w zwiąku z orzecznictwem Trybunatu Konstytucyjnego, „Przegląd Sejmowy” 2009, nr 5.

Kuca G., Zasada podziału i równowagi władz a inne organy państwowe, [w:] Ustroje, doktryny, instytucje polityczne. Księga jubileuszowa Profesora zw. dra hab. Mariana Grzybowskiego, red. J. Czajowski, J. Karp, G. Kuca, A. Kulig, P. Mikuli, A. Opałek, Wydawnictwo Uniwersytetu Jagiellońskiego, Kraków 2007.

Kuca G., Zasada podziału władzy w Konstytucji RP z 1997 roku, Wydawnictwo Sejmowe, Warszawa 2014.

Kuciński J., Legislatywa - egzekutywa - judykatywa: konstytucyjne instytucje i mechanizmy stużace równowadze władz w polskim systemie trójpodziału, Dom Wydawniczy Elipsa, Warszawa 2010.

Linz J.J., Zagrożenia systemu prezydenckiego, „Res Publica” 1990, nr 12.

Ludwikowski R.R., Prawo konstytucyjne porównawcze, TNOiK, Torun 2000.

Lutz D.S., Principles of Constitutional Design, Cambridge University Press, Cambridge-New York, 2006, https://doi.org/10.1017/CBO9780511510267.002.

Małajny R.M., Idea rozdziału władzy państwowej i jej interpretacje, „Przegląd Sejmowy” 2009, $\mathrm{nr} 1$.

Małajny R.M., Klasyfikacja prawnych sfer działania państwa — próba reinterpretacji, [w:] Rozważania o państwie i prawie, Wydawnictwo Uniwersytetu Śląskiego, Katowice 1993. 
Małajny R.M., Podział czy trójpodziat władzy?, [w:] Prawowitość czy zgodność z prawem? Legitymizacja władzy w państwach demokratycznych, red. A. Preisner, Wydawnictwo Uniwersytetu Wrocławskiego, Wrocław 2010.

Małajny R.M., Pozycja ustrojowa Kongresu USA, t. III, Katowice 1995.

Małajny R.M., Zasada podziału władzy a system rządów parlamentarnych, „Państwo i Prawo” 2009, z. 12.

Państwo prawa - parlamentaryzm - sądownictwo konstytucyjne. Pamięci Profesora Zdzisława Czeszejki-Sochackiego, red. A. Jamróz, Temida 2, Białystok 2012.

Parlamentarny system rzadów. Teoria i praktyka, red. T. Mołdawa, J. Szymanek, M. Mistygacz, Dom Wydawniczy Elipsa, Warszawa 2012.

Pietrzykowski T., Ujarzmianie Lewiatana. Szkice o idei rządów prawa, Wydawnictwo Uniwersytetu Śląskiego, Katowice 2014.

Polskie prawo konstytucyjne na tle porównawczym, red. R.M. Małajny, C.H. Beck, Warszawa 2013.

Popławska E., Instytucja prezydenta $w$ systemie politycznym V Republiki Francuskiej, Wydawnictwo Sejmowe, Warszawa 1995.

Prokop K., Modele stanu nadzwyczajnego, Temida 2, Białystok 2012.

Pułło A., „Podział władzy”. Aktualne problemy w doktrynie, prawie i współczesnej dyskusji konstytucyjnej w Polsce, „Przegląd Sejmowy” 1993, nr 3.

Pułło A., Idea konstytucjonalizmu w systemie zasad prawa konstytucyjnego, „Przegląd Sejmowy” 1996, nr 5.

Pułło A., O jedno rozumienie podziału władz w nauce prawa konstytucyjnego, „Państwo i Prawo” 1983, z. 3.

Richter L., Die Vorgeschichte des Art. 48 der Weimarer Reichsverfassung. „Der Staat” 1998, nr 1.

Rousseau D., Sadownictwo konstytucyjne w Europie, Wydawnictwo Sejmowe, Warszawa 1999.

Sadurski W., Prawo przed sadem. Studium sądownictwa konstytucyjnego w postkomunistycznych państwach Europy Środkowej $i$ Wschodniej, Wydawnictwo Sejmowe, Warszawa 2008.

Sarnecki P., Rzad a parlament w Konfederacji Szwajcarskiej, Wydawnictwo Uniwersytetu Jagiellońskiego, Kraków 1978.

Sarnecki P., Spory kompetencyjne przed Trybunatem Konstytucyjnym, „Przegląd Sejmowy” 2009, nr 5.

Sady i trybunały w konstytucji i praktyce, red. W. Skrzydło, Wydawnictwo Sejmowe, Warszawa 2005.

Schmitt C., Der Hüter der Verfassung, Duncker und Humblot, Berlin 1996 (1931).

Serafin S., Szmulik B., Organy ochrony prawnej RP, C.H. Beck, Warszawa 2010.

Skrzydło W., Rola Trybunału Konstytucyjnego w rozstrzyganiu sporów kompetencyjnych, [w:] Konstytucja $i$ władza we współczesnym świecie. Doktryna-prawo-praktyka. Prace dedykowane Profesorowi Wojciechowi Sokolewiczowi na siedemdziesięciolecie urodzin, Wydawnictwo Sejmowe, Warszawa 2002.

Skrzydło W., Rozwiąanie Sejmu i jego prawne konsekwencje, „Przegląd Sejmowy” 1993, nr 1.

Sokolewicz W., Podział władz - idea polityczna czy zasada prawna? Z dylematów współczesnego ustrojodawcy, [w:] Prawo w okresie przemian ustrojowych w Polsce, Warszawa 1995.

Sokolewicz W., Status prawny sędziego Trybunatu Konstytucyjnego, [w:] Księga XX-lecia orzecznictwa Trybunatu Konstytucyjnego, red. M. Zubik, Trybunał Konstytucyjny, Warszawa 2006.

Starck Ch., Der demokratische Verfassungsstaat. Gestalt, Grundlagen, Gefährdungen, Mohr Siebeck, Tübingen 1995.

Starzewski M., Środki zabezpieczenia prawnego konstytucyjności ustaw, Wydawnictwo Sejmowe, Warszawa 2009 (Kraków 1928).

Stawecki T., Dyskusje wokół aktywizmu i pasywizmu sądów konstytucyjnych jako spór o wykładnię konstytucji, [w:] Wyktadnia konstytucji. Inspiracje, teorie, argumenty, red. T. Stawecki, J. Winczorek, Wolters Kluwer, Warszawa 2014. 
Stembrowicz J., Rzą w systemie parlamentarnym, PWN, Warszawa 1982.

Stepan A., Skach C., Modele konstytucyjne a umacnianie demokracji (Parlamentaryzm - system prezydencki), „Państwo i Prawo” 1994, z. 4.

Stern K., Das Staatsrecht der Bundesrepublik Deutschland, t. I, Grundbegriffe und Grundlagen des Staatsrechts, Strukturprinzipien der Verfassung, Beck, München 1980.

Stern K., Das Staatsrecht der Bundesrepublik Deutschland, t. II, Staatsorgane, Staatsfunktionen, Finanz- und Haushaltsverfassung, Notstandsverfassung, Beck, München 1984.

Sulikowski A., Tworzenie prawa przez sądy konstytucyjne i jego demokratyczność, „Państwo i Prawo" 2005, z. 8.

Sulikowski A., Wspótczesny paradygmat sądownictwa konstytucyjnego wobec kryzysu nowoczesności, Wydawnictwo Uniwersytetu Wrocławskiego, Wrocław 2008.

Sylwestrzak A., Aktualność problematyki podziału władz, [w:] Idee jako źródło instytucji politycznych i prawnych, red. L. Dubel, Wydawnictwo UMCS, Lublin 2003.

Sylwestrzak A., Władza czwarta - kontrolujaca, „Państwo i Prawo” 1992, z. 7.

Sylwestrzak A., Władza rządzaca, władza opozycji $i$ władza neutralna na tle tradycyjnych teorii podziału władz, [w:] Wokót wybranych problemów konstytucjonalizmu, red. J. Ciapała, P. Mijal, Wydawnictwo Sejmowe, Warszawa 2017.

Systemy rządów $w$ perspektywie porównawczej, red. J. Szymanek, Wydawnictwo Sejmowe, Warszawa 2014.

Szczurowski B., Prezydent Rzeczypospolitej jako organ czuwający nad przestrzeganiem konstytucji, Wydawnictwo Sejmowe, Warszawa 2016.

Szymanek J., Arbitraż polityczny głowy państwa, Dom Wydawniczy Elipsa, Warszawa 2009.

Szymanek J., Racjonalizacja parlamentarnego systemu rządów, „Przegląd Sejmowy” 2007, nr 1.

Tobor Z., Legalność a praworządność, [w:] Rozważania o państwie i prawie, Wydawnictwo Uniwersytetu Śląskiego, Katowice 1993.

Trzciński J., Czy Trybunat Konstytucyjny jest władza sadowniczą?, [w:] W kręgu zagadnień konstytucyjnych. Prof. Eugeniuszowi Zwierzchowskiemu w darze, red. M. Kudej, Wydawnictwo Uniwersytetu Śląskiego, Katowice 1999.

Tuleja P., Interpretacja konstytucji, [w:] Konstytucja i gwarancje jej przestrzegania. Ksiega pamiątkowa ku czci prof. Janiny Zakrzewskiej, Trybunał Konstytucyjny, Warszawa 1996.

Wiszowaty M., Zasada monarchiczna i jej przejawy we współczesnych ustrojach europejskich i pozaeuropejskich monarchii mieszanych, Wydawnictwo Uniwersytetu Gdańskiego, Gdańsk 2015.

Witkowski Z., Prezydent Republiki w systemie ustrojowym współczesnych Włoch, Wydawnictwo UMK, Toruń 1991.

Wołowski, Prezydent Republiki w powojennej Francji (IV i V Republika), PWN, Warszawa-Poznań 1973.

Wronkowska S., Kilka uwag o „prawodawcy negatywnym”, „Państwo i Prawo” 2008, z. 10.

Zajadło J., Wewnętrzna legitymacja sądu konstytucyjnego, „Przegląd Sejmowy” 2009, nr 4.

Zawadzka B., Samorząd jako forma sprawowania władzy publicznej, [w:] Prawo w okresie przemian ustrojowych w Polsce, Warszawa 1995.

Zubik M., O rozstrzyganiu , sporów kompetencyjnych” przez Trybunat Konstytucyjny, [w:] Prawa człowieka - społeczeństwo obywatelskie - państwo demokratyczne. Księa jubileuszowa dedykowana Profesorowi Pawłowi Sarneckiemu, red. P. Tuleja, M. Florczak-Wątor, S. Kubas, Wolters Kluwer, Warszawa 2010.

Zwierzchowski E., Wprowadzenie do nauki prawa konstytucyjnego państw demokratycznych, Wydawnictwo Uniwersytetu Śląskiego, Katowice 1992.

Zwierzchowski E., Sądownictwo konstytucyjne, Temida 2, Białystok 1994. 


\section{WSPÓLPRACA PARLAMENTÓW NARODOWYCH Z PARLAMENTEM EUROPEJSKIM W ZAKRESIE TWORZENIA PRAWA}

\section{COOPERATION OF NATIONAL PARLIAMENTS WITH THE EUROPEAN PARLIAMENT IN THE SCOPE OF LAWMAKING}

The article presents relations between parliaments of the European Union Member States (Poland, France, Sweden) and the European Parliament, from the perspective of the few years that had passed since the Treaty of Lisbon went into fore. The aim is to assess effectiveness of the legal norms laid down by the Treaty of Lisbon as regards regulations concerning national parliaments. Different manners of regulating the matter in question by individual states may have an impact on the sphere of trans-institutional activity (number of reasoned opinions, intensity of political dialogue etc.). Moreover, regulating cooperation between the national parliament and the European Parliament by the higher-ranking law may confer special legal value on those prerogatives of the parliament. Acknowledging these differences may initiate further analysis on expanding the EU law as regards national parliaments and their relations with European Parliament.

Słowa kluczowe: Parlament Europejski, parlamenty państw członkowskich, traktat z Lizbony

Key words: European Parliament, parliaments of the EU Member States, Treaty of Lisbon

* Mgr Rafal Czarski, Kancelaria Sejmu, Biuro Spraw Międzynarodowych, rafal.czarski@sejm.gov.pl,https://orcid.org/0000-0002-7321-2405

\section{WSTĘP}

Tedną z relacji instytucjonalnych, które w Unii Europejskiej powodują liczne dyskusje dotyczące pozycji i zakresu zbieżnych — wydawałoby się — ze sobą kompetencji, jest relacja między parlamentami narodowymi a Parlamentem Europejskim [dalej: PE]. Ten system współzależności został określony jako odgrywanie odrębnych, a zarazem komplementarnych ról w realizacji zasadniczego zadania, jakim jest wzmocnienie demokratycznej odpowiedzialności w sprawach Unii Europejskiej ${ }^{1}$. Należy jednak zauważyć znaczne różnice zakresu kompetencji między tymi organami: podstawową funkcją parlamentów państwowych jest ich funkcja prawodawcza, z kolei uprawnienia ustawodawcze PE są znacznie zawężone, gdyż zakładają współpracę na różnych etapach i w ramach istniejących procedur z innymi instytucjami UE. W zależności od procedury legislacyjnej rola PE może dotyczyć współdecydowania (zwykła procedura ustawodawcza) lub jedynie roli konsultacyjnej (specjalne procedury legislacyjne).

${ }^{1}$ Resolution on the relations between the European Parliament and national parliaments, T4-0319/ 1997, 22 II 1997, s. 75, <http://www.europarl.europa.eu/calendar/calendar?APP=PDF\&TYPE=PV2\&FILE= 19970612EN.pdf\&LANGUE=EN>, dostęp 28 VII 2018. 
Przedmiotem niniejszego artykułu jest zaprezentowanie, w szczególności z perspektywy kilku lat od wejścia w życie Traktatu z Lizbony, relacji parlamentów narodowych z PE. Zakres omawianego zagadnienia obejmuje doświadczenia polskiego parlamentu: Sejmu i Senatu, a także dwóch innych parlamentów państw członkowskich Unii: Zgromadzenia Narodowego i Senatu Republiki Francuskiej oraz Riksdagu Królestwa Szwecji. O wyborze zadecydowały następujące czynniki: Republika Francuska - to jedno z państw założycieli UE, Szwecja - to państwo odznaczające się dużą aktywnością w sferze interakcji instytucjonalnej z PE, i Polska - państwo badania. Ukazanie tych trzech perspektyw ma przedstawić obraz doświadczeń i wewnętrznych ram współpracy między parlamentami a instytucjami unijnymi, głównie Parlamentem Europejskim.

Temat współpracy parlamentów narodowych z PE wydaje się szczególnie aktualny w związku z podejmowaniem na różnych forach europejskich dyskusji na temat zwiększenia roli parlamentów narodowych w procesie decyzyjnym Unii Europejskiej. Jeden $\mathrm{z}$ takich głosów w debacie na ten temat zaprezentowano podczas posiedzenia plenarnego Konferencji Komisji do Spraw Unijnych Parlamentów Unii Europejskiej, LIX COSAC 2018, które odbyło się 17-19 czerwca 2018 r. w Sofii. W propozycji francuskiej wskazano na potrzebę rozbudowy uprawnień parlamentów państwowych w zakresie ich aktywności europejskiej dotyczącej sfery gospodarczej — negocjacji umów handlowych ${ }^{2}$. Wśród postulatów o zoptymalizowaniu współpracy parlamentarnej i przyznaniu większej roli parlamentom narodowym pojawiają się liczne opinie dotyczące wprowadzenia zielonych i czerwonych kartek, umożliwiających parlamentom inicjatywę ustawodawczą ${ }^{3}$ lub też możliwość blokowania projektu ustawodawczego. Propozycje te dowodzą tego, jak istotny z punktu widzenia parlamentów narodowych jest udział w procesie decyzyjnym $\mathrm{UE}^{4}$.

W tym opracowaniu zamierzeniem autora jest zaprezentowanie rozwoju relacji między parlamentami Polski, Francji i Szwecji a Parlamentem Europejskim w celu oceny skuteczności norm Traktatu z Lizbony z punktu widzenia uregulowań dotyczących parlamentów narodowych. Odmienne sposoby regulacji przedmiotowej kwestii w porządkach prawnych poszczególnych państw mogą mieć przełożenie na sferę aktywności międzyinstytucjonalnej (liczby zgłaszanych uzasadnionych opinii, intensywność dialogu politycznego itp.). Dodatkowo umieszczenie niekiedy w aktach wyższego rzędu przepisów prawnych o współpracy parlamentu z PE może nadawać tej części uprawnień parlamentu szczególny walor prawny. Zauważenie tych różnic może stanowić przyczynek do dalszej analizy na temat rozbudowy regulacji unijnych odnoszących się

${ }^{2}$ List J. Bizet, przewodniczącego Komisji Stałej do Spraw Europejskich w Senacie Republiki Francuskiej z 6 grudnia 2017 r. (LIX COSAC).

${ }_{3}^{3}$ Propozycja dotycząca zielonej kartki została sformułowana przez brytyjską Izbę Lordów w dokumencie Komisji do Spraw Unii Europejskiej na temat: Roli parlamentów narodowych w Unii Europejskiej, $<$ https://publications.parliament.uk/pa/ld201314/ldselect/ldeucom/151/151.pdf>, dostęp 28 VII 2018.

${ }^{4}$ Więcej na ten temat $\mathrm{w}$ Report on the implementation of the Treaty provisions concerning national parliaments (2016/2149(INI)), 28.03.2018, Committee on Constitutional Affairs of the European Parliament oraz w Working document on the implementation of the Treaty provisions concerning national parliaments, Committee on Constitutional Affairs of the European Parliament, 5.10.2017. 
do parlamentów narodowych i ich relacji z PE. Omówienie zasadniczej części pracy zostanie jednak poprzedzone historią kształtowania się podstaw prawnych relacji między parlamentami narodowymi a Parlamentem Europejskim ze szczególnym rozróżnieniem etapu sprzed i po wejściu w życie Traktatu z Lizbony. Liczba szczegółowych zagadnień związanych relacjami bilateralnymi Polski, Francji i Szwecji mogłaby z powodzeniem stać się przedmiotem wielu publikacji. Jednak należy podkreślić, że niniejszy artykuł nie wyczerpuje tematu, a stanowi zaledwie jego zarys. Ze względu na wcześniej wymienione cele $\mathrm{w}$ artykule zastosowano metodę historyczno-prawną. Opracowanie uwzględnia stan prawny na dzień 28 lipca $2018 \mathrm{r}$.

\section{HISTORIA REGULACJI}

Podstawy prawne współpracy między parlamentami narodowymi a Parlamentem Europejskim zostały uregulowane w art. 12 Traktatu o Unii Europejskiej [dalej: TUE], załączonym do niego Protokole $\mathrm{nr} 1 \mathrm{w}$ sprawie roli parlamentów narodowych w Unii Europejskiej $(\operatorname{art.} 2,3,9)$ oraz w Protokole $\mathrm{nr} 2 \mathrm{w}$ sprawie stosowania zasad pomocniczości i proporcjonalności (art. 6 i 7). Ponadto zasady tej relacji międzyinstytucjonalnej zostały również zawarte w regulaminie Parlamentu Europejskiego (art. 142, 143 i 144). W ramach tzw. funkcji europejskiej wzmocnieniu uległy m.in. dwie sfery aktywności: współpraca między parlamentami narodowymi oraz współpraca z Parlamentem Europejskim ${ }^{5}$.

\section{Ramy współpracy parlamentarnej przed Traktatem z Lizbony}

Pierwsze propozycje dotyczące wzmocnienia pozycji parlamentów narodowych na poziomie unijnym znalazły się $\mathrm{w}$ niewiążących dokumentach o charakterze politycznym, tj. w deklaracji nr 13, dotyczącej roli parlamentów krajowych w UE dołączonej do traktatu z Maastricht z 1992 r., która przewidywała zwiększenie wymiany informacji między parlamentami państw członkowskich a PE, oraz deklaracji nr $14 \mathrm{w}$ sprawie konferencji parlamentów zachęcającej do spotkań w ramach konferencji parlamentów, mającej udzielać konsultacji w sprawach dotyczących głównych kierunków rozwoju $\mathrm{UE}^{6}$. Pierwszym dokumentem o charakterze prawnym dotyczącym tej materii był Protokół nr 9 dołączony do traktatu z Amsterdamu w sprawie roli parlamentów narodowych państw członkowskich UE. Pierwsza część dokumentu dotyczyła udzielania informacji parlamentom narodowym. Druga odnosiła się do Konferencji Organów Wyspecjalizowanych w Sprawach Wspólnotowych [dalej: COSAC]. W ramach traktatu z Amsterdamu wprowadzono również Protokół nr $7 \mathrm{w}$ sprawie stosowania zasad pomocniczości i proporcjonalności. Protokoły te jednak nie zostały ze sobą powiązane, co ujawniło się w ich stosunku do traktatów założycielskich?

${ }^{5}$ A. Pudło, Funkcja europejska parlamentów państw czlonkowskich, „Przegląd Sejmowy” 2015, nr 1 , s. 7.

${ }^{6}$ E. Popławska, Rola parlamentów narodowych w świetle Traktatu z Lizbony, „Przegląd Sejmowy” 2010, nr 5, s. 160.

${ }^{7}$ C. Mik, Pozycja prawna parlamentów narodowych w Unii Europejskiej w świetle Traktatu Lizbony, „Ruch Prawniczy, Ekonomiczny i Socjologiczny” 2010, z. 2, s. 52. 
W dniach 14-15 grudnia 2001 r. na posiedzeniu Rady Europejskiej w Laeken przyjęto z kolei Deklarację w sprawie przyszłości Unii, dołączoną do traktatu z Nicei w 2001 r. W rezultacie Deklaracji z Laeken ustanowiono Konwent w Sprawie Przyszłości Europy. Dokument końcowy Czwartej Grupy Roboczej Konwentu stał się podstawą rozwiązań prawnych przewidzianych w Traktacie ustanawiającym Konstytucję dla Europy ${ }^{8}$, mimo że ten Traktat nie wszedł w życie, to stał się zbiorem postanowień włączonych w dużej mierze do Traktatu z Lizbony ${ }^{9}$. Dnia 3 lipca 2004 r., wraz z przyjęciem wytycznych w sprawie współpracy międzyparlamentarnej w Unii Europejskiej (wytyczne haskie) ${ }^{10}$, stwierdzono poszanowanie autonomii parlamentów i podkreślono, że głównym celem współpracy międzyparlamentarnej jest wymiana informacji oraz wzmocnienie kompetencji we wszystkich dziedzinach objętych zakresem prawa wspólnotowego. W wytycznych wspomniano również o różnych formatach współpracy międzyparlamentarnej.

$\mathrm{Na}$ przestrzeni lat efektywnym narzędziem międzyparlamentarnej współpracy administracyjnej oprócz Europejskiego Centrum Badań Parlamentarnych i Dokumentacji [dalej: ECPRD] ${ }^{11}$, utworzonego w 1977 r., stała się również platforma IPEX (funkcjonująca od 2006 r.). Celem tych projektów było usprawnienie systemów wymiany informacji, przekładające się na zaangażowanie parlamentów krajowych w sprawy Wspólnot Europejskich (później Unii Europejskiej).

\section{Współpraca parlamentarna po grudniu 2009 r.}

Do najważniejszych zmian — przełomowych po wejściu w życie Traktatu z Lizbony — należy przede wszystkim zaliczyć uwzględnienie parlamentów narodowych w Traktacie o Unii Europejskiej i dwóch załączonych protokołach. W zakresie współpracy parlamentów narodowych z PE po wejściu w życie tego aktu prawnego stworzono nowe elementy oddziaływania na decyzje unijne, także wzmocnieniu uległy istniejące już instrumenty: rozszerzono zakres dokumentów podlegających obowiązkowi wymiany informacji, przyznano prawo weta przy zmianie traktatów, prawo czuwania nad przestrzeganiem zasady pomocniczości, wprowadzono możliwość monitorowania przestrzeni wolności, bezpieczeństwa i sprawiedliwości, stworzono nowe formaty współpracy międzyparlamentarnej.

Niewątpliwą zmianą jakościową, jaka się dokonała po 2009 r., było oddziaływanie parlamentów krajowych na decyzje UE, jednocześnie nie nakładając na parlamenty

${ }^{8}$ A. Kurczuk, Rola parlamentów narodowych w świetle Traktatu Lizbońskiego, „Zeszyty Naukowe Akademii Podlaskiej w Siedlcach” 2010, nr 84, s. 127, <http://www.tstefaniuk.uph.edu.pl/zeszyty/archiwalne/ 84-2010_9.pdf>, dostęp 28 VII 2018.

9 C. Mik, Pozycja prawna parlamentów narodowych w Unii Europejskiej..., s. 52.

10 Przyjęte w Hadze 3 lipca 2004 r. przez Konferencję Przewodniczących Parlamentów UE, zmienione podczas konferencji w Lizbonie (19-21 czerwca 2008 r.).

11 Międzynarodowa sieć parlamentarnych wydziałów ds. badań i dokumentacji; jej członkami są: Parlament Europejski, Zgromadzenie Parlamentarne Rady Europy oraz izby parlamentów, których przewodniczący są członkami Europejskiej Konferencji Przewodniczących Parlamentów. Działalność ECPRD obejmuje organizację seminariów, przyjmowanie zapytań na określony temat oraz wydawanie publikacji. 
konkretnych zobowiązań ${ }^{12}$. Parlamenty krajowe uzyskały możliwość blokowania decyzji dzięki monitorowaniu zgodności unijnych aktów ustawodawczych z zasadą subsydiarności, przy zachowaniu określonych warunków formalnych niektórych propozycji uprawnionych podmiotów unijnych za pomocą tzw. żółtej lub pomarańczowej kartki w ramach mechanizmu wczesnego ostrzegania. Ponadto dzięki obowiązkom informacyjnym parlamenty narodowe dostały możliwość zapoznania się z projektami aktów prawnych $\mathrm{z}$ odpowiednim wyprzedzeniem ${ }^{13}$. Jedną z konsekwencji takiego ożywienia dialogu międzyparlamentarnego wewnątrz UE było również nadanie nowego impulsu istniejącym już formom współpracy parlamentarnej, takim jak Konferencje przewodniczących parlamentów UE (najwyższe rangą spotkanie parlamentarne), COSAC, wspólne spotkania parlamentarne, wspólne spotkania Komisji, Zgromadzenie Parlamentarne Unii dla Śródziemnomorza, ale i stworzenie nowych, np. Konferencja Międzyparlamentarna ds. Wspólnej Polityki Zagranicznej i Bezpieczeństwa oraz Wspólnej Polityki Bezpieczeństwa i Obrony, Konferencja Międzyparlamentarna ds. Stabilności, Koordynacji i Zarządzania Gospodarczego w Unii Europejskiej, Europejski Tydzień Parlamentarny czy Zgromadzenie Parlamentarne EURONEST. Kolejny obszar uprawnień przyznany zarówno PE, jak i parlamentom narodowym to ocena działalności Eurojustu ${ }^{14}$ (art. 85 Traktatu o funkcjonowaniu Unii Europejskiej, dalej: TfUE) i kontroli działań Europolu ${ }^{15}$ (art. 88 TfUE). Przejawem współpracy w tym zakresie jest funkcjonująca od października 2017 r. Grupa Wspólna ds. Kontroli Parlamentarnej Europolu. Wzajemne relacje obejmują również spotkania na szczeblu sekretarzy generalnych (szefów kancelarii) parlamentów narodowych, których celem jest przygotowanie Konferencji Przewodniczących Parlamentów. Do istniejących form współpracy należy również zaliczyć funkcjonowanie przedstawiciela parlamentów przy UE oraz udział deputowanych Parlamentu Europejskiego $\mathrm{w}$ pracach izb. Ponadto Traktat z Lizbony podniósł rangę parlamentów narodowych poprzez uwzględnienie ich stanowisk w procesie tworzenia acquis communautaire.

\section{DOŚWIADCZENIA WYBRANYCH PARLAMENTÓW NARODOWYCH W RELACJACH Z PARLAMENTEM EUROPEJSKIM}

Parlament Europejski jest instytucją odgrywającą kluczową rolę w relacjach międzyparlamentarnych w UE. Po pierwsze, jest on jednym z podmiotów funkcjonujących w ramach różnych form współpracy międzyparlamentarnej (często je inicjuje), a pod drugie, otrzymuje opinie wydawane przez parlamenty narodowe w sprawie

12 E. Popławska, Rola parlamentów narodowych..., s. 157.

13 Przepływ informacji dotyczących aktywności europejskiej parlamentów państw członkowskich z instytucjami unijnymi został usprawniony przez utworzenie w 2004 r. platformy IPEX (Interparliamentary EU Information Exchange).

${ }^{14}$ Europejska Jednostka Współpracy Sądowej (Eurojust), utworzona w 2002 r., jest agencją Unii Europejskiej. Jej celem jest wspieranie i wzmacnianie współpracy oraz koordynacji działań krajowych organów wymiaru sprawiedliwości w walce z przestępczością ponadgraniczną dotykającą kraje Unii Europejskiej.

15 Europejski Urząd Policji (Europol) to unijna agencja egzekwowania prawa, utworzona w 1999 r., której zadaniem jest zwiększanie poziomu bezpieczeństwa w Europie poprzez zapewnianie pomocy organom ścigania w państwach członkowskich UE. 
zgodności z zasadą subsydiarności ${ }^{16}$. Zakres tej współpracy jest również określony w szóstym tytule Regulaminu Parlamentu Europejskiego. Ten akt wewnętrzny zawiera regulacje dotyczące wymiany informacji, kontaktów, wzajemnych udogodnień (art. 142), udziału w COSAC (art. 143) oraz w innych konferencjach parlamentarnych (art. 144). Dodatkowo relacje między PE a parlamentami państw członkowskich były przedmiotem wielu rezolucji Parlamentu Europejskiego ${ }^{17}$ i opracowań.

Organami parlamentów wyspecjalizowanymi do kontaktu z instytucjami unijnymi są odpowiednie komisje, które w zależności od państwa mają większe lub mniejsze prerogatywy w zakresie współpracy z PE oraz z innymi organami Unii Europejskiej. Komisje te stanowią ważne ogniwo parlamentarnego procesu prawodawczego, kontrolnego i opiniotwórczego, a także tworzą system pomostów między legislacją unijną a krajowymi ciałami przedstawicielskimi ${ }^{18}$. Ramy współpracy z PE zostały określone m.in. w art. 9 Protokołu nr 1 w sprawie roli parlamentów narodowych w Unii Europejskiej oraz w wytycznych haskich. Strukturą w PE odpowiedzialną za kontakty z parlamentami narodowymi jest Dyrekcja ds. Stosunków z Parlamentami Narodowymi.

$\mathrm{Na}$ podstawie wspomnianych propozycji uwzględnione w regulacjach na poziomie unijnym parlamenty narodowe stworzyły własne mechanizmy wewnętrzne, będące realizacją norm traktatowych. Doświadczenia parlamentów Francji, Szwecji i Polski z PE różnią się między sobą intensywnością kontaktów oraz specyfiką regulacji własnych procedur wewnętrznych. Celem tego rozdziału jest ogólne omówienie rozwoju tych relacji, a także przedstawienie niektórych efektów tej współpracy po wejściu w życie przepisów Traktatu z Lizbony.

\section{Parlament Rzeczypospolitej Polskiej}

Początki współpracy polskiego parlamentu z Parlamentem Europejskim sięgają 1993 r., kiedy to utworzono Parlamentarną Komisję Wspólną RP i UE (PKWRPiUE) ${ }^{19}$. Następnie, po podpisaniu 16 kwietnia 2003 r. Traktatu akcesyjnego do wejścia do Unii Europejskiej, 54 polskich parlamentarzystów, delegowanych zarówno z Sejmu, jak i z Senatu, uczestniczyło w pracach Parlamentu Europejskiego w charakterze obserwatorów. Po przystąpieniu Polski do Unii Europejskiej w 2004 r. istotnym forum współpracy z PE stała się Konferencja Organów Wyspecjalizowanych w Sprawach Wspólnotowych

${ }^{16}$ M. Remáč, Working with national parliaments on EU affairs, European Parliamentary Research Service, PE 603.271 — October 2017, <http://www.europarl.europa.eu/thinktank/en/document.html?refe rence=EPRS_STU \%282017\%29603271>, dostęp 28 VII 2018.

17 Do najważniejszych należy zaliczyć m.in. rezolucję z 7 maja 2009 r. w sprawie rozwoju stosunków między Parlamentem Europejskim a parlamentami narodowymi w kontekście Traktatu z Lizbony, rezolucję z 16 kwietnia 2014 r. w sprawie stosunków między Parlamentem Europejskim a parlamentami narodowymi, rezolucję z 19 kwietnia 2018 r. w sprawie stosowania postanowień Traktatu dotyczących parlamentów narodowych.

18 M. Serowaniec, Parlamentarne Komisje do Spraw Europejskich, Warszawa 2016, s. 8.

19 Vide szerzej J. Borkowski, Role of the Poland-EU Joint Parliamentary Committee in Poland's Preparations for European Union Membership, <http://www.ce.uw.edu.pl/pliki/pw/y3-1999_Borkowski.pdf>, dostęp 28 VII 2018. 
i Europejskich Parlamentów Unii Europejskiej $(\mathrm{COSAC})^{20}$. Dzięki temu parlament uzyskał możliwość dostępu do informacji o zamierzeniach PE oraz kierowania sugestii w sprawie kierunku jego prac. Sejm 11 marca 2004 r. uchwalił ustawę będącą podstawą współpracy naczelnych organów państwowych z organami Unii Europejskiej. Obecnie ta materia jest regulowana ustawą kooperacyjną ${ }^{21} \mathrm{z} 8$ października 2010 r., o tym samym tytule, co poprzednia. Ten akt prawny normalizuje stosunki między Sejmem, Senatem i Radą Ministrów a organami Unii Europejskiej, przyznając prawo do otrzymywania m.in. projektów umów międzynarodowych, dokumentów UE podlegających konsultacjom z państwami członkowskimi (białe i zielone księgi), komunikaty Komisji Europejskiej, planów prac Rady UE czy rocznych planów legislacyjnych Komisji Europejskiej. Ponadto sferę działalności organów obu izb wyspecjalizowanych w sprawach europejskich reguluje regulamin Sejmu ${ }^{22}$ i regulamin Senatu ${ }^{23}$. Zgodnie z ich przepisami Komisja do spraw Europejskich (Sejm) ${ }^{24}$ oraz Komisja Spraw Zagranicznych i Unii Europejskiej (Senat) ${ }^{25}$ mogą uchwalać opinie o projekcie aktu prawnego UE, opinie o stanowiskach Rzeczypospolitej Polskiej zajmowanych w trakcie procedur stanowienia prawa Unii, a także opinie w sprawie informacji Rady Ministrów o stanowisku Rzeczypospolitej Polskiej, jakie Rada Ministrów ma zamiar zająć podczas rozpatrywania projektu w Radzie (art. 148c regulaminu Sejmu i art. 75b regulaminu Senatu). Możliwość procedowania nad projektami unijnych aktów prawnych oraz stanowisk Rady Ministrów dała władzy ustawodawczej wpływ na proces rozwoju $\mathrm{UE}^{26}$. Zgodnie z art. 7 ust. 4 ustawy kooperacyjnej komisje ds. europejskich mogą ponadto wyrażać opinię o projekcie aktu ustawodawczego, a także o projekcie aktu nieustawodawczego (art. 8 ust. 2). Inne kompetencje dotyczą możliwości wyrażenia opinii na temat stanowisk zajmowanych przez Radę Ministrów w trakcie procedur stanowienia prawa UE (art. 10 ust. 2) albo opinię o stanowisku, które Rada Ministrów zamierza zająć podczas rozpatrywania tego aktu na posiedzeniu Rady UE (art. 11 ust. 1 i art. 12 ust. 1) lub Rady Europejskiej (art. 12

${ }^{20}$ Obecna nazwa: Konferencja Komisji do Spraw Unijnych Parlamentów Unii Europejskiej (COSAC), [w:] Leksykon Konferencji Komisji do Spraw Unijnych Parlamentów Unii Europejskiej (COSAC), <http:// oide.sejm.gov.pl/oide/index.php?option=com_content\&view $=$ article\&id=14727\&Itemid=776>, dostęp 28 VII 2018.

${ }^{21}$ Ustawa z dnia 8 października 2010 r. o współpracy Rady Ministrów z Sejmem i Senatem w sprawach związanych z członkostwem Rzeczypospolitej Polskiej w Unii Europejskiej (Dz.U. z 2010 r. nr 213, poz. 1395) zastąpiła wcześniej obowiązującą ustawę z dnia 11 marca 2004 r. o współpracy Rady Ministrów z Sejmem i Senatem w sprawach związanych z członkostwem Rzeczypospolitej Polskiej w Unii Europejskiej (Dz.U. z 2004 r. nr 52, poz. 515).

${ }_{22}$ Rozdział 13a: art. 148a-148e uchwały Sejmu Rzeczypospolitej Polskiej z dnia 30 lipca 1992 r. — Regulamin Sejmu Rzeczypospolitej Polskiej (M.P. z 2012 r. poz. 32 z późń. zm.).

${ }^{23}$ Rozdział 8a: art. 75a-75g uchwały Senatu Rzeczypospolitej Polskiej z dnia 23 listopada 1990 r. Regulamin Senatu (M.P. z 2017 r. poz. 827 z późn. zm.).

${ }^{24}$ Wcześniej Komisja Integracji Europejskiej (1993-2001, II i III kadencja Sejmu), Komisja do Spraw Układu Europejskiego (1992-1993, I kadencja Sejmu).

${ }^{25}$ Wcześniej Komisja Spraw Unii Europejskiej (2004-2011, V-VII kadencja Senatu), Komisja Spraw Zagranicznych i Międzynarodowych Stosunków Gospodarczych (listopad-grudzień 1997 r., IV kadencja Senatu) oraz Komisja Spraw Zagranicznych i Integracji Europejskiej (1997-2001).

${ }^{26}$ M. Serowaniec, Parlamentarne Komisje..., s. 230. 
ust. 2). Należy podkreślić, że opinie Komisji do Spraw Unii Europejskiej nie mają charakteru bezwzględnie wiążącego, a raczej pomocniczy ${ }^{27}$.

Postanowienia ustawy kooperacyjnej z 2010 r. różnicują pozycję Sejmu i Senatu, w tym ich komisji w odniesieniu do spraw UE. Różnica ta jest widoczna chociażby w tym, że komisja senacka nie ma możliwości wyrażania opinii w sprawie kandydatów państwa na najważniejsze stanowiska w instytucjach UE. Jednak obu izbom przyznano taki sam zakres informacji przekazywanych przez Radę Ministrów. Ze względu na zakres uprawnień pozycja komisji sejmowej jest mocniejsza od senackiej. Ważnym elementem aktywności europejskiej polskich izb parlamentarnych jest badanie unijnych aktów ustawodawczych pod względem zgodności z zasadą pomocniczości. Procedura jest uruchamiana od momentu wpływu do sekretariatu Komisji do Spraw Unii Europejskiej listu przewodniego (lettre de saisine) zawierającego informację o przekazaniu wszystkich wersji językowych parlamentom państw członkowskich i określającego procedurę oraz wyznaczającego termin. Od tego momentu zaczyna biec termin ośmiu tygodni na ewentualne przekazanie przez parlament państwa członkowskiego uzasadnionej opinii.

Wymiana dokumentów oraz cykliczne spotkania w ramach różnych form współpracy międzyparlamentarnej nie są jedynymi narzędziami kształtowania relacji między Sejmem i Senatem a Parlamentem Europejskim. Polscy deputowani do Parlamentu Europejskiego (51 posłów), poprzez uczestniczenie w różnych koalicjach i działalności organów Parlamentu Europejskiego, mają bezpośredni wpływ na prace Parlamentu. Warto również zwrócić uwagę na rolę przedstawicieli obu izb przy UE, których zadaniem jest zapewnienie szczegółowej bieżącej informacji o wydarzeniach istniejących $\mathrm{w}$ instytucjach unijnych i innych parlamentach państw członkowskich oraz o przebiegu wspólnotowego procesu legislacyjnego, w szczególności w odniesieniu do projektów aktów prawa opiniowanych przez sejmową Komisję do Spraw Unii Europejskiej i senacką Komisję Spraw Zagranicznych i Unii Europejskiej.

\section{Riksdag Królestwa Szwecji}

Wraz z przystąpieniem Szwecji do Unii Europejskiej w 1995 r. Riksdag uzyskał możliwość wywierania wpływu na prace prowadzone w Unii oraz podejmowane przez nią decyzje. Prace parlamentu zostały zorganizowane w ten sposób, aby mogły oddziaływać na działania rządu w ramach UE. Współpraca z rządem jest prowadzona w różnej formie na posiedzeniach plenarnych, w ramach prac komisji Riksdagu a także w Komisji Doradczej do spraw Unii Europejskiej. Parlament szwedzki należy do tej grupy państw, które mają duży wpływ na pracę państwa w Unii Europejskiejej. Od 1995 r. sposób zajmowania się sprawami unijnymi przez Riksdag zmienił się kilkanaście razy ${ }^{29}$, w tym

27 Ibidem.

${ }_{28}$ Zapis spotkania Komisji Integracji Europejskiej z przewodniczącym Komisji Doradczej do spraw Unii Europejskiej Riksdagu, 17 styczeń 2001 r., Biuletyn Komisji Sejmowych 3719/III, Komisja Integracji Europejskiej, nr 83.

${ }_{29}$ The Riksdag and the European Union, s. 6, <http://www.ipex.eu/IPEXL-WEB/parliaments/insti tution/serik>, dostęp 28 VII 2018. 
m.in. w 2007 r. wprowadzono zmiany umożliwiające Izbie wkroczenie we wczesnym stadium w proces podejmowania decyzji i które wiązały się z nowymi zadaniami komisji. Komisje uzyskały w ten sposób możliwość podejmowania dyskusji z rządem o sprawach europejskich, które znajdowały się w zakresie ich kompetencji. Komisje otrzymały również prawa badania inicjatyw unijnych instytucji. Po wejściu w życie Traktatu z Lizbony wprowadzono do Riksdag Akt postanowienia dotyczący badania przestrzegania zasady subsydiarności i udziału w zmianie traktatów unijnych ${ }^{30}$.

W parlamencie szwedzkim działa obecnie 15 komisji, które mają za zadanie monitorowanie spraw związanych z Unią Europejską. W praktyce komisje te badają propozycje unijne i sporządzają sprawozdanie, a dopiero wówczas zajmuje się tym rząd. Sekretariaty komisji dzięki specjalnej jednostce koordynacyjnej UE otrzymują wsparcie we wszelkich kwestiach proceduralnych i instytucjonalnych $\mathrm{UE}^{31}$. Specjalnym organem jest wspomniana Komisja Doradcza do spraw Unii Europejskiej funkcjonująca przy Riksdagu, która przedstawia swoją opinię Radzie Ministrów przed spotkaniami Rady Unii Europejskiej ${ }^{32}$. Komisja ds. Europejskich składa się z nieparzystej liczby członków, lecz z nie mniej niż 15, wybieranych ze wszystkich partii politycznych proporcjonalnie do układu sił w Izbie (7.4. Riksdag Act). Wszelka aktywność instytucji unijnych jest monitorowana przez rząd, który jest zobligowany do konsultacji z komisjami parlamentarnymi we wszelkich kwestiach dotyczących spraw europejskich. Rząd - w celu wzmocnienia swojego mandatu dla reprezentowania swojego kraju — ma również obowiązek konsultowania z Komisją ds. Europejskich wszelkich kwestii przedłożonych na agendzie Rady Unii Europejskiej (7.14. Riksdag Act). Obowiązki informacyjne rządu w tym zakresie są wypełniane zarówno podczas prac komisji branżowych, Komisji ds. Europejskich, a także in pleno na posiedzeniu całej Izby ${ }^{33}$. Debaty w sprawach europejskich odbywają się w sali posiedzeń Riksdagu. Część uprawnień związanych z tworzeniem prawa została przekazana Parlamentowi Europejskiemu. Zasady współpracy między tymi trzema ośrodkami zostały uregulowane w Instrument of Government ${ }^{34}$ oraz w Riksdag Act ${ }^{35}$. Każdego roku odbywa się debata lub przedstawiany jest raport w sprawie polityki europejskiej, która jest monitorowana przez Komisję do spraw Konstytucyjnych $^{36}$.

Zgodnie z Riksdag Act parlament przeprowadza kontrolę subsydiarności wszystkich projektów aktów legislacyjnych w obszarach należących zarówno do kompetencji

${ }^{30}$ The Riksdag and the European Union, s. 6 <http://www.ipex.eu/IPEXL-WEB/parliaments/insti tution/serik>, dostęp 28 VII 2018.

31 Wystąpienie sekretarza generalnego Riksdagu Claesa Mårtenssona podczas spotkania Sekretarzy Generalnych w Wilnie, 26-27 stycznia 2014 r.

32 The Riksdag and the European Union, < http://www.ipex.eu/IPEXL-WEB/parliaments/institu tion/serik>, dostęp 28 VII 2018.

33 Strona internetowa Riksdagu <http://www.cosac.eu/subs-sweden>, dostęp 28 VII 2018.

34 Strona internetowa Riksdagu < http://www.riksdagen.se/globalassets/07.-dokument--lagar/the-con stitution-of-sweden>, dostęp 28 VII 2018.

35 Ibidem.

${ }^{36}$ Na podstawie informacji ze strony internetowej Riksdagu $<$ http://www.riksdagen.se/en/committees/ the-parliamentary-committees-at-work>, dostęp 28 VII 2018. 
członków UE, jak i PE. Zasada subsydiarności zakłada, aby decyzje podejmowane na poziomie politycznym były zgodne $\mathrm{z}$ wolą wyborców ${ }^{37}$. Podobnie jak w przypadku innych parlamentów państw UE badanie propozycji legislacyjnych stanowi jeden z głównych obszarów aktywności. W odniesieniu do parlamentu szwedzkiego projekt jest przekazywany komisji, która zajmuje się zagadnieniami przedstawionymi w akcie. W razie wątpliwości właściwa komisja przeprowadza kontrolę subsydiarności. W wypadku stwierdzenia naruszenia przedstawia całej Izbie oświadczenie z propozycją uzasadnionej opinii skierowanej do przewodniczącego PE, Rady i Komisji. Na wniosek co najmniej pięciu członków Komisji o naruszaniu w projekcie legislacyjnym zasady subsydiarności sporządza się oświadczenie. Następnie projekt jest zatwierdzany przez Riksdag (10.3 Riksdag Act).

Stanowisko formułowane przez Komisję Doradczą jest uwzględniane przy opracowywaniu mandatu negocjacyjnego przed posiedzeniami Rady, a także stanowi ono forum współpracy i konsultacji parlamentarzystów z członkami rządów w sprawach związanych z integracją europejską ${ }^{38}$. Riksdag należy do parlamentów państw Unii Europejskiej, które zgłaszają najwięcej uzasadnionych opinii i wspierają różne formy współpracy, jak np. IPEX, Europol ${ }^{39}$. Czynnikiem wpływającym na taki wynik jest to, że każda komisja ma możliwość poddania swoich ekspertyz przeglądowi pod względem subsydiarności.

Do końca 2017 r. Riksdag przyjął 59 uzasadnionych opinii. Szwecja jako państwo członkowskie ma również możliwość bezpośredniego wpływania na pracę Parlamentu Europejskiego przez swoich 20 eurodeputowanych. Ponadto funkcjonujący od 2005 r. stały przedstawiciel Riksdagu w instytucjach europejskich zapewnia wraz z Sekretariatem Koordynacyjnym EU informacje o wydarzeniach w instytucjach unijnych oraz w innych parlamentach państw członkowskich ${ }^{40}$.

\section{Parlament Republiki Francuskiej}

Republika Francuska jest państwem najdłużej związanym z procesem integracji europejskiej (od 1957 r.), tym samym również relacje francuskiego parlamentu z Parlamentem Europejskim sięgają początków istnienia tej instytucji. We Francji delegacje parlamentarne dla Wspólnot Europejskich zostały utworzone wraz z przyjęciem ustawy 6 lipca 1979 r. ${ }^{41}$ Następnie ustawą z 10 czerwca 1994 r. (Loi Pandraud

${ }^{37}$ The Riksdag and the European Union..., dostęp 28 VII 2018.

${ }_{38}^{38}$ M. Serowaniec, Parlamentarne Komisje..., s. 108-109.

${ }^{39}$ Wystąpienie przewodniczącego Riksdagu U. Ahlina 24 maja 2016 r. w Luksemburgu na temat „Roli parlamentów narodowych i współpracy międzyparlamentarnej podczas Konferencji Przewodniczących Parlamentów Europejskich", <http://www.ipex.eu/IPEXLWEB/euspeakers/getspeakers.do?id=082dbcc54d8d4e af0>, dostęp 28 VII 2018.

${ }^{40}$ The Riksdag and the European Union..., dostęp 28 VII 2018.

${ }^{41}$ Loi n $^{\circ} 79-654$ du 6 juillet 1979 modifiant l'ordonnance $n^{\circ}$ 58-1000 du 17 novembre 1958 relative au fonctionnement des assemblées parlementaires en veu de la creation des delegations parlementaires pour les communautés européennes, <http://www.assemblee-nationale.fr/europe/loi_juillet.asp >, dostęp 28 VII 2018. 
$\mathrm{n}^{\circ}$ 94-476 du 10 juin 1994) ${ }^{42}$ wprowadzono zobowiązanie rządu do przekazywania delegaturze „wszelkich niezbędnych dokumentów sporządzonych przez różne instytucje Unii Europejskiej”. Z kolei ustawą konstytucyjną z 23 lipca 2008 r. ustanowiono w obu izbach parlamentu Komisję do Spraw Europejskich, która przejęła delegatury. W trakcie przeglądu regulaminu izby niższej (Règlement de l'Assemblée nationale) z 27 maja 2009 r. zwiększono liczbę członków z 36 do 48 i uproszczono procedury przyjmowania rezolucji europejskich ${ }^{43}$. Regulacje dotyczące nowych funkcji parlamentu (po 2009 r.) zostały zawarte zarówno w Konstytucji Republiki Francuskiej (art. 88-6 i art. 88-7), jak i w aktach niższego rzędu, tzn. Règlement du Sénat ${ }^{44}$ oraz Règlement de l'Assemblée nationale ${ }^{45}$.

Warto zaznaczyć, że francuska ustawa zasadnicza w 15. rozdziale bezpośrednio odwołuje się do Traktatu z Lizbony, wskazując explicite uprawnienia obu izb parlamentu, m.in. w zakresie badania zasady subsydiarności oraz wyrażenia sprzeciwu w kwestii zmiany norm dotyczących stanowienia aktów UE na podstawie uproszczonej nowelizacji traktatów lub współpracy sądowej w sprawach cywilnych. Zgodnie z nimi to rezolucje dotyczące projektów lub wniosków mogą być przyjmowane zarówno na sesjach, jak i poza nimi według regulacji wewnętrznych każdej z izb (art. 88-4). Wszelkie akty zatwierdzające ratyfikację traktatu w sprawie przystąpienia państwa do Unii Europejskiej są przedkładane w drodze referendum prezydentowi Republiki (art. 88-5). Każda izba parlamentu francuskiego może zaskarżyć do Trybunału Sprawiedliwości UE europejski akt prawny, który narusza zasadę subsydiarności. Na wniosek 60 deputowanych lub 60 senatorów zaskarżenie jest dokonywane z mocy prawa (art. 88-6). Uprawnienia obu izb parlamentu w zakresie badania zasady pomocniczości, jak i wnoszenia skargi do Trybunału Sprawiedliwości zostały zrównane.

Spośród wymienionych państw Francja posiada najliczniejszą 74-osobową reprezentację w Parlamencie Europejskim i podobnie jak polski parlament ma dwóch przedstawicieli (po każdym z izby) przy UE.

\section{PODSUMOWANIE}

Współpraca parlamentów narodowych z Parlamentem Europejskim w zakresie tworzenia prawa jest procesem złożonym i wieloetapowym. Niewątpliwie Traktat z Lizbony ożywił międzynarodowy dialog parlamentarny przyznając większy wpływ na proces decyzyjny w Unii Europejskiej i podnosząc rangę parlamentów państw członkowskich po przez zamieszczenie norm prawnych o ich roli w swojej treści. Akt ten dał również

${ }^{42}$ Les relations internationales, $<$ http://www.assemblee-nationale.fr/qui/relations-inter.pdf $>$, dostęp 28 VII 2018.

${ }^{43}$ Na podstawie informacji ze strony internetowej Zgromadzenia Narodowego Republiki Francuskiej, $<$ http://www2.assemblee-nationale.fr/15/autres-commissions/commission-des-affaires-europeennes/liens>, dostęp 28 VII 2018.

${ }_{44}$ Art. 73 regulaminu Senatu odnosi się do kompetencji Komisji Spraw Europejskich, <http://www. senat.fr/reglement/reglement_mono>, dostęp 28 VII 2018.

${ }^{45}$ Art. 151-1 - 151-12 regulaminu Zgromadzenia Narodowego odnoszą się do kompetencji Komisji Spraw Europejskich, <http://www.assemblee-nationale.fr/connaissance/reglement>, dostęp 28 VII 2018. 
impuls do dalszych zmian na tym polu, a prowadzone debaty w ramach różnych form współpracy parlamentarnych na ten temat są tego potwierdzeniem.

Zapewnienie dywersyfikacji instrumentów do współtworzenia polityki europejskiej — również tych na poziomie parlamentarnym — jest warunkiem koniecznym do dalszego wzmacniania Unii Europejskiej i pozycji państw członków. Usprawnianie współpracy dwustronnej między parlamentami państw członkowskich a PE jest korzystne dla obu stron: parlamenty państw członkowskich zyskują większy wpływ na proces decyzyjny UE i następuje umocnienie legitymacji demokratycznej Parlamentu Europejskiego. Ewolucja relacji parlamentów Polski, Francji i Szwecji z Parlamentem Europejskim pokazuje różnice w podejściu do sposobu regulacji wewnętrznych tej kwestii, odmiennym sposobie procedowania nad aktami unijnymi, rozbieżności w przyznawaniu prerogatyw poszczególnym organom izb parlamentarnych oraz zdolności wywierania wpływu na rząd w sprawach unijnych. Regulacje relacji międzyparlamentarnych mają również bezpośrednie odzwierciedlenie w danych statystycznych dotyczących liczby zgłaszanych uzasadnionych opinii (największą aktywność, jaką przyznał parlamentom narodowym Traktat z Lizbony w sferze mechanizmu wczesnego ostrzegania, przejawiał szwedzki Riksdag). Zebrane informacje na temat stosunków wybranych parlamentów państw członkowskich UE z Parlamentem Europejskim skłaniają do refleksji na temat roli parlamentów narodowych w procesie decyzyjnym Unii Europejskiej i ewentualnych możliwościach jej zwiększania.

\section{BIBLIOGRAFIA}

ŹRÓDŁA

P o l s k a

Ustawa z dnia 8 października 2010 r. o współpracy Rady Ministrów z Sejmem i Senatem w sprawach związanych z członkostwem Rzeczypospolitej Polskiej w Unii Europejskiej, Dz.U. z 2010 r. nr 213, poz. 1395.

Uchwała Sejmu Rzeczypospolitej Polskiej z dnia 30 lipca 1992 r. — Regulamin Sejmu Rzeczypospolitej Polskiej, tekst jedn. M.P. z 2012 r. poz. 32 z późń. zm.).

Uchwała Senatu Rzeczypospolitej Polskiej z dnia 23 listopada 1990 r. — Regulamin Senatu, M.P. z 2017 r. poz. 827 z późn. zm.

$\mathrm{S} z \mathrm{w}$ e c j a

The Constitution of Sweden. The Fundamental Law and the Riksdag Act, <http://www.riksda gen.se/globalassets/07.-dokument--lagar/the-constitution-of-sweden-160628.pdf>.

Fra n c j a

Constitution de la République française. Constitution du 4 octobre 1958 (Version mise à jour en janvier 2015), <http://www.assemblee-nationale.fr/connaissance/constitution.asp $>$.

Le Règlement du senat et instruction generale du bureau (mise à jour en 16 janvier 2018), $<$ http://www.senat.fr/reglement/reglement_mono.html\#toc0>.

Le Règlement de l'Assemblée nationale (mise à jour en juin 2018), <http://www.assemblee-na tionale.fr/connaissance/reglement.pdf $>$. 
Loi $n^{\circ} 79-654$ du 6 juillet 1979 modifiant l'ordonnance no 58-1000 du 17 novembre 1958 relative au fonctionnement des assemblées parlementaires en veu de la creation des delegations parlementaires pour les communautés européennes, <http://www.assemblee-nationale.fr/ europe/loi_juillet.asp $>$.

Un i a E ropej s k a

Traktat o Unii Europejskiej, wersja skonsolidowana 2016, Dz. Urz. UE 2016 C 202. Traktat o funkcjonowaniu Unii Europejskiej 2016, Dz. Urz. UE 2016 C 202, s.1.

Regulamin Parlamentu Europejskiego, VIII kadencja, lipiec 2018, <http://www.europarl.europa. eu/sides/getDoc.do?pubRef=//EP//TEXT+RULESEP+20180731+TOC+DOC+XML+V0// PL\&language $=\mathrm{PL}>$.

\section{PIŚMIENNICTWO}

Borkowski J., Role of the Poland-EU Joint Parliamentary Committee in Poland's Preparations for European Union Membership, <http://www.ce.uw.edu.pl/pliki/pw/y3-1999_Borkowski.pdf>.

Kurczuk A., Rola parlamentów narodowych $w$ świetle Traktatu Lizbońskiego, „Zeszyty Naukowe Akademii Podlaskiej w Siedlcach" 2010, nr 84.

Mik C., Pozycja prawna parlamentów narodowych w Unii Europejskiej w świetle Traktatu Lizbony, „Ruch Prawniczy, Ekonomiczny i Socjologiczny”, 2010, z. 2.

Popławska E., Rola parlamentów narodowych $w$ świetle Traktatu z Lizbony, „Przegląd Sejmowy" 2010, nr 5.

Pudło A., Funkcja europejska parlamentów państw członkowskich, „Przegląd Sejmowy” 2015, nr 1.

Remáč M., Working with national parliaments on EU affairs, European Parliamentary Research Service, PE 603.271-October 2017, <http://www.europarl.europa.eu/thinktank/en/document. html?reference=EPRS_STU\%282017\%29603271>.

Serowaniec M., Parlamentarne Komisje do Spraw Europejskich, Wydawnictwo Sejmowe, Warszawa 2016.

STRONY INTERNETOWE

Strona internetowa COSAC (Konferencja Komisji do Spraw Unijnych Parlamentów Unii Europejskiej), $<$ http://www.cosac.eu/subs-sweden>.

Strona internetowa IPEX (Międzyparlamentarna Wymiana Informacji w Sprawach UE), <http:// www.ipex.eu/IPEXL-WEB/parliaments/institution/serik.do>, The Riksdag and the European Union.

Strona internetowa Parlamentu Europejskiego, $<$ http://www.europarl.europa.eu/calendar/ca lendar?APP=PDF\&TYPE=PV2\&FILE=19970612EN.pdf\&LANGUE=EN $>$, Resolution on the relations between the European Parliament and national parliaments, T4-0319/1997, 22.02.1997.

Strona internetowa Parlamentu Królestwa Szwecji, <http:/www.riksdagen.se/en/ committees/ the-parliamentary-committees-at-work $>$.

Strona internetowa Parlamentu Zjednoczonego Królestwa Wielkiej Brytanii i Irlandii Północnej Rola parlamentów narodowych w Unii Europejskiej, <https://publications.parliament.uk/ pa/ld201314/ldselect/ldeucom/151/151.pdf>.

Strona internetowa Zgromadzenia Narodowego Republiki Francji, $<$ http://www2.assemblee-na tionale.fr/15/autres-commissions/commission-des-affaires-europeennes/liens/presenta tion-de-la-commission-des-affaires-europeennes>. 



\title{
DYSKRYMINACJA ZE WZGLĘDU NA RELIGIĘ W MIEJSCU PRACY W KONTEKŚCIE ORZECZNICTWA TRYBUNAŁU SPRAWIEDLIWOŚCI UNII EUROPEJSKIEJ
}

\author{
RELIGIOUS DISCRIMINATION IN A WORKPLACE IN VIEW \\ OF THE CASE LAW OF THE COURT OF JUSTICE \\ OF THE EUROPEAN UNION
}

The author discusses the issue of religion or belief discrimination in a workplace (private company), based on the conclusions drawn from the analysis of judgments of the Grand Chamber of the Court of Justice of the European Union of 14 March 2017 in cases of S. Achbita and A. Bougnaoui, and in the context of regulations referring to the EU Council Directive 2000/78/EC establishing a general framework for equal treatment in employment and occupation.

Słowa kluczowe: orzecznictwo TSUE, równe traktowanie, dyskryminacja z powodu religii lub przekonań, zakaz noszenia w miejscu pracy widocznych symboli politycznych, światopoglądowych lub religijnych, zakaz noszenia przez pracowników islamskiej chusty

Key words: case law of the Court of Justice of the European Union, equal treatment, discrimination because of religion or belief, internal rule of a private undertaking prohibiting the visible wearing of any political, philosophical, or religious signs, prohibition of wearing an Islamic headscarf, genuine and determining occupational requirement

* Dr hab. Jacek Falski, Polska Akademia Nauk, Instytut Nauk Prawnych, mail: <inp@inp.pan.pl>, https://orcid.org/0000-003-0893-3887

\section{WSTĘP}

$\mathrm{O}$ kreślenie dopuszczalnych według standardów UE granic i warunków, z jednej strony uzewnętrzniania, np. poprzez ubiór, przekonań religijnych w miejscu pracy (w tym przypadku w przedsiębiorstwie prywatnym), z drugiej zaś ograniczania w tym zakresie wolności religii stanowi współcześnie istotną przesłankę kształtowania ładu i pokoju religijnego, kwestii szczególnie ważnej w społeczeństwach o znaczącej i wciąż wzrastającej różnorodności wyznaniowej. Nie do przecenienia jest tu rola europejskich trybunałów: Trybunału Sprawiedliwości Unii Europejskiej [dalej: TSUE] i Europejskiego Trybunału Praw Człowieka [dalej: ETPC], które mają moc rozstrzygania, ale i moderowania pojawiających się we wskazanym obszarze konfliktów i sporów ${ }^{1}$.

Celem autora tego opracowania jest wskazanie istotnych w tym zakresie wniosków płynących z orzecznictwa, przede wszystkim na podstawie analizy dwóch kluczowych,

${ }^{1}$ W. Sobczak, Wolność myśli, sumienia i religii. Poszukiwanie standardu europejskiego, Toruń 2013, s. 275. 
stosunkowo niedawnych wyroków Wielkiej Izby $\mathrm{TSUE}^{2}$, które odbiły się szerokim echem na świecie. Stały się one przedmiotem naukowych analiz ${ }^{3}$, a przez komentatorów były z dużym uproszczeniem kwalifikowane jako upoważnienie prywatnych przedsiębiorstw do wprowadzania zakazu noszenia chust islamskich w miejscu pracy przez zatrudnione w nich kobiety wyznania muzułmańskiego. Wskazane wyroki były pierwszymi z wydanych przez Wielką Izbę luksemburskiego Trybunału w sprawach dotyczących dyskryminacji spowodowanej uzewnętrznianiem przekonań religijnych w miejscu pracy od dnia wejścia w życie dyrektywy Rady Unii Europejskiej, z 27 listopada 2000 r. [dalej: dyrektywa 2000/78/WE], ustanawiającej ogólne warunki ramowe równego traktowania w zakresie zatrudnienia i pracy ${ }^{4}$.

Dotychczasowe orzecznictwo TSUE w tym zakresie dotyczyło przede wszystkim dyskryminacji związanej z wiekiem, płcią, niepełnosprawnością, rasą, pochodzeniem etnicznym i orientacją seksualną ${ }^{5}$. Problem dyskryminacji religijnej w miejscu pracy nie był w nim dotąd poruszany.

\section{DYREKTYWA 2000/78/WE}

Warto przypomnieć ogólną definicję dyrektywy jako źródła prawa UE. Zgodnie z art. 288 Traktatu o funkcjonowaniu UE, dyrektywa jest aktem prawnym wiążącym co do rezultatu przy zachowaniu swobody w doborze form i środków implementacji (transpozycji) do krajowego porządku prawnego. Cel ten jest najczęściej określony w sposób szczegółowy, nie pozostawiając państwu zbyt dużej swobody co do zakresu czy też sposobu wypełniania tego obowiązku6. Przedmiotem wspomnianej dyrektywy jest — zgodnie z brzmieniem jej art. 1 - wyznaczenie ogólnych ram walki z dyskryminacją ze względu na religię lub przekonania, niepełnosprawność, wiek lub orientację seksualną w odniesieniu do zatrudnienia i pracy, w celu realizacji w państwach członkowskich zasady równego traktowania. W kontekście celów dyrektywy ,zasada równego traktowania" oznacza brak jakichkolwiek form bezpośredniej lub pośredniej dyskryminacji z wymienionych wcześniej przyczyn (art. 2 ust. 1).

Pojęcie dyskryminacji jest definiowane (w art. 2) dychotomicznie jako dyskryminacja bezpośrednia (ust. 2a) lub pośrednia (ust. 2b). Pierwsza występuje w przypadku,

${ }^{2}$ Wyroki Wielkiej Izby TSUE z 14 marca 2017 r. w sprawach: S. Achbita, Centrum voor gelijkheid van kansen en voor racismebestrijding $v$. G4S Sesure Solution NV, sprawa nr C-157/15; A. Bougnaoui, Association de défance des droits de l'homme (ADDH) $v$. Micropole SA, sprawa nr C-188/15.

3 Vide T. Ufarte, La liberté de concience des salariés face au culte de liberté d'entreprise prôné par C.J.U.E; Une nouvelle guerre de religion? „La Revue des Droits de l'Homme” 2017, nr 6; E. Bribosia, I. Rorive, Affaires Achbita et Bougnaoui entre neutralité et préjugés (obs. Sous C.J.U.E. Gde Ch. arrêts Achbita et Bougnaoui 14 mars 2017), „Revue Trimestrelle des Droits de l'Homme” 2017, nr 112, s. 1017 I n.

${ }^{4}$ Dyrektywa Rady 2000/78/WE z dnia 27 listopada 2000 r. ustanawiająca ogólne warunki ramowe równego traktowania w zakresie zatrudnienia i pracy, Dz.Urz. L 303 z 2.12.2000, s. 16.

${ }^{5}$ C. O'Cinneide, The Evolution and Impact of the Case - Law of the Court of Justice of the European Union on Directives 2000/43/EC and 2000/78/EC, European Network of Legal Experts in the non-discrimination field, Komisja Europejska, Bruksela 2012.

${ }^{6}$ Ustrój Unii Europejskiej, red. J. Barcz, Warszawa 2010, s. III 27-III 31. 
gdy osobę traktuje się mniej przychylnie niż traktuje się, traktowano lub traktowano by inną osobę w porównywalnej sytuacji z jakiejkolwiek przyczyny wymienionej w art. 1 dyrektywy. $Z$ dyskryminacją pośrednią mamy natomiast do czynienia w przypadku, gdy przepis, kryterium lub pozornie neutralna praktyka może doprowadzić do szczególnej, niekorzystnej sytuacji dla osób danej religii lub przekonań, niepełnosprawności, wieku lub orientacji seksualnej, w stosunku do innych osób, chyba że taki przepis, praktyka lub kryterium są obiektywnie uzasadnione zgodnym z prawem celem, a środki mające służyć jego osiągnięciu są właściwe i konieczne (art. 2 ust. 2b). Dyrektywą nie naruszono przy tym środków przewidzianych przepisami krajowymi, które w społeczeństwie demokratycznym są niezbędne w celu zapewnienia bezpieczeństwa publicznego, utrzymania porządku i zapobiegania działaniom podlegającym sankcjom karnym, ochrony zdrowia i ochrony praw i wolności innych osób (art. 2 ust. 5). Zastrzeżono ponadto (art. 4 ust. 1), że państwa członkowskie mogą uznać, że odmienne traktowanie ze względu na cechy związane z jedną z przyczyn wymienionych $\mathrm{w}$ art. 1 nie stanowi dyskryminacji w przypadku gdy ze względu na rodzaj działalności zawodowej lub warunki jej wykonania dane cechy są istotnym i determinującym wymogiem zawodowym, pod warunkiem, że cel jest zgodny z prawem, a wymóg jest proporcjonalny. Zezwolono przy tym (art. 4 ust. 2) na obowiązywanie przepisów krajowych, na mocy których w przypadku działalności zawodowej kościołów lub innych organizacji publicznych bądź prywatnych, których etyka opiera się na religii lub przekonaniach odmienne traktowanie ze względu na religię lub przekonania osobiste nie stanowi dyskryminacji, w przypadku gdy ze względu na charakter działalności lub kontekst, w którym jest prowadzona, religia lub przekonania stanowią podstawowy, zgodny z prawem i uzasadniony wymóg zawodowy, uwzględniający etykę organizacji. Tego rodzaju odmienne traktowanie powinno być realizowane z poszanowaniem zasad i postanowień konstytucyjnych państw członkowskich oraz ogólnych zasad prawa wspólnotowego. Nie może ono być usprawiedliwieniem dla dyskryminacji, u podstaw której leżą inne przyczyny. Dyrektywa nie narusza zatem prawa Kościołów i innych podmiotów prywatnych i publicznych, których etyka wynika z religii bądź przekonań.

Zgodnie z postanowieniami dyrektywy istnieje szeroki margines swobody w zakresie krajowej oceny przedmiotowych kwestii. Warto także przypomnieć, że w Karcie praw podstawowych Unii Europejskiej [dalej: KPP UE] $]^{7}$ zawarto gwarancję równości wszystkich (art. 20) i zakazano dyskryminacji, w szczególności ze względu na płeć, rasę, kolor skóry, pochodzenie etniczne lub społeczne, cechy genetyczne, język, religię lub przekonania, poglądy polityczne lub wszelkie inne poglądy, przynależność do mniejszości narodowej, majątek, urodzenie, niepełnosprawność, wiek lub orientację seksualną (art. 21 ust. 1). W KPP UE sformułowano też zasadę równości kobiet i mężczyzn: „Należy zapewnić równość kobiet i mężczyzn we wszystkich dziedzinach, w tym w zakresie zatrudnienia, pracy i wynagrodzenia" (art. 23 ust. 1) ${ }^{8}$.

${ }^{7}$ Karta praw podstawowych z 12 grudnia 2007 r., tekst skonsolidowany Dz.Urz. C 83/389 z 30.3.2010.

${ }^{8}$ Confer art. 157 ust. 3 Traktatu o funkcjonowaniu Unii Europejskiej, Dz.Urz. C/47 z 9.5.2008. 


\section{WYROKI WIELKIEJ IZBY TSUE Z 14 MARCA 2017 R. W SPRAWACH ACHBITA I BOUGNAOUI}

Wydarzenia - i w efekcie skargi będące podstawą rozpatrywanych wyroków zaszły w Belgii i we Francji, w dwóch europejskich krajach, w których kwestia dotycząca noszenia chusty — szczególnie emblematycznego symbolu wciąż mniejszościowej, ale niezwykle ekspansywnej religii muzułmańskiej — od końca ubiegłego wieku jest tematem debaty publicznej w kontekście edukacji, prawa pracy, bezpieczeństwa publicznego, a także wolności i równości religii 9 .

W obu przypadkach przedmiotem rozpatrywanych przez TSUE spraw były wnioski sądów kasacyjnych Belgii i Francji o wydanie na podstawie art. 267 Traktatu o funkcjonowaniu Unii Europejskiej wyroków w trybie prejudycjalnym w przedmiotowych postępowaniach. Wniosek belgijski dotyczący wykładni art. 2 ust. 2a dyrektywy 2000/78/WE został przedstawiony w ramach sporu między S. Achbitą, wspieraną przez Centrum Równości Szans i Zwalczania Rasizmu (Centrum voor gelijkheid van kansen en voor racismebestrijding), a zatrudniającą powódkę spółką G4S Secure Solutions NV z siedzibą w Belgii. Spór ten dotyczył wprowadzonego przez pracodawcę zakazu noszenia przez pracowników wszelkich widocznych symboli przekonań politycznych, światopoglądowych lub religijnych oraz uczestniczenia w obrzędach związanych z tymi przekonaniami. Natomiast wniosek francuski, dotyczący wykładni art. 4 ust. 1 dyrektywy, został przedstawiony w ramach sporu między A. Bougnaoui i wspierającym ją Stowarzyszeniem Obrony Praw Człowieka (Association de défense des droits de l'homme, dalej: ADDH) a Micropole SA, dotyczącego wypowiedzenia A. Bougnaoui umowy o pracę ze względu na odmówienie przez nią zdjęcia chusty islamskiej w trakcie wykonywania czynności zawodowych.

Warto poprzedzić analizę odnośnych wyroków TSUE przedstawieniem stanów faktycznych i stanowisk sądów krajowych w obu sprawach.

W pierwszej z nich S. Achbita, od trzech lat zatrudniona jako recepcjonistka w prywatnym przedsiębiorstwie ubezpieczeniowym G4S Secure Solutions NV, w maju 2006 r. poinformowała pracodawcę o zamiarze noszenia w miejscu pracy islamskiej chusty. Pracodawca był jednak temu zdecydowanie przeciwny ze względu na politykę przedsiębiorstwa, zgodnie z którą jego pracownicy w miejscu pracy powinni ubierać się

${ }^{9}$ M. Monot-Fouletier, De la régulation du port de signes religieux dans les établissements et l'espace publics - l'exemple français, „Revue Trimestrielle des Droits de l'Homme” 2016, nr 105, s. 115; J. Falski, Ograniczenia $w$ zakresie eksponowania symboliki religijnej (nowe restrykcje dotyczace ubioru) $w$ przestrzeni publicznej wspótczesnej Francji, „Przegląd Sejmowy” 2018, nr 3, s. 39. We Francji od 2004 r. obowiązuje zakaz noszenia strojów i symboli religijnych w szkołach, gimnazjach i liceach publicznych. (Loi nr 2004-228 du 15 mars 2004 encadrant en application du principe de laicité le port de signes ou de tenues manifestant une appartenance religiéuse dans les école, colleges et licées publics, „Journal Officiel” 2004, nr 65, s. 5190), a od 11 kwietnia 2011 r. (kiedy wszedł w życie) zakaz zasłaniania twarzy w miejscach publicznych (Loi nr 2010-1192 du 11 octobre interdisant la dissimulation du visage dans l'espace public, „Journal Officiel” 2010, nr 237, s. 18344. W Królestwie Belgii od 1 czerwca 2011 r. obowiązuje zakaz noszenia wszystkich ubiorów zakrywających całkowicie lub w sposób zasadniczy twarz, „Moniteur Belge” 2011, nr 2011000424, s. 41734. 
neutralnie. 29 maja 2006 r. rada zakładowa firmy zatwierdziła mającą wejść w życie 13 czerwca 2006 zmianę regulaminu, polegającą na wprowadzeniu zakazu uzewnętrzniania w pracy przekonań politycznych, światopoglądowych lub religijnych lub związanych z nimi obrzędów za pomocą symboli. Pracownica mimo to naruszała zakaz. Próba ugody między stronami, do której próbowało doprowadzić Federalne Centrum Równości i Walki z Dyskryminacją, zakończyła się porażką. S. Achbita 12 czerwca 2006 r. otrzymała wypowiedzenie umowy o pracę, wypłacono jej też stosowną odprawę. Pracownica odwołała się od wypowiedzenia do Sądu Pracy pierwszej instancji w Antwerpii, który oddalił jej odwołanie ${ }^{10}$.

Oddalono także apelację rozpatrywaną przez Sąd Pracy drugiej instancji w Antwerpii ${ }^{11}$. Sąd drugiej instancji argumentował m.in., że wypowiedzenie umowy o pracę nie może zostać uznane w tych okolicznościach za nieuzasadnione, ponieważ ogólny zakaz noszenia w miejscu pracy widocznych symboli przekonań politycznych, światopoglądowych lub religijnych nie stanowi dyskryminacji bezpośredniej, a występowanie w tym przypadku dyskryminacji pośredniej bądź naruszenie wolności osobistej lub religijnej nie jest ewidentne. Sąd apelacyjny podniósł m.in., że nie ma wątpliwości, iż umowa o pracę nie została wypowiedziana ze względu na wyznanie skarżącej, ale ze względu na jej intencję uzewnętrzniania wiary poprzez noszenie chusty islamskiej w miejscu i w czasie pracy. Naruszone przez S. Achbitę postanowienie regulaminu pracy stanowi normę o charakterze generalnym, ponieważ obowiązuje wszystkich pracowników. Nie ma zatem podstaw, aby uważać, że w przypadku pracownika w porównywalnej sytuacji mającego inne przekonania religijne lub światopoglądowe, który łamałyby postanowienia zakazu reakcja firmy G4S Secure Solutions NV, byłaby odmienna. Argument dyskryminacji bezpośredniej został w apelacji oddalony, ponieważ zakaz obejmował nie tylko symbole związane z przekonaniami religijnymi, ale również symbole związane z przekonaniami światopoglądowymi, co odpowiada kryterium ochrony zawartemu w dyrektywie 2000/78/WE, w której jest mowa o „religii lub przekonaniach”.

Powódka wniosła skargę kasacyjną od tego wyroku, w której podniosła w szczególności, że Sąd Pracy drugiej instancji w Antwerpii naruszył zawarte w art. 2 ust. 2 dyrektywy 2000/78/WE interpretacje pojęć „,dyskryminacji bezpośredniej” i „dyskryminacji pośredniej", stwierdzając, że przekonania religijne, których dotyczy wprowadzony zakaz, stanowią kryterium neutralne, oraz nie stwierdzając, że skutkiem tego zakazu jest odmienne traktowanie pracowników noszących chustę islamską w porównaniu z pracownikami, którzy takiego symbolu nie noszą, jako że zakaz ten nie jest wymierzony w określone przekonania religijne, ale adresowany do ogółu pracowników.

Warto przypomnieć, że powódkę wspierało Centrum Równości Szans i Zwalczania Rasizmu, dla którego sprawa miała charakter precedensowy. Organizacja ta chciała uzyskać skierowanie pytania prejudycjalnego do TSUE w celu wyjaśnienia warunków,

${ }_{10}$ Wyrok Sądu Pracy pierwszej instancji w Antwerpii (Arbeidsrechtbank te Antwerpen) z 27 kwietnia 2010 r., sprawa nr 06/397639/A.

${ }^{11}$ Wyrok Sądu Pracy drugiej instancji w Antwerpii (Arbeidshof te Antwerpen) z 23 grudnia 2011 r., sprawa nr 2010/AA/453. 
w jakich na pracowników prywatnego przedsiębiorstwa może zostać nałożony wymóg neutralności. Te starania zostały uwieńczone sukcesem. Belgijski sąd kasacyjny postanowił zawiesić postępowanie i zwrócić się do TSUE z następującym pytaniem prejudycjalnym: „Czy art. 2 ust. 2a dyrektywy 2000/78 należy interpretować w ten sposób, że zakaz noszenia przez muzułmankę chusty na głowie w miejscu pracy nie stanowi dyskryminacji bezpośredniej, jeżeli reguła obowiązująca u pracodawcy zakazuje wszystkim pracownikom manifestowania w miejscu pracy, za pomocą znaków, swoich przekonań politycznych, światopoglądowych i religijnych?"12. Pytanie prejudycjalne sądu kasacyjnego było zwięzłe, pominięto w nim dodatkowy zarzut powódki dotyczący dyskryminacji pośredniej w rozumieniu dyrektywy 2000/78/WE.

Wielka Izba TSUE na wstępie odrzuciła zarzut dyskryminacji bezpośredniej, uznając, że postanowienie regulaminu pracy odnoszące się do noszenia widocznych symboli przekonań politycznych, światopoglądowych lub religijnych, a zatem obejmujące wszelkie sposoby uzewnętrzniania takich przekonań, nie wprowadza w tym względzie jakiegokolwiek różnicowania. Tym samym należy uznać, że postanowienie to odnosi się do wszystkich pracowników przedsiębiorstwa, na wszystkich został bowiem nałożony obowiązek noszenia neutralnego stroju, który wyklucza możliwość noszenia symboli religijnych. W ocenie TSUE z akt sprawy nie wynikało, aby postanowienia regulaminu pracy były stosowane wobec S. Achbity w sposób odmienny niż wobec pozostałych pracowników G4S. Można zatem stwierdzić, że takim postanowieniem regulaminu pracy nie wprowadzono odmiennego traktowania $\mathrm{w}$ rozumieniu art. 2 ust. 2a. dyrektywy ${ }^{13}$.

Następnie Wielka Izba TSUE wychodząc — zgodnie zresztą z praktyką utrwaloną w swoim orzecznictwie - poza zakres pytania prejudycjalnego zadanego przez belgijski sąd kasacyjny, podniosła, że nie można wykluczyć, że sąd odsyłający może dojść do wniosku, że spornym postanowieniem regulaminu wprowadzono odmienne traktowanie, które pośrednio wynika $\mathrm{z}$ religii lub przekonań danej osoby (w rozumieniu art. 2 ust. 2 b dyrektywy 2000/78/WE) w przypadku ustalenia, że pozornie neutralny obowiązek w rzeczywistości stawia osoby wyznające określoną religię lub mające określone przekonania w niekorzystnej sytuacji ${ }^{14}$. Zbadanie tego należałoby w takim przypadku do sądu odsyłającego ${ }^{15}$. TSUE uznał $\mathrm{w}$ tym kontekście, że chęć realizowania przez przedsiębiorcę polityki neutralności politycznej, światopoglądowej lub religijnej w relacjach $\mathrm{z}$ klientami zarówno w sektorze publicznym, jak i prywatnym należy uznać za prawnie uzasadnioną. Zakazanie postanowieniem regulaminu pracy noszenia przez pracowników widocznych symboli ich przekonań politycznych, światopoglądowych lub religijnych jest bowiem właściwym środkiem do zapewnienia pożądanej polityki neutralności, pod warunkiem, że ta polityka jest faktycznie realizowana w sposób spójny i systematyczny.

12 Postanowienie belgijskiego Sądu Kasacyjnego z 9 marca 2015 r., sprawa nr S.12.00.62.N.

${ }^{13}$ Wyrok Wielkiej Izby TSUE z 14 marca 2017 r. w sprawie S. Achbita..., pkt 30-32.

${ }^{14}$ Ibidem, pkt 33-34.

${ }^{15}$ Ibidem, pkt 37, 40, 42 (vide: wyroki TSUE: z 10 marca 2009 r. w sprawie Hartlauer, sprawa nr C-169/07, pkt 55; z 12 stycznia 2010 r. w sprawie Petersena, sprawa nr C-341/08, pkt 53). 
Jeśli chodzi o uznanie konieczności wprowadzenia rozpatrywanego zakazu, to ocena zależy od tego, czy można uznać, że ogranicza się on do ścisłego minimum, tzn. dotyczy wyłącznie tych pracowników G4S, którzy wchodzą w relacje z klientami. Tylko w takiej sytuacji regulaminowy zakaz można uznać za konieczny do realizacji zamierzonego celu $^{16}$. Trybunał zwrócił też uwagę, że sąd odsyłający powinien ustalić, czy przed wypowiedzeniem stosunku pracy powódce jej pracodawca prowadził generalną i jednolitą politykę zakazującą pracownikom kontaktującym się z klientami noszenia widocznych symboli swoich przekonań ${ }^{17}$. W wyroku wskazano, że ograniczenie w pewnych granicach wolności religii w kontekście rozpatrywanego celu znajduje także potwierdzenie w orzecznictwie ETPC. Przywołano spektakularny wyrok w sprawie Eweida i inni v. Wielka Brytania ${ }^{18}$.

W drugiej ze spraw stan faktyczny był następujący. Skarżąca A. Bougnaoui w dniu 4 lutego 2008 r. została zatrudniona w prywatnym przedsiębiorstwie świadczącym usługi informatyczne Micropole SA na stanowisku inżyniera ds. badań. Na wszystkich etapach kontaktu między powódką a przedsiębiorstwem Micropole (targi studenckie, staż w tej firmie) poprzedzających jej zatrudnienie pojawiała się informacja, że noszenie przez nią chusty islamskiej (podczas stażu nosiła zwykłą chustę) może stanowić problem w relacjach z klientami spółki. Skarga klienta, który uznał, że noszenie przez powódkę chusty wywołuje uczucie skrępowania u niektórych jego pracowników — powódka świadczyła wtedy usługi w firmie klienta — spowodowała zwolnienie jej za naruszenie obowiązków pracowniczych, a zatem bez wynagrodzenia za okres wypowiedzenia. A. Bougnaoui (wsparta przez ADDH) złożyła skargę do Sądu Pracy w Paryżu, w której stwierdziła, że wypowiedzenie jej umowy było przejawem dyskryminacji. Wyrokiem z 4 maja $2011 \mathrm{r}$. sąd zasądził na jej rzecz odszkodowanie ze względu na niewskazanie w wypowiedzeniu wagi zarzucanego uchybienia, lecz oddalił powództwo w pozostałym zakresie.

Sąd apelacyjny w wyroku z 18 kwietnia 2013 r. utrzymał w mocy wyrok Sądu Pracy, uznając w szczególności, że wypowiedzenie umowy o pracę nie stanowiło dyskryminacji z powodu przekonań religijnych pracownicy, ponieważ nadal mogła je ona w przedsiębiorstwie wyrażać (tzn. w jego siedzibie poza percepcją klientów), oraz że było ono uzasadnione w kontekście prawnie uzasadnionego ograniczenia mającego chronić interesy przedsiębiorstwa, w sytuacji gdy korzystanie przez pracownicę ze swobody wyrażania swoich przekonań religijnych wykraczało poza sferę wewnętrzną przedsiębiorstwa i naruszało tym samym prawa klientów ${ }^{19}$. Sąd Kasacyjny, do którego odwołała się powódka wspierana przez ADDH, postanowił zawiesić postępowanie i zwrócić się do TSUE z następującym pytaniem prejudycjalnym: „Czy przepis art. 4 ust. 1 dyrektywy 2000/78/WE należy interpretować w ten sposób, że ze względu na rodzaj działalności zawodowej lub warunki jej wykonywania istotny i determinujący

${ }^{16}$ Ibidem, pkt 41.

17 Ibidem, pkt 39.

18 Wyrok ETPC z 15 stycznia 2013 r. w sprawie Eweida i inni v. Wielka Brytania, skargi nr: 48420/10, 59842/10, 51671/10, 36516/10.

${ }_{19}$ Wyrok Wielkiej Izby TSUE z 14 marca 2017 r. w sprawie A. Bougnaoui..., pkt 16. 
wymóg zawodowy stanowi życzenie klienta spółki doradztwa informatycznego, aby świadczenie usług informatycznych przez tę spółkę nie było już wykonywane przez pracownicę noszącą islamską chustę?"’0.

W swym wyroku Wielka Izba TSUE w związku z tym, że postanowienie sądu odsyłającego nie pozwalało na ustalenie, czy pytanie zostało zadane w związku ze stwierdzeniem, iż jest to przypadek bezpośredniej dyskryminacji w powodu przekonań religijnych, czy też przypadek dyskryminacji pośredniej, rozpatrzyła obie ewentualności. TSUE w kwestii dyskryminacji pośredniej, która mogłaby ewentualnie wynikać z wewnętrznego regulaminu przedsiębiorstwa zakazującego noszenia wszelkich widocznych symboli przekonań politycznych, światopoglądowych lub religijnych, odesłał do omówionego wcześniej wyroku w sprawie $\mathrm{S}$. Achbita $v$. G4S $\mathrm{S}^{21}$. Trybunał zajął się zaś przede wszystkim analizą zarzucanej dyskryminacji bezpośredniej z powodu religii. W tym też zakresie miał odpowiedzieć na pytanie prejudycjalne. TSUE przypomniał, że zgodnie z jego wcześniejszym orzecznictwem ${ }^{22}$ z art. 4 ust. 1 dyrektywy 2000/78/WE wynika, że istotnym i determinującym wymogiem zawodowym nie jest przyczyna, z której wynika odmienne traktowanie, ale cecha $\mathrm{z}$ tą przyczyną związana. Trybunał podkreślił ponadto, że - jak wynika z motywu 23 dyrektywy - cecha związana w szczególności z religią może stanowić istotny i determinujący wymóg zawodowy niezwykle rzadko. Zgodnie z art. 4 ust. 1 dyrektywy określona cecha może stanowić wspomniany wymóg wyłącznie ,ze względu na rodzaj działalności zawodowej lub warunki jej wykonywania”. W ocenie TSUE wszystko to wskazuje, że ,istotny, determinujący wymóg zawodowy" w rozumieniu dyrektywy 2000/78/WE obejmuje okoliczności obiektywnie podyktowane rodzajem działalności zawodowej bądź warunkami jej wykonywania. Nie może natomiast odnosić się do względów natury subiektywnej jak chęć uwzględnienia

${ }^{20}$ Postanowienie francuskiego Sądu Kasacyjnego z 9 kwietnia 2015 r., nr 630. Należy wskazać, że skarżąca zarzucała w skardze kasacyjnej, że Sąd Apelacyjny naruszył art. L1121-1, L1321-3, L 132-1 kodeksu pracy. Zgodnie z tymi przepisami „Nikt nie może ograniczać praw osobistych ani swobód indywidualnych i zbiorowych w sposób nieuzasadniony charakterem powierzonych obowiązków lub nieproporcjonalny do zamierzonego celu” (L 1121-1); „Regulamin pracy nie może zawierać: 1) postanowień sprzecznych z przepisami ustaw lub rozporządzeń lub z postanowieniami porozumień i układów zbiorowych pracy obowiązujących w przedsiębiorstwie lub zakładzie; 2) postanowień przewidujących ograniczenia praw osobistych oraz swobód indywidualnych i zbiorowych, które nie są uzasadnione charakterem powierzonych obowiązków lub nie są proporcjonalne do zamierzonego celu; 3) postanowień dyskryminujących pracowników wykazujących się takimi samymi umiejętnościami zawodowymi w odniesieniu do ich zatrudnienia lub pracy, z uwagi na ich pochodzenie, płeć, zachowanie, orientację seksualną, wiek [...], poglądy polityczne, działalność w związku zawodowym lub radzie pracowniczej, przekonania religijne, wygląd zewnętrzny, nazwisko, stan zdrowia lub niepełnosprawność” (L 1321-3); „Nikt nie może zostać wykluczony z [...], żaden pracownik nie może zostać ukarany, zwolniony lub poddany dyskryminującemu traktowaniu, niezależnie od tego, czy bezpośrednio, czy pośrednio, w rozumieniu art. 1 ustawy nr 2008-496 z dnia 27 maja 2008 r. o niektórych przepisach dostosowujących do prawa wspólnotowego $\mathrm{w}$ dziedzinie walki z dyskryminacją w szczególności odnośnie do wynagrodzenia [...], ze względu na pochodzenie, płeć, prowadzenie się, orientację lub tożsamość seksualną, wiek [...], poglądy polityczne, działalność związkową lub samopomocową, przekonania religijne, wygląd zewnętrzny, nazwisko czy stan zdrowia lub niepełnosprawność” (L 1132-1).

${ }^{21}$ Wyrok Wielkiej Izby TSUE z 14 marca 2017 r. w sprawie A. Bougnaoui..., pkt 32 i 33.

22 Przykładowo wyroki TSUE z 12 stycznia 2010 r. w sprawie Wolfe, sprawa nr C-229/08, pkt 35; z 15 listopada 2016 r. w sprawie Salaberria Sorrondo, sprawa nr C-258/15, pkt 33 i inne. 
przez pracodawcę konkretnych życzeń klienta ${ }^{23}$. Ostatecznie Wielka Izba TSUE w sentencji wyroku w sprawie A. Bougnaoui uznała, że wykładni art. 4 ust. 1 dyrektywy 2000/78/WE należy dokonywać w ten sposób, że chęć uwzględnienia przez pracodawcę życzeń klienta, aby świadczone przez niego usługi nie były już wykonywane przez pracownicę noszącą chustę islamską, nie może być uznana za istotny i determinujący wymóg zawodowy w rozumieniu tego przypisu ${ }^{24}$.

Warto wspomnieć, że kontrowersje związane z oceną muzułmańskiego zwyczaju noszenia chusty nie ominęly także samego TSUE i np. we wstępnych stanowiskach rzeczników generalnych spojrzenie i perspektywa ujęcia problemu były odmienne w obu analizowanych przypadkach ${ }^{25}$. W sprawie S. Achbita rzecznik generalny podkreślił w swej opinii delikatny charakter poddawanej rozpatrzeniu kwestii, szczególnie w Europie konfrontowanej z bezprecedensowym napływem emigrantów. Według niego w tej sytuacji najbardziej istotne jest stwierdzenie, jaką skalę różnorodności i odmienności można przyjąć w europejskim, otwartym i pluralistycznym społeczeństwie i jakiego zakresu integracji ze strony mniejszości można w zamian oczekiwać. Ocenił też, że dyskusje dotyczące chusty islamskiej były i są często niezwykle interesujące ${ }^{26}$. Natomiast w opinii rzecznika w sprawie A. Bougnaoui zawarto bardzo trafną uwagę systemową, że podnoszone w skardze kwestie nie dotyczą wyłącznie religii islamskiej czy też tylko kobiet. Noszenie ubiorów o charakterze religijnym nie ogranicza się bowiem do określonej religii ani jednej $\mathrm{płci}^{27}$.

\section{SZEROKIE UJECCIE RELIGII W INTERPRETACJI TSUE}

Obie sprawy stały się dla TSUE m.in. okazją do rozwinięcia wykładni pojęcia religii $^{28}$, stanowiącej w obu przypadkach tło sporu. Ponieważ dyrektywa 2000/78/WE nie służy w tym zakresie pomocą, Trybunał przyjął, że pojęcie „religia” zawarte w interpretowanym akcie prawnym należy interpretować szeroko, zgodnie z art. 9 ust. 1 EKPC i art. 10 ust. 1 KPP UE, zarówno jako forum internum (posiadanie i przeżywanie przekonań) jak i forum externum (manifestowanie swej wiary indywidualnie lub wspólnie z innymi, publicznie lub prywatnie). Pełnoformatowe ujmowanie pojęć „religia” tout

${ }^{23}$ Sentencja Wyroku Wielkiej Izby TSUE z 14 marca 2017 r. w sprawie A. Bouganaoui...

${ }^{24}$ Wyrok Wielkiej Izby TSUE z 14 marca 2017 r. w sprawie A. Bouganaoui..., pkt 37-40.

${ }^{25}$ Rzecznik generalny (fr. Avocat général, ang. Advocat General) jest wysokim urzędnikiem wchodzącym w skład korpusu TSUE. Rzecznik generalny wydaje opinie wstępne co do sposobu rozpatrywania spraw wpływających do Trybunału. Opinie te nie są co prawda wiążące dla sędziów TSUE, a także dla sądów krajowych, zdarza się jednak często, że treść wyroku pokrywa się z treścią opinii (szerzej vide M. Koszowski, Granice zwiazania orzecznictwem Trybunału Sprawiedliwości Unii Europejskiej, [w:] Granice państwa jako granice jurysdykcji Unii Europejskiej, red. S.M. Grochalski, Dąbrowa Górnicza 2012). Rzecznikiem generalnym w sprawie S. Achbita była J. Kokott, opinia rzecznika generalnego z 31 maja 2016 r., sprawa nr C-157/17, a w sprawie A. Bougnaoui - E. Sharpston, opinia rzecznika generalnego z 13 lipca 2016 r., sprawa nr C-188/1.

${ }^{26}$ Opinia rzecznika generalnego z 31 maja 2016..., pkt 2, 3, 4.

27 Opinia rzecznika generalnego z 13 lipca 2016..., pkt 30.

${ }^{28}$ Podobnie jak w przypadku kwestii niepełnosprawności; confer wyrok TSUE z 11 kwietnia 2013 r. w sprawie HK Danmark, sprawa nr C-335/11. 
court i „wolność religii” można uznać za jeden z elementów stabilnej linii orzeczniczej TSUE, w ramach której „,wolność myśli, sumienia i religii stanowi jeden z fundamentów społeczeństwa demokratycznego"29. Taka interpretacja wolności religii zainspirowana orzecznictwem ETPC służy możliwie najpełniejszej realizacji celu dyrektywy 2000/78/WE, a mianowicie sprzyjaniu tworzenia środowiska pracy pozbawionego dyskryminacji, i eksponuje zasadę równości ${ }^{30}$. TSUE — podobnie zresztą jak ETPC — nie analizował kwestii, czy noszenie przez skarżącą chusty można uznać za wymóg narzucony względami religijnymi. Trybunały nie chciały zajmować się tą płaszczyzną zagadnienia, bo mogłoby to narazić je na zarzut przyjmowania przez nie roli sądów wiary ${ }^{31}$. TSUE, ponownie inspirując się stanowiskiem ETPC ${ }^{32}$, przyjął subiektywną koncepcję wolności religii, uznając, że do włączenia aktu noszenia chusty w zakres ochrony przed dyskryminacją religijną (przedmiot ochrony wolności religii) wystarczy, aby zachowanie to było efektem szczerej i niezaprzeczalnej przynależności skarżącej do religii muzułmańskiej33.

\section{DYSKRYMINACJA BEZPOŚREDNIA, POŚREDNIA CZY ZWIELOKROTNIONA?}

Warto wskazać, że TSUE przy rozpatrywaniu skarg S. Achbita i A. Bougnaoui nie wziął pod uwagę innego (np. płeć, pochodzenie etniczne) niż religijny kontekstu domniemanej dyskryminacji. Tak samo zresztą procedowało sądownictwo krajowe. Tymczasem oczywiste jest, że przesłanki dyskryminacji mogą się na siebie nakładać, wzmacniać czy uzupełniać, co może prowadzić do zwielokrotnienia jej skali ${ }^{34}$. Trybunał uważa jednak - co wydaje się dyskusyjne — że jeśli nie można stwierdzić, że określona regulacja krajowa narusza zasadę równego traktowania ze względu na przesłankę

${ }^{29}$ W wyroku Wielkiej Izby TSUE z 5 września 2012 r. w sprawie Bundesrepublik Deutshland $v$. Y i Z, sprawy nr C-71/11, C-99/11) znajduje się (pkt 33) odniesienie do odwołań rzecznika generalnego dotyczących wyroku ETPC z 25 maja 1995 r. w sprawie Kokkinakis $v$. Grecja, skarga nr 14307/88. Vide też pkt 57, 70 wyroku Wielkiej Izby z 5 września w sprawie Bundesrepublik Deutshland $v$. Y i Z.

${ }^{30}$ Confer art. 20 i 21 KPP UE.

${ }^{31}$ Confer opinia rzecznika generalnego z 31 maja 2016..., pkt 34-38.

32 Confer wyroki Wielkiej Izby ETPC z 10 listopada 2005 r. w sprawie Leyla Sahin $v$. Turcja, skarga nr 44774/98, pkt 78, 111; wyrok ETPC z 15 stycznia 2013 r. w sprawie Eweida..., skargi nr: 48420/10, 59842/10, 51671/10, 35516/10, pkt 83, 84, 97.

${ }^{33}$ Uznanie, że strona pozwana wkroczyła w sferę wolności sumienia i wyznania skarżącego, dokonane na podstawie kryterium oceny szczerości jego przekonan, wydaje się jednak ryzykowne i może być zawodne. Podobny mechanizm stosował wprawdzie ETPC (confer np. wyroki Wielkiej Izby z 7 lipca 2011 r. w sprawie Bayatyan $v$. Armenia, skarga nr 23459/03). Wydaje się jednak, że będzie starał się obiektywizować tę kwestię i zamiast bazować na ocenie subiektywnych, indywidualnych przekonań, wiązać je raczej z bardziej obiektywnymi kryteriami wynikającymi z przynależności do konkretnych ugrupowań religijnych (np. wyrok ETPC z 22 listopada 2011 r. w sprawie Erçep $v$. Turcja, skarga nr 43965/04) i wynikającymi z tego faktu konsekwencjami. W tym zakresie niezwykle istotne mogą się okazać informacje uzyskane od stron trzecich postępowania np. organów decyzyjnych stowarzyszeń religijnych.

${ }^{34}$ Uwagi dotyczące tzw. dyskryminacji zwielokrotnionej zawarte są np. w punkcie 4.4 Raportu wspólnego Komisji Parlamentu Europejskiego i Rady UE o stosowaniu dyrektywy 2000/43/WE i dyrektywy 2000/78/WE z 17 stycznia 2014 r. (vide na stronie <www.egalitylaw.eu>). Także sama dyrektywa 2000/78/CE daje asumpt do takich rozważań, np. w art. 4 ust. 2 wspomina się o: „dyskryminacji, u podstaw której leżą inne przyczyny". 
rozpatrywaną pojedynczo, nie można też stwierdzić dyskryminacji, gdy przesłanki te potraktuje się kumulatywnie, nie ma bowiem dotychczas nowej kategorii dyskryminacji wynikającej z kombinacji wielu przesłanek ${ }^{35}$. Zarówno w opinii dotyczącej sprawy Achbita, jak i Bougnaoui rzeczniczki generalne przywołują jednak inne konteksty potencjalnej dyskryminacji niż Trybunał. Odwołania te nie mają, co prawda, charakteru przesądzającego, uzmysławiają jednak złożoność zagadnienia. W pierwszej z opinii zawarto sugestię, że należałoby sprawdzić, czy w tej sprawie można stwierdzić inne kryteria nierównego traktowania i czy wprowadzony zakaz jest szczególnie niekorzystny dla pracowników określonej płci, koloru skóry lub pochodzenia etnicznego. W takiej sytuacji przyjęty środek mógłby się okazać nieproporcjonalny. Rzecznik uważa jednak, że w tym przypadku taka okoliczność nie zachodziła ${ }^{36}$. W kolejnej opinii rzecznik proponował, aby TSUE przyjął punkt widzenia ETPC i w większym stopniu rozpatrywał chustę islamską jako symbol wolności kulturowej i religijnej niż symbol opresji wobec kobiet wyznania muzułmańskiego ${ }^{37}$.

W obu rozpatrywanych sprawach kluczową kwestią było określenie, z jakiego rodzaju dyskryminacją mamy do czynienia: bezpośrednią czy pośrednią. Jest to niezwykle istotne, ponieważ od tego zależy, jakie (odmienne w każdym przypadku) przesłanki czy okoliczności mogłyby ewentualnie stanowić — zgodnie z postanowieniami dyrektywy 2000/78/WE - uprawnione uzasadnienie odmiennego traktowania. Rozróżnienie z powodu religii nie stanowi dyskryminacji wyłącznie w przypadku, gdy cechy związane $\mathrm{z}$ tą przyczyną są istotnym i determinującym wymogiem zawodowym, cel jest zgodny z prawem, a wymóg proporcjonalny (art. 4 ust. 1 dyrektywy 2000/78 WE) lub gdy charakter rodzaju działalności lub kontekst jej prowadzenia sprawia, że religia lub przekonania stanowią podstawowy, zgodny z prawem i uzasadniony wymóg zawodowy (art. 4 ust. 2 dyrektywy 2000/78/WE) ${ }^{38}$. Rozróżnienie wynikające pośrednio z religii jest zaś

${ }^{35}$ Wyrok Wielkiej Izby TSUE z 24 listopada 2016 r. w sprawie David L. Parris, sprawa nr C-443/15, pkt 79-80.

${ }^{36}$ Opinia rzecznika generalnego z 31 maja 2016..., pkt 121.

37 Opinia rzecznika generalnego z 13 lipca 2016..., pkt 30. Rzecznik generalna przywołała wyrok Wielkiej Izby ETPC z 1 lipca 2014 r. w sprawie S.A.S. v. Francja, skarga nr 43835/11. ETPC uznał w tym wyroku, że areligijnie sformułowany francuski zakaz zakrywania twarzy w przestrzeni publicznej jest zgodny z EKPC i uzasadnioną ochroną wartości ,życia razem” w ramach ochrony praw i wolności innych osób, ale wyraził przy tym cały szereg uwag i zastrzeżeń co do wprowadzonego we Francji (i Belgii) zakazu i stwierdził: ,silny, negatywny wpływ na sytuację kobiet” decydujących się nosić zasłony twarzy i wiążące się z tym ryzyko „poczucia izolacji i naruszenia ich niezależności jak również możliwości korzystania z wolności uzewnętrzniania przekonań i prawa do poszanowania życia prywatnego”, a także „ryzyko przyczynienia się do umocnienia stereotypów dotyczących pewnych grup ludzi, ośmielających do przejawów nietolerancji”, wreszcie ryzyko ograniczenia ,pola pluralizmu” (wyrok Wielkiej Izby ETPC w sprawie S.A.S. v. Francja..., pkt 146, 149, 150, 153).

${ }^{38}$ Orzecznictwo ETPC dotyczące sporów wyznaniowych między pracownikami a pracodawcami jest bogate. Konflikty dotyczą z reguły właśnie etyki religijnej, którą kieruje się pracodawca. Confer np. wyroki Wielkiej Izby ETPC z 9 lipca 2013 r. w sprawie Sindicatul „Păstorul cel Brun” v. Rumunia, skarga nr 2330/09, i z 12 czerwca 2014 r. w sprawie Fernandez Martinez $v$. Hiszpania, skarga nr 56030/07; wyroki ETPC z 23 września 2010 r. w sprawach Obst $v$. Niemcy, Schüth $v$. Niemcy, skargi nr: 425/03, 1620/03; z 3 lutego 2011 r. w sprawie Siebenhaar $v$. Niemcy, skarga nr 18136/02. 
dopuszczalne wtedy, kiedy jest obiektywnie uzasadnione zgodnym z prawem celem, a środki jego realizacji są właściwe i konieczne ${ }^{39}$. Rozróżnienie to jest kluczowe i determinuje sposób rozstrzygnięcia sprawy, ale — jak widać — sądy krajowe miały wątpliwości związane z adekwatną oceną kwalifikacyjną działań objętych skargą.

W sprawie S. Achbita TSUE, podzielając interpretację rządów Francji, Wielkiej Brytanii i rzecznika generalnego, oddalił zarzut dyskryminacji bezpośredniej, a dopuścił ewentualność zaistnienia dyskryminacji pośredniej, podczas gdy rząd Belgii i Centrum Równości Szans i Zwalczania Rasizmu uznały, że w tej sprawie naruszono zakaz dyskryminacji bezpośredniej ${ }^{40}$. Trybunał stwierdził, że wprowadzone w przedsiębiorstwie G4S postanowienie regulaminu pracy zakazujące noszenia widocznych symboli przekonań politycznych, światopoglądowych lub religijnych nie było — w świetle akt sprawy - stosowane wobec powódki w sposób inny niż wobec pozostałych pracowników. Przepisy regulaminu odnosiły się do wszystkich pracowników jednakowo, na wszystkich nałożono bowiem obowiązek noszenia neutralnego stroju, który wyklucza możliwość noszenia takich symboli, jak np. chusta. Nie wprowadzono zatem zasady odmiennego traktowania bezpośrednio z powodu religii lub przekonan ${ }^{41}$.

Wydaje się, że rozumowanie TSUE we wskazanym zakresie nie wyczerpuje wszystkich kontekstów regulacji art. 2 ust. 2a dyrektywy 2000/78/WE i budzi w tym zakresie pewien niedosyt. Trybunał powinien bowiem nie tylko skontrolować, czy wprowadzona $\mathrm{w}$ przedsiębiorstwie zasada dotyczy analogicznie wszystkich pracowników, ale powinien też ustalić, czy wprowadzony punkt regulaminu (sporny zakaz) nie skutkuje mniej przychylnym traktowaniem z powodów przekonań w tym przypadku religijnych. Wprawdzie rzecznik generalna stwierdza w swej opinii, że wymóg neutralności w zakresie ubioru tak samo dotyka pracownika wierzącego, jak i zadeklarowanego ateistę, który manifestuje swe antyreligijne stanowisko poprzez ubiór lub aktywistę politycznego, który rozpowszechnia poprzez szczegóły swego ubioru partię polityczną, której jest zwolennikiem (np. przez przypinki, hasła na koszulce czy czapeczce) ${ }^{42}$. Takie stanowisko jest związane z zaproponowanym w opinii rzecznika rozróżnieniem na absolutnie zakazane powody dyskryminacji nierozerwalnie związane $\mathrm{z}$ osobą, jak np. płeć, kolor skóry, pochodzenie etniczne itd. i takie, które można „zostawić w szatni”, ponieważ wiążą się z ,zachowaniami uzależnionymi od decyzji lub subiektywnych przekonań, jak np. noszenie lub nienoszenie czapeczki" ${ }^{43}$. Zastosowanie w opinii podobnego rozróżnienia nie znajduje jednak uzasadnienia ani w treści samej dyrektywy 2000/78/WE, ani w dotychczasowym orzecznictwie TSUE, a jego praktyczne zastosowanie w odniesieniu do kwestii równie złożonej (komponent kulturowy, wychowawczy, tożsamościowy itd.) łączącej zarówno identyfikację osobistą, jak i wybór wydaje się niewłaściwe czy wręcz niemożliwe.

\footnotetext{
${ }^{39}$ Opinia rzecznika generalnego z 31 maja 2016..., pkt 39-40.

${ }^{40}$ Ibidem, pkt 41-57.

${ }^{41}$ Wyrok Wielkiej Izby TSUE z 14 marca 2017 r. w sprawie S. Achbita..., pkt 30-32.

42 Opinia rzecznika generalnego z 31 maja 2016..., pkt 52.

${ }^{43}$ Ibidem, pkt 45.
} 
Odmienną perspektywę rozumowania przyjęła druga rzecznik generalna, podkreślając w opinii w sprawie Bougnaoui, że: „Dla adeptów praktykujących religię identyfikacja religijna stanowi integralną część jestestwa. Wymogów wiary, dyscypliny i zasad życia, które narzuca, nie stosuje się tylko wtedy, kiedy nie przebywa się w miejscu pracy (np. wieczorem czy podczas weekendu dla tych, którzy pracują w biurze), ale można je grzecznie odrzucić w czasie godzin pracy”; „Można by pomylić się, sądząc, że o ile w pewnym sensie płeć lub kolor skóry towarzyszą osobie wszędzie, to religia już nie"; „Na tej podstawie nie można nie uznać, że pani Bougnaoui była traktowana w sposób mniej korzystny ze względu na swą wiarę niż inna osoba niebędąca w porównywalnej sytuacji. Inżynier ds. badań pracujący w Micropole, który nie zdecydowałby się na manifestowanie swoich przekonań religijnych przez noszenie szczególnego stroju, nie zostałby zwolniony. Zwolnienie pani Bougnaoui stanowi więc dyskryminację bezpośrednią z powodu przekonań religijnych, zgodnie z rozumieniem art. 2 ust. 2a dyrektywy 2000/78/WE" ${ }^{\prime 4}$.

TSUE w sprawie S. Achbita uznał, że sporne postanowienie regulaminu pracy nie skutkowało dyskryminacją bezpośrednią z powodu religii lub przekonań, zgodnie z rozumieniem art. 2 ust. 2a dyrektywy 2000/78/WE. Opierając się jednak na rozumowaniu przedstawionym przez rzecznik generalną $\mathrm{w}$ sprawie A. Bougnaoui, równie dobrze mógłby np. uznać, że powódka S. Achbita znajduje się w sytuacji porównywalnej z kolegami, których religia bądź ateizm nie wymagają wyrażania się przez noszenie widocznych symboli. Dlatego też zwolnienie z pracy S. Achbity oznacza dla niej mniej przychylne traktowanie z powodu religii. Ponieważ religia i przekonania są objęte ochroną przed jakąkolwiek formą dyskryminacji (art. 2 ust. $1 \mathrm{w}$ powiązaniu z art. 1 dyrektywy 2000/78/WE), postanowienie regulaminu pracy, którym narzucono pracownikom zakaz noszenia $w$ miejscu pracy widocznych symboli m.in. religijnych będących elementem ich identyfikacji, stanowi przejaw dyskryminacji bezpośredniej z powodu religii, z wyjątkiem przypadku, gdy ze względu na rodzaj działalności zawodowej lub warunki jej wykonywania, dane cechy są istotnym i determinującym wymogiem zawodowym, pod warunkiem, że cel jest zgodny z prawem, a wymóg jest proporcjonalny.

Wszystko zależy więc od dość płynnego w tej sytuacji określenia progu ochrony uzależnionego od subiektywnej kwalifikacji rodzaju dyskryminacji. Niemożliwe jest, co oczywiste, uznanie za dyskryminację bezpośrednią wszystkich regulacji zakazujących takich czy innych zachowań wynikających z przekonań religijnych. Trudno byłoby np. zakwalifikować tak stanowisko pracodawcy, który zwalnia pracownika odmawiającego wykonania obowiązku służbowego z powodu swoich przekonań.

Warto przypomnieć, że w trakcie wydarzeń stojących u podstaw zwolnienia S. Achbita nie było jeszcze w regulaminie pracy przedsiębiorstwa G4S wymogu w sprawie neutralnego ubioru, a pytanie prejudycjalne belgijskiego Sądu Kasacyjnego sformułowano

${ }_{44}$ Opinia rzecznika generalnego z 13 lipca 2016..., pkt 118. Warto wspomnieć, że TSUE w wyroku z 16 lipca 2015 r. (sprawa nr 83/14) w sprawie CEZ Razpredelenie Byłgarija AD, w pkt 82 wskazał, że działania wskazanego przedsiębiorstwa wynikające ze stereotypów lub przesądów wobec określonej grupy osób stanowią przesłankę dyskryminacji bezpośredniej ze względu na pochodzenie etniczne (romskie). 
w sposób lakoniczny, nie podano też wystarczająco dużo informacji o kontekście sporu. Pozornie neutralna regulacja mogła być w rzeczywistości skierowana przeciwko konkretnym osobom bądź ich grupom, sąd powinien więc dążyć do wskazania konieczności sprawdzenia (przez sąd krajowy) czy sporny zakaz nie wynikał ze stereotypów lub uprzedzeń wobec jednej lub wielu określonych religii bądź nawet wobec przekonań religijnych (ich wyrażania) jako takich. Rzecznik generalna uznała, że w takich przypadkach ,należałoby bez wątpienia stwierdzić dyskryminację bezpośrednią z powodu religii” ${ }^{45}$.

Natomiast w sprawie A. Bougnaoui rzecznik generalna mimo pewnych braków w opisie stanu faktycznego zawartego we wniosku sądu krajowego uznała, że odmienne traktowanie powódki ze względu na religię stanowi dyskryminację bezpośrednią. Rzecznik przeprowadziła dodatkowo analizę przypadku w kontekście dyskryminacji pośredniej, na wypadek gdyby Trybunał nie podzielił jej stanowiska. TSUE uznał jednak, że kwalifikowanie ewentualnej dyskryminacji należy do sądu odsyłającego, tzn. do francuskiego Sądu Kasacyjnego. Z sentencji wyroku wynika jednak, że TSUE uznał, że w tym przypadku tylko wystąpienie istotnego i determinującego wymogu zawodowego mogłoby usprawiedliwić dyskryminację bezpośrednią ${ }^{46}$.

Z jednej strony w regulacjach dyrektywy 2000/78/WE dopuszczono w określonych przypadkach (art. 4 ust. 2) odmienne traktowanie z powodu religii lub przekonań, uznając, że nie stanowi to dyskryminacji w określonych okolicznościach, z drugiej zaś neutralność służby publicznej (wliczając w to przedsiębiorstwa prywatne wykonujące zadania zlecone) w wielu krajach UE jest standardem, choć treść tego pojęcia, szczególnie w kontekście wymogów wobec pracowników, nie jest do końca jasna. Według jednych noszenie przez pracowników czy funkcjonariuszy w miejscu pracy symboli religijnych jest równoznaczne $\mathrm{z}$ wyrażaniem preferencji państwa w tym zakresie, inni zaś uznają takie zachowanie wyłącznie za ekspresję osobistych przekonań pracownika.

\section{NEUTRALNOŚĆ W PRZEDSIĘBIORSTWIE PRYWATNYM}

Neutralność w przedsiębiorstwach należących do sektora prywatnego i niewykonujących zadań zleconych przez państwo jest kwestią bardziej złożoną. Wyroki TSUE w sprawach S. Achbita i A. Bouganaoui pogłębiły wiedzę w zakresie precyzyjnej oceny neutralności, jaką może narzucić — zgodnie z dyrektywą 2000/78/WE - pracodawca prywatny ${ }^{47}$. Nie sformułowano $w$ nich natomiast $w$ pełni czytelnych wskazań $w$ tym

${ }^{45}$ Opinia rzecznika generalnego z 31 maja 2016..., pkt 55.

${ }^{46}$ Wyrok Wielkiej Izby TSUE z 14 marca 2017 r. w sprawie A. Bougnaoui...

${ }^{47}$ Zarówno w Belgii, jak i we Francji w regulaminach pracy mnożą się klauzule dotyczące neutralności w zakresie ubioru. Kwestie te są żywo dyskutowane. We Francji szczególnie głośna była sprawa Fatimy X., pracownicy prywatnego żłobka, zwolnionej z pracy z powodu naruszenia wewnętrznego regulaminu stowarzyszenia prowadzącego placówkę. Wykroczenie polegało na odmowie zdjęcia islamskiej chusty noszonej przez pracownicę w miejscu pracy. Sąd uznał m.in., że ,zasady laickości nie stosuje się do pracowników zatrudnionych przez prywatnego pracodawcę, który nie wykonuje zadań zleconych w ramach służby publicznej”. Wynika z tego, że ,przepis regulaminu wewnętrznego wprowadzający ogólne i nieprecyzyjne ograniczenia nie spełnia wymogów [...] kodeksu pracy i w związku z tym decyzja o zwolnieniu zatrudnionej z pracy pozbawiona jest mocy prawnej”. Sąd Kasacyjny w Paryżu 
zakresie $^{48}$. Dyrektywą wprowadzono teoretycznie dwie drogi (wyjątki) umożliwiające wdrażanie w prywatnym przedsiębiorstwie programowej neutralności bez ryzyka narażenia na uznanie takiej praktyki za dyskryminującą wobec pracowników, którzy uważają, że narusza ona ich prawo do wolności religii i przekonań. Jedna z nich wiedzie — jak się wydaje — przez uznanie, że neutralność czy też wiążące się z nią konsekwencje są istotnym i determinującym wymogiem zawodowym, pod warunkiem, że cel jest zgodny z prawem, a wymóg proporcjonalny. Z drugą mamy zaś do czynienia, kiedy organizacja publiczna bądź prywatna kieruje się w działalności zawodowej zasadami neutralności. Trzeba dodać, że takie same uprawnienia mają na mocy dyrektywy Kościoły i inne organizacje publiczne i prywatne, których podstawę działalności stanowi religia.

Oba analizowane wyroki TSUE nie odpowiadają jednak na pytanie, czy pojawiające się w dyrektywie regulacje można interpretować w kontekście zasady neutralności w zarysowany wcześniej sposób. Takie rozumowanie mogła jednak uzasadniać treść uwagi 24 do dyrektywy 2000/78/WE, zgodnie z którą: „Unia Europejska w swojej deklaracji nr $11 \mathrm{w}$ sprawie statusu kościołów i organizacji niewyznaniowych, dołączonej do Aktu końcowego Traktatu z Amsterdamu, wyraźnie stwierdziła, że Unia Europejska szanuje i nie narusza statusu, z którego korzystają, na mocy prawa krajowego, Kościoły i stowarzyszenia lub wspólnoty religijne w państwach członkowskich. Unia Europejska szanuje również status organizacji filozoficznych i niewyznaniowych. Uwzględniając powyższe, państwa członkowskie mogą utrzymywać lub wprowadzać zgodne z prawem i uzasadnione postanowienia szczególne dotyczące podstawowych wymagań zawodowych, które mogą być stawiane w zakresie prowadzenia działalności zawodowej" ${ }^{4}$. Wprawdzie deklaracja UE nr 11 została przyjęta pod wpływem żądań Kościoła, ale jej treść wskazuje na wolę zagwarantowania równości w zakresie uznania i konsekwencji statusu organizacji, bez względu

uznał też, że żłobek został przez sąd apelacyjny w Paryżu mylnie zakwalifikowany jako przedsiębiorstwo o charakterze laickim, ponieważ zadaniem tej placówki nie było szerzenie przekonań religijnych lub filozoficznych, ale przyjmowanie dzieci bez względu na różnice wyznaniowe (wyrok francuskiego Sądu Kasacyjnego z 19 marca 2013 r. i 25 czerwca 2014 r. w sprawie Fatima X v. Association Baby Loup, sprawy nr: 11-28.845, 13-28.369). Fatima X. złożyła w tej sprawie pozew przeciwko Francji w Komitecie Praw Człowieka ONZ, który 10 sierpnia 2018 r. wydał opinię, w której stwierdzał, że zwolnienie pracownicy żłobka ze wskazanych w wypowiedzeniu przyczyn narusza jej prawo do wolności religii, Francja nie wykazała bowiem, że noszenie chusty islamskiej w odnośnej placówce prowadziło do naruszenia podstawowych praw dziecka. Komitet rekomendował w tej sprawie wypłacenie stosownego odszkodowania. Na marginesie warto wspomnieć, że we Francji znowelizowany niedawno (tzw. ustawą El Khamiri) kodeks pracy (art. L 1321-2-1) zezwala na wpisanie do regulaminu wewnętrznego prywatnego przedsiębiorstwa zasady neutralności i do ograniczenia możliwości manifestowania przez pracowników ich przekonań ,jeśli ograniczenia te są uzasadnione korzystaniem z innych wolności i praw podstawowych lub koniecznością dobrego funkcjonowania przedsiębiorstwa".

${ }^{48}$ Rzecznik generalny w swojej opinii z 13 lipca 2016 r. wyklucza nawet — z powodu zakresu działalności - możliwość przyznania statusu prywatnej organizacji, której etyka opiera się na przekonaniach, takiemu przedsiębiorstwu, jak Micropole SA (pkt 106).

${ }^{49}$ Dyrektywa Rady 2000/78/WE..., uwaga 24. 
na ich charakter: wyznaniowy czy też wynikający z innych przesłanek etycznych. Ewidentne jest, że w kontekście wyroku TSUE w sprawie Bougnaoui cecha związana w szczególności z religią może stanowić istotny i determinujący wymóg zawodowy tylko w bardzo ograniczonej liczbie przypadków ${ }^{50}$, jeśli taki wymóg jest podyktowany rodzajem danej działalności zawodowej lub warunkami jej wykonywania. Nie dotyczy to natomiast przypadków o charakterze subiektywnym, jak np. wola uwzględnienia przez pracodawcę konkretnych życzeń klienta ${ }^{51}$. Wynika z tego, że opinie klientów prywatnego przedsiębiorstwa nie mogą stanowić usprawiedliwienia dla działań przedsiębiorstwa, które mogą zostać uznane za dyskryminujące pracownika.

W wyroku w sprawie S. Achbita TSUE uznał natomiast, że wolę realizowania przez przedsiębiorstwo polityki neutralności politycznej, światopoglądowej lub religijnej w relacjach z klientami należy uznać za cel prawnie uzasadniony, zwłaszcza jeśli w jego realizację zaangażowani są wyłącznie pracownicy, których zadaniem jest nawiązywanie kontaktów z klientami tego przedsiębiorstwa. TSUE oznajmił też w tym wyroku, że urzeczywistnianie wskazanego celu, tzn. realizacji przez przedsiębiorcę polityki neutralności, pozwala w pewnych granicach na ograniczenie wolności religii, co znajduje potwierdzenie w orzecznictwie ETPC dotyczącym art. 9 EKPC $^{52}$. TSUE przywołuje tu spektakularny wyrok ETPC z 15 stycznia 2013 r., w sprawie Eweida i inni v. Wielka Brytania $^{53}$. Jednak warto wskazać, że w pkt 94 wyroku ETPC, do którego TSUE się odwołuje, Trybunał w Strasburgu uznał wprawdzie, że cel ochrony wizerunku marki handlowej (British Airways) jest uprawniony, ale uczynił to po to, aby skonstatować, że orzecznictwo krajowe nadało mu zbyt dużą wagę w porównaniu z prawami skarżącej wynikającymi z art. 9 EKPC.

ETPC podniósł też fakt, że towarzystwo lotnicze zmieniło obowiązujący regulamin w zakresie dopuszczalnego odzienia, umożliwiając noszenie w sposób jawny biżuterii mającej charakter religijny, co dowodzi, że wcześniejszy zakaz nie miał istotnego znaczenia. Ostatecznie ETPC uznał, że pozwany kraj nie zapewnił wystarczającej ochrony prawa skarżącej do manifestowania swej religii, naruszając art. $9 \mathrm{EKPC}^{54}$.

Wyrok TSUE w sprawie S. Achbita wskazuje, że przedsiębiorstwo prywatne działające w ramach wolności gospodarczej może wdrażać zasadę neutralności, nawet jeśli generuje to dyskryminację pośrednią, o ile dyskryminacja ta jest usprawiedliwiona okolicznościami wymienionymi w art. 2 ust. 2b dyrektywy 2000/78/WE. Trybunał określił ponadto granicę takiej kwalifikacji. Po pierwsze, musi być przestrzegana

${ }^{50}$ Wyrok Wielkiej Izby TSUE z 14 marca 2017 r. w sprawie A. Bougnaoui..., pkt 38.

${ }^{51}$ Ibidem, pkt 40.

52 Wyrok Wielkiej Izby TSUE z 14 marca 2017 r. w sprawie S. Achbita..., pkt 37-39. Jak wiadomo, w art. 16 KPP UE uznano wolność prowadzenia działalności gospodarczej zgodnie z prawami Unii oraz ustawodawstwami i praktykami krajowymi.

${ }^{53}$ Wyrok ETPC z 15 stycznia 2013 r. w sprawie Eweida..., pkt 94, 95. Vide G. Gonzales, L'éléphant dans le magasin de porcelaine: entrée remarquée des manifestations de la liberté de religion sur lieu du travail (Cour eur. dr h. Eweida e.a.c. Reyaume - Uni 15 janvier 2013), „Revue Trimestrielle des Droits de l'Homme" 2013, nr 96, s. 975.

${ }^{54}$ Wyrok ETPC z 15 stycznia 2013 r. w sprawie Eweida..., pkt 94, 95. 
zasada proporcjonalności, tzn. że postanowienia regulaminu pracy przedsiębiorstwa, w których przewidziano całkowity zakaz noszenia w miejscu pracy widocznych symboli politycznych, światopoglądowych lub religijnych, są obiektywnie uzasadnione zgodnym z prawem celem, takim jak realizowana przez pracodawcę polityka neutralności w relacjach z klientami, a środki służące realizacji tego celu są właściwe i konieczne (czego zbadanie każdorazowo należy do właściwego sądu) ${ }^{55}$. Po wtóre, sporny zakaz ,jest dozwolony czy tolerowany”, tylko jeśli wynika z polityki neutralności realizowanej w sposób spójny i systematyczny ${ }^{56}$ i ogranicza się do koniecznego minimum, tzn. dotyczy wyłącznie tych pracowników, którzy wchodzą w relacje z klienta$\mathrm{mi}^{57}$. TSUE wskazuje też, że sąd krajowy powinien uwzględniać interesy wszystkich zainteresowanych - odpowiednio do materiału dowodowego — oraz zapewnić, że ograniczenia rozpatrywanych wolności (wolność religii, zakaz dyskryminacji) nie będą wykraczać poza to, co jest absolutnie konieczne ${ }^{58}$. Sąd krajowy w szczególności powinien ustalić, czy uwzględniając ograniczenia, jakim podlega przedsiębiorca i bez nakładania na niego dodatkowych ciężarów, możliwe jest zamiast rozwiązania stosunku pracy z pracownicą, odmawiającą zdjęcia islamskiej chusty czy też innego zabronionego w regulaminie pracy symbolu, zaproponować jej inne stanowisko, niewymagające kontaktów z klientami ${ }^{59}$.

\section{PODSUMOWANIE}

W przywoływanym przez TSUE wyroku ETPC w sprawie Eweida $v$. Wielka Brytania strasburski Trybunał uznał naruszenie przez pozwany kraj art. 9 EKPC, mimo ze pracodawca (British Airwais) zaproponował skarżącej, odmawiającej zdjęcia katolickiego krzyżyka inne stanowisko pracy niewymagające kontaktu z klientami. Tym samym można uznać, że ETPC wzmocnił standard ochrony wolności religii w zakresie jej pozytywnego manifestowania w miejscu pracy przez noszenie symbolu określonego wyznania. Trybunał odszedł też w tym wyroku od aksjomatycznie dotąd traktowanego argumentu, że przedstawienie alternatywy w formie zmiany miejsca pracy wyklucza skuteczność powoływania się skarżących na sprzeciw sumienia, włączając przesłankę możliwości zmiany pracy do okoliczności stanowiących przedmiot testu proporcjonalności przeciwstawnych interesów, przez co utraciła ona swoje dotychczasowe samoistne i determinujące znaczenie ${ }^{60}$.

55 Wyrok Wielkiej Izby TSUE z 14 marca 2017 r. w sprawie S. Achbita..., sentencja.

56 Ibidem, pkt 40.

${ }^{57}$ Ibidem, pkt 41-42.

58 Ibidem, pkt 43.

59 Ibidem, pkt 43.

${ }^{60}$ Wyrok ETPC z 15 stycznia 2013 r. w sprawie Eweida..., pkt 94, 95, sentencja. Wyrok ten był przełomowy, jeśli chodzi o zerwanie z aksjomatem ,podporządkuj się albo odejdź”, zgodnie z którym utożsamiano ostateczne gwarancje pracownika do wolności religii z wolnością odejścia z pracy, jeśli nie może on ze względów religijnych podporządkowywać się obowiązkom. Vide też M. Biddulph, D. Newman, Eweida v. United Kingdom (European Court of Human Rights), „Australian International Law Journal” 2013, t. 20, s. 183 i n. 
Wyrok TSUE odzwierciedla podobną tendencję, chociaż według jednych jest „mniej łaskawy” dla wolności religii w miejscu pracy lub sprzyja realizacji polityki neutralności, jak uważają inni ${ }^{61}$. Warto zwrócić też uwagę, że analizowane wyroki ETPC i TSUE dotyczą symboli odmiennych wyznań. TSUE nie chciał jednak wikłać się w kwestie etnicznego i płciowego kontekstu spornego symbolu religijnego, co być może zwielokrotnia zagrożenie dyskryminacyjne i jest — jak się wydaje — sprzeczne $\mathrm{z}$ wartościami UE, przynajmniej w dotychczas obowiązującej formule. Mimo tych wątpliwości i zastrzeżeń analizowane wyroki stanowią dla przedsiębiorstw prywatnych znaczącą pomoc przy interpretowaniu odnośnych postanowień dyrektywy 2000/78/WE.

\section{BIBLIOGRAFIA}

\section{ŹRÓDŁA}

Dyrektywa Rady 2000/78/WE z dnia 27 listopada 2000 r. ustanawiająca ogólne warunki ramowe równego traktowania w zakresie zatrudnienia i pracy, Dz.Urz. L 303 z 2.12.2000 r.

Karta praw podstawowych z 12 grudnia 2007 r., tekst skonsolidowany Dz.Urz. C 83/389 z 30.03.2010 r.

Loi $\mathrm{nr}$ 2010-1192 du 11 octobre interdisant la dissimulation du visage dans l'espace public, „Journal Officiel” 2010, nr 237.

„Moniteur Belge” 2011, nr 2002.

Opinia rzecznika generalnego z 13 lipca 2016 r., sprawa nr C-188/1.

Opinia rzecznika generalnego z 31 maja 2016 r., sprawa nr C-157/17.

Raport wspólny Komisji Parlamentu Europejskiego i Rady UE o stosowaniu dyrektywy 2000/43/WE i dyrektywy 2000/78/WE z 17 stycznia 2014 r.

Traktat o funkcjonowaniu Unii Europejskiej, Dz.Urz. C/47 z 9.05.2008 r.

\section{ORZECZNICTWO}

S ąd y K a s a c y ne

Postanowienie belgijskiego Sądu Kasacyjnego z 9 marca 2015 r., sprawa nr S.12.00.62.N.

Postanowienie francuskiego Sądu Kasacyjnego z 9 kwietnia 2015 r., nr 630.

Wyroki francuskiego Sądu Kasacyjnego z: 19 marca 2013 i 25 czerwca 2014 r. w sprawie Fatima X v. Association Baby Loup, sprawa nr 11-28.845.

Wy roki E T P C

Wyrok ETPC z 25 maja 1995 r. w sprawie Kokkinakis v. Grecja, skarga nr 14307/88.

Wyrok Wielkiej Izby ETPC z 10 listopada 2005 w sprawie Leyla Sahin v. Turcja, skarga nr 44774/98.

Wyrok ETPC z 23 września 2010 r. w sprawie Schüth $v$. Niemcy, skarga nr 1620/03.

Wyrok ETPC z 23 września 2010 r. w sprawie Obst $v$. Niemcy, skarga nr 425/03.

${ }^{61}$ E. Spaventa, What is the point of minimum harmonization of fundamental rights? Some further reflections on the Achbita case, EU Law Analysis, marzec 2017 (<http://eulawanalysis.blogspot.be>, dostęp $1 \mathrm{X}$ 2018); T. Ufarte, La Liberté de conscience des salariés face au culte de la liberté d'entrepise prôné par la C.J.U.E. Une nouvelle guerre de religion?, „La Revue des Droits d l'Homme” $2017<$ http://revdh. revues.org/3056>, dostęp 1 X 2018. 
Wyrok ETPC z 3 lutego 2011 r. w sprawie Siebenhaar $v$. Niemcy, skarga nr 18136/02.

Wyroki Wielkiej Izby ETPC z 7 lipca 2011 r. w sprawie Bayatyan v. Armenia, skarga nr 23459/03.

Wyrok ETPC z 22 listopada 2011 r. w sprawie Erçep $v$. Turcja, skarga nr 43965/04.

Wyrok ETPC z 15 stycznia 2013 r. w sprawie Eweida i inni v. Wielka Brytania, skargi nr: 48420/10, 59842/10, 51671/10,35516/10.

Wyrok Wielkiej Izby ETPC z 9 lipca 2013 r. w sprawie Sindicatul „Păstorul cel Brun” v. Rumunia, skarga nr 2330/09.

Wyrok Wielkiej Izby ETPC z 12 czerwca 2014 w sprawie Fernandez Martinez v. Hiszpania, skarga nr 56030/07.

Wyrok Wielkiej Izby ETPC z 1 lipca 2014 r. w sprawie S.A.S. v. Francja, skarga nr 43835/11.

S ąd y pracy

Wyrok Sądu Pracy pierwszej instancji w Antwerpii z 27 kwietnia 2010 r., sprawa nr 06/ 397639/A.

Wyrok Sądu Pracy drugiej instancji w Antwerpii z 23 grudnia 2011 r, sprawa nr 2010/AA/453.

Wy rok i T S U E

Wyrok TSUE z 10 marca 2009 r. w sprawie Hartlauer, sprawa nr C-169/07.

Wyrok TSUE z 11 kwietnia 2013 r. w sprawie HK Danmark, sprawa nr C-335/11.

Wyrok TSUE z 12 stycznia 2010 r. w sprawie Petersen, sprawa nr C-341/08.

Wyrok TSUE z 12 stycznia 2010 r. w sprawie Wolfe, sprawa nr C-229/08.

Wyrok TSUE z 15 listopada 2016 r. w sprawie Salaberria Sorrando, sprawa nr C-258/15.

Wyrok TSUE z 16 lipca 2015 r. w sprawie CEZ Razpredelenie Byłgarija AD, sprawa nr 83/14.

Wyrok Wielkiej Izby TSUE z 14 marca 2017 r. w sprawie Asma Bougnaoui, Association de défense des droits de l'homme (ADDH) $v$. Micropole SA, sprawa nr C-188/15.

Wyrok Wielkiej Izby TSUE z 14 marca 2017 r. w sprawie Samira Achbita, Centrum voor gelijkheid van kansen en voor racismebestrijding v. G4S Sesure Solution NV, sprawa nr C-157/15.

Wyrok Wielkiej Izby TSUE z 24 listopada 2016 r. w sprawie David L. Parris, sprawa nr C-443/15. Wyrok Wielkiej Izby TSUE z 5 września 2012 r. w sprawie Bundesrepublik Deutshland v. Y i Z, sprawy nr C-71/11, C 99/11.

PIŚMIENNICTWO

Biddulph M., Newman D., Eweida v. United Kingdom (European Court of Human Rights), „Australian International Law Journal” 2013, t. 20.

Bribosia E., Rorive I., Affaires Achbita et Bougnaoui entre neutralité et préjugés (obs. Sous C.J.U.E. Gde Ch. Arrêts Achbita et Bougnaoui 14 mars 2017), ,Revue Trimestrelle des Droits de l'Homme" 2017, nr 112.

Gonzales G., L'éléphant dans le magasin de porcelaine: entrée remarquée des manifestations de la liberté de religion sur lieu du travail (Cour eur. dr. h. Eweida e.a.c. Reyaume - Uni 15 janvier 2013), „Revue Trimestrielle des Droits de l'Homme” 2013, nr 96.

Falski J., Ograniczenia w zakresie eksponowania symboliki religijnej (nowe restrykcje dotyczace ubioru) w przestrzeni publicznej współczesnej Francji, „Przegląd Sejmowy” 2018, nr 3, s. 39.

Koszowski M., Granice związania orzecznictwem Trybunału Sprawiedliwości Unii Europejskiej, [w:] Granice państwa jako granice jurysdykcji Unii Europejskiej, red. S.M. Grochalski, Wydawnictwo WSB, Dąbrowa Górnicza 2012.

Monot-Fouletier M., De la régulation du port de signes religieux dans les établissements et l'espace publics - l'exemple français, „Revue Trimestrielle des Droits de l'Homme” 2016, nr 105. 
O'Cienneide C., The Evolution and Impact of the Case - Law of the Court of Justice of the European Union on Directives 2000/43/EC and 2000/78/EC, European Network of Legal Experts in the non-Discrimination field, Komisja Europejska, Bruksela 2012.

Sobczak W., Wolność myśli, sumienia i religii. Poszukiwanie standardu europejskiego, Dom Wydawniczy Duet, Torun 2013.

Spaventa E., What is the point of minimum harmonization of fundamenthal rights? Some further reflections on the Achbita case, EU Law Analysis, <http://eulawanalysis.blogspot.be>, marzec 2017.

Ufarte T., La liberté de concience des salariés face Au culte de liberté d'entreprise prôné par C.J.U.E; Une nouvelle guerre de religion? „La Revue des Droits de l'Homme” 2017, nr 6. Ustrój Unii Europejskiej, red. J. Barcz, Instytut Wydawniczy EuroPrawo, Warszawa 2010. 


\title{
SKARGA NADZWYCZAJNA - DOPELNIAJĄCY CZY KONKURENCYJNY WOBEC SKARGI KONSTYTUCYJNEJ INSTRUMENT OCHRONY KONSTYTUCYJNYCH WOLNOŚCI I PRAW JEDNOSTKI
}

\author{
EXTRAORDINARY COMPLAINT - A SUPPLEMENTING OR COMPETING INSTRUMENT \\ OF PROTECTING CONSTITUTIONAL FREEDOMS AND RIGHTS OF AN INDIVIDUAL \\ VIS-À-VIS THE CONSTITUTIONAL COMPLAINT
}

On 3 April 2018, a new law on the Supreme Court went into force, introducing a new institution - an extraordinary complaint. According to the intention of its authors, the construction of extraordinary complaint emphasises the need for the courts to respect constitutional principles and constitutionally protected freedoms, as well as human and civil rights. Not referring here to the aims, needs and anticipated effects of the functioning of this instrument in the legal system of Poland - taking into account the shape of the extraordinary complaint adopted by the legislator - it should be regarded as complementing the constitutional complaint (at least in the field of civil and criminal law) and an instrument to increase the effectiveness of protection of constitutional freedoms and individual rights. It is necessary to wait for the assessment of the introduction of this measure into the Polish legal system. At the same time, one cannot lose sight of fears and doubts raised against this instrument in the course of legislative procedure. However, if the extraordinary complaint supplements the constitutional complaint in those areas where the latter - due to its legal or practical limitations - is not effective, introduction of the same or similar institution into administrative proceedings shall be considered.

Słowa kluczowe: skarga konstytucyjna, skarga nadzwyczajna, prawa i wolności jednostki, zasady konstytucyjne, Sąd Najwyższy, Trybunał Konstytucyjny, stosowanie prawa, kontrola zgodności prawa z konstytucją

Key words: constitutional complaint, extraordinary complaint, individual rights and freedoms, constitutional principles, Supreme Court, Constitutional Tribunal, application of law, review of the constitutionality of law

* Dr Anna Michalak, Uniwersytet Łódzki, Wydział Prawa i Administracji, adiunkt w Katedrze Prawa Konstytucyjnego, amichalak@wpia.uni.lodz.pl, https//orcid.org/0000-0001-7430-5817

\section{WSTĘP}

Z dniem 3 kwietnia 2018 r. weszła w życie ustawa o Sądzie Najwyższym', którą wprowadzano nową instytucję — skargę nadzwyczajną. Zgodnie z intencją projektodawcy konstrukcja tej skargi uwypukla konieczność respektowania przez sądy przy orzekaniu zasad konstytucyjnych oraz chronionych konstytucyjnie wolności oraz praw człowieka i obywatela. Instytucja skargi nadzwyczajnej nie koliduje przy tym — jak wskazano w uzasadnieniu projektu ustawy — z instytucją skargi konstytucyjnej (art. 79 ust. 1 konstytucji), ponieważ skarga konstytucyjna nie służy

${ }^{1}$ Ustawa z dnia 8 grudnia 2017 r. (Dz.U. z 2018 r. poz. 5, ze zm.). 
ochronie konkretnych interesów jednostek, ale „odrywa się od generującego skargę konstytucyjną naruszenia wolności lub prawa, a rozstrzygnięcie obejmuje jedynie hierarchiczną kontrolę norm"². Orzecznictwo Trybunału Konstytucyjnego wskazuje, że niedopuszczalna jest skarga konstytucyjna, w której zarzuty dotyczą wadliwego ustalenia stanu faktycznego albo wyłącznie indywidualnego rozstrzygnięcia. Skarga konstytucyjna nie jest bowiem środkiem umożliwiającym bezpośrednią ochronę praw lub wolności konstytucyjnych, które naruszono w rezultacie wydania indywidualnego aktu stosowania prawa ${ }^{3}$, lecz jest jednym ze środków umożliwiających kontrolę hierarchicznej zgodności aktów normatywnych, który — w razie wydania wyroku stwierdzającego niezgodność aktu normatywnego będącego podstawą rozstrzygnięcia z aktem hierarchicznie wyższym - jedynie umożliwia żądanie wznowienia postępowania w sprawie. Z tego względu - w opinii projektodawcy ustawy o SN — niezbędne jest uzupełnienie systemu prawnego o instytucję chroniącą konstytucyjne wolności i prawa obywateli, w przypadku ich naruszenia wyrokami sądów, w sytuacjach nadzwyczajnych, gdy istniejące środki prawne są niewystarczające do ich ochrony ${ }^{4}$.

W trakcie prac legislacyjnych nad ustawą o SN zgłaszano istotne zastrzeżenia i wątpliwości co do potrzeby wprowadzenia proponowanego kształtu i przewidywanych skutków funkcjonowania skargi nadzwyczajnej w systemie prawa. Wśród najpoważniejszych zastrzeżeń wskazywano: możliwość sparaliżowania wymiaru sprawiedliwości oraz instytucji publicznych, za pośrednictwem których skarga ta ma być wnoszona do $\mathrm{SN}^{5}$; destabilizację porządku prawnego i obrotu prawnego ${ }^{6}$; naruszenie stabilności orzecznictwa i gwarantowanych konstytucyjnie zasad powagi rzeczy osądzonej oraz zaufania obywateli do państwa i stanowionego prawa ${ }^{7}$. Trudno nie zgodzić się z tymi zastrzeżeniami ekspertów, a sygnalizowane przez nich zagrożenia uznać za wyolbrzymione czy wręcz nierealne. Należy stwierdzić, że skarga nadzwyczajna w formie określonej w ustawie o SN — zwłaszcza wobec zastosowanej techniki legislacyjnej, polegającej na użyciu pojęć niedookreślonych i ocennych, do zdefiniowania przesłanek jej wniesienia, a także w związku z przyjętym założeniem, że sprawy te będą rozstrzygane z udziałem ławników — będzie instrumentem zakłócającym funkcjonowanie wymiaru

2 Z. Czeszejko-Sochacki, Formy naruszenia konstytucyjnych wolności lub praw, [w:] Skarga konstytucyjna, red. J. Trzciński, Warszawa 2003, s. 82.

3 Vide np. postanowienie TK z 16 czerwca 2014 r., sygn. akt Ts 214/13, OTK ZU 2015/5B/435.

4 Vide uzasadnienie prezydenckiego projektu ustawy o SN, <http://www.prezydent.pl/prawo>, dostęp 10 II 2018.

5 B. Banaszak, Opinia o zgodności z Konstytucją RP przedłożonego przez Prezydenta projektu ustawy o Sądzie Najwyższym, druk nr 2003, VIII kadencja Sejmu. Opinie Biura Analiz Sejmowych, s. 6, $<$ http://www.sejm.gov.pl>, dostęp 6 IV 2018.

${ }^{6}$ M. Matczak, Opinia prawna w sprawie konstytucyjności prezydenckiego projektu ustawy o Sądzie Najwyższym, druk nr 2003, VIII kadencja Sejmu. Opinie Biura Analiz Sejmowych, s. 7 i n., <http://www. sejm.gov.pl>, dostęp 26 VIII 2018; oraz M. Dobrowolski, Opinia o zgodności z Konstytucją RP przedłożonego przez Prezydenta projektu ustawy o Sądzie Najwyższym, druk nr 2003..., s. 8.

7 S. Patyra, Opinia prawna na temat zgodności z Konstytucja Rzeczypospolitej Polskiej przedstawionego przez Prezydenta Rzeczpospolitej Polskiej projektu ustawy o Sądzie Najwyższym, druk nr $2003 \ldots$, s. 18 i n. 
sprawiedliwości i zasad demokratycznego państwa prawnego z zasadą pewności prawa na czele. Niemniej skoro ustawodawca zdecydował się wprowadzić tę instytucję do polskiego porządku prawnego, nie należy liczyć, że będzie to instytucja martwa i niewykorzystywana w praktyce. Wręcz przeciwnie, należy raczej spodziewać się — przynajmniej w początkowym okresie jej funkcjonowania - dużego zainteresowania tym środkiem wzruszania prawomocnych orzeczeń ${ }^{8}$.

$\mathrm{Na}$ etapie opiniowania przepisów dotyczących skargi nadzwyczajnej zwracano uwagę na to, że skoro polski model skargi konstytucyjnej wyraźnie odbiega od standardów występujących w innych rozwiniętych państwach demokratycznych, w których ta skarga istnieje, to pożądane jest dostarczenie jednostce środka zaskarżenia o charakterze nadzwyczajnym; środka, który nie będzie konkurencją dla skargi konstytucyjnej, ale będzie ją uzupełniał, umożliwiając ochronę konstytucyjnych praw i wolności we wszystkich przypadkach, w których skorzystanie ze skargi konstytucyjnej nie jest możliwe9. W mojej ocenie — wobec braku efektywności skargi konstytucyjnej — uznanie, że skarga nadzwyczajna będzie jej dopełnieniem (przynajmniej w odniesieniu do stosowania przepisów z zakresu prawa cywilnego i karnego) i że może ona wpłynąć na zwiększenie efektywności ochrony konstytucyjnych wolności i praw jednostki stanowi jedyną przesłankę pozytywnej oceny nowej instytucji i uzasadnia jej utrzymanie w polskim systemie prawnym. Niemniej decyzja ta nie może abstrahować od praktyki funkcjonowania skargi nadzwyczajnej, a na dokonanie ewaluacji w tym zakresie trzeba poczekać.

Celem autora niniejszej publikacji jest wskazanie skali braku efektywności skargi konstytucyjnej i jej przyczyn oraz wykazanie, że skarga nadzwyczajna może stanowić - choć w ograniczonym zakresie — istotne wzmocnienie systemu ochrony konstytucyjnych wolności i praw jednostki.

\section{MODEL SKARGI KONSTYTUCYJNEJ W KONTEKŚCIE KONSTYTUCJI RP I ORZECZNICTWA TRYBUNALU KONSTYTUCYJNEGO}

Uregulowana w art. 79 konstytucji skarga konstytucyjna jest środkiem ochrony konstytucyjnych praw i wolności oraz jednym ze sposobów zainicjowania postępowania przed TK, którego celem jest zbadanie konstytucyjności przepisów prawa stanowionego. W art. 79 ust. 1 konstytucji jednoznacznie przesądzono o tym, że polska skarga konstytucyjna ma wąski charakter przedmiotowy (skargę można wnieść na przepis ustawy lub innego aktu normatywnego, na podstawie którego orzekł sąd lub organ administracji) i szeroki zakres podmiotowy (zdolność skargową posiada „każdy”).

${ }^{8}$ Do końca lipca 2018 r. do biura Rzecznika Praw Obywatelskich [dalej: RPO] spłynęło 1013 wniosków o skargę nadzwyczajną. Jak ustaliła „Rzeczpospolita”, liczba takich wniosków złożonych m.in. do Prokuratury Krajowej, Prokuratorii Generalnej czy Rzecznika Praw Dziecka może przekraczać 600 (vide Skarga nadzwyczajna: Polacy złożyli już ponad 600 wniosków, „Rzeczpospolita”, 3 V 2018. Natomiast 10 sierpnia 2018 r. RPO wniósł do SN pierwszą skargę nadzwyczajną (vide Pierwsza skarga nadzwyczajna RPO do SN: w imię Konstytucji niesie pomoc spadkobiercom rolniczki, <http://www.rpo.gov.pl>, dostęp 10 VIII 2018.

${ }_{9}^{9}$ B. Banaszak, Opinia o zgodności z Konstytucją RP..., s. 6. 
Polski ustrojodawca przyjął zatem taki model skargi na akt normatywny, który wyklucza możliwość kwestionowania w ramach tej procedury orzeczeń i decyzji wydawanych $\mathrm{w}$ indywidualnych sprawach ${ }^{10}$.

Następstwem uwzględnienia skargi konstytucyjnej jest usunięcie z systemu prawnego niekonstytucyjnego przepisu, który był podstawą prawną orzeczenia wydanego w sprawie skarżącego, oraz umożliwienie skarżącemu wzruszenia tego orzeczenia i uzyskania rozstrzygnięcia w nowym (zgodnym z konstytucją) stanie prawnym (art. 190 ust. 4 konstytucji). Dopiero możliwość skorzystania z prawa wznowienia postępowania, uchylenia decyzji lub innego rozstrzygnięcia czyni skargę konstytucyjną faktycznym środkiem ochrony konstytucyjnych praw i wolności ${ }^{11}$. Przyjęcie obecnego modelu skargi konstytucyjnej było zdeterminowane wieloma względami, przede wszystkim pragmatycznymi wynikającymi $\mathrm{z}$ obawy przed masowym korzystaniem przez obywateli z nowego środka ochrony praw i wolności jednostki, dotychczasową koncepcją TK jako ,organu rozstrzygającego o prawach w sensie przedmiotowym, a nie podmiotowym", a przede wszystkim wizją konfliktów z organami stosującymi prawo, zwłaszcza z sądami. Znaczące było także stanowisko sądów w tej kwestii, zwłaszcza Sądu Najwyższego, a także Krajowej Rady Sądownictwa. Nie budzi zatem wątpliwości, że polski ustrojodawca wyraźnie przyznał prymat przedmiotowej funkcji skargi konstytucyjnej, związanej z podstawowym celem sądu konstytucyjnego, jakim jest ochrona przestrzegania konstytucji. Natomiast na drugim planie pozostała kwestia ochrony jednostki (skarżącego), która stanowi jedynie refleks funkcji podstawowej (brak bezpośredniego charakteru ochrony udzielanej przez TK prawom lub wolnościom skarżącego) ${ }^{12}$. Należy przy tym zgodzić się z tezą, że brak możliwości kierowania skarg bezpośrednio przeciwko aktom indywidualnym, zwłaszcza orzeczeniom sądowym, a także bezpośredniego orzekania przez Trybunał w przedmiocie uchylania aktów indywidualnych, stanowią dwie główne cechy polskiego modelu skargi konstytucyjnej ${ }^{13}$.

Zdaniem wielu przedstawicieli doktryny regulacja konstytucyjna przesądziła o tym, że przyjęty środek jest $\mathrm{w}$ istocie wnioskiem indywidualnym, a nie środkiem ochrony wolności i praw w ścisłym tego słowa znaczeniu ${ }^{14}$. W orzecznictwie TK wyraźnie się podkreśla, że skarga konstytucyjna dotyczy niezgodności z konstytucją przepisów

${ }^{10}$ B. Banaszak, Jakie zmiany w Konstytucji RP sa potrzebne, [w:] Aktualne problemy reform konstytucyjnych, red. S. Bożyk, Białystok 2013, s. 35 i n.

${ }^{11}$ M. Florczak-Wątor, Skarga konstytucyjna jako środek ochrony konwencyjnych praw $i$ wolności jednostki, [w:] Prawo międzynarodowe i europejskie a sądownictwo konstytucyjne, red. P. Tuleja, Kraków 2015, s. 68.

${ }^{12}$ S. Jarosz-Żukowska, Prawo do skargi konstytucyjnej - stan obecny i postulaty de lege ferenda, [w:] Realizacja i ochrona konstytucyjnych wolności i praw jednostki w polskim porządku prawnym, red. M. Jabłoński, Wrocław 2014, s. 827 i n.

${ }^{13}$ M. Safjan, Pozycja Trybunatu Konstytucyjnego w Konstytucji Rzeczypospolitej Polskiej z 1997 roku. Nowe instrumenty i metody działania, [w:] Pięć lat Konstytucji Rzeczypospolitej Polskiej, red. H. Jerzmański, Warszawa 2002, s. 37.

${ }^{14}$ Confer np. P. Tuleja, W. Wróbel, Skarga konstytucyjna, czyli dodatkowa gwarancja praw cztowieka. W Polsce i gdzie indziej, „Rzeczpospolita”, 14 XII 1997. 
ustawy lub innych aktów normatywnych, a nie indywidualnych rozstrzygnięć w konkretnej sprawie ${ }^{15}$. Z zakresu stosowania skargi wyłączone są zatem akty stosowania prawa, a także bezczynność organów władzy publicznej, w tym także zaniechanie ustawodawcy ${ }^{16}$. W moim przekonaniu o wiele bardziej znaczący wpływ na brak efektywności skargi konstytucyjnej, jako środka ochrony wolności i praw konstytucyjnych, miało jednak — wykształcone w kontekście ustawy o TK z 1997 r. ${ }^{17}$ — orzecznictwo $^{18}$, które ze względu na powtórzenie takich samych rozwiązań legislacyjnych w kolejnych ustawach o $\mathrm{TK}^{19}$ także obecnie znajduje odpowiednie zastosowanie przy interpretowaniu przesłanek funkcjonowania tej instytucji. W szczególności negatywnie należy ocenić te orzeczenia, w których zastosowana wykładnia przesłanek warunkując dopuszczalność skargi konstytucyjnej ${ }^{20}$ wpłynęła na zawężenie nie tylko przedmiotu ${ }^{21}$,

${ }^{15}$ Wyrok TK z 12 listopada 2002 r., sygn. akt SK 40/01, OTK ZU 2002/6A/81.

${ }^{16}$ S. Jarosz-Żukowska, Prawo do skargi konstytucyjnej..., s. 833.

17 Ustawa z dnia 1 sierpnia 1997 r. o Trybunale Konstytucyjnym (Dz.U. nr 102, poz. 643, ze zm.).

${ }^{18}$ Napiał o tym P. Tuleja, wskazując, że kształt skargi konstytucyjnej zdeterminowany jest również orzecznictwem TK. Orzekając w konkretnych sprawach, Trybunał rozstrzygał bowiem wiele istotnych problemów związanych m.in. z interpretacją art. 79, których nie przewidzieli twórcy obowiązującej konstytucji, a które powstały w praktyce funkcjonowania omawianej instytucji; vide P. Tuleja, Skarga konstytucyjna w Polsce — dziesięć lat doświadczeń, „Przegląd Legislacyjny” 2007, nr 3, s. 29-30.

${ }_{19}$ Mam na myśli ustawę o TK z 1997 r., ustawy o Trybunale Konstytucyjnym z dnia: 25 czerwca 2015 r. (Dz.U. poz. 1064), 22 lipca 2016 r. (Dz.U. poz. 1157), ustawę z dnia 13 grudnia 2016 r. — Przepisy wprowadzające ustawę o organizacji i trybie postępowania przed Trybunałem Konstytucyjnym oraz ustawę o statusie sędziów Trybunału Konstytucyjnego (Dz.U. poz. 2074), z dnia 30 listopada 2016 r. o statusie sędziów Trybunału Konstytucyjnego (Dz.U. poz. 2073), z dnia 30 listopada 2016 r. o organizacji i trybie postępowania przed Trybunałem Konstytucyjnym (Dz.U. poz. 2072).

${ }^{20}$ Wśród przesłanek formalnych warunkujących dopuszczalność skargi wątpliwości budzi przede wszystkim przesłanka oczywistej bezzasadności (a poniekąd także brak uprawdopodobnienia naruszenia wolności i praw konstytucyjnych) jako podstawa odmowy nadania skardze konstytucyjnej dalszego biegu. Nie mają one charakteru formalnego - do ich stwierdzenia konieczna jest $\mathrm{w}$ istocie ocena meritum skargi. W orzecznictwie TK można znaleźć stwierdzenie, że przesłanka ta występuje, gdy zarzuty podniesione w skardze wobec danej regulacji „,choćby w najmniejszym stopniu nie uprawdopodabniają negatywnej jej kwalifikacji konstytucyjnej" (postanowienie TK z 23 października 2014 r., sygn. akt Ts 81/13, OTK ZU 2014/5B/417). Oczywistą bezzasadność TK stwierdza także, gdy skarga nie ma ścisłego związku z konkretnym przepisem ustawy albo zakres zaskarżonych przepisów nie ma związku ze stawianymi przez skarżącego zarzutami naruszenia wskazanych wzorców konstytucyjnych (postanowienia TK z dnia: 3 lipca $2014 \mathrm{r}$., sygn. akt Ts 43/14, OTK ZU 2014/4B/357, 11 lipca 2014 r., sygn. akt Ts 22/14, OTK ZU 2014/4B/353, 4 kwietnia 2014 r., sygn. akt Ts 309/13, OTK ZU 2014/2B/176).

${ }^{21}$ Stosując rozszerzającą wykładnię wymogów warunkujących dopuszczalność skarg konstytucyjnych (np. w zakresie obowiązku wyczerpania drogi prawnej, istnienia tzw. przesłanki funkcjonalnej) Trybunał doprowadził do takiego stopnia sformalizowania koniecznych wymogów procesowych skargi konstytucyjnej, że w konsekwencji możliwość realizacji prawa podmiotowego, o którym mowa w art. 79 ust. 1 konstytucji, stała się mało realna. Szczególnie, gdy ukształtowało się już jednolite rozumienie przepisów, które mają stać się przedmiotem skargi konstytucyjnej, lub gdy jednostka już na etapie postępowania w I instancji podnosi zarzut niekonstytucyjności aktu, ale sąd nie podziela tych wątpliwości i nie występuje z pytaniem prawnym do TK. W takiej sytuacji strona postępowania musi skorzystać ze wszystkich środków odwoławczych, godząc się niejako z góry na niekorzystne rozstrzygnięcie, aby móc skorzystać z prawa do złożenia skargi (D. Dudek, Konstytucyjna wolność człowieka a tymczasowe aresztowanie, 
podmiotu ${ }^{22}$ i podstaw ${ }^{23}$ skargi konstytucyjnej, ale również skutków, jakie orzeczenie TK o niezgodności z konstytucją wydane w trybie skargowym wywiera na polski system prawny ${ }^{24}$.

Lublin 2000, s. 223). Jak wynika z ustalonego orzecznictwa TK, rozpoznanie skargi jest dopuszczalne tylko wtedy, gdy jej rozstrzygnięcie ma znaczenie dla sytuacji prawnej skarżącego, w tym sensie, że w razie orzeczenia niezgodności z konstytucją kwestionowanej normy skarżący mógłby uzyskać należną mu ochronę konstytucyjnej wolności lub prawa, której — wobec obowiązywania zaskarżonej normy — mu odmówiono (confer wyrok TK z 22 listopada 2005 r., sygn. akt SK 8/05, OTK ZU 2005/10A/117, postanowienie TK z 13 czerwca 2011 r., sygn. akt SK 26/09, OTK ZU 2011/5A/46). W przypadku zaś, gdy wyrok stwierdzający pominięcie prawodawcze wymaga stosownej aktywności ustawodawcy i nie wywołuje samoistnie skutków, o których mowa w art. 190 ust. 4 konstytucji (prawo do wznowienia postępowania), powyższa przesłanka nie jest spełniona (confer zdanie odrębne sędzi TK M. Pyziak-Szafnickiej do wyroku TK z 13 czerwca 2011 r., sygn. akt SK 41/09, OTK ZU 2011/5A/40).

${ }^{22} \mathrm{~W}$ postanowieniach z 8 listopada 2005 r., sygn. akt Ts 203/04 (OTK ZU 2005/6B/237) i sygn. akt Ts 204/04 (OTK ZU 2005/6B/239), wydanych w składzie trzyosobowym, TK uwzględnił zażalenie spółki KGHM Polska Miedź S.A. na odmowę nadania skardze biegu ze względu na brak zdolności skargowej. Natomiast w postanowieniu z 20 grudnia 2007 r. (sygn. akt SK 67/05, OTK ZU 2007/11A/168), wydanym w składzie pięcioosobowym, Trybunał umorzył postępowanie ze względu na niedopuszczalność wydania wyroku. Confer także postanowienie odmawiające legitymacji spółce KGHM Polska Miedź S.A. z 8 kwietnia 2008 r. (sygn. akt SK 80/06, OTK ZU 2008/3A/51), a także jednoosobowej spółce Skarbu Państwa (Polskie Sieci Elektroenergetyczne S.A.) w postanowieniu z 6 kwietnia 2011 r. (sygn. akt SK 21/07, OTK ZU 2011/3A/28). Podobnie w postanowieniu TK o uwzględnieniu zażalenia z 18 grudnia 2013 r., sygn. akt Ts 13/12, OTK ZU 2014/IIB/833).

${ }^{23}$ Np. brak możliwości uznania art. 2 i art. 32 konstytucji za samodzielne wzorce kontroli w trybie skargi konstytucyjnej (vide postanowienia pełnego składu TK z 23 stycznia 2002 r., sygn. akt Ts 105/00, OTK ZU 2002/1B/60 oraz 16 lutego 2009 r., sygn. akt Ts 202/06, OTK ZU 2009/1B/23). Confer także krytyczne stanowisko w sprawie uznania przez TK art. 31 ust. 3 i art. 32 konstytucji jedynie za ,wzorce o charakterze subsydiarnym, a nie zasadniczym, samodzielnym"; vide M. Masternak-Kubiak, J. Zakolska, Naruszenie zasady proporcjonalności jako podstawa skargi konstytucyjnej, [w:] W stużbie dobru wspólnemu. Ksiegga dedykowana Profesorowi Januszowi Trzcińskiemu, red. M. Masternak-Kubiak, R. Balicki, Warszawa 2012, s. 234-237.

${ }^{24} \mathrm{Na}$ brak efektywności skarg konstytucyjnych jako środka ochrony wolności i praw konstytucyjnych miała wpływ m.in. linia orzecznicza dotycząca skutków „derogacji trybunalskiej” (odjęciu prawa do wznawiania postępowań w ogóle; confer wyrok TK z dnia 24 października 2007 r., sygn. akt SK 7/06, OTK ZU 2007/9A/, poz. 108, dotyczący sprawowania wymiaru sprawiedliwości przez asesorów sądowych) lub w związku z wydaniem orzeczenia o niekonstytucyjności odraczającego utratę mocy obowiązującej zaskarżonych przepisów (szerzej o sporze w doktrynie odnośnie skutków wydania przez TK wyroku z klauzulą odraczającą dla realizacji prawa do wznowienia postępowania vide D. Daniluk, Skutki wyroku Trybunału Konstytucyjnego z klauzulą odraczająca w postępowaniu sądowoadministracyjnym, „Przegląd Prawa Konstytucyjnego" 2011, nr 4, s. 121 i n.). Należy zwrócić uwagę, że Trybunał podjął próbę wypracowania orzecznictwa (vide postanowienie TK z 14 grudnia 2004 r., sygn. akt SK 26/02, OTK ZU 2004/11A/120, wyrok TK z 26 maja 2008 r., sygn. akt SK 25/07, OTK ZU 2008/4A/62) umożliwiającego w pewnych sytuacjach uprzywilejowanie skarżących (tzw. przywilej korzyści lub premia za aktywność (vide T. Liszcz, Głos w dyskusji, [w:] Księga XXV-lecia Trybunału Konstytucyjnego. Ewolucja funkcji i zadań Trybunatu Konstytucyjnego — założenia a ich praktyczna realizacja, red. K. Budziło, Warszawa 2010, s. 263). Praktyka ta spotkała się z krytyką jako pozbawiona podstaw konstytucyjnych (vide P. Radziewicz, „,Przywilej korzyści” jako skutek prawny orzeczenia Trybunatu Konstytucyjnego, „Przegląd Legislacyjny” 2006, nr 4, s. 9 i n. Ostatecznie sam Trybunał uznał brak swej kognicji w tym zakresie: „TK nie posiada kompetencji do określenia, czy i jaki środek prawny przysługuje skarżącej w związku z wydaniem orzeczenia o niekonstytucyjności przepisu, na podstawie którego zostało wydane ostateczne orzeczenie" (vide postanowienie TK z 4 września 2007 r., sygn. akt SK 47/06, OTK ZU 2007/8A/99). 


\section{Tabela 1. Wpływ skarg konstytucyjnych do TK w latach 1997-2016 ${ }^{25}$}

\begin{tabular}{|c|c|c|c|}
\hline Rok & $\begin{array}{c}\text { Liczba } \\
\text { wniesionych } \\
\text { do TK skarg } \\
\text { konstytucyjnych }\end{array}$ & $\begin{array}{l}\text { Liczba skarg konstytucyj- } \\
\text { nych przekazanych } \\
\text { do merytorycznego } \\
\text { rozpoznawania }\end{array}$ & $\begin{array}{l}\text { Skargi konstytucyjne a inne } \\
\text { sprawy, które wpłynęły } \\
\text { do merytorycznego } \\
\text { rozpoznania (\%) }\end{array}$ \\
\hline $1997^{a}$ & 27 & b.d. & b.d. \\
\hline 1998 & 168 & 23 & 13 \\
\hline 1999 & 185 & 31 & 16 \\
\hline 2000 & 200 & 22 & 11 \\
\hline 2001 & 181 & 44 & 24 \\
\hline 2002 & 195 & 44 & 22 \\
\hline 2003 & 210 & 69 & 32 \\
\hline 2004 & 224 & 57 & 25 \\
\hline 2005 & 220 & 70 & 31 \\
\hline 2006 & 294 & 100 & 34 \\
\hline 2007 & 309 & 50 & 16 \\
\hline 2008 & 405 & 66 & 16 \\
\hline 2009 & 321 & 45 & 14 \\
\hline 2010 & 351 & 33 & 9 \\
\hline 2011 & 358 & 30 & 8 \\
\hline 2012 & 320 & 67 & 20 \\
\hline 2013 & 331 & 71 & 21 \\
\hline 2014 & 375 & 44 & 11 \\
\hline 2015 & $408^{b}$ & 48 & 11 \\
\hline 2016 & 267 & 31 & 11 \\
\hline 2017 & 234 & 32 & 13 \\
\hline
\end{tabular}

a Przepisy dotyczące skargi konstytucyjnej weszły w życie z dniem 17 października 1997 r., brak więc danych o przekazaniu ich do merytorycznego rozpoznania za 1997 r. Do 31 grudnia 1997 r. wydano jedynie siedem postanowień o odmowie nadania skardze konstytucyjnej dalszego biegu.

b W tym 103 skargi konstytucyjne wniesione na podstawie przepisów ustawy o TK z 2015 r. (tj. w odniesieniu do których — w przypadku wydania postanowienia o odmowie nadania dalszego biegu na etapie wstępnej kontroli — nie przysługiwało zażalenie).

Źródło: Opracowanie własne na podstawie danych dostępnych na stronie internetowej TK, <www.trybunal. gov.pl>, dostęp 11 II 2018.

${ }^{25}$ Należy podkreślić, że TK nie prowadzi statystyk, które umożliwiałyby stwierdzenie, jaki procent skarg konstytucyjnych przekazanych do merytorycznego rozpoznania skutkuje wydaniem orzeczenia o niekonstytucyjności, które umożliwia skarżącemu wznowienie odpowiedniego postępowania w celu wzruszenia ostatecznego orzeczenia wydanego na podstawie niezgodnego z konstytucją unormowania. 
Tabela 2. Orzeczenia wydawane przez TK na etapie merytorycznego rozpoznania w latach 1997-2016

\begin{tabular}{|c|c|c|c|c|}
\hline Rok & Ogółem & Wyroki & $\mathrm{NK}^{\mathrm{a}}$ & \% ogółu \\
\hline $1997^{b}$ & b.d. & b.d. & b.d. & b.d. \\
\hline 1998 & 55 & 33 & 15 & 27 \\
\hline 1999 & 66 & 52 & 29 & 43 \\
\hline 2000 & 85 & 52 & 29 & 34 \\
\hline 2001 & 93 & 64 & 27 & 29 \\
\hline 2002 & 93 & 61 & 31 & 33 \\
\hline 2003 & 91 & 70 & 27 & 29 \\
\hline 2004 & 116 & 79 & 44 & 37 \\
\hline 2005 & 137 & 92 & 41 & 29 \\
\hline 2006 & 143 & 104 & 47 & 32 \\
\hline 2007 & 146 & 73 & 49 & 33 \\
\hline 2008 & 166 & 93 & 49 & 29 \\
\hline 2009 & 158 & 78 & 38 & 24 \\
\hline 2010 & 117 & 68 & 37 & 31 \\
\hline 2011 & 114 & 59 & 25 & 21 \\
\hline 2012 & 122 & 67 & 35 & 28 \\
\hline 2013 & 127 & 71 & 39 & 30 \\
\hline 2014 & $119^{c}$ & 71 & 38 & 31 \\
\hline 2015 & 173 & 63 & 35 & 20 \\
\hline 2016 & 99 & 39 & 17 & 17 \\
\hline $2017^{d}$ & $89^{\mathrm{e}}$ & 36 & b.d. & b.d. \\
\hline
\end{tabular}

a Wyroki o niezgodności z konstytucją co najmniej jednego z zakwestionowanych przepisów. W latach 1998-2014 TK wydał 1187 wyroków, w tym w 600 orzekł o niezgodności z konstytucją co najmniej jednego przepisu, co stanowi 51\% wszystkich wydawanych wyroków. W latach 2015-2016 wyroki takie stanowiły $44 \%$ wyroków wydawanych przez TK.

b Wraz z wejściem w życie w dniu 17 października 1997 r. nowej ustawy zasadniczej zmieniły się zasady funkcjonowania TK, m.in. wprowadzono instytucję skargi konstytucyjnej. Do 31 grudnia 1997 r. na podstawie nowych przepisów TK nie wydał ani jednego wyroku z sprawie ze skargi konstytucyjnej.

c Wydając 119 orzeczeń, TK rozpoznał 157 spraw (część z nich rozpoznana została łącznie).

d Należy podkreślić, że na dzień 31 grudnia 2017 r. nierozpoznanych pozostało nadal 59 skarg przekazanych do merytorycznego rozpoznania w latach: 2013 r. — jedna skarga, 2014 r. — pięć skarg, 2015 r. — 10, 2016 r. $-16,2017$ r. -27.

e Rozpoznano 100 spraw, z których niektóre zostały przekazane do łącznego rozpoznania.

Źródło: Opracowanie własne na podstawie danych dostępnych na stronie internetowej TK, <www. trybunal.gov.pl>, dostęp 11 II 2018. 
Brak efektywności skargi konstytucyjnej w kontekście kolejnych ustaw o TK (które przy modelu skargi konstytucyjnej wykreowanym w konstytucji nie mogły znacząco zmienić praktyki jej funkcjonowania) jest szeroko komentowany przez przedstawicieli doktryny ${ }^{26}$, a przyczyny takiej oceny ilustruje m.in. tabela 1 . Jeśli dodatkowo zwrócimy uwagę na fakt, że średni czas rozpatrywania skargi konstytucyjnej wynosi pięć lat ${ }^{27}$, a uzyskanie orzeczenia o niezgodności przepisu z konstytucją dopiero otwiera skarżącemu drogę do wzruszenia ostatecznego orzeczenia w trybie wznowienia odpowiedniego postępowania (przy czym wniesienie skargi konstytucyjnej — co do zasady — nie wstrzymuje przecież wykonania tego orzeczenia), to możemy uznać, że tylko najwytrwalsi obywatele i kwerulanci sądowi zdecydują się skorzystać z tego instrumentu ochrony.

\section{SKARGA NADZWYCZAJNA JAKO INSTRUMENT OCHRONY KONSTYTUCYJNYCH WARTOŚCI}

Zgodnie z art. $89 \S 1$ pkt 1 ustawy o SN, jeżeli jest to konieczne w celu zapewnienia zgodności z zasadą demokratycznego państwa prawnego urzeczywistniającego zasady sprawiedliwości społecznej, od prawomocnego orzeczenia sądu powszechnego lub sądu wojskowego kończącego postępowanie w sprawie może zostać wniesiona skarga nadzwyczajna, o ile:

a) orzeczenie narusza zasady lub wolności i prawa człowieka i obywatela określone w konstytucji;

b) orzeczenie w sposób rażący narusza prawo przez błędną jego wykładnię albo niewłaściwe zastosowanie lub

c) zachodzi oczywista sprzeczność między istotnymi ustaleniami sądu a treścią zebranego w sprawie materiału dowodowego, a orzeczenie nie może zostać uchylone lub zmienione w trybie innych nadzwyczajnych środków zaskarżenia.

26 Vide np. A. Łabno, Skarga konstytucyjna jako środek ochrony praw człowieka. Przyczynek do dyskusji, „Przegląd Prawa Konstytucyjnego” 2012, nr 4, s. 39-59; S. Jarosz-Żukowska, Prawo do skargi konstytucyjnej...; M. Wiącek, Formalne przesłanki skargi konstytucyjnej (w świetle orzecznictwa TK), „Państwo i Prawo” 2011, z. 9, s. 20-34; S. Jarosz-Żukowska, W sprawie pożądanych zmian polskiego modelu skargi konstytucyjnej, [w:] Konieczne i pożądane zmiany Konstytucji RP z 2 kwietnia 1997 r., red. B. Banaszak, M. Jabłoński, Wrocław 2010, s. 251-282.

${ }^{27}$ Należy podkreślić, że w podawanym przez TK w opracowaniach statystycznych średnim czasie rozpoznawania sprawy zakończonej wyrokiem jako wynoszący w 2015 r. 17 miesięcy (Informacja o istotnych problemach wynikających z działalności i orzecznictwa Trybunału Konstytucyjnego w 2016 r., s. 85, <http:// trybunal.gov.pl>, dostęp 29 VI 2018) nie uwzględnia się czasu między wniesieniem skargi konstytucyjnej a przekazaniem jej do merytorycznego rozpoznania. Aby ustalić faktyczny czas, jaki upływa między wniesieniem skargi a uzyskaniem orzeczenia trybunalskiego, warto przytoczyć parę przykładów: w sprawie o sygn. akt SK 18/17 (termin do wytoczenia powództwa o zaprzeczenie ojcostwa) skarga wpłynęła 14 grudnia 2015 r., a wyrok zapadł 16 maja 2018 r.; w sprawie o sygn. akt SK 8/14 (ochrona informacji niejawnych) skarga wpłynęła 7 października 2013 r., a wyrok zapadł 23 maja 2018 r.; w sprawie o sygn. akt SK 13/14 (prawo do sądu; pozbawienie skarżącego prawa do udziału w posiedzeniu sądu w przedmiocie wykonywania środka zabezpieczającego - umieszczenie w zamkniętym zakładzie psychiatrycznym) skarga została wniesiona 18 grudnia 2012 r., a wyrok zapadł 22 marca 2017 r. Do wyjątków należą skargi rozpatrywane w terminie krótszym. 
Biorąc pod uwagę literalne brzmienie tego przepisu, należy przyjąć, ze skarga nadzwyczajna jako środek ochrony konstytucyjnych wolności i praw jednostki jest dopuszczalna, gdy kumulatywnie zostają spełnione następujące przesłanki:

a) istnieje prawomocne orzeczenie kończące postępowanie w sprawie,

b) orzeczenie to zostało wydane przez sąd powszechny lub wojskowy ${ }^{28}$,

c) orzeczenie to nie może być uchylone lub zmienione w trybie innych nadzwyczajnych środków zaskarżenia,

d) orzeczenie to narusza konstytucyjne zasady lub wolności i prawa jednostki określone w konstytucji, orzeczenie w sposób rażący narusza prawo przez błędną jego wykładnię lub niewłaściwe zastosowanie, lub zachodzi oczywista sprzeczność istotnych ustaleń sądu $\mathrm{z}$ treścią zebranego w sprawie materiału dowodowego,

e) wzruszenie prawomocnego orzeczenia jest konieczne do zapewnienia zgodności z zasadą demokratycznego państwa prawnego urzeczywistniającego zasady sprawiedliwości społecznej.

Uzasadniając potencjalną rolę skargi nadzwyczajnej w ochronie konstytucyjnie poręczonych wolności i praw jednostki, należy zatem - w kontekście ustawy o SN — rozważyć:

a) co oznacza termin prawomocne orzeczenie w kontekście potencjalnego wymogu wyczerpania drogi prawnej i ostateczności tego orzeczenia,

b) czy skorzystać z prawa do wniesienia skargi nadzwyczajnej można wyłącznie w imieniu bądź na wniosek strony postępowania ${ }^{29}$, w którym to orzeczenie zapadło,

c) jak rozumieć wymóg, zgodnie z którym podstawą skargi nadzwyczajnej nie mogą być zarzuty, które były przedmiotem rozpoznawania przez SN przy rozpatrywaniu skargi kasacyjnej lub kasacji (art. 90 § 2 ustawy o SN),

d) naruszenie jakich konstytucyjnych zasad, czyich wolności i praw może stanowić podstawę skargi nadzwyczajnej,

e) co oznacza wymóg zapewnienia zgodności z zasadą demokratycznego państwa prawnego urzeczywistniającego zasady sprawiedliwości społecznej.

Zgodnie z regulacją art. $363 \S 1$ k.p.c. orzeczenie sądu staje się prawomocne, jeżeli nie przysługuje do niego środek odwoławczy lub inny środek zaskarżenia. Z uzyskaniem przez orzeczenie prawomocności formalnej mamy do czynienia, w sytuacji gdy: od orzeczenia nie przewidziano w prawie żadnego środka zaskarżenia, strona zrzekła się prawa do wniesienia środka zaskarżenia, upłynął termin do wniesienia środka zaskarżenia, wniesiony w terminie środek zaskarżenia nie został uwzględniony.

${ }^{28}$ Skarga nadzwyczajna nie przysługuje zatem od orzeczeń wydawanych przez sądy administracyjne, a należy podkreślić, że znaczący procent skarg konstytucyjnych jest wnoszonych w odniesieniu do przepisów prawa administracyjnego oraz podatkowego. W wielu przypadkach nie mogą one być rozpoznane, ponieważ w istocie stanowią skargi na stosowanie prawa (tzn. wiążą naruszenie konstytucyjnych wolności i praw skarżącego z niewłaściwym zastosowaniem prawa w ich sprawie, brakiem ich jednolitej wykładni).

${ }^{29}$ Wątpliwości w tym zakresie mogą dotyczyć zwłaszcza pokrzywdzonego niedziałającego jako oskarżyciel posiłkowy w postępowaniu przed sądem; confer art. 53 ustawy z dnia 6 czerwca 1997 r. Kodeks postępowania karnego (Dz.U. z 2017 r. poz. 1904, ze zm.; dalej: k.p.k.), a także organizacji pozarządowych, które nie uczestniczyły w sprawie, art. 63 ustawa z dnia 17 listopada 1964 r. — Kodeks postępowania cywilnego (Dz.U. z 2016 r. poz. 1822, ze zm.; dalej: k.p.c.). 
Natomiast w kodeksie postępowania karnego nie zawarto definicji pojęcia ,prawomocność". Orzeczenie sądu staje się prawomocne, gdy od niego nie przysługują już zwykłe środki zaskarżenia. Wyrok może być prawomocny nie tylko w całości, ale także w części (jeśli zostanie zaskarżony jedynie wobec jednego oskarżonego lub w zakresie jednego czynu oskarżonego). W takim przypadku wyrok staje się prawomocny w niezaskarżonej części. Orzeczenie sądu staje się zatem prawomocne, w sytuacji gdy: bezskutecznie upłynął termin do wniesienia zwyczajnego środka odwoławczego (termin ten musi upłynąć bezskutecznie dla wszystkich osób uprawnionych do wniesienia środka odwoławczego); prezes sądu I instancji odmówił przyjęcia wniesionego środka odwoławczego (art. 429 § 1 k.p.k.); sąd odwoławczy pozostawił wniesiony środek odwoławczy bez rozpoznania (art. $430 \S 1$ k.p.k.); sąd pozostawił bez rozpoznania cofnięty środek odwoławczy (art. $432 \S 1$ k.p.k.); nie wniesiono wniosku o sporządzenie uzasadnienia wyroku (art. $422 \S 1$ k.p.k.); został wyczerpany tok instancji wskutek wydania przez sąd II instancji orzeczenia kończącego postępowanie.

W uzasadnieniu prezydenckiego projektu ustawy czytamy, że skarga nadzwyczajna będzie mogła być wniesiona od każdego prawomocnego orzeczenia, a więc także od wyroku, który nie był przedmiotem apelacji, oraz od wyroku, który był przedmiotem postępowania kasacyjnego przed SN. Ograniczeniem jest natomiast to, że od tego samego orzeczenia w interesie tej samej strony może być wniesiona tylko jedna skarga nadzwyczajna (art. $90 \S 1$ ustawy o SN). Biorąc to pod uwagę, należy uznać, że w przypadku skargi nadzwyczajnej ustawodawca przewidział bardziej uproszczoną drogę ochrony konstytucyjnych wolności i praw jednostki niż w odniesieniu do skargi konstytucyjnej. W przypadku skargi konstytucyjnej skarżący musi bowiem wykazać, że posiada nie tylko ostateczne orzeczenie wydane w jego sprawie oraz że wyczerpał drogę prawną, tzn. skorzystał z wszystkich przewidzianych prawem instrumentów instancyjnej kontroli tego rozstrzygnięcia. Trybunał wielokrotnie podkreślał, że obowiązek ,wyczerpania drogi prawnej" (art. 46 ust. 1 ustawy o TK z 1997 r.) wyklucza wniesienie skargi konstytucyjnej od takich prawomocnych wyroków, ostatecznych decyzji lub innych ostatecznych rozstrzygnięć, które stały się prawomocne lub ostateczne, dlatego że zainteresowany nie wykorzystał możliwości wyczerpania całego dostępnego toku instancji w postępowaniu sądowym czy administracyjnym. Sformułowanie „orzekł ostatecznie” (art. 79 ust. 1 konstytucji) należy zatem rozumieć jako merytoryczne rozstrzygnięcie (orzeczenie co do istoty), w stosunku do którego nie przysługują środki odwoławcze lub inne środki zaskarżenia, ponieważ zapadło ono ,po wyczerpaniu drogi prawnej”30.

Zgodnie z art. 79 konstytucji skarga konstytucyjna może dotyczyć wyłącznie aktu normatywnego, na podstawie którego sąd lub organ administracji publicznej orzekł ostatecznie o określonych w konstytucji wolnościach, prawach lub obowiązkach skarżącego. Wymienione w ustawie zasadniczej przesłanki skargi konstytucyjnej zostały rozwinięte i sprecyzowane przez ustawodawcę zwykłego w ustawie o TK z 1997 r. ${ }^{31}$

30 Vide np. postanowienie TK z 10 października 2007 r., sygn. akt Ts 91/07, OTK ZU 2007/5B/254.

31 Podobnie przesłanki te doprecyzowano w art. 64 ustawy o TK z 2015 r. i w art. 77 ust. 1 ustawy o TK z 2016 r. 
Odpowiednio do art. 46 ust. 1 ustawy o TK z $1997 \mathrm{r}^{32}$ skarga konstytucyjna może zostać wniesiona w określonym terminie od doręczenia skarżącemu prawomocnego wyroku, ostatecznej decyzji lub innego ostatecznego rozstrzygnięcia. Rozpoznając wniesioną skargę konstytucyjną, należy przede wszystkim odpowiedzieć na pytanie, czy na podstawie zaskarżonych przepisów sąd lub organ administracji publicznej orzekł o konstytucyjnych wolnościach, prawach lub obowiązkach skarżących. Wyrażenie „orzekł ostatecznie" o prawach, wolnościach lub obowiązkach jednostki stanowiło przedmiot wykładni już w pierwszych postanowieniach TK dotyczących skargi konstytucyjnej.

Trybunał zwracał uwagę na fakt, że pojęcia „ostatecznego orzeczenia” nie można ustalić, odwołując się do obowiązującego ustawodawstwa, ponieważ termin ten nie jest powtórzeniem żadnego z ustawowych unormowań proceduralnych. Odmienności terminologiczne ,dają wyraz intencji ustawodawcy konstytucyjnego do użycia pojęcia nowego (odrębnego), o możliwie najogólniejszym charakterze, odnoszącego się do wszelkiego rodzaju końcowych rozstrzygnięć, podejmowanych we wszelkiego rodzaju postępowaniach przed sądami i organami administracji publicznej" (vide np. postanowienie TK z 5 grudnia 1997 r., sygn. akt Ts 14/97, OTK ZU 1998/1, s. 41 oraz postanowienie pełnego składu TK z 4 grudnia 2000 r., sygn. akt SK 10/99, OTK ZU 2000/8/300). Zdaniem TK, aby można było mówić o „ostatecznym orzeczeniu”, działanie organów sądowych i administracyjnych musi mieć władczy charakter i określać sytuację prawną indywidualnie określonego podmiotu. Rozwijając i precyzując konstytucyjne pojęcie „orzeczenia” o wolnościach, prawach lub obowiązkach jednostki, TK stwierdził, że obejmuje ono rozstrzygnięcia, które nakładają, zmieniają lub uchylają obowiązki albo przyznają, zmieniają lub znoszą uprawnienia. Do orzeczeń o wolnościach, prawach lub obowiązkach należy zaliczyć również rozstrzygnięcia, w których autorytatywnie stwierdzono istnienie obowiązku lub uprawnienia, jeżeli rozstrzygnięcia te mają znaczenie dla realizacji określonych uprawnień lub obowiązków jednostki. Do orzeczeń o wolnościach, prawach lub obowiązkach mogą należeć także rozstrzygnięcia polegające na odmowie wydania jednego z wymienionych wcześniej rozstrzygnięć. Trybunał uznawał także, że szczegółowe obowiązki lub uprawnienia jednostki, których dotyczą wymienione rozstrzygnięcia, muszą mieścić się w zakresie wolności, praw lub obowiązków określonych w konstytucji. Podkreślał, że do istoty „orzeczenia o wolnościach, prawach lub obowiązkach” jednostki zawsze należy jego wiążący charakter, wyrażający się w powstaniu, zmianie lub zniesieniu obowiązków ciążących na określonych podmiotach. Podmiotami tymi są zawsze organy władzy publicznej, które realizują określone uprawnienia jednostki lub które egzekwują obowiązki ciążące na jednostce. Takim podmiotem może być również jednostka, należy jednak zauważyć, że nie każde rozstrzygnięcie o wolnościach lub prawach jednostki musi pociągać za sobą powstanie, zmianę lub zniesienie obowiązku ciążącego na osobie fizycznej.

${ }^{32} \mathrm{Na}$ tle przepisów tej ustawy (z racji najdłuższego okresu jej obowiązywania) rozwinęło się bogate orzecznictwo trybunalskie będące także i obecnie - wobec braku zasadniczych zmian dokonywanych przez ustawodawcę $\mathrm{w}$ tym zakresie w kolejnych aktach normatywnych — punktem odniesienia do interpretowania przesłanek określających dopuszczalność skargi konstytucyjnej. 
Nie ulega zatem wątpliwości, że skarga nadzwyczajna w omawianym zakresie będzie stanowić - w porównaniu ze skargą konstytucyjną - mniej sformalizowany instrument ochrony wartości konstytucyjnych, a procedura inicjowania wniesienia skargi nadzwyczajnej będzie mniej czasochłonna. Ponadto perspektywa uzyskania judykatu SN nie będzie tak odległa w czasie jak w przypadku TK ${ }^{33}$. Należy także zwrócić uwagę na inną przesłankę dopuszczalności skargi nadzwyczajnej, tj. wymóg, że orzeczenie, w związku z którym wnosi się ten środek zaskarżenia, nie może zostać uchylone lub zmienione w trybie innych nadzwyczajnych środków zaskarżenia ${ }^{34}$. Jak się wydaje, przesłanka ta w praktyce nie będzie stanowić ograniczenia dla korzystania $\mathrm{z}$ tego środka, inne są bowiem przesłanki wzruszania orzeczeń w trybie nadzwyczajnym, a odmowa przyjęcia kasacji (czy wniosku o wznowienie postępowania) nie ogranicza prawa skazanego do wystąpienia do podmiotów uprawnionych o wniesienie skargi nadzwyczajnej ${ }^{35}$.

Zgodnie z art. 89 § 2 ustawy o SN skargę nadzwyczajną może wnieść prokurator generalny, Rzecznik Praw Obywatelskich ${ }^{36}$, oraz — w zakresie swojej właściwości — prezes Prokuratorii Generalnej RP, Rzecznik Praw Dziecka, Rzecznik Praw Pacjenta, przewodniczący Komisji Nadzoru Finansowego i rzecznik finansowy i prezes Urzędu Ochrony Konkurencji i Konsumentów. W ustawie nie sprecyzowano, w jakim trybie i kto może zwrócić się do podmiotów uprawnionych z inicjatywą wniesienia skargi nadzwyczajnej w konkretnej sprawie. Pewną wskazówką interpretacyjną jest art. 90 $\S 1$ ustawy o SN, zgodnie z którym od tego samego orzeczenia w interesie tej samej strony skarga nadzwyczajna może być wniesiona tylko raz. Wynika z tego, że skargę nadzwyczajną wnosi się w interesie, a nie w imieniu strony. Zatem nie tylko strona postępowania może domagać się wzruszenia orzeczenia w trybie skargi nadzwyczajnej.

${ }^{33}$ W przypadku skarg kasacyjnych i kasacji czas oczekiwania na orzeczenie SN wynosi od trzech miesięcy do roku (K. Żaczkiewicz-Zborska, Coraz więcej zaległości w Sądzie Najwyższym, na stronie internetowej <https://www.prawo.pl>, dostęp 29 VI 2018). Nie są to jednak dane urzędowe. Z informacji o działalności SN wynika jedynie, że czas oczekiwania na rozpoznanie sprawy jest zadowalający (vide Informacja o działalności Sądu Najwyższego w roku 2017, <https:/www.sn.pl>, dostęp 29 VI 2018). Niemniej jest to okres znacznie krótszy niż czas oczekiwania na rozstrzygnięcie TK.

34 Należy podkreślić, że tryby nadzwyczajne (kasacja i skarga kasacyjna w postępowaniu przed $\mathrm{SN}$ ) i ewentualna możliwość wznowienia postępowania zakończonego prawomocnym wyrokiem w kontekście dopuszczalności wniesienia skargi konstytucyjnej nie mają znaczenia. Orzeczenie prawomocne jest zatem orzeczeniem, którego nie można już zaskarżyć w drodze zwykłych środków odwoławczych (vide np. postanowienie TK z 21 grudnia 2010 r., sygn. akt Ts 16/10, OTK ZU 2014/IIB/798).

35 Postanowienie SN Izba Karna z 14 czerwca 2018 r., sygn. akt II KZ 19/18.

36 Należy zauważyć, że zgodnie z art. 521 k.p.k. RPO może wnieść kasację od każdego prawomocnego orzeczenia sądu kończącego postępowanie. Natomiast Rzecznik Praw Dziecka może wnieść kasację od każdego prawomocnego orzeczenia sądu kończącego postępowanie, jeżeli przez wydanie orzeczenia doszło do naruszenia praw dziecka. Jednocześnie zgodnie z art. $398^{1}$ k.p.c. od wydanego przez sąd II instancji prawomocnego wyroku lub postanowienia w przedmiocie odrzucenia pozwu albo umorzenia postępowania kończących postępowanie w sprawie stron prokurator generalny, RPO lub Rzecznik Praw Dziecka może wnieść skargę kasacyjną do SN, chyba że przepis szczególny stanowi inaczej. Wniesienie skargi kasacyjnej przez stronę wyłącza jednak — w zaskarżonym zakresie — wniesienie skargi kasacyjnej przez prokuratora generalnego, RPO lub Rzecznika Praw Dziecka. 
Co więcej - choć wydaje się to mało prawdopodobne - podmioty uprawnione do bezpośredniego wniesienia tego środka będą mogły działać w tym zakresie z urzędu.

Skarga nadzwyczajna będzie miała zatem szerszy zakres zastosowania niż skarga konstytucyjna. Podmiotem uprawnionym do korzystania $\mathrm{z}$ tego drugiego środka ochrony jest bowiem wyłącznie ten, czyje konstytucyjne wolności lub prawa doznały rzeczywistego i bezpośredniego naruszenia wskutek zastosowania kwestionowanej regulacji ustawy lub innego aktu normatywnego (vide postanowienie TK z 15 lutego 2012 r., sygn. akt Ts 318/11, OTK ZU 2013/1B/97). Ponadto prawa konstytucyjne, których ochrony chce się dochodzić w trybie skargi konstytucyjnej, muszą przysługiwać bezpośrednio podmiotowi, który występuje do TK z tym środkiem prawnym. Legitymowana do wniesienia skargi konstytucyjnej jest bowiem wyłącznie ta osoba, która jest podmiotem naruszonego prawa lub wolności o charakterze konstytucyjnym. Nie ma zatem możliwości wnoszenia skargi konstytucyjnej jako actio popularis (vide postanowienie TK z 13 lipca 2005 r., sygn. akt Ts 85/05, OTK ZU 2005/4B/178).

Natomiast w przypadku skargi nadzwyczajnej z żądaniem jej wniesienia będzie mógł wystąpić - na co wskazuje literalna wykładnia odpowiednich przepisów ustawy o SN — np. pokrzywdzony nieusatysfakcjonowany wyrokiem sądu karnego lub organizacja pozarządowa, która nie uczestniczyła w sprawie w postępowaniu cywilnym. Jednocześnie należy wskazać, że zarówno w przepisach kodeksu postępowania cywilnego, jak i w odpowiednich regulacjach kodeksu postępowania karnego przewidziano prawo wglądu do akt sprawy. Zgodnie z art. 156 § 1 k.p.k., stronom, obrońcom, pełnomocnikom i przedstawicielom ustawowym udostępnia się akta sprawy sądowej oraz daje możność sporządzenia z nich odpisów lub kopii. Za zgodą prezesa sądu akta te mogą być udostępnione również innym osobom. Odpowiednio do art. 9 § 1 k.p.c. rozpoznawanie spraw jest jawne, chyba że przepis szczególny stanowi inaczej. Strony i uczestnicy postępowania mają prawo przeglądać akta sprawy i otrzymywać odpisy, kopie lub wyciągi $\mathrm{z}$ tych akt. W postępowaniu nieprocesowym akta sprawy dostępne są dla uczestników postępowania oraz za zezwoleniem przewodniczącego dla każdego, kto potrzebę przejrzenia dostatecznie usprawiedliwi. Na tych samych zasadach dopuszczalne jest sporządzanie i otrzymywanie odpisów i wyciągów z akt sprawy oraz otrzymywanie zapisu dźwięku albo obrazu i dźwięku z akt sprawy (art. 525 k.p.c.). Natomiast Naczelny Sąd Administracyjny w uchwale z 9 grudnia 2013 r. (sygn. akt I OPS 7/13) uznał że żądanie udostępnienia akt sprawy jako całości, także akt zakończonego postępowania przygotowawczego, nie jest wnioskiem o udostępnienie informacji publicznej, ale żądaniem udostępnienia określonego zbioru materiałów. Zatem tak sformułowany wniosek nie wskazuje na informacje publiczne, których udostępnienia domaga się wnioskodawca i nie może zostać uwzględniony na podstawie przepisów ustawy z dnia 6 września $2001 \mathrm{r}$. o dostępie do informacji publicznej (Dz.U. z 2016 r. poz. 1764, ze zm.). Jednocześnie w wyroku z 19 grudnia 2017 r. (sygn. akt I OSK 1003/17) NSA potwierdził, że uchwała ta dotyczyła kwestii nieokreślonego bliżej żądania udostępnienia całości akt sprawy jako zbioru materiałów, odnosiła się zatem do odrębnej instytucji uregulowanej w przepisach procesowych. Wyrażone w niej stanowisko nie ma natomiast zastosowania w odniesieniu 
do wniosku o informację publiczną znajdującą się w aktach sprawy w postaci konkretnego dokumentu (np. orzeczenia).

Dostęp do orzeczeń wydawanych w postępowaniach karnych i cywilnych można zatem uzyskać w trybie dostępu do informacji publicznej. Jednocześnie, skoro skargi nadzwyczajnej nie musi wnosić strona postępowania, można wyobrazić sobie sytuację, w której każdy potencjalny obywatel będzie mógł wnieść do uprawnionego podmiotu żądanie wniesienia takiej skargi w odniesieniu do dowolnego orzeczenia wydanego przez sąd powszechny lub wojskowy, z zastrzeżeniem ram czasowych ich wzruszania określonych w ustawie o SN. Z wielkim prawdopodobieństwem należy więc przypuszczać, że zwłaszcza w początkowej fazie funkcjonowania skarga nadzwyczajna będzie postrzegana przez różnego rodzaju kwerulantów sądowych jako kolejny instrument walki z wymiarem sprawiedliwości. Tym większego znaczenia nabiera zatem wypracowanie przez wszystkie podmioty uprawnionego do wnoszenia skarg nadzwyczajnych jednolitej interpretacji pojęć ustawowych określających przesłanki dopuszczalności tego środka.

Skargi nadzwyczajnej nie można oprzeć na zarzutach, które były przedmiotem rozpoznawania przez SN przy rozpatrywaniu skargi kasacyjnej lub kasacji (art. 90 § ustawy o SN). Należy więc rozważyć, czy w sytuacji gdy w skardze kasacyjnej (kasacji) podnoszono zarzuty natury konstytucyjnej (a szczególnie, gdy sformułowano wniosek o skierowanie pytania prawnego do TK $)^{37}$, a SN niepodzielający tych wątpliwości skarżącego

${ }^{37}$ Może także dojść do sytuacji, w której sąd skieruje pytanie prawne do TK, ale Trybunał postępowanie w tej sprawie umorzy. Czy taki bieg postępowania będzie miał znaczenie w kontekście dopuszczalności skargi nadzwyczajnej? Warto przywołać sprawę zakończoną wyrokiem SN z 15 września 2017 r. (sygn. akt III CSK 241/16). Sprawa zawisła przed Sądem Okręgowym w Krakowie dotyczyła wniosku powoda o wydanie orzeczenia stwierdzającego obowiązek Gminy Wyznaniowej Żydowskiej [dalej: GWŻ] w Krakowie, zastępującego jej oświadczenie o przyjęciu powoda w poczet jej członków. Podstawą prawną powództwa był art. 64 ustawy z dnia 23 kwietnia 1964 r. - Kodeks cywilny (Dz.U. z 2014 r. poz. 121; dalej: k.c.), który brzmi: „Prawomocne orzeczenie sądu stwierdzające obowiązek danej osoby do złożenia oznaczonego oświadczenia woli, zastępuje to oświadczenie”. Sąd zwrócił się do TK z następującym pytaniem prawnym: „Czy przepis art. 2 ust. 1 ustawy z dnia 20 lutego 1997 r. o stosunku Państwa do gmin wyznaniowych żydowskich w Rzeczypospolitej Polskiej (Dz.U. nr 41, poz. 251, ze zm.; dalej: u.g.w.ż.) jest zgodny z art. 32 w związku z art. 53 ust. 1 i 2 Konstytucji Rzeczypospolitej Polskiej w zakresie, w jakim uniemożliwia pełnoletnim osobom wyznania mojżeszowego, zamieszkującym na terenie Rzeczypospolitej, lecz nieposiadającym obywatelstwa polskiego, przyjęcie w poczet członków gminy wyznaniowej”, zawieszając postępowanie do czasu rozstrzygnięcia sprawy przez TK. Trybunał postanowieniem z 18 lutego 2015 r., sygn. akt P 48/13 (OTK ZU 2015/2A/22), umorzył postępowanie ze względu na niedopuszczalność wydania wyroku. Uznał, że w sprawie zawisłej przed Sądem Okręgowym w Krakowie brak jest podstaw prawnych do uznania istnienia cywilnoprawnego obowiązku GWŻ w Krakowie przyjęcia powoda w poczet swych członków. Pytanie prawne sądu nie spełniało zatem przesłanki funkcjonalnej, ponieważ udzielenie odpowiedzi przez Trybunał na to pytanie nie było warunkiem podjęcia przez sąd rozstrzygnięcia z zastosowaniem kwestionowanego przepisu u.g.w.ż. Stwierdzenie niekonstytucyjności art. 2 ust. 1 u.g.w.ż. w zakwestionowanym zakresie nie przesądziłoby również o uwzględnieniu powództwa. Do postanowienia TK zdanie odrębne zgłosił sędzia W. Hermeliński, który nie zgodził się z tym rozstrzygnięciem. Jednocześnie postanowieniem z 18 lutego 2015 r., sygn. akt S 2/15 (OTK ZU 2015/2A/23) TK przedstawił Sejmowi uwagi o stwierdzonym uchybieniu w art. 2 ust. 1 u.g.w.ż. co do polskiego obywatelstwa jako ustawowego kryterium dopuszczalności członkostwa w gminach wyznaniowych żydowskich, uznając, że usunięcie tego kryterium jest niezbędne w celu zapewnienia spójności systemu 
nie przychylił się do wniosku, w skardze nadzwyczajnej należy podnieść innego rodzaju wątpliwości. Za niepodważalną należy przy tym uznać kompetencję sądu do oceny, czy zakwestionowany przepis nasuwa wątpliwości konstytucyjne, czy też nie, oraz do dokonania takiej jego interpretacji, która zapewnia zgodność z ustawą zasadniczą ${ }^{38}$.

Należy podkreślić, że do niedawna akceptowano w orzecznictwie interpretację, zgodnie z którą sądy oraz organy stosowania prawa nie mają kompetencji do orzekania o niekonstytucyjności przepisu ustawy i odmowy jego zastosowania. Domniemanie zgodności ustawy z konstytucją, które można obalić jedynie w wyroku TK ${ }^{39}$,

prawnego RP. W konsekwencji sąd okręgowy oddalił powództwo, a sąd apelacyjny wniesioną od wyroku sądu okręgowego apelację. Rozpatrując skargę kasacyjną, SN podniósł, że „interpretacja art. 2 ust. 1 ustawy z dnia 20 lutego 1997 r., zgodnie z którą przepis ten przewiduje powstanie ex lege członkostwa w gminie wyznaniowej [...], pozostawałaby w sprzeczności z art. 53 Konstytucji dotyczącym wolności sumienia i wyznawania religii, a ściślej z przepisami art. 2 pkt 1 i 2a ustawy z dnia 17 maja 1989 r. o gwarancjach wolności sumienia i wyznania (tekst jedn.: Dz.U. z 2017 r. poz. 1153), według których korzystanie z wolności sumienia i wyznania obejmuje w szczególności możność tworzenia wspólnot religijnych, zwanych «kościołami i innymi związkami wyznaniowymi», oraz należenia lub nienależenia do kościołów i innych związków wyznaniowych. Osoba wyznania mojżeszowego może więc, według swojego wyboru, albo należeć do jednej z wyznaniowych gmin żydowskich, zrzeszonych w Związku Gmin Wyznaniowych Żydowskich w Rzeczypospolitej Polskiej, albo należeć do innego związku wyznaniowego, albo nie należeć do żadnego związku”. Dodał także, uchylając wyroki sądów I i II instancji, że kwestia wyboru np. członków zarządu nie podlega sądowej kontroli merytorycznej zarówno w gminach wyznaniowych, jak i w takich korporacjach, jak spółdzielnie czy spółki kapitałowe i stanowi dyskrecjonalne uprawnienie właściwego organu. Natomiast stosownej kontroli mogą podlegać kwestie związane z członkostwem w Kościele lub innym związku wyznaniowym. Stosunek członkostwa ma niewątpliwie charakter cywilnoprawny, skoro Kościół (inny związek wyznaniowy) ma osobowość prawną jako całość lub mają ją jego wyodrębnione jednostki, a prawo wewnętrzne Kościoła (innego związku wyznaniowego) jest statutem osoby prawnej w rozumieniu art. 35 i 38 k.c. (vide uchwała SN z 19 grudnia 2008 r., sygn. akt III CZP 122/08, postanowienie SN z 12 stycznia 2011 r., sygn. akt CSK 182/10, wyrok SN z 13 kwietnia 2012 r., sygn. akt I CSK 451/11). Tym samym SN podważył stanowisko TK przedstawione w postanowieniu z 18 lutego 2015 r., w którym TK uznał, że pragnącym przystąpić do tej wspólnoty nie przysługuje roszczenie cywilnoprawne na mocy art. 2 ust. 1 u.g.w.ż.

${ }^{38}$ L. Garlicki, Sądy a Konstytucja Rzeczypospolitej Polskiej, „Przegląd Sądowy” 2016, nr 7-8, s. 15.

${ }^{39}$ Za interesujący w omawianym zakresie należy uznać wyrok SN z 17 marca 2016 r., sygn. akt V CSK 337/15, oraz wyrok NSA z 12 kwietnia 2016 r., sygn. akt II FSK 330/15, oba dotyczące przepisu art. 70 ordynacji podatkowej i nawiązujące do wyroku TK z 8 października 2013 r. (sygn. akt SK 40/12, OTK ZU 2013/7A/97), w którym uznano niekonstytucyjność przepisu o niemal identycznej treści, tyle że dotyczącego innego okresu. Co więcej, TK wskazał też na konieczność dokonania zmiany w przepisie, który stał się przedmiotem oceny SN i NSA. W obu tych orzeczeniach stwierdzono, że wyrok TK uznający niekonstytucyjność przepisu ustawy daje sądowi podstawę do odmowy zastosowania identycznego treściowo przepisu, nawet jeżeli nie był on bezpośrednim przedmiotem orzekania przez TK. Odmiennie orzekł NSA w postanowieniu z 6 sierpnia 2014 r., sygn. akt II FSK 115/14, w którym odrzucił skargę podatników i wyjaśnił, że moc wiążącą mają tylko rozstrzygnięcia zawarte w sentencji wyroku TK. Sentencja wyroku Trybunału z 8 października 2013 r., zgodnie z zasadą skargowości, dotyczy tylko przepisu, który został zaskarżony w postępowaniu przed TK (w sprawie o sygn. SK 40/12 był nim art. 70 § 6 ordynacji podatkowej). W konsekwencji podstawą wznowienia postępowania nie mogą być wywody zawarte w uzasadnieniu wyroku TK w sprawie o sygn. SK 40/12, dotyczące zastrzeżeń co do konstytucyjności art. 70 $\S 8$ ordynacji podatkowej obowiązującego od 1 stycznia 2003 r., tj. przepisu, który nie był przedmiotem orzekania w sprawie o sygn. SK 40/12. Wyrok Trybunału nie dotyczy zatem przepisu art. $70 § 8$ ordynacji podatkowej, który był podstawą wydanych wobec skarżących decyzji administracyjnych, poddanych następnie kontroli sądowoadministracyjnej. 
oraz związanie sędziego ustawą, o którym mowa w art. 178 ust. 1 konstytucji, obowiązuje dopóty, dopóki ustawa ta obowiązuje. Jeżeli sąd jest przekonany o niezgodności przepisu z konstytucją lub ma w tym względzie wątpliwości, powinien - na podstawie art. 193 konstytucji — zwrócić się do TK z odpowiednim pytaniem prawnym ${ }^{40}$. Należy przy tym podkreślić, że — zgodnie $\mathrm{z}$ tą koncepcją — jednocześnie nie neguje się tzw. wykładni prokonstytucyjnej na podstawie odczytywania norm zawartych w przepisach ustawowych, przy uwzględnianiu właściwych dla danej części systemu prawa wzorców konstytucyjnych, od której należy odróżnić wykładnię ustaw w zgodzie z konstytucją ${ }^{41}$. Syntetycznie kwestię tę ujął Piotr Tuleja, podkreślając, że „nieco inna jest funkcja wykładni ustaw w zgodzie z Konstytucją, gdy posługuje się nią TK w procesie kontroli konstytucyjności prawa, a inna, gdy odwołują się do niej sądy realizujące wymiar sprawiedliwości. W pierwszym przypadku chodzi przede wszystkim o ustalenie wiążącego dla innych organów znaczenia przepisu ustawy na poziomie generalno-abstrakcyjnym, w drugim — o ustalenie normatywnej treści ustawy będącej podstawą dla konkretno-indywidualnej normy" ${ }^{\prime 2}$.

W tym znaczeniu model związany z konstytucyjną kompetencją sądów powszechnych do współstosowania konstytucji i ustaw oraz powinności stosowania prokonstytucyjnej wykładni nie stanowi zagrożenia dla funkcji TK, w żaden sposób nie wpływa bowiem na proces abstrakcyjnej hierarchicznej kontroli norm, pozostający w wyłącznej kompetencji Trybunału, oraz nie prowadzi do zakwestionowania tej kompetencji w przedmiocie usuwania w sposób powszechnie obowiązujący niezgodnych z konstytucją aktów normatywnych z porządku prawnego $\mathrm{RP}^{43}$. Należy więc wskazać, że kompetencje SN przyznane ustawą o SN stanowią w tym zakresie swego rodzaju novum. Konstatacja ta wpływa na postrzeganie kognicji SN w sprawach skarg nadzwyczajnych jako kontroli konstytucyjności nie prawa stanowionego, ale procesu jego stosowania w formie wydawanych przez sądy powszechne i wojskowe orzeczeń (skarga na stosowanie prawa).

Biorąc przedstawione rozważania pod uwagę — w moim przekonaniu — nie można uznać, że podniesiony w skardze kasacyjnej (kasacji) zarzut niekonstytucyjności przepisów stanowiących podstawę orzekania przez sądy I i II instancji, a powiązany następnie w skardze nadzwyczajnej z tymi samymi wzorcami konstytucyjnymi jest zarzutem tożsamym. W trybie skargi kasacyjnej (kasacji) SN mógł bowiem dokonać wyłącznie prokonstytucyjnej (zgodnej z konstytucją) wykładni regulacji prawa stanowionego lub skierować pytanie prawne do TK, natomiast w trybie skargi nadzwyczajnej będzie kontrolował zgodność orzeczenia - zwłaszcza dokonanej przez sąd wykładni przepisów, nie zaś jego podstaw prawnych - z określonymi wartościami zawartymi w ustawie zasadniczej. W tym znaczeniu kontrola zainicjowana skarga nadzwyczajną będzie miała

40 Vide wyrok TK z 10 grudnia 2002 r., sygn. akt P 6/02, OTK ZU 2002/7A/91 i wyrok SN z 24 listopada 2015 r., sygn. akt II CSK 517/14.

${ }^{41}$ Szerzej na ten temat vide M. Gutowski, P. Kardas, Sądowa kontrola konstytucyjności prawa. Kilka uwag o kompetencjach sądów powszechnych do bezpośredniego stosowania konstytucji, „Palestra” 2016, nr 4, s. 5-30.

42 P. Tuleja, Stosowanie Konstytucji RP w świetle zasady jej nadrzędności, Kraków 2003, s. 307 i n.

43 M. Gutowski, P. Kardas, Sądowa kontrola..., s. 5-30. 
szerszy kontekst. Należy zatem zwrócić uwagę na dotychczasowe orzecznictwo TK, zgodnie z którym przedmiotem badania TK nie są akty stosowania prawa, a więc prawomocne orzeczenia lub ostateczne decyzje zapadłe $\mathrm{w}$ indywidualnych sprawach, ale wyłącznie akty normatywne, na podstawie których rozstrzygnięcia te zostały wydane. Zadaniem Trybunału jest bowiem orzekanie w sprawach zgodności z konstytucją aktów normatywnych, mające na celu wyeliminowanie z systemu prawnego przepisów prawa, które z konstytucją są niezgodne. Nie ulega zatem wątpliwości, że jedynym dopuszczalnym przedmiotem skargi konstytucyjnej w polskim prawie jest przepis prawny wykazujący dwojaką kwalifikację: po pierwsze - wydane przez sąd lub organ administracji publicznej ostateczne orzeczenie naruszające konstytucyjne prawa lub wolności podmiotu występującego ze skargą; po drugie - bezpośrednia przyczyna takiego naruszenia powinna tkwić w normatywnej treści kwestionowanego przepisu. Chociaż więc uprzedni akt stosowania przepisu będącego przedmiotem skargi nie pozostaje bez znaczenia w kontekście dopuszczalności korzystania z tego środka ochrony, to jednak nie ostateczne orzeczenie wydane na jego podstawie, ale sam przepis prawny będący taką podstawą stanowi jedyny dopuszczalny przedmiot skargi konstytucyjnej. Innymi słowy, niedopuszczalna jest skarga konstytucyjna skierowana wyłącznie przeciwko orzeczeniu wydanemu w sprawie skarżącego, tzw. skarga na stosowanie prawa ${ }^{44}$.

$\mathrm{Z}$ przedstawionych względów skarga nadzwyczajna niewątpliwie z założenia wzmacnia standard ochrony konstytucyjnych wolności i praw jednostki w takim zakresie, w jakim są one związane z normami prawa cywilnego i karnego. Zgodnie z art. 79 ust. 1 konstytucji skargę konstytucyjną może wnieść „każdy, czyje konstytucyjne wolności lub prawa zostały naruszone". Oznacza to, że warunkiem złożenia skargi konstytucyjnej nie jest każde naruszenie konstytucji, ale tylko naruszenie wyrażonych w niej norm regulujących wolności lub prawa człowieka i obywatela. W skardze konstytucyjnej trzeba zatem wskazać zarówno konkretną osobę, której wolności lub prawa naruszono, jak i te wolności i prawa (poręczone, zapewnione, gwarantowane, chronione) określone w konstytucji, które naruszono, a także określić sposób tego naruszenia ${ }^{45}$. Niemniej legitymowaną do wniesienia skargi konstytucyjnej jest wyłącznie ta osoba, która jest podmiotem naruszonego prawa lub wolności o charakterze konstytucyjnym.

Natomiast w ustawowej regulacji skargi nadzwyczajnej zaakcentowano związek między prawomocnym orzeczeniem a naruszeniem zasad lub wolności oraz praw człowieka i obywatela określonych w konstytucji. Jednocześnie w celu skorzystania z tego środka ochrony nie wymaga się: po pierwsze, bycia stroną w sprawie, w której wydano prawomocne orzeczenie (podmioty legitymowane do wniesienia skargi nadzwyczajnej mogą zatem działać z inicjatywy własnej lub osób trzecich), a po drugie — bycia podmiotem naruszonych wartości konstytucyjnych (skarga nadzwyczajna może zatem

44 Vide np. postanowienie TK z 21 marca 2006 r., sygn. akt Ts 49/06, OTK ZU 2006/5B/237. Niedopuszczalna jest więc taka skarga konstytucyjna, w której przedstawione zarzuty dotyczą wykładni dokonanej przez sąd, błędnej subsumpcji stanu faktycznego czy też wadliwości kierunku argumentacji wykorzystanej w ostatecznym orzeczeniu (tzw. skarga na stosowanie prawa; vide postanowienie TK z 2 grudnia 2010 r., sygn. akt SK 11/10, OTK ZU 2010/10A/131.

45 Vide postanowienie TK z 30 kwietnia 2014 r., sygn. akt Ts 73/14, OTK ZU 2014/4B/362. 
zostać wniesiona w interesie osób trzecich, a nie stron postępowania, w którym zapadło prawomocne orzeczenie). $\mathrm{Z}$ tych powodów katalog wolności i praw konstytucyjnych, które będą stanowić wzorce kontroli, w przypadku skargi nadzwyczajnej będzie niezwykle szeroki, a przede wszystkim będzie mógł pozostać niezależny od inicjatora wniesienia skargi nadzwyczajnej oraz stron postępowania, w którym zapadło skarżone orzeczenie. Ponadto — odmiennie niż w przypadku skargi konstytucyjnej — wzorcami kontroli będą także zasady konstytucyjne, a zatem unormowania konstytucyjne o charakterze aksjologicznym. Zawarte są one przede wszystkim w I rozdziale konstytucji, zatytułowanym „Rzeczpospolita” i określają ustrój polityczny, gospodarczy i społeczny państwa. Zasady te odnaleźć można także w innych regulacjach konstytucyjnych (w szczególności w rozdziale II). Należy też pamiętać, że podstawowe zasady wyrażone w ustawie zasadniczej można odnaleźć także w treści preambuły do konstytucji. W tym kontekście należy też podkreślić, że takie ujęcie skargi nadzwyczajnej umożliwi SN traktowanie m.in. zasady demokratycznego państwa prawnego, zasady równości i zasady proporcjonalności jako samodzielnych wzorców kontroli ${ }^{46}$. Niemniej takim

${ }^{46} \mathrm{Na}$ temat możliwości powoływania się na naruszenie art. 2 konstytucji w skardze konstytucyjnej TK wypowiadał się wielokrotnie, a najpełniej w sprawie o sygn. akt Ts 105/00 (postanowienia TK z 12 grudnia 2000 r. oraz 23 stycznia 2002 r., OTK ZU 2002/1B/59 i 60). Trybunał badał, czy możliwe jest dochodzenie ochrony zasad wynikających z art. 2 ustawy zasadniczej w trybie skargi konstytucyjnej. Zwrócił uwagę zwłaszcza na konieczność precyzyjnego określenia wolności lub prawa podmiotowego (wyinterpretowanych z przepisu), których naruszenie ma uzasadnić legitymację do wniesienia skargi konstytucyjnej. Trybunał podkreślił przy tym, że chodzi tu o prawa lub wolności przyjmujące normatywną formę praw podmiotowych. To znaczy o prawa, których adresatem jest obywatel (lub inny podmiot prawa) i które kształtują jego sytuację prawną oraz dają mu możliwość wyboru zachowania się, tj. spełnienia lub niespełnienia normy prawnej. Powołanie się na naruszenie - wynikającej z art. 2 konstytucji — zasady sprawiedliwości społecznej nie jest podstawą do wniesienia skargi, ponieważ zasada ta ma charakter przedmiotowy, jest adresowana do ustawodawcy i wyznacza sposób regulowania poszczególnych dziedzin życia publicznego. Trybunał podkreślił, że odwołanie się do niej (a także pozostałych, wywodzonych z zasady demokratycznego państwa prawnego) może mieć znaczenie tylko wtedy, gdy skarżący wskaże równocześnie wolność lub prawo podmiotowe mające swoje źródło w innym przepisie konstytucji i jest ograniczone wskutek naruszenia wymienionych zasad (vide postanowienia TK z: 19 grudnia 2001 r., sygn. akt SK 8/01, OTK ZU 2001/8/272; 26 czerwca 2002 r., sygn. akt SK 1/02, OTK ZU 2002/4A/53 oraz 1 października 2003 r., sygn. akt SK 29/02, OTK ZU 2003/8A/87). Na temat charakteru normy określonej w art. 32 konstytucji Trybunał wypowiedział się w wydanym w pełnym składzie postanowieniu z 24 października $2001 \mathrm{r}$. W sprawie o sygn. akt SK 10/01 TK orzekł, że ,,art. 32 Konstytucji wyraża przede wszystkim zasadę ogólną, i dlatego winien być w pierwszej kolejności odnoszony do konkretnych przepisów Konstytucji, nawet jeżeli konstytucyjna regulacja danego prawa jest niepełna i wymaga konkretyzacji ustawowej. W takim zakresie wyznacza on także konstytucyjne prawo do równego traktowania. Mamy tu do czynienia z sytuacją «współstosowania» dwóch przepisów Konstytucji, a więc nie tylko z prawem do równego traktowania, ale ze skonkretyzowanym prawem do równej realizacji określonych wolności i praw konstytucyjnych. W skardze konstytucyjnej należy powołać oba przepisy Konstytucji, dopiero one wyznaczają bowiem konstytucyjny status jednostki, który przez regulację ustawową lub podustawową został naruszony. Natomiast gdy chodzi o uprawnienia określone w innych niż Konstytucja aktach normatywnych — jeśli treść konkretnego prawa ustala się wyłącznie na ich podstawie art. 32 Konstytucji stanowi zasadę systemu prawa, a nie wolność lub prawo o charakterze konstytucyjnym" (OTK ZU 2001/7/225). Trzeci ze wskazanych wzorców kontroli, tj. art. 33 konstytucji, jest rozwinięciem i konkretyzacją ogólnej zasady równości, w związku z czym przytoczone argumenty odnoszą się także do niego (postanowienie TK z 30 kwietnia 2014 r., sygn. akt Ts 73/14, OTK ZU 2014/4B/362). 
wzorcem będą również zasady: bezpieczeństwa prawnego, bezpieczeństwa obywateli, równowagi budżetowej, dobra wspólnego. Biorąc zatem pod uwagę szeroki katalog wartości konstytucyjnych, na które może powołać się wnoszący skargę nadzwyczajną, żądając wzruszenia ostatecznego orzeczenia, pozytywnie należy ocenić wprowadzenie przez ustawodawcę dodatkowej przesłanki, której wystąpienie umożliwi uchylenie tego judykatu, tj. konieczności zapewnienia zgodności z zasadą demokratycznego państwa prawnego urzeczywistniającego zasady sprawiedliwości społecznej, które to wartości — co istotne — także stanowią zasady konstytucyjne.

Zasada demokratycznego państwa prawa stanowi podstawę ustroju politycznego Polski. Stanowi ona źródło nie tylko pozostałych zasad zawartych w konstytucji, ale zawiera w sobie inne niewyrażone wprost w przepisach ustawy zasadniczej komponenty, jak: zasada niedziałania prawa wstecz, zasada ochrony praw słusznie nabytych czy zasada zaufania do państwa i stanowionego przez nie prawa. Natomiast zasada sprawiedliwości społecznej z jednej strony generuje sama z siebie nakaz urzeczywistniania przez organy państwowe zasad sprawiedliwości społecznej, z drugiej — obejmuje konglomerat tych zasad (norm) o charakterze materialnym i proceduralnym oraz wspólną im wszystkim wartość w formie imperatywu sprawiedliwego działania władz publicznych i uwzględniania wymogu sprawiedliwości w kształtowaniu treści wydawanych przez nie aktów prawnych ${ }^{47}$. Mimo że TK od początku swojej działalności często sięgał i wciąż sięga do zasad sprawiedliwości społecznej jako podstawy swoich orzeczeń, a w konstytucji nie zdefiniowano tego zwrotu, w doktrynie prawa nadal brakuje precyzyjnego, a przede wszystkim jednoznacznego określenia treści tych zasad. Zatem stwierdzenie, że prawomocne orzeczenie narusza konstytucyjne zasady, wolności lub prawa jednostki nie będzie wystarczające do jego uchylenia. Sąd Najwyższy — a wcześniej podmiot wnoszący skargę nadzwyczajną — będzie musiał zatem także wykazać, że wzruszenie takiego orzeczenia jest konieczne w celu zapewnienia zarówno zasady demokratycznego państwa prawnego, jak i sprawiedliwości społecznej.

\section{WNIOSKI}

Pierwsze głosy rozczarowania funkcjonowaniem skargi konstytucyjnej — po nadziejach związanych z wprowadzeniem tej instytucji — pojawiły się już w 1997 r. Wynikało to przede wszystkim z rozbieżności między oczekiwaniami a realnym kształtem skargi konstytucyjnej, jak również krótką praktyką stosowania nowych regulacji. Dopiero w kolejnych latach liczba skarg kierowanych do TK zaczęła wzrastać. Trybunał orzekając w konkretnych sprawach, rozstrzygnął wiele istotnych $\mathrm{z}$ punktu widzenia obywateli zagadnień konstytucyjnych, nierzadko formułując w stosunku do ustawodawcy fundamentalne i brzegowe warunki zgodności procesu tworzenia prawa z konstytucją. Niemniej praktyka związana z funkcjonowaniem skargi konstytucyjnej skłania do negatywnej oceny tej instytucji.

${ }^{47}$ A. Domańska, Zasady sprawiedliwości społecznej we współczesnym polskim prawie konstytucyjnym, Łódź 2001, s. 138. 
Skarga nadzwyczajna jest niewątpliwie instrumentem naruszającym zasadę zaufania do państwa i stanowionego przez nie prawa, godzi w stabilność orzecznictwa oraz w zasadę powagi rzeczy osądzonej, a określenie całokształtu negatywnych skutków jej wprowadzenia do systemu prawa w tej chwili nie jest możliwe. Za konieczne i pożądane należy zatem uznać zmiany, jakie w modelu skargi nadzwyczajnej wprowadzono ustawą z dnia 10 maja 2018 r. o zmianie ustawy — Prawo o ustroju sądów powszechnych, ustawy o Sądzie Najwyższym oraz niektórych innych ustaw (Dz.U. poz. 1045), a zwłaszcza te, które ograniczyły możliwość wnoszenia tych skarg w odniesieniu do orzeczeń, które uprawomocniły się przed jej wejściem w życie.

$\mathrm{Na}$ kompleksową ocenę wprowadzenia skargi nadzwyczajnej do systemu polskiego prawa jednak trzeba poczekać. Nie można przy tym tracić z pola widzenia obaw i wątpliwości, które zgłaszano wobec tego instrumentu w toku prac legislacyjnych. W konsekwencji organy, za pośrednictwem których można wnieść skargę nadzwyczajną oraz SN, powinny zwrócić szczególną uwagę na wypracowanie tożsamej wykładni niedookreślonych i ocennych pojęć, które definiują przesłanki umożliwiające skorzystanie $\mathrm{z}$ tego środka ochrony konstytucyjnych praw i wolności. Biorąc pod uwagę mnogość podmiotów inicjujących postępowanie przed SN, może to być utrudnione, więc tym większa w tym zakresie rola doktryny. Niemniej w przypadku, gdyby skarga ta stała się uzupełnieniem skargi konstytucyjnej w tych obszarach, gdzie ta druga — z racji ograniczeń prawnych lub praktycznych — nie może być efektywna, należy postulować objęcie tą (lub podobną instytucją) postępowań w sprawach administracyjnych.

BIBLIOGRAFIA

ŹRÓDŁA

Ustawa z dnia 17 listopada 1964 r. - Kodeks postępowania cywilnego, (Dz.U. z 2016 r. poz. 1822 , ze zm.).

Ustawa z dnia 6 czerwca 1997 r. — Kodeks postępowania karnego (Dz.U. z 2017 r. poz. 1904, ze zm.).

Ustawa z dnia 1 sierpnia 1997 r. o Trybunale Konstytucyjnym (Dz.U. nr 102, poz. 643, ze zm.).

Ustawa z dnia 25 czerwca 2015 r. o Trybunale Konstytucyjnym (Dz.U. poz. 1064).

Ustawa z dnia 22 lipca 2016 r. o Trybunale Konstytucyjnym (Dz.U. poz. 1157).

Ustawa z dnia 13 grudnia 2016 r. - Przepisy wprowadzające ustawę o organizacji i trybie postępowania przed Trybunałem Konstytucyjnym oraz ustawę o statusie sędziów Trybunału Konstytucyjnego (Dz.U. poz. 2074).

Ustawa z dnia 30 listopada 2016 r. o statusie sędziów Trybunału Konstytucyjnego (Dz.U. poz. 2073).

Ustawa z dnia 30 listopada 2016 r. o organizacji i trybie postępowania przed Trybunałem Konstytucyjnym (Dz.U. poz. 2072).

Informacja o istotnych problemach wynikających z działalności i orzecznictwa Trybunatu Konstytucyjnego w 2016 r., <http://trybunal.gov.pl>, Warszawa 2016.

Informacja o działalności Sądu Najwyższego w roku 2017, <https://www.sn.pl>, Warszawa 2018. 


\section{ORZECZNICTWO}

Wy roki T K

Wyrok TK z 12 listopada 2002 r., sygn. akt SK 40/01, OTK ZU 2002/6A/81.

Wyrok TK z 10 grudnia 2002 r., sygn. akt P 6/02, OTK ZU 2002/7A/91.

Wyrok TK z 22 listopada 2005 r., sygn. akt SK 8/05, OTK ZU nr 2005/10A/117.

Wyrok TK z 24 października 2007 r., sygn. akt SK 7/06, OTK ZU 2007/9A/108.

Wyrok TK z 26 maja 2008 r., sygn. akt SK 25/07, OTK ZU 2008/4A/62.

Wyrok TK z 8 października 2013 r., sygn. akt SK 40/12, OTK ZU 2013/7A/97.

\section{Postanowienia T K}

Postanowienie TK z 19 grudnia 2001 r., sygn. akt SK 8/01, OTK ZU 2001/8/272.

Postanowienie TK z 24 października 2001 r., sygn. akt SK 10/01, OTK ZU 2001/7/225.

Postanowienie pełnego składu TK z 23 stycznia 2002 r., sygn. akt Ts 105/00, OTK ZU 2002/1B/60.

Postanowienie TK z 26 czerwca 2002 r., sygn. akt SK 1/02, OTK ZU 2002/4A/53.

Postanowienie TK z 1 października 2003 r., sygn. akt SK 29/02, OTK ZU 2003/8A/87.

Postanowienie TK z 14 grudnia 2004 r., sygn. akt SK 26/02, OTK ZU 2004/11A/120.

Postanowienia TK z 8 listopada 2005 r., sygn. akt: Ts 203/04, OTK ZU 2005/6B/237.

Postanowienie TK z 8 listopada 2005 r., sygn. akt Ts 204/04, OTK ZU 2005/6B/239.

Postanowienie TK z 21 marca 2006 r., sygn. akt Ts 49/06 OTK ZU 2006/5B/237.

Postanowienie TK z 4 września 2007 r., sygn. SK 47/06, OTK ZU 2007/8A/99.

Postanowienie TK z 10 października 2007 r., sygn. akt Ts 91/07, OTK ZU 2007/5B/254.

Postanowienie TK z 20 grudnia 2007 r., sygn. akt SK 67/05, OTK ZU 2007/11A/168.

Postanowienie TK z 8 kwietnia 2008 r., sygn. akt SK 80/06, OTK ZU 2008/3A/51.

Postanowienia pełnego składu TK z 16 lutego 2009 r., sygn. akt Ts 202/06, OTK ZU nr 2009/1B/23.

Postanowienie TK z 2 grudnia 2010 r., sygn. akt SK 11/10, OTK ZU 2010/10A/131.

Postanowienie TK z 21 grudnia 2010 r., sygn. akt Ts 16/10, OTK ZU 2014/2B/798.

Postanowienie TK z 6 kwietnia 2011 r., sygn. akt SK 21/07, OTK ZU 2011/3A/28.

Postanowienie TK z 13 czerwca 2011 r., sygn. akt SK 26/09, OTK ZU 2011/5A/46.

Postanowienie TK z 18 grudnia 2013 r., sygn. akt Ts 13/12, OTK ZU 2014/IIB/833.

Postanowienie TK z 4 kwietnia 2014 r., sygn. akt Ts 309/13,OTK ZU 2014/2B/176.

Postanowienie TK z 30 kwietnia 2014 r., sygn. akt Ts 73/14, OTK ZU 2014/4B/362.

Postanowienie TK z 16 czerwca 2014 r. sygn. akt Ts 214/13, OTK ZU 2015/5B/435.

Postanowienie TK z 3 lipca 2014 r., sygn. akt Ts 43/14, OTK ZU 2014/4B/357.

Postanowienie TK z 11 lipca 2014 r., sygn. akt Ts 22/14, OTK ZU 2014/4B/353.

Postanowienie TK z 23 października 2014 r., sygn. akt Ts 81/13, OTK ZU 2014/5B/ 417.

Postanowienie TK z 18 lutego 2015 r., sygn. akt P 48/13, OTK ZU 2015/2A/22.

Postanowienie TK z 18 lutego 2015 r., sygn. akt S 2/15, OTK ZU 2015/2A/23.

Orzeczenia innych sądów

Uchwała SN z 19 grudnia 2008 r., sygn. akt III CZP 122/08.

Postanowienie SN z 12 stycznia 2011 r., sygn. akt CSK 182/10.

Wyrok SN z 13 kwietnia 2012 r., sygn. akt I CSK 451/11.

Postanowienie NSA z 6 sierpnia 2014 r., sygn. akt II FSK 115/14.

Wyrok SN z 24 listopada 2015 r., sygn. akt II CSK 517/14.

Wyrok SN z 17 marca 2016 r., sygn. akt V CSK 337/15. 
Wyrok NSA z 12 kwietnia 2016 r., sygn. akt II FSK 330/15.

Wyrok SN z 15 września 2017 r., sygn. akt III CSK 241/16.

Postanowienie SN Izba Karna z 14 czerwca 2018 r., sygn. akt II KZ 19/18.

PIŚMIENNICTWO

Banaszak B., Jakie zmiany w Konstytucji RP sa potrzebne, [w:] Aktualne problemy reform konstytucyjnych, red. S. Bożyk, Temida 2, Białystok 2013.

Banaszak B., Opinia o zgodności z Konstytucja RP przedłożonego przez Prezydenta projektu ustawy o Sązie Najwyższym, druk nr 2003, VIII kadencja Sejmu. Opinie Biura Analiz Sejmowych, <http://www.sejm.gov.pl>.

Czeszejko-Sochacki Z., Formy naruszenia konstytucyjnych wolności lub praw, [w:] Skarga konstytucyjna, red. J. Trzciński, Wydawnictwo Sejmowe, Warszawa 2003.

Daniluk D., Skutki wyroku Trybunału Konstytucyjnego z klauzula odraczająca w postępowaniu sądowoadministracyjnym, „Przegląd Prawa Konstytucyjnego” 2011, nr 4.

Dobrowolski M., Opinia o zgodności z Konstytucją RP przedlożonego przez Prezydenta projektu ustawy o Sądzie Najwyższym, druk nr 2003, VIII kadencja Sejmu. Opinie Biura Analiz Sejmowych, <http://www.sejm.gov.pl>.

Domańska A., Zasady sprawiedliwości społecznej we współczesnym polskim prawie konstytucyjnym, Wydawnictwo Uniwersytetu Łódzkiego, Łódź 2001.

Dudek D., Konstytucyjna wolność człowieka a tymczasowe aresztowanie, Lubelskie Wydawnictwa Prawnicze, Lublin 2000,

Florczak-Wątor M., Skarga konstytucyjna jako środek ochrony konwencyjnych praw $i$ wolności jednostki, [w:] Prawo międzynarodowe i europejskie a sadownictwo konstytucyjne, red. P. Tuleja, Wydawnictwo Jak, Kraków 2015.

Garlicki L., Sąy a Konstytucja Rzeczypospolitej Polskiej, „Przegląd Sądowy” 2016, nr 7-8.

Gutowski M., Kardas P., Sąowa kontrola konstytucyjności prawa. Kilka uwag o kompetencjach sądów powszechnych do bezpośredniego stosowania konstytucji, „Palestra” 2016, nr 4.

Jarosz-Żukowska S., Prawo do skargi konstytucyjnej - stan obecny i postulaty de lege ferenda, [w:] Realizacja i ochrona konstytucyjnych wolności i praw jednostki w polskim porzadku prawnym, red. M. Jabłoński, Wydawnictwo Uniwersytetu Wrocławskiego, Wrocław 2014 r.

Jarosz-Żukowska S., W sprawie pożądanych zmian polskiego modelu skargi konstytucyjnej, [w:] Konieczne i pożądane zmiany Konstytucji RP z 2 kwietnia 1997 r., red. B. Banaszak, M. Jabłoński, Wydawnictwo Uniwersytetu Wrocławskiego, Wrocław 2010.

Liszcz T., Głos w dyskusji, [w:] Księga XXV-lecia Trybunału Konstytucyjnego. Ewolucja funkcji i zadań Trybunału Konstytucyjnego — założenia a ich praktyczna realizacja, red. K. Budziło, Biuro Trybunału Konstytucyjnego, Warszawa 2010.

Łabno A., Skarga konstytucyjna jako środek ochrony praw człowieka. Przyczynek do dyskusji, „Przegląd Prawa Konstytucyjnego” 2012, nr 4.

Matczak M., Opinia prawna w sprawie konstytucyjności prezydenckiego projektu ustawy o Sadzie Najwyższym, druk nr 2003, VIII kadencja Sejmu. Opinie Biura Analiz Sejmowych, $<\mathrm{http}: / /$ www.sejm.gov.pl $>$.

Masternak-Kubiak M., Zakolska J., Naruszenie zasady proporcjonalności jako podstawa skargi konstytucyjnej, [w:] W stużbie dobru wspólnemu. Księga dedykowana Profesorowi Januszowi Trzcińskiemu, red. M. Masternak-Kubiak, R. Balicki, Wydawnictwo Sejmowe, Warszawa 2012, s. 234-237.

Patyra S., Opinia prawna na temat zgodności z Konstytucją Rzeczypospolitej Polskiej przedstawionego przez Prezydenta Rzeczpospolitej Polskiej projektu ustawy o Sadzie Najwyższym, druk nr 2003, VIII kadencja Sejmu. Opinie Biura Analiz Sejmowych, <http://www.sejm.gov.pl>. 
Radziewicz P., ,Przywilej korzyści” jako skutek prawny orzeczenia Trybunału Konstytucyjnego, „Przegląd Legislacyjny” 2006, nr 4.

M. Safjan, Pozycja Trybunału Konstytucyjnego w Konstytucji Rzeczypospolitej Polskiej z 1997 roku. Nowe instrumenty i metody działania, [w:] Pięć lat Konstytucji Rzeczypospolitej Polskiej, red. H. Jerzmański, Warszawa 2002.

Tuleja P., Skarga konstytucyjna w Polsce — dziesięć lat doświadczeń, „Przegląd Legislacyjny” 2007, nr 3(61).

Tuleja P., Stosowanie Konstytucji RP w świetle zasady jej nadrzędności, Wolters Kluwer, Kraków 2003.

Tuleja P., Wróbel W., Skarga konstytucyjna, czyli dodatkowa gwarancja praw człowieka. W Polsce i gdzie indziej, „Rzeczpospolita” nr 265, 14 XII 1997.

Wiącek M., Formalne przesłanki skargi konstytucyjnej (w świetle orzecznictwa TK), „Państwo i Prawo" 2011, z. 9. 


\title{
KONCEPCJA JURYDYZACJI CZWARTEJ GENERACJI PRAW CZLOWIEKA W MIEDZYNARODOWYM SYSTEMIE OCHRONY
}

\author{
THE CONCEPT OF JURIDIZATION OF THE FOURTH GENERATION \\ OF HUMAN RIGHTS IN THE INTERNATIONAL \\ PROTECTION SYSTEM
}

The article analyzes the protection of human rights heretofore provided by the international law. The author carried out a research of the systems guaranteeing fundamental rights. Herein, it is indicated what the fourth generation of human rights shall encompass and its significance against the present system is analyzed. Advantages and disadvantages of the proposed solutions are discussed, referring directly to the theory of human rights protection. The conclusion contains a response to the question whether or not the concept of juridization of human rights is necessary and whether it shall prove rather harmful than beneficial.

Słowa kluczowe: ochrona praw człowieka, generacje praw człowieka, czwarta generacja praw człowieka, systemy ochrony praw człowieka

Key words: protection of human rights, generations of human rights, fourth generation of human rights, systems of protection of human rights

* Mgr Kamil Stępniak, Uniwersytet w Białymstoku, Wydział Prawa, doktorant w Katedrze Prawa Konstytucyjnego, kamilstepniak@o2.pl, https://orcid.org/0000-0002-6844-0817

\section{UWAGI WPROWADZAJĄCE}

$\mathrm{P}$ rawa człowieka można określić jako prawa przysługujące każdemu człowiekowi bez względu na posiadanie innych przymiotów. Innymi słowy, niezależnie od podejmowania wszelkich działań ludzkich czy też posiadania określonych cech każdemu człowiekowi przysługuje grupa praw, które są niezbywalne. Wśród ich podstawowych właściwości wymienia się: niezbywalność, przyrodzoność i powszechność ${ }^{1}$.

Genezy świadomości dotyczącej istnienia praw człowieka należy upatrywać w źródłach pisanych wielu epok, a także w myśli filozoficznej (chociażby dorobek Pawła Włodkowica ${ }^{2}$, pojęcie ,prawa jednostki” Williama Ockhama, dzieła Johna Locka Dwa traktaty o rzadzie lub List o tolerancji czy chociażby dzieło Umowa społeczna Jeana-Jacques'a Rousseau), jednak prawdziwa ekspansja tych praw nastąpiła dopiero po zakończeniu II wojny światowej3 . Wynikało to z ówczesnych doświadczeń, które

1 Confer C. Wellman, An Approach to Rights: Studies In the Philosophy of Laws and Morals, Dordrecht 1997, s. 81; J. Hersch, Human Rights in Western Thoughts, [w:] Philosophical Foundations of Human Rights, ed. A. Diemer Paris 1986, s. 132.

2 Vide S. Wielgus, Polska średniowieczna doktryna ius gentium, Lublin 1996.

3 Vide B.H. Weston, Human Rights, „Human Rights Quarterly” 1984, nr 3, s. 257. 
pokazały, że można dokonywać zbrodni względem ludzi, którzy posiadali pewne określone cechy (np. kolor skóry, przynależność etniczna). W tym szczególnie okrutnym czasie można było zostać pozbawionym statusu człowieka z powodu niezbywalnych ludzkich cech. Czas pokazał, że prawo stanowione może stać się systemem zbrodniczym. Gustaw Radbruch w swoich analizach nazywał takie zjawisko ustawowym bezprawiem ${ }^{4}$. Odpowiedzią na te doświadczenia były nowe instytucje międzynarodowe, które miały na celu zapewnienie skuteczniejszej ochrony praw człowieka. Dodatkowo rozwój prawa konstytucyjnego spowodował, że implementowano mechanizmy chroniące prawa podstawowe w ustawodawstwie krajowym - stały się one nie tylko istotnym elementem współczesnej kultury, ale zostały także wyeksplikowane jako podwaliny sprawiedliwego porządku społecznego oraz systemu urzeczywistniającego demokratyczne zasady ${ }^{5}$.

Na marginesie należy zwrócić uwagę na pewien paradoks dyskursu nad współczesnymi koncepcjami praw człowieka. Podczas gdy na płaszczyźnie praktycznej, doktrynalnej oraz w prawie pozytywnym uznaje się ich obowiązywanie i stara się poszerzyć istniejące koncepcje w celu lepszego zagwarantowania ich realizacji, to na płaszczyźnie teoretycznej część autorów uznaje niemożliwość istnienia praw człowieka w ogóle lub w pewnych sferach (chociażby w zakresie ich podstawowych właściwości). Podnoszony jest argument, że o ile deklaratoryjnie prawa podstawowe obowiązują, to w sferze interpretacyjnej formułowane są zastrzeżenia związane z koniecznością ich właściwego pojmowania. Za tym „właściwym” pojmowaniem często kryje się odrzucenie podstawowych właściwości tych praw (np. powszechności lub przyrodzoności) bądź odrzucenie ich w ogóle 6 . Wydaje się jednak, że jest to powodowane kłopotami z ich teoretycznym ujęciem, a także z określeniem wszystkich istotnych cech praw człowieka. Wystarczy wskazać, że przyjęcie dominującego poglądu, że samym prawem lub podstawą jego rozumienia jest zespół norm uznawanych za wypowiedzi językowe pewnego typu, prowadzi zwykle do odrzucenia praw człowieka jako praw przyrodzonych istniejących niezależnie od działań człowieka, ponieważ trudno wskazać niezależną od ludzkich działań podstawę istnienia takich norm. Inną koncepcją jest próba ulokowania praw człowieka w obszarze tzw. domniemanych praw moralnych. Takie ujęcie jednak tylko przesuwa problem na inną płaszczyznę rozumowania ${ }^{7}$.

${ }^{4}$ G. Radbruch, Gesetzliches Unrecht Und übergesetzliches Recht, [w:] idem, Der Mensch im Recht. Ausgewählte Vorträge und Aufsätze über Grundfragen des Rechts, Göttingen 1961, s. 111-124.

${ }^{5}$ Vide K. Stępniak, Walka z terroryzmem i cyberterroryzmem a ochrona konstytucyjnych praw $i$ wolności, [w:] Internet. Strategie bezpieczeństwa, red. A. Gryszczyńska, G. Szpor, Warszawa 2017, s. 119-122.

${ }^{6} \mathrm{Na}$ ten problem zwrócono uwagę w publikacji B. Tierney, Orgins of Natural Rights Language: Texts and Contexts, „History of Political Thought” 1989, nr 4, s. 615.

7 Vide J. Donnelly, Universal Human Rights In Theory and Practice, Ithaca 1989, s. 16; W. Osiatyński, Filozofia i historia praw człowieka, [w:] Prawa człowieka a policja, red. A. Rzepliński, Legionowo 1994, s. 20. 
Znalezienie odpowiedniej koncepcji prawnej nie oznacza końca problemów. Te pojawiają się też w zakresie podstaw, czyli antropologii filozoficznej, która mogłaby stanowić filar pozanormatywnej koncepcji praw człowieka. W warstwie filozoficznej istnieje bowiem spór co do zakresu obowiązywania praw człowieka - momentu powstania ochrony oraz jej przedmiotu. Z takimi wątpliwościami mierzą się sądy konstytucyjne poszczególnych państw oraz międzynarodowe trybunały. Badacze kontestują jednak orzecznictwo i pytają o logiczną dedukcję w odniesieniu do omawianych praw. Niekiedy naturę człowieka uważa się bowiem za produkt praktyki społecznej czy kultury, co

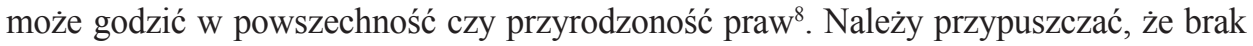
narzędzi teoretycznych jest jednym z powodów kontestowania istnienia praw człowieka, dlatego tak ważne jest zarówno prawne, jak i filozoficzne poszukiwanie takich narzędzi poznania praw podstawowych, które nie będą ograniczały zdolności percepcyjnej i nie będą powodowały anihilacji sensu ich istnienia9. Ze względu na przedmiot prowadzonych badań należy odpowiedzieć sobie na pytania nie tylko natury jurydycznej, ale także filozoficznej: dlaczego prawa człowieka istnieją, czym są i jaka jest ich ontyczna racja bytu ${ }^{10}$ ? Jaka jest zasadność oraz możliwość wprowadzenia do obrotu prawnego czwartej generacji praw człowieka? Oczywiście w akcie normatywnym możemy przyjąć każdą fikcję prawną, należy jednak zastanowić się, jak będzie ona funkcjonowała w rozwijającym się społeczeństwie oraz jakie uzasadnienie w zakresie obowiązywania wprowadzanych norm będzie na tyle racjonalne, aby ich ratio legis nie było podważane przez przedstawicieli judykatury i nauki ${ }^{11}$.

\section{PRAWA CZLOWIEKA - OD GODNOŚCI DO PODMIOTOWEJ WOLNOŚCI}

Wychodząc od zarysowanych wcześniej rozważań natury historycznej i filozoficznej, należy dokonać rzetelnej analizy naukowej przedmiotu niniejszego opracowania, czyli koncepcji określenia i jurydyzacji czwartej generacji praw człowieka. Zasadne wydaje się więc dokonanie operacjonalizacji w zakresie zmiennych, paradygmatów oraz wstępnych wiadomości dotyczących praw człowieka. Samo pojęcie ,prawa człowieka" jest wieloznaczne, co wynika $\mathrm{z}$ wielości koncepcji formułowanych w przedmiotowej dziedzinie. Wydaje się także, że taki stan rzeczy wynika też z interdyscyplinarności badań prowadzonych nad człowiekiem i jego prawami. Życie społeczne nie jest podzielone na dziedziny naukowe i czasami ciężko jest formułować jednoznaczne paradygmaty, pojęcia czy określone metody badawcze. W niniejszym artykule „prawa człowieka" będą oznaczały doniosłe prawa, które przysługują jednostce zgodnie z jakąś koncepcją filozoficzną, odnoszącą się do jej pozycji w państwie (płaszczyzna filozoficzna), czy też przysługują jej zgodnie z normami prawa międzynarodowego, wewnętrznego lub ponadpaństwowego (płaszczyzna prawna) ${ }^{12}$.

\footnotetext{
${ }^{8}$ Confer np. J. Donnelly, op. cit., s. 18.

${ }^{9}$ Confer J. Maritain, Człowiek i państwo, thum. A. Grobler, Kraków 1993, s. 87.

10 Vide J. Finnis, Natural Law and Natural Rights, Oxford 1992.

${ }^{11}$ Confer K. Stępniak, Legislacja w Polsce. Aspekty prawne i aksjologiczne, Warszawa 2017, s. 12-15.

${ }^{12}$ Definicja za: J. Hołda i in., Prawa człowieka. Zarys wykładu, Warszawa 2011, s. 11.
} 
Bezsprzecznie prawa podstawowe działają wertykalnie, czyli w stosunkach państwo-jednostka. Obecnie potwierdza się również horyzontalne oddziaływanie tych norm, czyli między dwiema jednostkami lub jednostką a innym podmiotem niebędącym częścią aparatu państwowego ${ }^{13}$. O ile obowiązywanie wertykalne nie budzi niczyich wątpliwości, o tyle koncepcja horyzontalna jest dość nowa zarówno w war-

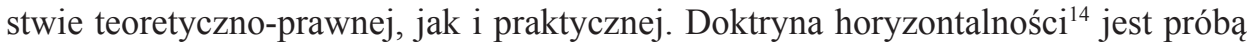
naukowej, teoretycznej analizy fenomenu ochrony praw i wolności, rozszerzającej się na sferę stosunków między jednostkami. Jest to jednak — co trzeba odnotować fenomen rodzący wiele wątpliwości i obaw wśród przedstawicieli nauk prawnych na całym świecie. Nie wchodząc zbyt głęboko w szczegóły tej problematyki, należy jedynie zauważyć, że koncepcja ta się umacnia, a sądy w swoich orzeczeniach coraz częściej sięgają do tego rozwiązania nawet w sprawach związanych ze stosunkami prywatnymi ${ }^{15}$.

Współcześnie przedstawiciele doktryny mówią głównie o trzech generacjach praw człowieka, wśród których wyróżnia się: prawa obywatelskie i polityczne, prawa gospodarcze, socjalne i kulturalne, wolności i prawa solidarnościowe. Natomiast obecnie coraz częściej pojawia się koncepcja tzw. czwartej generacji praw człowieka, które wszystkim istotom ludzkim mają zapewnić m.in. prawo do życia od samego poczęcia aż po jego kres. Przyjmuje się powszechnie, że prawa człowieka wynikają z przyrodzonej godności człowieka, dlatego też bez znaczenia jest to, czy prawa te są aprobowane przez ustawodawstwo państwowe. Przynależą one bowiem każdemu człowiekowi i dla ich ważności nie jest konieczne uzyskanie aprobaty ze strony wspólnoty państwowej. Ich przyjęcie do krajowego porządku prawnego (np. przez wprowadzenie do konstytucji) ma charakter deklaratoryjny, a nie konstytutywny. Dzieje się tak, ponieważ godność człowieka i jego wolność stanowią pierwotną postawę wobec państwa i jego sytemu prawnego ${ }^{16}$.

Prawa podstawowe pełnią trzy funkcje: pierwszą stanowi ochrona jednostki przed naruszeniem wolności przez państwo; drugą — konieczność stworzenia przez państwo możliwości realizacji praw jednostki; trzecią — chronienie przez państwo praw i wolności jednostki przed naruszaniem ich przez osoby trzecie ${ }^{17}$. Wiktor Osiatyński porównuje prawa człowieka do tarczy, która chroni jednostkę, a zwłaszcza jej wolność przed państwem. Jego zdaniem, istotą państwa jest władza, która jest

13 Confer T. Raphael, The Problem of Horizontal Effect, „European Human Rights Review” 2000, t. 5, s. 493 .

${ }^{14} \mathrm{~W}$ literaturze przedmiotu znana także jako: promieniowanie konstytucji (drittwirkung), pozytywne obowiązki państwa (state action) czy wreszcie tzw. efekt trzeciej strony (third party effect).

15 Confer wyroki TK z 23 czerwca 2015 r., sygn. akt SK 32/14, OTK ZU 2015/6A/83; z 23 marca 1999 r., sygn. akt K 2/98, OTK ZU 1999/3/38; z 8 października 2002 r., sygn. akt K 36/00, OTK ZU 2002/5A/63; z 25 lipca 2013 r., sygn. akt P 56/11, OTK ZU 2013/6A/85.

${ }^{16}$ M. Piechowiak, Filozofia praw człowieka. Prawa człowieka w świetle ich międzynarodowej ochrony, Lublin 1999, s. 13.

17 W. Osiatyński, Wprowadzenie do praw człowieka, stron internetowa Helsińskiej Fundacji Praw Człowieka, <http://www.hfhr.pl>, dostęp 3 III 2018. 
realizowana za pomocą pewnego aparatu, który może korzystać ze środków przymusu. Dowolność decyzji podejmowanych przez urzędników umożliwia arbitralne rozstrzygnięcia. Dlatego tak ważna jest konieczność ochrony jednostki przed ingerencją ze strony władzy państwowej ${ }^{18}$.

Prawa człowieka można scharakteryzować za pomocą przymiotów, którymi one się cechują. Zgodnie z doktrynalnym ujęciem są one: przyrodzone, tzn. istnieją niezależnie od woli władzy i prawa pozytywnego i przysługują każdej istocie ludzkiej; nienabywalne — nie można ich kupić ani pozyskać w inny sposób; nienaruszalne — państwo nie może naruszać i ograniczać w sposób dowolny praw człowieka z wyjątkiem pewnych szczególnych sytuacji przewidzianych w przepisach prawa; powszechne — przysługują wszystkim ludziom bez wyjątku, niezależnie od pochodzenia społecznego, statusu majątkowego, koloru skóry, religii, płci czy poglądów politycznych; podstawowe stanowią minimum uprawnień jednostki, bez których nie mogłaby ona korzystać ze wszelkich innych praw ${ }^{19}$.

Godność człowieka uznawana jest za źródło praw podstawowych, ponieważ jest ona pierwotna wobec państwa i jego systemu prawnego. Ochrona godności człowieka jest jedną z głównych funkcji praw podstawowych. Godność człowieka jest wrodzona, w związku z tym przysługuje ona wszystkim ludziom, bez względu na ich zasługi czy też występki (zarówno ludziom zasłużonym społecznie, jak i zbrodniarzom). Dzieje się tak, ponieważ w omawianej koncepcji chodzi o godność osobową (przynależną każdemu bez względu na jego postawę moralną), a nie o osobistą (ta zaś jest relatywna i uzależniona od zasług lub win). Tę drugą można utracić w wyniku postępowania powszechnie uważanego za nieetyczne bądź poprawić w związku z wyjątkowym postępowaniem i szacunkiem w społeczeństwie.

Jak wskazano wcześniej, istnieje możliwość limitowania praw człowieka ze względu na szczególny stan w państwie bądź szeroko pojęte dobro wspólne ${ }^{20}$. Są jednak takie prawa człowieka, które uznawane są za absolutne i nienaruszalne i, co za tym idzie, nie można ich relatywizować w żadnych okolicznościach. Wśród nich można wymienić chociażby: zakaz bycia karanym bez podstawy prawnej, zakaz bycia karanym ponownie za ten sam czyn, zakaz poddawania torturom i nieludzkiemu traktowaniu czy zakaz niewolnictwa. Do tych praw należy zaliczyć także prawo do życia, które jest prawem fundamentalnym. Warto jednak wskazać, że w aktach prawa międzynarodowego nie zawarto jego bezwarunkowej ochrony. Przykładowo w europejskiej Konwencji o ochronie praw człowieka i podstawowych wolności [dalej: EKPC] w art. 2 ust. 2 zawarto wyłączenie spod zakazu zabicia drugiego człowieka ${ }^{21}$. W kontekście

18 Ibidem.

19 L. Koba, M. Nowicki, Prawa i wolności człowieka, [w:] B. Chmielewska i in., Prawa człowieka. Poradnik nauczyciela, Warszawa 2002, s. 12-13.

${ }^{20}$ Limitację, a raczej czasowe zawieszenie części praw przewidziano w art. 4 ust. 1 Międzynarodowego Paktu Praw Obywatelskich i Politycznych z 19 grudnia 1966 r. (Dz.U. z 1977 r. nr 38, poz. 167).

${ }^{21}$ Konwencja o ochronie praw człowieka i podstawowych wolności sporządzona w Rzymie dnia 4 listopada 1950 r. (Dz.U. z 1993 r. nr 61, poz. 284, ze zm.). 
przedmiotowych rozważań i w celu zachowania logicznej poprawności wywodu należy też wskazać, że jako „koncepcję jurydyzacji” rozumiem postulat unormowania w prawie międzynarodowym publicznym bądź w prawodawstwie krajowym pewnej specyficznej (wyodrębnionej ze względu na cechy relewantne) grupy praw człowieka, które będą stanowiły oddzielną całość względem pozostałych norm z zakresu praw podstawowych. Koncepcja ta, zdaniem jej autorów, jest związana z koniecznością wprowadzenia do obrotu prawnego praw człowieka, które wynikają z praw naturalnych i które jak dotąd nie mają jednak swojej bezpośredniej eksplikacji w aktach normatywnych.

\section{III. ŹRÓDLA PRAW CZLOWIEKA W KONTEKŚCIE CZWARTEJ GENERACJI PRAW CZLOWIEKA}

Katalog praw podstawowych można sformułować na przykładzie wielu aktów prawa międzynarodowego lub krajowego. Aby unaocznić wielość rozwiązań w tym zakresie, należy dokonać charakterystyki źródeł praw człowieka. Organizacją, która szczególnie przyczyniła się do realizacji idei ochrony praw człowieka, była Organizacja Narodów Zjednoczonych. Zgromadzenie Ogólne ONZ 10 grudnia 1948 r. uchwaliło Powszechną Deklarację Praw Człowieka, potocznie nazywaną biblią praw człowieka. W dokumencie tym wyeksplikowano podstawowe wartości i prawa przysługujące każdemu człowiekowi niezależnie od jego pochodzenia, koloru skóry czy innej różnicującej cechy, która mogłaby wpływać na odmienne traktowanie. Jej charakter prawny od początku nie był do końca przesądzony. Nie ma wątpliwości, że pierwotnie akt ten uznawano wyłącznie za deklarację, standard i jednocześnie postulat dotyczący praw człowieka, a nie - z legalistycznego punktu widzenia — za akt prawa międzynarodowego ${ }^{22}$. Obecnie wyznaje się pogląd, że deklarację należy zaliczać do prawa zwyczajowego powszechnie respektowanego przez prawników. Niemniej należy uznać, że deklaracja stała się asumptem do uchwalenia Międzynarodowych Paktów Praw Człowieka, czyli Międzynarodowego Paktu Praw Gospodarczych, Społecznych i Kulturalnych ${ }^{23}$ oraz Międzynarodowego Paktu Praw Obywatelskich i Politycznych ${ }^{24}$. W systemie stworzonym przez ONZ uchwalano ponadto akty bezpośrednio ukierunkowane na ochronę danej grupy praw podstawowych albo nawet pojedynczych praw, np. Konwencję o prawach dziecka czy Konwencję dotyczącą statusu uchodźców.

Wielkim osiągnięciem Organizacji Narodów Zjednoczonych było wypracowanie złożonych mechanizmów prawnomiędzynarodowych, które wpływają na poziom poszanowania przedmiotu ochrony. Powołano agendy, które swoją działalność skupiają właśnie na ochronie praw podstawowych. W Genewie usytuowano Komitet Praw

${ }^{22}$ L. Koba, M. Nowicki, Historia praw czlowieka..., s. 44.

${ }^{23}$ Międzynarodowy Pakt Praw Gospodarczych, Społecznych i Kulturalnych otwarty do podpisu w Nowym Jorku dnia 19 grudnia 1966 r. (Dz.U. z 1977 r. nr 38, poz. 169).

${ }^{24}$ Międzynarodowy Pakt Praw Obywatelskich i Politycznych otwarty do podpisu w Nowym Jorku dnia 19 grudnia 1966 r. (Dz.U. z 1977 r. nr 38, poz. 167). 
Człowieka - specjalny organ quasi-sądowy ${ }^{25}$, do którego każdy może skierować indywidualną skargę w przypadku naruszenia jego praw obywatelskich czy politycznych, pod warunkiem, że państwo, wobec którego skonstruowano skargę, ratyfikowało Protokół Fakultatywny z 1966 r. do Międzynarodowego Paktu Praw Obywatelskich i Politycznych ${ }^{26}$.

Organizacja Narodów Zjednoczonych oraz jej postępowanie determinowały powstawanie podobnych systemów ochrony. Można powiedzieć, że struktura ta przez swoje działania prawne nie tylko wpłynęła na zwiększenie bezpieczeństwa w tym zakresie, ale także zapoczątkowała pewnego rodzaju modę na wdrażanie systemów nadzoru nad prawami człowieka ${ }^{27}$. Gdy w 1949 r. powstawała Rada Europy, nie budziło żadnych wątpliwości, że na kanwie wydarzeń militarnych, które dotknęły Stary Kontynent, oraz w celu osiągnięcia jak najbardziej satysfakcjonujących rozwiązań pokojowych ochrona praw człowieka będzie jedynym z priorytetów państw członkowskich. Tak też się stało, gdy w 1950 r. przyjęto Konwencję o ochronie praw człowieka i podstawowych wolności. W odróżnieniu od Powszechnej Deklaracji Praw Człowieka (której charakter prawny jest złożony i różnie opiniowany w środowisku prawniczym) dokument ten ma niekwestionowaną moc wiążącą — jest umową międzynarodową, która zapewnia poszanowanie i ochronę praw podstawowych każdemu człowiekowi poszkodowanemu przez kraj, który ratyfikował tę Konwencję ${ }^{28}$. Konwencja została uzupełniona o szesnaście protokołów dodatkowych ${ }^{29}$.

W celu realizacji postanowień Konwencji ustanowiono instytucje, które miały realizować postanowienia w niej zawarte. Była to Europejska Komisja Praw Człowieka (organ ten nie działa od 31 października 1999 r.) ) $^{30}$, a także Europejski Trybunał Praw

${ }^{25} \mathrm{~W}$ literaturze przedmiotu podnosi się, że jest to organ politycznym lub quasi-sądowy; vide A. Michalska, Komitet Praw Człowieka. Kompetencje, funkcjonowanie, orzecznictwo, Warszawa 1994).

${ }^{26}$ R. Rosa, Bezpieczeństwo i prawa czlowieka (wybrane aspekty filozoficzne i edukacyjne), [w:] Bezpieczeństwo człowieka wobec współczesnych i przyszłych wyzwań, red. J. Dębowski, E. Jarmoch, A.W. Świderski, Siedlce 2005, s. 67-76.

${ }^{27}$ L. Koba, M. Nowicki, Historia praw czlowieka..., s. 68.

${ }^{28}$ Polska przystąpiła do Rady Europy 26 listopada 1991 r. Tego samego dnia podpisała EKPC (co było politycznym wymogiem uzyskania członkostwa w Radzie Europy). KKPC została przez Polskę ratyfikowana 19 stycznia 1993 r. i tego samego dnia weszła w życie. Deklarację o uznaniu jurysdykcji Trybunału złożono 1 maja 1993 r. Po uznaniu przez rząd RP jurysdykcji Europejskiej Komisji Praw Człowieka oraz ETPC można było składać skargi do Trybunału w Strasburgu przeciwko Rzeczypospolitej. 26 lipca 1994 r. Polska ratyfikowała Protokoły nr 1 i 4; 18 października 2000 r. — Protokół nr 6; 4 listopada 2002 r. — Protokół nr 7 (ponadto ratyfikowała Protokoły nr 2, 9 i 11+ dotyczące kwestii proceduralnych).

${ }_{29}$ Vide M.A. Nowicki, Wokót Konwencji Europejskiej. Krótki komentarz do Europejskiej konwencji praw człowieka, Kraków 2003, passim.

${ }^{30}$ Komisja zajmowała się badaniem dopuszczalności skarg, ustaleniami faktycznymi i prawnymi, negocjacjami ugodowymi i wydawaniem opinii na temat naruszeń EKPC, skierowanymi do ETPC przez osoby fizyczne (grupę osób, organizacje pozarządowe) oraz państwa należące do Rady Europy; zmianę w funkcjonowaniu organów Rady Europy (Komisji i Trybunału) wprowadzono Protokołem nr 11. z 1994 r., zgodnie z którym 1 października 1998 r. zamiast dwóch organów powołano jeden — stały Europejski Trybunał Praw Człowieka, który przejął sprawy rozpatrywane przez Komisję. 
Człowieka w Strasburgu [dalej też: ETPC]. Orzecznictwo ETPC dotyczy problematyki przestrzegania Konwencji oraz protokołów dodatkowych. Skargę do tego organu może złożyć każdy obywatel po wyczerpaniu środków ochrony prawnej przysługujących stronie, zgodnie z prawem jej kraju. Rada Europy przyjęła także Europejską Kartę Społeczną ${ }^{31}$, w której zawarto katalog praw socjalnych i ekonomicznych, które uzupełniły przedmiot ochrony przyjęty w EKPC. Z czasem w systemie tym uzgadniano także dodatkowe dokumenty, mające na celu ochronę szczególnych grup i pojedynczych osób narażonych na łamanie praw człowieka. Wśród nich należy wyróżnić m.in.: Europejską konwencję o zapobieganiu torturom oraz nieludzkiemu lub poniżającemu traktowaniu albo karaniu — wraz z dwoma dodatkowymi protokołami ${ }^{32}$, Konwencję ramową o ochronie mniejszości narodowych ${ }^{33}$ czy Europejską Kartę Samorządu Terytorialnego ${ }^{34}$.

Szczególną uwagę należy zwrócić także na Konwencję o ochronie praw człowieka i godności istoty ludzkiej w dziedzinie zastosowania biologii i medycyny, znana także jako europejska konwencja bioetyczna ${ }^{35}$, oraz trzy dodatkowe protokoły do niej ${ }^{36}$. Konwencję tę podpisano 4 kwietnia 1997 r. w Oviedo, chcąc zapewnić wzmożoną ochronę przed posuniętą ingerencją w prawa podstawowe. Rada Europy już wiele lat temu dostrzegła problem etyczny związany $\mathrm{z}$ medyczną ingerencją $\mathrm{w}$ integralność natury ludzkiej, ponieważ dzięki postępowi technologii człowiek jest w stanie przeprowadzać daleko idące zmiany w żywych organizmach. Konwencja ta zdecydowanie zwiększyła poziom ochrony przed nieuprawnioną interwencją bioinżynieryjną w ludzkie ciało oraz przed wszystkimi próbami instrumentalizacji ludzkiej cielesności. Konwencja ma kilka charakterystycznych cech. Przede wszystkim jej celem jest ochrona godności, tożsamości oraz integralności każdej istoty ludzkiej. Oprócz występujących w dokumencie wyrażeń „osoba”, „każda osoba” (person, everyone), zarówno w tytule, jak i w innych zasadniczych miejscach użyto szerszego pojęcia ,istota ludzka” (human being). Zabieg ten zastosowano głównie w celu uniknięcia wszelkich sporów interpretacyjnych. Jednocześnie możliwie wyczerpująco określono podmiotowy zakres ochrony. Podkreślono, że dobro pojedynczego człowieka jest ważniejsze niż interes społeczeństwa i nauki (art. 2). Zakazano przeprowadzania interwencji medycznej bez wyraźniej i swobodnej zgody osoby zainteresowanej (art. 5), a interwencja mająca na celu dokonanie zmian w genomie ludzkim może być przeprowadzona wyłącznie w celach profilaktycznych, terapeutycznych lub diagnostycznych (art. 13). Do tej problematyki

31 Europejska Karta Społeczna sporządzona w Turynie dnia 18 października 1961 r. (Dz.U. z 1999 r. nr 8, poz. 67).

32 Europejska Konwencja o zapobieganiu torturom oraz nieludzkiemu lub poniżającemu traktowaniu albo karaniu, sporządzona w Strasburgu w dniu 26 listopada 1987 r. (Dz.U. z 1995 r. nr 46, poz. 238).

33 Konwencja ramowa o ochronie mniejszości narodowych, sporządzona w Strasburgu dnia 1 lutego 1995 r. (Dz.U. z 2002 r. nr 22, poz. 209).

34 Europejska Karta Samorządu Terytorialnego, sporządzona w Strasburgu dnia 15 października 1985 r. (Dz.U. z 1994 r. nr 124, poz. 607).

35 Polska konwencji nie ratyfikowała.

36 Protokół dodatkowy: o zakazie klonowania istot ludzkich; dotyczący transplantacji organów i tkanek pochodzenia ludzkiego; dotyczący badań biomedycznych. 
odniosę się szczegółowo w dalszej części artykułu, pragnę tylko zwrócić uwagę, że europejska konwencja biomedyczna jest aktem prawnym, który zapewnia wysoki poziom ochrony prawno-międzynarodowej w zakresie problematyki, która w przyszłości coraz bardziej będzie zyskiwała na znaczeniu ${ }^{37}$.

Od systemu ochrony praw człowieka Rady Europy należy odróżnić ochronę zagwarantowaną prawem Unii Europejskiej (chociaż wszystkie państwa UE są jednocześnie członkami Rady Europy). W 2000 r. w Nicei podpisano Kartę praw podstawowych Unii Europejskiej ${ }^{38}$. W dokumencie tym zawarto katalog chronionych praw i wolności człowieka oraz mechanizmy realizacji jej postanowień. W zakresie ochrony praw, które miałyby być zaliczane do czwartej generacji praw człowieka, interesujący wydaje się przede wszystkim art. 3 , zgodnie z którym każdy ma prawo do poszanowania integralności fizycznej i psychicznej (ust. 1), a w medycynie i biologii muszą być stosowane w szczególności: świadoma i swobodna zgodna osoby zainteresowanej (ust. 2a), zakaz praktyk eugenicznych (ust. 2b), zakaz wykorzystywania ciała ludzkiego i poszczególnych jego części jako źródła zysku (ust. 2c) oraz zakaz reprodukcyjnego klonowania istot ludzkich (ust. 2d). W kontekście art. 3 ust. $2 \mathrm{~d}$ konserwatywni działacze zgłaszali postulat poszerzenia przedmiotu ochrony i wprowadzenie zakazu klonowania zarodków ludzkich w celach terapeutycznych. Postulat ten jednak nie został uwzględniony. Karta praw podstawowych UE zapewnia ochronę wszystkim obywatelom ludziom, a nad jej przestrzeganiem czuwa Trybunał Sprawiedliwości UE.

Na marginesie należy zauważyć, że funkcjonują także pozaeuropejskie systemy ochrony praw człowieka. Rozwiązania kontynentalne są oczywiście bliższe naszej kulturze prawnej, warto jednak odnotować także inne rozwiązania stosowane na świecie.

W 1948 r. w Bogocie podpisano Kartę Organizacji Państw Amerykańskich, w ramach którego funkcjonuje międzyamerykański system ochrony praw człowieka. Podczas tej samej konferencji przyjęto także Amerykańską Deklarację Praw i Obowiązków Człowieka, dokument bardzo zbliżony swoim charakterem do Powszechnej Deklaracji Praw Człowieka. Sformułowano w nim prawa zarówno pierwszej, jak i drugiej generacji praw człowieka i podobnie jak w systemie uniwersalnym deklaracja ta była punktem wyjścia do prac nad traktatem z zakresu ochrony praw człowieka. W 1969 r. w San Jose podpisano Amerykańską Konwencję Praw Człowieka, która weszła w życie w 1978 r. Mechanizm kontroli sprawuje powołany w tym akcie Międzyamerykański Trybunał Praw Człowieka ${ }^{39}$.

Afrykański system ochrony funkcjonuje $\mathrm{w}$ ramach organizacji międzynarodowej zrzeszającej państwa tego kontynentu. Od 2002 r. jest to Unia Afrykańska, w której skład wchodzą 53 państwa, czyli niemal wszystkie kraje Afryki. Ochrona praw

${ }^{37}$ Confer M.A.M. Wachter, The European Convention on Bioethics, „The Hastings Center Report” 1997, nr 27, s. 13-23.

${ }^{38}$ Dz.Urz. UE C 83 z 30.03.2010 r.

${ }^{39}$ B. Gronowska, T. Jasudowicz, M. Balcerzak, M. Lubiszewski, R. Mizerski, Prawa człowieka i ich ochrona, Torun 2010, s. 87-90. 
człowieka opiera się na Afrykańskiej Karcie Praw Człowieka i Ludów, podpisanej w 1981 r. w Nairobi. Wiąże ona wszystkie państwa Unii Afrykańskiej. Oprócz chronionych praw pierwszej i drugiej generacji cechą immanentną tego aktu jest połączenie praw człowieka z prawami ludów, co stanowi ewenement. W Afrykańskiej Karcie Praw Człowieka i Ludów uwzględniono także takie prawa trzeciej generacji, jak prawo do rozwoju gospodarczego, społecznego i kulturalnego, a także prawo do pokoju i bezpieczeństwa ${ }^{40}$.

Chcąc sformułować katalog praw człowieka, najlepiej sięgnąć do systematyki Powszechnej Deklaracji Praw Człowieka. Wynika to z fenomenu tego aktu, który został uchwalony przez olbrzymią społeczność międzynarodową. To pierwszy dokument, w którym zawarto kompleksowy katalog praw człowieka. Powstanie tego aktu było wynikiem kompromisu między zwolennikami różnych koncepcji filozoficznych. Deklaracja stanowi emanację podstawowego znaczenia ,przyrodzonej godności oraz równych i niezbywalnych praw wszystkich członków wspólnoty ludzkiej”. W związku z tym, że większość państw zaaprobowała Powszechną Deklarację Praw Człowieka (dzięki jej otwartemu charakterowi i brakowi kontroli międzynarodowej część mogła potraktować ją jako ,,program do zrealizowania”, inne zaś jako wektor przestrzeganych standardów), można na jej podstawie stworzyć katalog praw człowieka ${ }^{41}$.

Odwołując się do pracy Anny Michalskiej, można wyodrębnić trzy grupy wolności i praw zawartych w deklaracji ${ }^{42}$ :

A. P r a a i w o l n o ś c i o s o b i s t e, do których należą: prawo do życia, wolności i bezpieczeństwa (art. 3), zakaz niewolnictwa (art. 4), zakaz tortur lub okrutnego traktowania i karania (art. 5), prawo do uznawania osobowości prawnej (art. 6), równość wobec prawa i prawo do jednakowej ochrony prawnej (art. 7), prawo do ochrony sądowej w razie pogwałcenia podstawowych praw przyznanych przez prawo wewnętrzne (art. 8), zakaz arbitralnego pozbawiania wolności lub wygnania z kraju (art. 9), prawo do rzetelnego sądu (art. 10), domniemanie niewinności, prawo do obrony i publicznej rozprawy, zasada nullum crimen, nulla poena sine lege penali anteriori (art. 11), prawo do prywatności i poszanowania życia rodzinnego, tajemnicy korespondencji, honoru i dobrego imienia (art. 12), prawo do swobodnego poruszania się i zamieszkania, do opuszczenia państwa i powrotu (art. 13), prawo do ubiegania się o azyl (art. 14), prawo do małżeństwa i prawa małżeńskie równe dla kobiety i mężczyzny (art. 16), prawo własności (art. 17), wolność myśli, sumienia i wyznania (art. 18).

B. Prawa i wolności publi c zne, do których zaliczamy: prawo do obywatelstwa (art. 5), wolność słowa (art. 19), wolność zgromadzeń i stowarzyszeń (art. 20), prawo do udziału w rządzeniu krajem, dostępu do funkcji publicznych i demokratycznych wyborów (art. 21).

40 Ibidem, s. 90-32.

${ }^{41}$ Więcej na ten temat vide np. K. Motyka, Prawa człowieka. Wprowadzenie. Wybór źródeł, Lublin 1999, s. 52 i n.

42 Vide A. Michalska, Podstawowe prawa człowieka w prawie wewnętrznym a Pakty Praw Człowieka, Warszawa 1976, s. 173 i n. 
C. Prawa ekonomiczne, socjalne i kulturalne, do których należą przede wszystkim: prawo do pracy i słusznego wynagrodzenia za nią, ochrona przed bezrobociem, prawo do przystępowania do związków zawodowych (art. 24), prawo do urlopu i wypoczynku (art. 24), prawo do godziwego poziomu życia, opieki lekarskiej, zabezpieczenia społecznego, prawo matki i dziecka do opieki i pomocy (art. 25), prawo do bezpłatnej nauki przynajmniej na poziomie podstawowym (art. 26), prawo do kultury (art. 27).

Eksplikacji wymaga fakt, że prace nad kodyfikacją praw człowieka w zakresie tzw. systemu uniwersalnego trwały niemal 20 lat i były prowadzone w ramach ONZ. Rozpoczęto je już w 1947 r., a zakończono uchwaleniem przez Zgromadzenie Ogólne w dniu 16 grudnia 1966 r. Międzynarodowych Paktów Praw Człowieka. W czasie prac nad projektami pojawiały się różne koncepcje. Spory dotyczyły wielu zagadnień, w tym katalogu, w jakim powinny zostać ujęte (kontrowersje wzbudzały przede wszystkim prawa ekonomiczne, społeczne i kulturalne), oraz mechanizmu kontroli międzynarodowej. Dzięki wielu kompromisom co do normatywnej treści paktów, a także dzięki sprzyjającej atmosferze politycznej wszystkie państwa zagłosowały za ich przyjęciem obu paktów. Po uzyskaniu odpowiedniej liczby ratyfikacji weszły one w życie w 1976 r. Polska ratyfikowała je w 1977 r. ${ }^{43}$

W zakresie krajowej ochrony praw człowieka kluczowe znaczenie ma Konstytucja $\mathrm{RP}^{44}$, gdzie w rozdziale II wymieniono katalog chronionych przez Polskę praw podstawowych. Akt ten posiada własną systematykę. Główną część rozdziału stanowi regulacja dotycząca poszczególnych wolności i praw człowieka i obywatela. Zostały one sformułowane jako: wolności i prawa osobiste, wolności i prawa polityczne, wolności i prawa ekonomiczne, socjalne i kulturalne. Unormowanie poszczególnych praw zostało jednak poprzedzone sformułowaniem pewnych przepisów, które zgodnie z intencjami ustawodawcy są ogólnymi zasadami regulacji wolności i praw. Mowa tutaj o koncepcji źródła praw człowieka, a także o wartościach, jakimi są godność, wolność i równość. Podkreślenia wymaga również fakt, że w rozdziale II konstytucji unormowano także środki ochrony wolności i praw (art. 77-81) oraz

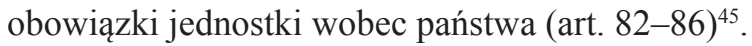

\section{GENERACJE PRAW CZLOWIEKA}

Oprócz rozmaitych katalogów praw człowieka, które można formułować na podstawie wszystkich aktów międzynarodowych poświęconych tej tematyce, zaczęto wyróżniać również generacje praw człowieka. W literaturze przedmiotu najczęściej przyjmuje się, że istnieją trzy generacje ${ }^{46}$.

Warto zwrócić uwagę na fakt, że podjęcie tematyki generacji (czyli inaczej kategorii) praw człowieka zostało zapoczątkowane pod koniec lat siedemdziesiątych

43 Dz.U. z 1977 r. nr 38, poz. 167 i 169.

44 Konstytucja Rzeczypospolitej Polskiej z dnia 2 kwietnia 1997 r. (Dz.U. nr 78, poz. 483).

45 Vide M. Granat, Prawo konstytucyjne w pytaniach i odpowiedziach, Warszawa 2012, s. 101-131.

46 Trzecia generacja praw człowieka nie jest powszechnie aprobowana przez wszystkich autorów. 
XX w. za sprawą Karela Vasaka, który odniósł koncepcję ochrony praw podstawowych do haseł wielkiej rewolucji francuskiej: wolność, równość i braterstwo ${ }^{47}$. Francuski prawnik bazował na kryteriach o charakterze historycznym i filozoficznym ${ }^{48}$. Obok powszechnie uznanych kategorii, tzn. praw obywatelskich i politycznych (pierwsza generacja) oraz praw gospodarczych, społecznych i kulturalnych (druga generacja), wprowadził nową kategorię — prawa solidarnościowe (trzecia generacja) ${ }^{49}$.

Do praw człowieka pierwszej generacji zalicza się powszechnie uznane prawa obywatelskie i polityczne, których pierwsze koncepcje sformułowano już pod koniec XVIII w. pod wpływem liberalnych nurtów myślowych ${ }^{50}$. Miały one na celu urzeczywistnienie zasady wolności w odniesieniu do jednostek, a w kontekście historycznym miały uwolnić ludzi z ograniczeń narzucanych przez ustrój feudalny. Stały się one podstawowymi prawami gwarantowanymi przez większość państw w ustawodawstwie krajowym. Po upadku feudalizmu nastąpiła zmiana suwerena stanowiącego prawo. Przestała nim być monarchia. Od tej pory to naród był najważniejszym podmiotem państwa. Przeszliśmy od krępującej działania jednostki zasady „wolno mi tylko tyle, na ile pozwala mi władca" do obowiązującej dziś zasady wolnościowej: „,mogę robić wszystko, czego nie zabrania mi prawo”. Vasak wskazał, że prawa pierwszej generacji to tzw. prawa negatywne, w ramach których państwo zobowiązane jest powstrzymać się od ingerencji w ludzką działalność. Wyjątkiem jest tworzenie ram organizacyjnych w celu urzeczywistniania tych praw. Jedynym możliwym powodem ingerencji w państwa w prawa pierwszej generacji jest wyznaczenie granic ochrony dóbr innych osób i dobra społecznego oraz realizacji tej ochrony ${ }^{51}$.

Genezy praw człowieka drugiej generacji można upatrywać w rewolucjach socjalistycznych z XIX i XX w., których ekspansja była związana z dynamicznym rozwojem ruchu robotniczego oraz partii socjalistycznych. Ze względu na wzmożoną eksploatację pracowników, złe warunki pracy oraz brak zabezpieczeń socjalnych w wyniku rozwoju koncepcji socjalistycznych wykształciły się prawa człowieka drugiej generacji. W literaturze przedmiotu wyróżnia się wśród nich prawa o charakterze gospodarczym, socjalnym i kulturalnym. Prawa te często określane są mianem praw pozytywnych, wywodzonych z szeroko pojętej równości. Realizacja tych postulatów wymaga od państwa aktywnych działań w celu ich zapewnienia. Stanowią one zbiór postulatów, norm programowych, które państwo powinno realizować w stosunku do obywateli. Zadaniem państwa jest określenie ram, w których prawa te będzie realizować ${ }^{52}$.

${ }^{47}$ Confer M. Piechowiak, op. cit., s. 13; K. Motyka, op. cit., s. 125.

48 Vide M. Nowak, Trzy generacje praw człowieka. Ich znaczenie w świetle przesłanek ideowych i historycznych oraz w świetle ich genezy, [w:] Prawa człowieka. Geneza, koncepcje, ochrona, red. B. Banaszak, Wrocław 1993, s. 105 i n.

49 Vide K. Vasak, A 30-year struggle. The sustained efforts to give force of law to the Universal Declaration of Human Rights, ,The UNESCO Courier” 1997, s. 29-33.

50 Confer chociażby Deklaracja Niepodległości z 1776 r., Konstytucja Stanów Zjednoczonych z 1787 r., czy też Deklaracja Praw Człowieka i Obywatela z 1789 r.

51 K. Vasak, A 30-year..., s. 29.

52 B. Zawadzka, Prawa ekonomiczne, socjalne i kulturalne, Warszawa 1996, s. 7. 
Koncepcję wprowadzenia trzeciej generacji praw człowieka K. Vasak zaprezentował w 1979 r. podczas wykładu inauguracyjnego z okazji X Sesji Międzynarodowego Instytutu Praw Człowieka w Strasburgu ${ }^{53}$. Zgodnie z intencjami autora koncepcja ta miała nie tylko służyć celom teoretycznym, ale także uwzględniać najnowsze tendencje zarówno w stosunkach międzyludzkich, jak i tych międzynarodowych. W zamyśle była ona syntezą uniwersalnych ludzkich aspiracji i miała wskazać pożądane kierunki rozwoju praw człowieka dla dobra całej ludzkości. Propozycja sklasyfikowania i wyodrębnienia praw solidarnościowych była poparta próbą wstępnego określenia ich podstawowych właściwości. Zdaniem Vasaka, prawa te stanowią wypadkową wspólnych cech obowiązujących na całym świecie w odniesieniu do problemów i wyzwań, a jednocześnie są próbą uchwycenia i rozwiązania podstawowych zadań stojących przed krajami i politykami, związanych z redukcją nierówności między krajami rozwijającymi się i rozwiniętymi, rozpadem kolonializmu, degradacją środowiska w wyniku ekstensywnej gospodarki ${ }^{54}$.

Zdaniem Krzysztofa Drzewickiego koncepcja trzeciej generacji praw człowieka została oparta na czterech filarach: generacyjnym rozwoju praw człowieka, dynamizmie rozwoju praw człowieka, partycypacjonizmie i kolektywizmie praw człowieka i solidaryzmie praw człowieka ${ }^{55}$. Istotne jest, że prawa solidarnościowe nie stanowią katalogu zamkniętego, co znaczy, że mogą ulegać pewnym zmianom i modyfikacjom ${ }^{56}$. Vasak podkreślał, że przedmiotem trzeciej generacji praw człowieka są wartości wyrażające uniwersalne ludzkie aspiracje, wśród których można wyróżnić chociażby pokój, rozwój, środowisko czy wspólne dziedzictwo ludzkości. W związku z tym do praw trzeciej generacji można zaliczyć chociażby prawo do pokoju, rozwoju czy do ochrony środowiska naturalnego ${ }^{57}$. Vasak postulował także dołączenie do tego katalogu innych praw, jak chociażby prawo do pomocy humanitarnej, jednak postulat ten nie zyskał aprobaty innych ${ }^{58}$. Dokonań Vasaka nie należy uznawać za rewolucyjne ze względu na określenie nowych praw człowieka objętych ochroną jurysdykcyjną, ponieważ większość ze formułowanych przez niego przedmiotów ochrony istniała już wcześniej. Niemniej jego pogląd o generacyjnym rozwoju praw człowieka odbił się na świecie szerokim echem. Francuski prawnik dokonał podziału praw człowieka, uwzględniając nie tylko ich specyficzne cechy, ale także podnosząc ich ewolucyjny charakter oraz historyczne uwarunkowania.

W kontekście dalszych rozważań, w szczególności dotyczących koncepcji jurydyzacji czwartej generacji praw człowieka, należy zwrócić uwagę na jeszcze jeden aspekt działalności Vasaka, który wywołał najwięcej kontrowersji. Chodzi o posługiwanie się

53 Vide K. Drzewicki, Prawo do rozwoju. Studium z zakresu praw człowieka, Gdańsk 1988, s. 12-21.

${ }^{54}$ Vide C. Wellman, Solidarity, the Individual and Human Rights, „Human Rights Quarterly” 2000, nr 3, s. 644 .

${ }^{55}$ K. Drzewicki, op. cit., s. 30-37.

${ }^{56} \mathrm{Ch}$. Swinarski, Studies and Essays on International Humanitarian Law and Red Cross Principles in Honour of Jean Pictet, Hague 1984, s. 843.

${ }^{57}$ Ibidem, s. 838-839.

${ }^{58}$ K. Drzewicki, op. cit., s. 21-25. 
— przyjętym zresztą w środowisku — terminem „generacja”. Takie rozważanie koncepcji ochrony praw człowieka mogłoby sugerować, że kolejne generacje są przez siebie zastępowane. To znaczy, że druga generacja miałaby moc derogującą względem generacji pierwszej, a przecież tak nie jest. Przedstawiciele doktryny podkreślają, że użycie terminu „generacja” miało na celu wyeksplikowanie dynamizmu praw człowieka oraz uwypuklenie znaczenia praw solidarnościowych. Mimo przyjętej koncepcji, także w zakresie warstwy dialektycznej ${ }^{59}$, Vasak podkreślał, że stanowi ona niepodzielną i komplementarną całość. Zgodnie z tym twierdzeniem niemożliwe byłoby kreowanie dalszych idei dotyczących kolejnych generacji praw człowieka (np. czwartej). Jak zauważył K. Drzewicki, „teza o ewolucji praw człowieka w kierunku pogłębiania partycypacji społecznej wypływa na zasadzie antytezy z indywidualizmu dotychczasowych praw człowieka" ${ }^{90}$. Według Vasaka prawa trzeciej generacji są niezbędne w celu przezwyciężenia nadmiernego indywidualizmu praw człowieka i ich dotychczasowego „egoizmu”, ponieważ jednostka nie jest w stanie w pełni rozwinąć swojego potencjału bez udziału w życiu ludzkiej wspólnoty. W odniesieniu do praw pierwszej generacji zakładano bowiem obszary nieingerencji państwa w życie jednostki, natomiast w przypadku praw drugiej generacji wymagano zaś od prawodawcy ustalenia ram aktywnych działań na rzecz pojedynczego człowieka. Dlatego też, aby móc w pełni realizować zasadę wolności i równości, niezbędna stała się solidarna partycypacja wszystkich ludzi ${ }^{61}$.

Zgodnie z koncepcją Cezarego Mika solidarność trzeciej generacji należy rozpatrywać $\mathrm{w}$ aspekcie przedmiotowym i podmiotowym. Podmiotowy charakter tych praw wyraża się w solidarnym udziale wszystkich ludzi, natomiast przedmiotowy uwidacznia się w specyfice dóbr, do których prawa solidarności przysługują. Są to dobra powszechne, globalne, reprezentujące wartości dotyczące jednocześnie wszystkich ludzi i dla wszystkich jednakowo cenne ${ }^{62}$. Natomiast zgodnie z koncepcją Vasaka prawa solidarnościowe — w przeciwieństwie do praw pierwszej i drugiej generacji praw człowieka - mają charakter kolektywny. Według Drzewickiego nadano im jednak wielowymiarowy charakter, dlatego też powinny one być możliwe do zastosowania zarówno w wymiarze kolektywnym, jak i indywidualnym ${ }^{63}$. Vasak twierdzi, że trzecia generacja praw może być urzeczywistniana wyłącznie przez wspólną akcję wszystkich aktorów gry społecznej, dlatego też za podmiot uprawniony należy uznać zarówno człowieka, jak i wszystkich ludzi in corpore (np. za pośrednictwem podmiotów prawa publicznego czy społeczności międzynarodowej $)^{64}$.

W kontekście zaprezentowanych rozważań należy zastanowić się, jak w ideę zapoczątkowaną przez Vasaka wpisuje się możliwość sformułowania praw czwartej

${ }^{59} \mathrm{~Np}$. M. Piechowiak podnosi, że właściwszym terminem jest „rodzina praw” lub „kategoria praw"; vide M. Piechowiak, op. cit., s. 65 i n.

${ }^{60}$ K. Drzewicki, op. cit., s. 31.

${ }^{61}$ Ch. Swinarski, op. cit., s. 839.

${ }^{62}$ Confer C. Mik, Zbiorowe prawa człowieka. Analiza krytyczna koncepcji, Toruń 1992, s. 94.

${ }^{63}$ K. Drzewicki, op. cit., s. 45.

${ }^{64}$ C. Mik, op. cit., s. 105. 
generacji. Jaki mógłby być ich przedmiot i czy słuszne jest wyodrębnienie ich jako kolejnego zbioru praw? Czym miałyby się one wyróżniać w ramach obecnie przyjętej klasyfikacji? Wobec zachodzących zmian społecznych i globalizmu wydaje się, że koncepcja trzech generacji jest słuszna. Moim zdaniem, bez wątpienia istnieją prawa człowieka, które musimy realizować jako wspólnota. Jakie miejsce w tej koncepcji zajmowałaby kolejna generacja?

\section{CZWARTA GENERACJA PRAW CZLOWIEKA JAKO POSTULAT JURYDYZACJI W MIĘDZYNARODOWYM SYSTEMIE OCHRONY}

Mimo że Karel Vasak uznawał, że jego koncepcja generacji praw człowieka stanowi zamkniętą i spójną całość, od kilkunastu lat słychać polityków, ale także moralistów i badaczy, którzy podkreślają potrzebę wprowadzenia do systemu międzynarodowej ochrony czwartej generacji praw człowieka. Moim zdaniem postulat ten jest chybiony (przynajmniej w proponowanej formie). Koncepcja normatywnego uregulowania kolejnej generacji praw człowieka, czyli de facto zbioru praw wyróżniających się pewnymi immanentnymi cechami, które determinują możliwość sklasyfikowania tych praw jako spójnej grupy, wynika z braku zrozumienia charakteru ochrony praw człowieka i z potrzeby prowadzenia dalszej ekspansji gwarancji podstawowych oraz daleko posuniętego, a jednocześnie nieusprawiedliwionego normatywizmu. Ponadto wiadomo, że jurydyzacji podlegają poszczególne prawa podmiotowe, a nie koncepcje teoretyczno-prawne. A taki właśnie jest podział praw wedle generacji.

Proponowany zakres potencjalnej czwartej generacji praw człowieka jest różny w zależności od środowisk, które postulują ich wprowadzenie. Jednak tendencje te możemy podzielić na mocniejsze i słabsze. Zacznę od tych drugich, ponieważ postulaty grup wyrażających te tendencje są mniej zintensyfikowane i sformalizowane. Pewne środowiska wolnościowe chciałyby wprowadzić do ochrony międzynarodowej czy też do systemu uniwersalnego prawa związane z ochroną tożsamości narodowej, deklaracją praw dla poszczególnych grup etnicznych czy też prawa do wolności i do - szerzej — akceptacji wyznania ${ }^{65}$. Natomiast „mocniejszą" grupę naciskającą na normatywne

${ }^{65}$ Vide szerzej D.G. Evans, Human Rights: Four Generations of Practice and Development, [w:] Educating for Human Rights and Global Citizenship, red. A. Shultz, L. Shultz, New York 2007, s. 1-12. Ponadto warto zobaczyć stanowiska w partykularnych sprawach poszczególnych praw, np.: K. Czubocha, Separatyzm etniczny $w$ dobie praw człowieka - nowe wyzwanie dla państwa narodowego i społeczności międzynarodowej, Torun 2012; B. De Witte, Politices versus Law in the EU's Approach to the Ethnic Minorities, „EUI Working Papers” 2004, nr 4, s. 20-28, B. Anderson, Wspólnoty wyobrażone, Rozważania o źródtach i rozprzestrzenianiu się nacjonalizmów, Kraków 1997, passim; P. Daranowski, Prawa mniejszości w powszechnym prawie międzynarodowym, [w:] Sytuacja ludności polskiej na Wschodzie w świetle obowiazującego prawa i praktyki, red. D. Górecki, Toruń 2009, s. 29-68. Autorzy bezpośrednio nie odnoszą się do konieczności wprowadzenia czwartej generacji praw człowieka, piszą jednak o konieczności obrony pewnych praw mniejszości, które z tą koncepcją są związane. Postulaty wynikające z omawianego przedmiotu postulatu regulacji nie doczekały się głębszych uregulowań naukowych, ponieważ można je wywodzić z już ustanowionych praw człowieka. W związku z tym pomysł regulacji tych praw w formie oddzielnego zbioru jest raczej postulatywny i zgłaszany przez określone grupy środowiskowe, a nie przez prawników czy naukowców. 
uregulowanie czwartej generacji praw człowieka stanowią przede wszystkim bioetycy i moraliści, których zdaniem konieczna jest ochrona życia istot ludzkich na etapie ich rozwoju prenatalnego. Podnoszą oni, że zagwarantowanie zwiększonej (względem obecnego stanu prawnego) ochrony jest konieczne, aby w przyszłości jednostki te w ogóle miały możliwość skorzystania z jakichkolwiek praw. W takim ujęciu prawo do życia jawi się jako prawo pierwotne względem innych, przysługujące każdej jednostce aż od poczęcia. Unicestwienie płodu spowodowałoby bowiem brak możliwości skorzystania z jakichkolwiek praw z powodu ontycznego faktu nieistnienia. Koncepcja ta jest wywodzona z godności człowieka i jej niezbywalności, którą podkreśla się we wszystkich aktach międzynarodowych. Personaliści, którzy są za wprowadzeniem takiej ochrony, podnoszą, że doniosłe deklaracje w preambułach są — w odniesieniu do śmierci płodu - wyłącznie chwytem retorycznym ${ }^{66}$.

Zwolennicy tej koncepcji argumentują, że nie ma przeszkód formalnoprawnych w zakresie objęcia uprawnieniami istot nienarodzonych. Podnoszą chociażby, że w EKPC mówi się wprost o „każdej istocie ludzkiej” (every human being). Sięgając do nauk biologicznych, stwierdzają, że zygota, embrion czy płód jest niewątpliwie istotą ludzką (a o jej przynależności do homo sapiens świadczy jej DNA), należy zatem przyjąć, że mamy do czynienia z dzieckiem, tylko jeszcze nienarodzonym. Takiego samego wyrażenia (human being) użyto także w art. 6 Międzynarodowego Paktu Praw Obywatelskich i Politycznych. Rada Europy, która w Konwencji o prawach człowieka i biomedycynie wskazuje na konieczność ochrony tożsamości ,istoty ludzkiej”, której dobro należy przedkładać nad interes społeczeństwa czy nauki (art. 1), zdaniem etycznych personalistów również przyczyniła się do propagowania koncepcji ochrony ${ }^{67}$.

Natomiast przeciwnicy tej koncepcji argumentują, że jest różnica między ,istotą ludzką” a „człowiekiem”. Dlatego też płód z pewnością jest w sensie gatunkowym istotą ludzką, ale w sensie ontycznym nie jest jeszcze człowiekiem, któremu należą się takie same prawa, jak każdemu narodzonemu. Dlatego też zwolennicy ,prawa wyboru” starają się znaleźć konstytutywne cechy każdego człowieka i wskazać moment, kiedy ludzki zarodek czy też płód w trakcie swojego rozwoju je nabywa. Moment ten miałby być również chwilą pojawienia się bytu osobowego, któremu przysługują prawa człowieka ${ }^{68}$.

W kontrargumentacji personaliści nawiązują do klasycznej filozofii, zgodnie z którą przejawy bytu są wtórne w stosunku do jego istnienia. Marek Piechowiak przedstawił to w sposób następujący: ,Skoro człowiek jest osobą, jest rozumny i ma godność,

${ }^{66}$ Vide P. Alston, M. Robinson, The Challenges of Ensuring the Mutuality of Human Rights and Development Endeavours, [w:] Human Rights and Development, red. P. Alston, M. Robinson, Oxford 2005, s. 1-18.

${ }^{67}$ M. Ciszek, Personalistyczny i utylitarystyczny model uprawiania bioetyki i biopolityki, [w:] W poszukiwaniu Prawdy, Dobra i Piękna, red. R.T. Ptaszek, J. Dębowski, Siedlce 2007, s. 53-56.

${ }^{68}$ P. Singer i utylitaryści wskazują, że świadomość i odczuwanie bólu jest możliwe dopiero po ukształtowaniu się centralnego układu nerwowego płodu (kryterium neurologiczne). Lewicowi politycy podnoszą, że prawo do życia powinno być traktowane analogicznie do stwierdzenia śmierci mózgowej, kiedy uznaje się śmierć pacjenta, mimo że jego organizm pełni jeszcze funkcje życiowe. 
niezależnie od uwarunkowań biologicznych czy społecznych, to podmiotowa racja rozumności i godności jest czymś różnym od tego, co dostępne badaniom typu przyrodniczego. Współczesny paradygmat rozumienia praw człowieka, uniezależniając godność i posiadanie praw od jakichkolwiek mierzalnych cech, zakłada pewnego typu element niematerialny w bycie ludzkim, co dobrze odpowiada rozwiązaniom proponowanym na gruncie teorii Akwinaty" ${ }^{\prime \prime}$.

Zakres podmiotowy ewentualnych regulacji będzie zatem trudny do ustalenia. Wiadomo bowiem, że ścieranie się różnych koncepcji filozoficznych i biologicznych będzie powodowało, że zawsze któraś strona będzie nieusatysfakcjonowana przyjętymi rozwiązaniami. Personaliści chcieliby, aby życie było chronione już od momentu poczęcia, a liberałowie, aby ochrona przysługiwała dopiero narodzonemu dziecku. Sprawa nie jest jednak zero-jedynkowa, dlatego też nie da się ustalić stanowiska jedynego i słusznego. Konieczne jest odwołanie się do koncepcji prawno-filozoficznych, ponieważ chęć objęcia płodu taką ochroną, jaka przysługuje człowiekowi urodzonemu (a momentami jeszcze większą), wymusza na nas stworzenie pewnej fikcji prawnej, która będzie powszechnie akceptowana. Ratio legis prawa międzynarodowego w tym zakresie wcale nie musi być zatem oczywiste.

Zakres przedmiotowy ochrony jest szerszy, niż mogłoby się wydawać na podstawie przeprowadzonego wywodu oraz informacji, które obiegają polską prasę i telewizję. W naszym kraju toczy się spór głównie o zniesienie tzw. kompromisu aborcyjne$\mathrm{go}^{70}$. Natomiast przedstawiciele ruchu związanego z czwartą generacją praw człowieka sięgają o wiele głębiej. Postulują nie tylko ochronę przed aborcją (co do zasady w każdym przypadku), ale także brak możliwości ingerencji genetycznej w odniesieniu do płodu. Ponadto wykluczają wykorzystywanie nowych technologii do ewentualnego poprawiania DNA lub wspomagania rozwoju płodu, jeśli mogłyby one w jakikolwiek sposób zakłócić możliwość urodzenia dziecka. Postulują także uniemożliwienie stosowania nowoczesnych leków (testów klinicznych) w celu ewentualnego zapobieżenia niepożądanym ułomnościom $\mathrm{w}$ dorosłym życiu narodzonego dziecka. Prawa te miałyby zakazywać także zapłodnienia in vitro, a także regulować kwestie związane z zapłodnionymi komórkami niewykorzystanymi w takich zabiegach. Wszelkie działania eugeniczne także mogłyby zostać uregulowane ${ }^{71}$.

$\mathrm{Z}$ tej perspektywy należy podkreślić, że każdej osobie, także nienarodzonej ma przysługiwać prawo do życia, ale także do tożsamości osobistej związanej z brakiem konfiguracji kodu genetycznego, prawo do zachowania unikalnego kodu DNA, który będzie mógł być przekazywany potomkom bez biologicznej manipulacji. Zgodnie

${ }^{69}$ M. Piechowiak, op. cit., s. 353.

70 Vide ustawa z dnia 7 stycznia 1993 r. o planowaniu rodziny, ochronie płodu ludzkiego i warunkach dopuszczalności przerywania ciąży (Dz.U. nr 17, poz. 78). Zgodnie z jej przepisami, aborcji można dokonywać w trzech przypadkach: gdy ciąża stanowi zagrożenie dla życia lub zdrowia kobiety, gdy jest duże prawdopodobieństwo ciężkiego i nieodwracalnego upośledzenia płodu albo nieuleczalnej choroby zagrażającej jego życiu, gdy ciąża powstała w wyniku czynu zabronionego, a więc gwałtu lub kazirodztwa.

71 S. Popescu, Legal Sociology, Bucharest 2012, s. 149. 
ze skrajnymi koncepcjami, ochrona płodu miałaby szerszy zakres przedmiotowy niż ochrona człowieka żyjącego. Wynika to z myśli, aby — oprócz omówionych gwarancji pozytywnych - dziecku nienarodzonemu przysługiwały takie same prawa, jak każdemu z nas. Rodzi to wiele wątpliwości, a nawet sprzeczności prawnych. Czy nienarodzona istota może bowiem korzystać chociażby z praw politycznych, społecznych czy kulturalnych? Oczywiście, że nie. Dlatego też w dalszej części artykułu pozostaję przy pierwotnej koncepcji ochrony przede wszystkim istnienia takiego bytu. Jako negatywne przykłady determinujące konieczność wprowadzenia regulacji niepozwalających na jakąkolwiek ingerencję w życie płodu podawane są historyczne założenia nazistowskie dotyczące wyższości rasy aryjskiej, co wymagało eliminacji innych (co spowodowało chociażby Holokaust), koncepcje legalnej eutanazji osób psychicznie chorych, sterylizacje bękartów oraz osób z niepełnosprawnościami czy też zakaz interakcji między grupami etnicznymi. Dlatego też zwolennicy koncepcji jurydyzacji czwartej generacji praw człowieka głoszą, że genom ludzki jest częścią jego dziedzictwa ${ }^{72}$.

Analizując pomysł wprowadzenia jurydyzacji czwartej generacji praw człowieka, należy uznać, że jest ona chybiona. Przynajmniej w obecnie postulowanej formie. Zarówno postulaty dotyczące ochrony tożsamości etnicznej, jak i postulaty skomasowanego ruchu etycznych personalistów dążących do ochrony zygoty i płodu przed ingerencją osób trzecich nie powinny zostać przyjęte. Przede wszystkim należy odnieść się do już obowiązujących regulacji prawnych oraz gwarancji pozytywnych ich ochrony. Pomocne może być wskazanie stanowiska sądów międzynarodowych na temat zakresu ochrony praw człowieka. Europejski Trybunał Praw Człowieka wielokrotnie wypowiadał się na temat zakresu kognicji art. 2 EKPC i wskazywał, że w odniesieniu do możliwości określenia pozytywnego obowiązku ochrony życia kluczowe jest określenie początkowej i końcowej granicy „życia każdego człowieka”.

W swoim orzecznictwie dotyczącym płodu ludzkiego Trybunał orzuca dwa skrajne poglądy, zgodnie z którymi:

A. Płód podlega takiej samejochronie, jak żywy człow i e k. Trybunał zauważył, że takie rozwiązanie w wielu państwach europejskich jest odrzucane, nie może więc być uznawane za standardowe. Trybunał wskazał, że rozwiązanie bezwzględnie zakazujące przerywania ciąży byłoby absurdalne, ponieważ życie płodu jest ściśle związane z życiem matki. Niekiedy sam poród bądź przebieg ciąży może zagrażać rodzicielce. Przyjęcie zasady, zgodnie z którą nawet w takim przypadku przerwanie ciąży nie jest dopuszczalne, oznaczałoby trudne do uzasadnienia przyznanie bezwzględnego pierwszeństwa życiu płodu.

B. Płód ni e podlega ża dnej ochronie. W swoim orzecznictwie Trybunał podnosi, że nie można uznać, że ciąża całkowicie należy do prywatnej sfery życia kobiety. Co za tym idzie, nie może ona całkowicie dowolnie decydować o przerwaniu ciąży.

72 V. Duculescu, Juridical protection of human rights. Internal and international means, Bucarest 2008, s. 294-306. 
Konstatując takie rozważania Trybunału, należy uznać, że zgodnie z EKPC płód podlega już prawnej ochronie, przy czym nie jest ona równa ochronie przyznanej osobom narodzonym. Państwa jednak mają pewien margines w określaniu zakresu ochrony prawa płodu do życia, zgodnie z art. $2 \mathrm{EKPC}^{73}$.

W doktrynie prezentowane są rozbieżne stanowiska. Zdaniem Piotra Hofmańskiego, „byłoby rzeczą co najmniej dziwaczną, gdyby art. 2 miał bezwzględnie chronić życie płodu, choć w pewnych sytuacjach dopuszcza pozbawienie życia osoby narodzonej”74. Jakub Czepek podnosi, że „konwencja, w przeciwieństwie do Europejskiej Konwencji Bioetycznej, nie wprowadza określenia «istota ludzka». W związku z powyższym, skoro prawo do życia przysługuje «osobie», należałoby domniemywać, że momentem, od kiedy rozpoczyna się ochrona prawa do życia w znaczeniu EKPC jest moment narodzin człowieka"75. Oktawian Nawrot sugeruje natomiast, że można przyjąć, iż prawo do życia przysługuje również ludzkim płodom ${ }^{76}$. Na podstawie najnowszego orzecznictwa sądów międzynarodowy, a także krajowych należy uznać, że coraz powszechniejsza jest koncepcja, że podstawowe prawa człowieka, w tym także prawo do życia, przysługują każdemu człowiekowi, także poczętemu. Wobec płodu prawo to musi być jednak ograniczone ze względu na specyficzną sytuację, w jakiej on się znajduje. Przede wszystkim jego byt jest warunkowany złączeniem z ciałem matki i o ile nie może ona dowolnie dysponować swoją ciążą, o tyle kolizja wartości matki i dziecka nie może zostać rozstrzygnięta bez uwzględnienia dobra osoby, która dziecko poczęła. $\mathrm{Na}$ takim stanowisku stają także sądy, które w swoim orzecznictwie podnoszą, że ochrona dziecka w łonie matki istnieje, ale ma inny charakter niż gwarancje w stosunku do osoby żyjącej. Takie stanowisko wydaje się uprawnione, ponieważ prawo musi chronić płód, ale w celu tej ochrony musi mu zapewnić inne przymioty niż osobie dorosłej. Należy także podnieść, że w stosunku do ludzi żyjących prawo do życia pod pewnymi warunkami również może ulegać limitacji, w związku z czym różnicowanie poziomu ochrony w stosunku do sytuacji jednostki nie stanowi o jej braku ${ }^{77}$.

W odniesieniu do ochrony bioetycznej zarówno płodu, jak i człowieka żyjącego sprawa również została uregulowana już dawno temu w licznych aktach prawa międzynarodowego. Rada Europy wiele lat zajmowała się sprawami związanymi z postępem biologii i medycyny. Świadczy o tym liczba podejmowanych rekomendacji Zgromadzenia Parlamentarnego i rezolucji Komitetu Ministrów. Zostały one wydane

${ }^{73}$ Confer sprawy Vo v. Francja (2004 r.; Evans v. Wielka Brytania (2007 r., sprawa A.B.C. v. Irlandia (2010 r.).

74 P. Hofmański, Europejska Konwencja Praw Człowieka i jej znaczenie dla prawa karnego materialnego, procesowego $i$ wykonawczego, Białystok 1993, s. 158.

75 J. Czepek, Zobowiąania pozytywne państwa $w$ sferze praw czlowieka pierwszej generacji na tle Europejskiej Konwencji Praw Człowieka, Olsztyn 2014, s. 82.

${ }_{76}$ Vide O. Nawrot, Ludzka biogeneza w standardach bioetycznych Rady Europy, Warszawa 2011, S. 101.

77 A. Preisner, Prawo do ochrony życia $i$ do zachowania naturalnej integralności psychofizycznej człowieka, [w:] Wolności i prawa jednostki oraz ich gwarancje w praktyce, red. L. Wiśniewski, Warszawa 2006, s. 135-146. 
jeszcze przed podpisaniem w 1997 r. tzw. konwencji biomedycznej. Można postawić tezę, że wcześniej wydane rekomendacje wpłynęły na późniejsze normatywne uregulowanie kwestii biomedycznych. Wśród najważniejszych dokumentów należy wymienić takie akty, jak: rekomendacja 779(1976) Zgromadzenia Parlamentarnego Rady Europy w sprawie praw chorych i umierających; rekomendacja 818(1977) Zgromadzenia Parlamentarnego Rady Europy dotycząca sytuacji osób psychicznie chorych; rezolucja (78)29 Komitetu Ministrów Rady Europy dotycząca harmonizacji ustawodawstwa państw członkowskich związanego z pobieraniem i przeszczepianiem ludzkich tkanek i organów; rekomendacja 934(1982) Zgromadzenia Parlamentarnego Rady Europy dotycząca inżynierii genetycznej; rekomendacja 1046(1986) Zgromadzenia Parlamentarnego Rady Europy określająca reguły rządzące wykorzystaniem embrionów i płodów ludzkich w celach diagnostycznych, terapeutycznych, naukowych, przemysłowych i handlowych; rekomendacja R(90)3 Komitetu Ministrów Rady Europy dotycząca badań medycznych na istotach ludzkich; rekomendacja R(90)13 Komitetu Ministrów Rady Europy w sprawie prenatalnych genetycznych badań przesiewowych, prenatalnej diagnostyki genetycznej oraz związanego $\mathrm{z}$ tym poradnictwa ${ }^{78}$.

W Konwencji o ochronie praw człowieka i godności istoty ludzkiej w kontekście zastosowań biologii i medycyny wskazano wyraźny prymat ochrony praw człowieka nad dokonaniami medycyny. Wszelkie działania biomedyczne muszą być podejmowane z poszanowaniem praw podstawowych. Dobro istoty ludzkiej ma prymat nad dobrem państwa i nauki (art. 2). Warto zwrócić uwagę, co podkreślają także obrońcy praw człowieka oraz sądy, że w Konwencji w celu zapewnienia uniwersalności przepisów obok terminów „osoba” i ,każda osoba” (person, everyone) w tytule oraz zasadniczych miejscach (art. 1, 2, 15, 16) stosuje się określenie „istota ludzka” (human being). To przesądza o tym, że ochrona przed nieuprawnioną inżynierią genetyczną przysługuje także każdemu życiu poczętemu.

Ostatecznie należy podnieść, że system Vasaka miał — zgodnie z jego koncepcją — tworzyć zamkniętą całość. W związku z tym ciężko jest postulować zmianę w tym zakresie, chociaż z metodologicznego punktu widzenia byłaby ona jak najbardziej możliwa. Pojawia się jednak pytanie, jaką immanentną cechą wspólną miałaby się wyróżniać kolejna generacja. Klasyfikacja Vasaka jest ułożona wedle pewnego klucza (np. prawa osobiste, prawa kolektywne). Wydaje się, że wspólny przedmiot regulacji, czyli w tym przypadku człowiek nienarodzony, to zbyt mało, aby ustanowić całkowicie nową generację.

Postulat jurydyzacji czwartej generacji praw człowieka jest nietrafny także z powodu podstawowego błędu w zakresie formułowania postulatów przez obrońców praw człowieka. Należy zauważyć, że generacje są bytem przede wszystkim teoretycznym i jako takie nie podlegają normatywizmowi. Poszczególne prawa podmiotowe są ujmowane w różnych, rozproszonych aktach normatywnych i pozanormatywnych (zarówno

\footnotetext{
${ }^{78}$ Przywoływane dokumenty można znaleźć w: Europejskie standardy bioetyczne: wybór materiatów, tłum. i red. T. Jasudowicz, Toruń 1998, passim.
} 
w ustawodawstwie krajowym, jak i międzynarodowym). Dlatego też o ile koncepcja wprowadzenia kolejnej generacji praw człowieka jest zrozumiała, o tyle nie możemy wymagać od ustawodawcy zebrania wszelkich praw z niej wynikających i usystematyzowania ich w jednym akcie. A nawet jeśli by się tak stało, to wcale nie oznacza to, że w piśmiennictwie uznano by te zapisy za kolejną generację praw. Ponadto at last but not least, większość postulowanych praw jest już objęta ochroną międzynarodową. Oznacza to, że nie są potrzebne nowe akty prawne, w których powtarzano by postanowienia zawarte już w systemie uniwersalnym. Wraz z rozwojem medycyny i technologii z pewnością będą potrzebne nowe prawa pozytywne, ale tak jak w przypadku konwencji biomedycznej, tak i w tym przypadku zapewne zostaną one ujęte w systemie ochrony praw człowieka.

Na marginesie należy zauważyć, że z pewnością konieczne będzie unormowanie kolejnych praw związanych z pojawiającymi się nowymi technologiami i nowymi obszarami działalności człowieka. Zapewne nie będzie to jednak ochrona takich podstawowych wartości, jak życie czy prawo gromadzenia się, które - w moim odczuciu - mają zapewnioną dostateczną ochronę prawną. Kolejne działania będą ewentualnie podejmowane w zakresie realizacji gwarancji pozytywnych. Nie należy jednak wykluczać, że z biegiem lat mogą pojawić się nowe prawa, dla nas zupełnie abstrakcyjne, a wymagające ochrony międzynarodowej. Mogą potrzebować jej takie wartości, jak chociażby prawo dostępu do czystej wody, obowiązek zapewnienia dostępu do świeżego powietrza czy też prawo równego dostępu do przestrzeni kosmicznej. Już teraz podnosi się konieczność zapewnienia prawa do komunikacji elektronicznej z innymi osobami. O ile w tym momencie wskazane przedmioty potencjalnej ochrony mogą wydawać się abstrakcyjne i metafizyczne, o tyle za jakiś czas możemy rozmawiać o nich zupełnie poważnie.

\section{PODSUMOWANIE}

Postulat dotyczący jurydyzacji i kreowania koncepcji czwartej generacji praw człowieka wydaje się może nie tyle błędny, co źle sformułowany. Wiele lat debat i prac, podczas których prawa człowieka podlegały umiędzynarodowieniu i co za tym idzie, stały się przedmiotem prawa międzynarodowego, unaoczniło, jak ważne są gwarancje ponadpaństwowe, które stanowią nierozerwalną część praw człowieka w dzisiejszym rozumieniu. Wspólnota międzynarodowa dość sprawnie reaguje na potrzeby regulacji zupełnie nowych zagadnień związanych z prawami podstawowymi, czego idealnym przykładem było wprowadzenie tzw. konwencji bioetycznej, która dopełniła system prewencji w zakresie najnowszych technologii genetycznych odnoszących się do ludzkiego istnienia. $\mathrm{Z}$ metodologicznego punktu widzenia główną przeszkodą we wprowadzeniu do systemu ochrony praw człowieka kategorii praw czwartej generacji jest fakt, że Vasak uznał swoją koncepcję za zamkniętą, czyli wykluczył dalszą ingerencję w nią. Zakładając jednak, że można niejako adaptować przyjęte przez niego rozwiązanie i dokonać jego modyfikacji — co według mnie byłoby możliwe pod warunkiem przyjęcia odpowiednich metod badawczych — należałoby najpierw potwierdzić zasadność takiego rozwiązania. Należy 
zauważyć, że jurydyzacji podlegają przede wszystkim prawa człowieka, którym przynależy ochrona, podział na generacje jest wyłącznie teoretyczny. Prawa ujęte w poszczególne generacje zostały poddane procedurze legislacyjnej dużo wcześniej niż powstała koncepcja generacji. W związku z tym postulaty zwolenników jurydyzacji są chybione i powinny dotyczyć raczej poszczególnych przedmiotów i podmiotów ochrony, a nie uznania praw czwartej generacji. Pomijając ten błąd w powszechnym rozumowaniu, należy podkreślić brak konieczności kolejnych regulacji normatywnych w tym zakresie.

Postulaty zwolenników jurydyzacji odnoszą się w szczególności do ochrony życia poczętego, natomiast trzeba pamiętać, że ono już jest chronione zarówno w systemie uniwersalnym, jak i europejskim, amerykańskim czy afrykańskim. Chęć wprowadzenia szczegółowych regulacji prawnych w następną część ludzkiego życia jest naganna. Nie można wymagać od prawa w ogóle, a także od prawa międzynarodowego, że będzie regulowało szczegółowo każdy aspekt życia człowieka w sposób nader szczegółowy. Zwolennicy czwartej generacji nie zauważają faktu, że życie poczęte jest chronione, o czym wielokrotnie wypowiadały się sądy międzynarodowe. Oczywiste wydaje się, że poziom tej ochrony musi być zróżnicowany — co nie znaczy mniejszy — w kontekście ochrony praw człowieka już narodzonego. W literaturze przedmiotu wskazuje się, że każdy płód korzysta z ochrony prawnej. Natomiast niezapisanie wprost ochrony życia nienarodzonego w aktach międzynarodowych nie stanowi o jej braku. Przedstawiciele doktryny oraz działacze na rzecz praw człowieka są zgodni, że gwarancje międzynarodowe są na odpowiednim poziomie. Wątpliwości może budzić poziom wykonywania norm prawnych przez poszczególne państwa, ale nie powinniśmy szukać winy w legislacji, tylko w sposobie realizacji postanowień prawa.

Koniecznie trzeba też zaznaczyć, że z pewnością zaistnieje potrzeba szukania nowych rozwiązań legislacyjnych w zakresie gwarantowania nowych praw człowieka. Nie odważę się jednak nazwać ich kolejną generacją, ponieważ nie jestem przekonany, czy będą one spełniały kryterium metodyczne dotyczące jednej cechy relewantnej. Myślę, że mogą być to prawa $\mathrm{z}$ różnych grup, np. prawo do czystej wody, prawo do świeżego powietrza czy może nawet prawo do Internetu. W moim odczuciu jednak nie będzie rewolucji, zarówno jeśli chodzi o konieczność nowych unormowań, jak i o rozwijanie koncepcji naukowych. Prawdopodobnie będziemy dążyć do integracji wielu państw wokół coraz większej liczby gwarancji pozytywnych, ponieważ tylko takie postępowanie może zapewnić ludzkości względny spokój w relacjach wertykalnych i horyzontalnych. Prawdziwym wyzwaniem, jakie będą zmuszeni podjąć obrońcy praw człowieka, może być ponowny rozwój ruchów populistycznych. Jeśli coraz więcej rządów będzie obierało tę drogę w połączeniu z możliwym rozwojem nacjonalizmu, to najważniejszym problemem do rozwiązania będzie takie ukształtowanie norm prawnych, aby każdemu z nas zapewnić jak najlepszą ochronę. Możliwy jest scenariusz, który będzie determinował poszukiwanie nowych rozwiązań prawnych i faktycznych. Wydaje się, że jeśli chodzi o system ochrony, to właśnie to może być prawdziwym problem, ponieważ zamiast ekspansji (i postulatów tworzenia coraz to nowych generacji) możemy mieć do czynienia z erozją praw człowieka. 
BIBLIOGRAFIA

ŹRÓDŁA

A kty prawne

Europejska Karta Samorządu Terytorialnego, sporządzona w Strasburgu dnia 15 października 1985 r. (Dz.U. z 1994 r. nr 124, poz. 607).

Europejska Karta Społeczna sporządzona w Turynie dnia 18 października 1961 r. (Dz.U. z 1999 r. nr 8, poz. 67).

Europejska Konwencja o zapobieganiu torturom oraz nieludzkiemu lub poniżającemu traktowaniu albo karaniu, sporządzona w Strasburgu w dniu 26 listopada 1987 r. (Dz.U. z 1995 r. nr 46, poz. 238).

Karta praw podstawowych Unii Europejskiej z 7 grudnia 2000 r. (Dz.Urz. UE C 83 z 30.3.2010).

Konstytucja Rzeczypospolitej Polskiej z dnia 2 kwietnia 1997 r. (Dz.U. z 1997 r. nr 78, poz. 483).

Konwencja Ramowa o ochronie mniejszości narodowych, sporządzona w Strasburgu dnia 1 lutego 1995 r. (Dz.U. z 2002 r. nr 22, poz. 209).

Konwencja o ochronie praw człowieka i podstawowych wolności sporządzona w Rzymie dnia 4 listopada 1950 r. (Dz.U. z 1993 r. nr 61, poz. 284, ze zm.).

Międzynarodowy Pakt Praw Gospodarczych, Społecznych i Kulturalnych otwarty do podpisu w Nowym Jorku dnia 19 grudnia 1966 r. (Dz.U. z 1977 r. nr 38, poz. 169).

Międzynarodowy Pakt Praw Obywatelskich i Politycznych otwarty do podpisu w Nowym Jorku dnia 19 grudnia 1966 r. (Dz.U. z 1977 r. nr 38, poz. 167).

Ustawa z dnia 7 stycznia 1993 r. o planowaniu rodziny, ochronie płodu ludzkiego i warunkach dopuszczalności przerywania ciąży (Dz.U. z 1993 r. nr 17, poz. 78).

Orzecznictwo

Wyrok TK z 23 marca 1999 r., sygn. akt K 2/98, OTK ZU 1999/3/38.

Wyrok TK z 8 października 2002 r., sygn. akt K 36/00, OTK ZU 2002/5A/63.

Wyrok TK z 25 lipca 2013 r., sygn. akt P 56/11, OTK ZU 2013/6A/85.

Wyrok TK z 23 czerwca 2015 r., sygn. akt SK 32/14, OTK ZU 2015/6A/83.

PIŚMIENNICTWO

Alston P., Robinson M., The Challenges of Ensuring the Mutuality of Human Rights and Development, Endeavours, [w:] Human Rights and Development, red. P. Alston, M. Robinson, Oxford University Press, Oxford 2005, https://doi.org/10.1093/acprof:oso/9780199284627.003.0001.

Anderson B., Wspólnoty wyobrażone, Rozważania o źródłach i rozprzestrzenianiu się nacjonalizmów, Wydawnictwo Znak, Kraków 1997.

Ciszek M., Personalistyczny i utylitarystyczny model uprawiania bioetyki i biopolityki, [w:] W poszukiwaniu Prawdy, Dobra i Piękna, red. R.T. Ptaszek, J. Dębowski, Wydawnictwo Akademii Podlaskiej, Siedlce 2007.

Czepek J., Zobowiazania pozytywne państwa w sferze praw człowieka pierwszej generacji na tle Europejskiej Konwencji Praw Człowieka, Wydawnictwo Uniwersytetu Warmińsko-Mazurskiego, Olsztyn 2014.

Czubocha K., Separatyzm etniczny $w$ dobie praw czlowieka - nowe wyzwanie dla państwa narodowego i społeczności międzynarodowej, Wydawnictwo Adam Marszałek, Torun 2012.

Daranowski P., Prawa mniejszości w powszechnym prawie międzynarodowym, [w:] Sytuacja ludności polskiej na Wschodzie w świetle obowiąujacego prawa i praktyki, red. D. Górecki, Wydawnictwo Tow. Nauk. Organizacji i Kierownictwa. Dom Organizatora, Torun 2009. 
Diemer A., Philosophical Foundations of Human Rights, Oxford University Press, Paris 1986.

Donnelly J., Universal Human Rights In Theory and Practice, Cornell University Press, Ithaca 1989.

Drzewicki K., Prawo do rozwoju. Studium z zakresu praw człowieka, Wydawnictwo Uniwersytetu Gdańskiego, Gdańsk 1988.

Duculescu V., Juridical protection of human rights. Internal and international means, Lumina Lex, Bucharest 2008.

Evans D.G., Human Rights: Four Generations of Practice and Development, [w:] Educating for Human Rights and Global Citizenship, eds. A. Shultz, L. Shultz, New York 2007.

Finnis J., Natural Law and Natural Rights, Oxford University Press, Oxford 1992.

Granat M., Prawo konstytucyjne w pytaniach i odpowiedziach, LexisNexis, Warszawa 2012.

Gronowska B., Jasudowicz T., Balcerzak M., Lubiszewski M., Mizerski R., Prawa człowieka i ich ochrona, Wydawnictwo TNOiK, Toruń 2010.

Hofmański P., Europejska Konwencja praw człowieka i jej znaczenie dla prawa karnego materialnego, procesowego i wykonawczego, Temida 2, Białystok 1993.

Hołda J., Hołda Z., Ostrowska D., Rybczyńska J.A., Prawa człowieka. Zarys wykładu, Wolters Kluwer Polska, Warszawa 2011.

Jasudowicz T., Europejskie standardy bioetyczne: wybór materiałów, Wydawnictwo Tow. Nauk. Organizacji i Kierownictwa. Dom Organizatora, Toruń 1998.

Koba L., Nowicki M., Historia praw człowieka, Warszawa 2002.

Koba L., Nowicki M., Prawa i wolności człowieka, [w:] Prawa człowieka. Poradnik nauczyciela, Centralny Ośrodek Doskonalenia Nauczycieli, Warszawa 2002.

Locke J., Dwa traktaty o rzadzie, Wydawnictwo Naukowe PWN, Warszawa 1992.

Locke J., List o tolerancji, Wydawnictwo Naukowe PWN, Warszawa 1963.

Maritain J., Człowiek i państwo, tłum. A. Grobler, Wydawnictwo Znak, Kraków 1993.

Michalska A., Podstawowe prawa człowieka w prawie wewnętrznym a Pakty Praw Człowieka, Wydawnictwo Prawnicze, Warszawa 1976.

Mik C., Zbiorowe prawa człowieka. Analiza krytyczna koncepcji, Wydawnictwo Uniwersytetu Mikołaja Kopernika, Toruń 1992.

Motyka K., Prawa człowieka. Wprowadzenie. Wybór źródeł, Oficyna Wydawnicza VERBA, Lublin 1999.

Nawrot O., Ludzka biogeneza w standardach bioetycznych Rady Europy, Wolters Kluwer, Warszawa 2011.

Nowak M., Trzy generacje praw człowieka. Ich znaczenie $w$ świetle przesłanek ideowych $i$ historycznych oraz w świetle ich genezy, [w:] Prawa człowieka. Geneza, koncepcje, ochrona, red. B. Banaszak, Wydawnictwo Uniwersytetu Wrocławskiego, Wrocław 1993.

Nowicki M.A., Wokół Konwencji Europejskiej. Krótki komentarz do Europejskiej konwencji praw człowieka, Wolters Kluwer, Kraków 2003.

Osiatyński W., Filozofia i historia praw człowieka, [w:] Prawa człowieka a policja, red. A. Rzepliński, Wydawnictwo Centrum Szkolenia Policji, Legionowo 1994.

Osiatyński W., Wprowadzenie do praw człowieka, http://www.hfhr.pl.

Piechowiak M., Filozofia praw człowieka. Prawa człowieka w świetle ich międzynarodowej ochrony, Towarzystwo Naukowe KUL, Lublin 1999.

Popescu S., Legal Sociology, Lumina Lex Publishing House, Bucharest 2012.

Preisner A., Prawo do ochrony życia $i$ do zachowania naturalnej integralności psychofizycznej człowieka, [w:] Wolności i prawa jednostki oraz ich gwarancje w praktyce, red. L. Wiśniewski, Wydawnictwo Sejmowe, Warszawa 2006.

Radbruch G., Der Mensch im Recht, Göttingen 1961.

Raphael T., The Problem of Horizontal Effect, „European Human Rights Review” 2000, vol. 5. 
Rosa R., Bezpieczeństwo i prawa człowieka (wybrane aspekty filozoficzne i edukacyjne), [w:] Bezpieczeństwo czlowieka wobec współczesnych i przyszłych wyzwań, red. J. Dębowski, E. Jarmoch i A.W. Świderski, Siedlce 2005.

Rousseau J.-J., Umowa społeczna, Wydawnictwo Naukowe PWN, Warszawa 1966.

Stępniak K., Walka z terroryzmem i cyberterroryzmem a ochrona konstytucyjnych praw $i$ wolności, [w:] Internet. Strategie bezpieczeństwa, red. A. Gryszczyńska, G. Szpor, C.H. Beck, Warszawa 2017.

Stępniak K., Legislacja w Polsce. Aspekty prawne i aksjologiczne, Wydawnictwo Naukowe Think \& Make, Warszawa 2017.

Tierney B., Origins of Natural Rights Language: Texts and Contexts, „History of Political Thought" 1989.

Wachter M.A.M., The European Convention on Bioethics, „The Hastings Center Report” 1997, nr 27.

Wellman C., An Approach to Rights: Studies In the Philosophy of Laws and Morals, Springer Netherlands, Dordrecht 1997.

Wellman C., Solidarity, the Individual and Human Rights, „Human Rights Quarterly” 2000, https://doi.org/10.1353/hrq.2000.0040.

Weston B.H., Human Rights, „Human Rights Quarterly” 1984.

Wielgus S., Polska średniowieczna doktryna ius gentium, Lublin 1996.

Witte B., Politices versus Law in the EU's Approach to the Ethnic Minorities, „EUI Working Papers" 2004, nr 4.

Vasak K., A 30-year struggle. The sustained efforts to give force of law to the Universal Declaration of Human Rights, „The UNESCO Courier” 1997.

Swinarski Ch., Studies and Essays on International Humanitarian Law and Red Cross Principles in Honour of Jean Picket, Hague 1984.

Zawadzka B., Prawa ekonomiczne, socjalne i kulturalne, Wydawnictwo Sejmowe, Warszawa 1996. 



\section{POZAUSTAWODAWCZE PROCEDURY PARLAMENTARNE W PIERWSZYM SEJMIE ODRODZONEJ RZECZYPOSPOLITEJ POLSKIEJ (1919-1922). REGULACJA PRAWNA I PRAKTYKA PARLAMENTARNA}

\section{EXTRA-LEGISLATIVE PARLIAMENTARY PROCEDURES IN THE FIRST SEJM OF THE RENASCENT REPUBLIC OF POLAND (1919-1922). LEGAL REGULATIONS AND PARLIAMENTARY PRACTICE}

The first Sejm of the Renascent Republic of Poland — the Legislative Sejm — performed not only the legislative function, but also other systemic functions: oversight over the executive, creative function and the function of the guardian of Deputies' immunity. In order to perform those functions, the chamber applied various detailed parliamentary procedures - variants of the so-called motion proceedings. The sources of law of these procedures contained norms rudimentarily included in the Small Constitution of 20 February 1919 and principally, in the Standing Orders of the Sejm, although there predominated legal-customary norms, partially implemented from Western European parliamentarism, and partially established domestically, on the basis of parliamentary practice. The majority of extra-legislative procedures and proceedings commenced on their basis, were those within the oversight function of the Sejm (including proceedings related to government investments, interpellations and proceedings involving investigative committees), and further, proceedings related to immunity, including mostly proceedings in matters to express the chamber's consent to waive a Deputy's immunity and interventions related to infringement of a Deputy's immunity by organs of administration. The proceedings established by the Legislative Sejm in relation to immunity proceedings, in the scope of bringing Deputies to extra-immunity accountability, applied eight times before the intra-chamber peer courts - Marshal's Court and Court of Honour - were an originality in all of the European parliamentarism of the time.

Słowa kluczowe: exposé premiera, funkcja kontrolna, funkcja kreacyjna, immunitet poselski, inwestytura rządu, komisje sejmowe, komisje śledcze, konstytuanta, mała konstytucja z 1919 r., marszałek Sejmu, organy Sejmu, poseł sprawozdawca, postępowania okołoimmunitetowe, postępowania interpelacyjne, praktyka parlamentarna, procedura parlamentarna, prawo pozytywne, prawo zwyczajowe, rząd koalicyjny, rząd pozaparlamentarny, sąd honorowy, sąd marszałkowski, Tymczasowy Regulamin Obrad Sejmu Ustawodawczego, wniosek poselski, wotum nieufności, wotum zaufania, zwyczaj parlamentarny, źródła prawa

Key words: Prime Minister's exposé, oversight function, creative function, Deputies' immunity, government investment, Sejm committees, investigative committees, constituent assembly, Small Constitution of 1919, Marshal of the Sejm, organs of the Sejm, Deputy-Rapporteur, immunity proceedings, interpellation proceedings, parliamentary practice, parliamentary procedure, positive law, custom law, coalition government, extra-parliamentary government, court of honour, Marshals' court, Provisional Rules of Procedure of the Legislative Sejm, Deputy's motion, vote of no confidence, vote of confidence, parliamentary custom, sources of law

* Dr hab. Piotr A. Tusiński, prof. w Instytucie Prawa, Administracji i Ekonomii Uniwersytetu Pedagogicznego im. KEN w Krakowie, ptusinski@up.krakow.pl, https://orcid.org/0000-0002-4430-0967 


\section{WPROWADZENIE}

D ierwszy parlament odrodzonej Rzeczypospolitej Polskiej - Sejm Ustawodawczy [dalej: SU] pełnił obok wiodącej funkcji ustawodawczej kilka innych ról ustrojowych, z których najistotniejszymi były kompetencje kontrolna i kreacyjna ${ }^{1}$. W obrębie każdej z tych funkcji ustrojowych Sejm działał w ramach określonej procedury parlamentarnej (trybu postępowania) rozumianej jako regulowany normami prawa i zwyczajami zbiór czynności, układających się w sukcesywny (etapowy) łańcuch decyzyjny, podejmowanych wyłącznie przez podmioty wskazane normami kompetencyjnymi, w kolejności wyznaczonej normami formalnymi i organizacyjnymi, prowadzący do załatwienia (rozstrzygnięcia) jakiejś sprawy mieszczącej się w uprawnieniach parlamentu ${ }^{2}$. Kształt procedur parlamentarnych stosowanych w SU w latach 1919-1922 był regulowany aktami normatywnymi rangi konstytucyjnej, ustawami zwykłymi, aktem wewnętrznego prawa parlamentarnego - regulaminem sejmowym oraz normami prawa zwyczajowego.

W ramach funkcji kontrolnej egzekutywy SU stosował procedury stricte kontrolne, takie jak postępowanie: w sprawie inwestytury rządu, w sprawie votum zaufania dla rządu lub votum nieufności dla rządu i Naczelnika Państwa, interpelacyjne, z udziałem komisji śledczej oraz procedury łączące w sobie elementy postępowania kontrolnego sensu stricto z elementami postępowania ustawodawczego, do których można zaliczyć: procedurę wyrażania zgody na ratyfikację umów międzynarodowych i procedurę zatwierdzania ustawodawstwa dekretowego stanowionego przez egzekutywę. Dwie ostatnie z wymienionych procedur miały więcej cech charakterystycznych dla postępowania ustawodawczego niż kontrolnego, stąd opisano je w innym miejscu ${ }^{3}$. W obrębie funkcji kreacyjnej konstytuanta stosowała procedury wyłaniania obsady personalnej jej organów wewnętrznych: marszałka, wicemarszałków, sekretarzy izby (odnoszące się także do przyjęcia ich rezygnacji bądź odwołania), kwestorów, składu osobowego komisji sejmowych, a także wyboru osób do składu niektórych organów państwowych. SU stosował też inne procedury szczególne niemieszczące się w ramach trzech wymienionych wcześniej funkcji ustrojowych parlamentu. Do grupy tych procedur należy zaliczyć postępowania w szeroko rozumianych sprawach immunitetowych (okołoimmunitetowych): ważności mandatu poselskiego, wyrażenia zgody na uchylenie immunitetu poselskiego (formalnego), interwencji w zakresie naruszenia nietykalności poselskiej przez organy administracji, a także egzekwowania odpowiedzialności pozaimmunitetowej posłów.

${ }^{1}$ Confer B. Banaszak, Prawo konstytucyjne, Warszawa 2012, s. 435-438.

2 Vide m.in. Stownik języka polskiego, t. II, L-P, Warszawa 1979, s. 926; E. Kustra, Proces ustawodawczy jako proces decyzyjny, „Acta Universitatis Nicolai Copernici. Prawo XII. Nauki Humanistyczno-Społeczne" 1973, z. 56, s. 110; P.A. Tusiński, Postępowanie ustawodawcze w Sejmie i w Senacie II Rzeczypospolitej 1919-1939. Prawo - zwyczaje - praktyka parlamentarna, Radom 2008, s. 25.

3 Vide P.A. Tusiński, Procedury ustawodawcze w pierwszym Sejmie Odrodzonej Rzeczypospolitej Polskiej (1919-1922). Regulacja prawna i praktyka parlamentarna, „Przegląd Sejmowy” 2018, nr 6. 


\section{KONSTYTUCYJNE I USTAWOWE ŹRÓDLA PRAWA PROCEDUR KONTROLI RZĄDU}

W okresie bezpośrednio poprzedzającym zebranie się SU oraz w czasie jego kadencji obowiązywały trzy akty prawne pełniące rolę prowizorycznej (tymczasowej) konstytucji. Wszystkie one zawierały przepisy odnoszące się do szeroko rozumianej materialnej i formalnej kontroli rządu. Pierwszym był wydany przez Radę Regencyjną dekret z dnia 3 stycznia 1918 r. o tymczasowej organizacji władz naczelnych w Królestwie Polskim 4 . Drugim ustanowiony przez Radę Ministrów i Tymczasowego Naczelnika Państwa dekret z dnia 22 listopada 1918 r. o najwyższej władzy reprezentacyjnej Republiki Polskiej. Trzecim zaś uchwalona przez SU tzw. mała konstytucja z 20 lutego $1919 \mathrm{r}^{6}$

Dekret z 3 stycznia 1918 r. o tymczasowej organizacji władz naczelnych w Królestwie Polskim miał fundamentalne znaczenie dla kształtu ustrojowego rządu do czasu wejścia w życie konstytucji z 17 marca 1921 r. ${ }^{7}$, a częściowo — w odniesieniu do podstawy prawnej działalności wielu ministerstw — zachowywał aktualność nawet do końca międzywojnia. Dekret powierzał władzę zwierzchnią w Królestwie Radzie Regencyjnej [dalej: RR], która miała ją sprawować za pośrednictwem prezydenta Ministrów (premiera), Rady Ministrów oraz poszczególnych ministrów. Wszelkie akty RR musiały być kontrasygnowane przez prezydenta Ministrów. Dekret z 3 stycznia 1918 r. nie określał ani podmiotu powołującego prezydenta Ministrów, ani trybu, w jakim miało się to dokonywać. W literaturze historycznoprawnej zauważono, że kompetencja do powoływania premiera przysługiwała Radzie Regencyjnej ,z samej istoty jako tymczasowej głowie państwa". Dekret stanowił natomiast wprost, że RR powoływała na wniosek prezydenta Ministrów poszczególnych ministrów, podsekretarzy stanu, dyrektorów departamentów i kancelarii oraz prezesów rad działających poza strukturą ministerstw.

W odniesieniu do egzekutywy i jej kontroli dekret z dnia 22 listopada 1918 r. o najwyższej władzy reprezentacyjnej Republiki Polskiej utrzymywał w mocy zasadnicze zręby prawne konstrukcji ustrojowej określone w stosownym akcie Rady Regencyjnej z 3 stycznia $1918 \mathrm{r}$. W dalszym ciągu władza wykonawcza miała charakter dwuczłonowy, a rząd tworzyli mianowani przez naczelnika i przed nim odpowiedzialni prezydent Ministrów i ministrowie, łączący się w Radę Ministrów (art. 1-3, art. 6). W dekrecie z 22 listopada 1918 r. zabrakło tylko, obecnego w akcie z 3 stycznia 1918 r., postanowienia o powoływaniu ministrów na wniosek premiera. Akty rządowe głowy państwa nadal miały być kontrasygnowane przez szefa rządu (art. 4). Nowością w porównaniu

${ }^{4}$ Dziennik Praw Królestwa Polskiego [dalej: Dz.P.K.P.] z 1918 r. nr 1, poz. 1. Treść dekretu omówił W. Komarnicki, Polskie prawo polityczne (Geneza i system), Warszawa 1922, s. 44-47.

${ }^{5}$ Dziennik Praw Państwa Polskiego [dalej: Dz.P.P.P.] z 1918 r. nr 17 poz. 41.

${ }^{6}$ Uchwała Sejmu z dnia 20 lutego 1919 r. o powierzeniu Józefowi Piłsudskiemu dalszego sprawowania urzędu Naczelnika Państwa, Dz.P.P.P. nr 19 poz. 226.

7 Ustawa z dnia 17 marca 1921 r. Konstytucja Rzeczypospolitej Polskiej, Dz.U. nr 44, poz. 267.

${ }^{8}$ Z.J. Winnicki, Rada Regencyjna Królestwa Polskiego i jej organy (1917-1918), Wrocław 1991, s. 73. Vide M.M. Lipska, Urząd ministra w latach 1918-1939. Podstawy prawne, „Roczniki Nauk Prawnych" 2009, t. XIX, nr 1, s. 222. 
z poprzednim stanem prawnym była jurydyzacja odpowiedzialności politycznej ministrów, którzy mieli ją ponosić, obok premiera, przed Tymczasowym Naczelnikiem Państwa, choć dekret listopadowy nie określał wyraźnie charakteru tej odpowiedzialności (art. 2)9.

Uchwalona przez SU 20 lutego 1919 r. mała konstytucja była w odniesieniu do kwestii kontroli rządu aktem równie zwięzłym regulacyjnie, jak dekret z 22 listopada 1918 r. W jej artykule pierwszym konstytuanta podziękowała Józefowi Piłsudskiemu ze sprawowania przezeń urzędu głowy państwa w okresie od 14 listopada 1918 r. do 20 lutego 1919 r. W artykule drugim powierzyła mu zaś dalsze sprawowanie urzędu Naczelnika Państwa do czasu uchwalenia przepisów stałej konstytucji, określających ustrój naczelnych władz państwowych. Można zatem stwierdzić, iż Piłsudski otrzymał wotum zaufania Sejmu ${ }^{10}$. Uchwała z 20 lutego 1919 r. była więc pierwszym aktem kontroli parlamentarnej władzy wykonawczej w II Rzeczypospolitej w pełnym tego słowa znaczeniu. Należy przy tym przyjąć, że skoro Rada Ministrów była powoływana przez Tymczasowego Naczelnika Państwa i przed nim odpowiedzialna politycznie, to również ona, jako drugi człon egzekutywy, uzyskała na mocy tego aktu ,absolutorium” ze sprawowania swych funkcji.

W małej konstytucji kontroli parlamentarnej władzy wykonawczej poświęcone zostały przepisy art. II ust. 3-5. W odniesieniu do zagadnienia tworzenia rządu postanowiono, że gabinet miał być powoływany w pełnym składzie przez Naczelnika Państwa, który powinien to czynić ,na podstawie porozumienia z Sejmem”"11. W małej konstytucji nie regulowano szczegółowo kwestii trybu powoływania rządu oraz skutku braku porozumienia naczelnika z Sejmem, co miało w przyszłości zrodzić poważny spór między nimi. Należy zaznaczyć, że 16 czerwca 1922 r. SU zainspirowany wątpliwościami Naczelnika Państwa dokonał wykładni autentycznej art. II ust. 3 małej konstytucji, noszącej wszelkie znamiona nowelizacji tymczasowej ustawy zasadniczej. W wykładni tej, uszczuplającej kompetencje Naczelnika Państwa i zwiększającej uprawnienia Sejmu, przyjęto założenie, że inicjatywa w sprawie desygnowania kandydata na premiera należy „z reguły” do Naczelnika Państwa. Jednak gdyby on z niej nie skorzystał lub Sejm za pomocą organu regulaminowo ustanowionego kandydatury tej nie zatwierdził, inicjatywa wyznaczenia kandydata na szefa gabinetu miała przechodzić na izbę zastępowaną przez tenże organ. Organem tym miała być ustanowiona w tym czasie przez Sejm Komisja Główna. We wspomnianej wykładni postanowiono ponadto, że nowo mianowany rząd miał obowiązek uzyskania od plenum Sejmu wotum zaufania, co miało być ostatnim aktem jego inwestytury ${ }^{12}$. W literaturze przedmiotu podkreślono, że zagwarantowanie sobie przez Sejm uprawnienia do uczestnictwa w powoływaniu rządu

9 Z. Witkowski, Status ustrojowy Rady Ministrów w konstytucjach polskich okresu międzywojennego, [w:] Rada Ministrów. Organizacja i funkcjonowanie, red. A. Bałaban, Kraków 2002, s. 51.

10 Ibidem, s. 64-65.

11 Z. Witkowski (ibidem, s. 53) określa ten wymóg jako ,wyraźny, chociaż nie wystarczająco precyzyjnie prawniczo sformułowany".

12 Sprawozdanie stenograficzne z 318. posiedzenia Sejmu Ustawodawczego w dniu 16 czerwca 1922 r. [dalej: spr. sten. SU], 1. 9-75; „Kurier Polski”, 17 VI 1922, nr 163. 
oznaczało usankcjonowanie w polskim prawie pozytywnym praktyki ustrojowej wytworzonej w drodze zwyczaju w parlamentaryzmie zachodnioeuropejskim ${ }^{13}$.

W świetle ugruntowanej w doktrynie wykładni małej konstytucji prawo udzielenia inwestytury rządowi przysługiwało łącznie dwu organom władzy naczelnej — aspirującemu do roli suwerena SU oraz głowie państwa. Wszystkie czynności procesu powoływania gabinetu i modelowania jego składu, takie jak: prowadzenie rozmów i konsultacji ze stronnictwami politycznymi, desygnowanie i mianowanie premiera, łączenie funkcji szefa rządu z urzędem ministra resortowego, powoływanie wicepremiera, mianowanie ministrów i podsekretarzy stanu oraz ewentualnych ministrów bez teki, łączenie stanowisk w rządzie z zasiadaniem w parlamencie, zaprzysiężenie gabinetu, a także przedstawienie się nowo powołanego rządu Sejmowi wraz z programem jego prac i wyrażenie dlań akceptacji przez parlament - poza wskazaniem na Naczelnika Państwa, jako podmiot powołujący rząd w pełnym składzie ,na podstawie porozumienia z Sejmem” — nie znajdowały umocowania w przepisach tymczasowej ustawy zasadniczej. Część z wymienionych kwestii była już jednak unormowana w pozytywnym prawie ustrojowym, a konkretnie w ciągle obowiązującym dekrecie Rady Regencyjnej z 3 stycznia 1918 r., którego odnośne przepisy omówiono wcześniej. Pozostałe kwestie odnoszące się do budowy rządu i procedury jego powoływania podlegały wykształconej w parlamentaryzmie zachodnioeuropejskim regulacji prawnozwyczajowej, recypowanej w początkach drugiej niepodległości na grunt polski, a także wypracowanej ad casum rodzimej praktyce ustrojowej.

Enigmatyczność przepisów małej konstytucji w kwestii powoływania rządu rodziła jeszcze jedną zasadniczą trudność odnoszącą się do zagadnienia zmian personalnych w gabinecie (na stanowiskach ministrów). Traktując literalnie treść odnośnej regulacji konstytucyjnej, należało przyjąć, co podkreśla powojenna literatura przedmiotu, że każdorazowa zmiana na stanowisku ministra wymagała akceptacji Sejmu ${ }^{14}$. Praktyka ustrojowa nie poszła jednak w tym kierunku i zmiany w obrębie gabinetów dokonywane były samodzielnie przez Naczelnika Państwa, działającego motu proprio w odniesieniu do resortów ,zastrzeżonych” dla jego gestii, bądź na wniosek szefa rządu w stosunku do pozostałych ministrów. Sejm był jedynie zawiadamiany pisemnie post factum o dokonanej rekonstrukcji gabinetu ${ }^{15}$.

Zarówno naczelnik, jak i rząd ponosili odpowiedzialność przed Sejmem za sprawowanie swych urzędów. Zrównanie przesłanek i zakresu odpowiedzialności głowy państwa z rządem określono w doktrynie powojennej jako kuriozalne w świetle ,teoretycznych założeń systemu parlamentarnego"16. Odpowiedzialność ta miała charakter łączny (podwójny), bowiem, jak to już zaznaczono, każdy akt państwowy Naczelnika Państwa

13 M. Pietrzak, Rzady parlamentarne w Polsce w latach 1919-1926, Warszawa 1969, s. 48-49.

14 Ibidem, s. 163-164; P. Kierończyk, Nadrzędność parlamentu - mit czy realna alternatywa ustrojowa? Analiza wybranych przykładów, Gdańsk 2009, s. 177.

15 M. Pietrzak, op. cit., s. 164; P. Kierończyk, op. cit., s. 177; Z. Witkowski, op. cit., s. 54.

16 J. Stembrowicz, Z problematyki głowy państwa w Polsce, „Kultura i Społeczeństwo” 1977, nr 2, s. 44; R. Mojak, Instytucja prezydenta w polskim prawie konstytucyjnym w latach 1918-1935, cz. 1, „Annales Universitatis Mariae Curie Skłodowska. Sectio G” 1989, t. XXXVI, nr 19, s. 236; W.J. Wołpiuk, Naczelnik Państwa 1918-1922. Przedprezydencka forma władzy państwowej, „Przegląd Sejmowy” 2005, nr 6, s. 32. 
wymagał kontrasygnaty odnośnego (właściwego) ministra. Użycie w małej konstytucji zwrotu o odpowiedzialności Naczelnika Państwa i rządu ,za sprawowanie urzędu” zostało zinterpretowane w przedwojennej doktrynie prawa państwowego jako poddanie obu tych podmiotów zarówno odpowiedzialności politycznej, jak i konstytucyjnej, indywidualnej i solidarnej ${ }^{17}$. Teza ta $\mathrm{w}$ odniesieniu do odpowiedzialności konstytucyjnej wydaje się o tyle wątpliwa, że nosiła ona zasadnicze cechy odpowiedzialności prawnokarnej, która bez dokładnego uprzedniego określenia jej przedmiotu i formuły procesowej prowadziłaby przy próbie egzekwowania do naruszenia podstawowych zasad liberalno-demokratycznego porządku prawnego ${ }^{18}$, ujętych w postać reguł: nullum crimen sine lege poenalis anteriori oraz nulla poena sine lege poenalis anteriori. Należy przyjąć, że brak w małej konstytucji przepisów odnoszących się do rodzajów odpowiedzialności egzekutywy, w konfrontacji z ogólnymi zasadami odpowiedzialności konstytucyjnej, zbliżonej zakresowo i proceduralnie do odpowiedzialności karnej, daje podstawy do zastosowania reguły interpretacyjnej: lege non distinguente nec nostrum est distinguere (czego ustawa nie rozróżnia, tego nam nie wolno rozróżniać). Nie budzi natomiast wątpliwości w świetle przepisów małej konstytucji pociąganie egzekutywy do odpowiedzialności parlamentarnej. Jej przesłanką merytoryczną była bowiem wszelka niezgodność działania poddanego jej podmiotu (rządu) z wolą większości parlamentarnej (kwalifikacja polityczna), skutkiem zaś nie jest kara, a więc dezaprobata w postaci potępienia czynu i jego sprawcy o szczególnej intensywności, dotykającego takich podstawowych wartości dla człowieka jak życie, mienie, wolność itp. ${ }^{19}$ (charakterystyczna dla odpowiedzialności karnej i częściowo również konstytucyjnej), lecz jedynie dymisja (pozbawienie sprawowanego urzędu). Sformułowania przepisów małej konstytucji nie budzą również wątpliwości co do tego, że rząd ponosił odpowiedzialność polityczną przed Sejmem zarówno kolegialną, jak i poszczególni jego członkowie indywidualną. Indywidualną odpowiedzialność ponosił również Naczelnik Państwa. Nie może również budzić wątpliwości, że odpowiedzialność gabinetu i naczelnika nosiła charakter solidarny. Ponadto usytuowanie Naczelnika Państwa i rządu w jednakowej pozycji do Sejmu oznaczało osłabienie gabinetu w stosunku do konstytuanty, gdyż nie mógł on w razie konfliktu z nią liczyć na wsparcie głowy państwa, która nie dysponowała środkami równoważącymi odpowiedzialność polityczną, np. prawem weta ustawodawczego lub możliwością rozwiązania parlamentu²0.

17 W. Komarnicki, op. cit., Warszawa 1922, s. 67. Tezę tę, ale odwołując się do okoliczności nierozróżniania przez małą konstytucję obu rodzajów odpowiedzialności i reguł logiki, podtrzymują również m.in.: M. Pietrzak, op. cit., s. 49-50; Z. Witkowski, Prezydent Rzeczypospolitej Polskiej 1921-1935, „Studia Iuridica" 1987, t. XVIII, z. 1, s. 21; idem, Status ustrojowy..., s. 55; D. Górecki, Powstawanie władz naczelnych w odradzajacej się Polsce (1914-1919), „Acta Universitatis Lodziensis. Folia Iuridica” 1983, nr 13, s. 193; R. Mojak, op. cit., s. 236; M.M. Lipska, op. cit., s. 226. Tymczasem „nierozróżnianie” to nie to samo, co brak regulacji w uchwale z 20 lutego 1919 r. odnoszącej się do kwestii różnicowania form odpowiedzialności.

${ }_{18}$ Dostrzega problem, ale go nie rozwija Z. Witkowski, Status ustrojowy..., s. 55.

19 Confer S. Lelental, Kara kryminalna, [w:] Wielka encyklopedia prawa, Białystok-Warszawa 2000, s. 320.

${ }^{20}$ M. Pietrzak, op. cit., s. 50; Z. Witkowski, Prezydent..., s. 21; J. Zaleśny, Odpowiedzialność konstytucyjna w Drugiej Rzeczypospolitej, Warszawa 2003, s. 13. 
Pierwszym aktem uchwalonym przez SU, zmierzającym do wypełnienia licznych deficytów pozytywnego prawa ustrojowego w dziedzinie kontroli rządu była nowelizacja małej konstytucji z dnia 13 lutego 1920 r. dotycząca emisji biletów Polskiej Krajowej Kasy Pożyczkowej ${ }^{21}$, w której konstytuanta zastrzegła sobie prawo dokonywania kontroli wstępnej szeregu poczynań rządu z zakresu finansów publicznych (emisja pieniądza, innych papierów dłużnych, zaciąganie pożyczek państwowych i udzielanie gwarancji Skarbu Państwa), poprzez udzielanie na nie swej zgody. Jakkolwiek omawiana nowela nie rozstrzygała formy prawnej wymaganego ,zezwolenia”, praktyka parlamentarna już od pierwszych tygodni działalności konstytuanty antycypująco wypełniła tę lukę wymogiem sięgania po formę ustawy.

Uchwała SU z 20 lutego 1919 r. nie miała formalnie rangi ustawy, ale zarówno ówczesna doktryna, jak i praktyka ustrojowa nie podważały jej rangi konstytucyjnej. Częściowo ów formalny mankament małej konstytucji usuwała ustawa przechodnia $\mathrm{z}$ dnia 18 maja $1921 \mathrm{r}^{22}$, uchwalona w związku z zamierzonym vacatio legis dla konstytucji z 17 marca $1921 \mathrm{r}$. Ustawa przechodnia ze względu na jej treść normatywną miała, niewątpliwie, charakter ustawy konstytucyjnej. Art. 1 powołanej ustawy stanowiąc, że: „Sejm Ustawodawczy sprawuje swą władzę w dotychczasowym zakresie do chwili ukonstytuowania się władzy ustawodawczej na zasadach ustawy konstytucyjnej z dnia 17 marca 1921 roku", pośrednio nadawał sankcję ustawy konstytucyjnej tym przepisom uchwały z 20 lutego 1919 r., które określały kompetencje konstytuanty. Z kolei w art. 2 ustawy już expressis verbis określono, że: „Prawa i obowiązki obecnego Naczelnika Państwa określone w uchwale Sejmu z dnia 20 lutego 1919 r. [...] trwają do chwili objęcia urzędu przez Prezydenta Rzeczypospolitej, wybranego na podstawie ustawy konstytucyjnej z dnia 17 marca 1921 roku" ${ }^{\prime 23}$.

Z funkcją kontrolną parlamentu korespondowały bezpośrednio przepisy poprzedzającego o kilka dni inaugurację SU dekretu z dnia 7 lutego 1919 r. o Najwyższej Izbie Kontroli Państwa ${ }^{24}$ [dalej: NIKP]. Dekret ów powoływał do życia samodzielny, podlegający bezpośrednio tylko Naczelnikowi Państwa, organ przeznaczony do stałej i wszechstronnej kontroli dochodów i wydatków państwowych, wykonywania budżetu państwa, prawidłowości administrowania jego majątkiem oraz gospodarki podmiotów publicznych i prywatnych korzystających z dotacji lub gwarancji Skarbu Państwa (art. 1 ust. 1, art. 11). Prezes, wiceprezes i członkowie kolegium NIKP nie mogli równocześnie zasiadać $\mathrm{w}$ ławach poselskich ani piastować innych stanowisk publicznych i prywatnych związanych z pobieraniem wynagrodzenia (art. 4-5). Kolegium

${ }^{21}$ Uchwała Sejmu z dnia 13 lutego 1920 r. uzupełniająca uchwałę Sejmu z dnia 20 lutego 1919 r. o powierzeniu Józefowi Piłsudskiemu dalszego sprawowania urzędu Naczelnika Państwa, Dz.U. nr 17 poz. 84.

22 Ustawa przechodnia z dnia 18 maja 1921 r. do ustawy konstytucyjnej z dnia 17 marca 1921 r. w sprawie tymczasowej organizacji władzy zwierzchniej Rzeczypospolitej, Dz.U. nr 44, poz. 268.

${ }^{23}$ W czasie przesilenia rządowego w czerwcu 1922 r. o włączeniu przepisów małej konstytucji do „Wielkiej Konstytucji” - na mocy ustawy przechodniej z 18 maja 1921 r. — był przekonany poseł H. Lieberman, spr. sten. SU, pos. 321. z 23 czerwca 1922 r., ł. 6.

${ }^{24}$ Dz.P.P.P. z 1919 r. nr 14, poz. 183. 
izby rozpatrywało m.in. sprawy absolutorium dla rządu, kwestie dotyczące zamknięć rachunków państwowych oraz opinie dla władz centralnych (art. 7 ust. 1 i 3), a więc jak można domniemywać — również dla Sejmu, który mógł tym samym zażądać ich przedstawienia sobie. Prezes NIKP lub delegowany przezeń jego przedstawiciel miał prawo brać udział w obradach Sejmu, komisjach i innych ciał parlamentarnych w celu referowania wniosków izby bądź udzielania informacji i wyjaśnień. Sejm mógł zażądać obecności prezesa NIKP w obradach plenum lub innego ciała parlamentarnego (art. 8). Szczegółowe przepisy dotyczące formy rocznych zamknięć rachunków państwowych oraz kwestii absolutorium dla rządu miała wydać sama NIKP w porozumieniu z zainteresowanymi ministerstwami (art. 17 ust. 2). W dekrecie nie wspomniano wprost o stawianiu przez NIKP wniosku o udzieleniu lub odmowie udzielenia absolutorium rządowi. Zgodnie z zasadą nemo iudex in causa sua kontrola wykonania budżetu izby, stanowiącego część budżetu państwa, należała do Sejmu (art. 10) ${ }^{25}$.

\section{PROCEDURY KONTROLI EGZEKUTYWY W ŚWIETLE PRZEPISÓW TYMCZASOWEGO REGULAMINU OBRAD SEJMU USTAWODAWCZEGO ORAZ PRAKTYKI PARLAMENTARNEJ}

Do sprawowania przez konstytuantę szeroko pojętej funkcji kontrolnej oraz ustanowionych w jej ramach procedur szczegółowych odnosiły się przepisy art. 14-16, 22, 35, 45, 47-49, 51-53, 53a (ostatni artykuł wprowadzony nowelą z 17 czerwca 1922 r.) oraz art. 65 (znowelizowany uchwałą z 1 marca 1921 r.) tymczasowego regulaminu obrad SU ${ }^{26}$ z 14 lutego 1919 r. Spośród wymienionych tylko art. 53a, dotyczący utworzenia Komisji Głównej posiadającej kompetencje w dziedzinie powoływania rządu, oraz art. 45 i 65 dotyczące interpelacji, bezpośrednio wiązały się ze sprawowaniem parlamentarnej kontroli egzekutywy. Pozostałe przepisy normowały kwestie wspólne dla wykonywania wszystkich funkcji konstytuanty, z postępowaniem ustawodawczym na czele.

Do czerwca 1922 r. jedyną normą prawa pozytywnego regulującą procedurę powoływania gabinetu pod rządami małej konstytucji, jeśli nie liczyć nadal obowiązujących przepisów dekretu Rady Regencyjnej z 3 stycznia 1918 r., o czym była już mowa, był art. II ust. 3 uchwały Sejmu Ustawodawczego z 20 lutego 1919 r. W czerwcu 1922 r., w czasie poważnego kryzysu konstytucyjnego, wywołanego pociągnięciem przez Naczelnika Państwa (bez udziału konstytuanty) do odpowiedzialności politycznej drugiego gabinetu Antoniego Ponikowskiego, Sejm uchwalił nowelizację regulaminu, dodając doń w rozdziale poświęconym komisjom art. 53a, wprowadzający instytucję Komisji

${ }^{25}$ Szczegółowe omówienie przepisów dekretu z 7 lutego 1919 r. o NIKP przedstawił m.in.: R. Szawłowski, Najwyższe państwowe organy kontroli II Rzeczypospolitej, Warszawa 2004, s. 55-66.

${ }^{26}$ Tymczasowy regulamin obrad Sejmu Ustawodawczego Rzeczypospolitej Polskiej, Sejm Ustawodawczy RP 1919-1922, druk nr 1; Tymczasowy regulamin obrad Sejmu Ustawodawczego Rzeczypospolitej Polskiej z uwzględnieniem zmian [...], Sejm Ustawodawczy RP, druk nr 1, Warszawa 15 września 1921 r. Pierwotny tekst regulaminu opublikował też T. Rzepecki, Sejm Rzeczypospolitej Polskiej 1919 roku, Poznań 1920, s. 40-48. Tekst regulaminu z wykazem jego nowelizacji — z błędami i pominięciami w opracowaniu T. Koperskiej opublikowano w „Przeglądzie Sejmowym” 1993, nr 1, s. 99-110. 
Głównej ${ }^{27}$. Przepis ten głosił, że Komisja Główna została wyposażona w kompetencje: „do ustalania stanowiska większości Sejmu w stosunku do spraw przez Sejm jej zleconych, a w szczególności w stosunku do zadań z przesileniem rządowym związanych" (ust. 1). Komisję, obradującą pod przewodnictwem marszałka izby (ust. 1 in fine), tworzyło od jednego do sześciu delegatów poszczególnych klubów lub grup poselskich, wyłonionych wg parytetu jeden delegat na minimum pięciu posłów (ust. 2). Głosowanie w Komisji Głównej polegało na „rzucaniu na szalę” przez każdą delegację tylu głosów, ilu posłów reprezentowała (ust. 3), przy czym dla podjęcia decyzji odpowiadającej większości Sejmu wymagane było poparcie przez ,delegacje, reprezentujące połowę plus jeden wszystkich członków Sejmu" (ust. 4). Kształt ustrojowy ustanowionej w czerwcu 1922 r. Komisji Głównej wskazuje na inspirowanie się jej twórców przepisami konstytucji Republiki Austriackiej z 1 października 1920 r. (art. 55, 70, 75), przewidującej takąż komisję, oraz § 54 konstytucji Czechosłowacji z 29 lutego 1920 r., dotyczącym Komisji Wykonawczej ${ }^{28}$.

Spośród wymienionych wcześniej szczegółowych procedur parlamentarnych dotyczących kontroli rządu bieżącej i następczej w okresie SU tylko jedna — procedura interpelacyjna — została unormowana przepisami pozytywnego prawa parlamentarnego na poziomie regulaminu izby. W myśl art. 45 ust. 1 regulaminu grupa co najmniej 15 posłów miała prawo kierować do rządu interpelacje ${ }^{29}$. Powinny być one

27 Spr. sten. SU, pos. 319. z 17 czerwca 1922 r., 1. 3-31.

${ }^{28}$ Nowe konstytucje. Przełożone pod kierunkiem Dra Juliana Makowskiego, Warszawa 1925, s. $290-292,463,468-469$.

${ }^{29}$ Ojczyzną interpelacji jest Francja, skąd przeniknęła ona do innych krajów na kontynencie europejskim. We francuskim wydaniu z punktu widzenia formalnego interpelacja ,jest to pewien szczególny rodzaj p o s tę p o w a n i a [podkreślenia w oryginale - P.A.T.] parlamentarnego (procedury parlamentarnej); tylko w niektórych krajach nazwą tą oznacza się nie określoną procedurę, lecz d o k u m e n t na piśmie, sporządzony — w zależności od kraju — przez jednego lub grupę deputowanych, odpowiadający niekiedy dalszym jeszcze - określonym zazwyczaj w regulaminie izby — wymogom; wnoszony na ręce przewodniczącego izby, ale skierowany do rządu lub do jednego z jego członków w celu wywołania określonych skutków prawno-politycznych. Wniesienie interpelacji ma z reguły na celu uzyskanie od rządu informacji i wyjaśnień w sprawie, która nie znajduje się na porządku obrad izby; otwarcie — za zgodą izby — debaty parlamentarnej nad tą sprawą, tj. stworzenie możliwości wyłożenia i wymiany poglądów jej dotyczących; wywarcie przez parlament wpływu na działalność rządu w dziedzinie obejmującej sprawę, o którą chodzi; urzeczywistnienie politycznej odpowiedzialności rządu lub określonego ministra przez udzielenie mu — w związku z przebiegiem debaty nad interpelacją — wotum zaufania lub wotum nieufności"; A. Gwiżdż, Interpelacja i procedury podobne w burżuazyjnym prawie państwowym, „Państwo i Prawo” 1963, z. 4, s. 615-616. Przedwojenna doktryna polska na podstawie obserwacji rodzimej praktyki nadawała interpelacji węższe, w odniesieniu do celów, znaczenie, twierdząc, że: „Interpelacja, jako jedna z form parlamentarnej kontroli działalności rządu, posiada charakter interwencji, skierowanej za pośrednictwem izby do rządu lub ministra w pewnej konkretnej sprawie. Przedmiot i zakres interpelacji może dotyczyć całokształtu działalności rządu, tj. wszystkich dziedzin, spraw i materii z funkcją rządzenia związanych, nie wyłączając aktów rządowych natury personalnej, jak nominacje, awanse itp. — jednak w części nie wkraczającej w swobodną decyzję władzy, wyraźnie ustawą zastrzeżoną. Przedmiotem interpelacji nie mogą być również te decyzje natury personalnej, których powzięcie pozostaje z związku z pracami komisji dyscyplinarnych i kompetencją sądów. Celem interpelacji jest przywrócenie naruszonego porządku prawnego, naprawienie wyrządzonej krzywdy lub inne zadośćuczynienie zasadom słuszności albo powszechnemu poczuciu społecznej sprawiedliwości”. A. Majkowski, Uwagi ogólne o technice prac parlamentarnych, Warszawa 1937, s. 21. 
składane do marszałka, który miał je komunikować „Prezydentowi Rady Ministrów z zapytaniem, kiedy Rząd zechce udzielić wyjaśnień". Po otrzymaniu odpowiedzi, „a w każdym razie nie później niż po upływie miesiąca”, należało rozumieć, że następowało to również w sytuacji zwłoki rządu w udzieleniu odpowiedzi na interpelację, co potwierdził w jednej ze swych wypowiedzi na plenum marszałek - miał on umieszczać interpelację na porządku dziennym plenum izby. Z brzmienia omawianego przepisu wynikało, że odnosiło się to do każdej interpelacji, ale dyskusja nad interpelacją miała być dopuszczana tylko wówczas, gdy Sejm „uzna jej potrzebę”, a więc miała być otwierana - z zasady — tylko wyjątkowo. $Z$ ust. 2 cytowanego artykułu regulaminu wynika, że gabinet miał odpowiadać na interpelacje z reguły ustnie, a fakultatywnie (wedle własnego uznania) na piśmie. Jeśli odpowiedź miała być ustna, to należało sądzić, że musiało się to odbyć z trybuny sejmowej. Cytowany przepis postanawiał też, że Sejm miał odpowiedź rządu na interpelację (każdą) przyjmować bądź nie do wiadomości. Należało więc przypuszczać, że stanowisko izby miało być przyjmowane w głosowaniu lub tacite. W literaturze przedmiotu zwrócono uwagę, że przepisy art. 45 regulaminu konstytuanty nie dawały jej marszałkowi żadnej jurysdykcji nad zgłaszanymi interpelacjami ${ }^{30}$. W dniu 1 marca $1921 \mathrm{r}$. SU uzupełnił dotychczasowy art. 65 regulaminu o drugi ustęp, w którym postanawiał, że pełne teksty m.in. interpelacji, wniesionych zgodnie z regulaminem i w całości bądź ogłoszonych w izbie z tytułu, stawały się częścią składową obrad tego posiedzenia, na którym zostały zgłoszone do laski marszałkowskiej i miały być (w postaci drukowanej) dołączane do druków (protokołów, stenogramów) sejmowych ${ }^{31}$. Uzupełnienie to istotnie modyfikowało normę zawartą $\mathrm{w}$ art. 45 regulaminu, bowiem z pierwotnego jej brzmienia wynikało, że o treści interpelacji plenum Sejmu miało się dowiadywać dopiero po udzieleniu na nią odpowiedzi przez rząd i po postawieniu jej przez marszałka na porządku dziennym obrad. Choć nie było to pewne ze względu na niejasność powołanego przepisu, od marca 1921 r. treść interpelacji, nawet gdy była zakomunikowana izbie tylko z tytułu — co było powszechną praktyką od początku funkcjonowania konstytuanty, a teraz znalazło umocowanie w przepisie regulaminu - musiała być wydrukowana i dołączona (jako załącznik) do protokołu obrad posiedzenia Sejmu. Praktyka interpelowania rządu w okresie konstytuanty od początku wyraźnie odbiegała w wielu miejscach od litery art. 45 regulaminu, o czym będzie jeszcze mowa.

Wcześniej powiedziano, że $\mathrm{w}$ ramach funkcji kontrolnej rządu konstytuanta stosowała pięć szczegółowych procedur parlamentarnych. Były nimi postępowania: w sprawach inwestytury rządu, w sprawach wotum zaufania dla gabinetu (ministra), w sprawach wotum nieufności dla rządu (ministra), w sprawach interpelacji oraz postępowanie z udziałem komisji śledczej. Niżej przedstawione zostaną syntetyczne uwagi obrazujące cechy tych procedur w kolejności, w jakiej zostały wymienione.

\footnotetext{
${ }_{30}$ A. Gwiżdż, Prawo interpelacji posła na Sejm PRL, „Państwo i Prawo” 1956, z. 11, s. 762.

${ }^{31}$ Spr. sten. SU, pos. 214. z 1 marca 1921 r., 1.16.
} 
W odniesieniu do postępowania w sprawach inwestytury rządu należy zauważyć, że z chwilą zebrania się SU oraz tymczasowego określenia podstawowych zasad ustroju politycznego RP w małej konstytucji zaistniały wszystkie niezbędne wymogi formalne do zainicjowania systemu rządów parlamentarnych, których podstawowym warunkiem było posiadanie przez rząd poparcia parlamentu (większości parlamentarnej). Ponieważ rząd Ignacego Paderewskiego kontynuował działalność potwierdzoną udzieleniem mu ponownej inwestytury, tym razem przez Naczelnika Państwa i Sejm Ustawodawczy, a nie posiadał poparcia większości izby skupionej w koalicji rządowej zawiązanej na jej forum, miał charakter gabinetu pozaparlamentarnego (uważanego w systemie parlamentarnym za rząd tymczasowy, przejściowy), który miał działać do momentu zawiązania się większościowej koalicji rządowej w Sejmie.

W okresie funkcjonowania SU działalność prowadziło osiem gabinetów rządowych (w kolejności: pozaparlamentarny Paderewskiego, koalicyjny Leopolda Skulskiego, pozaparlamentarny Władysława Grabskiego, rząd „,wielkiej koalicji” Wincentego Witosa, dwa pozaparlamentarne rządy Antoniego Ponikowskiego, pozaparlamentarny Artura Śliwińskiego oraz pozaparlamentarny Juliana Nowaka) ${ }^{32}$. Pięć rządów, począwszy od gabinetu Skulskiego, a skończywszy na drugim ministerium Ponikowskiego, zostało utworzonych przy czynnym zaangażowaniu konstytuanty działającej via Konwent Seniorów i relatywnie biernej, z wyjątkami obsady stanowisk niektórych ministrów, postawie Naczelnika Państwa. Natomiast dwa ostatnie gabinety zostały utworzone w warunkach głębokiego kryzysu konstytucyjnego wywołanego przez J. Piłsudskiego po zdymisjonowaniu na początku czerwca 1922 r. drugiego rządu Ponikowskiego.

Rząd Paderewskiego utworzony na miesiąc przed ukonstytuowaniem się SU, w dniu złożenia przez Naczelnika Państwa władzy w ręce konstytuanty i podjęcia rzeczonej uchwały o powierzeniu mu dalszego sprawowania urzędu głowy państwa, ustami I. Paderewskiego przedstawił izbie sprawozdanie z dotychczasowej działalności ${ }^{33}$ i zgłosił swoje ustąpienie. Deklaracja dymisji powinna stanowić otwarcie przesilenia rządowego i rozpoczynać rokowania w sprawie powołania nowego gabinetu. Ponieważ jednak funkcję głowy państwa sprawował nadal J. Piłsudski, który w myśl przepisu dopiero co uchwalonej małej konstytucji, jako Naczelnik Państwa powoływał „Rząd w pełnym składzie na podstawie porozumienia z Sejmem" i — sięgając do wcześniejszej praktyki ustrojowej - miał również prawo odwoływania gabinetu, premier Paderewski złożył jeszcze tego samego dnia właśnie na jego ręce pisemną prośbę o zwolnienie „wraz z całym gabinetem ministrów” z zajmowanych urzędów. Piłsudski do prośby rządu jednak się nie przychylił, odpowiadając Paderewskiemu w następujących słowach: „W porozumieniu z Sejmem Ustawodawczym w osobie Jego Marszałka, zawiadamiam Pana Prezydenta, że do zgłoszonej przez niego wraz z całym gabinetem w dniu 20 lutego 1919 r. dymisji, jako wywołanej względami natury

32 Gabinety Drugiej Rzeczypospolitej, red. J. Faryś i J. Pajewski, Szczecin-Poznań 1991, s. 41-104; Kto byt kim w Drugiej Rzeczypospolitej, red. J.M. Majchrowski i in., Warszawa 1994, s. 21-24; Exposé premierów polskich 1918-2001, oprac. B. Sygit, Toruń 2001, s. 29.

${ }^{33}$ Spr. sten. SU, pos. 3. z 20 lutego1919 r., 1. 59-74. 
formalnej, przychylić się nie mogę i powierzam Panu oraz wszystkim Jego Kolegom ministrom sprawowanie nadal dotychczasowych urzędów"34.

Ponieważ Naczelnik Państwa odmówił przyjęcia dymisji gabinetu Paderewskiego, izba podjęła debatę nad sprawozdaniem premiera oraz uzupełniającym je wystąpieniem ministra skarbu. W debacie, nie licząc głosów w sprawie sprostowań, wzięło udział 15 mówców, którzy przemawiali łącznie przez ok. osiem godzin. Wszyscy, z wyjątkiem jednego, reprezentowali kluby sejmowe, bądź, jak w przypadku posłów żydowskich, poszczególne frakcje wyodrębniające się w zrzeszającym ich klubie federacyjnym. Zgodnie z ustaleniami podjętymi przez Konwent Seniorów SU, posłowie „przemawiali po kolei według tego, jak silną przedstawiają frakcję" ${ }^{35}$. „Ponieważ w dyskusji nad exposé premiera rządu wolno poruszać wszystkie sprawy państwowe - notował bezpośredni świadek debaty - a w danym razie było to w dodatku pierwsze publiczne wystąpienie stronnictw [w Sejmie - P.A.T.], więc przedstawiciele ich starali się skorzystać ze sposobności i ustosunkować się do wszystkich spraw najważniejszych"36. Zgłoszony w czasie debaty przez prawicowy klub Związku Sejmowego Ludowo Narodowego wniosek o wotum zaufania dla rządu Paderewskiego przeszedł większością w trybie głosowania ,przez powstanie z miejsc ${ }^{\prime 37}$.

${ }^{34}$ Ibidem, pos. 4. z 22 lutego 1919 r., ł. 95. Zacytowane wyżej pismo Naczelnika Państwa wymaga kilku zdań komentarza. Otóż mamy w nim do czynienia z noszącą charakter precedensu notyfikacją odwrotności postępowania naczelnika w porównaniu z formułą przyjętą przy powoływaniu rządu. Dowiadujemy się, że J. Piłsudski porozumiał się z Sejmem „w osobie Jego Marszałka”, a więc przewodniczący izby stał się tu niejako personifikacją całej konstytuanty i zastąpił ją stanowiąco w ustaleniach z Naczelnikiem Państwa. J. Piłsudski stwierdził, że zgłoszona dymisja rządu była spowodowana „względami natury formalnej”, podczas gdy — w domyśle — złożenie przezeń urzędu w ręce SU motywowane było okolicznościami natury zasadniczej (prawnokonstytucyjnej) i stanowiło wypełnienie dyspozycji normy zawartej w art. 1 dekretu z 22 listopada $1918 \mathrm{r}$. Względy natury formalnej (proceduralnej), podyktowane normą prawa zwyczajowego zaczerpniętą z praktyki konstytucyjnej krajów zachodnich, nakazujące złożenie dymisji przez dotychczasowy rząd po zebraniu się parlamentu nowej kadencji, miały mieć — w rozumieniu Naczelnika Państwa i reprezentującego Sejm marszałka - niejako znaczenie drugorzędne w porównaniu z względami natury materialnoprawnej, zobowiązującymi naczelnika do złożenia urzędu. Wykładnia taka budzi wątpliwości o tyle, że art. 2 powołanego dekretu nie tylko zakładał wygaszenie z chwilą zebrania się SU kompetencji naczelnika do mianowania rządu, ale stanowił również o przejściu z tą chwilą uprawnienia do egzekwowania odpowiedzialności gabinetu na konstytuantę. Normy z art. 2 dekretu miały, podobnie jak norma z art. 1 , charakter materialnoprawny, a nie formalny. Należy zauważyć, że oświadczenie Piłsudskiego o odrzuceniu prośby o dymisję rządu Paderewskiego uzupełnione jest jednak konstytutywnym stwierdzeniem o powierzeniu wszystkim członkom gabinetu sprawowania „nadal dotychczasowych urzędów”. Zastosowano tu więc formułę typową dla nadawania gabinetowi inwestytury w ramach tzw. inwestytury podzielonej czy też dwustopniowej, dokonującej się z udziałem głowy państwa i parlamentu. Naczelnik Państwa, postępując tym razem w myśl przepisu małej konstytucji i działając w porozumieniu z marszałkiem Sejmu zastępującym izbę, nadał rządowi Paderewskiego nową inwestyturę, której drugi akt, w postaci wotum zaufania izby, miał się dokonać kilka dni później po debacie nad exposé premiera i ministra skarbu.

${ }^{35}$ Ibidem, pos. 4. z 22 II 1919 r., ł. 153.

${ }^{36}$ R. Wojdaliński, Relacje posta na Sejm Ustawodawczy (1919-1922), t. I, s. 102, mps w Bibliotece Zakładu Narodowego im. Ossolińskich we Wrocławiu [dalej: Ossolineum], sygn. 14108/II.

${ }^{37}$ Spr. sten. SU, pos. 4. z 22 lutego 1919 r., 1. 101-151; pos. 5. z 24 lutego 1919 r., 1. 160-193; pos. 6. z 25 lutego 1919 r., ł. 203-240; R. Wojdaliński, op. cit., s. 108. 
Upadek rządu I. Paderewskiego późną jesienią 1919 r. doprowadził do wykształcenia się charakterystycznej dla okresu konstytuanty procedury powoływania (inwestytury) rządu, w której odgrywała ona dominującą rolę. Praktyka ta aż po czerwiec 1922 r. układała się następująco. Przyjęcie dymisji gabinetu przez Naczelnika Państwa powodowało zawieszenie obrad plenarnych Sejmu, a nierzadko również komisji sejmowych. Marszałek izby zwoływał niezwłocznie posiedzenie Konwentu Seniorów, w czasie którego była rozstrzygana na początku formuła polityczna przyszłego gabinetu, a mianowicie, czy ma to być rząd parlamentarny, oparty na koalicji stronnictw sejmowych, czy też gabinet pozaparlamentarny, popierany, a raczej tolerowany, przez frakcje skupiające większość posłów konstytuanty na zasadzie ,jak się nie ma, co się lubi, to się lubi, co się ma". W okresie do czerwca 1922 r. tylko dwa gabinety, spośród sześciu utworzonych do tego momentu, miały formułę rządów parlamentarnych (gabinety Skulskiego i Witosa), przy czym żaden z nich nie był klasycznym rządem większościowym. Rząd Skulskiego był gabinetem koalicyjnym, ale mniejszościowym, uciekającym się do udziału w jego składzie ministrów niepartyjnych (rząd taki nazywano też „półparlamentarnym” lub „półfachowym”), zmuszonym do korzystania z „tolerancji” niewchodzących do jego koalicyjnego zaplecza dwóch klubów centrowych. Rząd Witosa był zaś w pierwszym okresie swego istnienia gabinetem „wielkiej koalicji”, zawiązanym w okolicznościach politycznych określanych mianem sytuacji „Ojczyzna w niebezpieczeństwie”. Formalne powołanie obydwu wymienionych rządów, a ściśle określenie ich formuły politycznej i wytypowanie kandydatur szefów gabinetów przez Konwent Seniorów, poprzedzone było konsultacjami politycznymi toczącymi się poza jego obrębem (w przypadku rządu Skulskiego między zainteresowanymi stronnictwami, w odniesieniu do gabinetu Witosa zaś na posiedzeniu Rady Obrony Państwa), sfinalizowanymi formalnym zawiązaniem koalicji sejmowych. Posiedzenie i decyzja konwentu miały w takiej sytuacji jedynie charakter deklaratoryjny.

W sytuacji gdy zawiązanie sejmowej koalicji rządowej — ze względu na różnice programowe i taktyczne dzielące stronnictwa parlamentarne - było niemożliwe, rola Konwentu Seniorów rosła. Ciało to musiało bowiem wytypować kandydata na premiera przyszłego rządu i zgrupować kluby, które gotowe byłyby zapewnić tworzonemu gabinetowi pozaparlamentarnemu poparcie bezwzględnej większości posłów. Różnice między klubami sejmowymi prowadziły nierzadko w takiej sytuacji do zwoływania kilku kolejnych posiedzeń konwentu, w czasie których następowało „ucieranie” kandydatur premiera i ważniejszych ministrów (w znaczeniu obsady kluczowych ministerstw) oraz kompletowanie poparcia klubów sejmowych. Często posiedzenia Konwentu Seniorów przedzielały rundy rokowań międzyklubowych i indywidualne konsultacje prowadzone przez marszałka Trąmpczyńskiego z przywódcami stronnictw parlamentarnych w jego sejmowym mieszkaniu. Niekiedy — jak zdarzyło się przy misjach Paderewskiego na przełomie listopada i grudnia 1919 r., przed wyłonieniem się kandydatury W. Grabskiego w czerwcu 1920 r. oraz przed wypracowaniem koalicyjnej formuły „rządu obrony narodowej” w lipcu tegoż roku — do rozmów na 
temat konkretnej formuły rządu włączał się Belweder, do którego Naczelnik Państwa zapraszał liderów frakcji parlamentarnych na indywidualne konsultacje bądź zbiorowe narady. Rzadziej natomiast J. Piłsudski zjawiał się w gmachu Sejmu dla odbycia zbiorowej narady ze stronnictwami. We wrześniu 1921 r. i marcu 1922 r., a więc przed utworzeniem obu gabinetów Ponikowskiego, Naczelnik Państwa zaniechał wpływania na stronnictwa sejmowe w sprawach poszukiwania formuły politycznej gabinetu i typowania kandydata na premiera. Zdawał się zatem zajmować jeszcze bardziej wyczekującą i spolegliwą wobec konwentu i jego decyzji postawę niż zwykł to czynić do lata $1920 \mathrm{r}$. Nie pozostawał natomiast bierny w kwestiach planowanej przez polityków desygnowanych przezeń formalnie na stanowisko premiera, obsady personalnej resortów uważanych za sferę swych wpływów w rządzie (tzw. resortów belwederskich), czyli ministerstw spraw wojskowych, zagranicznych i wewnętrznych.

Kandydat na szefa rządu przed formalną decyzją konwentu albo w trakcie jego posiedzenia (jeżeli nie brał w nim udziału, to drogą telefoniczną), a w ostateczności tuż po zakończeniu jego posiedzenia składał na ręce marszałka Sejmu deklarację podjęcia się misji utworzenia rządu. Osiągnięcie kompromisu w sprawie formuły personalno-afirmacyjnej wszystkich czterech tworzonych przed czerwcem 1922 r. rządów pozaparlamentarnych odbywało się zawsze na posiedzeniu konwentu. Przewodniczący obradom marszałek izby wymieniał nazwisko potencjalnego kandydata na szefa rządu i wzywał po kolei reprezentantów zasiadających w konwencie klubów parlamentarnych do składania deklaracji poparcia dla proponowanego szefa nowego gabinetu. Liderzy frakcji sejmowych w swych wypowiedziach za lub przeciw rzucali na szalę taką liczbę głosów, jaką reprezentował ich klub. Zdarzały się jednak przy takiej okazji, $i$ to stosunkowo często, wypowiedzi niejasne, obwarowane licznymi zastrzeżeniami i warunkami, na podstawie których trudno było jednoznacznie wywnioskować, czy dany klub jest za postawioną kandydaturą, czy też przeciw niej. Głosy poparcia były skrzętnie zliczane i obwieszczano zebranym, czy przyszły gabinet, personifikowany przez wymienionego kandydata na premiera, może liczyć na poparcie bezwzględnej większości posłów. Jeżeli tak, to rola konwentu zastępującego cały Sejm dobiegała końca, jeżeli nie, posiedzenie zamykano i rozpoczynała się nowa runda konsultacji poprzedzająca zwołanie kolejnego zebrania. Pozytywna decyzja Konwentu Seniorów typująca kandydata na premiera nabierała charakteru konstytutywnego. Było to więc faktyczne wyznaczenie szefa przyszłego rządu, czyli desygnacja w znaczeniu materialnym. Marszałek Sejmu udawał się następnie osobiście do Belwederu i komunikował ją na piśmie oraz ustnie Naczelnikowi Państwa, zawiadamiając go o wytypowanym kandydacie oraz wymieniając frakcje parlamentarne gotowe poprzeć tworzony przezeń rząd. Naczelnik, co potwierdzają fakty, akceptował bez wyjątku (lub raczej przyjmował do wiadomości, nieraz z wyraźną niechęcią) decyzję konwentu co do charakteru gabinetu (parlamentarny lub pozaparlamentarny) i osoby jego szefa. Następnie wzywał niezwłocznie do siebie kandydata na premiera, formalnie pytał go o zgodę na podjęcie się misji utworzenia gabinetu i wręczał mu dekret desygnacyjny z użyciem w jego osnowie formuły: „w porozumieniu z Sejmem Ustawodawczym w osobie 
Jego Marszałka"38. Dokonywał zatem desygnacji premiera tylko w znaczeniu formalnym, bo materialna, jak już wspomniano, należała do konwentu.

Akty desygnacji premiera i rządu (materialny i formalny) dokonywane od jesieni 1919 r. nie kończyły w systemie ustrojowym małej konstytucji procesu inwestytury rządu, ale stanowiły tylko jego pierwszy etap. Drugim było uzyskanie wotum zaufania Sejmu, które w okresie poprzedzającym wspomnianą wykładnię autentyczną tymczasowej ustawy zasadniczej z czerwca 1922 r. stało się wymogiem prawno-zwyczajowym recypowanym z parlamentaryzmu zachodnioeuropejskiego.

W sytuacji przejęcia inicjatywy w dziedzinie wyłaniania rządu przez konstytuantę, począwszy od późnej jesieni 1919 r. (od chwili utworzenia gabinetu L. Skulskiego ${ }^{39}$ ), procedura udzielenia inwestytury parlamentarnej rządowi przebiegała różnie od postępowania w sprawie debaty nad exposé rządu Paderewskiego z końca lutego 1919 r. Etap formalnego udzielenia inwestytury parlamentarnej nowemu rządowi obejmował od końca 1919 r. następujący ciąg czynności na plenum Sejmu: exposé premiera uzupełnione odrębnym wystąpieniem programowym ministra skarbu; przyjęcie wniosku o otwarcie debaty nad deklaracją programową rządu i jej odłożenie do następnego posiedzenia w celu odbycia narad w klubach poselskich; debata nad exposé polegająca na wystąpieniach mówców wytypowanych przez kluby w kolejności odzwierciedlającej wielkość frakcji — od największej do najmniejszej (rzutowało to również wprost proporcjonalnie na długość przemówienia, ale z wyjątkiem debaty po powołaniu pierwszego rządu Ponikowskiego ${ }^{40}$ ); głosowanie nad postawionym w dyskusji wnioskiem o ,przyjęcie do wiadomości" deklaracji programowej rządu, a więc o udzielenie mu wotum zaufania (tak w przypadku rządu Nowaka, kiedy to udzielenie wotum zaufania - wymagane na skutek uchwały Sejmu z 16 czerwca 1922 r. dotyczącej wykładni autentycznej małej konstytucji — odbyło się jako głosowanie ,przez drzwi”"41), względnie o odmowę

${ }^{38}$ Confer spr. sten. SU, pos. 318. z 16 czerwca 1922 r., ł. 11-12, 17-18, 21, 40-43; M. Rataj, Pamiętniki, Warszawa 1965, s. 62-63; S. Krukowski, Sejm Ustawodawczy 1919-1922. Uwagi o składzie i dziatalności, „Czasopismo Prawno-Historyczne” 1986, z. 1, s. 106-107; Z. Kaczmarek, Wojciech Trampczyński, Poznań 1993, s. 140-145; G. Koksanowicz, Prawnoustrojowa pozycja marszałka Sejmu w okresie II Rzeczypospolitej, „Przegląd Sejmowy” 2003, nr 2, s. 68-69. Zatem nie znajduje potwierdzenia w faktach zdanie A. Próchnika (Pierwsze piętnastolecie Polski niepodległej. Zarys dziejów politycznych, Warszawa 1983, s. 103), jakoby w okresie od jesieni 1919 r. do czerwca 1922 r. początkowo wolę Sejmu wyrażał jego marszałek, a następnie Konwent Seniorów, gdyż od początku podmiotem decydującym był konwent, a marszałek przedstawiał Naczelnikowi Państwa jedynie jego decyzję.

39 Powołanie gabinetu Skulskiego poprzedziło podpisanie przez zjednoczony klub Polskiego Stronnictwa Ludowego oraz frakcje Narodowego Zjednoczenia Ludowego i Narodowego Związku Robotniczego „Umowy większości sejmowej”, konstytuującej przyszłą koalicję rządową. Koalicja ta miała charakter mniejszościowy, ale ,życzliwą neutralność” w stosunku do niej zadeklarowały jeszcze dwie niewielkie frakcje centrowe Narodowo Chrześcijański Klub Robotniczy i Zjednoczenie Mieszczańskie, co zapowiadało głosowanie przez nie, wespół z koalicjantami, za wnioskiem o wotum zaufania dla nowego gabinetu; vide m.in.: K. Badziak, W oczekiwaniu na przełom. Na drodze od odrodzenia do załamania państwa polskiego listopad 1918-czerwiec 1920, Łódź 2004, s. 97-121.

40 „Kurier Polski”, 1 X 1921, nr 266.

${ }^{41}$ Spr. sten. SU, pos. 333. z 3 sierpnia 1922 r., 1. 7-39; „Kurier Polski”, 4 VIII 1922, nr 211; J. Nowak, Wspomnienia z ławy rządowej, Kraków 1938, s. 45. 
wotum zaufania (tak w przypadku gabinetu Śliwińskiego, co spotkało się z poparciem większości, udzielonym — precedensowo — w głosowaniu imiennym ${ }^{42}$ ).

Przedstawiony schemat postępowania nie był jednak kanonem sztywnym, miał liczne odstępstwa generowane okolicznościami bieżącej sytuacji politycznej. Listę tych odstępstw otwierał często stawiany i skwapliwie uchwalany przez większość regulaminowy wniosek formalny o zamknięcie rozprawy po wystąpieniach mówców z ważniejszych klubów poselskich, a przed mowami zapisanych do głosu reprezentantów małych frakcji, najczęściej radykalnie lewicowych, które w takiej sytuacji głośno wyrażały swoje niezadowolenie (tak w przypadkach gabinetów: Skulskiego, Grabskiego, pierwszego rządu Ponikowskiego, Śliwińskiego ${ }^{43}$ ). Drugim często stosowanym wyjątkiem od podanego schematu było udzielanie wotum zaufania nowemu rządowi w sposób dorozumiany, tacite, bez postawienia i głosowania wniosku w tej sprawie (tak w przypadkach gabinetów: Skulskiego i obu rządów Ponikowskiego ${ }^{44}$ ). Następnym odejściem od podanej formuły udzielania inwestytury parlamentarnej nowemu ministerium było łączenie exposé szefa gabinetu i towarzyszącej mu debaty parlamentarnej z rozprawą nad ważnym, okolicznościowo fundamentalnym i pilnym, projektem ustawy wniesionym przez rząd. Uchwalenie ustawy było równoznaczne z udzieleniem wotum zaufania nowemu gabinetowi inicjującemu swój polityczny żywot od przedłożonego projektu ustawy. W czasie debaty nad takim projektem ustawy odstępowano od formuły przemawiania posłów według siły reprezentowanej frakcji i zastępowano ją kolejnością wynikającą z układu listy mówców zapisanych do głosu (tak w przypadkach gabinetów Grabskiego, kiedy to procedowano projekt ustawy o Radzie Obrony Państwa ${ }^{45}$ oraz drugiego rządu Ponikowskiego, kiedy przeprowadzano I czytanie projektu budżetu państwa ${ }^{46}$ ). Sygnalizowana zmiana kolejności wystąpień poselskich była praktykowana również w debatach nad deklaracjami programowymi rządów Śliwińskiego i Nowaka ${ }^{47}$. Wspomniane łączenie debaty nie ograniczało się tylko do rządowych projektów ustaw, ale odnosiło się również do ważnych ze względu na okoliczności polityczne sprawozdań komisji sejmowych dotyczących wniosków poselskich (tak w przypadku gabinetu Witosa ${ }^{48}$ ). Innym odstępstwem od proceduralnego kanonu udzielania inwestytury parlamentarnej nowemu

42 Spr. sten. SU, pos. 324. z 5 lipca 1922 r., 1. 10-55; pos. 325. z 6 lipca 1922 r., ł. 24-49; pos. 326. z 7 lipca 1922 r., 1. 3-57; „Kurier Polski”, 29 VI 1922, nr 175; 6 VII 1922, nr 182; 7 VII 1922, nr 183; R. Wojdaliński, op. cit., t. IV, s. 119-121.

${ }^{43}$ Spr. sten. SU, pos. 106. z 19 grudnia 1919 r., ł. 23-24; pos. 156. z 30 czerwca 1920 r., 1. 8-39; pos. 157 z 1 lipca 1920 r., ł. 22-38; pos. 247. z 27 września 1921 r., ł. 6-22; pos. 248. z 30 września 1921 r., ł. 15-62; pos. 249. z 1 października 1921 r., ł. 2-48; pos. 324. z 5 lipca 1922 r., 1. 10-18; pos. 325. z 6 lipca 1922 r., 1. 24-47; „Kurier Polski”, 29 VI 1922, nr 175; 6 VII 1922, nr 182.

${ }^{44}$ Spr. sten. SU, pos. 106. z 19 grudnia 1919 r., 1. 23-24; pos. 249. z 1 października 1919 r., 1. 48; pos. 303. z 5 maja 1922, ł. 102.

45 Ibidem, pos. 156. z 30 czerwca 1920 r., 1. 8-39; pos. 157. z 1 lipca 1920 r., 1. 22-38.

46 Ibidem, pos. 296. z 4 kwietnia 1922 r., 1. 104; pos. 301. z 28 kwietnia 1922, 1. 14-34; pos. 302. z 4 maja 1922 r., ł. 12-85; pos. 303. z 5 maja 1922 r., ł. 4-102.

${ }^{47}$ Ibidem, pos. 324. z 5 lipca 1922 r., 1. 10-55; pos. 325. z 6 lipca 1922 r., 1. 24-47; pos. 326. z 7 lipca 1922 r., 1. 3-57; pos. 333. z 3 sierpnia 1922 r., ł. 7-39.

48 Ibidem, pos. 166. z 24 lipca 1920 r., 1. 7-23. 
rządowi było odwlekanie w czasie otwarcia plenarnej rozprawy nad exposé szefa gabinetu (tak w przypadku drugiego rządu Ponikowskiego), ale zdarzało się również postępowanie zupełnie odmienne - niezwłocznie przystępowanie do rozprawy bez zwyczajowej przerwy na narady w klubach (tak w przypadkach gabinetów Śliwińskiego i Nowaka). Osobliwością była również schematyzacja debaty nad exposé, sprowadzająca się do krótkich, odczytywanych z trybuny sejmowej deklaracji klubowych (tak w przypadkach rządów Witosa i Nowaka).

Dymisja drugiego rządu A. Ponikowskiego otwarła najdłuższe w dziejach II RP przesilenie rządowe trwające dwa miesiące, w czasie którego Sejm dokonał wykładni autentycznej przepisu małej konstytucji w sprawie powoływania rządu i powołał do życia, w miejsce tracącego swoją rolę (ale tylko w tym procesie) Konwentu Seniorów, Komisję Główną. W trakcie tego przesilenia prawica sejmowa usiłowała usunąć z urzędu Naczelnika Państwa J. Piłsudskiego. W trakcie przesilenia naczelnik powołał 28 czerwca 1922 r. gabinet Artura Śliwińskiego. Rząd ten został de facto narzucony przez Naczelnika Państwa luźnej większości centroprawicowej SU, zastępującego się Komisją Główną, która skapitulowała na rzecz Piłsudskiego i poparła większością głosów powołanie tego gabinetu (podobnie stało się z rządem Nowaka). Nic więc dziwnego, że stronnictwa ją tworzące, a zwłaszcza ugrupowania endeckie, odebrały go jako poważne upokorzenie doznane od Piłsudskiego, którego pozycję ustrojową konstytuanta usiłowała osłabić poprzez wspomnianą wykładnię tymczasowej ustawy zasadniczej z 20 lutego 1919 r. Cenę za to, jedyną taką w całym okresie funkcjonowania SU, zapłacił gabinet Śliwińskiego, któremu izba odmówiła wotum zaufania.

Instytucja wotum zaufania dla rządu w okresie konstytuanty była nie tylko środkiem $\mathrm{w}$ procedurze inwestytury gabinetu, ale również samodzielnym narzędziem w wykonywaniu parlamentarnej kontroli egzekutywy ${ }^{49}$. Na przestrzeni całego okresu funkcjonowania SU do jej zastosowania doszło tylko raz, na początku 1921 r., w czasie funkcjonowania gabinetu W. Witosa. Rząd ten rozpoczął działalność w lipcu 1920 r. jako „,ząd wielkiej koalicji”, ale od końca listopada tegoż roku jego zaplecze parlamentarne zaczęło się stopniowo kruszyć poprzez wyłamywanie się kolejnych klubów, najpierw prawicowych (ZLN i chadecji), następnie PPS, a potem kolejnych. Zaniepokojony premier Witos zwołał 17 stycznia $1921 \mathrm{r}$. naradę stronnictw uczestniczących jeszcze w pracach gabinetu, z pytaniem o istnienie zaplecza koalicyjnego dla rządu. Obecni na naradzie przedstawiciele części klubów sejmowych uzależnili swe poparcie dla gabinetu od wystąpienia premiera z exposé na forum Sejmu ${ }^{50}$. Witos zdecydował się w tej sytuacji zabiegać o wotum zaufania konstytuanty. Exposé (zawierało w swej treści zarówno elementy sprawozdania, jak i mowy programowej) wygłosił 27 stycznia $1921 \mathrm{r}$. na plenum izby przed zaplanowanym porządkiem dziennym obrad (w myśl przepisu

${ }^{49} \mathrm{~W}$ ujęciu doktryny współczesnej wotum zaufania to ,uchwała parlamentu wyrażająca zaufanie dla rządu lub poszczególnych ministrów bądź też akceptację programu działania rządu oraz prowadzonej przez niego polityki”; S. Bożyk, Wotum zaufania, [w:] Wielka encyklopedia..., s. 1157.

${ }^{50}$ Vide A. Wątor, Gabinet Wincentego Witosa 24 VII 1920-13 IX 1921, [w:] Gabinety..., s. 72-73; spr. sten. SU, pos. 203. z 27 stycznia 1921 r., ł. 25. 
art. 22 regulaminu przedstawiciel rządu miał prawo przemawiania poza kolejnością i bez ograniczeń czasowych). Izba jeszcze tego samego dnia, na wniosek przedstawiciela Związku Parlamentarnego Polskich Socjalistów, rozpoczęła debatę nad wystąpieniem szefa rządu, która rozciągnęła się na istotne części następnych sześciu posiedzeń plenarnych (z przerwą na posiedzenia od 205. do 207.) zwołanych w okresie od 28 stycznia do 22 lutego $1921 \mathrm{r}$. W długiej debacie (nie licząc wystąpień dla sprostowań) zabrało głos 19 posłów reprezentujących większość klubów sejmowych, ale w kolejności według zapisów, a nie wielkości frakcji parlamentarnych. Jako ostatni w celach polemicznych głos zabrał ponownie premier Witos. W przedostatnim dniu debaty prezes Klubu Pracy Konstytucyjnej, poseł Jan Kanty Federowicz, zgłosił dwuczęściową rezolucję (wniosek) o wotum zaufania dla gabinetu. Obydwie części wniosku uzyskały w odrębnych głosowaniach poparcie większości posłów w trybie ,przez powstanie z miejsc” ${ }^{51}$. Tym samym rząd Witosa uzyskał zaufanie Sejmu już tylko jako gabinet większościowy.

W okresie funkcjonowania SU uruchomiono co najmniej czterokrotnie procedurę egzekwowania odpowiedzialności politycznej egzekutywy z wykorzystaniem instytucji wotum nieufnościs ${ }^{52}$. Co charakterystyczne, rozpatrywanie stosownego wniosku w osobnym punkcie porządku obrad (w odrębnym postępowaniu) zdarzyło się tylko jeden raz w odniesieniu do Naczelnika Państwa, natomiast w przypadkach dwóch szczegółowo odnotowanych w stenogramach SU postępowań tego rodzaju doszło do nich nie w osobnych punktach porządku obrad, lecz wpadkowo w ramach innych postępowań. Czwarty wspomniany przypadek jest odnotowany w stenogramie tylko wzmiankowo, bowiem podana jest tylko informacja o wniosku o wotum nieufności wobec niewskazanego konkretnie ministra sprawiedliwości, co miało się zdarzyć przed kwietniem 1922 r..$^{53}$

51 Spr. sten. SU, pos. 203. z 27 stycznia 1921 r., ł. 5-56; pos. 204. z 28 stycznia 1921 r., 1. 19-58; pos. 208. z 10 lutego 1921 r., ł. 7-67; pos. 209. z 11 lutego 1921 r., ł. 44-63; pos. 210 . z 15 lutego 1921 r., ł. 55-67; pos. 211. z 18 lutego 1921 r., 1. 20-59; pos. 212. z 22 lutego 1921 r., 1. 9-55.

${ }^{5}$ Przez pojęcie wotum nieufności rozumie się we współczesnej polskiej doktrynie uchwałę parlamentu podjętą na wniosek uprawnionej liczby deputowanych, wyrażającą brak zaufania lub dezaprobatę dla działalności rządu bądź ministra, powodującą zwykle ich dymisję. Wniosek w sprawie uchwalenia wotum nieufności może wynikać z negatywnej oceny działalności gabinetu lub ministra bądź ze zmieniających się układów partyjno-koalicyjnych; vide B. Banaszak, Wotum nieufności, [w:] Encyklopedia prawa, red. U. Kalina-Prasznic, Warszawa 1999, s. 860; A. Preisner, Wotum nieufności, [w:] Słownik wiedzy o Sejmie, red. A. Preisner, Warszawa 1995, s. 149; W. Sokolewicz, Odpowiedzialność parlamentarna Rządu RP (votum zaufania, votum nieufności, absolutorium), Warszawa 1993, s. 31-33.

53 Spr. sten. SU, pos. 296. z 4 kwietnia 1922 r., 1. 100. Jeśli taki wniosek rzeczywiście postawiono, to wiele wskazuje na to, że został on przez Sejm odrzucony, gdyż żaden z ministrów sprawiedliwości nie złożył do tego okresu dymisji w związku z uchwaleniem mu wotum nieufności. Warto też nadmienić, że instytucji wotum nieufności wobec ministra użyto skutecznie poza plenum Sejmu. Uczyniła to Komisja Spraw Zagranicznych izby (jednomyślnie, ale bez wcześniejszego formalnego postawienia wniosku w tej sprawie) na swym posiedzeniu 12 maja 1921 r. wobec (nieobecnego na jej posiedzeniu) szefa resortu spraw zagranicznych w rządze Witosa, Eustachego Sapiehy. Na skutek tej uchwały, bez zaangażowania plenum Sejmu w obalenie ministra, Sapieha podał się 24 maja 1921 r. do dymisji, która została przyjęta przez Naczelnika Państwa; vide P.A. Tusiński, Komisja Spraw Zagranicznych Sejmu Ustawodawczego (1919-1922) jako podmiot polityki zagranicznej w pierwszych latach II Rzeczypospolitej, „Wschodni Rocznik Humanistyczny” 2015, t. XII, s. 144-145. 
Pierwszy raz w konstytuancie wniosek o wotum nieufności postawiono 13 lutego 1920 r. w stosunku do gabinetu L. Skulskiego w wystąpieniu sprawozdawcy mniejszości Komisji Skarbowo-Budżetowej, socjalistycznego posła Hermana Diamanda, który zarzucił rządowi nakręcanie spirali inflacji. Wniosek sformułowano przy okazji debaty nad rządowym projektem „ustawy w przedmiocie dalszej emisji biletów Polskiej Krajowej Kasy Pożyczkowej”. Co ciekawe, funkcjonujący od kilku tygodni gabinet Skulskiego miałby ponieść odpowiedzialność polityczną za poczynania poprzedzającego go rządu Paderewskiego, a ściśle zasiadającego w jego składzie w fotelu ministra skarbu, Leona Bilińskiego. Odpowiadając, sprawozdawca większości komisji zarzucał autorom wniosku o wotum nieufności stricte polityczne, a nie merytoryczne motywy działania, wynikające z zajmowania opozycyjnego stanowiska względem rządu. W konsekwencji Sejm w głosowaniu ,przez powstanie z miejsc” odrzucił większością głosów wniosek o wotum nieufności, a następnie uchwalił w II i III czytaniu rządowy projekt ustawy zatwierdzającej dodatkową emisję pieniądza oraz rezolucję większości komisji nowelizującą małą konstytucję ${ }^{54}$, o której wzmiankowano już wcześniej. Drugi wniosek o wotum nieufności postawił na początku kwietnia 1922 r. poseł Juliusz Poniatowski z PSL „Wyzwolenie” wobec prezesa Głównego Urzędu Ziemskiego (urząd miał charakter centralnego organu administracji rządowej, podlegającego ministrowi rolnictwa) Władysława Kiernika, którego obciążono główną odpowiedzialnością za aferę sprzedaży Polsko-Amerykańskiemu Bankowi Ludowemu majątku Dojlidy w Białostockiem. Wniosek, postawiony w ramach postępowania interpelacyjnego zainicjowanego przez posłów ZLN, izba uchwaliła w trybie głosowania przez powstanie z miejsc, ale w brzmieniu zgłoszonym przez posła Witolda Teofila Staniszkisa, że: „Sejm nie przyjmuje do wiadomości odpowiedzi [na interpelację — P.A.T.] p. Prezesa Głównego Urzędu Ziemskiego" 55 . W następstwie uchwały Kiernik podał się do dymisji.

Trzeci odnotowany szerzej w źródłach przypadek sięgnięcia przez konstytuantę po procedurę egzekwowania odpowiedzialności egzekutywy zdarzył się latem 1922 r., w trakcie wspomnianego wcześniej długotrwałego przesilenia rządowego po upadku II gabinetu Ponikowskiego. Tym razem jej oścień skierowano z inicjatywy obu klubów Narodowej Demokracji przeciwko osobie Naczelnika Państwa, w odwecie za odmowę powołania gabinetu pod prezesurą Wojciecha Korfantego. Wniosek nagły odmawiający zaufania naczelnikowi wpłynął do laski marszałkowskiej 25 lipca 1922 r., a większość izby zdecydowała się go rozpatrywać w trybie pilnym na specjalnie zwołanym w tym celu posiedzeniu plenarnym Sejmu w dniu następnym ${ }^{56}$. Sytuacja wywołana wnioskiem była o tyle niebezpieczna, że ewentualna dymisja J. Piłsudskiego ze stanowiska głowy państwa, połączona $\mathrm{z}$ brakiem rządu (formalnie funkcjonował w ramach prowizorium rządowego gabinet Śliwińskiego, ale przecież i jemu odmówiono wcześniej zaufania Sejmu) pozostawiłaby państwo bez legitymizowanej konstytucyjnie całej egzekutywy.

${ }_{54}^{54}$ Spr. sten. SU, pos. 119. z 13 lutego 1920 r., 1. 23-60.

${ }_{55}$ Ibidem, pos. 296. z 4 kwietnia 1922 r., 1. 87-101.

${ }_{56}$ J. Faryś, Konflikt Naczelnika Państwa z Sejmem Ustawodawczym w 1922 roku, „Dzieje Najnowsze” 1975, nr 3, s. 50; spr. sten. SU, pos. 329. z 25 lipca 1922 r., ł. 59. 
W głosowaniu imiennym wniosek o wotum nieufności został jednak odrzucony większością 206 głosów przeciw 186, przy czterech wstrzymujących się ${ }^{57}$.

Zgłaszanie interpelacji parlamentarnych było podstawową formą — w przeważającej mierze indywidualnej - aktywności posłów SU w dziedzinie sprawowania kontroli nad rządem. Formalnie interpelacja musiała być zgłoszona przez co najmniej 15 posłów (art. 65 regulaminu), ale uzyskanie podpisu kolegów pod interpelacją, nawet z innego klubu parlamentarnego, nie sprawiało żadnej trudności, skoro w okresie konstytuanty wpłynęło ich do laski marszałkowskiej aż $3697^{58}$. Wcześniej już powiedziano, że w myśl powołanego przepisu regulaminu — wszczynanie debaty nad interpelacją miało następować co do zasady wyjątkowo, gdy Sejm „uzna jej potrzebę”. Tak też było w praktyce. $Z$ jej obserwacji wynika, że konstytuanta stosowała w istocie dwie procedury postępowania w sprawach interpelacji - uproszczoną i rozwiniętą.

Postępowanie uproszczone wykorzystywane w odniesieniu do przygniatającej liczby zgłoszonych interpelacji polegało na złożeniu jej tekstu na piśmie marszałkowi, a następnie - na najbliższym po tym fakcie posiedzeniu plenarnym izby — na odczytaniu przez urzędującego sekretarza obrad nazwiska pierwszego interpelanta pod nią podpisanego (wyjątkowo czytano kilka pierwszych nazwisk) i skwitowaniu dalszych podpisanych zwrotem „i tow.[arzyszy]”, wskazaniu adresata interpelacji oraz na określeniu kwestii, której dotyczyła, a także — na końcu prezentacji nagłówków wszystkich zgłoszonych interpelacji - wygłoszeniu przez marszałka formuły, że interpelacje prześle prezydentowi Rady Ministrów „na drodze regulaminem przepisanej”59. Wnioskowanie na podstawie danych źródłowych dotyczących biegu rozwiniętej procedury interpelacyjnej pozwala sądzić, że odpowiedzi rządu na interpelacje (na ogół udzielane na piśmie bezpośrednio przez zaczepionych ministrów, jednak relatywnie często bez dotrzymania miesięcznego terminu ${ }^{60}$ ), kierowane na ręce marszałka, były następnie doręczane przezeń interpelantom bez zawiadamiania o tym fakcie plenum Sejmu. Praktyka nieabsorbowania uwagi całej izby w tym względzie została najprawdopodobniej wymuszona ogromną liczbą zgłaszanych interpelacji. Dostarczenie odpowiedzi interpelantowi/om kończyło bieg uproszczonej procedury interpelacyjnej.

Rozwinięta procedura interpelacyjna w SU, stosowana — z założenia — wyjątkowo, biegła do momentu wpłynięcia pisemnej odpowiedzi rządu na interpelację na ręce marszałka izby bądź zawiadomienia go o zamiarze (dacie) udzielenia odpowiedzi ustnej, identycznie jak procedura uproszczona. Różnica pojawiała się od chwili wyrażenia

57 Spr. sten. SU, pos. 330. z 26 lipca 1922 r., 1. 9-22.

58 Katalogi i bazy, Parlamentaria polskie 1919-1997, Sejm 1919-1939, Sejm Ustawodawczy 1919-1922, Interpelacje; <bs.sejm.gov.pl>.

59 Dla przykładu spr. sten. SU, pos. 21. z 29 marca 1919 r., ł. 1-3; pos. 37. z 13 maja 1919 r., 1. 1-3.

${ }^{60} \mathrm{~W}$ przypadku opóźnienia odpowiedzi główny interpelant składał oświadczenie przed porządkiem dziennym o zwłoce, a marszałek zobowiązywał się do niezwłocznego zapytania ministra o przyczynę opóźnienia; np. ibidem, pos. 147. z 14 maja 1920 r., ł. 4; pos. 282. z 31 stycznia 1922 r., 1. 4-5. W ostatnim przypadku marszałek oświadczył, że na życzenie posłów zawsze interweniował w rządzie w sprawach zwłoki udzielania odpowiedzi na interpelacje, grożąc, że zgodnie z regulaminem postawi sprawę takiej interpelacji na porządku dziennym plenum izby. 
przez przedstawiciela gabinetu woli wystąpienia na plenum izby z ustną odpowiedzią na interpelację. Wówczas to norma regulaminowa wymagała od marszałka umieszczenia sprawy interpelacji na porządku dziennym plenarnego posiedzenia Sejmu. Praktyka dostarcza jednak co najmniej kilku przykładów postawienia sprawy interpelacji na porządku dziennym obrad izby nawet w przypadkach udzielenia pisemnej odpowiedzi rządu. $\mathrm{Z}$ brzmienia powołanego przepisu regulaminu nie wynika, kto rozstrzygał w sensie inicjatywnym o umieszczeniu takiej odpowiedzi na plenum - marszałek motu proprio, rząd czy też interpelanci. Pewne wzmianki źródłowe na ten temat pozwalają jednak sądzić, że najczęściej działo się to z inicjatywy gabinetu. Umieszczenie sprawy interpelacji na porządku dziennym, sygnowanej formalnie najczęściej jako odpowiedź na nią zaczepionego ministra, uruchamiało dalsze czynności postępowania interpelacyjnego teraz już z udziałem całej izby. Układ tych czynności został zasadniczo ustalony przy okazji pierwszego przypadku postawienia sprawy interpelacji na porządku dziennym obrad SU, co zdarzyło się w końcu marca 1919 r., na 21. i 22. posiedzeniu. Procedurę rozpoczynało wystąpienie zaczepionego ministra, następnie głównego interpelanta, który zgłaszał na końcu rezolucję (lub rezolucje) żądające od rządu wykonania wskazanych działań, po nim zaś zabierali głos posłowie zapisani na listę mówców. Debatę kończyło uchwalenie rezolucji interpelanta lub wniosku o przyjęcie/nieprzyjęcie odpowiedzi rządu, względnie — jak w wywołanym przypadku — odesłanie rezolucji do komisji, bowiem marszałek był zdania, że: „Podług regulaminu właściwie wolno po interpelacjach głosować tylko nad tem, czy Sejm przyjmuje odpowiedź do wiadomości, czy nie" ${ }^{61}$.

Opisana rozwinięta procedura interpelacyjna nie zawsze miała dokładnie taki przebieg w odniesieniu do innych przypadków interpelacji rozpatrywanych na plenum SU. Niekiedy izba rozpoczynała postępowanie od razu od umieszczonej w porządku dziennym obrad (albo przed porządkiem dziennym) odpowiedzi ustnej interpelowanego ministra bądź premiera bez odczytywania treści interpelacji. Następnie bez otwierania debaty odpowiedź tę przyjmowano tacite do wiadomości ${ }^{2}$ bądź czynność ta następowała po debacie $^{63}$. Innym wariantem rozwiniętej procedury interpelacyjnej było włączanie interpelacji do plenarnego biegu czynności w postępowaniach dotyczących spraw wniosków poselskich zgłaszanych pod adresem rządu, jeśli łączyła je wspólna tematyka ${ }^{64}$. Zdarzało

${ }^{61}$ Ibidem, pos. 21. z 29 marca 1919 r., 1. 33-71; pos. 22. z 31 marca 1919 r., 1. 17-50. Omawiany przypadek odesłania odpowiedzi rządu na interpelację do komisji nie był odosobniony, o czym świadczy sprawozdanie Komisji Zdrowia i Opieki Społecznej o jednej z interpelacji na posiedzeniu izby w końcu lutego 1922 r.; ibidem, pos. 289. z 25 lutego 1922 r., ł. 4-8.

${ }^{62}$ Spr. sten. SU, pos. 149. z 19 maja 1920 r., ł. 3-9; pos. 172 . z 14 października 1920 r., 1. 4-5; pos. 298. z 7 kwietnia 1922 r., 1. 35-79.

${ }^{63}$ Spr. sten. SU, pos. 145. z 7 maja 1920 r., 1. 58-63. Nieprzyjęcie przez izbę odpowiedzi rządu i prezesa NIKP na interpelację zaistniało na początku kwietnia 1922 r. we wspomnianym wcześniej postępowaniu dotyczącym afery dojlidzkiej. Odrzucenie odpowiedzi rządu nie oznaczało jednak wotum nieufności wobec gabinetu A. Ponikowskiego, lecz tylko wobec prezesa Głównego Urzędu Ziemskiego, Kiernika, obciążonego odpowiedzialnością za wprowadzenie premiera w błąd; spr. sten. SU, pos. 296. z 4 kwietnia 1922 r., 1. 53-101.

${ }^{64}$ Ibidem, pos. 25. z 4 kwietnia 1919 r., 1. 29-88; pos. 37. z 13 maja 1919 r., ł. 69-88. 
się również Sejmowi rozpatrywanie w ramach procedury rozwiniętej interpelacji kwalifikowanych jako nagłe ${ }^{65}$.

Doktryna wiąże postępowanie kontrolne z udziałem nadzwyczajnej komisji śledczej z tzw. prawem ankiety parlamentarnej. Istotą takiej komisji było wyposażenie jej w odpowiednie instrumenty oddziaływania politycznego i prawnokarnego, przy czym te ostatnie są właściwe dla katalogu uprawnień prokuratora i sądu (np. prawo wzywania świadków z obowiązkiem ich stawiennictwa, zaznaczenie obowiązku składania prawdziwych zeznań). Cel powoływania komisji śledczych przez parlament ma wyraźnie polityczny charakter (często odbywa się to pod naciskiem opinii publicznej). Uprawnienia kontrolne $w$ ramach ankiety parlamentarnej wykraczają poza rutynowy obszar działalności parlamentu i obejmują np. kontrolę organów administracji specjalnej i terenowej oraz przesłuchania osób fizycznych niezatrudnionych w aparacie rządowym. Zatem parlamentarne postępowanie śledcze stanowi swoistą konkurencję dla procesu karnego, chociaż może ono również zbierać materiał dowodowy na jego użytek. Polityczne piętno ankiety parlamentarnej powoduje, że sprawozdanie komisji śledczej ma z reguły opisową formę (nienormatywną, nieodpowiadającą formule aktu oskarżenia). Podkreśla ono nieprawidłowości działań administracji i może prowadzić do zastosowania środków odpowiedzialności członków gabinetu zarówno politycznej, jak i konstytucyjnej ${ }^{66}$.

Regulamin SU nie zawierał szczególnego umocowania prawnego dla nadzwyczajnych komisji śledczych. Podstawy normatywne ich działalności określały przepisy ogólne dotyczące komisji sejmowych oraz normy zwyczajowe. W okresie funkcjonowania konstytuanty złożono kilkanaście wniosków o powołanie nadzwyczajnej komisji śledczej ${ }^{67}$, przy czym w większości były to wnioski poselskie, ale zdarzały się również pojedyncze wnioski zgłaszane przez komisje stałe, w których postulowano nadanie uprawnień komisji śledczej własnej podkomisji, której skład odzwierciedlał parytet klubowy Sejmu. Pierwsze takie wnioski z żądaniem nadania im charakteru nagłego

${ }^{65}$ Ibidem, pos. 213. z 25 lutego 1921 r., 1. 48-79; pos. 214. z 1 marca 1921 r., ł. 22-24; pos. 218. z 11 marca 1921 r., ł. 79-83; pos. 224. z 15 kwietnia 1921 r., ł. 70-73; pos. 247. z 27 września 1921 r., ł. 23; pos. 248. z 30 września 1921 r., 1. 5-14; pos. 291. z 23 marca 1922 r., 1. 7-11.

${ }^{66}$ H. Pajdała, Komisje w parlamencie wspótczesnym, Warszawa 2001, s. 171-172; B. Banaszak, Sejmowa komisja śledcza jako forma sprawowania kontroli przez Sejm, „Przegląd Sejmowy” 2008, nr 3, s. 116; idem, Komisje śledcze we wspótczesnym parlamentaryzmie państw demokratycznych, Warszawa 2007, s. 60-67 i 121-123.

${ }^{67}$ Problematyka działalności komisji śledczych w SU nie znajdowała szerszego odzwierciedlenia w literaturze przedmiotu, a jeśli już to była traktowana pobieżnie i z licznymi błędami. Najczęściej zdarzało się błędne kwalifikowanie niektórych sejmowych komisji specjalnych lub podkomisji do grona śledczych, podczas gdy ich zadania nierzadko miały charakter wspierający dla administracji rządowej oraz Sejmu i nie wiązały się $\mathrm{z}$ badaniem zarzutów stawianych egzekutywie oraz podległym jej organom i strukturom. W literaturze nie podejmowano w ogóle zagadnień proceduralnych funkcjonowania komisji śledczych; confer M. Pietrzak, Rzady..., s. 281-283; A.J. Madera, Sejmowe komisje śledcze. Studium prawno-historyczne, Kraków-Rzeszów 2008, s. 77-78; idem, Sejmowe komisje śledcze. Polskie tradycje i doświadczenia współczesne, Toruń 2011, s. 29-30. 
wpłynęły do laski marszałkowskiej już w marcu 1919 r. i zostały odesłane przez izbę na wniosek marszałka do Komisji Administracyjnej ${ }^{68}$.

Istotny z punktu widzenia odtworzenia pełnej procedury sejmowej z udziałem komisji śledczej był wniosek o powołanie takowej wywołany interpelacją zgłoszoną 10 kwietnia 1919 r. przez posłów Nojacha Priłuckiego i Izaaka Grünbauma oraz towarzyszy w sprawie tragedii w Pińsku z 5 kwietnia 1919 r., polegającej na rozstrzelaniu przez wojsko kilkudziesięciu mieszkańców miasta narodowości żydowskiej. Po odpowiedzi ministra spraw wojskowych na interpelację marszałek Sejmu przedstawił wniosek podpisany przez posłów żydowskich, wspartych przez posłów polskich z klubów lewicowych, o powołanie złożonej z 10 posłów komisji specjalnej z udziałem dwóch posłów żydowskich dla zbadania na miejscu przebiegu zdarzeń w Pińsku. Sejm przyjął wniosek jednomyślnie i powierzył wykonanie uchwały, czyli wyłonienie składu komisji specjalnej, Komisji Prawniczej izby. Komisja poprosiła większe kluby poselskie o przedstawienie kandydatur do komisji śledczej. Czynności komisji w sprawie pińskiej trwały ponad dwa lata, bowiem ostateczne sprawozdanie ze swych prac złożyła ona izbie dopiero 24 maja $1921 \mathrm{r}$. Komisja potwierdziła w większości zarzuty podniesione w interpelacji posłów żydowskich i przedstawiła rezolucję pod adresem rządu żądającą postawienia przed sądem wojskowym sprawców egzekucji i innych represji wojskowych jej towarzyszących, zwrotu nałożonej na ludność żydowską miasta kontrybucji oraz wypłaty odszkodowania rodzinom niewinnie rozstrzelanych. Sejm przyjął tę rezolucję ${ }^{69}$.

Postępowanie w sprawie wyłonienia komisji śledczej w sprawie pińskiej oraz jej czynności stały się precedensem, który stosunkowo szybko doprowadził do wykształcenia się zwyczajowej procedury postępowania kontrolnego z udziałem komisji śledczej. Zasadniczymi cechami tej procedury były: zgłoszenie na plenum Sejmu wniosku podpisanego przez co najmniej 15 posłów; nadanie mu przez izbę klauzuli nagłości po krótkiej dyskusji (niekiedy jednak wniosek stawiał sam marszałek); uchwalenie meritum wniosku; odesłanie przez marszałka wniosku do Komisji Prawniczej Sejmu; skompletowanie przez Komisję Prawniczą składu osobowego komisji śledczej (liczącego zależnie od treści wniosku od trzech do dziewięciu posłów) na podstawie zgłoszeń klubów sejmowych; ukonstytuowanie się komisji śledczej i przyjęcie przez nią harmonogramu prac i podziału czynności; czynności terenowe komisji in gremio bądź przez upoważnionych członków; przygotowanie przez przewodniczącego komisji sprawozdania z załączonymi rezolucjami dla plenum (najczęściej ustnego, ale zdarzały się również drukowane); wygłoszenie sprawozdania na plenum izby i głosowanie nad rezolucją (rezolucjami) końcową bądź jej przyjęcie (najczęściej) tacite. Od przedstawionego schematu zdarzały się częściowe odstępstwa polegające, np. na: odsyłaniu wniosku uchwalonego na plenum nie do Komisji Prawniczej, lecz do Komisji Administracyjnej, co miało już swoje precedensy w pierwszych tygodniach konstytuanty; uzupełnieniu

${ }^{68}$ Sejm Ustawodawczy RP, druk nr 145; spr. sten. SU, pos. 13. z 11 marca 1919 r., 1. 675-679; pos. 14. z 14 marca 1919 r., ł. 775.

${ }^{69}$ Spr. sten. SU, pos. 29. z 10 kwietnia 1919 r., 1. 61-65; pos. 30. z 11 kwietnia 1919 r., ł. 47; pos. 61. z 2 lipca 1919 r., 1. 3-4; pos. 229. z 24 maja 1921 r., ł. 46-48; Sejm Ustawodawczy RP, druk nr 1856. 
składu komisji o urzędników delegowanych przez zainteresowane ministerstwa; rozszerzeniu kompetencji komisji o prawo składania wniosków do właściwych władz administracyjnych, cywilnych i wojskowych oraz sądowych; składaniu sprawozdania cząstkowego z prac komisji, które poprzedzało o kilka miesięcy sprawozdanie końcowe. Jednak zdarzały się przypadki, że prace komisji śledczej nie znajdowały finalizacji w postaci sprawozdania na plenum i przyjęcia stosownych rezolucji końcowych ${ }^{70}$.

\section{POSTĘPOWANIA W RAMACH FUNKCJI KREACYJNEJ W ŚWIETLE PRAWA POZYTYWNEGO I PRAKTYKI PARLAMENTARNEJ}

W ramach funkcji kreacyjnej SU dokonywał obsady swych organów wewnętrznych ${ }^{71}$ oraz wskazanych ustawą organów państwowych. Podstawę normatywną procedury wyborczej stanowiły odnośne przepisy regulaminu. Spośród organów wewnętrznych izba dokonywała wyboru marszałka, pięciu jego zastępców (wicemarszałków), ośmiu sekretarzy (od 21 października 1919 r. dziewięciu), sześciu kwestorów oraz składu osobowego komisji stałych. Marszałek był wybierany bezwzględną większością głosów posłów obecnych na posiedzeniu, w głosowaniu tajnym. Jeśli pierwsze głosowanie nie dało rezultatu, w drugim wybierano spośród pięciu kandydatów, którzy otrzymali największą liczbę głosów. Niedokonanie wyboru prowadziło do trzeciego głosowania, w którym marszałka wybierano spośród dwóch kandydatów, którzy otrzymali największą liczbę głosów w drugiej rundzie. W razie równości głosów rozstrzygać miało losowanie. Głosy posłów wstrzymujących się (oddających „,białe kartki”) nie były brane pod uwagę (art. 7 regulaminu). Regulamin Sejmu, poza postanowieniem o głosowaniu tajnym, nie zawierał dokładnych przepisów określających tryb wyboru zastępców marszałka i sekretarzy (art. 8), co oznaczało, że deficyt ten izba musiała przezwyciężyć w drodze praktyki. Należało przypuszczać, że Sejm stosowałby odpowiednio przepisy dotyczące wyboru marszałka, ale praktyka (o czym niżej) przyjęła tu procedurę uzgadniania kandydatur na posiedzeniu Konwentu Seniorów i ich akceptacji na plenum w drodze aklamacji. Instytucja kwestorów miała charakter pozaregulaminowy i zapożyczono ją z parlamentaryzmu zachodnioeuropejskiego. Ich celem było kontrolowanie rachunków parlamentu. Odnośnie do wyłaniania składu osobowego komisji sejmowych (tzw. wielkich, liczących początkowo 30, a od 9 lipca 1919 r. - 31 członków oraz małych, liczących 15 posłów) regulamin postanawiał, że miało się to odbywać „wedle klucza, odpowiadającego sile liczebnej grup poselskich" (art. $49 \mathrm{zd}$. 2).

Wyboru marszałka SU dokonywał dwukrotnie. Pierwszy raz na drugim posiedzeniu plenarnym 14 lutego 1919 r., kiedy to odbyły się dwie tury głosowania, które

${ }^{70}$ Spr. sten. SU, pos. 38. z 15 maja 1919 r., 1. 31-37; pos. 42. z 27 maja 1919 r., 1. 65-66; pos. 66. z 9 lipca 1919 r., ł. 4-23; pos. 96. z 7 listopada 1919 r., 1. 14-17; pos. 102. z 21 listopada 1919 r., 1. 4-23; pos. 104. z 27 listopada 1919 r., ł. 32; pos. 127. z 5 marca 1920 r., ł. 45-69; pos. 136. z 26 marca 1920 r., ł. 52-54; pos. 160. z 8 lipca 1920 r., ł. 50-55; pos. 232. z 7 czerwca 1921 r., ł. 66-68; pos. 242. z 8 lipca 1921 r., ł. 85-87; pos. 325. z 6 lipca 1922 r., 1. 49-55; pos. 326. z 7 lipca 1922 r., ł. 59-64; Sejm Ustawodawczy RP, druk nr 576; nr 1650.

${ }^{71}$ Vide szerzej na temat wyłaniania organów wewnętrznych SU P.A. Tusiński, Norma prawna..., s. $70-75$. 
doprowadziły do wyboru na to stanowisko prawnika, byłego posła do Reichstagu Rzeszy Niemieckiej, Wojciecha Trąmpczyńskiego. Trąmpczyński miał dwóch kontrkandydatów — Wincentego Witosa z PSL „Piast” oraz Józefa Ostachowskiego z Polskiego Zjednoczenia Ludowego. Posłowie głosowali kartkami, wywoływani imiennie do urny przez tymczasowego sekretarza, a głosy obliczała wyłoniona spośród nich komisja skrutacyjna. Po ogłoszeniu wyniku głosowania marszałek-senior zapytał elekta, czy przyjmuje wybór. Po potwierdzeniu, wybrany niezwłocznie objął urząd i wygłosił krótkie przemówienie ${ }^{72}$. Drugi raz wybory marszałka konstytuanty odbyły się 5 czerwca 1919 r., po wyborach sejmowych w Poznańskiem. Kontrkandydatem Trąmpczyńskiego był Błażej Stolarski z PSL „Wyzwolenie”. Dotychczasowy marszałek wygrał je zdecydowanie w pierwszej rundzie ${ }^{73}$. Wybór wicemarszałków oraz sekretarzy dokonał się przez aklamację na drugim posiedzeniu izby, w następstwie uzgodnień poczynionych na posiedzeniu Konwentu Seniorów przez kluby poselskie w nim reprezentowane, czyli liczące co najmniej 12 członków $^{74}$. Należy zaznaczyć, że funkcje sekretarzy obsadzili najmłodsi wiekiem posłowie klubów je delegujących, co stało się zwyczajem kontynuowanym w całym dwudziestoleciu międzywojennym. Wyboru kwestorów izba dokonała na wniosek Konwentu Seniorów na trzecim posiedzeniu plenarnym przez aklamację, przy czym liczba sześciu kwestorów wynikała z ówczesnej struktury frakcyjnej Sejmu, obejmującej tyleż klubów ${ }^{75}$.

Proces powoływania komisji stałych SU przebiegał na przestrzeni dwóch pierwszych lat jego pracy. W okresie tym powołano 28 komisji ,wielkich” i „,małych” (w tym złożoną z siedmiu członków Komisję Kontroli Długów Państwa). Ponadto izba wyłoniła na przestrzeni całego okresu swej działalności 21 komisji specjalnych (w tym trzy formalnie były podkomisjami; w tej liczbie mieściły się wzmiankowane wyżej komisje śledcze) ${ }^{76}$. Składy osobowe wszystkich komisji sejmowych okresu konstytuanty były obsadzane na podstawie zasady proporcjonalności Victora d'Hondta. Liczbę miejsc przypadających poszczególnym frakcjom poselskim (ale też parytet obsady prezydiów komisji) ustalano $\mathrm{w}$ zależności od ich liczebności, ale z uprawnienia tego korzystały wyłącznie kluby reprezentowane w Konwencie Seniorów, czyli liczące co najmniej 12 posłów ${ }^{77}$.

72 Spr. sten. SU, pos. 2. z 14 lutego 1919 r., ł. 32-35. Wybór Trąmpczyńskiego został poprzedzony poufnymi uzgodnieniami między kilkoma większymi klubami poselskimi, co stało się zwyczajem stosowanym do końca lat dwudziestych; A. Ajnenkiel, Sejm jako czynnik integracji narodu i państwa, [w:] Sejmy Drugiej Rzeczypospolitej, red. A. Zakrzewski, Warszawa 1990, s. 29.

${ }_{73}$ Spr. sten. SU, pos. 46. z 5 czerwca 1919 r., 1. 3-4.

74 Ibidem, pos. 2. z 14 lutego 1919 r., ł. 35-37. W trakcie prac Sejmu nastąpiły dwie zmiany na stanowisku wicemarszałka; pos. 59. z 30 czerwca 1919 r., ł. 4; pos. 90 . z 21 października 1919 r., ł. 4.

${ }^{75}$ Ibidem, pos. 3. z 20 lutego 1919 r., 1. 90-91.

${ }^{76}$ Vide A. Tomaszewska, Aneksy, [w:] A. Ajnenkiel, Historia Sejmu polskiego, t. II, cz. II: II Rzeczpospolita, Warszawa 1989, s. 283-284.

${ }^{77}$ L. Zieleniewski, Regulamin Senatu na tle regulaminów i praktyki izb ustawodawczych w Polsce i innych państwach, t. II, Warszawa 1933, s. 22-23 i 30; J. Dębski, Wspomnienia, mps Ossolineum, sygn. 15354/II, s. 181, 646. Praktykę tę zapowiedział marszałek Trąmpczyński: „Obsadzenie tych komisyj odbędzie się według klucza, odpowiadającego sile liczebnej grup, które potem tylko biuru sejmowemu doniosą, kogo do komisji delegują [...] Wybór komisji odbędzie się poza plecami plenum w ten sposób, że każda grupa doniesie kogo deleguje do komisji i ci delegaci automatycznie staną się członkami komisji”; spr. sten. SU, pos. 2. z 14 lutego 1919 r., 1.37 i 47. 
Na marginesie tej kwestii należy zaznaczyć, że układ polityczny w konstytuancie był niestabilny, ponieważ częstym zjawiskiem były rozłamy i fuzje klubów, a także „wędrówki" posłów między frakcjami, co wywoływało fluktuację składów komisji. Praktyka parlamentarna tego okresu dopracowała się ponadto zwyczajowej instytucji zastępcy członka komisji (niekiedy stałego, ale zazwyczaj pro tempore ${ }^{78}$.

Sejm Ustawodawczy od 1920 r. realizował obsadzanie składów osobowych różnych organów państwowych na podstawie regulacji ustawowych. W sytuacji braku wyraźnej normy regulaminowej w sprawie przebiegu takich wyborów należało sądzić, że izba powinna była dla ich przeprowadzania stosować odpowiednio przepisy dotyczące wyboru marszałka (głosowanie tajne kartkami, z zastosowaniem trzech tur elekcji) ${ }^{79}$. Praktyka parlamentarna przyjęła w tym względzie jednak różne formy wyboru: zasadę aklamacji, podobnie jak w odniesieniu do obsady stanowisk wicemarszałków, kwestorów i sekretarzy; zasadę głosowania kartkami oraz zasadę głosowania przez powstanie z miejsc. Według reguły aklamacji konstytuanta dokonała, zgodnie z wnioskami zawartymi w sprawozdaniach odpowiednich komisji, wyboru członków i zastępców członków Tymczasowego Wydziału Samorządowego w byłej Galicji (spoza swojego składu, na wniosek rządu) ${ }^{80}$ oraz Rady Obrony Państwa z ramienia Sejmu ${ }^{81}$, a także ośmiu przedstawicieli Sejmu w Państwowej Radzie Emigracyjnej (utworzonej na podstawie uchwały Rady Ministrów ${ }^{82}$. Na zasadzie głosowania kartkami wybrano członków Głównej Komisji Ziemskiej ${ }^{83}$. Poprzez powstanie z miejsc dokonano wyboru, na wniosek większości Komisji Przemysłowo-Handlowej, dwóch spośród sześciu członków Komitetu Dyrekcyjnego Pocztowej Kasy Oszczędności ${ }^{84}$.

\section{POSTĘPOWANIA W SPRAWACH OKOLO IMMUNITETOWYCH W ŚWIETLE PRAWA POZYTYWNEGO I PRAKTYKI PARLAMENTARNEJ}

Wcześniej zaznaczono, że do grupy tych procedur należy zaliczyć postępowania w kwestiach: ważności mandatu poselskiego, interwencji w zakresie naruszenia nietykalności poselskiej przez organy administracji, wyrażenia zgody na uchylenie immunitetu poselskiego (formalnego) oraz odnoszące się do egzekwowania odpowiedzialności pozaimmunitetowej posłów.

${ }^{78}$ Wspomina o tym zwyczaju zasiadający w ławach sejmowych w następnej kadencji poseł S. Rymar: „Jakkolwiek każdy klub delegował imiennie i na stałe swoich posłów [...] do wyznaczonej komisji, istniał przejęty już z pierwszego Sejmu zwyczaj, iż każdy inny członek tego klubu mógł zastępować swojego klubowego kolegę, za niego przemawiać i głosować. Wystarczyło, by się tego dnia wpisał na listę obecnych"; Pamiętnik. cz. II: W Polsce zjednoczonej, mps w Bibliotece Jagiellońskiej w Krakowie, sygn. 9797/III, s. 288.

79 Vide wystąpienie sprawozdawcy Komisji Administracyjnej Sejmu, W. Kiernika; spr. sten. SU, pos. 136. z 26 marca 1920 r., ł. 6.

${ }^{80}$ Ibidem, 1. 5-7; pos. 144. z 4 maja 1920 r., 1. 17; pos. 256. z 21 października 1921 r., 1. 27; pos. 291. z 23 marca 1922 r., 1. 6-7.

${ }^{81}$ Ibidem, pos. 157. z 1 lipca 1920 r., ł. 27-28; pos. 166. z 24 lipca 1920 r., ł. 6.

82 Ibidem, pos. 248. z 30 września 1921 r., 1. 4-5.

83 Ibidem, pos. 177. z 22 października 1920 r., 1. 32-39; pos. 178 . z 26 października 1920 r., 1. 67.

${ }^{84}$ Ibidem, pos. 208. z 10 lutego 1921 r., 1. 5-7. 
Kwestia ważności mandatu poselskiego była rozpatrywana na posiedzeniu plenarnym SU tylko jeden raz, w początkach jego pracy. Sprawa dotyczyła posła Nojacha Priłuckiego, którego mandat zakwestionował poseł Narodowej Demokracji Stefan Rottermund. Marszałek odesłał sprawę do Komisji Regulaminowej i Nietykalności Poselskiej, która w sprawozdaniu na posiedzeniu plenarnym wnioskowała o przekazanie Sądowi Najwyższemu zbadania ważności mandatu w trybie art. 96 dekretu o ordynacji wyborczej ${ }^{85}$. Ponieważ sprawa należała do jurysdykcji sądu, dyskusja nie mogła zasadniczo dotyczyć kwestii natury merytorycznej, lecz wyłącznie aspektów proceduralnych. Po jej odbyciu izba zdecydowała się poprzeć większością głosów wniosek komisji. Sąd Najwyższy uznał zasadność zarzutu nieważności mandatu poselskiego, a Priłuckij jako nieposiadający obywatelstwa polskiego w chwili wyboru utracił miejsce w ławach sejmowych ${ }^{86}$.

Sprawy zarzutów kierowanych pod adresem organów administracji rządowej o naruszenie nietykalności poselskiej były wielokrotnie poruszane w SU. Zasadniczo postępowania w takich sprawach były inicjowane przez posłów za pomocą instytucji wniosku nagłego lub oświadczenia na posiedzeniu plenarnym. W ich następstwie marszałek kierował sprawę do Komisji Regulaminowej i Nietykalności Poselskiej (w jej obradach udział brał minister lub inny przedstawiciel Ministerstwa Spraw Wewnętrznych w celu składania wyjaśnień), a następnie przedstawiał jej sprawozdanie na posiedzeniu plenarnym. Komisja kończyła sprawozdanie wnioskiem o uchwalenie stosownej rezolucji uznającej wyjaśnienia resortu, że do naruszenia nietykalności (scil. immunitetu formalnego) nie doszło ${ }^{87}$ bądź wzywającej rząd do ukarania winnych naruszenia immunitetu i złożenia w tej sprawie sprawozdania Sejmowi ${ }^{88}$. Zdarzało się jednak, że marszałek po oświadczeniu posła nie kierował sprawy do komisji, lecz zobowiązywał się sam zainteresować nią ministra spraw wewnętrznych ${ }^{89}$. Niekiedy też sprawy naruszenia nietykalności poselskiej były procedowane $\mathrm{w}$ trybie postępowania interpelacyjnego ${ }^{90}$.

Zdecydowanie najczęściej sprawy immunitetowe były rozpatrywane na forum konstytuanty z powodu wniosków ministra sprawiedliwości (występującego w imieniu sądu rozpoznającego wniosek z oskarżenia prywatnego bądź w imieniu prokuratora działającego w charakterze oskarżyciela publicznego) o zgodę na ściganie posła w trybie postępowania karnego (o uchylenie immunitetu poselskiego), zgłaszanych na podstawie stosownych przepisów ustawy z dnia 8 kwietnia 1919 r. o nietykalności posłów Sejmu Ustawodawczego ${ }^{91}$. Tryb postępowania w takich sprawach odpowiadał cechom regulaminowym ogólnego postępowania wnioskowego i był następujący: wpłynięcie wniosku ministra do marszałka Sejmu; przekazanie wniosku przez marszałka do Komisji Regulaminowej i Nietykalności Poselskiej; sprawozdanie komisji na posiedzeniu plenarnym

${ }^{85}$ Dz.P.P.P. nr 18, poz. 46.

${ }^{86}$ Spr. sten. SU, pos. 22. z 31 marca 1919 r., 1. 3-17; Kto byt kim..., s. 404.

87 Ibidem, pos. 28. z 8 kwietnia 1919 r., 1. 17-19; pos. 59 . z 30 czerwca 1919 r., 1. 4-15.

${ }^{88}$ Ibidem, pos. 80. z 29 lipca 1919 r., 1. 41-42; pos. 280. z 24 stycznia 1922 r., 1. 39-44.

${ }^{89}$ Ibidem, pos. 145 . z 7 maja 1920 r., 1. 4; pos. 317. z 8 czerwca 1922 r., ł. 3-4.

${ }^{90}$ Ibidem, pos. 180. z 29 października 1920 r., 1. 3; pos. 222. z 18 marca 1921 r., 1. 34-42; pos. 223. z 14 kwietnia 1921 r., $1.53-54$.

${ }_{91}$ Dz.U.R.P. nr 31, poz. 263. 
(najczęściej ustne), zakończone wnioskiem o wyrażenie zgody na ściganie bądź o odmowę zgody; ewentualna dyskusja; przyjęcie wniosku komisji tacite lub w drodze głosowania „przez powstanie z miejsc”.

Pierwszy wniosek ministra sprawiedliwości o uchylenie immunitetu posłowi SU wpłynął do laski marszałkowskiej niebawem po wejściu w życie powołanej ustawy. Izba, zgodnie z postulatem komisji, wniosek o ściganie oddaliła na posiedzeniu 30 czerwca 1919 r. ${ }^{92} \mathrm{~W}$ sumie do Sejmu wpłynęło 56 wniosków o uchylenie immunitetu poselskiego, ale tylko ośmiokrotnie izba przychylała się do wniosków ministra sprawiedliwości ${ }^{93}$. Stało się tak czterokrotnie w odniesieniu do komunizującego posła Tomasza Dąbala (którego dotyczyło aż siedem wniosków) ${ }^{94}$, trzykrotnie w stosunku do lewicowego radykała, ks. Eugeniusza Okonia (cztery wnioski) ${ }^{95} \mathrm{i}$ jeden raz wobec socjalistycznego posła Jerzego Kantora ${ }^{96}$. Trzy razy zdarzyło się, że większość izby nie przychyliła się do wniosku komisji rekomendującego wydanie posła sądowi ${ }^{97}$. Niekiedy Sejm wyrażał zgodę na uchylenie immunitetu na życzenie posła, który chciał się oczyścić przed sądem ze stawianych mu zarzutów ${ }^{98}$, jakkolwiek nie było to sztywną regułą ${ }^{99}$, bądź też przychylał się do wniosku komisji o zawieszenie toczącego się przeciw posłowi postępowania karnego z oskarżenia prywatnego, wszczętego przed objęciem mandatu poselskiego ${ }^{100}$.

Wspomniana ustawa o nietykalności posłów SU, zakreślając szeroko poselski immunitet materialny i formalny, utrudniała pociąganie członków izby do odpowiedzialności za wystąpienia — zarówno na forum parlamentu, jak i poza nim — godzące w powagę przedstawicielstwa narodowego oraz naruszające dobre imię osób trzecich. W tej

${ }^{92}$ Spr. sten. SU, pos. 59. z 30 czerwca 1919 r., ł. 15-16.

${ }_{93}$ Sprawozdawca komisji, poseł Z. Seyda, na jednym z posiedzeń izby stwierdził, że trzyma się komisja w takich sprawach ,przyjętej zasady, że jedynie w tych wypadkach, w których zachodzi jaskrawe jakieś naruszenie porządku publicznego obrażającego ogólne poczucie sprawiedliwości, należy z tej możliwości [czyli wydania posła sądowi - uwaga P.A.T.] skorzystać" (spr. sten. SU, pos. 146. z 11 maja 1920 r., ł. 65). W innym miejscu uzupełniał, że chodzi o ,zarzut jakiejś pospolitej zbrodni, o zarzut taki, który w oczach każdego [...] uczciwie myślącego człowieka jest w stanie podać w pogardę danego posła, jak też zachwiać zaufanie do całości instytucji Sejmu" i dodawał kolejną regułę, że: komisji nie przysługuje ,prawo badania winy posła [...] Komisja [bowiem] nie jest sądem. Sejmowi w całości również nie przysługuje prawo pełnienia funkcji sądu i dlatego winna komisja i winien Sejm [...] ograniczać się wyłącznie do stwierdzeń, czy rodzaj przestępstwa jest taki, że należy odstąpić od ogólnej zasady, że postępowania karne przeciw posłom nie mają być przeprowadzone"; pos. 184. z 11 listopada 1920 r., 1. 6-7.

${ }^{94}$ Spr. sten. SU, pos. 184. z 11 listopada 1920 r., $1.11-35$; pos. 211 . z 18 lutego 1921 r., 1. 10-17; pos. 262. z 18 listopada 1921 r., 1. 18-36; pos. 335. z 5 sierpnia 1922 r., ł. 30-37.

95 Ibidem, pos. 184. z 11 listopada 1920 r., ł. 35-36; pos. 262. z 18 listopada 1921 r., ł. 8-17; pos. 277. z 13 stycznia 1922 r., 1. 7-11.

${ }^{96}$ Ibidem, pos. 238. z 23 czerwca 1921 r., 1. 45-46.

${ }_{97}$ Ibidem, pos. 210. z 15 lutego 1921 r., ł. 11-15; pos. 262. z 18 listopada 1921 r., 1. 4-8; pos. 335. z 5 sierpnia 1922 r., 1. 6-8 i 36-37.

${ }_{98}$ Ibidem, pos. 145. z 7 maja 1920 r., 1. 63-66; pos. 161. z 9 lipca 1920 r., ł. 28-30; pos. 211. z 18 lutego 1921 r., 1. 9-10.

${ }_{99} \mathrm{~Np}$. w sprawie posła K. Wysockiego komisja wnioskowała, a izba to uwzględniła (wbrew woli posła), aby uchylić mu immunitet, o odmowę zgody na postępowanie karne z oskarżenia prywatnego; spr. sten. SU, pos. 184. z 11 listopada 1920 r., 1. 5-9.

${ }^{100}$ Ibidem, pos. 189. z 25 listopada 1920 r., ł. 40. 
sytuacji nierzadko jedynym sposobem powściągania tego typu zachowań była instytucja odpowiedzialności dyscyplinarnej posłów. Normy prawa pozytywnego (regulaminowe) oraz zwyczajowego obowiązujące w pierwszym parlamencie odrodzonej RP przewidywały dwa tryby odpowiedzialności dyscyplinarnej posłów. Pierwszy obejmował odpowiedzialność egzekwowaną przez marszałka izby, w trybie władczym, jednostronnym (art. 58-61 regulaminu). Odpowiedzialność ta była codziennością w pracach izby i nie miała zasadniczych związków z instytucją immunitetu, za którym w znaczącym stopniu mógł się ukryć poseł naruszający słowem lub czynem godność innej osoby lub dopuszczający się zachowań kwalifikowanych jako delikty prawne. W związku z powyższym pozostanie ona poza obszarem zainteresowania niniejszego opracowania. Drugi rodzaj odpowiedzialności dyscyplinarnej posłów obejmował odpowiedzialność o cechach kontradyktoryjnych, egzekwowaną przez wewnątrzizbowe organy quasi-sądowe — sąd marszałkowski oraz sąd honorowy. Ten rodzaj odpowiedzialności oparty był zrazu na normach prawa zwyczajowego, by od 25 listopada 1921 r. znaleźć częściowe umocowanie w normach regulaminowych. Obydwa rodzaje sądów były swoistymi i bezprecedensowymi na skalę światową parlamentarnymi substytutami powszechnych form odpowiedzialności obywateli za czyny niewyczerpujące znamion przestępstwa, lecz uchodzące za naruszenie etyki środowiskowej lub posiadające cechy deliktów prawa prywatnego ${ }^{101}$.

Jako pierwszy, w marcu 1920 r., pojawił się w konstytuancie sąd marszałkowski, ujmowany przez przewodniczącego izby jako instytucja o charakterze koleżeńskim, a przez doktrynę postrzegany przede wszystkim jako organ o charakterze dyscyplinarnym (wymierzający kary dyscyplinarne przypisane regulaminem do kompetencji marszałka). Swą nazwę wziął od składu, w którym zasiadali marszałek Sejmu jako przewodniczący oraz wszyscy obecni w czasie postępowania w Warszawie wicemarszałkowie izby. Zasadami działania sądu marszałkowskiego były: kolegialność, stałość składu (do 25 listopada 1921 r.), akuzacyjność, obok której występowały elementy oficjalności i inkwizycyjności, ograniczony formalizm procesowy, kontradyktoryjność, równość stron, bezpośredniość, niejawność, ustność, czynny udział stron w trakcie przewodu sądowego (z udziałem pełnomocników stron), dyspozytywność, swobodna ocena dowodów przez sąd, brak związania sądu zakresem żądań stron i dowodów przez nie dostarczonych, wyrokowanie większością głosów, stosowanie kar dyscyplinarnych, publikowanie wyroków, możliwość wniesienia apelacji od wyroku do plenum Sejmu. Z chwilą nowelizacji regulaminu Sejmu, dokonanej 25 listopada 1921 r., instytucja sądu marszałkowskiego została zastąpiona, ale tylko formalnie, gdyż w sensie materialnym sąd ten działał dalej — obok nowo powołanego i pod jego nazwą — jako sąd honorowy. W okresie od marca 1920 r. do listopada 1922 r. sąd marszałkowski przeprowadził pięć przewodów i wydał takąż liczbę wyroków, działając we wszystkich sprawach ze skargi posłów

${ }^{101}$ Na temat źródeł prawa, ustroju, procedur działania oraz praktyki funkcjonowania obu sądów, a także podstaw źródłowych i umocowania literaturowego poczynionych ustaleń vide P.A. Tusiński, Sąy honorowe i marszatkowskie w Sejmie i w Senacie II Rzeczypospolitej, „Przegląd Sejmowy” 2001, nr 5, s. 45-69. 
broniących swego dobrego imienia zaczepionego przez innych posłów bądź — jak w ostatniej sprawie - przez osobę spoza składu parlamentu (prokuratora w czasie rozprawy w sądzie powszechnym przeciw innemu posłowi, któremu izba uchyliła immunitet).

Pod koniec trzeciego roku obrad SU, 25 listopada 1921 r., izba dokonała uzupełnienia swego regulaminu powołując do życia instytucję sądu honorowego (art. 66). Tekst noweli nie zachował się, wobec czego o treści unormowań w nim zawartych można wnosić na podstawie przepisów Regulaminu Obrad Senatu z 1923 r. ${ }^{102}$ Przepisy senackie, poza niektórymi ujęciami szczegółowymi, były identyczne, jak obowiązujące w SU od listopada $1921 \mathrm{r}^{103} \mathrm{~W}$ ich świetle sąd honorowy był właściwy we wszystkich sprawach, „w których cześć posła została zakwestionowana”, a więc gdy obraził go drugi członek izby, jak i osoba spoza składu Sejmu. Ponieważ z chwilą swego pojawienia się sąd honorowy wchłonął wcześniejszy sąd marszałkowski, konstrukcja obu instytucji stała się identyczna, a różniła je jedynie procedura działania. Członkiem sądu honorowego, czyli kandydatem na arbitra lub superarbitra w składzie orzekającym, mógł być wicemarszałek izby lub poseł delegowany przez klub sejmowy. Członków sądu honorowego (kandydatów na arbitrów) delegowały po jednym kluby mające reprezentację w Konwencie Seniorów. Dopuszczalne było blokowanie się mniejszych klubów w celu wydelegowania wspólnego członka sądu. Członek sądu był nieusuwalny. W przypadku działania sądu honorowego jako marszałkowski, czyli w sprawie wszczętej z urzędu przez marszałka, możliwy był udział w postępowaniu zastępcy interesu publicznego, mianowanego przez marszałka spośród posłów. Skład orzekający sądu honorowego tworzyli dwaj arbitrzy i superarbiter jako przewodniczący. Arbitrów wskazywały spośród członków sądu strony postępowania w ciągu trzech dni od otrzymania wezwania ze strony marszałka. Brak wskazania uprawniał marszałka do wyznaczenia arbitra. Arbitrzy powołani do składu orzekającego mieli obowiązek ukonstytuowania sądu w ciągu 48 godzin od zakomunikowania im włączenia do składu, czyli dokonania wyboru superarbitra i powiadomienia o tym marszałka. Członkami składu orzekającego nie mogły być osoby związane ze stronami postępowania więzami rodzinnymi lub klubowymi, jak również w jakikolwiek sposób zainteresowane $\mathrm{w}$ danej sprawie bądź mogące wystąpić w przewodzie jako świadkowie. Postępowanie przed sądem miało cechy: kolegialności sądu, akuzacyjności, ograniczonego formalizmu procesowego, kontradyktoryjności, równości stron, bezpośredniości, niejawności, ustności, osobistego udziału stron (co wykluczało zastąpienie się pełnomocnikiem), dyspozytywności, związania sądu zakresem żądania stron oraz dostarczonym przez nie materiałem dowodowym ustalonym przez strony na pierwszym posiedzeniu sądu w postaci tzw. zapisu na sąd (zasada prawdy formalnej), swobodnej oceny dowodów, orzekania większością głosów z obowiązkiem uzasadnienia wyroku na piśmie, natychmiastowej mocy wyroku z chwilą jego ogłoszenia stronom, ostateczności oraz publikacji wyroku (poprzez ogłoszenie w czasie obrad plenarnych izby i odnotowanie treści w stenogramie), stosowania środków orzeczniczych charakterystycznych dla

102 Regulamin Obrad Senatu uchwalony dnia 24 marca 1923 r., Senat RP I kad., [brak numeru druku], art. 86-96.

103 L. Zieleniewski, op. cit., s. 87-88. 
sądów koleżeńskich i obywatelskich (mających znaczenie moralne w postaci potwierdzenia lub oddalenia zarzutów, z wykluczeniem użycia środków dyscyplinarnych stosowanych przed 25 listopada $1921 \mathrm{r}$. w sądzie marszałkowskim). Przepisy art. 66 regulaminu nie rozstrzygały o kosztach postępowania. O kwestii tej musiała zatem zdecydować praktyka. Sąd honorowy miał prawo — za pośrednictwem marszałka izby — żądać akt od instytucji pozaparlamentarnych, wzywać i przesłuchiwać świadków, powoływać rzeczoznawców, badać wszelkie dostarczone mu dokumenty, występować do sądów powszechnych o pomoc prawną w zakresie przesłuchania świadków. Strony w toku rozprawy miały prawo: zabierania głosu w celu wyjaśnienia lub sprostowania faktów, stawiania wniosków dowodowych i zadawania pytań osobom przesłuchiwanym przez sąd.

Od chwili pojawienia się aż do zakończenia działalności SU sąd honorowy wydał trzy wyroki. Posłużyły one obwinionym do skutecznego oczyszczenia się ze stawianych im na forum izby zarzutów, gdyż we wszystkich przewodach zapadły wyroki oddalające zarzuty. W jednej sprawie sąd ograniczył się tylko do stwierdzenia bezzasadności zarzutów, a w dwóch częściowo usprawiedliwił obwiniających działaniem bona fide, lecz z oparciem się na niesprawdzonych informacjach prasowych oraz uzyskanych od osób trzecich.

\section{UWAGI KOŃCOWE}

Pierwszy po latach niewoli narodowej parlament odrodzonej RP pełnił wszystkie klasyczne funkcje ustrojowe przypisane temu organowi władzy w systemie konstytucyjnym. Każda z nich niosła za sobą bogatą paletę szczegółowych procedur parlamentarnych, relatywnie słabo zakorzenionych (poza opisaną przez autora w innym miejscu procedurą ustawodawczą) $)^{104} \mathrm{~W}$ prawie pozytywnym, gros norm zawarte było w tymczasowym regulaminie obrad SU. Dla większości opisanych wcześniej procedur parlamentarnych bazę prawnopozytywną tworzyły przepisy regulaminowe normujące tzw. postępowanie wnioskowe (w sprawach wniosków składanych do laski marszałkowskiej przez wskazane podmioty inicjatywy wnioskodawczej). Poszczególne szczegółowe procedury parlamentarne były wyodrębnionymi instytucjonalnie wariantami postępowania wnioskowego. Konstatowany od początku prac Sejmu przez jej organy oraz zainteresowanych posłów deficyt reguł formalnoprawnych rodził konieczność implementacji zwyczajów parlamentarnych wykształconych $\mathrm{w}$ parlamentaryzmie zachodnioeuropejskim, a także dopracowania się rodzimych rozwiązań w toku praktyki. SU, dzięki m.in. dużemu zaangażowaniu posłów legitymujących się wiedzą prawniczą oraz doświadczeniem wyniesionym z organów przedstawicielskich państw zaborczych, poradził sobie z tym problemem w stopniu więcej niż zadowalającym. Dlatego też wiele szczegółowych rozwiązań proceduralnych wypracowanych $w$ okresie konstytuanty było kontynuowanych $w$ mniejszym lub większym zakresie w następnych kadencjach obu izb parlamentu II RP w systemie ustrojowym konstytucji marcowej aż do 1935 r., a niekiedy i dłużej. Na szczególne podkreślenie zasługują przede wszystkim rozwiązania proceduralne $\mathrm{w}$ ramach

104 P.A. Tusiński, Procedury..., passim. 
funkcji kontrolnej (zwłaszcza te dotyczące zagadnienia inwestytury parlamentarnej rządu, wotum nieufności oraz postępowania interpelacyjnego) oraz w sprawach około immunitetowych, z zagadnieniem egzekwowania odpowiedzialności pozaimmunitetowej parlamentarzystów w formach quasi-sądowych na czele. Forum sejmowe było szkołą kształtującej się polskiej kultury parlamentarnej, w której aspekty proceduralne ważyły znacząco na skuteczności i sprawności prac konstytuanty, a dokonania poczynione w tym zakresie mogą stanowić pole do odniesień porównawczych nie tylko o wartości historycznej.

\section{BIBLIOGRAFIA}

\section{ŹRÓDŁA}

Katalogi i bazy, Parlamentaria polskie 1919-1997, Sejm 1919-1939, Sejm Ustawodawczy 1919-1922, Interpelacje, <bs.sejm.gov.pl>.

Dębski J., Wspomnienia, mps w Bibliotece Zakładu Narodowego im. Ossolińskich we Wrocławiu, sygn. 15354/II.

„Dziennik Praw Królestwa Polskiego” 1918.

„Dziennik Praw Państwa Polskiego” 1918-1919.

„Dziennik Ustaw Rzeczypospolitej Polskiej” 1919-1921.

Exposé premierów polskich 1918-2001, oprac. B. Sygit, Wydawnictwo Zapolex Media, Toruń 2001.

„Kurier Polski” 1919-1922.

Nowak J., Wspomnienia z ławy rządowej, [b.o.w.], Kraków 1938.

Nowe konstytucje. Przełożone pod kierunkiem Dra Juliana Makowskiego, F. Hoesick, Warszawa 1925.

Rataj M., Pamiętniki, Ludowa Spółdzielnia Wydawnicza, Warszawa 1965.

Regulamin Obrad Senatu uchwalony dnia 24 marca 1923 r., Senat RP I kad., [brak numeru druku].

Rymar S., Pamiętnik, cz. II, W Polsce zjednoczonej, mps w Bibliotece Jagiellońskiej w Krakowie, sygn. 9797/III.

Sejm Ustawodawczy Rzeczypospolitej Polskiej 1919-1922, Druki.

Sejm Ustawodawczy Rzeczypospolitej Polskiej 1919-1922. Sprawozdania stenograficzne.

Tymczasowy Regulamin Obrad Sejmu Ustawodawczego Rzeczypospolitej Polskiej, oprac. T. Koperska, „Przegląd Sejmowy” 1993, nr 1.

Wojdaliński R., Relacje posła na Sejm Ustawodawczy (1919-1922), t. I-IV, mps Ossolineum, sygn.14108/II.

\section{PIŚMIENNICTWO}

Ajnenkiel A., Sejm jako czynnik integracji narodu i państwa, [w:] Sejmy Drugiej Rzeczypospolitej, red. A. Zakrzewski, Ludowa Spółdzielnia Wydawnicza, Warszawa 1990.

Badziak K., W oczekiwaniu na przełom. Na drodze od odrodzenia do załamania państwa polskiego listopad 1918-czerwiec 1920, Ludowa Spółdzielnia Wydawnicza, Łódź 2004.

Banaszak B., Komisje śledcze we współczesnym parlamentaryzmie państw demokratycznych, Wydawnictwo Sejmowe, Warszawa 2007.

Banaszak B., Prawo konstytucyjne, C.H. Beck, Warszawa 2012.

Banaszak B., Sejmowa komisja śledcza jako forma sprawowania kontroli przez Sejm, „Przegląd Sejmowy" 2008, nr 3. 
Banaszak B., Wotum nieufności, [w:] Encyklopedia prawa, red. U. Kalina-Prasznic, Wolters Kluwer, Warszawa 1999.

Faryś J., Konflikt Naczelnika Państwa z Sejmem Ustawodawczym w 1922 roku, „Dzieje Najnowsze" 1975, nr 3.

Gabinety Drugiej Rzeczypospolitej, red. J. Faryś, J. Pajewski, „Likon”, Szczecin-Poznań 1991.

Górecki D., Powstawanie władz naczelnych w odradzajacej się Polsce (1914-1919), „Acta Universitatis Lodziensis. Folia Iuridica" 1983, nr 13.

Gwiżdż A., Prawo interpelacji posła na Sejm PRL, „Państwo i Prawo” 1956, z. 11.

Gwiżdż A., Interpelacja i procedury podobne $w$ burżuazyjnym prawie państwowym, „Państwo i Prawo" 1963, z. 4.

Kaczmarek Z., Wojciech Trampczyński, Lega, Poznań 1993.

Kierończyk P., Nadrzędność parlamentu - mit czy realna alternatywa ustrojowa? Analiza wybranych przykładów, Gdańska Wyższa Szkoła Administracji, Gdańsk 2009.

Koksanowicz G., Prawnoustrojowa pozycja marszałka Sejmu w okresie II Rzeczypospolitej, „Przegląd Sejmowy” 2003, nr 2.

Komarnicki W., Polskie prawo polityczne (geneza i system), F. Hoesick, Warszawa 1922.

Krukowski S., Sejm Ustawodawczy 1919-1922. Uwagi o składzie i działalności, „Czasopismo Prawno-Historyczne" 1986, z. 1.

Kto byt kim w Drugiej Rzeczypospolitej, red. J.M. Majchrowski i in., Polska Oficyna Wydawnicza „BGW”, Warszawa 1994.

Kustra E., Proces ustawodawczy jako proces decyzyjny, „Acta Universitatis Nicolai Copernici, Nauki Humanistyczno-Społeczne, Prawo XII”, 1973, z. 56.

Lipska M.M., Urzad ministra w latach 1918-1939. Podstawy prawne, „Roczniki Nauk Prawnych" 2009, t. XIX, nr 1.

Madera A.J., Sejmowe komisje śledcze. Studium prawno-historyczne, Firma SAS Wanda Tarnawska, Kraków-Rzeszów 2008.

Madera A.J., Sejmowe komisje śledcze. Polskie tradycje i doświadczenia wspótczesne, Wydawnictwo Adam Marszałek, Toruń 2011.

Majkowski A., Uwagi ogólne o technice prac parlamentarnych, [b.o.w.], Warszawa 1937.

Mojak R., Instytucja prezydenta w polskim prawie konstytucyjnym w latach 1918-1935, cz. 1, „Annales Universitatis Mariae Curie Skłodowska. Sectio G” 1989, t. XXXVI, nr 19.

Pajdała H., Komisje w parlamencie współczesnym, Wydawnictwo Sejmowe, Warszawa 2001.

Pietrzak M., Rzady parlamentarne w Polsce w latach 1919-1926, „Książka i Wiedza”, Warszawa 1969.

Preisner A., Wotum nieufności, [w:] Słownik wiedzy o Sejmie, red. A. Preisner, Wydawnictwo Sejmowe, Warszawa 1995.

Próchnik A., Pierwsze piętnastolecie Polski niepodległej. Zarys dziejów politycznych, Wydawnictwa Szkolne i Pedagogiczne, Warszawa 1983.

Rzepecki T., Sejm Rzeczypospolitej Polskiej 1919 roku, Wielkopolska Księgarnia Nakładowa, Poznań 1920.

Słownik języka polskiego, t. II, L-P, PWN, Warszawa 1979.

Sokolewicz W., Odpowiedzialność parlamentarna Rząu RP (votum zaufania, votum nieufności, absolutorium), Biuro Studiów i Ekspertyz Kancelarii Sejmu, Warszawa 1993.

Stembrowicz J., Z problematyki głowy państwa w Polsce, „Kultura i Społeczeństwo” 1977, nr 2.

Szawłowski R., Najwyższe państwowe organy kontroli II Rzeczypospolitej, Wydawnictwo „von borowiecky”, Warszawa 2004.

Tomaszewska A., Aneksy, [w:] A. Ajnenkiel, Historia Sejmu polskiego, t. II, cz. II: II Rzeczpospolita, PWN, Warszawa 1989. 
Tusiński P.A., Norma prawna i obyczaj jako podstawa wyłaniania i funkcjonowania organów kierowniczych parlamentu II Rzeczypospolitej, „Prace Naukowe Politechniki Radomskiej im. Kazimierza Pułaskiego: Ekonomika” 1999, nr 1.

Tusiński P.A., Postępowanie ustawodawcze w Sejmie i w Senacie II Rzeczypospolitej 1919-1939. Prawo - zwyczaje - praktyka parlamentarna, Wydawnictwo Politechniki Radomskiej, Radom 2008.

Tusiński P.A., Komisja Spraw Zagranicznych Sejmu Ustawodawczego (1919-1922) jako podmiot polityki zagranicznej w pierwszych latach II Rzeczypospolitej, „Wschodni Rocznik Humanistyczny" 2015, t. XII.

Tusiński P.A., Procedury ustawodawcze w pierwszym Sejmie Odrodzonej Rzeczypospolitej Polskiej (1919-1922). Regulacja prawna i praktyka parlamentarna, „Przegląd Sejmowy” 2018, nr 6.

Tusiński P.A., Sąy honorowe i marszałkowskie w Sejmie i w Senacie II Rzeczypospolitej, „Przegląd Sejmowy" 2001, nr 5.

Wielka encyklopedia prawa, red. E. Smoktunowicz, „Prawo i Praktyka Gospodarcza”, Białystok-Warszawa 2000.

Winnicki Z.J., Rada Regencyjna Królestwa Polskiego i jej organy (1917-1918), Wydawnictwo „Wektory”, Wrocław 1991.

Witkowski Z., Prezydent Rzeczypospolitej Polskiej 1921-1935, „Studia Iuridica. Towarzystwo Naukowe w Toruniu" 1987, t. XVIII, z. 1.

Witkowski Z., Status ustrojowy Rady Ministrów w konstytucjach polskich okresu międzywojennego, [w:] Rada Ministrów. Organizacja i funkcjonowanie, red. A. Bałaban, Kantor Wydawniczy Zakamycze, Kraków 2002.

Wołpiuk W.J., Naczelnik Państwa 1918-1922. Przedprezydencka forma władzy państwowej, „Przegląd Sejmowy” 2005, nr 6.

Zaleśny J., Odpowiedzialność konstytucyjna w Drugiej Rzeczypospolitej, Elipsa, Warszawa 2003.

Zieleniewski L., Regulamin Senatu na tle regulaminów oraz praktyki izb ustawodawczych w Polsce i innych państwach, t. II, F. Hoesick, W. Łazarski, Warszawa 1933. 


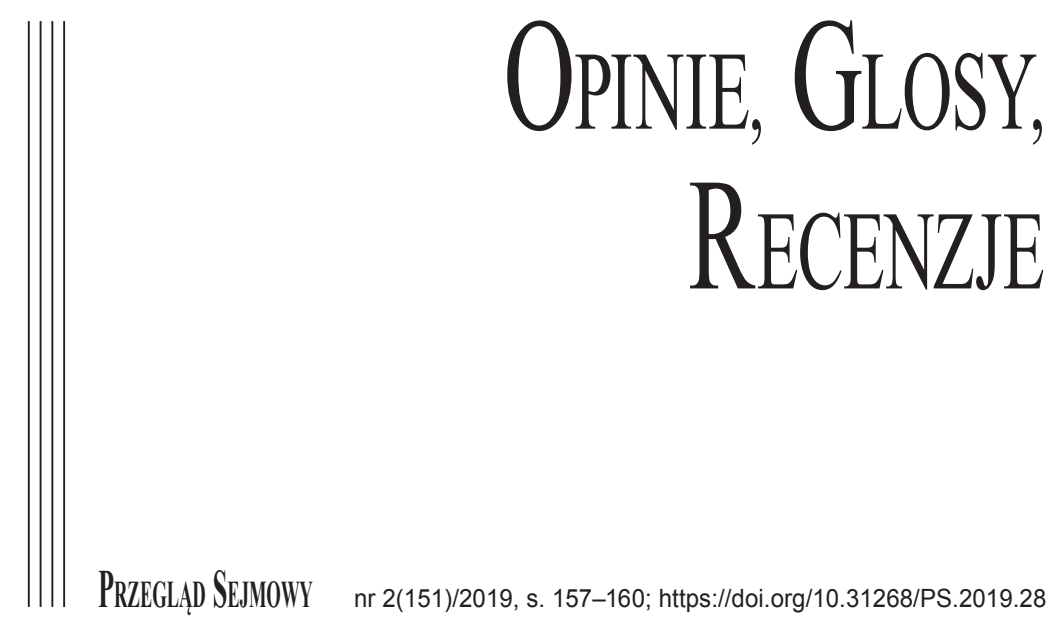

OPINIE

\section{NA TEMAT PROJEKTU UCHWALY SEJMU RP W SPRAWIE ZMIANY} REGULAMINU SEJMU RZECZYPOSPOLITEJ POLSKIEJ

\section{ON THE DRAFT RESOLUTION OF THE SEJM AMENDING THE STANDING ORDERS OF THE SEJM OF THE REPUBLIC OF POLAND}

The opinion refers to the draft resolution of the Sejm amending the Standing Orders of the Sejm of the Republic of Poland, stating that within six months of the beginning of a new term of the Sejm, the Petition Committee may re-submit a bill realizing the aim of a petition submitted in the previous term. In the context of the provisions in force, along with the termination of the term of a Sejm, bills serving the realization of the aim of a petition submitted by the Committee to the Marshal of the Sejm are subject to the principle of discontinuation. Since proceedings related to the consideration of a petition are formally terminated, there is no possibility to re-submit the bills of the former term to the Marshal of the Sejm. The reviewed draft does not raise legal reservations. The solution included therein shall allow to balance the protection of the rights of the petition's author on the one hand, and protection of values, which the principle of discontinuation of parliamentary works serves, on the other hand.

Słowa kluczowe: petycja, zasada dyskontynuacji prac parlamentu, Komisja do Spraw Petycji

Key words: petition, principle of discontinuation of parliament's works, Petition Committee

Projekt nie budzi zastrzeżeń prawnych. Zawarte w nim rozwiązanie prawne pozwoli z jednej strony wyważyć ochronę praw autora petycji, z drugiej zaś ochronę wartości, którym służy zasada dyskontynuacji prac parlamentarnych.

* Opinia została napisana 12 marca 2019 r. (przyp. red.). 


\section{PRZEDMIOT OPINII}

Przedmiotem opinii jest projekt uchwały Sejmu Rzeczypospolitej Polskiej w sprawie zmiany regulaminu Sejmu, zakładający, że w terminie sześciu miesięcy od rozpoczęcia nowej kadencji Sejmu Komisja do Spraw Petycji może wnieść ponownie projekt ustawy stanowiący realizację celu petycji wniesiony w poprzedniej kadencji. Projektowana zmiana polega na dodaniu do art. $126 \mathrm{~g}$ rS ust. 2 o następującym brzmieniu: „W przypadku gdy postępowanie w sprawie projektu, o którym mowa w art. 126c ust. 3 pkt 1 , nie zostało zakończone w trakcie kadencji Sejmu, w której został wniesiony przez Komisję - w terminie 6 miesięcy od rozpoczęcia następnej kadencji Sejmu Komisja może podjąć decyzję o wniesieniu tego projektu bez potrzeby ponownego wnoszenia petycji przez jej autora”. W uzasadnieniu projektu podkreślono, że „Celem projektowanej zmiany Regulaminu Sejmu RP jest doprowadzenie do sytuacji, w której Komisja do Spraw Petycji, w okresie 6 miesięcy od rozpoczęcia kadencji Sejmu, dokonuje przeglądu projektów ustaw wniesionych przez Komisję do Spraw Petycji minionej kadencji i podejmuje ewentualne decyzje o ponownym wniesieniu (z punktu widzenia merytorycznego o podtrzymaniu) tych projektów, które uznaje za zasadne — bez konieczności wniesienia ponownej petycji przez autora".

\section{ANALIZA SZCZEGÓŁOWA}

Zgodnie z art. $126 \mathrm{~b}$ ust. 1 oraz art. 126c ust. 1 rS organem właściwym do rozpatrywania petycji w imieniu Sejmu jest Komisja do Spraw Petycji (confer pkt 1a załącznika do regulaminu Sejmu „Przedmiotowy zakres działania komisji sejmowych”). Rozpatrzenie petycji przez Komisję kończy „rozstrzygnięcie w sprawie sposobu załatwienia petycji" (art. 126c ust. 1), a jednym ze sposobów załatwienia petycji jest wniesienie przez Komisję projektu ustawy lub uchwały do laski marszałkowskiej (art. 126c ust. 3 pkt 3). Wraz z wniesieniem projektu petycja zyskuje status ,petycji załatwionej”, a proces jej rozpatrzenia ulega zakończeniu. Informację o sposobie załatwienia petycji Komisja przekazuje marszałkowi Sejmu (art. 126d rS), który następnie zawiadamia podmiot wnoszący petycję o sposobie jej załatwienia (art. 126e rS). Natomiast zgodnie z art. $126 \mathrm{~g} \mathrm{rS}$, ,W przypadku gdy postępowanie w sprawie petycji nie zostanie zakończone przed upływem kadencji Sejmu, jest ono prowadzone przez Komisję w następnej kadencji Sejmu”. W przepisie tym przewidziano wyjątek od zasady dyskontynuacji, która oznacza, że wraz z końcem kadencji ,wszystkie sprawy, wnioski i przedłożenia, w których nie doszło do zamknięcia prac parlamentarnych, uważa się za ostatecznie załatwione w sensie niedojścia do skutku. Nie są więc one w żadnej formie przekazywane nowemu parlamentowi” (L. Garlicki, uwaga do art. 98, s. 30, [w:] Konstytucja Rzeczypospolitej Polskiej. Komentarz, red. L. Garlickiego t. I, Warszawa 1999). Co istotne, odstępstwo od zasady dyskontynuacji prac parlamentu odnosi się w tym przypadku wyłącznie do etapu rozpatrywania petycji, nie obejmuje natomiast prac nad projektem ustawy wniesionym przez Komisję do Spraw Petycji. 
Projekt uchwały będący przedmiotem niniejszej opinii stanowi realizację sygnalizowanej na forum Komisji potrzeby wzmocnienia ochrony praw autora petycji. Wraz z wniesieniem odpowiedniego projektu ustawy do laski marszałkowskiej petycja zyskuje bowiem status ,petycji załatwionej”, jak wspomniano w uzasadnieniu do projektu, ,podmiot wnoszący petycję i oczekujący uchwalenia przez Sejm ustawy traktuje wniesienie projektu ustawy przez Komisję do Spraw Petycji zaledwie jako pierwszy etap prac Sejmu, poprzedzający procedurę legislacyjną. [...] Adresatem petycji jest bowiem Sejm RP jako organ władzy ustawodawczej, a nie konkretna komisja”. Tymczasem zgodnie z obowiązującymi przepisami, wraz z końcem kadencji Sejmu projekty służące realizacji celu petycji wniesione do laski marszałkowskiej przez Komisję podlegają zasadzie dyskontynuacji. Jednocześnie z uwagi na fakt, że postępowanie w sprawie rozpatrzenia leżących u podstaw wniesienia projektów ustaw petycji zostało formalnie zakończone, Komisja do Spraw Petycji Sejmu nowej kadencji nie ma możliwości ponownego wniesienia projektów. Możliwość taką przewidziano właśnie w opiniowanym projekcie.

Do oceny zasadności projektowanej zmiany regulaminu Sejmu istotny jest również fakt, że postulat, aby projekty służące realizacji celów petycji uznane za wyjątki od zasady dyskontynuacji zostały w petycji skierowanej do Sejmu 14 lipca 2017 r. (Petycja nr BKSP-145-262/17 była przedmiotem obrad Komisji do Spraw Petycji 28 września 2017 r.). Z uwagi na wcześniej podjęte prace odpowiadające ujętemu w petycji postulatowi, Komisja nie uwzględniła żądania petenta (vide zapis przebiegu 95. posiedzenia Komisji do Spraw Petycji z 28 września 2017 r.). Petycja ta została zaopiniowana w opinii Biura Analiz Sejmowych o sygn. BAS-WAKiU-1618/17 z 29 sierpnia 2017 r. W opinii tej W. Odrowąż-Sypniewski zaznaczył, że: „Treść postulatu legislacyjnego zawartego w petycji nie wiąże Sejmu i jego organów, a jedynie stanowi inspirację dla ewentualnych zmian normatywnych. Petycja pozytywnie rozpatrzona przez Komisję do Spraw Petycji — również w tych przypadkach, gdy jej treścią jest żądanie przyjęcia załączonego do petycji projektu ustawy — może zostać zrealizowana («załatwiona») za pomocą różnych instrumentów prawnych (por. art. 126c ust. 3 regulaminu Sejmu). Nawet w tym przypadku, gdy Komisja do Spraw Petycji postanawia o wniesieniu projektu ustawy w celu realizacji petycji zawierającej żądanie uchwalania ustawy o określonej treści - nie jest ona związana projektem wnioskodawcy, lecz samodzielnie ustala treść swojej inicjatywy ustawodawczej.

Kształt normatywny projektu Komisji do Spraw Petycji — z natury rzeczy zawsze stanowi wynik rozstrzygnięcia podejmowanego w określonym układzie politycznym. Jakkolwiek służy on realizacji celu zawartego w petycji to jednak jego treść jest wyrazem określonej decyzji politycznej. Ustanowienie wyjątku od zasady dyskontynuacji prac parlamentarnych przeczyłoby w takim przypadku istocie tej zasady, która [...] w pierwszej kolejności służy uwolnieniu nowego parlamentu od konieczności rozpatrywania inicjatyw zgłoszonych w poprzednim układzie politycznym".

W mojej ocenie zaproponowane w opiniowanym projekcie uchwały Sejmu rozwiązanie, zgodnie z którym to Komisja do Spraw Petycji Sejmu nowej kadencji dokonuje 
przeglądu projektów wniesionych przez tę komisję w poprzedniej kadencji i decyduje o ponownym wniesieniu wybranych (bądź wszystkich) projektów, w pełni odpowiada argumentom przedstawionym w przywołanej opinii BAS. Rozwiązanie to pozwola bowiem z jednej strony wyważyć ochronę praw autora petycji, z drugiej zaś ochronę wartości, którym służy zasada dyskontynuacji prac parlamentarnych. Podlegające dyskontynuacji projekty ustaw będą bowiem mogły stać się przedmiotem rozszerzonej na mocy nowych unormowań regulaminowych inicjatywy ustawodawczej Komisji do Spraw Petycji. Ponadto wydaje się, że za wprowadzeniem projektowanej zmiany przemawiają także względy ekonomiki postępowania sejmowego, ponieważ ograniczy ono zjawisko ponownego kierowania do Sejmu petycji w tych samych sprawach i pozwoli skorzystać z efektu prac Komisji do Spraw Petycji Sejmu poprzedniej kadencji.

IV. PODSUMOWANIE

Podsumowanie w formie tez zostało zawarte w pkt 1. opinii.

Ewelina Gierach*

* Dr Ewelina Gierach, Uniwersytet Kardynała Stefana Wyszyńskiego w Warszawie, Wydział Prawa i Administracji, e.gierach@uksw.edu.pl, https://orcid.org/0000-0002-2689-786X 
W SPRAWIE USTALENIA, KTÓRY Z KANDYDATÓW DO PARLAMENTU EUROPEJSKIEGO UZYSKA PRZYSŁUGUJĄCY POLSCE 52. MANDAT, W PRZYPADKU POZOSTAWANIA ZJEDNOCZONEGO KRÓLESTWA WIELKIEJ BRYTANII I IRLANDII PÓŁNOCNEJ W UE NA POCZĄTKU KADENCJI PARLAMENTU EUROPEJSKIEGO WYBRANEGO NA LATA 2019-2024 I WYSTĄPIENIA PRZEZ ZJEDNOCZONE KRÓLESTWO Z UE W TRAKCIE TEJ KADENCJI

\author{
WITH REFERENCE TO ESTABLISHING WHICH OF THE CANDIDATES \\ TO THE EUROPEAN PARLIAMENT SHALL BE VESTED WITH THE 52ND MANDATE \\ ALLOCATED TO POLAND IN CASE THE UNITED KINGDOM OF GREAT BRITAIN \\ AND NORTHERN IRELAND REMAINS IN THE EU AT THE BEGINNING \\ OF THE TERM OF THE EUROPEAN PARLIAMENT ELECTED \\ FOR THE YEARS 2019-2024 AND WITHDRAWS DURING THAT TERM
}

In 2019, 52 Deputies to the European Parliament shall be elected to the European Parliament in Poland. If, however, the United Kingdom of Great Britain and Northern Ireland does not withdraw from the European Union, the number of mandates shall be reduced to 51. National Electoral Commission suggests difficulty with establishing which of the candidates shall take the $52^{\text {nd }}$ seat. This seems to be a potential threat. Hence, there is the need to amend the Electoral Code. The Commission suggests a solution similar to the one applied in 2010, when an incidental act was passed. This is not the only possible solution.

Słowa kluczowe: wybory, Parlament Europejski, podział mandatów, mandaty przysługujące Polsce, brexit, paradoks Alabamy

Key words: elections, European Parliament, distribution of seats, seats for Poland, Brexit, the Alabama paradox

1. Wskazanie przez Państwową Komisję Wyborczą [dalej: PKW] problemu z ustaleniem, który z kandydatów do Parlamentu Europejskiego uzyska przysługujący Polsce 52. mandat w przypadku pozostawania Zjednoczonego Królestwa Wielkiej Brytanii i Irlandii Północnej w Unii Europejskiej na początku kadencji Parlamentu Europejskiego [dalej: PE] wybranego na lata 2019-2024 i wystąpienia przez Zjednoczone Królestwo z Unii Europejskiej w trakcie tej kadencji, jest w pełni zasadne i zasługuje na wnikliwą analizę.

2. Postulat PKW dotyczący bardzo pilnego uchwalenia ustawy nowelizującej ustawę z 5 stycznia 2011 r. — Kodeks wyborczy (t.j. Dz.U. z 2018 r. poz. 754, ze zm.; dalej: k.w.) rozwiązującej problem z ustaleniem, który z kandydatów do PE uzyska 52. mandat, zasługuje na wnikliwe rozpatrzenie. Istnieje potrzeba opracowania przynajmniej projektu takiej ustawy, aby ewentualnie szybko ją uchwalić w przypadku pozostania Zjednoczonego Królestwa w UE po 30 marca 2019 r. ${ }^{1}$

\footnotetext{
* Opinia została napisana 20 lutego 2019 r. (przyp. red.)
} 
3. Propozycja PKW dotycząca rozwiązania przedstawionego problemu nie jest jedyną możliwą do zastosowania, stanowi jednak wyraźnie nawiązanie do innych regulacji kodeksu wyborczego i z tego względu zasługuje na szczególną uwagę.

\section{PRZEDMIOT OPINII}

Przedmiotem opinii jest wskazany przez PKW problem z ustaleniem, który z kandydatów do PE uzyska 52. przysługujący Polsce mandat, w przypadku pozostawania Zjednoczonego Królestwa Wielkiej Brytanii i Irlandii Północnej w UE na początku kadencji PE wybranego na lata 2019-2024 i wystąpienia przez Zjednoczone Królestwo z UE w trakcie tej kadencji.

\section{TREŚĆ OPINII}

W czerwcu 2016 r. przeprowadzono w Wielkiej Brytanii referendum, w którym — przy frekwencji wynoszącej $72,2 \%$ uprawnionych do głosowania - 51,89\% głosujących opowiedziało się za wystąpieniem Wielkiej Brytanii z UE. Wiążący wynik tego referendum zapoczątkował proces opuszczenia przez to państwo struktur europejskich. Nie wnikając w szczegóły, jako że nie jest to przedmiotem opinii, ustalono, że Wielka Brytania opuści UE 30 marca 2019 r. o godz. 00 (czyli 29 marca 2019 r. o godz. 23 wg czasu brytyjskiego).

Oznacza to, że podczas wyborów do PE w 2019 r. Wielka Brytania nie będzie już członkiem UE, a tym samym mandaty w Parlamencie muszą zostać podzielone między państwa członkowskie z pominięciem Zjednoczonego Królestwa. Bardzo szybko okazało się jednak, że wypracowanie porozumienia między Wielką Brytanią a Unią Europejską, które przede wszystkim zaakceptuje brytyjski parlament, jest sprawą niezwykle trudną. Możliwe jest nawet, że opuszczenie przez Wielką Brytanię Unii Europejskiej opóźni się, a tym samym, że będzie ona członkiem Wspólnoty jeszcze podczas wyborów do PE w 2019 r. Sytuacja ta jeszcze w ubiegłym roku wywarła wpływ na decyzję Rady Europejskiej (2018/937) z 28 czerwca 2018 r. ustanawiającą skład Parlamentu Europejskiego na kadencję 2019-2024 (Dz.U. L 165 z 2.7.2018).

$\mathrm{Z}$ jednej strony, kierując się zasadami określonymi w art. 14 ust. 2 akapit pierwszy Traktatu o Unii Europejskiej, ustalono podział liczby członków PE wybieranych w poszczególnych państwach członkowskich UE przy założeniu, że Wielka Brytania państwem członkowskim UE już nie będzie. Na tej podstawie w Polsce będziemy wybierać 52 członków PE.

$\mathrm{Z}$ drugiej strony uwzględniono jednak również ewentualność, że Zjednoczone Królestwo w dniach wyborów do PE będzie jeszcze pozostawać w strukturach europejskich, co automatycznie będzie oznaczać konieczność przeprowadzenia również w tym państwie wyboru przedstawicieli do PE. W art. 3 ust. 2 decyzji postanowiono, że w takim przypadku liczba obejmujących swoje funkcje przedstawicieli poszczególnych państw członkowskich w PE będzie odpowiadać liczbie określonej w art. 3 decyzji Rady Europejskiej 2013/312/UE z dnia 28 czerwca 2013 r. (Dz.U. L 181 z 29.6.2013, s. 57), jednak tylko do czasu, gdy wystąpienie Zjednoczonego Królestwa z Unii stanie się skuteczne. 
W drugim zdaniu tego ustępu podkreślono ponadto, że: „Po tym, jak wystąpienie Zjednoczonego Królestwa z Unii stanie się prawnie skuteczne, liczba przedstawicieli wybieranych do Parlamentu Europejskiego w każdym państwie członkowskim będzie odpowiadała liczbie określonej w ust. 1 niniejszego artykułu". Zastrzeżono jednocześnie w zdaniu trzecim, że: „Wszyscy przedstawiciele do Parlamentu Europejskiego, którzy zajmą dodatkowe miejsca wynikające $\mathrm{z}$ różnicy między liczbą miejsc przydzielonych zgodnie z pierwszym i drugim akapitem [w tłumaczeniu jest błąd, powinno być „ustępem" - K.S.], obejmą mandat w Parlamencie Europejskim w tym samym czasie".

Analizując art. 3 decyzji Rady Europejskiej, należy stwierdzić, że odróżnia się w niej ,wybór przedstawiciela” do PE od „objęcia mandatu”. Ponadto w decyzji ustanowiono rozwiązanie, zgodnie $\mathrm{z}$ którym w przypadku pozostawania Zjednoczonego Królestwa w strukturach UE liczba wybranych posłów może być większa od liczby posłów, którzy obejmą mandat; wybrani przedstawiciele, którzy nie obejmą mandatu, obejmą go dopiero po wyjściu Wielkiej Brytanii z UE. Dlatego też w przypadku przedłużania się procesu opuszczania Unii przez Wielką Brytanię mandat ten może nie zostać objęty nawet przez całą kadencję 2019-2024.

\section{Co to oznacza dla Polski?}

W wyborach do PE w 2019 r. musimy wybrać 52 przedstawicieli do Parlamentu Europejskiego, jednak w przypadku, gdyby Zjednoczone Królestwo pozostawało jeszcze w UE, mandat obejmie tylko 51 posłów, ponieważ tylu przedstawicieli wybieraliśmy w 2014 r. Mandat 52. zostanie objęty dopiero w momencie, gdy Wielka Brytania opuści struktury europejskie (gdy jej wyjście z Unii stanie się skuteczne).

Państwowa Komisja Wyborcza w piśmie z 13 lutego 2019 r. (sygn. ZPOW-50122/19) w pełni zasadnie wskazuje, że — w kontekście kodeksu wyborczego — może pojawić się problem z ustaleniem, który z kandydatów do PE uzyska ten 52. mandat. Jest to konsekwencją bardzo złożonego, składającego się z kilku etapów, przewidzianego w tym akcie prawnym procesu ustalania wyników wyborów. Bez problemu da się jedynie ustalić, który z komitetów wyborczych zdobędzie ten mandat — będzie to komitet, który weźmie udział $\mathrm{w}$ podziale mandatów, ponieważ przekroczy ustalony $\mathrm{w}$ art. 355 k.w. próg wyborczy oraz zgodnie z dokonanym na podstawie art. 356 k.w. podziałem mandatów między komitety wyborcze przy zastosowaniu metody d'Hondta uzyska 52. iloraz wyborczy.

Kolejny etap, w którym na podstawie art. 358 § 2 i 3 k.w. - przy zastosowaniu metody Hare'a-Niemeyera — następuje podział mandatów przypadających poszczególnym komitetom między okręgowe listy kandydatów, rodzi natomiast niebezpieczeństwo, że nie będzie możliwe ustalenie, który z uzyskanych mandatów jest tym 52. mandatem z ogólnej liczby wybieranych w Polsce przedstawicieli do PE. Może się tak stać, ponieważ zmniejszenie o jeden liczby mandatów przypadających temu komitetowi nie musi oznaczać zmniejszenia o jeden liczby mandatów przypadających jednej z okręgowych list kandydatów tego komitetu. PKW bardzo słusznie podnosi, że w tym przypadku może wystąpić tzw. paradoks Alabamy. 
Paradoks ten po raz pierwszy zauważono w 1880 r. w stanie Alabama (stąd jego nazwa), kiedy okazało się, że zwiększenie liczby miejsc w Izbie Reprezentantów Stanów Zjednoczonych z 299 do 300 spowoduje zmniejszenie reprezentacji tego stanu w Izbie z siedmiu mandatów do sześciu. Dzieje się tak dlatego, że zwiększenie liczby dostępnych mandatów powoduje zmniejszenie ilorazu wyborczego (kwoty), a więc liczby głosów niezbędnych do uzyskania mandatu w proporcjonalnych systemach wyborczych. Niebezpieczeństwo to istnieje w przypadku wszystkich metod podziału mandatów z grupy największych reszt (vide B. Michalak, hasło: Paradoks Alabamy, [w: ] A. Sokala, B. Michalak, P. Uziębło, Leksykon prawa wyborczego i referendalnego oraz systemów wyborczych, Warszawa 2013, s. 159).

Obowiązujący w Polsce na podstawie kodeksu wyborczego mechanizm przydzielania mandatów komitetowi wyborczemu może tym samym nie pozwolić na ustalenie, w którym okręgu wyborczym komitet wyborczy uzyskał ten 52., czyli ostatni przypadający temu komitetowi mandat. Dlatego też w pełni zasadny jest postulat PKW dotyczący bardzo pilnego uchwalenia ustawy zmieniającej ten stan rzeczy, ponieważ inaczej może się pojawić problem z objęciem mandatów przez wszystkich wybranych w Polsce przedstawicieli do PE. Jestem zdania, że pewnym minimum, które powinno się zrobić, jest bardzo szybkie opracowanie przynajmniej projektu takiej regulacji.

Niewątpliwie istnieje wiele możliwości rozwiązania tego problemu i to zarówno poprzez nowelizację kodeksu wyborczego bądź przyjęcie tzw. ustawy epizodycznej, jak i przyjęcie różnych rozwiązań. Z przykładem ustawy epizodycznej odnoszącej się do wyborów do PE mieliśmy już do czynienia w przeszłości, kiedy po wejściu w życie traktatu lizbońskiego i w związku ze zwiększeniem liczby wybieranych w Polsce posłów do PE uchwalono ustawę z dnia 4 marca 2010 r. o zasadach obsadzenia w kadencji trwającej w latach 2009-2014 dodatkowego mandatu posła do Parlamentu Europejskiego (Dz.U. 2010 poz. 337, ze zm.). Wówczas zaistniała sytuacja pozornie podobna do obecnej — również należało ustalić, który z kandydatów do PE uzyska nowy mandat. Porównując to z obecnym problemem, należało ustalić, który mandat był kolejnym zdobytym. PKW w pełni słusznie podkreśla jednak, że wówczas znane już były wyniki wyborów do PE przeprowadzone w 2009 r. i wiadomo było, że paradoks Alabamy nie występuje. Tym samym nie było kłopotu z ustaleniem, który z kandydatów komitetu wyborczego, któremu należy się ten mandat, uzyskał go w następstwie wyników głosowania. Obecnie jednak nie można wykluczyć wystąpienia paradoksu Alabamy — nawet jeżeli jest on mało prawdopodobny — ponieważ wyniki głosowania nie są oczywiście znane. Dlatego ustalenie w taki sam sposób, jak w 2010 r., który mandat jest 52., nie jest obecnie możliwe.

W moim przekonaniu najprostszym sposobem rozwiązania przedstawionego problemu jest nowelizacja kodeksu wyborczego i dokonanie zmiany polegającej na tym, że Polska nie będzie podzielona na 13 okręgów wyborczych, lecz stanie się jednym okręgiem wyborczym. Należy podkreślić, że rozwiązanie takie występuje w większości państw członkowskich i tylko w pięciu państwach (Belgia, Francja, Irlandia, Włochy i Zjednoczone Królestwo) przyjęto podział na regionalne okręgi wyborcze, a w trzech 
(Holandia, Niemcy i właśnie Polska) podział na okręgi dokonany jest ze względów administracyjnych służących odzwierciedleniu podziałowi na listy partyjne. Ustalenie, który mandat będzie mandatem 52., będzie w takim przypadku oczywiste. Nie uważam również, aby wprowadzenie tej zmiany naruszało wyrażony w dwóch wyrokach pogląd Trybunału Konstytucyjnego, że istotne zmiany w kodeksie wyborczym mogą być dokonywane najpóźniej pół roku przed pierwszą czynnością wyborczą. W wyroku z 3 listopada 2006 r. w sprawie o sygn. akt K 31/06 podkreślił on, że „konieczność zachowania co najmniej sześciomiesięcznego terminu od wejścia w życie istotnych zmian w prawie wyborczym do pierwszej czynności kalendarza wyborczego jest nieusuwalnym co do zasady normatywnym składnikiem treści art. 2 Konstytucji”. Wskazanej zmiany nie traktuję jako istotnej, ponieważ $\mathrm{w}$ istniejącym stanie prawnym - na co zwracałem uwagę - najważniejsze jest dokonanie podziału mandatów między komitety wyborcze $i$ to nie ulegnie zmianie. Kolejne etapy obowiązującej procedury rozdzielenia mandatów mają już charakter wtórny i jedynie w odmienny sposób od proponowanego przesądzają o tym, kto z danego komitetu uzyska mandat. Ewentualne przyjęcie wskazanego rozwiązania jedynie zwiększy sprawiedliwość wyborów.

Państwowa Komisja Wyborcza w piśmie z 13 lutego 2019 r. proponuje inne rozwiązanie, analogiczne do przyjętego w art. $368 \S 6$ k.w., odnoszącego się do obsady wakującego mandatu, w przypadku gdy nie może go objąć żaden z kandydatów tego samego komitetu wyborczego $\mathrm{z}$ tej samej listy kandydatów. W takim przypadku mandat obejmuje kandydat $\mathrm{z}$ innej listy kandydatów tego samego komitetu wyborczego, który w wyborach otrzymał największą liczbę głosów, o ile nie uzyskał mandatu. Komisja trafnie wskazuje, że ,przepisem tym ustawodawca ustanowił swego rodzaju kolejność obejmowania mandatów przez kandydatów, niezależną od tego, z której listy okręgowej kandydatów kandydowali i niezależną od metody podziału mandatów przypadających danemu komitetowi pomiędzy jego okręgowe listy kandydatów". Zgodnie z propozycją PKW 52. mandatem w wyborach do PE byłby mandat kandydata, który uzyskał największą liczbę głosów na okręgowych listach kandydatów komitetu wyborczego, któremu przypadł 52. mandat w następstwie przyznawania mandatów metodą d'Hondta. Proponowane rozwiązanie jest wprawdzie możliwe do zastosowania, nie jestem jednak przekonany o trafności jego uzasadnienia, że mandat ten zdobyłby kandydat najlepiej legitymowany do jego zdobycia z list tego komitetu wyborczego. Twierdzenie takie nie jest - w moim przekonaniu — prawdziwe w przypadku różnej liczby wyborców w poszczególnych okręgach wyborczych. Minimalnie mniejsza liczba głosów uzyskana w tzw. małym okręgu wyborczym, w którym podzielono małą liczbę mandatów, daje o wiele silniejszą legitymację niż nieznacznie większa liczba głosów w okręgu wyborczym, w którym podzielono zdecydowanie większą liczbę mandatów. Jednak samo dążenie do tego, aby ustalenie, który z mandatów uzyskanych przez komitet wyborczy jest ostatnim przypadającym mu z uwagi na legitymację będącą konsekwencją wyniku głosowania, jest w pełni zasadnym kierunkiem poszukiwania rozwiązania istniejącego problemu. Dlatego uważam, że należałoby ustalać to nie na podstawie liczby uzyskanych głosów, lecz procentów 
uzyskanych głosów w okręgu wyborczym. Kandydat, którego odsetek uzyskanych głosów jest wyższy, jest silniej legitymowany do zdobycia mandatu niż kandydat, w przypadku którego odsetek ten jest mniejszy.

Jak już podkreślałem, pokazanie tych dwóch rozwiązań bez wątpienia nie wyczerpuje możliwych do przyjęcia regulacji wskazanego problemu, można bowiem rozważać również inne, których wypracowanie wymaga więcej czasu.

Pilność przyjęcia ustawy przesądzającej o tym, który mandat do PE będzie tym 52., którego objęcie jest uzależnione od tego, czy i kiedy Zjednoczone Królestwo Wielkiej Brytanii i Irlandii Północnej opuści UE bądź czy i jak długo w niej jeszcze pozostanie, sprawia, że niewątpliwie najlepiej byłoby, aby regulacja taka została uchwalona i weszła w życie jeszcze przed zarządzeniem przez Prezydenta RP wyborów do Parlamentu Europejskiego. Wskazywany przez PKW termin wejścia w życia tej ustawy przed tegorocznym dniem wyborów do PE, aby przyjęte rozwiązanie było znane głosującym, a w każdym razie przed dniem pierwszego posiedzenia PE nowej kadencji, to kolejne możliwe warianty. Trzeba jednak pamiętać, że termin wejścia w życie tej regulacji może być zależny od przyjętego w niej rozwiązania. Jestem jednak zdania, że przynajmniej projekt ustawy rozwiązującej problem podniesiony w piśmie PKW powinien być opracowany na tyle szybko, aby w przypadku pozostawania 1 kwietnia 2019 r. Zjednoczonego Królestwa w UE mogła być ona błyskawicznie uchwalona.

Krzysztof Skotnicki*

* Prof. zw. dr hab. Krzysztof Skotnicki, Uniwersytet Łódzki, Wydział Prawa i Administracji, kskotnicki@wpia.uni.lodz.pl, https://orcid.org/0000-0002-9428-2103 
GLOSA

GLOSA DO WYROKU SĄDU APELACYJNEGO W GDAŃSKU

Z 14 GRUDNIA 2017 R., SYGN. AKT I ACA 187/17

\section{A COMMENTARY TO THE JUDGMENT OF THE COURT OF APPEAL IN GDAŃSK}

OF 14 DECEMBER 2017, REF. NO. I ACA 187/17

In its judgment of 14 December 2017 (ref. no. I Aca 187/17), the Court of Appeal in Gdańsk adjudicated that suggesting to a nursing mother that she shall take a seat other than the one chosen by her as the place to have a meal with her whole family in a restaurant is a manifestation of a less favourable treatment in comparison to other customers. This is a manifestation of unequal treatment on the basis of sex, as breastfeeding is an attribute of the female sex and is inseparable from motherhood. Extensive reflections presented in the statement of reasons (resentencing entirely the decision of the court of first instance) gave impulse to a deepened, multi-aspect legal analysis of direct discrimination on the basis of sex. The analysis is completed with the review of the case law of the Court of Justice of the European Union and national common courts as regards all manifestations of infringement of the principle of equal treatment of women and men in their access to publicly offered services and goods. In the conclusion it is pointed that in modern Europe there is a universal acceptance for behaviour based on categorizing persons due to their predominant features. The commented judgment is at the same time progressive and ground-breaking, therefore it deserves particular reflection, as it sanctions unjustified discrimination of a woman nursing a child at a restaurant, being in line with the antidiscrimination policy of the European Union.

Słowa kluczowe: dyskryminacja bezpośrednia, dyskryminacja ze względu na płeć, naruszenie zasady równego traktowania, dostęp do usług i towarów oferowanych publicznie, macierzyństwo, karmienie dziecka piersią w restauracji

Key words: direct discrimination, discrimination on the basis of sex, infringement of the principle of equal treatment, access to publicly offered goods and services, motherhood, nursing a child at a restaurant

W prawie unijnym już dawno przesądzono, że wszelkie uprawnienia związane z opieką nad dzieckiem nie mogą prowadzić do uprzywilejowania kobiet względem mężczyzn. Z racji tego mężczyznom przysługuje m.in. prawo zmniejszenia dziennego wymiaru czasu pracy w celu karmienia dziecka czy szczególna ochrona przed wypowiedzeniem umowy o pracę w okresie przebywania na urlopie ojcowskim. Zdziwienie budzi więc fakt, że kwestia karmienia małego dziecka w Polsce jest wciąż postrzegana wyłącznie przez pryzmat praw i obowiązków kobiet ${ }^{1}$. Wnioskowanie oparte na tym założeniu jest oczywiście błędne pod względem logicznym, gdyż równe traktowanie

${ }^{1} \mathrm{O}$ wpływie stereotypów na postrzeganie roli kobiety i kształtowanie uprzedzeń oraz dyskryminacji ze względu na płeć vide K. Sękowska-Kozłowska, Glosa do wyroku ETPC z dnia 25 lipca 2017 r., 17484/15, „Europejski Przegląd Sądowy” 2018, nr 2, s. 33-37. 
w tej materii nie musi ograniczać się do jednej tylko płci (w tym przypadku żeńskiej). Niemniej jest ono stale powielane. Prawdopodobnie z tych względów z ogromnym trudem przebija się do świadomości społeczeństwa konieczność stosowania zasady niedyskryminacji ze względu na płeć wobec kobiety karmiącej piersią dziecko w miejscu publicznym. Nikt bowiem nie zakłada, że do naruszenia owej zasady mogłoby dojść w sytuacji zamiany podmiotowej (pod względem płci). Do tego zaś sprowadza się istota problemu podjętego $\mathrm{w}$ glosowanym wyroku².

Dyskryminacja bezpośrednia występuje wtedy, gdy dana osoba traktowana jest mniej korzystnie ze względu na płeć niż jest, była lub byłaby traktowana inna osoba w porównywalnej sytuacji. Odnosząc to do powyższego wypada wskazać, że jeżeli występują różnice traktowania mężczyzn i kobiet karmiących dzieci w sferze dostępu do usług publicznych, których bezpośrednim powodem jest płeć, to mamy do czynienia właśnie z naruszeniem zasady niedyskryminacji. Wieloaspektowo i kompleksowo owo zagadnienie analizował niedawno Sąd Apelacyjny w Gdańsku. Rozstrzygnięcie tego Sądu niewątpliwie wpisuje się w politykę antydyskryminacyjną UE i choćby $\mathrm{z}$ racji tego wymaga omówienia w celu upowszechnienia właściwego kierunku wykładni obowiązującego prawa.

\section{STANOWISKO SĄDU PIERWSZEJ INSTANCJI}

Sąd Okręgowy w Gdańsku ustalił, że w niedzielę 2 listopada 2014 r. między godziną 16.30 a 17.00 do restauracji La Ma(...) przy ul. Bohaterów Monte Cassino XXX w Sopocie, której właścicielem jest pozwany, przyszli L.M. wraz z mężem R.M., sześciomiesięczną córką i siostrą A.W. Część stolików w lokalu była wówczas zajęta, a rodzina M. usiadła przy czteroosobowym stoliku w pobliżu wejścia. L.M. zajęła miejsce od wewnętrznej części sali po lewej stronie, patrząc z perspektywy wejścia i miała za plecami filar oraz ściankę działową, a dalej — pojedyncze krzesło w narożniku. Obok L.M. usiadł jej mąż, a naprzeciwko siostra. L.M. postawiła wózek obok siebie, który był zwrócony rączką w kierunku ścianki działowej po lewej stronie sali, a gondolą w kierunku ściany po prawej stronie sali. Wózek nie zasłaniał L.M., a jego

${ }^{2}$ Sąd Apelacyjny w Gdańsku w wyroku z 14 grudnia 2017 r. wydanym w sprawie z powództwa Polskiego Towarzystwa Prawa Antydyskryminacyjnego w Warszawie działającego na rzecz L.M. przeciwko J.P. przy udziale Rzecznika Praw Obywatelskich o zapłatę i nakazanie, na skutek apelacji powoda od wyroku Sądu Okręgowego w Gdańsku z 12 grudnia 2016 r. (sygn. akt I C 206/15), w punkcie pierwszym zmienił zaskarżony wyrok i zasądził od pozwanego J.P. na rzecz L.W. kwotę 2 tys. zł z ustawowymi odsetkami od 15 września 2015 r. do 31 grudnia 2015 r. i z ustawowymi odsetkami za opóźnienie od 1 stycznia 2016 r. do dnia zapłaty oraz nakazał pozwanemu opublikowanie na stronie startowej portalu www.trojmiasto.pl na własny koszt w terminie 14 dni od uprawomocnienia się orzeczenia oświadczenia o następującej treści: „J.P. prowadzący działalność gospodarczą pod nazwą PHU „C(...)”, właściciel restauracji La Ma(...) w Sopocie, przeprasza Panią L.M. za bezprawne uniemożliwienie jej nakarmienia dziecka przy stoliku w restauracji, co stanowiło dyskryminację ze względu na płeć", zaś w pozostałym zakresie powództwo oddalił, zmienił też zaskarżony wyrok w punkcie drugim w ten sposób, że zasądził od pozwanego na rzecz Skarbu Państwa kwotę 700 zł tytułem nieuiszczonych kosztów sądowych, od których powód był zwolniony, w pozostałych punktach oddalił apelację i orzekł o kosztach postępowania apelacyjnego. 
najwyższym elementem była rączka. Zamówienie od rodziny M. przyjęła kelnerka. Posiłki zostały wydane klientom i przystąpili oni do konsumpcji. Po pewnym czasie dziecko zaczęło płakać, w związku z czym L.M. postanowiła ją nakarmić, rozpięła guziki od bluzki i zaczęła karmić córkę piersią. Siedzący przy najbliższym stoliku po prawej stronie starsi państwo zwrócili się do obsługującego ich kelnera P.S., aby poprosił L.M. o dyskretniejsze karmienie dziecka. Kelner podszedł do stolika rodziny M. i przekazał prośbę, jednocześnie sugerując, aby odwróciła się w stronę męża, ewentualnie w celu nakarmienia córki L.M. może zająć miejsce na pobliskim pojedynczym krześle w narożniku sali, które jest często wykorzystywane w ten właśnie sposób. L.M. odmówiła nakarmienia córki na krześle zaproponowanym przez kelnera, a po krótkiej wymianie zdań rodzina M. opuściła lokal, uiszczając pełną należność za posiłek. Wszelką wiedzę o zdarzeniu z 2 listopada 2014 r. pozwany posiadał z relacji O.S. i P.S., gdyż nie było go tego dnia w restauracji.

Sąd pierwszej instancji, ustalając stan faktyczny w tej sprawie, oparł się na zeznaniach świadków O.S., P.S., pozwanego oraz częściowo zeznaniach świadków A.W., R.M. i L.M. W ocenie Sądu Okręgowego powództwo nie zasługiwało na uwzględnienie, gdyż zebrany materiał dowodowy nie pozwalał na przyjęcie, że doszło do dyskryminacji bezpośredniej L.M. w dostępie do usług ze względu na płeć. Przede wszystkim Sąd uznał, że ustawa z 3 grudnia 2010 r. o wdrożeniu niektórych przepisów Unii Europejskiej w zakresie równego traktowania (Dz.U. z 2016 r. poz. 691) nie implementowała w pełnym zakresie dyrektywy Rady 2004/113/WE wprowadzającej w życie zasadę równego traktowania mężczyzn i kobiet w zakresie dostępu do towarów i usług oraz dostarczania towarów i usług, a w szczególności jej art. 4. W konsekwencji Sąd meriti stwierdził, że przepisy tej ustawy nie mogą stanowić podstawy prawnej dochodzonego roszczenia.

Jednocześnie Sąd Okręgowy przyjął, że w tej sprawie bezpośrednie zastosowanie ma dyrektywa Rady 2004/113/WE z 13 grudnia 2004 r. i to na jej podstawie pozwany wykazał, że nie dopuścił się naruszenia, o którym mowa w art. 4. W ocenie tego Sądu, zeznania świadków O.S. i P.S. świadczyły o tym, że nie doszło do nierównego traktowania L.M. pod postacią nakazania określonego zachowania, a jedynie miało miejsce przekazanie prośby innych klientów o dyskretniejsze karmienie, ewentualne przeniesienie się w inne, bardziej intymne miejsce w restauracji. W tym stanie rzeczy Sąd a quo zważył, że przekazanie prośby innych osób nie oznacza nierównego traktowania i jako takie nie wypełnia dyspozycji art. 4 cytowanej dyrektywy (gdyż nikt nie zakazał L.M. karmienia piersią, nie wyprosił z restauracji, nie nakazał określonego zachowania, mającego znamiona dyskryminacji bezpośredniej, a opuszczenie restauracji było jej suwerenną decyzją). Sąd meriti zaznaczył jeszcze, że prośba innych klientów była tu uprawniona z uwagi na wskazywany przez świadka O.S. ostentacyjny sposób karmienia piersią przez L.M., jak i praktykę innych matek karmiących piersią polegającą na zajmowaniu w tym celu wskazanego miejsca.

Sąd pierwszej instancji nie wykluczył jednak, że L.M. w sytuacji, w której się znalazła, mogła się poczuć oburzona, urażona; miała bowiem prawo do karmienia 
piersią w miejscach publicznych, jednak swoje ewentualne roszczenia mogła wywodzić - jak uznał ten sąd - na podstawie ogólnych przepisów kodeksu cywilnego dotyczących naruszenia dóbr osobistych (tj. art. 23 k.c. i art. 24 k.c.).

\section{STANOWISKO SĄDU DRUGIEJ INSTANCJI}

Sąd Apelacyjny w Gdańsku podzielił ustalenia faktyczne sądu pierwszej instancji tylko co do samej bytności L.M. wraz z rodziną w restauracji pozwanego, zamówienia posiłku, odmowy skorzystania przez L.M. z miejsca wskazanego jej przez kelnera jako miejsca do karmienia dziecka oraz co do rodzaju prowadzonej przez pozwanego działalności gospodarczej. Sąd odwoławczy nie powielił natomiast ustaleń w zakresie przebiegu wizyty rodziny M., zwłaszcza co do tego, czy L.M. przystąpiła do karmienia dziecka piersią, albowiem w jego ocenie zdarzenie przebiegało inaczej niż zweryfikował to sąd okręgowy.

Sąd drugiej instancji wskazał na istotne rozbieżności między zeznaniami O.S. i P.S., skoro tylko O.S. zeznała, że L.M. karmiła dziecko ostentacyjnie, jednak świadek ta miała bezpośredni kontakt z rodziną M. wyłącznie przy przyjmowaniu zamówienia i podawaniu zamówionych dań, potem natomiast zajęła się innymi obowiązkami. Jak zeznała, nie słyszała ani tego, czego dotyczyła rozmowa drugiego kelnera P.S. z L.M., a o jej treści dowiedziała się od samego P.S., ani jego rozmowy z klientami, którzy rzekomo mieli zwrócić się do P.S. z prośbą o interwencję w sprawie karmiącej matki. W tej sytuacji zdziwienie Sądu Apelacyjnego wzbudził fakt, że świadek O.S. mogła zarejestrować okoliczność karmienia dziecka przez klientkę restauracji, i to w sposób ostentacyjny, przy jednoczesnym uwzględnieniu, że nie zdołała ona zauważyć innych zdarzeń nierozerwalnie z tym karmieniem związanych (prośba innych klientów, dłuższa rozmowa drugiego kelnera z L.M.). Sąd odwoławczy zwrócił przy tym uwagę, że P.S. nie potrafił przypomnieć sobie, zeznając przed Sądem Okręgowym, czy w ogóle jego rozmówczyni karmiła wówczas dziecko, czy też nie, a widział jedynie, że miała rozpiętą bluzkę, choć nie zdołał jednoznacznie przyznać, by widział wówczas jej pierś. W tej sytuacji Sąd Apelacyjny uznał za niewiarygodne, aby kelner prowadzący dłuższą dyskusję z klientką nie zauważył faktu karmienia przez nią piersią, zwłaszcza że rozmowa dotyczyła tej właśnie kwestii. W konsekwencji też obalił hipotezę Sądu Okręgowego, jakoby L.M. ostentacyjnie karmiła dziecko, zwłaszcza że zarówno L.M., jak i pozostali świadkowie strony powodowej zgodnie zeznali, że pani L. na skutek płaczu dziecka zaczęła jedynie rozpinać guziki bluzki, i wówczas właśnie nastąpiła interwencja kelnera. Do samego karmienia L.M. nie przystąpiła w restauracji, gdyż na skutek postawy kelnera zrobiła to po opuszczeniu lokalu.

W tym stanie rzeczy w ocenie sądu drugiej instancji straciła na znaczeniu okoliczność, czy reakcja personelu restauracji wynikała z wprowadzonego przez pozwanego generalnego zakazu karmienia przez matki niemowląt piersią przy stolikach, czy też była efektem przekazania przez kelnera prośby innych klientów. Nawet gdyby przyjąć — jak uznał ten Sąd — że taki generalny zakaz nie został wprowadzony, a świadek P.S. przekazał jedynie L.M. prośbę innych klientów o dyskretniejsze karmienie, to już samo 
zaproponowanie jej do nakarmienia córki miejsca w oddaleniu od stolika, który zajęła wraz z rodziną, na krześle usytuowanym w pobliżu wejścia do toalety, doprowadziło do tego, że L.M. jako klientce restauracji zaoferowano usługę gorszej jakości niż pozostałym gościom, z których żaden nie musiał opuszczać wybranego przez siebie stolika. Zaproponowanie jej do tego celu krzesła w pobliżu toalety nastąpiło — jak ustalił to sąd odwoławczy - w związku z sygnalizowanym przez nią zamiarem osobistego nakarmienia dziecka, która to czynność jest immanentnie związana z macierzyństwem, a tym samym — co oczywiste - z płcią żeńską. W tym stanie rzeczy Sąd Apelacyjny stwierdził, że doszło do nierównego traktowania L.M. jako klientki restauracji, niekorzystnie bowiem zróżnicowano jej sytuację w porównaniu z innymi osobami goszczącymi wówczas w lokalu. To zaś przemawiało za przyjęciem, że L.M. doświadczyła dyskryminacji w rozumieniu przepisów art. $6 \mathrm{w}$ zw. z art. 3 pkt 1 ustawy z 3 grudnia 2010 r. o wdrożeniu niektórych przepisów Unii Europejskiej w zakresie równego traktowania.

Sąd Apelacyjny zważył jednocześnie, że wbrew stanowisku sądu pierwszej instancji, w rozpoznawanej sprawie bezpośrednie zastosowanie miały właśnie przepisy ustawy z 3 grudnia 2010 r. o wdrożeniu niektórych przepisów UE w zakresie równego traktowania, w tym art. 14 ust. 3, zgodnie z który to pozwany powinien wykazać, że nie dopuścił się naruszenia zasady równego traktowania, czego nie uczynił w przywołanych okolicznościach. Sąd odwoławczy zaakcentował przy tym, że pozwany nie był obecny w restauracji podczas spornego zdarzenia, stąd jego zeznania nie można było uznać za dowód miarodajny dla rekonstrukcji stanu faktycznego.

Sąd drugiej instancji przyjął pogląd, zgodnie z którym powód wywiódł dochodzone roszczenie z faktu nierównego dostępu do usług oferowanych publicznie, co stało się udziałem L.M. z uwagi na jej płeć, a nie ze względu na naruszenie wobec niej zasady równego traktowania $\mathrm{z}$ racji macierzyństwa. Tylko bowiem z uwagi na swoją płeć L.M. mogła doświadczyć macierzyństwa oraz karmienia piersią, a to właśnie stało się przyczyną podjętych wobec niej działań personelu restauracji. Na kanwie tego przyjął, że w sprawie doszło do dyskryminacji bezpośredniej L.M. w rozumieniu art. 3 pkt 1 ww. ustawy oraz że zostały spełnione warunki sine qua non pozwalające stwierdzić, że jedynym motywem mniej przychylnego potraktowania pani M. była cecha chroniona przez ustawodawcę - jej płeć pozwalająca karmić dziecko piersią; gdyby bowiem nie sygnalizowała ona zamiaru nakarmienia dziecka, to nie zaproponowano by jej do tego celu krzesełka w pobliżu wejścia do toalety. Płeć i związane z nią macierzyństwo ukształtowało zatem pozycję L.M. jako klientki restauracji i to w sposób niekorzystny w porównaniu z innymi wówczas goszczącymi w niej klientami, wobec których z uwagi na ich osobiste cechy i przymioty, personel takiej propozycji nie składał. Zaakcentował też, że powoływana przez pozwanego okoliczność, jakoby kelner działał na prośbę innych gości lokalu nie miała znaczenia w świetle klauzul limitacyjnych wyrażonych w art. 8 ust. 2 cytowanej ustawy, którymi są: bezpieczeństwo publiczne, utrzymanie porządku i zapobieganie działaniom podlegającym sankcjom karnym, ochrona zdrowia i ochrona praw i wolności innych osób. W ocenie Sądu Apelacyjnego żadna $\mathrm{z}$ tych klauzul nie mogła mieć bowiem zastosowania w tej sprawie. 
Sąd drugiej instancji dostrzegł niekonsekwencję w rozumowaniu sądu okręgowego, który z jednej strony podkreślił, że karmienie piersią w miejscach publicznych nie może naruszać praw podmiotowych innych osób oraz przestrzegania przyjętych norm społecznych i moralnych, a następnie stwierdził, że L.M. miała prawo karmić piersią $\mathrm{w}$ miejscach publicznych, co uprawniałoby ją do wystąpienia ze stosownym roszczeniem o ochronę dóbr osobistych na podstawie art. 23 k.c. i art. 24 k.c. Podkreślił w związku z tym, że w zasadzie każdy przejaw dyskryminacji stanowi naruszenie godności osobistej, co powinno skłonić sąd okręgowy do przyjęcia, że także w tych okolicznościach mogło dojść do naruszenia jednego z dóbr osobistych L.M. w postaci jej godności.

Na zakończenie rozważań sąd odwoławczy wskazał na treść art. 18 konstytucji, zgodnie z którą macierzyństwo znajduje się pod ochroną i opieką Rzeczypospolitej Polskiej oraz odwołał się do zaleceń pediatrów karmienia dziecka w sposób naturalny przez pierwszych kilka miesięcy życia, jak też licznych kampanii promujących karmienie niemowląt piersią, w świetle których nie sposób było uznać, aby zaspokojenie przez matkę w ten sposób potrzeb żywieniowych dziecka w miejscu publicznym mogło stanowić naruszenie przez nią wolności innych osób, czy też naruszenie powszechnie przyjętych norm społecznych w europejskim kręgu kulturowym. Tym bardziej że w ustalonych okolicznościach sprawy L.M. dopiero zamierzała nakarmić dziecko, zaś rozmawiający z nią przez dłuższy czas kelner nie widział nawet jej obnażonej piersi.

\section{OCENA STANOWISKA PRZYJĘTEGO PRZEZ SĄD APELACYJNY W GDAŃSKU}

Pogląd zaprezentowany przez Sąd Apelacyjny w Gdańsku należy uznać za trafny i zasługujący na pełną aprobatę. Niewątpliwe jest, że przedstawienie w restauracji matce karmiącej piersią ( $\mathrm{w}$ rozumieniu stanu, a nie procesu) propozycji zajęcia innego miejsca niż wybrane przez nią jako docelowe miejsce spożywania posiłku z całą rodziną świadczy o traktowaniu jej mniej korzystnie niż innych gości tego lokalu gastronomicznego. To zaś wpisuje się w ramy nierównego traktowania ze względu na płeć, gdyż karmienie piersią stanowi przymiot płci żeńskiej i jest nierozerwalnie związane z macierzyństwem ${ }^{3}$. A przecież dyskryminacja ze względu na płeć ${ }^{4}$ to nic innego, jak wszelkie zróżnicowanie, wyłączenie lub ograniczenie ze względu na płeć, które powoduje lub ma na celu uszczuplenie albo uniemożliwienie jednej z płci przyznania bądź korzystania na równi z drugą płcią z praw człowieka oraz podstawowych wolności

${ }^{3}$ Należy jednak podnieść, że dyskryminacja nie odnosi się wyłącznie do sytuacji, w której kobiety są dyskryminowane przez mężczyzn albo mężczyźni przez kobiety, ale może zdarzyć się także wówczas, kiedy, stosując kryterium płci, jakaś kobieta dyskryminuje inne kobiety, a mężczyzna innych mężczyzn.

${ }^{4} \mathrm{Z}$ dyskryminacją ze względu na płeć mamy do czynienia zarówno wtedy, gdy dana osoba jest gorzej traktowana, gdyż przynależy do określonej płci (dyskryminacja bezpośrednia), jak i wtedy, gdy płeć nie jest oficjalnym kryterium nierówności, np. kiedy pozornie neutralne prawo, polityka czy praktyka dają negatywny efekt dla osób należących do określonej płci (dyskryminacja pośrednia). 
w dziedzinach życia politycznego, gospodarczego, społecznego, kulturalnego, obywatelskiego i innych. W skrócie jest to nierówne traktowanie kobiet lub mężczyzn ze względu na ich przynależność do danej płci, które nie jest uzasadnione obiektywnymi przyczynami, a które może przejawiać się w formie mechanizmów dyskryminujących kobiety lub mężczyzn jako całe grupy oraz w formie dyskryminacji konkretnej osoby ze względu na jej płeć ${ }^{5}$. Naruszenie zasady równego traktowania ze względu na płeć stanowi zaś obszar regulowany ustawą z dnia 3 grudnia 2010 r. o wdrożeniu niektórych przepisów Unii Europejskiej w zakresie równego traktowania (Dz.U. z 2010 r. nr 254 poz. 1700 ze zm.). Słusznie więc uznał Sąd Apelacyjny, że w przestawionej sprawie ustawa ta, a w szczególności przepis art. 6 , znajduje zastosowanie (vide: zakres przedmiotowy, art. 1).

Nielogiczne jest w tym względzie dokonywanie wyłącznie językowej wykładni przepisów dyrektywy Rady 2004/113/WE wprowadzającej w życie zasadę równego traktowania mężczyzn i kobiet w zakresie dostępu do towarów i usług oraz dostarczania towarów i usług i na tej podstawie wywodzenie, że ustawa ta nie implementowała w pełnym zakresie tego aktu prawa unijnego. Najprawdopodobniej błąd w tej materii wynika z tego, że w treści art. 4 dyrektywy 2004/113/WE mowa jest wprost o mniej korzystnym traktowaniu kobiet ze względu na ciążę lub macierzyństwo, podczas gdy w akcie krajowym zwrotu tego nie zawarto. Niemniej należy mieć tu na uwadze, że po pierwsze, idea dyrektywy pozwala wprowadzić jej rozwiązania do prawodawstwa krajowego na wiele różnych sposobów (poprzez zmianę ustawy, wprowadzenie nowych przepisów, czy uchylenie dotychczasowych itp.), a po drugie - dyrektywa unijna wiąże w odniesieniu do rezultatu, który ma być osiągnięty, co oznacza, że jej implementacja nie sprowadza się do wiernego odwzorowania przepisów aktu unijnego. Ustalenie rezultatu, który musi być osiągnięty, odbywa się zaś na drodze wykładni wszystkich przepisów dyrektywy i jej preambuły. W ten sposób ustala się generalny cel dyrektywy. Co istotne, dyrektywa unijna charakteryzuje się dwuetapowością, która wyraża prawny kompromis między dążeniem do możliwie jednolitej treści norm prawnych, które są ustanawiane na poziomie unijnym we wszystkich państwach członkowskich, a poszanowaniem odrębności poszczególnych porządków prawnych tych państw. W tym sensie dyrektywa jest instrumentem „legislacji pośredniej”.

Tymczasem w preambule dyrektywy Rady 2004/113/WE jednoznacznie przyjęto, że „równość mężczyzn i kobiet jest podstawową zasadą Unii Europejskiej. Art. 21 i 23 Karty praw podstawowych Unii Europejskiej zakazują wszelkiej dyskryminacji opartej na płci i wymagają zapewnienia równości mężczyzn i kobiet we wszystkich

${ }^{5}$ Najczęściej do tej formy dyskryminacji dochodzi na rynku pracy i ubezpieczeniowym. Z tych względów większość publikacji naukowych poświęcona jest tym zagadnieniom. Confer Z. Góral, M. Kuba, Zakaz dyskryminacji w zatrudnieniu pracowniczym, Warszawa 2017; H. Szewczyk, Równość ptci w zatrudnieniu, Warszawa 2017; L. Mitrus, Swoboda przemieszczania się pracowników po przystapieniu Polski do Unii Europejskiej, Warszawa 2003; I. Jaroszewska-Ignatowska, Zatrudnienie w niepetnym wymiarze czasu pracy, Warszawa 2018. W tym kontekście analizowane są też orzeczenia TSUE, vide J. Plaňavová-Latanowicz, Trybunat Sprawiedliwości Wspólnot Europejskich i ochrona praw podstawowych, Warszawa 2000. 
dziedzinach" (vide: pkt 4). Faktem jest, że w pkt 9 preambuły tej dyrektywy prawodawca unijny wprost wskazuje na dyskryminację ze względu na płeć w obszarze rynku pracy. Jednak dalej stwierdza, że taka dyskryminacja może być również szkodliwa, stanowić przeszkodę dla pełnej i skutecznej integracji mężczyzn i kobiet w życiu gospodarczym i społecznym, które to problemy uwidaczniają się w szczególności w zakresie dostępu do towarów i usług. I tak właśnie powinien być rozumiany cel cytowanej dyrektywy, tj. zapobieganie i znoszenie dyskryminacji ze względu na płeć w zakresie nabywania i zbywania wszelkich towarów i usług na każdym rynku prawnie regulowanym, co zresztą znajduje potwierdzenie w dalszej części preambuły gdzie zaakcentowano jeszcze, że popieranie takiej równości jest jednym z podstawowych zadań UE, od której wymaga się, aby zmierzała do zniesienia nierówności oraz wspierania równości mężczyzn i kobiet we wszystkich swoich działaniach. Założenia określone w preambule zostały powtórzone i uszczegółowione w części prawnej, tj. przepisach ogólnych, w tym w szczególności w art. 1 (sformułowano cel dyrektywy), art. 3 (oznaczono zakres podmiotowy i przedmiotowy) oraz art. 4 (zdefiniowano zasadę traktowania kobiet i mężczyzn), a także przepisach szczególnych (art. 8 i n.).

Ustawa z dnia 3 grudnia 2010 r. o wdrożeniu niektórych przepisów Unii Europejskiej [...] niewątpliwie dokonuje wdrożenia w zakresie regulacji dyrektywy 2004/113/WE, o czym świadczy choćby ogólny zapis art. $1 \mathrm{w}$ zw. z art. 4 pkt $1-4 \mathrm{e}^{6}$. Wprowadziła ona bowiem do systemu prawa polskiego przepisy, których celem jest ustanowienie gwarancji - materialnoprawnych, procesowych oraz instytucjonalnych - w wielu dziedzinach życia, w których prawodawca unijny uznał, że istnieje wysokie ryzyko pojawienia się nieobiektywnego, nierównego traktowania, czyli dyskryminacji. Innymi słowy, cel określony w dyrektywie 2004/113/WE został osiągnięty na skutek wprowadzenia w życie przepisów ustawy z 3 grudnia 2010 r., co zresztą znajduje potwierdzenie w uzasadnieniu projektu ustawy o wdrożeniu niektórych przepisów UE w zakresie równego traktowania (druk nr 3386, VI kadencja Sejmu), w treści którego rząd, przesyłając projekt tego aktu normatywnego do Sejmu, argumentował, że: „Takie rozwiązanie w pełni implementuje rozwiązania zawarte w dyrektywach". To, że w cytowanej ustawie nie zawarto sformułowań identycznych do tych znajdujących się w dyrektywie 2004/113/WE, a prawodawca krajowy zamknął $\mathrm{w}$ jej ramach listę cech objętych ochroną oraz ograniczył się jedynie do minimum wyznaczonego przez prawo unijne co do określenia zakresu przedmiotowego, nie ma żadnego znaczenia prawnego.

Trzeba zauważyć, że Sąd Apelacyjny nie kwestionował zakresu implementacji dyrektywy 2004/113/WE dokonanej ustawą z 3 grudnia 2010 r. Niemniej Sąd ten nie odwołał się w przedstawionych rozważaniach do celu tej dyrektywy, choć powinien był to uczynić choćby z racji tego, że powołał się na definicje - kluczowe w omawianej materii, jak dyskryminacja bezpośrednia oraz nierówne traktowanie kobiet

${ }^{6}$ Wypada zaznaczyć, że komentowany akt normatywny nie jest pierwszą ustawą, która wdraża unijny standard zakazu dyskryminacji. Od 2004 r. w kodeksie pracy funkcjonują regulacje, na mocy których pracownikom doświadczającym dyskryminacji umożliwiono dochodzenie odrębnego roszczenia w tym zakresie. 
i mężczyzn - które zostały opracowane na poziomie Unii i zredagowane po raz pierwszy w tej dyrektywie.

Trudno przy tym negować, aby macierzyństwo i wszelkie jego atrybuty były połączone z inną cechą osobistą niż płeć, podlegającą ochronie prawnej w analizowanym tu zakresie. Płeć oczywiście nie jest pojęciem legalnym. Należy mieć na względzie, że Trybunał Sprawiedliwości UE w wyroku z 1 marca 2011 r. (nr sprawy C-236/09) postawił tezę, że płeć jest cechą, która jak rasa czy pochodzenie etniczne jest nierozerwalnie związana z osobą, na którą to cechę nie ma ona żadnego wpływu. Inaczej niż np. wiek, płeć osoby nie podlega żadnym naturalnym zmianom. W naukach biologicznych powszechnie i jednogłośnie przyjmuje się, że płeć stanowi zespół cech pozwalających podzielić osobniki danego gatunku na dwie grupy oznaczane jako męskie i żeńskie. Niewątpliwie ten podział dychotomiczny został uwzględniony w redakcji przepisu art. 4 pkt a in principio rzeczonej dyrektywy. Wydaje się przy tym, że część dalsza przepisu stanowi wyłącznie podkreślenie tej kwestii w kontekście rynku pracy, na którym w najszerszym zakresie dochodzi do nierównego traktowania kobiet i mężczyzn ze względu na ciążę lub macierzyństwo.

Sąd Apelacyjny zasadnie przyjął, że w ustalonych okolicznościach faktycznych sprawy doszło do naruszenia zasady równego traktowania ${ }^{7}$ w rozumieniu art. 6 ustawy o wdrożeniu niektórych przepisów UE w formie dyskryminacji bezpośredniej. Równość zawiera w sobie dwa elementy: równość w prawie i równość wobec prawa. Odwołują się one do dwóch etapów działania prawa - jego tworzenia i stosowania. Równość w prawie (zwana także równością formalną) oznacza takie formułowanie przepisów, aby w jednakowy sposób kształtowały sytuację prawną takich samych podmiotów. Zasadę tę sformułował już Arystoteles, mówiąc, że podobne rzeczy powinny być traktowane podobnie, tymczasem niepodobne — różnie, jednak proporcjonalnie do ich zróżnicowania. Druga zasada - równości wobec prawa — oznacza natomiast, że prawo powinno być jednakowo, równo (zgodnie z jedną i tą samą regułą) stosowane wobec wszystkich członków społeczeństwa, posiadających określoną, istotną cechę wspólną. Równość, rozumiana jako podstawowe prawo człowieka ${ }^{8}$, na podstawie omawianych regulacji oznacza zatem „podobieństwo” podmiotów, biorąc pod uwagę cechę istotną, czyli płeć.

7 Jednak nie każde nierówne traktowanie jest dyskryminacją. Inaczej mówiąc, nadanie dwóm grupom różnych uprawnień jest prawnie dopuszczalne. Aby uznać, że dyskryminacja się zdarzyła, konieczne jest nie tylko stwierdzenie faktycznej i celowej nierówności tych grup, ale także brak usprawiedliwienia owego rozróżnienia, tzn. brak jakiegokolwiek uzasadnionego prawem celu bądź wprowadzenie różnego traktowania w nierównych proporcjach. Odstępstwa od zasady równego traktowania mogą się zdarzyć, jeśli są relewantne (racjonalnie uzasadnione), proporcjonalne (porównując wagę interesu, dla którego wprowadzono te normy, do interesów, które zostaną naruszone przez wprowadzenie zróżnicowania) oraz pozostają w związku z innymi wartościami konstytucyjnymi. Istotne jest także, że określone zróżnicowanie w prawach dwóch czy więcej grup może zostać uznane za dyskryminację dopiero wówczas, gdy zachodzi istotne podobieństwo między tymi grupami lub sytuacjami, w których się one znajdują.

${ }^{8}$ Jest też fundamentalną zasadą prawa UE, której celem jest likwidacja takich sytuacji, w których działania urzędów mogłyby dyskryminować rozróżnienia między pewnymi grupami (społecznymi lub zawodowymi). 
W ujęciu prawnym zasada niedyskryminacji ${ }^{9}$ sprowadza się zatem do prawnej równości (ergo podobieństwa) różnych podmiotów w ramach określonego systemu prawnego. Wypada przy tym wspomnieć, że zasada równości i niedyskryminacji wywodzona jest z godności ludzkiej, która przysługuje wszystkim ludziom niezależnie od posiadanych cech, zdolności i okoliczności, w których się znajdują ${ }^{10}$. Traktowanie kobiety karmiącej piersią w sposób odmienny od pozostałych gości restauracji, tj. na jej niekorzyść, jest więc przejawem dyskryminacji. Co więcej, przybiera ona formę dyskryminacji bezpośredniej, jako że jednostce dyskryminowanej zaoferowano usługę gorszej jakości wyłącznie z racji jej odmiennego stanu tymczasowego, co koliduje z prawem krajowym oraz UE.

Bezpośrednia dyskryminacja ${ }^{11}$ (określana też jawną dyskryminacją) jest wówczas, gdy jedna osoba traktowana jest mniej korzystnie ze względu na swoją płeć niż inna osoba w sytuacji porównywalnej. Efekt takiej dyskryminacji jest bezpośrednio widoczny. Zatem różnice między mężczyznami a kobietami w zakresie dostarczania publicznych usług gastronomicznych, które nie wynikają z fizycznych różnic między nimi, odnoszą się do sytuacji porównywalnych i mogą być przejawem tak rozumianej dyskryminacji. Co ważne, bez znaczenia w takiej sytuacji pozostaje motyw działania bądź zamiar osoby dyskryminującej, gdyż wystarczające jest już wskazanie na przyczynę mniej przychylnego traktowania, co sprowadza się do stwierdzenia, że zastosowano zakazane prawem kryterium.

Słusznie też Sąd Apelacyjny uznał, że w okolicznościach przedstawionej sprawy żadna z klauzul limitacyjnych wyrażonych w art. 8 ust. 2 ustawy o wdrożeniu niektórych przepisów UE w formie dyskryminacji bezpośredniej nie mogła znaleźć zastosowania. Przede wszystkim dlatego, że przepis obejmujący te klauzule stanowi wyjątek od zasady równego traktowania w zakresie innym niż dostęp i korzystanie z usług, rzeczy lub praw, o czym stanowi wprost dyspozycja art. 6 tej ustawy. W komentowanym przepisie nie wskazano opcji naruszenia zakazu nierównego traktowania ze względu na płeć, co oznacza, że ta cecha nie determinuje sytuacji, w której mimo że dochodzi do różnicowania sytuacji osób ze względu na nią właśnie, nie będziemy mieli do czynienia z dyskrymi-

${ }^{9}$ Klasyczne klauzule niedyskryminacyjne wśród podstaw wykluczających różnicowanie w korzystaniu z praw człowieka wymieniają: rasę, płeć, język, religię (art. 1 ust. 3 Karty Narodów Zjednoczonych z 1945 r.), kolor skóry, poglądy polityczne lub jakiekolwiek inne, pochodzenie narodowe lub społeczne, majątek i urodzenie (art. 2 Powszechnej Deklaracji Praw Człowieka z 1948 r.; art. 2 Międzynarodowego Paktu Praw Obywatelskich i Politycznych z 1966 r.; art. 2 ust. 2 Międzynarodowego Paktu Praw Gospodarczych Społecznych i Kulturalnych z 1966 r.), przynależność do mniejszości narodowej (art. 14 EKPC) lub jakąkolwiek inną sytuację (status). Konwencje szczegółowe uzupełniają ten klasyczny katalog o inne podstawy dyskryminacji, np. Konwencja o prawach dziecka z 1989 r. w art. 2 wyklucza dyskryminację w kwestiach dotyczących rodziców, opiekunów prawnych lub członków rodziny.

${ }_{10}$ Temida $w$ dobie rewolucji biotechnologicznej, red. O. Nawrot, A. Wnukiewicz-Kozłowska, Gdańsk 2015, s. 167.

${ }^{11}$ Pojęcie to zostało sprecyzowane przez orzecznictwo Trybunału Sprawiedliwości w sprawach dotyczących w głównej mierze dyskryminacji ze względu na przynależność państwową i dyskryminacji ze względu na płeć. Vide szerzej E. Krzysztofik, Wsparcie pokoju we współczesnych stosunkach międzynarodowych, Warszawa 2009. 
nacją. Ponadto trzeba mieć tu na uwadze, że osoba prowadząca restaurację nie wpisuje się w ramy podmiotowe określone w art. 8 ust. 1 ustawy, a tym samym do działań przez nią podejmowanych rzeczone klauzule nie będą stosowane nawet $\mathrm{w}$ zakresie środków koniecznych podejmowanych w demokratycznym państwie dla jego bezpieczeństwa publicznego i porządku, ochrony zdrowia lub ochrony wolności i praw innych osób oraz zapobiegania działaniom podlegającym sankcjom karnym. Wypada też odnotować, że normy moralne czy społeczne nie zostały objęte dyspozycją art. 8 ust. 2 cytowanej ustawy i z racji tego nie mogą być brane pod uwagę w kontekście jego wykładni, ponieważ wyjątków od zasady nie należy interpretować rozszerzająco, a tylko wtedy dopuszcza się odstąpienia od jednoznacznego sensu przepisu ustalonego za pomocą dyrektyw językowych, jeżeli przemawiają za tym szczególnie ważne racje prawne, społeczne, ekonomiczne lub moralne, a te w tej sprawie nie zaistniały.

Reasumując powyższe, trzeba stwierdzić, że Sąd Apelacyjny w Gdańsku dokonał poprawnej wykładni obowiązującego prawa, w wyniku czego słusznie uznał, że karmienie piersią dziecka w restauracji może stać się przyczyną bezpośredniej dyskryminacji ze względu na płeć. W mojej ocenie, glosowany wyrok może stać się fundamentalny dla kształtowania przyszłego orzecznictwa w Polsce. Doświadczenie pokazuje bowiem, że sądy krajowe najczęściej sięgają do poglądów własnej judykatury, a tylko partykularnie powołują się na stanowisko sądów unijnych i międzynarodowych, co niewątpliwie jest błędem na podstawie omawianej problematyki, gdyż rozwiniętą postać osiągnęła ona właśnie w prawie ponadnarodowym.

\section{DOTYCHCZASOWE POGLĄDY PREZENTOWANE W ORZECZNICTWIE KRAJOWYM I UNIJNYM ${ }^{12}$}

Omawiany wyrok Sądu Apelacyjnego w Gdańsku wpisuje się w całości w linię orzeczniczą Trybunału Sprawiedliwości Unii Europejskiej [dalej: TSUE] oraz ubogie jak dotąd orzecznictwo sądów krajowych w tej materii, które odnosi się wprawdzie do dyskryminacji ze względu na płeć, ale na gruncie regulacji zawartych w kodeksie pracy. Ustawa z 3 grudnia 2010 r. jest bowiem aktem normatywnym, który — jak się okazuje — nie jest w pełni wykorzystywany, a właściwie jest podstawą roszczeń tylko w nielicznych przypadkach, co jest niepokojące.

Przede wszystkim należy wskazać na wyroki TSUE z 8 listopada 1990 r. wydane w sprawie C-177/88 (ECLI:EU:C:1990:383) oraz w sprawie C-179/88 (ECLI: EU:C:1990:384), które zapoczątkowały orzecznictwo Trybunału dotyczące stricte dyskryminacji ze względu na macierzyństwo ${ }^{13}$. W pierwszym z tych rozstrzygnięć TSUE

12 Vide M. Domańska, Zakaz dyskryminacji ze względu na pleć w orzecznictwie TS, „Europejski Przegląd Sądowy" 2011, nr 6, s. 30-39.

${ }_{13}$ Linia ta jest kontynuowana w wyrokach z: 14 lipca 1994 r. w sprawie C-32/93 Webb, Rec. s. I-3567; 30 czerwca 1998 r. w sprawie C-394/96 Brown, Rec. s. I-4185; 19 listopada 1998 r. w sprawie C-66/96 Høj Pedersen i in., Rec. s. I-7327; 4 października 2001 r. w sprawie C-109/00 Tele Danmark, Rec. s. I-6993; 18 listopada 2004 r. w sprawie C-284/02 Sass, Zb. Orz. s. I-11143; 8 września 2005 r. w sprawie C-191/03 McKenna, Zb. Orz. s. I-7631; 16 lutego 2006 r. w sprawie C-294/04 Sarkatzis Herrero, Zb. Orz. s. I-1513. 
wprost uznał, że odmowa nawiązania stosunku pracy z powodu ciąży kandydatki stanowi przejaw dyskryminacji bezpośredniej ze względu na płeć. Podkreślił jednocześnie, że okoliczność, że żaden mężczyzna nie ubiegał się o tę pracę pozostaje bez znaczenia w takiej sytuacji. W drugim z powołanych orzeczeń TSUE zważył, że kobieta powinna być objęta ochroną przed zwolnieniem nie tylko w trakcie urlopu macierzyńskiego, ale również podczas całego okresu trwania ciąży. Zdaniem TSUE zwolnienie w tych okresach może dotyczyć jedynie kobiet i tym samym stanowi bezpośrednią dyskryminację ze względu na płeć.

W wyroku z 11 listopada 2010 r. (C-232/09, ECLI:EU:C:2010:674) TSUE uznał, że art. 10 dyrektywy 92/85/EWG w sprawie wprowadzenia środków służących wspieraniu poprawy w miejscu pracy bezpieczeństwa i zdrowia pracownic w ciąży, pracownic, które niedawno rodziły, i pracownic karmiących piersią, należy interpretować w ten sposób, że stoi on na przeszkodzie uregulowaniu krajowemu, które pozwala na odwołanie członka zarządu spółki kapitałowej bez żadnych ograniczeń, jeżeli osoba zainteresowana jest „pracownicą w ciąży” w rozumieniu tej dyrektywy, a uchwała o jej odwołaniu jest w głównej mierze uzasadniona tym, że zaszła ona w ciążę. Nawet gdyby przyjąć, że dany członek zarządu nie jest za taką osobę uznany, to wciąż odwołanie członka zarządu pełniącego funkcje jako integralna część tej spółki i świadczącego pracę na rzecz owej spółki i w zamian za swą działalność otrzymującego wynagrodzenie może dotyczyć jedynie kobiet i tym samym stanowi bezpośrednią dyskryminację ze względu na płeć sprzeczną z art. 2 ust. 1 i 7 oraz art. 3 ust. 1 lit. c) dyrektywy 76/207/EWG w sprawie wprowadzenia w życie zasady równego traktowania kobiet i mężczyzn w zakresie dostępu do zatrudnienia, kształcenia i awansu zawodowego oraz warunków pracy, zmienionej dyrektywą 2002/73/WE. Trybunał przypomniał jeszcze, że celem zamierzonym przez przepisy prawa Unii dotyczące równości kobiet i mężczyzn w dziedzinie praw kobiet ciężarnych i kobiet, które niedawno urodziły, jest ochrona pracownic w okresie przed urodzeniem i po porodzie. Ów cel, który przyświeca zarówno dyrektywie 92/85/ EWG, jak i dyrektywie 76/207/EWG, nie mógłby zostać osiągnięty, gdyby ochrona przed zwolnieniem przyznana przez prawo Unii kobietom w ciąży zależała od formalnej kwalifikacji ich stosunku pracy w prawie krajowym lub wyboru podstawy nawiązania stosunku prawnego dokonanego przy ich zatrudnieniu. Niezależnie od tego, która $\mathrm{z}$ tych dyrektyw znajduje $\mathrm{w}$ tym przypadku zastosowanie, istotne jest zapewnienie zainteresowanej ochrony przyznanej w prawie Unii kobietom w ciąży w sytuacji, gdy stosunek prawny łączący ją z inną osobą zostaje rozwiązany z powodu zajścia przez nią w ciążę.

Na uwadze należy też mieć wyrok TSUE z 18 listopada 2010 r., wydany w sprawie C-356/09 (ECLI:EU:C:2010:703), na kanwie którego Trybunał wywiódł, że przepisy krajowe promujące dostęp osób młodszych do zatrudnienia zezwalają pracodawcy na zwolnienie pracowników, którzy nabyli prawa emerytalne, w sytuacji gdy w przypadku kobiet wiek, z którym wiąże się nabycie takich praw, jest o pięć lat niższy niż w przypadku mężczyzn, stanowi dyskryminację bezpośrednią ze względu na płeć. A także wyrok TSUE z 1 marca 2011 r. (C-236/09; ECLI:EU:C:2011:100), w którym 
przesądzono, że zezwolenie państwom członkowskim na utrzymanie bez ograniczeń czasowych wyjątków od zasady równości płci (określonej w art. 5 ust. 1 dyrektywy Rady 2004/113/WE z 13 grudnia 2004 r. wprowadzającej życie zasadę równego traktowania mężczyzn i kobiet $\mathrm{w}$ zakresie dostępu do towarów i usług oraz dostarczania towarów i usług), jest sprzeczne z realizacją celu dyrektywy, tj. równego traktowania kobiet i mężczyzn w obliczaniu składek ubezpieczeniowych i świadczeń. Na podstawie tej dyrektywy TSUE wydał niewiele rozstrzygnięć, z czego większość odnosi się do obszaru zabezpieczenia społecznego, w tym ubezpieczeń.

Doniosłym polskim orzeczeniem w badanym zakresie (choć wydanym na kanwie regulacji prawa pracy) jest wyrok Sądu Okręgowego w Warszawie z 22 grudnia 2008 r., sygn. akt VII Pa 35/08 (niepubl.), w ramach którego przyjęto, że w stosunku do dyskryminowanego została naruszona zasada równego traktowania w zatrudnieniu na etapie rekrutacji na wolne stanowisko pracy, poprzez przyjęcie jako jednego z warunków zatrudnienia określonej płci kandydatów, bez obiektywnie istniejących w tej mierze powodów. W ocenie tego Sądu ogłoszenie prasowe oraz rozmowa telefoniczna prowadzona $\mathrm{w}$ imieniu pozwanej przez jej pracownika, jednoznacznie potwierdziły, że pozwana poszukiwała na wolne miejsce pracy na stanowisko asystentki/sekretarki jedynie kobiety, nie przedstawiając w procesie żadnych dowodów na okoliczność, że preferowanie zatrudnienia kobiety na tym stanowisku uzasadnione jest jakimś obiektywnym powodem, w tym ze względu na rodzaj pracy, warunki jej wykonywania lub wymagania zawodowe. Zdaniem Sądu, przeprowadzone dowody uprawdopodobniły więc w sposób wystarczający naruszenie przez pozwaną w stosunku do powoda zasady równego traktowania $\mathrm{w}$ zatrudnieniu na etapie rekrutacji.

Na podstawie ustawy z 3 grudnia 2010 r. znaczący stał się wyrok Sądu Apelacyjnego w Warszawie z 23 sierpnia 2016 r., sygn. akt I ACa 1522/15 (LEX nr 2149609), choć roszczenie dochodzone $\mathrm{w}$ tej sprawie nie zostało uwzględnione. Niemniej w uzasadnieniu wyroku Sąd ten nie tylko precyzyjnie wyjaśnił pojęcie dyskryminacji i nierównego traktowania, ale też wskazał na obowiązek wykładni prawa polskiego będącego implementacją dyrektywy w sposób zgodny z taką dyrektywą i interpretacją TSUE.

Należy zwrócić uwagę na wyrok Sądu Apelacyjnego w Warszawie z 28 września 2011 r., sygn. akt I ACa 300/11 (niepubl.) dotyczący dyskryminacji ze względu na niepełnosprawność. Sąd zważył, że uniemożliwienie skorzystania osobie niepełnosprawnej z usług restauracji z racji tego, że towarzyszył jej pies asystent stanowi przejaw dyskryminacji bezpośredniej, a nadto narusza jej dobra osobiste. Sąd ten wyjaśnił, że do dyskryminacji dochodzi nie tylko wtedy, gdy brakuje obiektywnego uzasadnienia różnicy traktowania osób będących w takiej samej lub porównywalnej sytuacji, ale również wówczas, gdy pozornie neutralne warunki, kryteria bądź praktyki są stosowane na równi wobec wszystkich, lecz w sposób szczególny dotykają pewną grupę społeczną. Powód w tej sprawie został bowiem potraktowany jak osoba zdrowa, która chce wprowadzić psa do restauracji, podczas gdy powinien zostać potraktowany w sposób szczególny, gdyż w jego przypadku pies asystent jest swoistym 
środkiem służącym do złagodzenia skutków niepełnosprawności. Innymi słowy, Sąd Apelacyjny w Warszawie uznał, że w tej konkretnej sprawie powód z psem asystentem powinien być traktowany tak samo jak osoba zdrowa bez psa.

Rozważając o podobnych zagadnieniach warto mieć też na względzie rozstrzygnięcie Sądu Apelacyjnego w Poznaniu z 29 lutego 2012 r. (sygn. akt I ACa 1162/11, LEX nr 1133337), który stwierdził, że odmowa umożliwienia powodowi wejścia do lokalu z uwagi na jego romskie pochodzenie stanowi naruszenie jego dobra osobistego, jakim jest prawo do godności osobistej i jest działaniem o charakterze dyskryminacyjnym. Sąd ten zaakcentował w tej sprawie, że zakaz dyskryminowania m.in. z uwagi na pochodzenie narodowe i etniczne wynika nie tylko z norm o charakterze konstytucyjnym (art. 32 konstytucji) oraz przepisów szczególnych (art. 6 ust. 1 ustawy z dnia 6 stycznia 2005 r. o mniejszościach narodowych i etnicznych oraz o języku regionalnym), ale też należy wręcz do podstawowych zasad funkcjonowania współczesnego, nowoczesnego społeczeństwa i państwa. Osoba decydująca się na prowadzenie działalności w przestrzeni publicznej ma obowiązek stosowania się do funkcjonujących w niej reguł i zasad postępowania, do których należy m.in. zakaz dyskryminacji. Sąd zaznaczył przy tym, że prawo własności, jak każde z praw majątkowych, nie ma charakteru absolutnego i podlega różnego rodzaju ograniczeniom. Przede wszystkim musi być ono wykonywane zgodnie z jego społeczno-gospodarczym przeznaczeniem i z uwzględnieniem usprawiedliwionych praw innych osób. $Z$ tych względów nie stanowi ono przesłanki egzoneracyjnej, na którą strona mogłaby się skutecznie powoływać w celu dowiedzenia uprawnienia do wprowadzenia ograniczeń dostępności do lokalu dla klientów pochodzenia romskiego.

Przedstawione wyroki przekonują, że TSUE od wielu lat dokłada wszelkich starań, aby państwa członkowskie Unii Europejskiej gwarantowały równość płci oraz równość szans kobiet i mężczyzn we wszystkich obszarach ich aktywności. Priorytetem wydaje się zapewnienie przejrzystości rozwiązań narodowych w ramach omawianego zagadnienia, co powinno ułatwić przepływ osób w ramach jednolitego rynku jako obszaru wolnego od dyskryminacji. Krajowa judykatura również podejmuje starania dla urzeczywistnienia zasady niedyskryminacji (choć niewystarczająco i z różnym skutkiem), co należy ocenić pozytywnie. Nie do zaakceptowania jest jednak fakt, że to, co jest już tendencją w orzecznictwie unijnym, nadal stanowi wyjątek w orzecznictwie krajowym. Zamiast bowiem czerpać z bogatego doświadczenia TSUE, sądy krajowe w większości niepotrzebnie skupiają się na analizie prawnoporównawczej regulacji unijnych i polskich, co odsuwa na dalszy plan istotę rzeczy.

Jednak wypada zaznaczyć, że przytoczone rozstrzygnięcia stanowią trwały wkład w zwalczanie stereotypów i dyskryminacji ze względu na płeć i pod tym względem zasługują na szczególne uznanie. Okazuje się bowiem, że we współczesnej Europie, pomimo postępującej społecznej akcji informacyjnej, wciąż powszechnie akceptowane są zachowania, u źródeł których leży kategoryzacja osób z powodu ich cech dominujących. Być może więc rozpowszechnienie orzecznictwa sądowego wyjaśniającego kwestie kluczowe w tym względzie okaże się najlepszą kampanią edukacyjną. 
Ponadto nie bez znaczenia jest fakt, że zacytowane wyroki w całości wpisują się w okazały dorobek orzeczniczy ETPC, którego interpretacje mają kluczowe znaczenie dla eliminacji dyskryminacji bezpośredniej i pośredniej ${ }^{14}$. Jednak z racji na przyjętą koncepcję i strukturę niniejszej glosy nie zostaną one tu omówione.

VI. PODSUMOWANIE

Kwestią oczywistą jest, że oceniamy i jesteśmy oceniani przez pryzmat naszych cech, takich jak płeć, wiek, niepełnosprawność, kolor skóry itd., którym to cechom przypisywane są określone uogólnienia i stereotypy mogące prowadzić do dyskryminacji. Stereotypy związane z płcią społeczno-kulturową polegające m.in. na postrzeganiu kobiet jako głównych opiekunek dzieci, a mężczyzn jako głównych żywicieli rodziny, nie mogą tymczasem być uważane za wystarczające usprawiedliwienie zróżnicowanego traktowania, podobnie jak stereotypy dotyczące rasy, pochodzenia etnicznego, koloru skóry czy orientacji seksualnej ${ }^{15}$. Pod tym kątem glosowany wyrok jest postępowy, gdyż zwraca uwagę na wrażliwą sferę życia, w której może dojść do dyskryminacji ze względu na płeć. Zapewne w przypadku mężczyzny żaden sąd nie uzasadniłby oddalenia powództwa o zapłatę odszkodowania ostentacyjnym sposobem karmienia dziecka w restauracji. Stąd konieczne i celowe było porównanie pod tym kątem sytuacji mężczyzny i kobiety, co właściwie uczynił Sąd Apelacyjny w Gdańsku. Ważne jest zatem, aby komentowane rozstrzygnięcie na trwałe wpisało się w krajową linię orzeczniczą w tej materii, gdyż każdą formę dyskryminacji ze względu na płeć należy bez wątpienia eliminować.

Aleksandra Nadolska*

* Dr Aleksandra Nadolska, radca prawny, a.j.nadolska@gmail.com, https://orcid.org/0000-0003-4903-8336

${ }^{14}$ Confer m.in. wyroki z: 9 czerwca 2009 r. w sprawie Opuz v. Turcja (skarga nr 33401/02); 17 lutego 2011 r. w sprawie Andrle v. Republika Czeska (skarga nr 6268/08); 3 lutego 2011 r. w sprawie Sporer v. Australia (skarga nr 35637/03); 2 grudnia 2014 r. w sprawie Emel Boyraz v. Turcja (skarga nr 61960/08); 7 stycznia 2014 r. w sprawie Cuzan i Fazzo v. Włochy (skarga nr 77/07); 25 lipca 2017 r. w sprawie Carvalho Pinto $v$. Portugalia (skarga nr 17484/15); 19 lutego 2013 r. w sprawie Garcia Mateos $v$. Hiszpania (skarga nr 38285/09); 22 marca 2012 r. w sprawie Konstantin Markin v. Rosja (skarga nr 30078/06); 28 maja 2013 r. w sprawie Leventoğlu Abdulkadiroğlu v. Turcja (skarga nr 7971/07); 2 marca 2017 r. w sprawie Talpis v. Włochy (skarga nr 41237/14); 7 listopada 2013 r. w sprawie Vallianatos i in. v. Grecja (skargi nr 29381/09 i 32684/09); 9 listopada 2010 r. w sprawie Losonci Rose i Rose $v$. Szwajcaria (skarga nr 664/06). Wszystkie wyroki zostały opublikowane na stronie <http://www.echr.coe.int>, dostęp 19 IX 2018.

15 Wyrok ETPC z 22 marca 2012 r. w sprawie 30078/06, <https:/www.echr.coe.int/sites/search_ eng/pages/search.aspx\#\{\%22fulltext\%22:[\%2230078/06\%22>, dostęp 19 IX 2018. 


\title{
RECENZJE
}

\author{
BŁAŻEJ KMIECIAK
}

\section{Prawa dziecka jako pacjenta}

Wydawnictwo C.H. Beck, Warszawa 2016, s. 338

\section{Rights of a Child as a Patient}

The development of medical law elicits the necessity for a deepened reflection on the legal position of a child as a patient. The keynote of the reviewed book is human rights, patients' rights and children's rights. It turns out that the analyzed role has more aspects than could be expected, and the solution to the problems is not always univocal. Legal analysis with an interesting sociological aspect contained therein is a valuable elaboration also from the perspective of legislative necessities. The development of medicine requires a reaction of law, and the lawmaking calls for answers to fundamental, remarkably difficult questions related to the rights of a child as a patient, requiring cross-disciplinary knowledge.

Słowa kluczowe: prawa człowieka, prawa dziecka, prawa pacjenta, prawo medyczne, zasady prawa medycznego, socjologia prawa

Key words: human rights, rights of the child, rights of the patient, medical law, principles of medical law, sociology of law

Dziecko we współczesnej kulturze prawnej znajduje się pod szczególną ochroną. Nie zawsze jednak tak było. Uzasadnieniem tej ochrony jest przede wszystkim stan fizyczny i psychiczny dziecka w okresie jego rozwoju. Pacjent również wymaga szczególnej ochrony z uwagi na swoją sytuację zdrowotną i ochronę życia i zdrowia jako wartości nadrzędnych. Koncepcja praw pacjenta, w swym rozwoju jest jeszcze bardziej współczesna niż sama idea praw dziecka. W sytuacjach, gdy dochodzi do połączenia tej ochrony przyznawanej dziecku i pacjentowi powstaje podwójne jej uzasadnienie. Wybór tematu będącego przedmiotem recenzowanej książki należy uznać za aktualny, a podjętą próbę pojawiających się problemów w kontekście rozwoju nauk medycznych i prawa medycznego za bardzo praktyczną. Warto również zastanowić się nad znaczeniem praw dziecka jako pacjenta w kontekście koncepcji zasad prawa medycznego ${ }^{1}$.

Recenzowana książka składa się sześciu rozdziałów, wstępu i podsumowania zawierającego wnioski. Konstrukcja monografii oparta jest na układzie stopniowania od zagadnień ogólnych do szczegółowych. W toku rozważań zabrakło jednak odrębnej części poświęconej zagadnieniom prawnoporównawczym. Jest to element przyjęty w klasycznym układzie monografii prawniczych. Zdecydowanie taka część umożliwiłaby pogłębioną refleksję nad polskimi rozwiązaniami. W pracy możemy znaleźć epizodyczne odniesienia do regulacji prawnych państw obcych. Autor za M. Śliwką przytacza regulacje państw obcych dotyczące praw dziecka do wyrażenia zgody na interwencję

\footnotetext{
${ }^{1}$ P. Dzienis, Zasady prawa medycznego, „Studia Prawnicze” 2000, nr 3-4.
} 
medyczną. Wzmiankę na temat prawa obcego można także znaleźć w analizach dotyczących skrócenia życia. Oczywiście autor nie pomija regulacji prawa międzynarodowego w zakresie praw człowieka i praw dziecka. Opracowanie nie jest klasyczną monografią prawniczą dotyczącą doktryny prawa, ale zawiera też elementy socjologii prawa ${ }^{2}$. W tym należy poszukiwać uzasadnienia odstępstwa od tradycyjnego układu. Przy omawianiu praw człowieka zabrakło jednak powołania Karty praw podstawowych Unii Europejskiej $^{3}$, która zapewnia obywatelom europejskim (a więc także dzieciom) poszanowanie ich praw m.in. do autonomii, godności, a której Polska dotychczas nie podpisała (z wyjątkiem tzw. protokołu brytyjskiego) oraz Konwencji o ochronie praw człowieka i godności istoty ludzkiej wobec zastosowań biologii i medycyny ${ }^{4}$, która zawiera wiele norm chroniących małoletnich. Wprawdzie Konwencja, chociaż podpisana w 1999 r., nie została ratyfikowana przez Polskę, lecz zgodnie z orzecznictwem Sądu Najwyższego ${ }^{5}$ stanowi istotną wskazówkę interpretacyjną wykładni prawa polskiego.

Jako korzystne rozwiązanie wybrane przez autora w zakresie stylu prowadzenia wywodu należy ocenić liczne odwołania do przykładów medialnych dotyczących problematyki praw pacjenta. Taki zabieg zdecydowanie podnosi poziom rozważań i je ożywia. Wskazuje na społeczną aktualność podnoszonych zagadnień i rozwiązywanych problemów. Pozwala osadzić je w konkretnej sytuacji. Pokazuje, że analiza prawna dokonywana jest metodą prawa $\mathrm{w}$ działaniu (law in action). Jest to zdecydowanie cecha charakterystyczna tej monografii. Zastrzeżenia budzi jednak niezbyt precyzyjne opisanie sprawy ze Szpitala Św. Rodziny w Warszawie z marca 2016 r., do której odwołanie znalazło się na s. 132. Należy też zauważyć, że w pracy zostały zawarte liczne odwołania do wypowiedzi L. Petrażyckiego. Dobrze się stało, że autor już we „Wstępie” odnosi się do analizy nurtu biojurysprudencji ${ }^{6}$.

Styl recenzowanej pracy może budzić wątpliwości w zakresie zbyt licznego cytowania wypowiedzi przedstawicieli doktryny in extenso. O ile w przypadku powoływania się na wypowiedzi o charakterze klasycznym nie budzi to wątpliwości, o tyle w przypadku pozostałych wypowiedzi może wywoływać pewne zastrzeżenia. Podnosiłoby walor pracy streszczenie stanowisk przedstawicieli doktryny z odwołaniem do przypisów, ale oczywiście wybór sposobu powoływania stanowisk przedstawicieli doktryny należy do autora i widocznie uznał on za ważne dosłowne cytowanie tych wypowiedzi

${ }^{2}$ Stanowiło to też trudność w recenzowaniu jej w ramach wymogów monografii prawniczej, jednak skoro praca ukazała się w serii „Monografie prawnicze” Wydawnictwa C.H. Beck, została oceniona według kryteriów rozprawy prawniczej.

${ }^{3}$ Karta praw podstawowych Unii Europejskiej, Dz.Urz. UE, C 2007.303.1.

${ }^{4}$ Konwencja o ochronie praw człowieka i godności istoty ludzkiej wobec zastosowań biologii i medycyny podpisana w Oviedo, 4 kwietnia 1997 r., „Prawo i Medycyna” 1999, nr 3, s. 140; w literaturze często określana jako Europejska konwencja bioetyczna.

${ }_{5}^{5}$ Postanowienie SN z 27 października 2005 r., sygn. akt III CK 155/05, OSN 2006, nr 7-8, poz. 137.

${ }^{6}$ R. Tokarczyk, Prawa narodzin, życia i śmierci, Warszawa 2012.

${ }^{7}$ Dotyczy to zwłaszcza cytowania długich fragmentów prac innych autorów, np. P. Winczorka, s. 66-67, D. Karkowskiej, s. 56-57, 81, E. Baszak-Radomańskiej i J. Wańczyk, s. 185; A. Augustynowicz oraz I. Wrześniewskiej-Wal, s. 92 i n. 
Rozprawa naukowa powinna cechować się przedstawieniem różnych stanowisk i poglądów oraz dokonaniem ich oceny z jednoczesnym zajęciem własnego stanowiska. Wskazuje na to chociażby jej nazwa, a zatem należy ,rozprawić” się z istniejącymi w doktrynie poglądami. Jest to szczególne ważne na tle recenzowanej monografii, gdy opisywane w pracy zagadnienia wywołują żywą dyskusję w nauce prawa i nie tylko. Rozprawa naukowa nie może być jednostronna, tj. przedstawiać tylko wybranych poglądów zgodnych z preferowanymi poglądami. Przedstawienie poglądów przeciwstawnych jest elementem koniecznym takiego rodzaju pracy. Nie budzi wątpliwości, że pozwala to na podkreślenie wagi i słuszności popieranego stanowiska. Można zatem stwierdzić, że podobnie jak w procesie ma tu zastosowanie zasada audiatur et altera pars. W recenzji zostaną wskazane takie zagadnienia, które wymagały rozwinięcia w monografii w celu zastosowania przywołanej zasady, a których w niej zabrakło.

Punktem wyjścia do rozważań w recenzowanej monografii jest przyjęcie definicji dziecka z art. 2 ust. 1 ustawy z dnia 6 stycznia 2000 r. o Rzeczniku Praw Dziecka ${ }^{8}$ jako „istoty od chwili poczęcia do osiągnięcia pełnoletniości”. Autor słusznie zauważył, że w zakresie granicy pełnoletności nie ma sporu w przeciwieństwie do początków życia. W monografii konsekwentnie broniony jest pogląd o początkach życia ludzkiego wynikający z powołanej definicji dziecka. Akcentowana jest rozbieżność w tym zakresie na płaszczyźnie konwencyjnej i orzeczniczej. Z prowadzonego wywodu wynika, jak fundamentalne znaczenie dla ochrony praw dziecka ma przyjęcie indywidualistycznego podejścia do zarodka. Sprowadza się ono do uznania, że zarodek to młoda istota, która zachowuje swoją tożsamość aż do późnej starości. To człowiek w najwcześniejszym etapie rozwoju podlega ochronie jako podmiot praw pacjenta.

W książce w rozważaniach nad początkiem dzieciństwa w zasadzie pominięto cywilistyczną konstrukcję dziecka poczętego, ale nienarodzonego (nasciturus). Tylko raz na s. 113 przy okazji cytowania pojawia się w ogóle pojęcie ,nasciturus”. Termin ten w prawie cywilnym ma ugruntowaną tradycję i cywilistyka posługuje się nim w opisywaniu praw dziecka poczętego ${ }^{9}$. W myśl paremii nasciturus pro iam nato habetur, quotiens de commodis eius agitur, czyli dziecko poczęte należy traktować tak, jakby było osobą fizyczną, ilekroć chodzi o jego korzyść. W pracy zagadnienia te analizowane są w sposób szeroki, jednak bez odwołania się wprost do tej konstrukcji prawnej.

Należy podzielić prezentowane przez autora dynamiczne ujęcie praw dziecka jako pacjenta oraz znaczenie wpływu na kształtowanie kultury praw dziecka wychowawczej i informacyjnej funkcji prawa. Dynamiczne ujęcie praw dziecka jako pacjenta przejawia się w dwóch aspektach. Po pierwsze, wraz z rozwojem dziecka następuje zmiana

${ }^{8}$ Ustawa z dnia 6 stycznia 2000 r. o Rzeczniku Praw Dziecka, tekst jedn. Dz.U. z 2015 r. poz. 2086 ze zm.

${ }^{9}$ P. Dzienis, [w:] Leksykon prawa medycznego, red. A. Górski, Warszawa 2012, s. 105-112 i powołana tam literatura; U. Drozdowska, Nasciturus jako podmiot praw pacjenta - zagadnienia dyskusyjne, „Zeszyty Naukowe WSAP. Administracja Publiczna” 2008, nr 1 s. 8-17. 
uprawnień pacjenta wynikająca z potrzeb ochrony. Po drugie, wraz z rozwojem nauk medycznych pojawią się tzw. nowe prawa dziecka. Walorem pracy jest zwrócenie uwagi na rolę edukacji prawnej samych dzieci i społeczeństwa w zakresie praw dziecka. Autor powołał interesujące przykłady działań w tej sferze. Konwencję o prawach dziecka ${ }^{10}$ nazywa „dziecięcą Konstytucją”.

Autor zwrócił uwagę analizując relacje pacjent-lekarz, że w procesie leczenia zaangażowane są też inne podmioty, które zobowiązane są do przestrzegania praw pacjenta. Wśród nich są również pielęgniarki i inny personel szpitalny, którzy są odpowiedzialni za stworzenie odpowiedniej atmosfery przy udzielaniu świadczeń medycznych dziecku.

Rozdział pierwszy zatytułowany „Prawa dziecka — próba definicji” wprowadza czytelnika w istotę praw człowieka, a w ich kontekście praw dziecka. Autor wyjaśnił, że nie zawsze dziecko było w centrum zainteresowań ochrony prawnej. Zmieniły to dopiero poglądy J.J. Rousseau, który „odkrył dziecko - jako dziecko” we francuskiej Deklaracji Praw Człowieka i Obywatela i Kodeksie Napoleona. W historycznym ujęciu problemu podkreślona została też rola i wkład $\mathrm{w}$ doktrynę ochrony praw dziecka J. Korczaka. W rozdziale tym przedstawione zostały tzw. naturalne prawa dziecka z jego perspektywy, a nie dorosłych na tle rozbieżności wizji dziecka a wizji rodziców i wcześniejszego historycznie władczego ujęcia praw człowieka. To właśnie tu zaprezentowane zostało stanowisko dotyczące definicji dziecka. Autor zwrócił uwagę na zagrożenia dla terapii w sytuacji, gdy człowiek nie zna swojego genetycznego pochodzenia.

Rozdział drugi zatytułowany jest „Prawa dziecka a prawa pacjenta”. Połączenie praw człowieka z prawami pacjenta w prawa dziecka to wszak jedna z myśli przewodnich recenzowanej pracy. Autor zauważył, że współpraca rzeczników praw dziecka i pacjenta doprowadziła do ogłoszenia Karty Praw Dziecka-Pacjenta. Dobrze stało się, że autor zaakcentował przewagę pozycji lekarza w relacjach medycznych oraz unikalność medycznej relacji, bo to właśnie one stanowią uzasadnienie praw pacjenta. Dokonał też oceny ustawy z dnia 6 listopada 2008 r. o prawach pacjenta i Rzeczniku Praw Pacjenta ${ }^{11}$ wraz z krytyczną oceną statusu Rzecznika Praw Pacjenta. To właśnie również w tym rozdziale autor powołał liczne przykłady działań w zakresie edukacji prawnej.

Rozważania zawarte w rozdziałach 3-5 stanowią zasadniczą część pracy. Rozdział trzeci zatytułowany „Prawo dziecka do świadczeń zdrowotnych” dotyczy już konkretnego prawa pacjenta w odniesieniu dziecka. Znaczna część rozważań została poświęcona aktualnym problemom związanym z początkiem życia ludzkiego, a w szczególności $\mathrm{w}$ aspekcie ochrony praw dziecka $\mathrm{w}$ fazie prenatalnej oraz prawnym aspektom zapłodnienia pozaustrojowego. Słusznie autor wyjaśnił, że pytania o ,przyszłe dziecko" są uzasadnieniem podjęcia tej tematyki w kontekście praw dziecka. Na tym polu

${ }^{10}$ Konwencja o prawach dziecka przyjęta przez ONZ w 1989 r. (Dz.U. z 1991 r. nr 120, poz. 526 ze zm.).

${ }^{11}$ Ustawa z dnia 6 listopada 2008 r. o prawach pacjenta i Rzeczniku Praw Pacjenta, tekst jedn. Dz.U. z 2016 r. poz. 186 ze zm. [dalej: u.p.p.R.P.P.]. 
pojawia się wiele zagrożeń dla praw dziecka i godności ludzkiej. Lekarz ukazywany jest tu jako gwarant bezpieczeństwa pacjenta. Zaprezentowana została wspominana już koncepcja zarodka jako podmiotu praw pacjenta, jako człowieka w najwcześniejszym etapie rozwoju. Dziecko od poczęcia (czyli od zapłodnienia naturalnego lub sztucznego) funkcjonuje jako samodzielny, niezależny podmiot. Koncepcja ta jednak powinna być wzmocniona, a zabrakło tu analizy jej skutków w odniesieniu do funkcjonujących norm prawnych. Trzeba pamiętać, że dawca nasienia do zapłodnienia in vitro staje się ojcem dziecka z wszelkimi konsekwencjami, nawet gdy nastąpi to po jego śmierci (post mortem $)^{12}$. Pojawia się zatem potrzeba odpowiedzi na pytania: Co z władzą rodzicielską? Jakie są konsekwencje w razie zniszczenia dziecka na etapie zarodka? Nie byłoby to bowiem zniszczenie zarodka zdolnego do prawidłowego rozwoju, podlegające odpowiedzialności karnej (art. 83 ustawy z dnia 25 czerwca 2015 r. o leczeniu niepłodności $^{13}$ ), lecz spowodowanie śmierci dziecka jeszcze $\mathrm{w}$ fazie nie tylko prenatalnej, lecz przedimplantacyjnej, za co grozi odpowiedzialność karna z art. 157a k.k. Zabrakło tu też odniesienia się do eksperymentów na embrionach (do 14 dni) i diagnostyki preimplantacyjnej genetycznej (dozwolonej przez art. 26 ust. 1 ustawy o leczeniu niepłodności).

Rozważania dotyczące wrażliwych problemów kolizji interesów matki i poczętego dziecka byłyby pełniejsze, gdyby zawierały odniesienie do wielu wypowiedzi doktryny w tym przedmiocie ${ }^{14}$, zwłaszcza że literatura w tym zakresie jest niezwykle bogata.

Autor w kontekście leczenia niepłodności zwrócił uwagę na charakterystyczny układ, w którym pacjentami są wprawdzie przyszli rodzice, ale również i dziecko, które powstaje w wyniku poczęcia. Zwrócono również uwagę na znaczenie prawa do poznania tożsamości biologicznej w kontekście obowiązku gromadzenia danych w prawie szwedzkim, brytyjskim i niemieckim i adopcji prenatalnej (w zestawieniu praw dziecka adoptowanego do praw dziecka poczętego). W rozdziale tym autor odnosi się też do aktualnego problemu szczepień dzieci przeciw chorobom zakaźnym. Zabrakło jednak jednoznacznego stanowiska. Odnosi się wrażenie, że autor nie opowiada się przeciwko obowiązkowym szczepieniom dzieci, ale jednocześnie nie popiera tzw. ruchu antyszczepionkowego. Mimo tego przywołuje argumenty niezachęcające do szczepień (s. 97). Trzeba zwrócić uwagę, że w dyskusji tej pominięte zostały istotne argumenty (i brak określenia ich znaczenia dla zasadności stanowisk)

12 Vide wyrok SA w Lublinie z 29 lipca 2009 r., sygn. akt I ACa 308/09, „Przegląd Sądowy” 2011, nr 1, z glosą M. Nesterowicza.

${ }_{13}$ Ustawa z dnia 25 czerwca 2015 r. o leczeniu niepłodności (Dz.U. z 2015 poz. 1087 ze zm.).

${ }^{14}$ Vide N. Karczewska-Kamińska, Przymus interwencji medycznych na kobiecie ciężarnej $w$ interesie dziecka poczętego w systemie prawnym anglo-amerykańskim i w prawie polskim, „Prawo i Medycyna” 2011, nr 4; J. Haberko, Cywilnoprawna ochrona dziecka poczętego a stosowanie procedur medycznych, Warszawa 2010; M. Szeroczyńska, Zgoda na leczenie operacyjne płodu, [w:] Prawo wobec problemów społecznych. Księga Jubileuszowa Prof. Eleonory Zielińskiej, Warszawa 2016, s. 819 i n.; E. Plebanek, Autonomia ciężarnej pacjentki wobec czynności medycznych. Prawnokarna ocena sprzeciwu ciężarnej pacjentki wobec czynności medycznej ratującej życie i zdrowie pacjentki lub dziecka nienarodzonego, cz. I, „Prawo i Medycyna” 2015, nr 2; M. Nesterowicz, Prawo medyczne, Toruń 2016, s. 172. 
odnośnie do odpowiedzialności cywilnej producenta szczepionki i państwa za szkody, które mogą się zdarzyć na skutek szczepień. W zakresie konstrukcji pracy istotne jest pytanie, czy rozważań dotyczących szczepień nie należało umieścić w części poświęconej przymusowi leczenia (s. 89-97). Odnośnie tej części trzeba zgłosić uwagę dotyczącą niezbyt precyzyjnych odesłań. Autor na s. 92 napisał: „J. Bujny formułuje w tym miejscu interesujące pytanie: Czy można dla ochrony innych osób przed jeszcze niezaistniałym, nakładać na jednostkę obowiązek działania, które niesie z sobą pewne zagrożenie dla jej życia i zdrowia". Tymczasem jest to pytanie sformułowane przez T. Dukiet-Nagórską ${ }^{15}$ cytowane przez J. Bujnego ${ }^{16}$ (s. 276-277). Dalej powołując się na J. Bujnego na s. 96 autor napisał: „Przykładem istotnej luki, zdaniem Autora, jest odnoszenie przez polskie ustawodawstwo obowiązku niepieniężnego wyłącznie do grupy ubezpieczonych”. Natomiast J. Bujny napisał: „Jak trafnie podnosi M. Iżycka-Rączka, prawodawca nie wskazał podmiotu odpowiedzialnego za wykonanie szczepień w stosunku do osób nieubezpieczonych" (s. 281).

Rozważania o aborcji, zagadnieniu niezwykle kontrowersyjnym i nie tylko w dyskursie publicznym, powinny zawierać ocenę również innych przeciwstawnych poglądów autorów polskich lub zagranicznych (np. prawa do autonomii prokreacji w USA — right to procreate i right to avoid procreation) czy ustalonego już w wielu polskich orzeczeniach „prawa do planowania rodziny" ${ }^{17}$. Nie sposób bowiem zanegować ich istnienia, nawet w sytuacji sprzeciwu wobec nich. Podniosłoby to wyniki badań naukowych. Przywołanie poglądów przeciwnych do stanowiska prezentowanego w pracy zapewniłoby obiektywność wywodu i pozwoliłoby na wzmocnienie zajętej pozycji.

Rozdział czwarty „Prawo dziecka — prawo do informacji” dotyczy tajemnicy lekarskiej i został poświęcony prawnym aspektom znaczenia informacji w procesie leczenia. Problem przedstawiony został w odniesieniu prawa do informacji dziecka do praw rodziców i opiekunów. Rozważane są w nim takie zagadnienia jak prawo dziecka do samodzielnych wizyt lekarskich, zakres poufności wobec rodziców dziecka, prawdziwość dokumentacji medycznej również w aspekcie karnym, a także relacja zjawiska przemocy w rodzinie wobec obowiązku denuncjacji i zasady poufności. Analizowane w tym rozdziale prawo pozostaje w ścisłym związku z zasadą ochrony godności człowieka-pacjenta. Trzeba o tym pamiętać interpretując to prawo pacjenta. W odniesieniu do analizy prawa do samodzielnych wizyt lekarskich warto zadać pytanie, jaki jest stosunek zaprezentowanego stanowiska do regulacji art. $10 \S 1$ kodeksu rodzinnego i opiekuńczego przewidującego, że kobieta powyżej 16 lat może za zgodą sądu zawrzeć małżeństwo, czy art. 9 ust. 2 u.p.p.R.P.P., stanowiącego, że: „Pacjent, w tym małoletni, który ukończył 16 lat, lub jego ustawowy przedstawiciel mają prawo do uzyskania od lekarza

${ }^{15}$ T. Dukiet-Nagórska, Uwagi na temat ustawy z 6 września 2001 r. o chorobach zakaźnych i zakażeniach, „Prawo i Medycyna” 2001, nr 11.

${ }^{16}$ J. Bujny, Prawa pacjenta - między autonomia a partnerstwem, Warszawa 2007.

17 Np. wyrok SN z 21 listopada 2003 r., sygn. akt V CK 16/03, OSP 10/2004, poz. 125, z glosą M. Nesterowicza; wyrok SA w Krakowie z 12 maja 2015 r., sygn. akt I ACa 204/15, OSP 5/2016, poz. 44 , z glosą M. Nesterowicza. 
przystępnej informacji [...]". Rodzice mają prawo do informacji o dziecku, jednak z powołanego przepisu nie wynika, że małoletni ma prawo do informacji kumulatywnej przy jednoczesnej obecności rodziców lub tylko za uprzednią zgodą rodziców.

Rozdział piąty pt. „Prawo dziecka do wyrażenia zgody na udzielenie świadczeń zdrowotnych" dotyczy ważnego prawa do samostanowienia oraz zasady prawa medycznego ochrony autonomii woli pacjenta. Analizując znaczenie zgody, autor pokazał, że skutkiem zgody pacjenta są trwałe prawnie zmiany ${ }^{18}$. W tej części istotne z punktu widzenia cywilistycznego jest spostrzeżenie, że art. $14 \S 1$ ustawy z dnia 23 kwietnia 1964 r. Kodeks cywilny ${ }^{19}$ nie ma zastosowania do zgody pacjenta, gdyż jej przedmiot nie należy do drobnych bieżących spraw życia codziennego. Pogląd ten należy podzielić. Praca szczególnie w tej części skłania do refleksji relacji zasady dobra chorego do zasady dobra dziecka rządzącej prawem rodzinnym. Poczynione zostały w niej rozważania terminologiczne na temat władzy rodzicielskiej i pieczy prowadzące do priorytetu autorytetu z uwzględnianiem samodzielności. W toku tej analizy podkreślony został również stosunek dobra dziecka do interesu społecznego jako wyznacznika obiektywnej oceny problemu. Wiele miejsca poświęcone zostało zgodzie kumulatywnej z art. 17 u.p.p.R.P.P. Autor przeprowadził jej krytyczną ocenę. Jednocześnie w monografii analizowane są postulaty de lege ferenda $\mathrm{w}$ odniesieniu do zgody opartej na stanowisku, że sztywne bariery wiekowe przy określaniu zdolności do wyrażenia zgody są błędne. Zostały one ocenione krytycznie z uwagi na to, że nie prowadzą do ułatwienia działań medycznych i nie uwzględniają dobra dziecka, a jedynie ogniskują wokół zagrożenia dla jego autonomii. Interesującą część rozważań tego rozdziału stanowi analiza prawna badań psychologicznych dzieci.

Ostatni szósty rozdział monografii pt. „Prawa dziecka w medycynie, nowe pytania - nowe wyzwania" dotyczy najbardziej kontrowersyjnych, drażliwych i wyjątkowych sytuacji i związanych z nimi problemów prawnych wynikających z rozwijającej się medycyny. Pierwsza część tytułu jest niezbyt fortunna z uwagi na to, że generalnie wszystkie prawa dziecka jak pacjenta opisane w pracy są prawami dziecka w medycynie. Być może należałoby go przeredagować na prawa dziecka wobec rozwijającej się medycyny. Zabrakło w tym miejscu chociażby wzmianki o roszczeniach wrongfull life i wrongfull birth ${ }^{20}$. W niezwykle trudnej etycznie i prawnie problematyce, gdy przyjmujemy, że człowiek ma nie tylko prawo do życia, lecz także do „godnej śmierci” nie można też pomijać ważnych dokumentów międzynarodowych, jak np. Rady Europy — rekomendacja 779 (1976 r.) w sprawie chorych i umierających, czy rezolucja 613 (1976 r.) w sprawie chorych i umierających; Deklaracja wenecka (1983 r.) Światowego Stowarzyszenia Medycznego (WMA) o stanach terminalnych. Oprócz sprawy Nancy Charlotte Fitzmaurice (o której autor napisał na s. 266-270) dotyczącej zaprzestania

18 Warto zwrócić uwagę na koncepcję wypowiedzi dokonawczych i teorię illokucji J. Austina, [w:] F. Studnicki, O wypowiedziach dokonawczych, „Studia Cywilistyczne” 1969, t. XIII-XIV, s. 343-353.

19 Ustawa z dnia 23 kwietnia 1964 r. Kodeks cywilny, tekst jedn. Dz.U. z 2016 r. poz. 380 ze zm.

${ }_{20}$ M. Safjan, Odpowiedzialność za wadliwa diagnoze prenatalna $w$ świetle orzecznictwa USA, „Państwo i Prawo” 1985, z. 10, s. 213 i n. 
uporczywej terapii, sztucznego podtrzymywania życia, skrócenia cierpień dziecka, na co sędzia się zgodził, a sędziowie angielscy są w tej materii bardzo rygorystyczni można też powołać sprawę Diane Pretty (wyrok Izby Lordów z 4 lutego 1993 r. w sprawie Airedale NHS Trust v. Bland, 1993, 1 All ER 821).

Należy podkreślić, że autor konsekwentnie udziela w „Podsumowaniu” odpowiedzi na pytania postawione we „Wstępie”. Pytania te zostały sformułowane również w założeniu przyjętym przy budowie konstrukcji pracy. Począwszy od pytań natury ogólnej, po wyzwania przyszłości. Jednocześnie na uwagę zasługuje wskazanie kierunkowe zawarte w tytule tej części „w stronę godności dziecka”. Praca nie uwzględnia skutków prawnych naruszenia praw pacjenta, a oparta jest na analizie ich treści. Jednak jest to tak obszerny temat, że istotnie nie mieści się w granicach jednego opracowania ${ }^{21}$.

Jednak w ocenianej pracy trzeba zauważyć występujące uchybienia warsztatowe, których nie udało się uniknąć: występujący czasami styl i język mało prawniczy i mało precyzyjny, np. s. 29 „,zaproponowany” przepis, s. 90 „przepis ten wynika”, s. 201-202 „z perspektywy zapisów kodeksu cywilnego wyłoniło się stanowisko [...] w relacji terapeutycznej, jaka pojawia się na terenie szpitala [...] Czy można leczyć na siłę? [...] W podobnej konstelacji zdarzeń medyk nie może jednak zbagatelizować stanowiska [...]; s. 116 - interwencji chirurgicznych, w istocie ,dedykowanych" nie tylko kobiecie w ciąży, ile jej nienarodzonemu jeszcze dziecku [...], oraz błędy literowe na s. 37 „szczekliwej”, s. 75 „naduszenia”, na s. XIX w wykazie literatury i na s. 236 w nazwisku jednego $\mathrm{z}$ autorów.

Podsumowując, lektura monografii jest interesująca z punktu widzenia zarówno poznawczego, jak i naukowego. Recenzowane dzieło stanowi istotny wkład w doktrynę intensywnie rozwijającego się prawa medycznego z uwzględnieniem ujęcia aspektów socjologii prawa. Recenzja ma charakter sprawozdawczy, a nie polemiczny. Uwagi zostały zgłoszone z recenzenckiego obowiązku. Pokazują one, z jak trudnymi i kontrowersyjnymi zagadnieniami przyszło zmierzyć się autorowi i jak różnorodne są w tym zakresie stanowiska doktryny. Istotnym i słusznym przesłaniem recenzowanej pracy jest myśl uzasadniająca szeroką w perspektywie czasowej ochronę dziecka z uwzględnieniem dynamicznego ujęcia praw pacjenta, w postaci uznania, że w ciągu życia człowiek jest tą samą istotą chociaż nie taką samą.

Pawet Dzienis*

* Dr Pawel Dzienis, sędzia i wiceprezes Sądu Rejonowego w Białymstoku, wykładowca Krajowej Szkoły Sądownictwa i Prokuratury, paweldzienis@wp.pl, https://orcid.org/0000-0002-8243-7147

21 Stanowi ona przedmiot odrębnych opracowań np. U. Drozdowska, Cywilnoprawna ochrona praw pacjenta, Warszawa 2007. 
EMIL BRIX, ERHARD BUSEK

\section{Mitteleuropa revisited. Warum Europas Zukunft in Mitteleuropa entschieden wird}

Verlag Kremayr \& Scheriau GmbH \& Co. KG, Wien 2018, s. 223

\section{Mitteleuropa revisited. Warum Europas Zukunft in Mitteleuropa entschieden wird}

The book discusses significant issues of Central Europe's place in the changing geopolitical and economic reality of our continent. Contained therein are diagnoses and prognoses of a possible development, based on the presentation of a historic, cultural and political context of our part of Europe, which was able to become a member of integration processes 15 years ago. This was possible thanks to transformations of 1989 - annus mirabilis of contemporary history. The book also comprises reflections on the relations between the Russian Federation and the Union, as well as the matters of European security in the coming years.

Słowa kluczowe: Europa Środkowa, państwa naddunajskie, Austria, geopolityka, bezpieczeństwo

Key words: Central Europe, Danubian states, Austria, geopolitics, security

Emil Brix — pierwszy z autorów recenzowanej książki jest austriackim dyplomatą, mi.in. był konsulem generalnym Republiki Austrii w Krakowie, ambasadorem w Londynie i w Moskwie, a od 2017 r. pełni funkcję dyrektora Akademii Dyplomatycznej w Wiedniu. Erhard Busek to z kolei polityk chrześcijańsko-demokratycznej Austriackiej Partii Ludowej (ÖVP), jej były sekretarz generalny, który w latach osiemdziesiątych i dziewięćdziesiątych XX w. pełnił funkcje rządowe - wicekanclerza, ministra do spraw nauki oraz oświaty. W latach 2002-2008 był koordynatorem Paktu Stabilizacyjnego dla Europy Południowo-Wschodniej, inicjatywy na rzecz utrwalania pokoju w regionie Bałkanów, będącej reakcją na doświadczenia wojen w byłej Jugosławii. Jest również prezydentem think tanku Instytutu Obszaru Dunaju i Europy Środkowej. Już w 1986 r., a zatem jeszcze przed upadkiem żelaznej kurtyny, obaj autorzy opublikowali książkę „Projekt Mitteleuropa”, natomiast E. Busek w 2008 r. wydał pracę „Dusza dla Europy. Zadania dla kontynentu".

Struktura wewnętrzna publikacji składa się z dziesięciu rozdziałów, „Prologu”, w którym opisano tereny między Rosją a Niemcami i powrotowi idei Międzymorza, „Epilogu” poświęconego rozwojowi demokracji w Europie Środkowej, podziękowania dla osób służących pomocą przy powstawaniu książki oraz wybór literatury, związanej z tytułowym zagadnieniem. Skoro o nim mowa, to przekonanie obu autorów o tym, że przyszłość Europy rozstrzygnie się w jej środkowej części, znajduje odzwierciedlenie we wszystkich dziesięciu rozdziałach.

Rozdział pierwszy to nakreślenie sytuacji w naszej części kontynentu po upadku komunizmu. W drugim przybliżona została droga do akcesji państw Środkowej Europy do Unii Europejskiej. Z kolei w trzecim znajdujemy opis podejścia UE do państw 
naszego obszaru. W rozdziale czwartym autorzy analizują sytuację w państwach bliskiego sąsiedztwa środkowoeuropejskich członków Unii: na Ukrainie, Białorusi, w Mołdawii i na Bałkanach Zachodnich. Piąty zawiera rozważania geopolityczne w kontekście roli Rosji i aktualnej architektury bezpieczeństwa naszego obszaru. Rozdział szósty dotyka zagadnienia nacjonalizmu, a szczególnie jego nawrotów i środków zaradczych w tym kontekście. W siódmym rozdziale uwagę skierowano na kwestie gospodarcze Europy Środkowej, ale też obszaru państw położonych nad Dunajem, a w przypadku Rumunii także w odniesieniu do procesów globalizacji. Ósmy rozdział został poświęcony doniosłej roli religii w szerszej perspektywie terytorialnej niż w rozdziałach poprzedzających, bo w odniesieniu do państw położonych między Niemcami a Rosją, w strefie mórz: Adriatyckiego, Bałtyckiego oraz Czarnego. Rozdział dziewiąty odnosi się do zagadnień migracji, a ostatni — dziesiąty - obejmuje kwestie wkładu Europy Środkowej dla przyszłości całego naszego kontynentu.

Istotne jest wyjaśnienie, jak obaj autorzy interpretują kluczowe w tej książce pojęcie „Europa Środkowa”. Odwołują się do przestrzeni kulturowej rozpostartej od Krakowa do Timişoary (Temesvar) i od Triestu do Lwowa oraz do czasów monarchii Habsburgów (s. 20), której 100. rocznica upadku przypadła w 2018 r. Zaliczają współcześnie do tego regionu: Polskę, Republikę Czeską, Słowację, Węgry, Austrię, Słowenię i Chorwację (s. 22), w czym można zauważyć żywy odnośnik do monarchii austro-węgierskiej. Przywołują inne obecne w literaturze przedmiotu określenia naszego regionu, jak np. „Europa Centralna”, „Europa Środkowo-Wschodnia”, „Międzyeuropa” (w domyśle: między Niemcami a Rosją), „obszar Dunaju” — to ostatnie oddaje w szczególny sposób austriacką perspektywę obu autorów. Wspominają również o koncepcji niemieckiego socjalliberała Friedricha Naumanna, bazującej na zachowaniu niemieckich wpływów, szczególnie w warstwie ekonomicznej w odniesieniu do państw regionu. Nawiązują też do międzywojennych projektów federacji małych i średnich państw położonych między Niemcami a ZSRR w okresie międzywojennym. Szkoda, że w tym miejscu nie wymienili wprost koncepcji Małej Ententy. Porównawczo można dodać, ale w nawiązaniu do kręgu niemieckojęzycznego, że minister obrony RFN w latach dziewięćdziesiątych XX w. w rządzie Helmuta Kohla — Volker Rühe — do państw Europy Środkowej zaliczał: Polskę, Czechy, Słowację, Węgry i Słowenię, ale znamienne jest, że Austrii w tym gronie nie widział' ${ }^{1}$. Brix oraz Busek zasadnie dostrzegają jeden z wymiarów także dzisiejszej percepcji Europy Środkowej — aspekt geopolityczny. Rzecz wiąże się ze sferą buforową między Europą Zachodnią a Wschodnią i zależnościami między tymi dwiema połowami naszego kontynentu (s. 12). Wskazują na utrwalony schemat postrzegania Europy Środkowej jako „peryferii Zachodu", co utrwalił jeszcze okres zimnej wojny (s. 25).

Naddunajscy autorzy odnoszą się do europejskiego kryzysu wartości, w tym niskiego kapitału społecznego oraz deficytu etyki politycznej. Podkreślają odpowiedzialność Europy za prześladowanych na Bliskim Wschodzie nie tylko przez

\footnotetext{
${ }^{1}$ V. Rühe, Deutschlands Verantwortung. Perspektiven für das neue Europa, Berlin 1994, s. 22.
} 
„pozostałości” po ISIS - chrześcijan (s. 14). Przypominają nieodzowność aksjologicznego wymiaru integracji europejskiej, odwołując się do „Duszy dla Europy”, o którą apelował Jacques Delors (s. 47).

Przypominają, że historia Europy to także historia granic między jej narodami i państwami. Dlatego wymieniają szereg zagrożeń dla kontynuowania integracji europejskiej, do których zaliczają: oderwanie elit polityczno-biurokratycznych od obywateli UE; przyspieszanie integracji według odgórnych planów zamiast widzenia jej jako procesu; antagonizmy gospodarcze między UE a Eurazjatycką Unią Gospodarczą tworzoną pod egidą Rosji; ruchy secesjonistyczne w obrębie państw (np. Katalonia, Szkocja); wyzwania związane z finalizacją brexitu; deficyt demokracji w instytucjach unijnych; pogłębianie się zależności gospodarek unijnych od dostaw gazu ziemnego i ropy naftowej od Rosji; spory graniczne między państwami członkowskimi (np. o przebieg granicy morskiej między Słowenią a Chorwacją); niestabilność polityczną Bliskiego Wschodu oraz państw południowo-wschodniej części basenu Morza Śródziemnego; „technokratyzację” procesu integracji kosztem autentyczności i pozytywnego nastawienia europejskiego demosu; zagrożenie populizmem o nastawieniu antyeuropejskim. Dlatego obaj autorzy odwołują się do katalogu propozycji austriackiej publicystki Trautl Brandstaller mających ożywić ideę europejską. Wśród nich znajduje się m.in. powrót do propozycji powołania drugiej izby Parlamentu Europejskiego (Senatu UE), w którym byłyby reprezentowane interesy państw członkowskich, czy wzmocnienie mechanizmów wspólnej polityki zagranicznej i bezpieczeństwa (s. 76-78).

Emil Brix i E. Busek przedstawiają w niniejszej książce zadania czekające decydentów austriackiej polityki zagranicznej. Przypominają, że Austria jako pierwsze państwo środkowoeuropejskie została przyjęta do UE i ów europejski wymiar jej dyplomacji jest szczególnie doniosły. Rok 2018 dla Republiki Austrii to przewodnictwo w pierwszym jego półroczu w Radzie UE. Dla tego państwa ze względów historycznych i kulturowych istotne jest też wzmacnianie potencjału gospodarczego państw naddunajskich. To też stworzenie — w szerszym dialogu z Rosją — jasnej perspektywy akcesji do Unii dla tych spośród państw Partnerstwa Wschodniego, które będą sobie tego życzyły. Wiedeń powinien dążyć na drodze dialogu do tego, aby pozostałe państwa Europy Środkowej nie były gospodarczo i politycznie skłócone z Niemcami, a politycznie także w obszarze bezpieczeństwa z Rosją, aby nie miały odczucia, że w UE są członkami „drugiej klasy” (s. 216).

Autorzy podają wiele przykładów regionalnych inicjatyw współpracy, m.in. Beneluks, Środkowoeuropejskie Porozumienie o Wolnym Handlu (CEFTA), powstałe w ramach procesów przygotowawczych państw Europy Środkowej do przystąpienia do UE. Przypominają postać Gianniego De Michelisa, włoskiego polityka - socjalistę, który sprawując funkcję ministra spraw zagranicznych, zaproponował latem $1989 \mathrm{r}$. zacieśnienie współpracy między Włochami, Austrią, ówczesną Jugosławią i innymi państwami kruszejącego już wtedy bloku wschodniego. Tak narodziła się koncepcja organizacji Pentagonale (przekształconej następnie w Heksagonale), Inicjatywy 
Środkowoeuropejskiej, organizacji nieco dzisiaj zapomnianej. Rzecz jasna nie mogło w tym kontekście zabraknąć odniesień do Grupy Wyszehradzkiej.

W kontekście niezbyt dobrej znajomości historii Europy Środkowej na Zachodzie Europy, autorzy przypominają tzw. aksamitny rozwód Czechów i Słowaków na przełomie lat 1992 i 1993 jako rzadki, konstruktywny przykład pokojowego rozwiązania państwa federalnego właśnie w tej części kontynentu, np. na tle konfliktu w Kraju Basków, w Irlandii Północnej czy na Korsyce.

Obaj autorzy dostrzegli też kwestię Polski, przypominając o przyjeździe do naszego kraju ponad miliona migrantów ekonomicznych z Ukrainy (s. 167). Trzykrotnie pojawia się Kraków (s. 20, we wspomnianym już wcześniej obszarze kulturowym monarchii habsburskiej; s. 28 - w kontekście problemu komunikacyjnego, bowiem w XIX w. pociąg z Krakowa do Wiednia jechał 5 godzin 43 minuty, a dzisiaj jedzie ponad 8 godzin; na s. 195 autorzy proponują, aby Kraków - jako miasto położone w Europie Środkowej — został ogłoszony przez UE jej drugą stolicą).

Książka porusza też aktualną kwestię udzielenia przez patriarchę ekumenicznego Konstantynopola autokefalii dla jednego z niekanonicznych kościołów prawosławnych działającego na Ukrainie (s. 140, 148).

Autorzy nie omijają trudnych zagadnień związanych np. z traumą Węgrów po traktacie z Trianon czy instrumentalizacji historii dla kształtowania tożsamości narodowej. W tym drugim kontekście przywołują zakłamanie najnowszej historii Austrii do lat osiemdziesiątych XX w., dokąd funkcjonował mit tego państwa jako „pierwszej ofiary Hitlera" w kontekście anszlusu w 1938 r. Skandal związany ze zbrodniczą kartą w biografii Kurta Waldheima, prezydenta Austrii, po raz kolejny przypomniał skalę zaangażowania Austriaków w latach 1938-1945 w różne formy totalitaryzmu III Rzeszy (s. 30, 32, 190).

Emil Brix oraz E. Busek odnoszą się także do muzułmanów w Austrii, opisując w sposób syntetyczny funkcjonowanie ustawy o islamie z 1912 r. Przytaczają interesujący fakt, że turecki ambasador w Wiedniu ma zadanie podejmowania wysiłku, aby zawsze przewodniczącym Wspólnoty Islamskiej w Austrii był Turek (s. 149). Wskazują na zasadnicze napięcie między europejskim podejściem, że to człowiek jest nosicielem praw i obowiązków, a ujęciem islamu, w którym te prawa i wolności człowiek może realizować wyłącznie jako członek wspólnoty wyznawców tej religii (s. 150-152).

W moim przekonaniu, autorzy, wzmiankując w książce o austriackim modelu neutralności ${ }^{2}$, mogli odnieść się do kwestii jego zastosowania w kontekście innych państw, np. Mołdawii. Brakuje też informacji o członkostwie Austrii w Radzie Europy — pierwszej organizacji integracyjnej powstałej w 1949 r., w której uczestnictwo nie kolidowało z neutralnością Republiki, przyjętą w traktacie państwowym w $1955 \mathrm{r}$. oraz w porządku konstytucyjnym. Z pewnością inspirujący jest pomysł zorganizowania

2 Vide w tym kontekście pogląd kanclerza Austrii B. Kreisky’ego; B. Kreisky, Erinnerungen. Das Vermächtnis des Jahrhundertpolitikers, Wien 2014, m.in. s. 311-313. 
konferencji „Helsinki II”, o czym wspominają obaj autorzy (s. 103), jakkolwiek nie pod auspicjami OBWE - ze względu na rozliczne podziały w obrębie tej organizacji, ale w zgoła odmiennym formacie negocjacyjnym i niezbyt bliskiej przyszłości, mianowicie NATO-OUBZ (Organizacja Układu o Bezpieczeństwie Zbiorowym). Autorzy nie wspomnieli też o uchwalonej w okresie rządów koalicji socjaldemokratyczno-chadeckiej nowej ustawy o islamie w 2015 r., która derogowała starą z 1912 r. Unormowano w niej wiele ważnych kwestii związanych także z bezpieczeństwem państwa. Opisując różne formy współpracy Austrii z Republiką Czeską (s. 179, 181), autorzy mogli przypomnieć o inicjatywie premiera Czech Bohuslava Sobotki (2013-2017), dotyczącej powołania nowego formatu kontaktów czesko-słowacko-austriackich, tzw. Trójkąta Slavkowskiego.

Książka zainteresuje z pewnością przede wszystkim politologów, prawników oraz historyków. Zasadne byłoby jej przetłumaczenie na język polski, ze względu na m.in. dowartościowanie Europy Środkowej w szerokim widzeniu przyszłości integracji europejskiej, w kontekście dziedzictwa kulturowego i doświadczeń historycznych państw tego regionu. Dla udostępnienia jej czytelnikom zasadne byłoby zaopatrzenie w nią m.in. bibliotek austriackich działających na niektórych naszych uczelniach.

\section{Pawet A. Leszczyński*}

* Dr hab. Pawel A. Leszczyński, prof. nadzw. Akademii im. Jakuba z Paradyża w Gorzowie Wielkopolskim, paw.lesz@wp.pl, https://orcid.org/0000 000277011758 
PRZEGLLD SEJMOWY $\quad$ nr 2(151)/2019, s. 195-214; https://doi.org/10.31268/PS.2019.33

Moldawia: postanowienie Sądu Konstytucyjnego nr 2 z 20 stycznia 2015 r. o wykładni art. 1 ust. 3 w związku z art. 69 i 70 Konstytucji Republiki Mołdawii (immunitet i wygaśnięcie mandatu deputowanego)

Mołdawia: judgment of the Constitutional Court of 20 January 2015 no. 2 on the interpretation of Article 1 para. 3 combined with Articles 69 and 70 of the Constitution of the Republic of Moldova (immunity and termination of mandate of a member of Parliament)

Judgment no. 2 of the Constitutional Court of Moldova of 20 January 2015 refers to the issue of parliamentary immunity and the cases of termination of a mandate of a member of Parliament as foreseen by the Constitution of the Republic of Moldova. The Constitutional Court laid down the scope interpretation of Articles 69 and 70 of the Constitution, adjudicating that a Deputy sentenced with a valid court judgment does not enjoy the privilege of parliamentary immunity. Also, the privilege is not applied where a national court recognizes a sentence passed by a court of a foreign state. A person sentenced with a valid court judgment for a crime committed with intention or sentenced to a prison term loses its right to be elected, hence cannot be legitimately elected to the Parliament. He/she also loses his/her mandate ex lege after the judgment had been passed.

Słowa kluczowe: immunitet parlamentarny, mandat przedstawicielski, Mołdawia, nietykalność parlamentarna, Sąd Konstytucyjny

Key words: parliamentary immunity, representative mandate, Moldova, parliamentary privilege, Constitutional Court

Sad Konstytucyjny Mołdawii dokonat wykładni postanowień ustawy zasadniczej dotyczacej immunitetu oraz przypadków wygaśnięcia mandatu deputowanego. Wniosek o wyktadnię art. 69 (,,Mandat deputowanego”) i art. 70 Konstytucji Republiki Moldawii (,,Niepołaczalność i immunitet”) w zwiqzku z art. 1 (,,Państwo prawa”) zostat złożony 6 lutego 2014 r. osobiście przez parlamentarzystę.

Wnioskodawca prosit w nim o udzielnie odpowiedzi na następujące pytania:

1. Czy deputowany Parlamentu Republiki Moldawii, skazany za popetnienie czynów korupcyjnych i/lub osiagnięcie korzyści z wpływów, zagrożonych karą pozbawienia 
wolności, która podlega wykonaniu, oraz poszukiwany międzynarodowym listem gończym nie może korzystać ze statusu deputowanego i ostatecznie nie może petnić mandatu z powodów politycznych i moralnych?

2. Czy immunitet deputowanego uznaje się za utracony z mocy prawa $w$ przypadku wydania ostatecznego i obowiazujacego wyroku i czy prezydent Republiki Mołdawii ma obowiązek wykazać inicjatywę i pozbawić deputowanego mandatu, aby zagwarantować wykonanie wyroku pozbawienia wolności?

3. Czy za utracony z mocy prawa uznaje się immunitet deputowanego w przypadku skazania go $w$ okresie sprawowania przez niego mandatu prawomocnym wyrokiem sądu innego państwa za popetnienie czynów korupcyjnych i/lub osiqgnięcia korzyści z wplywów, zagrożonych kara pozbawienia wolności, która podlega wykonaniu, poszukiwanego międzynarodowym listem gończym, odpowiednio do przepisów Karty Organizacji Narodów Zjednoczonych oraz umów podpisanych przez Republike Mołdawii, zgodnie z normami konstytucyjnymi, i czy kompetentne organy maja obowiazek wykonywać postanowienia ustawodawstwa krajowego oraz międzynarodowych/regionalnych/dwustronnych umów, dotyczacych udzielenia międzynarodowej pomocy prawnej na wniosek innego państwa, którego obywatelem jest skazany deputowany, w celu zapewnienia wykonania decyzji sądu?

Kluczowa dla niniejszej sprawy instytucja pozbawienia deputowanego mandatu parlamentarnego po raz pierwszy zostata zapisana w konstytucji Mołdawii z 1994 r. Uregulowanie przyczyn tego pozbawienia ustrojodawca pozostawit do uregulowania w ustawie. Postanowienia ustawy nr 39-XIII z dnia 7 kwietnia 1994 r. o statusie deputowanego Parlamentu, w których określono pozbawienia mandatu, byly wielokrotnie zmieniane. W ustawie $\mathrm{nr}$ 1157-XV z dnia 21 czerwca 2002 r. o statusie deputowanego pozbawienie mandatu deputowanego przewidziano $w$ dwóch przypadkach: a) niepołaczalności, b) skazania na mocy ostatecznej decyzji sadu w sprawie umyślnego przestępstwa (art. 2 ust. 1). Zgodnie z art. 2 ust. 11 ustawy, pozbawić mandatu deputowanego mógt Sąd Konstytucyjny na wniosek Parlamentu. Postanowienia te zostaly uchylone ustawa nr 141 $z$ dnia 21 marca 2003 r. Do momentu orzekania przez Są Konstytucyjny ta instytucja prawna była martwa wobec braku odpowiednich uregulowań w ustawie zwyktej.

$W$ wyniku zmian wprowadzonych 17 czerwca 2015 r. zagadnienie to zostało uregulowane art. 2 ust. $6^{1}$ i $8^{1}$ ustawy o statusie deputowanego Parlamentu, zgodnie $z$ którymi pozbawienie mandatu deputowanego może nastapić w przypadku:

a) stwierdzenia ostatecznym aktem dokonania bezpośrednio lub poprzez osobe trzecia transakcji, podjęcia lub uczestniczenia w podjęciu decyzji bez rozstrzygnięcia faktycznego konfliktu interesów zgodnie z ustawodawstwem dotyczącym regulowania konfliktu interesów;

b) niezłożenia deklaracji majątkowej [...] lub odmowy jej złożenia zgodnie $z$ ust. 8 art. 27 ustawy nr 132 z dnia 17 czerwca 2016 r. o Narodowym Organie ds. Korupcji;

c) nakazu konfiskaty niewykazanego majątku na podstawie prawomocnej decyzji sądu. 
W tych przypadkach decyzje o pozbawieniu mandatu podejmuje Parlament większościa głosów wybranych deputowanych na wniosek Narodowego Organu ds. Korupcji.

$W$ innym aspekcie immunitet parlamentarny konstytucyjnie $i$ ustawowo nie ewoluowat, choć w 2002 r. przygotowano projekt zmian do art. 70 i 71 konstytucji, w którym ograniczono immunitet parlamentarny. Zgodnie z projektem możliwe byłoby tymczasowe aresztowanie, przeszukanie i pociagnięcie deputowanego do odpowiedzialności bez zgody organu ustawodawczego. W okresie między rokiem 2011 a 2014 ponowie podjęto próbę zmiany art. 70 i 71 konstytucji, analogicznie do zmian postulowanych $w 2002$ r. Jednak projekt, którym starano się ograniczyć immunitet parlamentarny, nie uzyskat niezbędnej liczby głosów.

Odnośnie do wniosków w sprawie pozbawienia immunitetu z lat 2001-2011 składanych $w$ Parlamencie przez prokuratora generalnego można zauważyć, że organy prawne wystepujace o pozbawienie immunitetu parlamentarnego podejmowaty dziatania wytacznie wobec deputowanych opozycji parlamentarnej.

Ostatecznie w niniejszej sprawie Sąd Konstytucyjny Mołdawii rozpatrzyt trzy zagadnienia:

1. Czy przywilej nietykalności parlamentarnej przysługuje deputowanemu, wobec którego została wydana ostateczna decyzja sądu w sprawie popetnienia umyślnych przestęstw?

2. Czy przywilej nietykalności parlamentarnej przystuguje deputowanemu w ramach procedury uznania $i$ wykonania ostatecznej decyzji sadu wydanej przez sąd innego państwa $w$ sprawie popetnienia przestęstwa umyślnego?

3. Mandat deputowanego, wobec którego została wydana ostateczna decyzja sądu w sprawie popetnienia przestepstwa umyślnego.

\section{POSTANOWIENIE ${ }^{1}$}

$[\ldots]$

I. CZY PRZYWILEJ NIETYKALNOŚCI PARLAMENTARNEJ

PRZYSŁUGUJE DEPUTOWANEMU, WOBEC KTÓREGO

ZOSTAŁA WYDANA OSTATECZNA DECYZJA SĄDU

W SPRAWIE POPEŁNIENIA UMYŚLNYCH PRZESTĘPSTW?

\section{Argumenty autora wniosku}

35. Wychodząc z założeń art. 16 konstytucji, autor wniosku stwierdza, że wobec deputowanych, skazanych za popełnienie czynów korupcyjnych i/lub osiągnięcie korzyści z wpływów, powinny być stosowane takie same wymogi ustawy, jak wobec pozostałych obywateli.

\footnotetext{
1 Tekst postanowienia został opublikowany w jęz. rumuńskim i rosyjskim na stronie Sądu Konstytucyjnego Mołdawii: <http://www.constcourt.md>, dostęp 15 I 2017.
} 
36. W opinii autora wniosku ostateczny i posiadający klauzulę wykonalności wyrok prowadzi do utraty prawa do korzystania z przywileju nietykalności deputackiej, a właściwe organy mają obowiązek wykonania wyroku w trybie przewidzianym ustawą.

\section{Argumenty organów władzy państwowej}

37. W pisemnej opinii Parlamentu zauważono, że za naruszenia prawa niezwiązane $\mathrm{z}$ głosowaniem lub wyrażaniem poglądów politycznych w związku ze sprawowaniem mandatu deputowany ponosi odpowiedzialność prawną jak każdy inny obywatel, korzystając jedynie z ulg o charakterze proceduralnym. Jednak gwarancje proceduralne w żaden sposób nie zwalniają go z odpowiedzialności karnej, a jedynie odraczają moment wszczęcia postępowania karnego, postawienia przed sądem i postępowania sądowego za czyny kryminalne lub naruszenia administracyjne sprzeczne ze sprawowaniem mandatu.

38. Na otwartym posiedzeniu Sądu Konstytucyjnego przedstawiciel Parlamentu doprecyzował, że jeżeli deputowany został skazany, oznacza to, że pozbawiono go przywileju nietykalności, innej drogi nie ma. Jego zdaniem immunitet jest chroniony przez cały okres postępowania sądowego.

39. W opinii przedstawiciela Parlamentu, jeżeli naruszenie prawa zostało dokonane przed wybraniem na deputowanego Parlamentu, sąd ma prawo rozpatrzyć sprawę i nie występować o pozbawienie przywileju nietykalności. Jednak w praktyce sądy zawieszają rozpatrywanie sprawy i składają do Parlamentu wniosek o pozbawienie przywileju nietykalności. W takich przypadkach, jeżeli Parlament odmówi poparcia wniosku o pozbawienie deputowanego przywileju nietykalności, to zgodnie z postanowieniami kodeksu postępowania karnego rozpatrywanie sprawy zostaje zawieszone do czasu wygaśnięcia mandatu deputowanego.

\section{Ocena Sądu Konstytucyjnego}

40. Ze względu na swoją pozycję deputowany posiada określony status, z którego wynikają liczne prawa i obowiązki mające na celu zagwarantowanie mu swobodnego sprawowania mandatu i niezależności oraz ochronę przed naciskami mogącymi podważyć jego niezależność. Takimi gwarancjami są: system wynagradzania pracy, ochrona socjalna, niepołączalność i przywilej nietykalności deputowanego.

41. Zgodnie $\mathrm{z}$ art. 70 ust. 3 konstytucji deputowany nie może być zatrzymany, tymczasowo aresztowany, poddany przeszukaniu, oprócz przypadków zatrzymania na miejscu popełnienia przestępstwa, lub być pociągnięty do odpowiedzialności prawnej bez zgody Parlamentu wyrażonej po wysłuchaniu deputowanego.

42. Jednocześnie $w$ art. 71 konstytucji przewidziano, że deputowany nie może podlegać ściganiu lub pociągnięciu do odpowiedzialności prawnej za głosowanie lub za poglądy wyrażane w okresie sprawowania mandatu.

43. Wymienione normy konstytucyjne rozwinięto $\mathrm{w}$ ustawie o statusie deputowanego Parlamentu i w regulaminie Parlamentu. 
44. Sąd Konstytucyjny zauważa, że choć system konstytucyjny Republiki Mołdawii gwarantuje jednocześnie brak odpowiedzialności (immunitet materialny) i nietykalność (immunitet formalny), w rozpatrywanej sprawie Sąd Konstytucyjny przeanalizuje tylko aspekt nietykalności parlamentarnej. W tym kontekście Sąd Konstytucyjny uznaje za konieczne doprecyzowanie, że kwestie funkcjonowania w Republice Mołdawii przywileju nietykalności parlamentarnej i stosowania norm konstytucyjnych wobec deputowanego, w stosunku do którego została wydana ostateczna decyzja sądu w sprawie popełnienia umyślnych przestępstw, będą rozpatrywane in abstracto.

\subsection{Granice nietykalności parlamentarnej w praktyce innych państw}

45. Pojęcie „nietykalności parlamentarnej” nie ma jednolitego charakteru. Bez względu na różnorodność pojęć i definicji wykorzystywanych w ustawodawstwach krajowych oraz na granice ochrony w różnych państwach, w większości państw europejskich uznaje się dwie kategorie nietykalności deputackiej: z jednej strony ,brak odpowiedzialności deputowanego” lub „swobodę wyrażania”, kiedy mowa o ściganiu z urzędu w związku z głosowaniem i wyrażaniem poglądów podczas pełnienia obowiązków urzędowych; i z drugiej strony ,nietykalność parlamentarną” lub ,immunitet w ścisłym znaczeniu tego słowa", który chroni parlamentarzystę przed tymczasowym aresztowaniem, pozbawieniem wolności lub ściganiem z urzędu bez zgody izby, w skład której wchodzi.

[Opinia Komisji Weneckiej w sprawie immunitetu parlamentarnego (CDL-INF (96)7) przyjęta na 27. sesji plenarnej, która odbyła się 17-18 maja 1996 r.]

46. Gwarancje, które wynikają z tych dwóch aspektów przywileju nietykalności parlamentarnej (braku odpowiedzialności/nietykalności, ,wolności wyrażenia opinii/ prawa do niebycia aresztowanym") są dodatkami [Opinia Komisji Weneckiej w sprawie immunitetu parlamentarnego..., § 27].

47. W kwestii stosowania przywileju nietykalności Komisja Wenecka zauważyła, co następuje:

„184. Komisja Wenecka uważa, że regulacje dotyczące nietykalności parlamentarnej nie są niezbędne we współczesnej demokracji. W dobrze ukształtowanym systemie politycznym istnieją inne mechanizmy ochrony członków parlamentu, nie potrzebują oni immunitetu takiego typu.

185. Komisja Wenecka przyznaje, że w innych państwach regulacje dotyczące nietykalności mogą chronić demokratyczny parlament jako instytucję oraz opozycję parlamentarną, zwłaszcza przed niewłaściwymi naciskami lub prześladowaniem ze strony oponentów politycznych, władzy wykonawczej czy sądowniczej. Regulacje w sprawie nietykalności parlamentarnej są uzasadnione tam, gdzie nie ma innych adekwatnych środków ochrony członków Parlamentu, powinny one jednak podlegać ograniczającej wykładni i stosowaniu. Podobne regulacje muszą odpowiadać określonym ograniczeniom i warunkom, a pozbawienie deputowanego musi przebiegać zgodnie z jasną i bezstronną procedurą".

[Opinia o granicach i pozbawieniu przywileju nietykalność parlamentarnej (CDL-AD (2014)011), przyjęta na 98. sesji plenarnej, 21-22 marca 2014 r.] 
48. W zakresie charakteru i stopnia ochrony przywilej nietykalności deputowanych ma w różnych krajach różne wyróżniające je cechy. Różnice, odzwierciedlając polityczne i historyczne doświadczenia każdego państwa, wynikają z realnej sytuacji, jaka jest podstawą przywileju nietykalności parlamentarnej. Przywilej ten nierozerwalnie związany z podziałem władzy państwowej, zachowaniem autonomii parlamentarnej i ochroną opozycji w parlamencie — jest stosowany w każdym państwie w zależności od stopnia autonomii parlamentu, niezbędnego do pełnienia przez parlament swoich funkcji.

49. Granice nietykalności są różne w zależności od państwa. Charakter przywileju nietykalności wynika z różnorodności systemów prawnych. W niektórych państwach taka zasada nie istnieje (Holandia, San Marino). W niektórych państwach, jak Wielka Brytania, przywilej nietykalności jest stosowany jedynie przy rozpatrywaniu spraw cywilnych, natomiast w sprawach karnych deputowany jest traktowany tak, jak inni obywatele. W Irlandii i Norwegii deputowany podlega ograniczonej ochronie - nie może on być aresztowany w czasie sesji parlamentarnej, w drodze do miejsca przeprowadzenia sesji lub w drodze powrotnej.

50. Większość państw europejskich udziela deputowanym pozafunkcyjnego immunitetu w sprawach karnych na czas sprawowania mandatu (Albania, Niemcy, Austria - jeśli działania dotyczą funkcji politycznych - Cypr, Hiszpania, Grecja, Węgry, Litwa, Polska, Rosja, Seria, Szwajcaria) i/lub ochrony przed środkami przymusu i pozbawieniem wolności (tymczasowe aresztowanie lub pozbawienie wolności we wszystkich krajach, gdzie istnieją regulacje dotyczące immunitetu chroniące przed postępowaniem karnym, pośród nich: Belgia, Francja, Gruzja, Włochy, Portugalia i Rumunia). Postępowania karne i stosowanie środków przymusu nie jest możliwe bez zgody zgromadzenia (Cypr stanowi wyjątek).

51. W wielu krajach reformy konstytucyjne doprowadziły do ograniczenia przywileju nietykalności. Tak np. we Francji w wyniku reformy konstytucyjnej z 1995 r. zgoda izby na wszczęcie procedury karnej nie jest obowiązkowa, jest ona niezbędna tylko do zatrzymania, tymczasowego aresztowania i zastosowania innych środków kontroli sądowej. We Włoszech ustawą konstytucyjną nr 3 z dnia 29 października 1993 r. zostały uchylone regulacje dotyczące wstępnej zgody izby na wszczęcie procedury karnej wobec deputowanego. W Rumunii wskutek reformy konstytucyjnej z 2003 r. możliwe stało się postępowanie sądowe i postępowanie karne wobec deputowanego za czyny niemające odniesienia do głosowania lub wyrażania poglądów politycznych w trakcie sprawowania mandatu deputowanego.

52. W Niemczech (przy zwoływaniu Bundestagu) istnieje praktyka związana z pozbawianiem przywileju nietykalności deputackiej za wszystkie rodzaje przestępstw (oprócz zniesławienia z powodów politycznych), która ma chronić wszystkich członków Bundestagu przed prasą w przypadku wszczęcia wobec nich postępowania karnego.

53. Co zaś dotyczy zastosowania ratione materiae przywileju nietykalności parlamentarnej, konkretnie w odniesieniu do czynów związanych z przywilejem nietykal- 
ności parlamentarnej, w większości państw europejskich zauważa się tendencję do nieobejmowania parlamentarzystów przywilejem nietykalności w przypadku zatrzymania na miejscu popełnienia przestępstwa. W tym przypadku izba nie powinna wyrażać swojej zgody, co nie stanowi dla niej przeszkody do wypowiadania się później w sprawie postępowania karnego lub tymczasowego aresztowania, żeby w razie konieczności zażądać zawieszenia lub pozbawienia mandatu (Gruzja i Rumunia). Ustawodawstwa niektórych krajów wykluczają ze sfery stosowania przywileju nietykalności niektóre działania, zależnie od ich charakteru i wagi, a także kary (w konstytucji Portugalii w niektórych przypadkach wykluczono przestępstwa, za które przewidziano karę powyżej trzech lat pozbawienia wolności).

54. Okres przysługiwania przywileju nietykalności parlamentarnej także jest różny w zależności od państwa. W niektórych ustrojach parlamentarnych przywilej ten ma zastosowanie w odniesieniu do spraw karnych wszczętych do czasu wybrania deputowanego do parlamentu (Niemcy, Belgia, Hiszpania, Węgry, Włochy, Portugalia). W innych krajach chociaż na kontynuowanie wszczętej sprawy karnej nie jest wymagana zgoda parlamentu, zgromadzenie może zażądać - z własnej inicjatywy lub na prośbę zainteresowanej strony — zawieszenia procedury karnej lub uchylenia środków zapobiegawczych na okres sprawowania mandatu (Francja, Polska, Szwajcaria).

\subsection{Orzecznictwo ETPC}

55. Przy rozpatrywaniu spraw A. przeciw Wielkiej Brytanii (nr 35373/1997, CEDH-2002-X), Kordoba przeciwko Włochom (nr 45649/1999, CEDH 2003-I), C.G.IL przeciwko Włochom (nr 46967/2007 z 24 lutego 2009 r.) i Tsalkitzis przeciwko Grecji (nr 11801/2004 z 16 listopada 2006 r.). ETPC potwierdził zasadę kontroli zgodności realizacji przywileju nietykalności przez sąd z prawem do sądu przewidzianym $\mathrm{w}$ art. 6 ust. 1 Konwencji, co rozwinięto w postanowieniu Kart przeciwko Turcji z 3 grudnia 2009 r. (§ 58).

56. Wymienionymi postanowieniami, w szczególności dwoma postanowieniami z 2009 r. (C.G.IL przeciwko Włochom (nr 46967/2007 z 24 lutego 2009 r. i Kart z 3 grudnia 2009 r.), ETPC ograniczył efekt ochrony deputowanego przed sądem, zgodnie z zasadą, że niepodleganie sądom w sprawach karnych i cywilnych oraz zwalnianie całych grup lub kategorii osób z wszelkiej odpowiedzialności jest nie do pogodzenia z rządami prawa w demokratycznym społeczeństwie.

57. ETPC przyznał, że państwa przyznają deputowanym różne zakresy nietykalności parlamentarnej. Praktyka ta ma na celu ochronę swobody wyrażania opinii oraz zachowanie podziału władzy ustawodawczej i sądowniczej (A. przeciw Wielkiej Brytanii, §§ 75-78, Kordoba (nr 1), §55, Kordoba (nr 2), § 56 i De Jorio, § 49). Różne formy nietykalności parlamentarnej faktycznie służą demokracji politycznej, która stanowi podwalinę Konwencji w zakresie, w jakim zapewniają one ochronę autonomii ustawodawczej i opozycji parlamentarnej.

58. W kontekście zgodności z Konwencją to im szerszy jest zakres nietykalności parlamentarnej, tym poważniejsze powinny być powody, które ją uzasadniają 
(A. przeciw Wielkiej Brytanii, § 78). Brak wyraźnego związku z działalnością parlamentarną pociąga za sobą ograniczającą wykładnię pojęcia proporcjonalności między postulowanym celem a wykorzystywanymi środkami. Sytuacja ta ma zastosowanie szczególnie wówczas, gdy ograniczenia prawa dostępu wynikają z procedowania w organie politycznym (sprawa Tsalkitzis, § 49). W tym kontekście spór między osobami prywatnymi nie może uzasadnić odmowy w udzieleniu dostępu do wymiaru sprawiedliwości z tej prostej przyczyny, że odmowa może mieć polityczny charakter lub może być związana z działalnością polityczną (Kordoba, $\mathrm{nr} 1, \S 62$, Kordoba, nr 2, § 63 i De Jorio, § 53).

\subsection{Granice nietykalności parlamentarnej w Republice Mołdawii}

59. Zakres stosowania przywileju nietykalności parlamentarnej jest rozpatrywany w czterech aspektach, mających istotne znaczenie: ratione personae (podmioty ochrony), ratione temporis (początek i koniec ochrony), ratione loci (przestrzenne granice ochrony) i ratione materiae (akty podlegające działaniu przywileju nietykalności).

\section{Ratione personae}

60. Przywilej nietykalność stanowi intuitu personae i przysługuje wyłącznie osobom posiadającym status deputowanego.

\section{Ratione temporis}

61. Deputowani korzystają z przywileju nietykalności parlamentarnej od momentu ich wybrania, z możliwością niepotwierdzenia ich wybrania.

62. Ograniczony w czasie i określony przez specyficzne normy, które dotyczą szczególnie uchylenia przywileju nietykalności, immunitet stanowi tymczasową przeszkodę procesową w przeprowadzeniu procedury karnej, jednak nie uniemożliwia to osobie zainteresowanej możliwości uzyskania ostatecznego rozstrzygnięcia sporu.

63. Skutki nietykalności parlamentarnej dla prowadzenia procedury karnej mają charakter tymczasowy. Jednocześnie struktury parlamentarne nie mogą ingerować w proces wymiaru sprawiedliwości. Po rozpatrzeniu wniosku o pozbawienie przywileju nietykalności parlamentarnej, muszą one rozstrzygnąć, czy przywilej nietykalności, o charakterze środka tymczasowego zawieszenia procesu sądowego, powinien być uchylony niezwłocznie, czy lepsze będzie zaczekanie na wygaśnięcie mandatu parlamentarnego. W ten sposób Parlament może jedynie zawiesić proces wymiaru sprawiedliwości, nie ingerując weń i nie biorąc w nim udziału.

64. Procedury wszczęte przed otrzymaniem mandatu są kontynuowane - zgodnie z przepisami ustawy ogólnej — odpowiednio do ich etapu.

Należy odróżniać następujące przypadki:

— jeśli osoba została „pociągnięta do odpowiedzialności” za popełnienie przestępstwa karnego przed wybraniem jej do Parlamentu, procedura trwa, podobnie jak w przypadku każdego innego obywatela i nie ma konieczności pozbawiania jej immunitetu; 
— jeśli osoba nie została „pociągnięta do odpowiedzialności” przed wybraniem jej do Parlamentu, korzysta ona z przywileju nietykalności i pozbawienie jej immunitetu jest konieczne.

65. W związku z tym zawieszenie rozpatrywania sprawy i zwrócenie się z wnioskiem o pozbawienie przywileju nietykalności osoby ,pociągniętej do odpowiedzialności" przed wybraniem do Parlamentu jest sprzeczne z normami konstytucyjnymi.

\section{Ratione loci}

66. Miejsce naruszenia prawa nie wpływa na zastosowanie przywileju nietykalności parlamentarnej.

\section{Ratione materiae}

67. Zakres stosowania przywileju nietykalności parlamentarnej w Republice Mołdawii ograniczony jest do spraw karnych (i - analogicznie — administracyjnych). W konstytucji nie zawarto jakiegokolwiek rozróżnienia co do charakteru i wagi czynu.

68. Nietykalność nie uniemożliwia ścigania. Zgodnie z art. 70 ust. 3 konstytucji, bez zgody Parlamentu deputowany nie może być: zatrzymany, tymczasowo aresztowany, poddany rewizji, pociągnięty do odpowiedzialności sądowej — oprócz przypadków zatrzymania na miejscu popełnienia przestępstwa.

69. Tym samym zasada nietykalności działa tylko w odniesieniu do określonych i ograniczonych środków procesowych - wyraźnie wymienionych w konstytucji — jak: zatrzymanie, tymczasowe aresztowanie, rewizja. Jest jednak jeden wyjątek, a mianowicie „zatrzymanie na miejscu popełnienia przestępstwa”.

70. Tak więc sprawa jest wszczynana i prowadzone jest postępowanie karne tylko wobec deputowanego zatrzymanego na miejscu popełnienia przestępstwa, bez konieczności pozbawienia go przywileju nietykalności.

71. Po zakończeniu postępowania karnego prokurator sporządzający pisemny akt oskarżenia może skierować sprawę do sądu tylko po pozbawieniu deputowanego przywileju nietykalności, zgodnie z przepisami regulaminu Parlamentu.

72. Sąd Konstytucyjny dopuszcza, że postępowanie karne i stosowne środki przymusu wobec deputowanego mogą naruszać działalność Parlamentu i wpływać na pracę parlamentarną. W tym kontekście Sąd Konstytucyjny uznaje instytucjonalną funkcję tej prerogatywy, gwarantującą normalną pracę i nieprzekupność organu parlamentarnego. W tych okolicznościach odstąpienie od ogólnej zasady jest uzasadnione zakładanym celem.

73. Zgodnie $\mathrm{z}$ art. 70 ust. 3 konstytucji przywilej nietykalności parlamentarnej zapewnia deputowanym w Republice Mołdawii ochronę przed postępowaniem sądowym za działania, które nie mają związku z działalnością parlamentarną.

74. Niemniej wymogi rządów prawa zobowiązują do uwzględniania uzasadnionych celów przy ustanawianiu immunitetu parlamentarnego, jak zagwarantowanie nieprzekupności Parlamentu i ochrona opozycji. 
75. Uwzględniając sens istnienia immunitetu parlamentarnego, jego zbędne i bezmyślne używanie w sprawach niemających nic wspólnego z urzędem publicznym jest szkodliwe w kontekście zaufania społeczeństwa do samego systemu demokracji parlamentarnej. Im mniej dotyczy on zadań urzędu publicznego, tym poważniejsze muszą być podstawy do zastosowania tego przywileju, wobec czego niezbędne staje się uzasadnienie odmowy przyjęcia wniosku o pozbawienie immunitetu parlamentarnego. Kiedy immunitet wykorzystywany jest do ochrony osoby przed postępowaniem karnym, niezbędne są jasne i przekonujące podstawy do odmowy pozbawienia immunitetu.

76. Odnośnie do immunitetu prezydenta kraju w postanowieniu Uriekjan i Pawliczenko przeciwko Mołdawii ETPC zauważył, że w zakresie wyrażenia opinii przez prezydenta immunitet nie ma charakteru absolutnego, dotyczy on jedynie poglądów wynikających z prezydenckich uprawnień. Stosowanie postanowień dotyczących immunitetu bez analizy problemu konfliktu interesów wskazuje na formalne podejście do immunitetu. ETPC doszedł do wniosku, że konieczne jest odrzucenie formalnego podejścia do przywileju nietykalności i immunitetu.

77. Co zaś tyczy się wymogu walki z korupcją, Sąd Konstytucyjny zauważa, że zgodnie z rezolucją (97) 24 Komitetu Ministrów Rady Europy (uchwaloną 6 listopada 1997 r.), w sprawie 20 głównych zasad walki z korupcją, państwa „muszą ograniczać immunitet w przypadku dochodzenia, postępowania sądowego lub wydania decyzji sądu w sprawach dotyczących aktów korupcji odpowiednio do stopnia niezbędnego w demokratycznym społeczeństwie” (pkt 6) oraz „wspierać badania w obszarze korupcji” (pkt 18).

78. Zgodnie z art. 30 ust. 2 Konwencji ONZ przeciwko korupcji (z 31 października 2003 r.): „Każde Państwo Strona podejmuje takie środki, jakie mogą być konieczne w celu ustanowienia i utrzymania, zgodnie ze swoim systemem prawnym i zasadami konstytucyjnymi, stosownej równowagi pomiędzy wszelkimi immunitetami lub przywilejami jurysdykcyjnymi przyznanymi funkcjonariuszom publicznym z tytułu pełnienia przez nich funkcji a możliwością — o ile to konieczne — skutecznego dochodzenia, ścigania i orzekania w sprawie przestępstw ustanowionych zgodnie z niniejszą Konwencją".

79. Uwzględniając fakt, że deputowany zostaje pozbawiony immunitetu na etapie kierowania sprawy do sądu, wykonanie wyroku w sprawie karnej wobec deputowanego nie wymaga odrębnego pozbawienia immunitetu, ponieważ wykonalność stanowi nieodłączną część procesu sądowego i deputowany już nie korzysta z prawa do nietykalności.

\section{Wnioski}

80. W kontekście art. 70 ust. 3 konstytucji przywilej nietykalności parlamentarnej nie przysługuje deputowanemu, wobec którego została wydana ostateczna decyzja sądu. Od momentu ,pociągnięcia do odpowiedzialności” kończy się nietykalność. 


\section{CZY PRZYWILEJ NIETYKALNOŚCI PARLAMENTARNEJ PRZYSŁUGUJE DEPUTOWANEMU W RAMACH PROCEDURY UZNANIA I WYKONANIA OSTATECZNEJ DECYZJI SĄDU WYDANEJ PRZEZ SĄD INNEGO PAŃSTWA W SPRAWIE POPEŁNIENIA PRZESTĘPSTWA UMYŚLNEGO?}

\section{Argumenty autora wniosku}

81. Autor wniosku uważa, że w przypadku skazania deputowanego ściganego międzynarodowym listem gończym w sprawie czynu korupcyjnego ostatecznym i prawomocnym wyrokiem innego państwa przywilej nietykalności traci moc prawną i wygasa z mocy prawa.

82. Na poparcie swoich tez autor wniosku powołuje się na priorytet wykonywania zobowiązań międzynarodowych podjętych przez Republikę Mołdawii (art. 8 konstytucji) obejmujących także uznanie i wykonywanie decyzji obcych sądów.

\section{Argumenty wladz}

83. Z przedstawionej pisemnej opinii Parlamentu wynika, że do uznania za obowiązujący wyroku skazującego, wydanego przez sąd innego państwa w sprawie karnej, pozbawienie deputowanego przywileju nietykalności nie jest konieczne, jest jednak konieczne do jego wykonania, zgodnie z pojęciem ,pociągnięcie do odpowiedzialności" z art. 70 ust. 3 konstytucji. Parlament nie może podjąć z własnej inicjatywy decyzji o pozbawieniu deputowanego przywileju nietykalności parlamentarnej. Jednak, jeśli Republika Mołdawii uzna decyzję sądu innego państwa, to Komisja do Spraw Prawnych, Powoływania i Immunitetu może wszcząć procedurę pozbawiania immunitetu.

84. Prezydent Republiki Mołdawii stwierdza, że w kodeksie postępowania karnego przewidziano uznanie decyzji sądu innych państw w sprawach karnych w określonych przypadkach, a nie ich bezwarunkowe wykonanie na terytorium Republiki Mołdawii, pozbawienie immunitetu deputowanego skazanego za granicą jest więc konieczne. W tym kontekście przywileju nietykalność pozbawia deputowanego Parlament na wniosek ministerstwa sprawiedliwości lub prokuratora generalnego.

85. Rząd w przedstawionej opinii pisemnej zauważa, że do uznania i wykonania na terytorium Republiki Mołdawii decyzji o skazaniu deputowanego przez sąd innego państwa w sprawie karnej konieczne jest pozbawienie deputowanego immunitetu. Inicjatywa w sprawie pozbawienia deputowanego przywileju nietykalności parlamentarnej nie należy w tym przypadku do uprawnień organu ustawodawczego, a stanowi wyłączną prerogatywę prokuratora generalnego.

86. Na publicznym posiedzeniu Sądu Konstytucyjnego przedstawiciel rządu zwrócił uwagę na brak konieczności pozbawienia deputowanego immunitetu w celu uznania decyzji sądu innego państwa, ponieważ przywilej ten przysługuje deputowanemu na etapie w trakcie procedury uznania i wykonania wyroku innego państwa, a nie przysługuje mu już po zakończonym procesie karnym.

87. Przedstawiciel rządu zauważył także, że obowiązek uznania wyroku sądu innego państwa wynika z umów międzynarodowych, których stroną jest Republika 
Mołdawii, i zgodnie z Konwencją wiedeńską o prawie traktatów państwo nie można powoływać się na postanowienia wewnętrznego ustawodawstwa, aby nie wykonywać umowy. Odmowa uznania wyroku innego państwa jest dopuszczalna tylko wtedy, kiedy zostało to przewidziane w umowie, której stroną jest Republika Mołdawii. Tak więc na tym etapie powoływanie się na odmowę Parlamentu w sprawie pozbawienia deputowanego przywileju nietykalności w celu uznania i wykonania ostatecznego wyroku, wydanego przez sąd innego państwa, stronę tych samych aktów międzynarodowych, byłoby sprzeczne z umową międzynarodową.

88. W pisemnej opinii prokuratora generalnego zauważono, że wniosek o uznanie i wykonanie wyroku skazującego wydanego przez sąd innego państwa w sprawie karnej należy skierować do Ministerstwa Sprawiedliwości. W przypadku gdy zostanie stwierdzone, że przekazana do wykonania decyzja dotyczy deputowanego, Ministerstwo Sprawiedliwości zwraca się do prokuratora generalnego o złożenie do Parlamentu wniosku o pozbawienie deputowanego przywileju nietykalności.

\section{Ocena Sądu Konstytucyjnego}

89. Na wstępie Sąd Konstytucyjny podkreśla, że w kontekście wykładni norm konstytucyjnych nie jest istotne, czy skazany posiada obywatelstwo innego państwa wydającego wyrok, ponieważ procedura w danej sprawie nie ma jakiegokolwiek dyskryminacyjnego ani dowolnego charakteru. W tym kontekście Sąd Konstytucyjny przywołuje art. 17 Konwencji Rady Europy o obywatelstwie, przypominając o zobowiązaniu Republiki Mołdawii, podjętym na podstawie tego artykułu, do zagwarantowania wszystkim obywatelom mołdawskim posiadającym obywatelstwo innych państw takich samych praw i obowiązków, jakim podlegają pozostali obywatele Republiki Mołdawii [...].

90. Sąd Konstytucyjny zauważa, że w przepisach art. 558 ust. 1 kodeksu postępowania karnego przewidziano, że „ostateczne decyzje w sprawach karnych wydane przez zagraniczne sądy, a także decyzje, które w swoim charakterze są zgodne z prawem karnym Republiki Mołdawii, mogą mieć następstwa prawne i mogą zostać uznane przez Trybunał Narodowy na wniosek ministra sprawiedliwości lub prokuratora generalnego na podstawie umowy międzynarodowej lub porozumienia o wzajemności”.

91. Tak więc ani prokurator generalny, ani minister sprawiedliwości nie może z własnej inicjatywy zwrócić się do Trybunału Narodowego z wnioskiem o uznanie i wykonanie decyzji w sprawie karnej innego państwa. Zgodnie z art. 109 ust. 1 ustawy nr 371-XVI z 1 grudnia 2006 r. o międzynarodowej pomocy prawnej w sprawach karnych ,na terytorium Republiki Mołdawii wykonanie decyzji obcego sądu odbywa się na wniosek o jej uznanie i wykonanie sformułowany przez właściwy organ państwa, które wydało wyrok skazujący".

92. Zgodnie $\mathrm{z}$ art. 111 ust. 3 ustawy o międzynarodowej pomocy prawnej w sprawach karnych: „Ministerstwo Sprawiedliwości poprzez swoje wyspecjalizowane jednostki dokonuje kontroli zgodności wniosku o uznanie i wykonanie decyzji o skazaniu oraz załączonych do niego dokumentów z postanowieniami umów międzynarodowych 
i przekazuje go do właściwego sądu zgodnie z ust. 1 art. 559 kodeksu postępowania karnego lub przedstawia Prokuraturze Generalnej”.

93. Zgodnie z postanowieniami art. 558 kodeksu postępowania karnego Trybunał Narodowy w ramach procedury uznania decyzji w sprawie karnej sądu innego państwa sprawdza, czy zostały zachowane następujące warunki, a więc: czy decyzja została wydana przez uprawniony sąd; czy decyzja nie jest sprzeczna z porządkiem społecznym w Republice Mołdawii; czy decyzja może mieć następstwa prawne w kraju zgodnie z narodowym prawem karnym?

94. Ponadto w art. 534 kodeksu postępowania karnego przewidziano, że można odmówić międzynarodowej pomocy prawnej, jeżeli:

1) wniosek dotyczy przestępstw uznawanych w Republice Mołdawii za polityczne lub związanych z nimi. Wydanie odmowy jest niedopuszczalne w przypadku, gdy osoba jest podejrzana, oskarżana lub została skazana za dokonanie czynów przewidzianych w art. 5-8 statutu Międzynarodowego Trybunału Karnego;

2) wniosek dotyczy wyłącznie naruszenia dyscypliny wojskowej;

3) organ postępowania karnego lub sąd, do którego wystąpiono z wnioskiem o udzielnie pomocy prawnej, uznaje, że jego realizacja może zagrażać suwerenności, bezpieczeństwu lub porządkowi społecznemu państwa;

4) istnieją uzasadnione przyczyny, aby twierdzić, że wobec podejrzanego wszczęto dochodzenie lub orzeczono karę w sprawie karnej z przyczyn rasowych, religijnych, z powodu posiadania obywatelstwa określonego państwa, przynależności do określonej grupy lub z powodu podzielania określonych przekonań politycznych oraz że jego sytuacja może się pogorszyć z wymienionych powodów;

5) udowodniono, że państwo wnioskujące nie gwarantuje sprawiedliwego postępowania sądowego;

6) za dany czyn ustawodawstwo państwa wnioskującego przewiduje karę śmierci, a państwo wnioskujące nie udzieliło żadnych gwarancji niezastosowania lub niewykonania kary śmierci;

7) zgodnie z kodeksem karnym Republiki Mołdawii czyn lub czyny wymienione we wniosku nie są uznawane za przestępstwa;

8) zgodnie z ustawodawstwem krajowym osoba nie może zostać pociągnięta do odpowiedzialności karnej.

95. Z przepisów zawartych w ustawach Sąd Konstytucyjny wywodzi, że ani jedna $\mathrm{z}$ wymienionych przyczyn odmowy uznania decyzji sądu innego państwa nie odnosi się do immunitetu skazanej osoby.

96. Jednocześnie Sąd Konstytucyjny podkreśla, że zgodnie z wewnętrznymi przepisami ustaw międzynarodowych pomoc prawna udzielana jest na podstawie umowy międzynarodowej lub zasady wzajemności kanałami dyplomatycznymi. Odpowiednio do Konwencji o prawie traktatów umowy międzynarodowe są wykonywane sumiennie zgodnie z zasadą pacta sunt servanda. Republika Mołdawii nie może powoływać się na postanowienia swojego wewnętrznego ustawodawstwa w celu niewykonywania umowy, której jest stroną. 
97. Sąd Konstytucyjny przypomina, że zgodnie z normami konstytucyjnymi deputowany zostaje pozbawiony przywileju nietykalności tylko wtedy, kiedy stosuje się wobec niego określone procesowe środki przymusu (zatrzymanie, tymczasowe aresztowanie, rewizja), oprócz zatrzymania na miejscu popełnienia przestępstwa, a także w przypadku skierowania sprawy do sądu.

98. Sąd Konstytucyjny zauważa, że w procedurze uznania przez Trybunał Narodowy decyzji sądu innego państwa nie przewidziano postępowania sądowego co do istoty i rozpatrywania dowodów, ponieważ w tym zakresie zostały one już rozpatrzone przez sądy państwa wydającego wyrok skazujący. W tym kontekście procedura uznania decyzji sądu innego państwa ogranicza się do kontroli przez krajowe sądy gwarancji procesowych państwa skazującego. Zatem procedura uznania decyzji innego państwa w sprawie karnej nie jest równoznaczna ze „skierowaniem sprawy do sądu”.

99. Tak więc sytuacji osoby, wobec której sąd innego państwa wydał decyzję i wszczęta została procedura uznania tej decyzji, nie można zaliczyć do przypadków wymienionych $\mathrm{w}$ art. 70 ust. 3 konstytucji, które wymagają pozbawienia deputowanego przywileju nietykalności parlamentarnej. W celu uznania i wykonania ostatecznego wyroku sądu innego państwa w sprawie karnej nie ma zatem konieczności pozbawienia deputowanego przywileju nietykalności.

\section{LOS MANDATU DEPUTOWANEGO, WOBEC KTÓREGO WYDANO OSTATECZNĄ DECYZJĘ SĄDU W SPRAWIE POPEŁNIENIA PRZESTĘPSTWA UMYŚLNEGO}

\section{Argumenty autora wniosku}

100. W opinii autora wniosku w normach konstytucyjnych jasno nie określono, co dzieje się z mandatem deputowanego skazanego ostateczną decyzją sądu.

101. W tym kontekście autor wniosku uznaje, że w odniesieniu do czynów korupcyjnych zachowanie przez osobę skazaną za taki czyn statusu deputowanego wyrządza nieodwracalną szkodę Parlamentowi jako najwyższemu organowi władzy państwowej i dyskwalifikuje działalność parlamentarną.

102. Jego zdaniem podważa to zaufanie społeczeństwa do państwa w zakresie jego zdolności do skutecznego przeciwdziałania korupcji. W związku z tym zachowanie mandatu deputowanego przez takie osoby jest sprzeczne z zasadą państwa prawnego zawartą $\mathrm{w}$ art. 1 ust. 3 konstytucji.

103. Autor wniosku twierdzi, że wydanie wyroku, w tym także przez inne państwo, w sprawie popełnienia czynów korupcyjnych jest — ze względów politycznych i moralnych — nie do pogodzenia z mandatem skazanego deputowanego i w rezultacie oznacza brak możliwości pełnienia przez niego obowiązków urzędowych. Co za tym idzie, taki deputowany powinien zostać pozbawiony mandatu.

\section{Argumenty organów władzy}

104. W opinii Parlamentu osoby, które obejmują obejmujące kierownicze urzędy, powinny cechować się uczciwością. Niewypełnianie i ignorowanie tego warunku, 
powoływanie i pozostawianie na urzędach kierowniczych osób, których nieprzekupności nie można być pewnym, wywołuje poważne wątpliwości i stanowi przejaw lekceważenia wartości państwa prawa.

105. Przedstawiciel Parlamentu uznaje za niezbędne określenie tych aspektów przez Parlament. Jego zadaniem, Sąd Konstytucyjnych powinien stwierdzać okoliczności, które uzasadniają pozbawienie mandatu deputowanego, ponieważ mandat deputowanego potwierdza właśnie ten organ.

106. Prezydent Republiki Mołdawii w pisemnej opinii stwierdza, że luki prawnej w zakresie pozbawienia mandatu deputowanego skazanego ostateczną decyzją sądu nie można usunąć poprzez wykładnię Sądu Konstytucyjnego. Jedyne, co może uczynić Sąd Konstytucyjny, to złożyć wniosek do Parlamentu w celu realizacji postanowień art. 70 ust. 2 konstytucji.

107. Prezydent Republiki Mołdawii uważa, że za pomocą wykładni Sąd Konstytucyjny może określić, czy deputowany skazany za popełnienie przestępstw może czy nie może zostać pozbawiony mandatu. W związku z tym w podjęciu decyzji mogą pomóc przepisy konstytucji dotyczące prezydenta Republiki Mołdawii, który — podobnie jak deputowany — posiada immunitet. Zgodnie z tymi przepisami prezydent zostaje usunięty z urzędu z mocy prawa $\mathrm{z}$ dniem uprawomocnienia się wyroku skazującego (art. 81 ust. 3 konstytucji). Za logiczne prezydent Republiki Mołdawii uznaje więc wygaśnięcie z mocy prawa mandatu deputowanego $\mathrm{z}$ dniem uprawomocnienia się wyroku skazującego.

108. Rząd zauważa, że niepołączalność mandatu deputowanego z zajmowanym urzędem przewidziano $\mathrm{w}$ aktach normatywnych. Jednocześnie nie określono jasno w ustawie właściwej procedury i okoliczności skutkujących koniecznością pozbawienia deputowanego mandatu.

109. W pisemnej opinii rządu zauważano, że wyrok skazujący deputowanego nie pociąga za sobą rezygnacji z mandatu i nie odnosi się do zasady niepołączalności. Zdaniem rządu w przypadku wydania takiej decyzji pozbawienie mandatu deputowanego staje się obowiązkowe.

110. Przedstawiciel rządu wskazał jednocześnie, że pozbawienie mandatu deputowanego jest niemożliwe, ponieważ w obowiązującym ustawodawstwie Republiki Mołdawii tego nie przewidziano.

111. W tym kontekście przedstawiciel rządu zauważył, że przy dokonywaniu wykładni Sąd Konstytucyjny może określić, co dokładnie dopuszcza się w konstytucji, jakie postanowienia mogą być zawarte w ustawie, żeby ta była zgodna z konstytucją. Sąd Konstytucyjny powinien w ustawie określić wyczerpujące warunki wygaśnięcia mandatu oraz wskazać ich podstawę, aby nie wykraczać poza granice materii konstytucyjnej, uwzględniając fakt, że w konstytucji Republiki Mołdawii dopuszczono pozbawienie mandatu, jednak nie przewidziano jakichkolwiek kryteriów w tym zakresie.

112. Odnośnie do przypadków, kiedy mandat wygasa z mocy prawa, rząd uważa, że brak międzynarodowych standardów wskazujących na konieczność formalnej 
ingerencji władz państwowych, do których można by się odwołać. Zgodnie z opinią przedstawiciela rządu powinna istnieć jasna procedura wygaszania mandatu deputowanego, Rząd uważa, że można obejść się w tej sprawie bez ingerencji Parlamentu. Tym niemniej, rozumiejąc znaczenie mandatu deputowanego w demokratycznym państwie, należy unikać wygaszania mandatu z mocy prawa — nawet jeśli istnieją ku temu przekonujące argumenty — bez wskazania określonych procedur formalnych, analogicznych do procedury przyjęcia przez Parlament do wiadomości rezygnacji deputowanego $\mathrm{z}$ mandatu.

\section{Ocena Sądu Konstytucyjnego}

113. Na wstępie Sąd Konstytucyjny zauważa, że — zgodnie z art. 31 ust. 3 ustawy o Sądzie Konstytucyjnym - Sąd ten rozstrzyga wyłącznie kwestie prawne. Zatem Sąd Konstytucyjny rozpatrzył kwestię zasady niepołączalności mandatu deputowanego w kontekście prawnym.

114. W art. 69 ust. 2 konstytucji przewidziano wygaśnięcie mandatu deputowanego w następujących przypadkach: w dniu prawomocnego zwołania nowego składu Parlamentu, rezygnacji, pozbawienia mandatu, niepołączalności urzędów, śmierci.

115. Z norm konstytucyjnych wynika więc, że przedterminowe wygaśnięcie mandatu deputowanego zachodzi w czterech przypadkach: rezygnacji, pozbawienia mandatu, niepołączalności lub śmierci.

116. Z art. 69 ust. 2 konstytucji jasno wynika, że w tym akcie prawnym określono dwa różne przypadki wygaśnięcia mandatu deputowanego: pozbawienie mandatu, kiedy niezbędna jest ingerencja organu państwowego, oraz naruszenie zasady niepołączalność (oprócz śmierci i przypadków pozbawienia mandatu), kiedy procedura „pozbawienia mandatu” nie jest konieczna.

117. Sąd Konstytucyjny zauważa, że — jak wynika z normy konstytucyjnej — określenie przypadków przymusowego wygaśnięcia mandatu deputowanego stanowi prerogatywę Parlamentu, w tym także pozbawienie mandatu lub określenie naruszenie zasady niepołączalności mandatu deputowanego, z uwzględnieniem zasad i ducha konstytucji, wartości demokratycznych i praktyki innych państw w tym zakresie. Sąd Konstytucyjny bierze pod uwagę fakt, że do chwili obecnej Parlament nie przyjął regulacji, w których przewidziano by przypadki pozbawienia lub wygaszenia z mocy prawa mandatu deputowanego (hipoteza dopuszczana w konstytucji, która różni się od „pozbawienia” mandatu). Wobec tego nie są realizowane normy konstytucyjne.

118. W tym kontekście Sąd Konstytucyjny wychodzi z założenia, że norma musi być wykładana w sensie, w jakim dopuszcza się jej stosowanie, a nie w jakim jej stosowanie się wyklucza.

119. Z uwagi na brak jasnych przepisów warunki określone w odniesieniu do podobnej praktyki również należy wykreślić z tekstu konstytucji, stosując zasadę „minimalnego korzystnego działania”.

120. Sąd Konstytucyjny uznaje, że — wobec braku jasnych przepisów — warunki dotyczące przymusowego wygaśnięcia mandatu deputowanego należy wyprowadzić 
z tych, które są stosowane podczas wybierania na urząd, z uwzględnieniem tego, że zgodnie z logiką swobodnego przedstawicielstwa deputowany nie może być odwołany, wyborcy nie mogą wpłynąć na przedterminowe wygaśnięcie jego mandatu.

121. W art. 70 ust. 1 konstytucji przewidziano zasadę niepołączalność mandatu deputowanego z jakimkolwiek innym odpłatnym urzędem, z wyjątkiem działalności wykładowej i naukowej. Ta lista nie jest wyczerpująca. Zgodnie z ust. 2 tego artykułu, inne przypadki niepołączalności określono w ustawie organicznej.

122. Wykonując dyspozycję art. 70 konstytucji, w art. 3 ustawy nr 39-XIII z dnia 7 kwietnia 1994 r. w sprawie statusu deputowanego Parlamentu wyszczególniono urzędy niepołączalne z mandatem deputowanego, jednak nie przewidziano innych przypadków niepołączalności.

123. Natomiast $\mathrm{w}$ art. 69 ust. 1 konstytucji przewidziano, że deputowani przystępują do sprawowania mandatu pod warunkiem jego uznania.

124. W tym kontekście w art. 62 konstytucji przewidziano, że Sąd Konstytucyjny na wniosek Centralnej Komisji Wyborczej podejmuje decyzję: o uznaniu mandatów deputowanych, a w przypadku naruszenia prawa wyborczego o nieuznaniu ich.

125. Tak więc decydującym warunkiem sprawowania mandatu deputowanego jest uznanie tego. Jednocześnie normami konstytucji nie ograniczono w czasie możliwości „nieuznania” mandatu „w przypadku naruszenia prawa wyborczego”.

126. W art. 38 ust. 3 konstytucji przewidziano, że: „Prawo do bycia wybranym przysługuje obywatelom Republiki Mołdawii mającym prawo wybierania, $\mathrm{w}$ trybie określonym ustawą".

127. Tak więc zgodnie z art. 13 ust. 2 kodeksu wyborczego nie mogą zostać wybrani:

a) poborowi do wojska;

b) osoby, które nie mają prawa wybierania: osoby, które nie osiągnęły w dniu przeprowadzania wyborów wieku 18 lat; osoby pozbawione tego prawa w trybie przewidzianym ustawą, osoby uznane za niezdolne do pełnienia czynności prawnych prawomocną decyzją sądu;

c) osoby skazane na karę pozbawienia wolności ostateczną decyzją sądu i odbywające karę w miejscach pozbawienia wolności, a także mające niezatarte skazanie za popełnienie umyślnych przestępstw;

d) osoby pozbawione prawa do zajmowania odpowiedzialnych urzędów ostateczną decyzją sądu.

128. Analizując te ograniczenia, Sąd Konstytucyjny uwzględnia ich celowość. W art. 13 ust. 2 kodeksu wyborczego określono przypadki niewybieralności, które mają wpływ na uznanie mandatu deputowanego. Naruszenie tych warunków prowadzi do całkowitej nieważności wyboru. Warunków tych trzeba przestrzegać zarówno przed wyborami, jak i w trakcie sprawowania mandatu. Wymogów odnoszących się do kandydatów tym bardziej muszą przestrzegać ci, którzy wybrano na deputowanych.

129. Wobec braku jasnych przepisów ustawodawczych, mutatis mutandis, naruszenie warunków wybieralności po uznaniu mandatu stanowi podstawę do uznania 
naruszenia zasady niepołączalności mandatu deputowanego Parlamentu - w tym przypadku mandat wygasa $\mathrm{z}$ mocy prawa $\mathrm{z}$ przyczyn wynikających $\mathrm{z}$ naruszenia podstawowych wymogów właściwych dla zasady rządów prawa.

130. Niewybieralność — to nieusuwalna przeszkoda w wystawieniu kandydatury w wyborach.

131. Stwierdzenie lub zaistnienie w trakcie sprawowania mandatu warunku niewybieralności mutatis mutandis należy uznać za podstawę uznania naruszenia zasady niepołączalności mandatu deputowanego.

132. Skutki naruszenia zasady niewybieralności nie mogą być usunięte w trakcie sprawowania mandatu, ponieważ stanowią one nieusuwalną przeszkodę zarówno w odniesieniu do mandatu, jak i do uczestnictwa w wyborach. Następstwa prawne uznania niewybieralności polegają na uznaniu nieważności wyboru osoby niespełniającej wymogów wybieralności.

133. Tym samym utrata/naruszenie wymogów wybieralność prowadzi do dwóch następstw, które zależą od momentu ujawnienia naruszenia warunków wybieralności przed lub po uznaniu wyborów za ważne:

(1) Jeśli niewybieralność zostanie stwierdzona przed uznaniem wyborów za ważne i przed upływem terminu przewidzianego na zaskarżanie wyników wyborów, mandat danej osoby nie podlega uznaniu.

(2) Jeśli niewybieralność zostanie stwierdzona po uznaniu wyborów za ważne i po upływie terminu przewidzianego na zaskarżanie wyników wyborów lub jeśli $\mathrm{w}$ trakcie sprawowania mandatu zostanie stwierdzona jedna z podstaw niewybieralności przewidzianych w kodeksie wyborczym, w tym także skazanie ostateczną i prawomocną decyzją sądu za popełnienie przestępstwa umyślnego, mandat deputowanego Parlamentu wygasa z mocy prawa.

134. Co więcej, wydanie ostatecznej i prawomocnej decyzji sądu pociąga za sobą następstwa ipso iure. Możliwość ponownego rozpatrzenia sprawy przez Parlament, który jest wyłącznie organem politycznym, jest niedopuszczalne i sprzeczne z zasadą rządów prawa. Tym samym decyzja sądu pociąga za sobą utratę mandatu deputowanego. W rezultacie Parlament ogłasza zwolnienie się mandatu deputowanego.

135. Sąd Konstytucyjny zauważa, że analogiczne postanowienia zawarto w art. 81 ust. 3 konstytucji: „Prezydent traci urząd w dniu uprawomocnienia się wyroku skazującego".

136. W przeciwnym przypadku możliwe byłoby zajęcie urzędu przez osobę, która nie spełnia wymogów moralnych, a to jest sprzeczne z zasadami państwa prawa i demokracji parlamentarnej zawartymi w preambule oraz w art. 1 ust. 3 konstytucji.

137. W tym kontekście Sąd Konstytucyjny przywołuje swoje stanowisko zawarte w postanowieniu $\mathrm{nr} 4 \mathrm{z}$ dnia 22 kwietnia 2013 r., w którym odnośnie do państwa prawa zauważono co następuje:

„67. Wzmacnianie zaufania do Parlamentu, prezydenta i rządu, jako podstawowych organów państwowych, symbolizujących demokrację, bezpośrednio wiąże się ze skuteczną realizacją zasady państwa prawa. 
68. Zgodnie z podstawowymi zasadami państwa prawa osoby zajmujące stanowiska kierownicze powinny udowodnić, że spełniają wysokie wymogi moralne. Co więcej, w przypadku stwierdzenia, że ten warunek nie jest spełniany, ignorowanie tego faktu i powołanie/pozostanie na stanowisku kierowniczym osób, których nie cieszą się nieposzlakowaną opinią, oznacza zaniedbania zasad państwa prawa, ponieważ państwo prawa stanowi wartość konstytucyjną i należy ją chronić w pełnym zakresie".

138. Co zaś tyczy się walki z korupcją, Sąd Konstytucyjny zauważa, że w brytyjskiej ustawie „Akt o przedstawicielstwie ludu” przewidziano, że czyny korupcyjne pociągają za sobą albo niewybieralność, albo a posteriori utratę mandatu.

139. Podobne wnioski należy wyciągnąć również w przypadku wydania wyroku skazującego przez sąd innego państwa, ponieważ decyzje sądów innych państw uznawane i wykonywalne na terytorium Republiki Mołdawii wywierają takie same skutki prawne, jak decyzje podjęte przez sądy krajowe. Tym samym mandat deputowanego skazanego za popełnienie przestępstwa umyślnego przez sąd innego państwa podlega wygaśnięciu z mocy prawa z dniem uprawomocnienia się postanowienia o uznaniu wyroku skazującego.

140. Sąd Konstytucyjny podkreśla ważność i konieczność wyraźnego określenia podstaw i postanowień o wygaśnięciu mandatu deputowanego w formach i w zakresie określonych w konstytucji, w związku z czym składa wniosek do Parlamentu.

141. Bez tego [...] do przypadków wygaśnięcia z mocy prawa mandatu deputowanego powinno zaliczać się przypadki niewybieralności stwierdzone po uznaniu wyborów za ważne lub w trakcie sprawowania mandatu i uznane za podstawę całkowitej niepołączalności.

142. Skazanie deputowanego za popełnienie przestępstwa umyślnego i/lub orzeczenia kary pozbawienia wolności na mocy ostatecznej i prawomocnej decyzji sądu, w tym także innego państwa, nie pociąga za sobą pozbawienia mandatu deputowanego, a jego wygaśnięcie z mocy prawa.

143. Sąd Konstytucyjny przypomina, że wykładnia norm konstytucyjnych ma charakter oficjalny i obowiązuje wszystkie podmioty stosunków prawnych [...].

Zgodnie z powyższym, na podstawie art. 140 konstytucji, art. 26 ustawy o Sądzie Konstytucyjnym, art. 6, 60, 61, 62b i 68 kodeksu postępowania konstytucyjnego, Sąd Konstytucyjny

\section{POSTANAWIA}

1. Zgodnie z art. 70 ust. 3 konstytucji przywilej nietykalności parlamentarnej nie przysługuje deputowanemu skazanemu ostateczną i prawomocną decyzją sądu. Od momentu ,pociągnięcia do odpowiedzialności” kończy się działanie przywileju nietykalności.

2. Zgodnie z art. 70 ust. 3 konstytucji przywilej nietykalności parlamentarnej nie przysługuje deputowanemu w ramach procedury uznania przez sądy krajowe ostatecznego wyroku skazującego wydanego przez sąd innego państwa. 
3. Zgodnie art. 1 ust. 3, art. 38 ust. 2, art. 69 ust. 1 i art. 70 ust. 2 konstytucji w przypadku skazania za popełnienie przestępstwa umyślnego i/lub orzeczenia kary pozbawienia wolności na mocy ostatecznej i prawomocnej decyzji sądu, niezależnie od tego, czy została ona podjęta przed czy po uznaniu mandatu, deputowany znajduje się w sytuacji niewybieralności, co oznacza niepołączalność ze statusem deputowanego.

4. Zgodnie z art. 1 ust. 3, art. 38 ust. 2, art. 69 i art. 70 ust. 2 konstytucji osoba, której niewybieralność została udowodniona po uznaniu wyborów za ważne i po upływie terminu przewidzianego na zaskarżanie wyników wyborów lub która w trakcie sprawowania mandatu znajduje się w jednej z sytuacji niewybieralności przewidzianych kodeksem wyborczym, nie może sprawować mandatu i jej mandat wygasa $\mathrm{z}$ mocy prawa.

5. Niniejsze postanowienie jest ostateczne, nie podlega zaskarżeniu, wchodzi w życie z dniem przyjęcia i zostaje opublikowane w „Monitorul Oficial al Republicii Moldova".

Opracowanie i thumaczenie: Andrzej Pogtódek*

* Dr Andrzej Pogłódek, Uniwersytet Kardynała Stefana Wyszyńskiego, andrzejpoglodek@uksw.edu.pl, https://orcid.org/0000-0001-5549-283X 


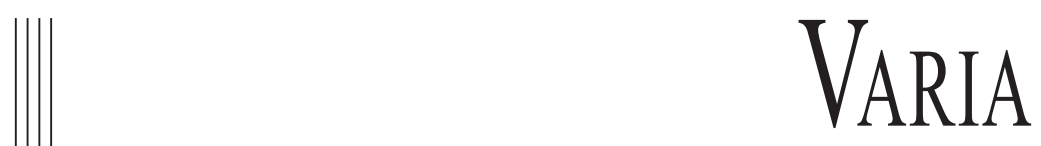

PRZFGLLD SEMNOWY $\quad$ nr 2(151)/2019, s. 215-217; https://doi.org/10.31268/PS.2019.34

SPRAWOZDANIE $Z$ OGÓLNOPOLSKIEJ KONFERENCJI NAUKOWEJ XXIII ZJAZD KATEDR TEORII I FILOZOFII PRAWA „PAŃSTWO - SPOLECZEŃSTWO - KULTURA: FORMALNE I NIEFORMALNE ŹRÓDLA PRAWA" LUBLIN, 23-26 WRZEŚNIA 2018 R.

\begin{abstract}
REPORT ON THE ALL-POLAND SCIENTIFIC CONFERENCE - 23 ${ }^{\text {RD }}$ MEETING OF THE DEPARTMENTS OF THEORY OF PHILOSOPHY OF LAW "STATE - SOCIETY - CULTURE: FORMAL AND INFORMAL SOURCES OF LAW", LUBLIN, 23-26 SEPTEMBER 2018
\end{abstract}

The report refers to the All-Poland Scientific Conference held on 23-26 September 2018, organized by the Department of Theory and Philosophy of Law at the Faculty of Law, Canon Law and Administration of the John Paul II Catholic University of Lublin — the $23^{\text {rd }}$ Meeting of the Departments of Theory of Philosophy of Law "State - Society - Culture: Formal and Informal Sources of Law". The conference dealt with the problems of the sources of law and lawmaking, significant due to the scale of activity of lawmaking, the scope of juridization of social life and dynamic socio-cultural transformations.

Słowa kluczowe: źródła prawa, tworzenie prawa, teoria i filozofia prawa, konferencja

Key words: sources of law, lawmaking, theory and philosophy of law, conference

W dniach 23-26 września 2018 r. odbyła się Ogólnopolska Konferencja Naukowa XXIII Zjazd Katedr Teorii i Filozofii Prawa, której temat przewodni był następujący: „Państwo - społeczeństwo - kultura: formalne i nieformalne źródła prawa”. Konferencję patronatem honorowym objął wojewoda lubelski prof. Przemysław Czarnek oraz dziekan Wydziału Prawa, Prawa Kanonicznego i Administracji Katolickiego Uniwersytetu Lubelskiego Jana Pawła II prof. Krzysztof Wiak.

Konferencja ta wpisuje się w długoletnią tradycję organizowania zjazdów katedr teorii i filozofii prawa przez poszczególne ośrodki naukowe. Zjazdy organizowane są co dwa lata. W roku 2018 trud, a zarazem i zaszczyt organizacji zjazdu przypadł Katedrze Teorii i Filozofii Prawa na Wydziale Prawa, Prawa Kanonicznego i Administracji Katolickiego Uniwersytetu Lubelskiego Jana Pawła II, której pracownikami są: ks. prof. Tomasz Barankiewicz - kierownik, prof. Jadwiga Potrzeszcz, dr Tomasz Barszcz. Rok 2018 jest dla Katolickiego Uniwersytetu Lubelskiego Jana 
Pawła II rokiem obchodów jubileuszu 100-lecia powstania, dlatego też organizacja zjazdu wpisała się w świętowanie tej stuletniej rocznicy.

Wybór przewodniego tematu zjazdu był zainspirowany faktem, że — jak podkreślają organizatorzy - ,współczesna i najnowsza problematyka tworzenia prawa jest znacząca, chociażby ze względu na skalę aktywności stanowienia prawa, zakres jurydyzacji życia społecznego oraz dynamiczne przemiany społeczno-kulturowe. Zasadniczo w europejskiej kulturze prawnej tworzenie (stanowienie) prawa sprowadzić można do warunków formalnych. Niemniej rzeczywisty proces kształtowania się treści prawa, zakłada szerszą perspektywę czynników społecznych, aksjologicznych, politycznych, ekonomicznych i kulturowych, dlatego też pierwszy człon w/w tematu naszej konferencji wskazuje na wieloobszarowy zakres analizy źródeł prawa w zgłaszanych referatach, z uwzględnieniem także różnych podejść i stanowisk filozoficznoprawnych. Zasadniczym przedmiotem Konferencji jest zagadnienie formalnych i nieformalnych źródeł prawa ujmowanych jednak w szerszej perspektywie badawczej trzech głównych obszarów zainteresowań w zgłaszanych referatach: Państwo działając w określonych ramach instytucjonalnych jest głównym, choć nie jedynym, twórcą prawa. Podejmowana problematyka może dotyczyć analizy normatywnej, koncentrującej się na kompetencjach, procesie i rezultatach stanowienia prawa, ale także może dotyczyć innych zagadnień, jak formy tworzenia prawa, zasady redagowania aktów normatywnych, polityka prawa, modele, jawność i racjonalność stanowienia prawa. Społeczeństwo jest również ważnym czynnikiem tworzenia prawa. Pod koniec XX w. rola państwa w procesie stanowienia prawa została znacznie ograniczona przez różne, integracyjne i dezintegracyjne procesy społeczne. W tym względzie analizy mogą dotyczyć różnych ujęć socjologicznych, teoretycznych i filozoficznych podkreślających bardziej lub mniej «etatystyczny» charakter prawa, uwypuklających jego uwarunkowania ekonomiczne, społeczne, polityczne, międzynarodowe. Kultura wyznacza, jak się wydaje, ostateczny horyzont myślenia o procesach kształtowania i tworzenia prawa, stanowiąc materialne źródło prawa. W tym wymiarze na szczególną uwagę zasługują kwestie systemów wartości, idei, zasad i wspólnych doświadczeń historycznych. Traktowane są one jako w dorobek uniwersalny, jak np. idea godności człowieka, prawo naturalne, prawa człowieka lub tylko partykularny, jako dorobek kulturowy danego społeczeństwa, narodu, mniejszych grup społecznych. Zgłaszane referaty mogą dotyczyć zatem różnych kulturowych uwarunkowań tworzonego prawa, zarówno co do treści, jak i w stosunku do instytucjonalno-prawnych struktur państwa oraz społeczeństwa" (<http://23zjazd.tifp.pl>, dostęp 5 XI 2018).

Uroczyste rozpoczęcie obrad odbyło się 24 września 2018 r. w Centrum Transferu Wiedzy Katolickiego Uniwersytetu Lubelskiego Jana Pawła II. Otwarcia Konferencji dokonali: ks. prof. Tomasz Barankiewicz, kierownik Katedry Teorii i Filozofii Prawa KUL, prof. Przemysław Czarnek, wojewoda lubelski, prof. Krzysztof Wiak, dziekan Wydziału Prawa, Prawa Kanonicznego i Administracji KUL oraz współorganizator zjazdu prof. Krzysztof Motyka, kierownik Katedry Socjologii Prawa i Moralności.

Po otwarciu konferencji odbyły się dwie sesje plenarne. 
Pierwszej sesji plenarnej „Formalne i nieformalne źródła prawa — państwo społeczeństwo - kultura" przewodniczył prof. Leszek Leszczyński (UMCS). Referaty wygłosili: prof. Przemysław Czarnek (KUL), Konstytucyjny system źródet prawa a rozszerzajacy się zakres nieformalnych źródet prawa; prof. Irena Lipowicz (UKSW), Formalne i nieformalne źródta prawa w świetle nowej nauki prawa administracyjnego; prof. Adam Sulikowski (UWr), Prawo w ,postliberalnej demokracji”; prof. Marek Piechowiak (SWPS), Uzasadnienie prawnonaturalne jako typ uzasadnienia aksjologicznego; dr Wojciech Arndt (Akademia Ignatianum w Krakowie, BAS), Znaczenie wymogu racjonalnego stanowienia prawa. Po dyskusji i przerwie na kawę odbyła się II sesja plenarna, której przewodniczył prof. Andrzej Korybski (UMCS). Referaty wygłosili: prof. Jacek Kurczewski (UW), Źródta prawa - perspektywa socjologiczna; prof. Jerzy Zajadło (UG), Amerykańskie slave codes jako formalne i nieformalne źródlo prawa; prof. Andrzej Bator (UWr), Naukowość a polityczność prawoznawstwa. Między ciagłościa, zmiana i rewolucją; prof. Bogdan Szlachta (UJ), Między normatywizmem a pozytywizmem prawniczym. Następnie odbyła się dyskusja.

Ze względu na zaplanowane liczne wystąpienia dalsze obrady odbywały się w równoległych sesjach tematycznych w grupach w Centrum Transferu Wiedzy Katolickiego Uniwersytetu Lubelskiego Jana Pawła II oraz w Hotelu Victoria w Lublinie.

W dniu 25 września 2018 r. odbyło się także walne zebranie Międzynarodowego Stowarzyszenia Filozofii Prawa i Filozofii Społecznej (Internationale Vereinigung für Rechts- und Socialphilosophie).

Jadwiga Potrzeszcz*

* Dr hab. Jadwiga Potrzeszcz, prof. Katolickiego Uniwersytetu Lubelskiego Jana Pawła II, Wydział Prawa, Prawa Kanonicznego i Administracji, Katedra Teorii i Filozofii Prawa, jagap@kul.lublin.pl, https:orcid.org/0000-0002-4358-7273 



\section{WSKAZÓWKI DLA AUTORÓW}

1. Teksty opracowań przysyłanych do „Przeglądu Sejmowego” w celu ich opublikowania powinny być dostarczane w postaci elektronicznej w formatach .doc lub .docx (Word). Długość tekstu artykułu: maksimum 60 tys. znaków ze spacjami, z uwzględnieniem przypisów.

Redakcja przyjmuje teksty w języku: polskim i angielskim.

2. Zasady edytorskie:

- formatowanie tekstu: czcionka tekstu głównego: Times New Roman 12 pkt, interlinia 1,5 pkt; krój tekstu w przypisach: Times New Roman 10 pkt; interlinia 1 pkt;

- niestosowanie wersalików w zapisywaniu tytułu artykułu oraz części artykułu;

— niestosowanie w tekście pogrubień, podkreśleń i dodatkowych spacji w celu rozstrzelenia tekstu;

— zapisywanie cytatów antykwą w cudzysłowach (bez stosowania kursywy);

- zapisywanie wyrazów obcojęzycznych kursywą, np. primo;

— umieszczenie odsyłaczy do przypisów przed znakiem przestankowym;

— podawanie po raz pierwszy pełnej nazwy organizacji lub instytucji, np. Organizacja Narodów Zjednoczonych;

— podawanie po raz pierwszy osoby z pełnym imieniem, np. Lech Nowakowski;

- zapisywanie w tekście polskojęzycznym nazw własnych w języku polskim, np. Organizacja Paktu Północnoatlantyckiego, Unia Europejska, Stany Zjednoczone Ameryki, a w tekście angielskojęzycznym w języku angielskim;

— nieodmienianie skrótowców, np. PSL zamiast PSL-u;

— zapisywanie dat: 25 października 2008 roku, 25 października, w październiku 2008 roku;

— zapisywanie dekad słownie, np. w latach osiemdziesiątych;

- stosowanie półpauz bez spacji w zakresach, np. 1945-1989.

3. Artykuł powinien być podzielony na mniejsze jednostki redakcyjne, najlepiej rozdzielone tytułami. Objętość artykułu powinna mieścić się w granicach $0,8-1,5$ arkusza autorskiego, tzn. $32000-60000$ znaków (liczonych ze spacjami, czyli z odstępami między wyrazami). Wraz z artykułem muszą być przysłane (również w postaci elektronicznej): jego streszczenie w języku polskim i angielskim, liczące nie więcej niż 1000 znaków (ze spacjami); słowa kluczowe w języku polskimi i angielskim, biogram autora (stopień/tytuł naukowy, afiliacja, adres e-mail).

4. Na końcu artykułu należy podać pełną Bibliografię w formie wykazu alfabetycznego z podziałem na dwie grupy — Źródła i Piśmiennictwo. Obowiązkowe formy zapisu bibliograficznego:

- Kowalski J., Tytut publikacji monograficznej, Oficyna Wydawnicza, Warszawa 2002.

- Nowak B., Tytuł artykutu, [w:] Tytut pracy zbiorowej, red. N. Kowalczyk, Oficyna Wydawnicza, Lublin 2014, s. 1-23.

- Piotrowski J., Tytuł artykułu, „Czasopismo Naukowe” 2005, nr 3, s. 1-23.

— Nowakowski T., Tytut artykutu, „Gazeta Codzienna”, 2 X 2013, nr 23, s. 3. 
— Nowak J., Tytut publikacji dostęnej w Internecie, <http://adresinternetowy.pl.>

— Strona internetowa MEN, <http://www.umcs.lublin.pl>, ,Materiały pomocnicze do nauczania historii”.

5. Na początku glosy powinna znaleźć się podana in extenso (kursywą) sentencja komentowanego orzeczenia.

6. Recenzja powinna mieć objętość 4000-24000 znaków (liczonych ze spacjami, czyli z odstępami między wyrazami). Nagłówek recenzji powinien być sporządzony według następującego wzorca:

— W odniesieniu do recenzowanej monografi i autorskiej — Jan Nowakowski, Pelny tytut monografii recenzowanej, Oficyna Wydawnicza, Miejsce wydania, Rok publikacji, s. 343.

- W odniesieniu do recenzowanej pracy zbiorowej — Petny tytut pracy zbiorowej, red. Jan Nowakowski, Oficyna Wydawnicza, Miejsce wydania, Rok publikacji, s. 343.

7. Materiały graficzne (zdjęcia, skany, mapy, diagramy, wykresy) należy zamieścić w tekście lub w osobnych plikach w formacie .jpg z jednoczesnym umiejscowieniem w tekście. Natomiast tabele należy przygotować w programie Word dla Windows i zamieścić tylko w tekście. Opis materiałów graficznych jest dokonywany według wzorca właściwego dla tabeli.

\section{Tabela 1}

\section{Tytut tabeli}

Źródło: Opis bibliograficzny wg zasad obowiązujących w przypisach.

8. W przypadku wykorzystywania publikacji w językach opartych na cyrylicy należy je zapisywać w tekście głównym i w przypisach za pomocą cyrylicy, natomiast w bibliografii należy dokonywać latynizacji zapisu publikacji zgodnie z przyjętymi w Polsce zasadami.

9. Przypisy należy umieścić na dole strony, stosując skróty łacińskie (ibidem, op. cit., idem, eadem, vide, confer).

10. Obowiązkowe formy stosowane w przypisach:

- monografia ${ }^{1}$;

- artykuł w pracy zbiorowej pod redakcją ${ }^{2}$;

— artykuł w czasopiśmie naukowym ${ }^{3}$;

— publikacja źródłowa w prasie (należy obowiązkowo podać datę dzienną oraz numer strony);

- akt prawny ${ }^{5}$;

— źródło archiwalne ${ }^{6}$;

${ }^{1}$ I. Nazwisko, Tytuł monografii kursywa, Warszawa 2010, s. xx.

${ }^{2}$ I. Nazwisko, Tytul artykulu kursywa, [w:] Tytut pracy zbiorowej kursywa, red. I. Nazwisko, Warszawa 2005, s. 24-25.

${ }^{3}$ I. Nazwisko, Tytuł artykułu kursywa, ,Tytuł Czasopisma” 2008, nr 4, s. 76.

${ }^{4}$ I. Nazwisko, Tytut publikacji źródtowej kursywa, ,Tytuł Gazety”, 23 IX 2013, nr 56, s. 7.

${ }^{5}$ Ustawa z dnia 23 stycznia 2014 roku o zasadach edytorskich, Dz.U. nr 56, poz. 72.

${ }^{6}$ Archiwum Akt Nowych, Akta Partii Politycznych, sygn. 21/B/34, t. 3, ,Tytuł dokumentu archiwalnego", k. 2. 
- dokument elektroniczny w postaci tekstu naukowego ${ }^{7}$;

— materiał źródłowy zamieszczony w Internecie (należy podać podmiot odpowiedzialny za stronę lub nazwę strony, jedynie skrócony adres internetowy, tytuł dokumentu internetowego, datę pozyskania danych — np. „dostęp: 1.03.2017”) ${ }^{8}$;

- orzeczenie sądu lub trybunału;

- materiał audiowizualny (film, audycja radiowa $)^{10}$.

Niezastosowanie się autora do wskazówek może stanowić argument, aby zrezygnować z publikacji lub odesłać tekst w celu dokonania koniecznych uzupełnień i poprawek.

Nie będą przyjmowane do opracowania redakcyjnego teksty, w których nie zachowano podstawowych zasad poprawności językowej właściwej dla języka polskiego lub angielskiego.

U w a g a. Artykułów niezamówionych nie zwracamy.

Zastrzegamy sobie prawo do skrótów w tekstach nadesłanych do publikacji.

${ }^{7}$ I. Nazwisko, Tytut publikacji naukowej zamieszczonej $w$ Internecie, $<$ http://www.biblioteka.pl>, s. 23, dostęp 23 VIII 2013.

${ }^{8}$ Strona internetowa Wydziału Prawa i Politologii, $<$ http://www.prawoipolitologia.pl $>$, ,Tytuł dokumentu internetowego", dostęp 23 VIII 2013.

${ }^{9}$ Nazwa orzeczenia, Nazwa organu orzekającego, Data wydania, Sygnatura akt oraz (jeśli orzeczenie było publikowane) wskazanie miejsca publikacji i numeru cytowanej albo powoływanej strony.

${ }^{10}$ Tytul filmu, reż. Jan Kowal, Francja-RFN, 2014, 9:10-9:13. 


\section{KSIECGARNIE WSPÓŁPRACUJĄCE \\ Z WYDAWNICTWEM SEJMOWYM}

\section{Katowice}

Księgarnia Liber

ul. Bankowa 11, 40-007 Katowice, tel. 323591272

\section{Kraków}

Główna Księgarnia Naukowa

Podwale 6, 31-118 Kraków, tel. 124223717

Księgarnia Akademicka

ul. św. Anny 6, 31-008 Kraków, tel. 124312743

Księgarnia Internetowa Poczytaj.pl

ul. Wallek-Walewskiego 4, 30-094 Kraków, tel. 126264804

\section{Lublin}

\section{Księgarnia Iuris Prudentia}

Plac M. Curie-Skłodowskiej 5 - Budynek Wydziału Prawa UMCS

20-031 Lublin, tel./fax 815375475

\section{Rzeszów}

Księgarnia Iuris Prudentia

ul. Jana III Sobieskiego 2d/2, 35-002 Rzeszów, tel. 178523926

\section{Szczecin}

Księgarnia Akademicka

aleja Jana Pawła II, 70-453 Szczecin, tel. 914890926

\section{Warszawa}

Księgarnia Ekonomiczna Kazimierz Leki

ul. Grójecka 67, 02-094 Warszawa, tel. 228229041

\section{Księgarnia Historyczna}

aleja Solidarności 105, 05-077 Warszawa,

tel. $226521959,607833337,602612251$

\section{Lexicon}

ul. Dereniowa 2, 02-776 Warszawa, tel. 226484123

\section{Księgarnia Profit}

plac Defilad 1, 00-110 Warszawa, tel. 226545517

\section{Wroclaw}

Księgarnia Wydziałowa MAJK

ul. Uniwersytecka 22/26, 50-145 Wrocław, tel. 713752603

\section{Zamość}

\section{Księgarnia Iuris Prudentia}

ul. Kolegiacka 2, 22-400 Zamość, tel. 846438585 


\section{NOWOŚCI WYDAWNICTWA SEJMOWEGO}

Piotr A. Tusiński

SEJM USTAWODAWCZY RZECZYPOSPOLITEJ POLSKIEJ 1919-1922

W opatrzonej bogatą ikonografią książce przedstawiono zagadnienia związane z kształtowaniem się polskiego parlamentaryzmu po odzyskaniu niepodległości przez Rzeczpospolitą. Autor opisał m.in. proces wyłaniania składu Izby, inaugurację jej obrad, organizację pracy, a ponadto scharakteryzował strukturę klubową Sejmu Ustawodawczego. Pozycja zawiera liczne fotografie postaci i dokumentów z początków XX w. na ziemiach II RP.

Marek Kornat, Wacław Uruszczak 550 YEARS OF POLISH PARLIAMENTARISM

Angielska wersja albumu „,550 lat parlamentaryzmu Rzeczypospolitej”, poświęconego historii polskiego parlamentaryzmu, wydanego z okazji obchodów 550-lecia parlamentaryzmu Rzeczypospolitej.

Pawet Pietrzyk

LEON ORŁOWSKI. POSE€ W BUDAPESZCIE (1936-1940). BIOGRAFIA DYPLOMATY

Biografia Leona Orłowskiego, ostatniego posła polskiego na Węgrzech z okresu przed wybuchem II wojny światowej. Autor ukazuje postać dyplomaty na szerokim tle wydarzeń historycznych, których był świadkiem i czynnym uczestnikiem. Równie interesujące są emigracyjne losy Orłowskiego w okresie powojennym, a także jego twórczość pisarska.

Beata Machul-Telus

ROLA KOMISJI MNIEJSZOŚCI NARODOWYCH I ETNICZNYCH SEJMU RZECZYPOSPOLITEJ POLSKIEJ W KSZTAŁTOWANIU POLSKIEJ POLITYKI NARODOWOŚCIOWEJ W LATACH 1989-2007

Przedmiotem publikacji jest opis i analiza roli Komisji Mniejszości Narodowych i Etnicznych Sejmu RP w kształtowaniu polskiej polityki narodowościowej, od momentu jej powstania w $1989 \mathrm{r}$. do czasu wprowadzenia w życie ustawy o mniejszościach narodowych i etnicznych oraz o języku regionalnym w latach 2005-2007. Podstawę badawczą książki stanowią źródła archiwalne, w tym stenogramy z posiedzeń plenarnych oraz biuletyny komisji sejmowych.

Cezary Mik

PARLAMENTY NARODOWE WOBEC ZASADY POMOCNICZOŚCI W ŚWIETLE PRAWA I PRAKTYKI UNII EUROPEJSKIEJ

Publikacja jest zaktualizowaną i znacząco uzupełnioną wersją książki wydanej pod tym samym tytułem w 2015 r. Praca została wzbogacona o dwa niezamieszczone w pierwszej edycji teksty autorstwa Marii Kruk i Krzysztofa Wójtowicza. Zawiera analizę normatywną zasady pomocniczości, prezentację praktyki parlamentów narodowych w zakresie oceny jej poszanowania oraz ogólniejszą refleksję nad przyczynami dysfunkcji mechanizmu kontrolnego oraz perspektywami zmian.

\section{Seria „Mniejszości Narodowe i Etniczne w Polsce”} ROMOWIE

Redakcja naukowa Beata Machul-Telus

Książka ma charakter interdyscyplinarny, złożona jest z tekstów specjalistów różnych dyscyplin naukowych, których łączy badawcze zainteresowanie społecznością romską. Autorzy zaprezentowanych tekstów przybliżają czytelnikom skomplikowane losy Romów — niezwykle różnorodnej mniejszości etnicznej zamieszkałej w Polsce — i ukazują wiele stereotypów, które dominują w powszechnym postrzeganiu tej fascynującej społeczności. 
